\title{
SPUTNIK EDUCATION
}

giới thiệu

\section{NHẬP MÔN TOÁN TÀI CHÍNH}

GS. Nguyễn Tiến Dũng và GS. Đỗ Đức Thái

Hà Nội - Toulouse, 2014 
Quyển sách này được soạn thảo trong quãng thời gian 2009-2011. Bản ebook này, với sự giúp đỡ của Sputnik Education, được công bố miễn phí cho bạn đọc, nhằm đóng góp vào sự nghiệp giáo dục ở Việt Nam. Nó có thể dùng làm tài liệu cho một khoá học về toán tài chính dành cho những người theo các ngành toán học hay kinh tế và tài chính. Bản quyền thuộc về các tác giả.

Sputnik Education, do một nhóm những chuyên gia có trình độ cao và rất tâm huyết với nền giáo dục lập nên, với mục đích đem lại các tài liệu học tập có chất lượng cao nhất cho học sinh, và cả người lớn, giúp cho việc học trở nên vui và hiệu quả hơn. Xin mời tìm đọc các sách do Sputnik Education xuất bản! 


\section{Lời giới thiệu}

Mục đích của cuốn sách này là nhằm giúp các bạn sinh viên các ngành kinh tế, tài chính, và toán học nắm bắt được một số kiến thức cơ bản của toán tài chính, với các ứng dụng thực tế trong tài chính, qua đó có thể tiếp tục tìm hiểu sâu thêm về lĩnh vực này. Do nhằm phục vụ cả sinh viên toán còn thiếu kiến thức về tài chính, lẫn sinh viên kinh tế - tài chính còn thiếu kiến thức về toán, chúng tôi đã thiết kế quyển sách này với những chương có tính chất bổ túc về tài chính, và đồng thời đã cố gắng giảm nhẹ về mặt hình thức toán học so với một số tài liệu cao cấp bằng tiếng Việt khác [14, 20, 28].

Vào thời điểm chúng tôi biên soạn cuốn sách này, toán tài chính là một ngành còn khá mới mẻ ở Việt Nam, tuy rằng trên thế giới nó đã trở thành một ngành lớn và rất quan trọng, có thể coi là không thể thiếu trong các hoạt động của các tổ chức tài chính như ngân hàng, bảo hiểm, đầu tư, cũng như trong việc quản lý tài chính của các chính phủ, các doanh nghiệp lớn. Hệ thống tài chính quốc tế ngày càng trở nên tinh vi và phức tạp, và để cạnh tranh trong hệ thống này, ngày càng cần nhiều đến các công cụ toán học để mô hình hóa, phân tích và tính toán. Không chỉ đối với các tổ chức và doanh nghiệp lớn, mà các cá nhân cũng cần có những hiểu biết tối thiểu về tài chính và toán tài chính, sẽ rất có ích trong các quyết định tài chính của mình, nhằm đạt được một tương lai đảm bảo hơn và tự do hơn về tài chính, tránh được các rủi ro.

Nhận thấy nhu cầu phát triển đào tạo ngành toán tài chính ở Việt Nam, Khoa Toán trường Đại học Sư phạm Hà nội dưới sự hỗ trợ của Trung tâm Toán Tài chính và Công nghiệp Hà nội gần đây đã mở ra mã ngành đào tạo bậc cử nhân về toán tài chính. Quyển sách này ra đời cũng là để nhằm phục vụ cho trương trình đào tạo cử nhân này.

Cấu trúc của quyển sách này như sau: nó gồm có 8 chương, có thể chia làm 3 phần. Phần thứ nhất gồm 2 chương đầu, là chương về tiền tệ và chương về thị trường tài chính. Phần này hầu như không có toán, và mục đích chính của phần này là nhằm làm quen các sinh viên ngành toán với các khái niệm cơ bản về tài chính. Phần thứ nhất này cũng có một số thông tin cập nhật về thị trường tài chính thế giới, có thể thú vị đối với bạn đọc đã có kiến thức về tài chính. Phần thứ hai gồm 4 chương tiếp theo, về kinh doanh chênh lệch giá, phân tích trái phiếu, phân tích cổ phiếu, và quản lý danh mục đầu tư. Phần này bắt đầu có nhiều công thức toán học và định lý, nhưng ở mức độ phức tạp vừa phải, các sinh viên kinh tế và tài chính chắc cũng sẽ không gặp khó khăn gì đặc biệt về toán khi đọc phần này, đặc biệt nếu đã có một số kiến thức cơ sở về giải tích và xác suất thống 
kê. Định lý về kinh doanh chênh lệch giá (arbitrage), được giới thiệu trong chương 3, còn được gọi là định lý cơ bản của toán tài chính, bởi vì các định lý về định giá trong toán tài chính là dựa trên cơ sở của định lý này. Chương 4 và Chương 5 là giới thiệu về phân tích cổ phiếu và trái phiếu từ quan điểm nhà đầu tư, và Chương 6 là về một số nguyên tắc định tính và định lượng cơ bản trong việc quản lý danh mục đầu tư. Phần thứ ba, gồm hai chương cuối, là phần nặng về toán. Chương 7 là chương về giải tích ngẫu nhiên, làm cơ sở cho việc mô hình hóa các biến động giá cả trên thị trường về toán. Một số khái niệm cơ bản của giải tích nhẫu nhiên, trong đó có martingale, chuyển động Brown, tích phân Itô, và thay đổi phân bố xác suất, được bàn đến ở đây. Các tác giả đã cố gắng viết chương này một cách nhẹ về toán và dễ hiểu hơn so với các sách chuyên khảo về giải tích ngẫu nhiên, và cho các liên hệ trực tiếp với giá chứng khoán, với hy vọng là các bạn đọc không phải người học ngành toán cũng có thể hiểu được và thấy được ứng dụng của giải tích ngẫu nhiên. Chương 8 là chương về việc định giá các quyền chọn, là các chứng khoán phái sinh đã trở thành rất phổ biến trên thị trường tài chính. Các mô hình định giá được bàn đến trong chương này, cụ thể là mô hình Black-Scholes và mô hình nhị phân Cox-Ross-Rubinstein, đều dựa trên kiến thức về giải tích ngẫu nhiên được trình bầy trong Chương 7.

Để hiểu tốt quyển sách này, bạn đọc sẽ cần một số kiến thức cơ sở về giải tích toán học, đại số tuyến tính, và xác suất thống kê. Tất cả các khái niệm xác suất thông kê được dùng trong quyển sách này, mà không được giải thích chi tiết ở đây, đều có thể tìm thấy trong quyển sách [7] do chúng tôi biên soạn. Ngoài ra, nếu có thêm một số kiến thức toán cao cấp khác, ví dụ như khái niệm về tập compact, về nhân tử Lagrange trong tối ưu hóa, v.v., thì sẽ dể hiểu hơn các chứng minh của các định lý có tính toán học trong quyển sách này. Nếu không, thì có thể tạm thời bỏ qua chứng minh của các định lý, mà chú trọng vào việc hiểu ý nghĩa của các định lý đó, để có thể dùng được chúng.

Do khuôn khổ của cuốn sách có hạn, và mục đích là sách nhập môn để cho sinh viên đại học có thể đọc hiểu được, nên có rất nhiều vấn đề quan trọng của toán tài chính mà chúng tôi bỏ qua không đề cập tới trong sách. Chúng tôi hy vọng sẽ có thể viết các quyển sách khác, chuyên sâu hơn, nối tiếp quyển sách này. Đây là lần đầu chúng tôi viết sách về toán tài chính, một ngành mà đối với bản thân chúng tôi cũng còn tương đối mới mẻ, bởi vậy quyển sách này chắc sẽ không tránh khỏi nhiều thiếu sót. Chúng tôi mong được bạn đọc góp ý, để có thể chỉnh sửa lại sách cho được tốt hơn. 


\section{Lời cảm ơn}

Một phần của quyển sách này được viết khi tác giả Nguyễn Tiến Dũng đến thăm và làm việc tại Trung tâm Liên khoa Bernoulli (Centre Interfacultaire Bernoulli), Đại học Bách khoa Liên bang Lausanne (EPFL), Thụy Sĩ, một thời gian trong năm 2010, theo lời mời của GS. Tudor Ratiu. Chúng tôi chân thành cảm ơn GS. Ratiu và Trung tâm Bernoulli đã tạo điều kiện làm việc rất tốt để viết quyển sách này. Một phần của quyển sách cũng được soạn thảo khi tác giả Đỗ Đức Thái đến thăm và làm việc tại Khoa Toán, Đại học Toulouse, Cộng hoà Pháp, một thời gian trong năm 2010, theo lời mời của GS. Thomas Pascal và tác giả NTD. Chúng tôi chân thành cảm ơn GS. Thomas Pascal và ĐH Toulouse đã tạo điều kiện cho chúng tôi làm việc và hợp tác chặt chẽ hơn trong việc soạn thảo cuốn sách.

Trong quá trình soạn thảo quyển sách này, chúng tôi có may mắn được thảo luận trực tiếp với nhiều chuyên gia về toán tài chính và bảo hiểm, và một số chuyên gia cao cấp trong các tập đoàn tài chính, qua đó hiểu rõ hơn các vấn đề thực sự của toán tài chính. Chúng tôi xin chân thành cảm ơn tất cả các chuyên gia đó, đặc biệt là ông Nguyễn Nam Kim, bà Đặng Thu Hương, GS Trần Hùng Thao, GS Adrien Blanchet, GS Jaksa Cvitanic, GS Paul Embrechts, GS Jean-David Fermanian, GS. Max Hongler, GS Bernt Oksendal, GS Juan-Pablo Ortega, GS Christian Y. Robert, GS Michel Simoni, GS Christine Thomas, GS Anne Vanhems, và GS Stéphane Villeneuve.

Trong quá trình soạn thảo quyển sách này, các tài liệu dùng để tham khảo, và các chương sách viết dở hay còn đang sửa chữa, được đem ra thảo luận tại xêmina toán tài chính thuộc Trung tâm Toán Tài chính và Công nghiệp Hà nội, xêmina Toán tài chính tổ chức tại Toulouse, và tại xemina về toán tài chính tại Đại học Kinh Tế - Luật, ĐHQG TPHCM. Các thành viên tham gia ba xêmina này đã đóng góp nhiều ý kiến bổ ích cho quyển sách này. Chúng tôi xin chân thành cảm ơn tất cả các thành viên của ba xêmina, đặc biệt là: PGS Lê Anh Vũ, TS Lưu Hoàng Đức, TS Hà Bình Minh, TS Nguyễn Thịnh, các NCS Lũ Hoàng Chinh, Phạm Việt Hùng, Nguyễn Văn Minh, Trương Hồng Minh, Lê Văn Tuấn, Nguyễn Thanh Thiên, Phan Thanh Tùng, Lê Hải Yến, v.v.

Đặc biệt, chúng tôi xin chân thành cảm ơn TS Nguyễn Hồng Hải, TS Trần Trọng Nguyên, và ThS Lê Văn Tuấn đã đọc kỹ bản thảo đầu của quyển sách này, và cho rất nhiều ý kiến đóng góp về việc sửa chữa quyển sách sao cho tốt hơn. Nhờ các ý kiến đó, mà chúng tôi đã nhận ra và sửa chữa rất nhiều chỗ cần thiết trong sách. 


\section{Mục lục}

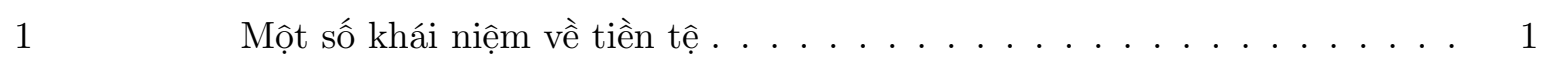

$1.1 \quad$ Các tính chất đặc trưng của tiền $\ldots \ldots \ldots \ldots \ldots \ldots \ldots$

$1.2 \quad$ Nguyên tắc tổng tiền bằng $0 \ldots \ldots \ldots \ldots \ldots \ldots$

$1.3 \quad$ Lượng cung tiền $\ldots \ldots \ldots \ldots \ldots \ldots \ldots \ldots$

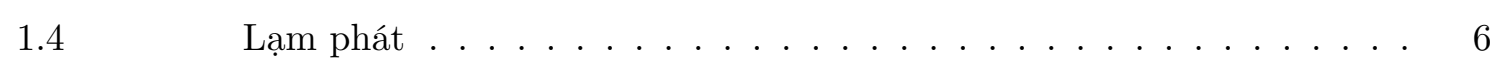

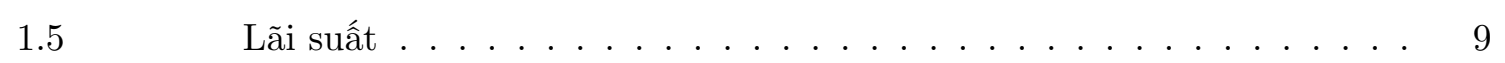

$1.6 \quad$ Hệ thống ngân hàng và chính sách tiền tệ $\ldots \ldots \ldots \ldots \ldots \ldots$

$1.7 \quad$ Ngoại tệ và tỷ giá ngoại tệ $\ldots \ldots \ldots \ldots \ldots \ldots \ldots$

$2 \quad$ Thị trường tài chính $\ldots \ldots \ldots \ldots \ldots$

$2.1 \quad$ Chức năng và cấu trúc của thị trường tài chính $\ldots \ldots \ldots \ldots \ldots$

$2.2 \quad$ Các sản phẩm nợ $\ldots \ldots \ldots \ldots \ldots \ldots \ldots \ldots \ldots \ldots$

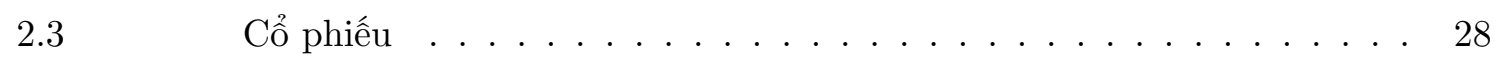

$2.4 \quad$ Các chứng khoán phái sinh $\ldots \ldots \ldots \ldots \ldots \ldots$

$2.4 .1 \quad$ Hợp đồng kỳ hạn và hợp đồng tương lai $\ldots \ldots \ldots \ldots$. . . . . . . . 33

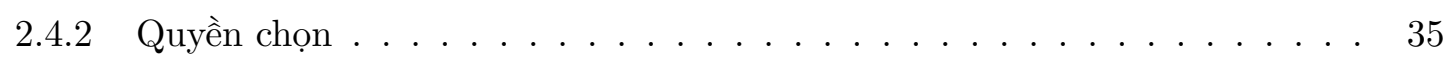

$2.4 .3 \quad$ Hợp đồng hoán đổi $\ldots \ldots \ldots \ldots \ldots \ldots \ldots \ldots \ldots \ldots$

$2.5 \quad$ Các trung gian tài chính $\ldots \ldots \ldots \ldots \ldots \ldots \ldots \ldots$

$2.6 \quad$ Quản lý hệ thống tài chính $\ldots \ldots \ldots \ldots \ldots \ldots \ldots \ldots$

$3 \quad$ Kinh doanh chênh lệch giáa $\ldots \ldots \ldots \ldots \ldots \ldots$

$3.1 \quad$ Khái niệm kinh doanh chênh lệch giă . . . . . . . . . . . . 47

$3.2 \quad$ Dịnh lý kinh doanh chênh lệch giáa $\ldots \ldots \ldots \ldots \ldots \ldots$

$3.3 \quad$ Định lý đối ngẫu của qui hoạch tuyến tính $\ldots \ldots \ldots \ldots \ldots$

$3.4 \quad$ No-arbitrage và xác suất trung hòa rủi $\mathrm{ro} \ldots \ldots \ldots \ldots . \ldots$

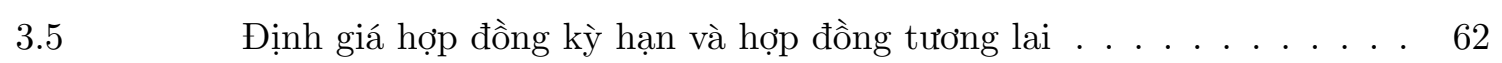


4 Lãi suất và trái phiếu $\ldots \ldots \ldots \ldots \ldots \ldots \ldots$. . . . . . . . . 67

4.1 Các cánh tính lãi suất . . . . . . . . . . . . . . . . 67

4.1 .1 Lãi đơn $\ldots \ldots \ldots \ldots \ldots$. . . . . . . . . . . . . . . . . . 67

4.1 .2 Lãi suất chiết khấu . . . . . . . . . . . . . . . . . . . . . . . . 70

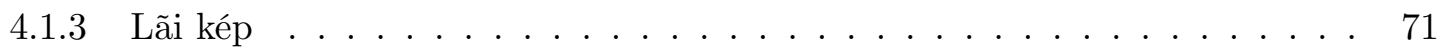

$4.1 .4 \quad$ Lãi suất hiệu dụng và lợi suất trái phiếu . . . . . . . . . . . . . . . . . . . 72

4.1 .5 Qui ước về tính số ngày $\ldots \ldots \ldots$. . . . . . . . . . . . . . . . . 74

4.1 .6 Lãi kép liên tục . . . . . . . . . . . . . . . . . . . . . . . . . . . 74

$4.2 \quad$ Giá trị và lợi suất của dòng tiền tệ $\ldots \ldots \ldots \ldots \ldots$. . . . . . 76

4.2 .1 Công thức dòng tiền chiết khấu $\ldots \ldots \ldots \ldots$. . . . . . . . 76

$4.2 .2 \quad$ Dòng niên kim . . . . . . . . . . . . . . . . . . . . . . 78

4.2 .3 Trái phiếu coupon và trái phiếu vô thời hạn $\ldots$. . . . . . . . . . . . . . . 81

4.2 .4 Lãi suất hoàn vốn ‥ . . . . . . . . . . . . . . . . . . . . . . . . . . 83

$4.3 \quad$ Duration của trái phiếu $\ldots \ldots \ldots \ldots \ldots \ldots \ldots$

$4.4 \quad$ Đường lợi suất $\ldots \ldots \ldots \ldots \ldots \ldots$. . . . . . . . . . . . . 89

$4.5 \quad$ Cấu trúc kỳ hạn tổng quát $\ldots \ldots \ldots \ldots \ldots \ldots \ldots$

$4.6 \quad$ Cấu trúc rủi ro của lãi suất $\ldots \ldots \ldots \ldots \ldots \ldots$

$5 \quad$ Phân tích giá cổ phiếu $\ldots \ldots \ldots \ldots \ldots \ldots \ldots \ldots$

$5.1 \quad$ Giá thị trường và giá trị thật $\ldots \ldots \ldots \ldots$. . . . . . . . 99

$5.2 \quad$ Ước lượng giá trị thật của cổ phiếu $\ldots \ldots$. . . . . . . . . . . . . . 104

5.2 .1 Dòng tiền lợi tức, và lợi suất của cổ phiếu . . . . . . . . . . . . . . . . . . 104

5.2 .2 Ước lượng giá trị của cổ phiếu tăng trưởng . . . . . . . . . . . . . . . . . . 108

$5.3 \quad$ Các lực tác động đến giá cổ phiếu . . . . . . . . . . . . . . . . 111

5.3 .1 Chênh lệch giữa giá thị trường và giá trị thật . . . . . . . . . . . . . . . . . 113

5.3 .2 Tâm lý thị trường ～. . . . . . . . . . . . . . . . . . . . . . 115

$5.3 .3 \quad$ Các ngoại lực $\ldots \ldots \ldots$. . . . . . . . . . . . . . . . . . 117

$5.3 .4 \quad$ Phạm vi ảnh hưởng của các lực $\ldots \ldots \ldots$. . . . . . . . . . . . . 118

$5.3 .5 \quad$ Các lực ngẫu nhiên . . . . . . . . . . . . . . . . . . . . . . . . . . . . . . . 119

$5.4 \quad$ Phân tích thống kê cho giá cổ phiếu $\ldots \ldots \ldots$. . . . . . . . . . 122

5.4 .1 Hệ số volatility . . . . . . . . . . . . . . . . . . . . . . . . . . . . 122

5.4 .2 Hệ số beta ． . . . . . . . . . . . . . . . . . . . . . . . . . . . . . . 124

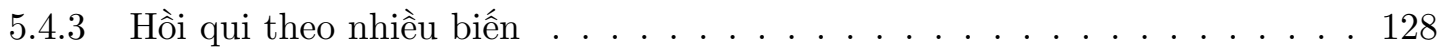


6 Quản lý danh mục dầu tu $\ldots \ldots \ldots$. . . . . . . . . . . . . 131

6.1 Một số nguyên tắc chung về đầu tư $\ldots$. . . . . . . . . . . . . . . . . . 133

6.1 .1 Quan hệ giữa rủi ro và lợi nhuận . . . . . . . . . . . . . . . . . . . 133

6.1 .2 Đa dạng hóa $\ldots \ldots \ldots \ldots$. . . . . . . . . . . . . . . . 133

6.1 .3 Đòn bẩy tài chính . . . . . . . . . . . . . . . . . . . . 134

6.1 .4 Đệm an toàn . . . . . . . . . . . . . . . . . . . . . . 135

6.1 .5 Độ dài thời gian . . . . . . . . . . . . . . . . . . . . . . . . 136

6.1 .6 Đầu tư có tổ chức … . . . . . . . . . . . . . . . . . . 136

$6.2 \quad$ Các loại hình đầu tu $\ldots \ldots$. . . . . . . . . . . . . . 137

6.2 .1 Vàng bạc châu báu . . . . . . . . . . . . . . . . . . . . . . 137

6.2 .2 Bất động sản . . . . . . . . . . . . . . . . . . . . . . . . . . 138

$6.2 .3 \quad$ Các sản phẩm nọ . . . . . . . . . . . . . . . . . . . . . . . 139

6.2 .4 Cổ phiếu . . . . . . . . . . . . . . . . . . . . . . . . . 140

6.2 .5 Chứng khoán phái sinh ． . . . . . . . . . . . . . . . . . . . . . . 141

6.3 Lợi nhuận và lợi nhuận kỳ vọng . . . . . . . . . . . . . . . . . . . . . . 142

6.3 .1 Các công thức tính lợi nhuận . . . . . . . . . . . . . . . . . . . . . . . 142

6.3 .2 Lợi nhuận kỳ vọng . . . . . . . . . . . . . . . . . . . . . . . . . . . . . . 144

$6.4 \quad$ Hàm thỏa dụng $\ldots \ldots \ldots$. . . . . . . . . . . . . . . 146

6.4 .1 Khái niệm hàm thỏa dụng . . . . . . . . . . . . . . . . . . . 146

6.4 .2 Hàm thỏa dụng Bernoulli . . . . . . . . . . . . . . . . . . . . . . . 147

$6.4 .3 \quad$ Tính lõm của hàm thỏa dụng . . . . . . . . . . . . . . . . . . . . . . . . . 149

$6.5 \quad$ Các thước đo rủi $\mathrm{ro} \ldots \ldots \ldots \ldots \ldots \ldots$

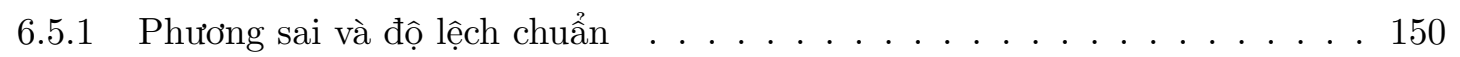

6.5 .2 Rủi ro thâm hụt (shortfall risk) . . . . . . . . . . . . . . . . . . 152

6.5 .3 Giá trị chịu rủi ro (value at risk) $\ldots$. . . . . . . . . . . . . . . 153

$6.6 \quad$ Lý thuyết Markowitz . . . . . . . . . . . . . . . . . 155

6.6 .1 Trường hợp có hai chứng khoán $\ldots \ldots$. . . . . . . . . . . . . . . 156

6.6 .2 Trường hợp có nhiều chứng khoán . . . . . . . . . . . . . . . . . . . . . . 160

6.6 .3 Biên hiệu quả . . . . . . . . . . . . . . . . . . . . . . . . 162

6.7 Mô hình định giá tài sản vốn $(\mathrm{CAPM})$. . . . . . . . . . . . . . . 164

6.7 .1 Đường thị trường vốn ～. . . . . . . . . . . . . . . . . . . . . 165

6.7 .2 Nhân tử beta và đường thị trường chứng khoán ～. . . . . . . . . . . . . . 167 


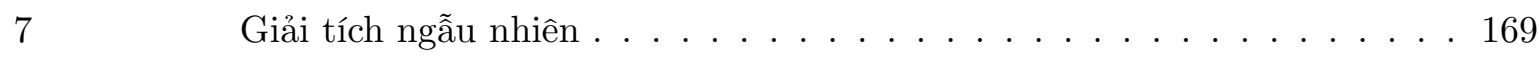

7.1 Một số mô hình biến động giá chứng khoán ‥ . . . . . . . . . . . . 169

7.1 .1 Quá trình ngẫu nhiên . . . . . . . . . . . . . . . . . . . . . . . . . 170

7.1 .2 Mô hình một bước thời gian . . . . . . . . . . . . . . . . . . . . . . 173

7.1 .3 Mô hình với thời gian rời $\mathrm{rạc} \ldots$. . . . . . . . . . . . . . . . 176

7.1 .4 Mô hình cây nhị phân . . . . . . . . . . . . . . . . . . . . . . . 177

$7.1 .5 \quad$ Mô hình với thời gian liên tục . . . . . . . . . . . . . . . . . . . . . . . . . 180

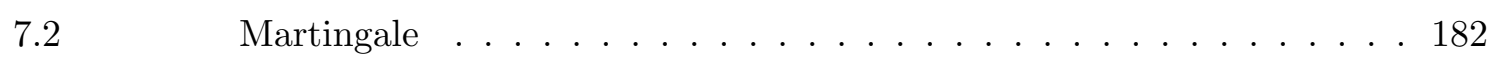

$7.2 .1 \quad$ Định nghĩa tính chất martingale . . . . . . . . . . . . . . . . . . . . . 182

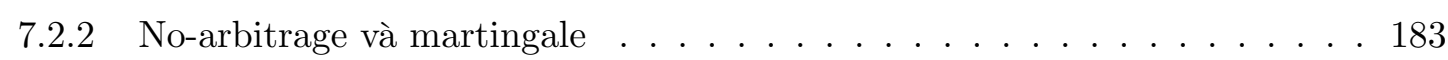

$7.3 \quad$ Chuyển động Brown $\ldots \ldots \ldots$. . . . . . . . . . . . 190

7.3 .1 Định nghĩa chuyển động Brown . . . . . . . . . . . . . . . . . . . . . . 190

7.3.2 Phân bố xác suất của chuyển động Brown . . . . . . . . . . . . . . . . . . . 192

7.3 .3 Du dộng ngẫu nhiên . . . . . . . . . . . . . . . . . . . . . . . . . . . . . 194

7.3.4 Một số tính chất của chuyển động Brown . . . . . . . . . . . . . . . . . 197

7.3.5 Biến phân và biến phân bình phương . . . . . . . . . . . . . . . . . . . . . 199

$7.3 .6 \quad$ Chuyển động Brown hình học . . . . . . . . . . . . . . . . . . . . . . . . . 201

7.4 Vi phân của các quá trình ngẫu nhiên $\ldots$. . . . . . . . . . . . . 202

7.4 .1 Vi phân của chuyển động Brown hình học . . . . . . . . . . . . . . . . . . 202

7.4 .2 Bồ đề Itô $\ldots \ldots \ldots \ldots$. . . . . . . . . . . . . . . . . 205

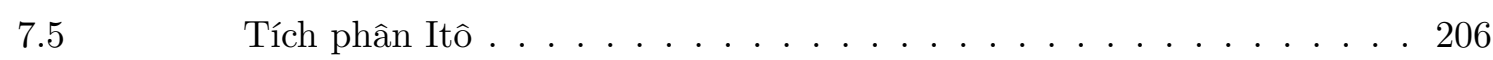

7.5 .1 Tích phân Riemann-Stieltjes . . . . . . . . . . . . . . . . . 207

7.5 .2 Định nghĩa tích phân Itô ． . . . . . . . . . . . . . . . . . . . . 209

7.5.3 Một số tính chất cơ bản của tích phân Itô . . . . . . . . . . . . . . . . . . 212

7.6 Thay đổi phân bố xác suất . . . . . . . . . . . . . . . . 215

7.6 .1 Đạo hàm Radon-Nikodym . . . . . . . . . . . . . . . . . . . . . . . 215

7.6 .2 Định lý Cameron-Martin … . . . . . . . . . . . . . . . . . 217

7.6 .3 Ứng dụng vào định giá quyền chọn có giới hạn . . . . . . . . . . . . . . . . 218

7.6 .4 Định lý Girsanov . . . . . . . . . . . . . . . . . . . . . . . . 220

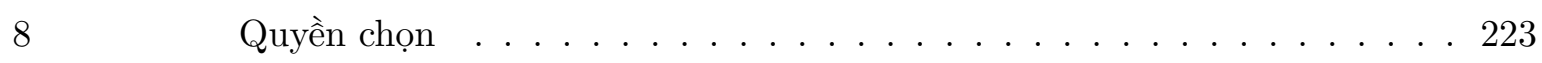

8.1 Một số tính chất cơ bản của giá quyền chọn . . . . . . . . . . . . . . . 224

8.1 .1 Giá quyền chọn tại thời điểm đáo hạn . . . . . . . . . . . . . . . . . . . 225 
8.1 .2 Giá quyền chọn tính theo phân bố xác suất trung hòa rủi ro . . . . . . 225

8.1 .3 Quan hệ giữa quyền chọn kiểu Âu và kiểu Mỹ . . . . . . . . . . . . . . . . . 226

8.1 .4 Quan hệ tương ứng giữa Call và Put . . . . . . . . . . . . . . . . . . . . . 227

8.1 .5 Một số chặn trên và chặn dưới của giá quyền chọn . . . . . . . . . . . . . . 230

8.2 Sự phụ thuộc của giá quyền chọn vào giá cổ phiếu và giá thực hiện 231

$8.2 .1 \quad$ Sự phụ thuộc vào giá thực hiện ․ . . . . . . . . . . . . . . . . . . . . 231

8.2 .2 Sự phụ thuộc vào giá của cổ phiếu . . . . . . . . . . . . . . . . . . . . . 233

$8.3 \quad$ Phương trình Black-Scholes . . . . . . . . . . . . . . . . . 234

$8.4 \quad$ Công thức định giá quyền chọn kiểu Âu $\ldots \ldots \ldots$. . . . . . . . . . 238

$8.5 \quad$ Các chũ cái Hy Lạp ～. . . . . . . . . . . . . . . . . . . . . . . 242

8.6 Mô hình Cox-Ross-Rubinstein . . . . . . . . . . . . . . . . . 243 


\section{Chương 1}

\section{Một số khái niệm về tiền tệ}

\subsection{Các tính chất đặc trưng của tiền}

Như chúng ta biết, trên thế giới hiện tại có nhiều loại tiền khác nhau, trong đó có tiền Đồng Việt Nam (ký hiệu: VND), tiền Dollar Mỹ (ký hiệu: USD, hay \$), tiền Euro của Châu Âu (ký hiệu: EUR), tiền Nhân Dân Tệ của Trung Quốc (ký hiệu: RMB), vân vân. Các đồng tiền khác nhau đó có chung 3 chức năng sau:

- Đơn vị đo lường giá trị. Muốn đánh giá và so sánh giá trị của các tài sản khác nhau với nhau, người ta có thể quy đổi chúng ra thành tiền. Chẳng hạn một cái nhà nào đó được tính giá trị là 10 tỷ VND, còn một cái ô tô được tính giá trị là 500 triệu VND, thì cái nhà sẽ được coi là có giá trị bằng 20 lần cái ô tô. Khi người ta nói một tỷ phú nào đó có 30 tỷ USD, thì có nghĩa là toàn bộ tài sản của người đó nếu qui đổi ra tiền thì được tổng cộng 30 tỷ USD.

- Trao đổi hàng hóa. Từ hàng hóa ở đây được dùng theo nghĩa rộng, để chỉ mọi thứ tài sản, sản phẩm và dịch vụ có thể được đem trao đổi. Chẳng hạn một người nông dân muốn đổi thóc lấy gạch để xây nhà, thì không cần thiết phải mang thóc đến đổi trực tiếp cho người làm gạch, mà có thể bán thóc đi lấy tiền rồi đem tiền đi mua gạch, như vậy tiện lợi hơn, vì người làm gạch có thể đang cần thứ khác chứ không cần thóc. Người làm gạch sẽ dùng tiền bán gạch để mua thứ mình cần.

- Tích trữ tài sản. Vì có thể dễ dàng đổi tiền lấy các hàng hóa cần thiết vào thời điểm cần thiết, nên giữ tiền là một hình thức tích trữ tài sản để dùng trong tương lai.

Nói theo ngôn ngữ tài chính, những thứ tài sản có được cả ba chức năng trên thì được gọi là tiền. Tất nhiên, 3 chức năng trên gắn liền với nhau. Để đảm nhiệm được tốt 3 chức 
năng đó, tiền cần có một số tính chất như:

- Dễ bảo quản, dễ vận chuyển, dễ chia nhỏ, để tiện lợi cho việc tích trữ tài sản và trao đổi hàng hóa.

- Tính thống nhất. Dù là tiền bằng chất liệu gì, phát hành vào thời điểm nào, nhưng nếu có cùng tổng mệnh giá như nhau theo cùng một đơn vị tiền nào đó (ví dụ như cùng là 1 triệu VND) thì có giá trị bằng nhau.

- Dược tin tưởng và chấp nhận. Tức là mọi người chấp nhận là tiền có giá trị, sẵn sàng đổi hàng hóa của mình lấy tiền. Để được tin tưởng và chấp nhận, tiền phải có được giá trị ổn định, lượng cung hạn chế, và khó làm giả.

Tuy nhiên, các tính chất này không phải lúc nào cũng được thỏa mãn. Chẳng hạn, hầu như nước nào cũng từng trải qua những giai đoạn siêu lạm phát, tức là giai đoạn mà đồng tiền của nước đó mất giá rất nhanh. Ví dụ, vào tháng 7 năm 1946, giá cả ở Hungary trung bình cứ 13,5 tiếng đồng hồ thì tăng gấp đôi, chỉ trong một tháng lạm phát lên đến con số khổng lồ là $4.19 \times 10^{16}$ phần trăm, và người ta phải in tờ tiền mệnh giá đến 100 000000000000000000 (tức là 10 mũ 20) pengđ(1). Ở Việt Nam, lạm phát của năm 1986 cũng lên đến xấp xỉ 800\%, tức là 9 Đồng vào cuối năm 1986 chỉ có sức mua bằng 1 Đồng vào đầu năm.

Các loại tiền như VND, USD, EUR, v.v. là tiền pháp định, tức là các chính phủ đứng ra đảm bảo giá trị của các đồng tiền đó, và sự chấp nhận chúng được qui định bởi luật pháp của các nước. Tiền pháp định thường có ở dạng tiền giấy, tiền xu, và đặc biệt phổ biến ngày nay là dạng tiền điện tử (tức là tiền ở dạng con số trong nhà băng, và thanh toán mua bán bằng cách chuyển khoản ngân hàng thông qua mạng máy tính), bởi vì tiền điện tử đáp ứng được tốt hơn các tính chất phía trên (dễ bảo quản, dễ vận chuyển, dễ chia nhỏ, khó làm giả, v.v.) so với các loại tiền khác.

Trong lịch sử thế giới, từ thời cổ đại, một số loại tài sản chia nhỏ như thóc gạo, rồi đến các đồ quí hiếm như vàng, bạc, kim cương, v.v., đặc biệt là vàng, đã được dùng làm tiền để tích trữ và trao đổi của cải. (Xem chẳng hạn [6] hay là tra trang web của Glyn Davies về lịch sử các loại tiền tệ từ thời cổ đại). Cho đến nay, vàng vẫn được coi là thứ công cụ đặc biệt quan trọng cho việc dự trũ tài sản. Vào thời điểm 06/2009, Quĩ Tiền Tệ Quốc Tế (International Money Fund - viết tắt là IMF) có dự trữ vàng là 3217 tấn (khoảng 103 triệu lượng vàng). Vàng vẫn đang được sử dụng như là tiền để mua bán các thứ khác ở một số nơi trên thế giới. Tuy nhiên, chức năng làm công cụ giao dịch của vàng đã giảm

${ }^{(1)}$ Xem: http://en.wikipedia.org/wiki/Hyperinflation 
đi nhiều, và hầu hết các giao dịch thương mại trên thế giới là dùng tiền pháp định, trong đó có hai đồng tiền quan trọng nhất vào năm 2010 là USD (khoảng 60\% các giao dịch ngoại thương được thanh toán bằng USD) và EUR (chiếm khoảng $30 \%$ các thanh toán ngoại thương).

Theo Hiệp ước Bretton Wood ${ }^{(2)}$ vào năm 1944, nước Mỹ đảm bảo giá trị của USD bằng cách cố định tỷ giá giữa USD là 35USD = 1 lượng vàng. Nhưng đến năm 1971 Mỹ đã phải đơn phương tuyên bố từ bỏ tỷ giá cố định đó, sau một thời gian dài dự trữ vàng của Mỹ đi xuống, do các nước khác, đặc biệt là Đức và Nhật, siêu xuất khẩu sang Mỹ đã đổi nhiều tiền USD mà họ có được sang thành vàng. Ngày nay, vẫn có những người muốn cố định tỷ giá giữa tiền pháp định và vàng, như một hình thức chống lạm phát và đảm bảo giá trị của tiền. Tuy nhiên, trong nền kinh tế hiện đại, vàng cũng chỉ là một thứ hàng hóa trong số nhiều hàng hóa thông dụng. Vàng chỉ chiếm một phần nhỏ (dưới 1\%) tổng giá trị các tài sản hữu hình trên thế giới, ngoài vàng ra còn có nhiều thứ quan trọng khác như gạo, dầu hỏa, sắt thép, v.v., và không có vàng thì người ta vẫn sống được. Nếu chỉ "độc tôn" vàng, mà không tính đến các tài sản quan trọng khác, thì sẽ tạo một sự thiên lệch làm kìm hãm sự phát triển của nền kinh tế.

\subsection{Nguyên tắc tổng tiền bằng 0}

Mọi khoản tiền dương mà một tổ chức hay cá nhân nào đó đang có đều ứng với các khoản nợ mà những tổ chức và cá nhân khác nợ người này, và ngược lại mọi khoản tiền âm của ai đó đều ứng với các khoản tiền dương mà những người khác cho người đó vay. Ví dụ, nếu một người $\mathrm{X}$ có dương $3000 \$$ gửi ở một nhà băng $\mathrm{A}$, thì tức là $\mathrm{X}$ cho $\mathrm{A}$ vay $3000 \$$, và $\mathrm{A}$ có một khoản $-3000 \$$ trong bảng cân đối tài chính vì là đang vay $\mathrm{X}$ khoản đó. Ngược lại, khi $\mathrm{A}$ đem khoản tiền vay của $\mathrm{X}$ cho những đối tác khác vay, thì các khoản cho vay đó hiện lên trong bảng cân đối kế toán của $\mathrm{A}$ như là các con số dương, còn những người vay $\mathrm{A}$ thì lại có các khoản âm tương ứng trong tài sản của mình vì là đang nợ $\mathrm{A}$. Kể cả tiền dư của ngân hàng $\mathrm{A}$ mà không đem cho ai vay cả, thì cũng có thể hiểu là đang cho ngân hàng trung ương vay, vì để dự trữ ở ngân hàng trung ương. Tính tổng cộng tất cả các khoản tiền dương (cho vay) và tiền âm (vay) của mọi bên vào với nhau, ta được con số 0 . Điều này có thể được gọi là nguyên tắc tổng tiền bằng $\mathbf{0}$.

Đối với tiền giấy cũng vậy: khi một người giữ tiền giấy, thì có thể hiểu là người đó đang cho chính phủ vay. Các khoản tiền giấy mà chính phủ phát hành có thể hiểu là các

${ }^{(2)}$ Xem http://en.wikipedia.org/wiki/Bretton_Woods_system 
khoản nợ của chính phủ, được đảm bảo bởi các tài sản của chính phủ, tức là các tài sản chung của đất nước. Khi một người Việt Nam giữ USD tiền giấy, thì tức là người đó đang cho chính phủ Mỹ (chứ không phải chính phủ Việt Nam) vay, và khoản cho vay đó không có lãi suất. Có một lượng USD tiền giấy lớn lưu hành trên thế giới (ở ngoài nước Mỹ), và có thể coi đây là khoản tiền mà chính phủ Mỹ vay mà không phải trả lãi.

Tiền ở trong nguyên tắc tổng tiền bằng 0 là tiền pháp định, tức là không tính đến các tài sản vật chất như vàng, kim cương có thể được dùng với các chứng năng như là tiền. Tất nhiên, nếu một người có $1 \mathrm{~kg}$ vàng để dưới gầm giường, thì không có nghĩa là có ai đang vay người đó $1 \mathrm{~kg}$ vàng. Đây là điểm khác biệt giữa vàng và tiền pháp định.

Nguyên tắc tổng tiền bằng 0 cho ta thấy một điều rất rõ là: tổng cộng giá trị của tất cả các tài sản trên thế giới chính là do giá trị của các tài sản (ngoài tiền) tạo thành, chứ không phải do giá trị của tiền tạo thành. Tiền chỉ có tác dụng làm thước đo của tài sản và làm công cụ giao dịch tài sản, chứ tổng cộng tất cả các khoản tiền cả âm lẫn dương lại với nhau là bằng 0 , thêm tiền pháp định lưu hành trên thế giới không có nghĩa là thế giới có thêm tài sản.

\subsection{Lượng cung tiền}

Tổng tiền pháp định kể cả các khoản âm và khoản dương là bằng 0 , nhưng nếu ta chỉ tính các khoản dương thôi, và cộng chúng vào với nhau, thì được một con số gọi là tổng cung tiền (monetary aggregate) để đo lượng cung tiền (money supply). Nói một cách chi tiết hơn, thì có một số loại tổng cung tiền (của một đồng tiền nào đó, ví dụ như USD) khác nhau, được biết đến dưới những tên gọi như M0, M1, M2, M3, v.v.; sự khác nhau của chúng là nằm ở công thức tính, tức là những khoản tiền nào được cho vào công thức(3),

- M0 là "tiền mặt" (currency), theo nghĩa tổng của toàn bộ số tiền giấy và tiền xu đang lưu hành (không kể khoản tiền giấy và tiền xu mà ngân hàng trung ương đã thu hồi lại, hoặc đã in ra nhưng để dự trữ chưa lưu hành). Tiền giấy và tiền xu được coi là loại tiền lưu thông nhanh nhất, tức là có số lần quay vòng (trao tay) trung bình cao nhất trong một năm.

- M1 gồm M0 cộng với các khoản tiền ký gửi ở ngân hàng ở dạng tài khoản thanh toán (checking account), tức là có thể rút ra bất cứ lúc nào bằng cách viết séc.

${ }^{(3)}$ Xem chi tiết tại: http://en.wikipedia.org/wiki/Money_supply 
- M2 gồm có M1 cộng với các khoản tiền ký gửi ở ngân hàng trong tài khoản tiết kiệm (savings account, tức là các tài khoản gửi có trả lãi suất, không qui định kỳ hạn, nhưng không viết séc trên đó được) và các khoản tiền gửi có kỳ hạn với kỳ hạn không dài (dưới 4 năm) và số lượng không lớn (ví dụ dưới 100 nghìn USD nếu là ở Mỹ). M2 được coi là thước đo cung tiền tốt nhất trong các thước đo. Khi các nhà kinh tế nói đến tổng cung tiền mà không nói cụ thể là loại nào, thì tức là họ nói đến M2.

- M3 gồm có M2 cộng thêm những khoản khác, như là những khoản tiền gửi có kỳ hạn ở mức lớn, các khoản tiền để ở nhà băng nước ngoài (nước ngoài ở đây có nghĩa là nước mà không phát hành đồng tiền đó; đối với USD thì nước ngoài có nghĩa là không phải nước Mỹ), v.v. Từ năm 2006, Mỹ đã thôi không công bố các số liệu M3 chính thức nữa vì thấy nó không cho thêm thông tin gì quan trọng hơn M2, tuy vẫn có các con số ước lượng.

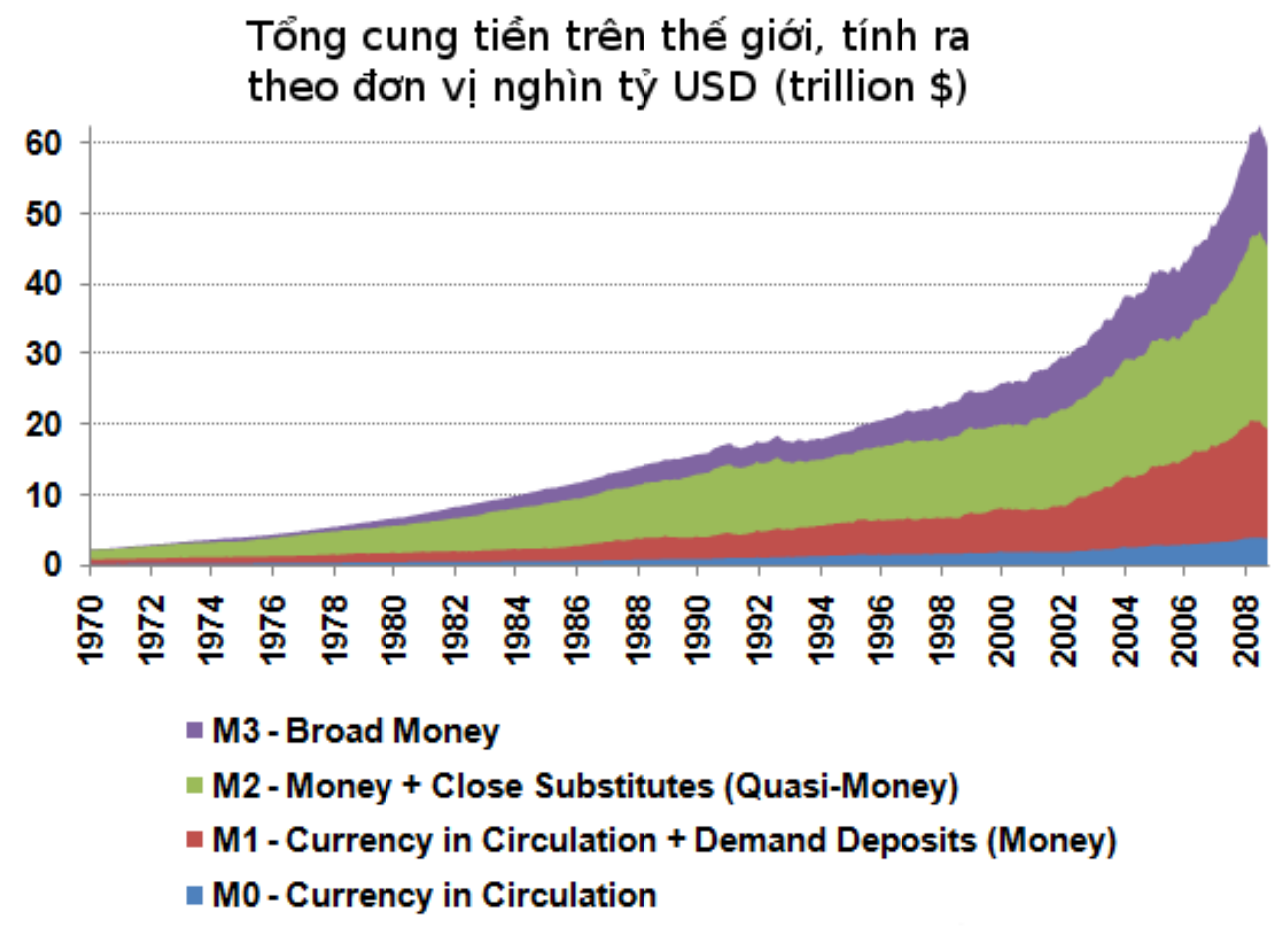

Hình 1.1: Lượng cung tiền trên thế giới, 1970-2008

Theo Hình 1.1, tổng cung tiền M2 trên thế giới vào năm 2008 (tất cả các loại tiền khác nhau) tương đương với khoảng 46 nghìn tỷ USD, và tốc độ tăng trưởng cung tiền 
trung bình trên thế giới hàng năm trong giai đoạn 1970-2008 là vào khoảng 14\%/năm.

\subsection{Lạm phát}

Lạm phát (inflation) là khái niệm chỉ sự giảm giá trị (sức mua) của tiền theo thời gian. Ví dụ, tỷ lệ lạm phát ở Việt Nam trong năm 2010 là vào khoảng 10,5\%. Điều đó có nghĩa là, giá cả của các hàng hóa và dịch vụ thông dụng ở Việt Nam tăng lên trung bình $10,5 \%$ trong năm 2010 , và 110,5 nghìn $(=(1+10.5 \%) \times 100000)$ VND vào thời điểm cuối năm chỉ có sức mua bằng 100 nghìn VND vào thời điểm đầu năm.

Một trong các cách để tính mức lạm phát là: người ta dùng một rổ tài sản, đại diện cho các hàng hóa và dịch vụ phổ biến và quan trọng nhất, rồi tính giá của rổ đó tại các thời điểm khác nhau. Con số nhận được gọi là chỉ số CPI (consumer price index). Tỷ lệ thay đổi của chỉ số CPI theo thời gian chính là tỷ lệ lạm phát. Mỗi nước có một cách tính chỉ số CPI khác nhau, dựa trên một rổ hàng hóa và dịch vụ khác nhau, phụ thuộc vào quan niệm về những gì cần cho vào rổ với tỷ trọng bao nhiêu. Theo thông báo của Ngân hàng nhà nước Việt Nam, lượng cung tiền M2 của Việt Nam tăng 25.3\% trong năm 2010. Vào thời điểm 01/2010, rổ tính CPI của Việt Nam được kết cấu như trong bảng phía sau.

\begin{tabular}{|l|l|}
\hline Nhóm hàng và dịch vụ & Tỷ trọng (\%) \\
\hline I. Hàng ăn và dịch vụ ăn uống & 39,93 \\
- I1. Lương thực & 8,18 \\
- I2. Thực phẩm & 24,35 \\
- I3. Ăn uống ngoài gia đình & 7,40 \\
II. Đồ uống và thuốc lá & 4,03 \\
III. May mặc, mũ nón, giầy dép & 7,28 \\
IV. Nhà ở, điện nước, chất đốt, vật liệu xây dựng & 10,01 \\
V. Thiết bị và đồ dùng gia đình & 8,65 \\
VI. Thuốc và dịch vụ y tế & 5,61 \\
VII. Giao thông & 8,87 \\
VIII. Bưu chính viễn thông & 2,73 \\
IX. Giáo dục & 5,72 \\
X. Văn hóa, giải trí, du lịch & 3,83 \\
XI. Hàng hóa dịch vụ khác & 3,34 \\
\hline Tổng cộng & 100 \\
\hline
\end{tabular}


Nếu như giá cả trung bình không tăng lên, mà lại giảm đi, tức là tỷ lệ lạm phát là số âm, thì người ta gọi hiện tượng đó là giảm phát . Hình 1.2 cho thấy nước Nhật Bản có tỷ lệ lạm phát khá cao trong những năm 1980, nhưng có giảm phát trong phần lớn thập kỷ đầu tiên của thế kỷ 21.

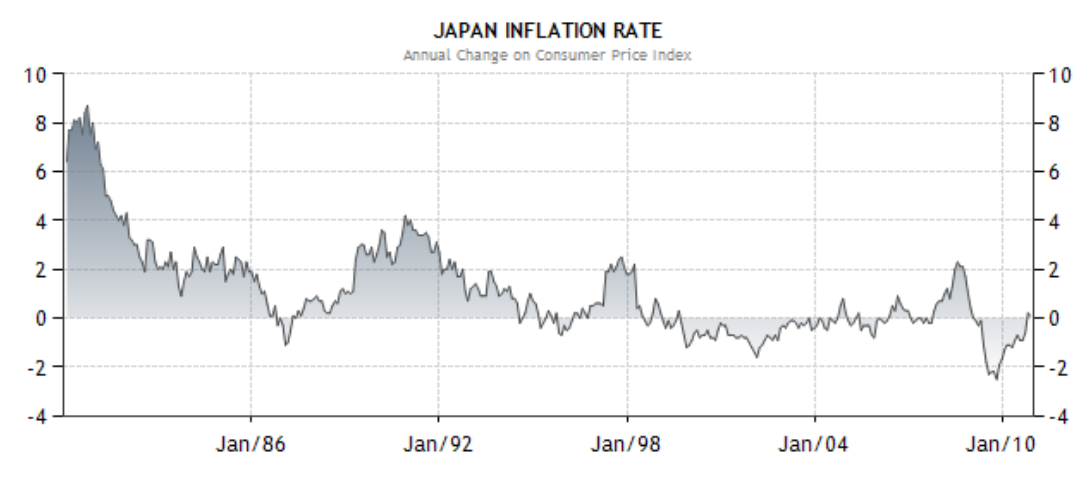

Hình 1.2: Tỷ lệ lạm phát ở Nhật Bản, 1980-2010

Giá cả thay đổi trên thị trường theo qui tắc cung-cầu: nếu cung lớn hơn cầu ở một mức giá nào đó thì giá có xu hướng giảm xuống, và ngược lại nếu cung nhỏ hơn cầu thì giá tăng lên cho đến khi cung cầu cân bằng. Bởi vậy, các yếu tố ảnh hưởng đến lạm phát cũng có thể chia làm hai nhóm chính, là nhóm gây thay đổi cầu, và nhóm gây thay đổi cung. Các nhà kinh tế gọi nhóm thứ nhất là nhóm "cầu kéo" (demand pull), và nhóm thứ hai gọi là nhóm "giá đẩy" (cost push). Việc chia này tất nhiên chỉ có tính tương đối, vì có những yếu tố ảnh hưởng đến cả cung lẫn cầu.

Một số yếu tố ảnh hưởng đến cung là:

- Sự khan hiếm hàng hóa, tạo nên bởi nhiều lý do khác nhau như thiên tai, thiếu hụt nguồn nhân lực, quản lý kinh tế kém, khai thác quá mức, v.v. Ví dụ, hạn hán xảy ra ở châu Âu năm 2010 làm cho giá lương thực toàn thế giới tăng lên cao. Cá hồi đỏ ngày càng khan hiếm vì bị đánh bắt quá mức, nên giá của chúng ngày càng tăng lên. Sự khan hiếm cũng có thể là giả tạo, do giới đầu cơ tạo ra để đẩy giá lên.

- Thay đổi công nghệ. Có những mặt hàng và dịch vụ quan trọng, ví dụ như máy tính và dịch vụ viễn thông, có giá thành giảm đi nhanh do công nghệ phát triển nhanh.

- Xuất nhập khẩu. Xuất nhập khẩu làm thay đổi lượng cung hàng hóa ở thị trường trong nước. Ví dụ nếu xuất khẩu gạo quá mức, thì tạo khan hiếm gạo ở trong nước. 
- Giá cả trên thế giới. Giá thành trên thế giới thay đổi cũng kéo theo giá thành trong nước thay đổi. Ví dụ như giá dầu hỏa trên thế giới ảnh hưởng trực tiếp đến giá xăng dầu tại Việt Nam.

- Thâm hụt ngân sách và nợ nước ngoài. Nếu như nhà nước có thâm hụt ngân sách lớn và nợ nước ngoài nhiều, thì điều này làm giảm giá trị của đồng nội tệ so với các đồng ngoại tệ, dẫn đến giá thành các hàng nhập khẩu tăng lên, gây ra lạm phát

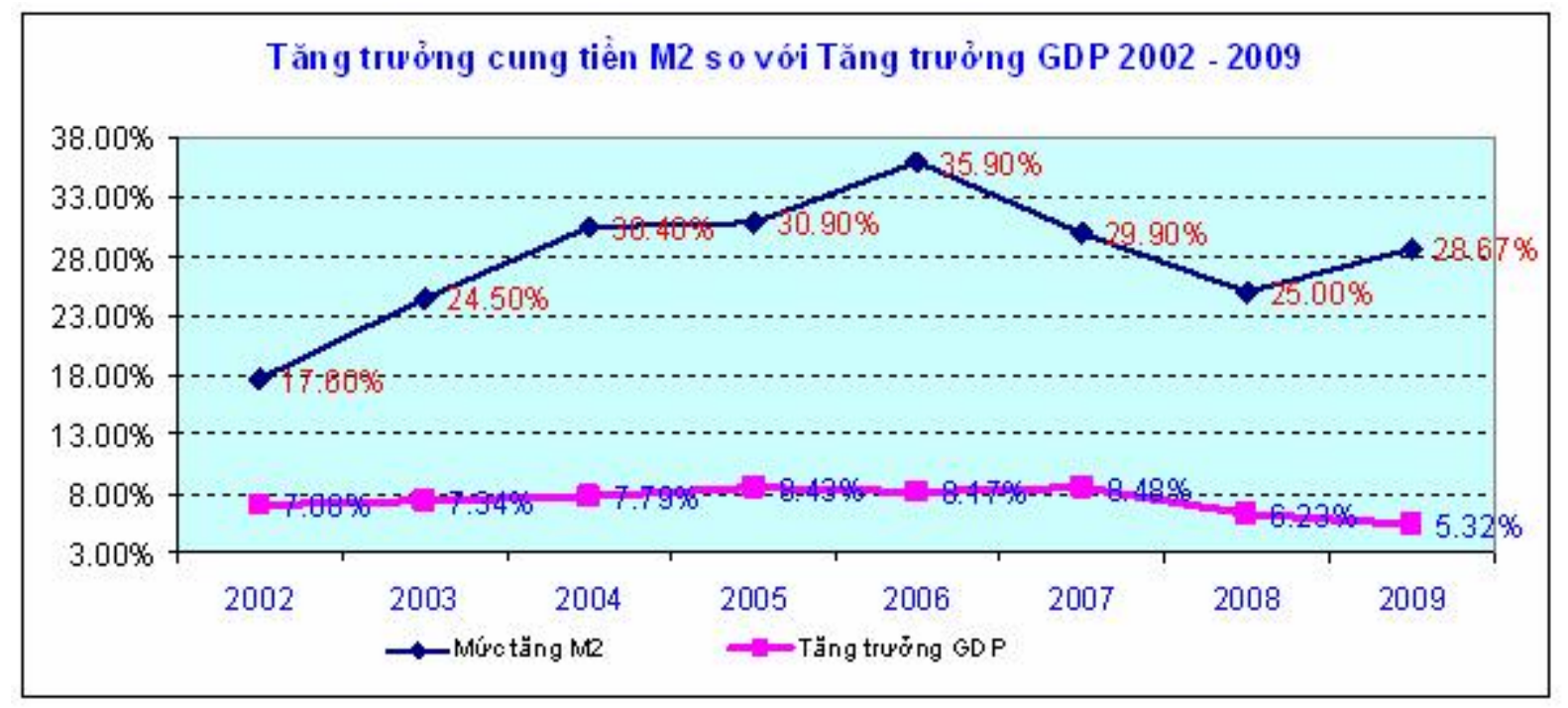

Hình 1.3: Tỷ lệ tăng lượng cung tiền M2 và GDP của Việt Nam

Một số yếu tố ảnh hưởng đến cầu là:

- Sự tăng dân số. Ví dụ dân số tăng lên kéo theo nhu cầu về đất đai tăng lên, nhưng diện tích đất không tăng lên, và đó là một trong những nguyên nhân khiến giá đất tăng lên.

- Sự tăng thu nhập. Khi thu nhập trung bình của người dân tăng lên, thì nhu cầu của họ cũng tăng lên. Bởi vậy những nước đang phát triển nhanh về kinh tế thì có xu hướng lạm phát.

- Tham nhũng. Những khoản tiền do sự tham nhũng đem lại (ví dụ như khoét ruột các công ty hay công trình của nhà nước) cũng phải được tiêu vào đâu đó, và khi những khoản này rất lớn, thì nó gây ra lạm phát. 
- Chi tiêu của chính phủ. Các chính sách kích cầu và chi tiêu của chính phủ có thể ảnh hưởng trực tiếp đến lượng cầu. Nếu chính phủ chi tiêu quá nhiều thì tạo áp lực đẩy giá tăng lên.

- Lượng cung tiền. Giả sử số lượng hàng hóa và dịch vụ không thay đổi, mà chỉ có lượng cung tiền tăng lên gấp đôi, thì tức là có một lượng tiền nhiều gấp đôi trước kia "chạy theo" một lượng hàng hóa và dịch vụ như cũ, và điều này sẽ đẩy giá của hàng hóa dịch vụ tăng dần lên đến gấp đôi (nếu các yếu tố khác không thay đổi).

Hình 1.3 cho thấy lượng cung tiền ở Việt Nam tăng rất nhanh trong thập kỷ đầu tiên của thế kỷ 21, với tốc độ cao hơn nhiều lần tốc độ tăng trưởng của nền kinh tế. Đây là một trong những nguyên nhân chính giải thích vì sao tỷ lệ lạm phát ở Việt Nam cao (trung bình đến $9 \%$ một năm) trong giai đoạn đó.

\subsection{Lãi suất}

Khi một tổ chức hay cá nhân cần tiền thì có thể đi vay nợ bằng nhiều kiểu khác nhau, ví dụ như vay trực tiếp nhà băng, hoặc là phát hành trái phiếu. Một trái phiếu là một hợp đồng qui định bên phát hành trái phiếu phải trả cho bên giữ trái phiếu những khoản tiền nào đó vào các thời điểm nào đó. Bên giữ trái phiếu có thể hiểu là bên cho vay tiền (khoản tiền cho vay là khoản tiền trả cho bên phát hành trái phiếu để đổi lấy các trái phiếu đó), còn bên phát hành trái phiếu là bên đi vay tiền (các khoản tiền nhận được từ việc phát hành trái phiếu là tiền vay được, còn các khoản tiền phải trả theo hợp đồng của trái phiếu là các khoản trả lãi và gốc cho chỗ tiền vay được đó). Vay qua hình thức phát hành trái phiếu khác với vay từ ngân hàng ở chỗ người cho vay thường không phải là ngân hàng, mà là những tổ chức hay cá nhân có tiền dự trữ muốn cho vay, ví dụ như các nhà đầu tư nhỏ lẻ hay là các quỹ hưu trí. Việc vay nợ bằng trái phiếu này "cắt bớt" được trung gian ngân hàng, và vì thế có thể có lợi hơn cho cả bên cho vay lẫn bên đi vay, không bị ngân hàng "ăn chặn” ở giữa.

Trong tài chính, tất cả các khoản nợ theo các kiểu khác nhau, kể cả trái phiếu lẫn vay trực tiếp ngân hàng, được gọi chung là các sản phẩm nợ. Giá của các sản phẩm nợ thể hiện qua lãi suất (interest rate), tức là tỷ lệ giữa số tiền lãi phải trả hàng năm cho số tiền nợ ban đầu. (Nếu như khoản nợ có kỳ hạn khác một năm, thì cũng qui đổi ra thành tỷ lệ tiền lãi nếu tính theo năm là bao nhiêu). Ví dụ, một người vay nhà băng 200 triệu VND và sau một năm phải trả thành 232 triệu VND, trong đó 200 triệu là tiền gốc còn 
32 triệu là tiền lãi. Tỷ lệ giữa tiền lãi và tiền gốc là 32 chia cho 2 , tức là $16 \%$, và con số này được gọi là lãi suất.

Có nhiều qui ước tính lãi suất khác nhau (cho ra kết quả không tương đương), mà chúng ta sẽ bàn cụ thể hơn trong Chương 4. Khi các nhà kinh tế nói đến lãi suất mà không nói cụ thể là tính theo qui ước nào, thì được hiểu là tính theo qui ước lãi kép theo năm, hay còn được gọi là lợi suất trái phiếu, hay lãi suất hoàn vốn.

Vì lãi suất là giá của các sản phẩm nợ, nên sự thay đổi của nó cũng tuân theo qui tắc cung cầu trên thị trường đối với các sản phẩm nợ. Có thể kể đến một số yếu tố có ảnh hưởng lớn đến lãi suất như sau:

- Lượng cung tiền. Khi lượng cung tiền được tăng lên, thì tức là lượng cung các sản phẩm nợ tăng lên, dẫn đến xu hướng giảm lãi suất. Hiệu ứng này được nhà kinh tế Milton Friedman gọi là hiệu ứng lưu thông tiền (liquidity effect). Tuy nhiên, sự tăng lượng cung tiền cũng có thể dẫn đến xu hướng lạm phát trong tương lai, và điều này thì lại dẫn đến triển vọng tăng lãi suất trong tương lai. Khi tỷ lệ tiết kiệm ở trong nước cao, thì tức là cũng có nhiều tiền để cho vay hơn, và do đó lãi suất sẽ thấp hơn, so với nếu tỷ lệ tiết kiệm thấp.

- Độ tăng trưởng kinh tế. Khi một nền kinh tế đang ở trong giai đoạn phát triển nhanh, thì thường có lãi suất cao, còn ngược lại khi nền kinh tế bị chựng lại hoặc đi vào suy thoái, thì lãi suất sẽ có xu hướng giảm thấp xuống. Qui luật kinh tế này có thể được giải thích như sau: khi nền kinh tế phát triển nhanh, tức là có nhiều cơ hội phát triển, và các doanh nghiệp sẽ muốn có thêm vốn để phát triển và nắm bắt các cơ hội đó, dẫn đến cầu về các sản phẩm nợ tăng lên. Ngược lại, khi nền kinh tế ở trong giai đoạn trì trệ, thì các doanh nghiệp không nhìn thấy nhiều cơ hội phát triển, do đó ít có nhu cầu về vốn để phát triển, khiến cho cầu về nợ trên thị trường giảm xuống, và điều này kéo lãi xuất đi xuống.

- Lãi suất tham chiếu của ngân hàng trung ương. Ngân hàng trung ương thường đặt ra một mức lãi suất gọi là lãi suất tham chiếu (reference rate), để dựa vào đó các ngân hàng thương mại điều chỉnh các mức lãi suất nhận vay và cho vay của mình. Khi ngân hàng trung ương tăng/giảm lãi suất tham chiếu, thì lãi suất cho vay và lãi suất huy động vốn của các ngân hàng thương mại cũng sẽ tăng/giảm theo. (Xem chi tiết hơn ở Mục 1.6).

- Độ rủi ro vỡ nợ (default risk). Tổ chức hay cá nhân nào có mức tín nhiệm (credit rating hay credit score) càng cao, tức là được coi là có độ rủi ro vỡ nợ càng thấp, 
thì càng có thể vay với lãi suất thấp. Độ chênh lệch giữa lãi suất của một khoản nợ có rủi ro và một khoản nợ không có rủi ro được gọi là chi phí rủi ro hay phí mạo hiểm (risk premium). Độ rủi ro vỡ nợ càng cao thì chi phí rủi ro càng cao. Chúng ta sẽ tìm hiểu kỹ hơn về vấn đề này trong Mục 4.6

- Thời hạn của khoản nợ. Thông thường, các khoản nợ dài hạn hơn, thì được coi là có rủi ro cao hơn là các khoản nợ ngắn hạn hơn, dẫn đến lãi suất của nợ dài hạn cao hơn là lãi suất của nợ ngắn hạn. Tuy nhiên, điều này không phải lúc nào cũng đúng, mà có những lúc nợ ngắn hạn lại có lãi suất cao hơn nợ dài hạn. Chúng ta sẽ thảo luận kỹ hơn về vấn đề này trong Mục 4.4 .

- Lạm phát. Khi mà mức lạm phát kỳ vọng cao, thì ít ai muốn cho vay nếu lãi suất thấp dưới tỷ lệ lạm phát kỳ vọng, vì sợ bị thiệt hại tài sản do tiền lãi không bù lại được sự mất giá của tiền do lạm phát. Bởi vậy, khi lạm phát cao thì lãi suất cũng cao lên theo, và ngược lại khi lạm phát giảm thì cũng kéo lãi suất xuống theo.

Yếu tố lạm phát là yếu tố tác động rất mạnh đến lãi suất, và nó liên quan đến khái niệm lãi suất thực, được nhà kinh tế học Irving Fisher (1867-1947) đ(4) đưa ra để đo độ tăng trưởng thực sự của sức mua của một khoản tiền cho vay. Lãi suất thực không những phụ thuộc vào lãi suất (hay còn gọi là lãi suất danh nghĩa) mà khoản tiền gửi đó nhận được, mà còn phụ thuộc vào tỷ lệ lạm phát. Nếu giả sử lãi suất danh nghĩa là $R$, và tỷ lệ lạm phát là $\Pi$, thì lãi suất thực $\mathcal{R}$ được cho bởi công thức sau, gọi là công thức Fisher:

$$
\mathcal{R}=\frac{1+R}{1+\Pi}-1=\frac{R-\Pi}{1+\Pi} .
$$

Thật vậy, nếu ta gửi 1 đồng với lãi suất $R$ thì sau một năm nó thành $1+R$ đồng. Nhưng do tỷ lệ lạm phát là $\Pi$ trong một năm đó, nên số tiền $1+R$ nhận được sau một năm chỉ có sức mua bằng $(1+R) /(1+\Pi)$ vào thời điểm hiện tại. Như vậy, sau một năm, sức mua của khoản tiền gửi không phải là tăng lên từ 1 thành $(1+R)$, mà chỉ là từ 1 thành $(1+R) /(1+\Pi)$. Độ tăng trưởng sức mua sau 1 năm chính là $\mathcal{R}=\frac{1+R}{1+\Pi}-1=\frac{R-\Pi}{1+\Pi}$.

Trong công thức phía trên, thì lãi suất $R$ là số có thể xác định được trong các hợp đồng gửi tiền hay vay nợ, thế nhưng tỷ lệ lạm phát trong một năm sẽ tới là điều không ai biết trước được chính xác vào đầu năm, mà người ta chỉ có thể dự đoán nó sẽ bằng bao nhiêu. Bởi vậy, ta có thể coi П là tỷ lệ lạm phát dự đoán cho thời gian tới, và lãi suất thực ở đây cũng sẽ là lãi suất thực dự đoán.

\footnotetext{
${ }^{(4)}$ Xem: http://en.wikipedia.org/wiki/Irving_Fisher
} 
Trong trường hợp mà tỷ lệ lạm phát thấp (I nhỏ, ví dụ không quá 5\%), thì người ta coi $1+\Pi$ xấp xỉ bằng 1 , và thay công thức Fisher phía trên bằng công thức gần đúng sau đây, không được chính xác bằng nhưng dễ nhớ hơn:

$$
\mathcal{R} \approx R-\Pi
$$

tức là lãi suất thực xấp xỉ bằng lãi suất danh nghĩa trừ đi tỷ lệ lạm phát.

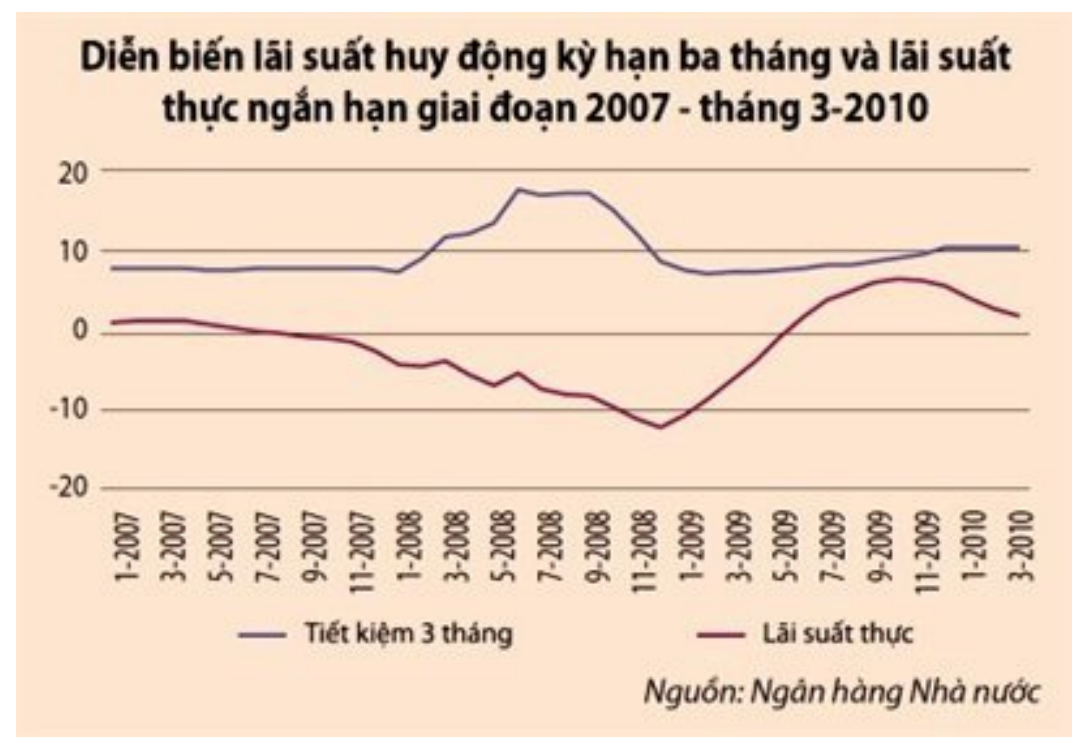

Hình 1.4: Lãi suất thực ở Việt Nam trong những năm 2007-2009

Hình 1.4 biểu diễn đồ thị các đường lãi suất huy động vốn kỳ hạn 3 tháng là lãi suất thực ngắn hạn trong giai đoạn 01/2007 đến 03/2010. Trong năm 2008, lãi suất có lúc lên hơn $17 \%$, nhưng lạm phát có lúc còn cao hơn $20 \%$, dẫn đến lãi suất thực bị âm. Hình 1.5 là đồ thị đường tỷ lệ lạm phát và lãi suất trái phiếu chính phủ ngắn hạn (T-Bills) ở Mỹ trong hai thập kỷ 1970 và 1980. Trong phần lớn thập kỷ 1970, nước Mỹ có lãi suất của trái phiếu chính phủ khá cao, nhưng lãi suất thực vẫn âm, do tỷ lệ lạm phát còn cao hơn.

Để đảm bảo người cho vay nhận được lãi suất thực dương (làm như vậy khuyến khích được người có tiền cho vay), trên thế giới có bán các loại trái phiếu chống lạm phát (tiếng Anh là inflation-linked bonds, hay inflation-indexed bonds). Lãi suất của các trái phiếu này không cố định, mà được tính theo tỷ lệ lạm phát. Trái phiếu đầu tiên được biết đến như vậy xuất hiện trên thế giới từ năm 1870, do chính quyền vùng Massachusetts ở Mỹ phát hành. Thị trường trái phiếu chống lạm phát bắt đầu phát triển mạnh từ khi chính phủ Anh bán loại trái phiếu này vào năm 1981. Vào thời điểm 2008, tổng giá trị của các trái phiếu chống lạm phát trên thị trường nợ thế giới lên đến 1,5 nghìn tỷ USD, 


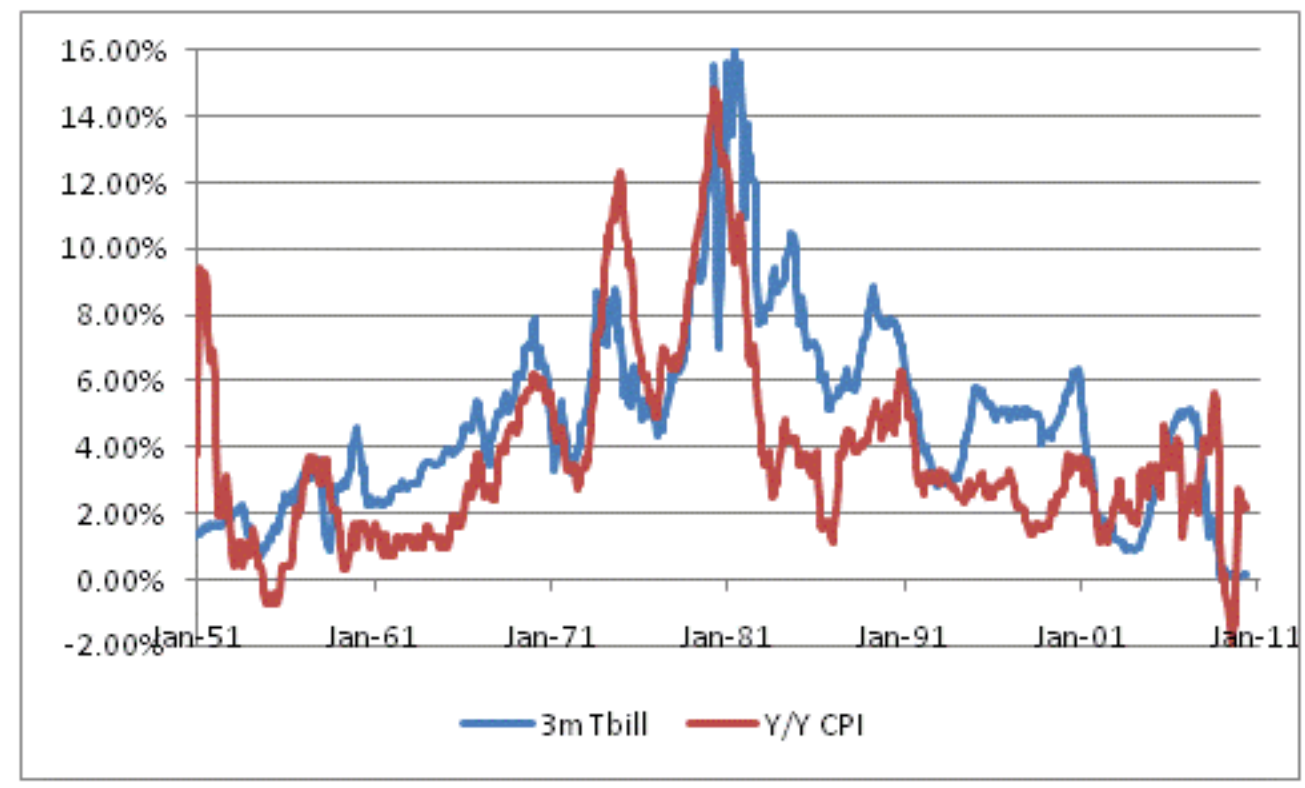

Hình 1.5: Lãi suất tín phiếu chính phủ và lạm phát ở Mỹ, 1951-2011

chủ yếu là do các chính phủ (Mỹ, Anh, Pháp, Canada, Nhật Bản, Italia, Đức, v.v.) phát hành (5).

\subsection{Hệ thống ngân hàng và chính sách tiền tệ}

Nói đến tiền tức là nói đến ngân hàng, bởi vì phần lớn tiền là được để ở ngân hàng: tổng cung tiền mặt M0 nhỏ hơn 10\% tổng cung tiền M2. Vào năm 2010, tổng tài sản của 1000 nhà băng lớn nhất trên thế giới lên đến khoảng 100 nghìn tỷ USD (gấp gần 1000 lần GDP của Việt Nam).

Trong hệ thống ngân hàng, ngoài các ngân hàng thương mại (ví dụ như Vietcombank hay HSBC), các công ty làm dịch vụ thanh toán điện tử (ví dụ như VISA), các công ty làm bảo hiểm cho các khoản vay nợ (ví dụ như American International Group), v.v., còn có các ngân hàng đặc biệt, không vị lợi nhuận, đóng vai trò đặc biệt quan trọng trong hệ thống ngân hàng, gọi là ngân hàng trung ương. Ở Mỹ, ngân hàng trung ương được gọi là Federal Reserves (gọi tắt là FED), trên danh nghĩa là ngân hàng tư nhưng hoạt động vì quyền lợi chung của nước Mỹ, còn ở Việt Nam ngân hàng trung ương là Ngân hàng Nhà nước Việt Nam, trực thuộc Chính phủ Việt Nam.

${ }^{(5)}$ Xem: http://en.wikipedia.org/wiki/Inflation-indexed_bond 
Hệ thống ngân hàng trên thế giới hoạt động theo nguyên tắc gọi là fractional reserve (nguyên tắc dự trữ một phần). Điều đó có nghĩa là, khi một người $\mathrm{X}$ gửi tiền vào một ngân hàng $\mathrm{A}$ một khoản tiền nào đó, thì ngân hàng $\mathrm{A}$ phải dự trữ (tức là gửi tại ngân hàng trung ương) ít nhất một phần của khoản tiền đó theo một tỷ lệ do ngân hàng trung ương qui định, gọi là tỷ lệ dự trữ bắt buộc , còn phần còn lại có thể đem cho đối tác Y khác vay.

Ví dụ, tỷ lệ dự trữ bắt buộc ở Mỹ là 10\% trong năm 2010. Nếu một người X có một khoản tiền $M$ nào đó đem gửi ở ngân hàng nào đó, thì ngân hàng đó phải dự trữ $10 \% M$ ở ngân hàng trung ương, và có thể đem $90 \% M$ cho một người $\mathrm{Y}$ vay. Người $\mathrm{Y}$ có thể để khoản tiền vay đó ở một ngân hàng nào đó, và ngân hàng đó lại phải dự trữ $10 \%$ của $90 \% M$ ở ngân hàng trung ương, và có thể cho một người $\mathrm{Z}$ khác vay chỗ còn lại, tức là $0.9^{2} M=0.81 M$, và cứ như thế. Tức là, từ một lượng tiền ban đầu là $M$ được gửi vào ngân hàng, qua sự khuyếch đại của hệ thống ngân hàng, có thể sinh ra một lượng cung tiền tổng cộng là 10 lần $M$ :

$$
\left(1+0.9+0.9^{2}+0.9^{3}+0.9^{4}+\ldots\right) M=10 M .
$$

Hệ số 10 ở đây gọi là hệ số khuyếch đại, và nó bằng 1 chia cho tỷ lệ dự trữ bắt buộc. Như vậy, hệ thống ngân hàng có tác dụng làm khuếch đại lượng cung tiền lên (đến 10 lần, trong trường hợp của nước $\mathrm{M} \tilde{y})$ từ những khoản tiền ban đầu. Những khoản tiền ban đầu là những khoản tiền xuất phát từ chính phủ (thông qua ngân hàng trung ương), bởi vì phát hành tiền là đặc quyền của chính phủ, chứ các ngân hàng thương mại không được phép phát hành tiền.

Chính phủ (có thể là dưới sự kiểm soát của Quốc hội) có quyền phát hành tiền (nói nôm na là in tiền), và thường ủy quyền việc phát hành đó cho ngân hàng trung ương thực hiện. Khi chính phủ phát hành tiền cho các tổ chức và cá nhân (đổi lại lấy các tài sản hay dịch vụ nào đó cho chính phủ), thì có nghĩa là chính phủ nợ các tổ chức và cá nhân đó các khoản tiền đó. Nếu chính phủ lạm dụng hình thức in tiền để vay nợ, thì điều đó sẽ làm tăng lượng cung tiền nhanh chóng (thông qua sự khuyếch đại của hệ thống ngân hàng), và điều đó có thể dẫn đến lạm phát, thậm chí siêu lạm phát. Kiểu in tiền dẫn đến lạm phát như vậy là một hình thức bắt nhân dân (những người giữ tiền) phải miễn cưỡng đóng thuế, qua việc tiền của họ bị giảm giá trị đi, và giá trị bị giảm đi đó chính là do chính phủ lấy mất qua việc in tiền. Khi chính phủ muốn vay tiền một cách "đàng hoàng" hơn và không gây ra lạm phát, thì có thể phát hành các trái phiếu, thay vì in tiền vô tội vạ.

Ngoài việc in tiền cho chính phủ, nhiệm vụ chính của các ngân hàng trung ương là 
kiểm soát sự hoạt động của hệ thống ngân hàng (chẳng hạn như đóng cửa các ngân hàng thương mại không đủ thanh khoản và có nguy cơ phá sản), và đưa ra các chính sách tiền tệ nhằm đảm bảo một môi trường tiền tệ thuận lợi cho nền kinh tế, tức là làm sao vừa chống được lạm phát vừa tạo được đủ cung tiền và mức lãi suất hợp lý cho các doanh nghiệp và cá nhân. Để làm việc đó, ngân hàng trung ương có các công cự chủ yếu sau

- Tăng/giảm lượng tiền phát hành.

- Tăng/giảm tỷ lệ dự trữ bắt buộc.

- Tăng/giảm lãi suất tham chiếu.

Mức lãi suất tham chiếu mà ngân hàng trung ương đưa ra không phải là mức lãi suất thực thi cho các khoản vay nợ, mà chỉ là một mức lãi suất để dựa vào đó các ngân hàng thương mại xác định các mức lãi suất huy động vốn và lãi suất cho vay của mình. Các khoản vay ưu đãi, rất ngắn hạn, giữa ngân hàng trung ương và các ngân hàng thương mại, hay giữa các ngân hàng thương mại với nhau cho khoản dự trữ bắt buộc cần có ở ngân hàng trung ương, có thể được thực hiện ở mức lãi suất gần bằng lãi suất tham chiếu, còn hầu hết các sản phẩm nợ khác, kể cả trái phiếu dài hạn của chính phủ, có thể có lãi suất cao hơn đáng kể so với lãi suất tham chiếu. Khi ngân hàng trung ương tăng hay giảm lãi xuất tham chiếu, thì kích thích các ngân hàng thương mại tăng hay giảm các mức lãi suất khác theo. Các ngân hàng thương mại có thể không bị bắt buộc phải làm theo như vậy, nhưng vẫn làm theo, vì uy tín và sức mạnh tài chính của ngân hàng trung ương khiến cho tất cả các ngân hàng thương mại khác cũng làm theo, ai không theo thì thiệt. Bởi vậy việc thay đổi lãi suất tham chiếu của ngân hàng trung ương có ảnh hưởng mạnh trực tiếp đến các lãi suất trên thị trường.

\subsection{Ngoại tệ và tỷ giá ngoại tệ}

Một số đồng tiền trên thế giới, trong đó có đồng đô la Mỹ, đồng Euro, đồng bảng Anh, đồng Yên Nhật, đồng Franc Thụy Sĩ, được gọi là các đồng tiền mạnh (hard currency), hay ngoại tệ mạnh (nếu là tiền nước ngoài). Một số đặc trưng của một đồng tiền mạnh là:

• Là đồng tiền của một nước có nền kinh tế mạnh trên thế giới.

- Có giá trị tương đối ổn định và mức lạm phát tương đối thấp. 
- Có tính thanh khoản cao: được chấp nhận làm công cụ thanh toán ở nhiều nước trên thế giới, dễ dàng chuyển đổi sang các đồng tiền của các nước khác, và được nhiều người nước ngoài giữ làm dự trữ tài sản.

Vào năm 2011, hai đồng tiền mạnh nhất thế giới là USD (chiếm khoảng $60 \%$ các thanh toán ngoại thương trên thế giới) và đồng Euro (chiếm khoảng $30 \%$ các thanh toán ngoại thương). Tuy Trung Quốc là nước có nền kinh tế lớn thứ hai trên thế giới vào năm 2011, nhưng đồng RMB của Trung Quốc chưa được liệt vào danh sách các đồng tiền mạnh, bởi vì nó chưa thỏa mãn đặc trưng thứ 3 kể trên, tức là còn quá ít người trên thế giới giữ tiền RMB, và nó còn hầu như chưa được dùng để làm công cụ thanh toán ngoài Trung Quốc. Tuy nhiên chính phủ Trung Quốc đang đưa ra các chính sách nhằm biến đồng tiền RMB trở thành đồng tiền phổ biến hơn trên thế giới.

Các nước đang còn yếu về kinh tế, để đảm bảo cho đồng nội tệ của mình khỏi bị mất giá, có thể thực hiện chính sách cố định tỷ giá (pegging) đồng nội tệ với một đồng ngoại tệ mạnh nào đó. Ví dụ, nhiều nước ở châu Phi (Senegal, Cameroon, Benin, Mali, Gabon, v.v., tổng cộng 14 nước vào năm 2011) dùng đồng tiền gọi là "CFA Franc" (Franc châu Phi), có tỷ giá được cố định với đồng Euro là 100 CFA Franc $=1$ Franc của Pháp trước khi có Euro = 0.152449 Eurd (6). Một số nước khác như Ả Rập Xê Út (Saudi Arabia), Li Băng (Lebanon), Hồng Kông, Bermuda, Panama, Ecuador chọn lựa cố định tỷ giá tiền nội tệ của mình với đồng USD.

Việc cố định (hay gần cố định, với biên độ giao động nhỏ) tỷ giá của một đồng tiền yếu với một đồng tiền mạnh đòi hỏi phải có kỷ luật trong các chính sách tiền tệ và tài khóa (fiscal policies), bởi vì nếu in tiền nhiều quá hay vay nợ nước ngoài nhiều quá thì ắt dẫn đến mất giá đồng tiền, không còn đảm bảo tỷ lệ giá cố định với một đồng ngoại tệ mạnh được nữa. Đấy là điều đã xảy ra ở Thái Lan năm 1997, đánh dấu mở đầu cuộc khủng hoảng tài chính ở châu Á giai đoạn 1997-1998: sau khi vay nợ quá nhiều và đầu tư tràn lan, vào ngày 02/07/1997 chính phủ nước này đã tuyên bố thả nổi đồng Baht Thái vì không giữ nổi tỷ giá gần cố định với USD, và chỉ trong vòng ít lâu sau đó đồng Baht mất giá đến $50 \%$ so với USD (xem Hình 1.6).

Tình hình đối với đồng RMB thì ngược lại: chính phủ Trung Quốc cũng muốn giữ tỷ giá RMB/USD gần như cố định, nhưng gặp sự phản đối của chính phủ Mỹ. Mỹ cho rằng (vào năm 2011) tỷ giá RMB/USD quá thấp, tạo ra lợi thế xuất khẩu bất thường cho Trung Quốc, và muốn Trung Quốc phải tăng giá đồng RMB lên thành quãng 1 USD = 4

${ }^{(6)}$ Xem: http://en.wikipedia.org/wiki/CFA_franc 


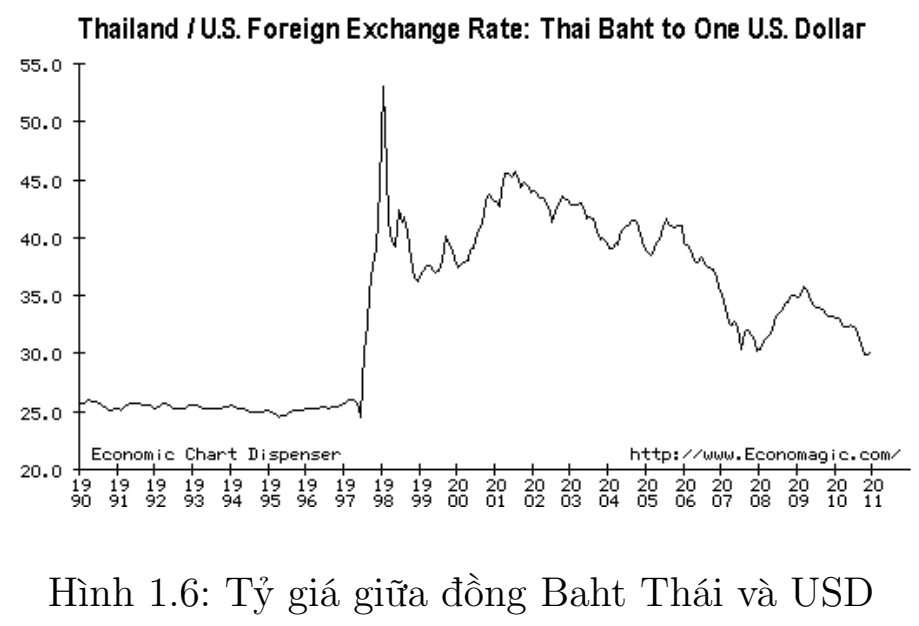

RMB hay 5 RMB, thay vì 1 USD = 6,5 RMB. Nói một cách tổng quát, khi tỷ giá đồng nội tệ đi xuống so với ngoại tệ thì điều đó có lợi cho xuất khẩu, vì nó làm cho giá thành các mặt hàng sản xuất ở trong nước trở nên rẻ hơn so với ở nước ngoài, và ngược lại nó gây bất lợi cho nhập khẩu. Chính sách "đồng tiền yếu" của Trung Quốc (tức là giữ tỷ giá của RMB thấp so với các ngoại tệ mạnh) là một trong những nguyên nhân vì sao Trung Quốc có xuất siêu rất lớn, đến quãng 200 tỷ USD một năm vào những năm 2008-2010. Vào những năm, khi Nhật Bản ở vào tình hình tương tự, với xuất siêu quá lớn sang Mỹ, Mỹ đã thành công trong việc ép Nhật Bản nâng tỷ giá đồng Yên lên 2 lần so với USD: từ 254 Yền = 1 USD vào đầu năm 1985 thành 127 Yên = 1 USD vào đầu năm 1988.

Đồng VND của Việt Nam hiện là một đồng tiền yếu và khó chuyển đổi ở nước ngoài. Việt Nam có chính sách giữ giá đồng VND so với USD (không phải là cố định giá, mà là cho phép giao động trong biên độ hẹp, và thỉnh thoảng trượt giá với tốc độ chậm). Tuy nhiên, Việt Nam có tăng trưởng cung tiền quá cao, kéo theo lạm phát cao. Trong tình hình như vậy, việc giữ giá VND so với USD không những khó thực hiện, mà chưa chắc đã có lợi cho nền kinh tế nếu giá được giữ ở mức cao, bởi vì nó có thể làm cho hàng hóa sản xuất tại Việt Nam trở nên có giá thành đắt so với thế giới, gây khó khăn cho suất khẩu và kích thích nhập khẩu, dẫn đến nợ nước ngoài quá nhiều.

Kể cả giữa các đồng ngoại tệ mạnh với nhau, tỷ giá cũng có thể có những lúc giao động rất mạnh chứ không hẳn là ổn định. Ví dụ, chỉ trong vòng 6 tháng từ 07/2008 đến $01 / 2009$, tỷ giá EUR/USD rơi từ 1,60 xuống 1,25 (giảm hơn 20\%) rồi lại lên trên 1,45 (xem hình 1.7). Một phần của sự giao động mạnh này là do khủng hoảng tài chính 2008-2009, nhưng một phần lớn sự giao động cũng có thể đổ tội cho lượng đầu cơ quá lớn trên thị trường chứng khoán thế giới. Trong tình hình như vậy, việc cố định tỷ giá của 
một đồng tiền yếu với một đồng tiền mạnh vẫn làm cho giá của nó so với các đồng tiền mạnh khác giao động rất lớn. Để giảm sự bất ổn định này, thay vì chỉ chọn 1 đồng tiền mạnh để làm tham chiếu, có thể chọn 1 rổ đồng tiền mạnh. Đây là chính sách mà vào năm 2011 nước Belorussia đang thực hiện, và Trung Quốc cũng đang muốn thực hiện.

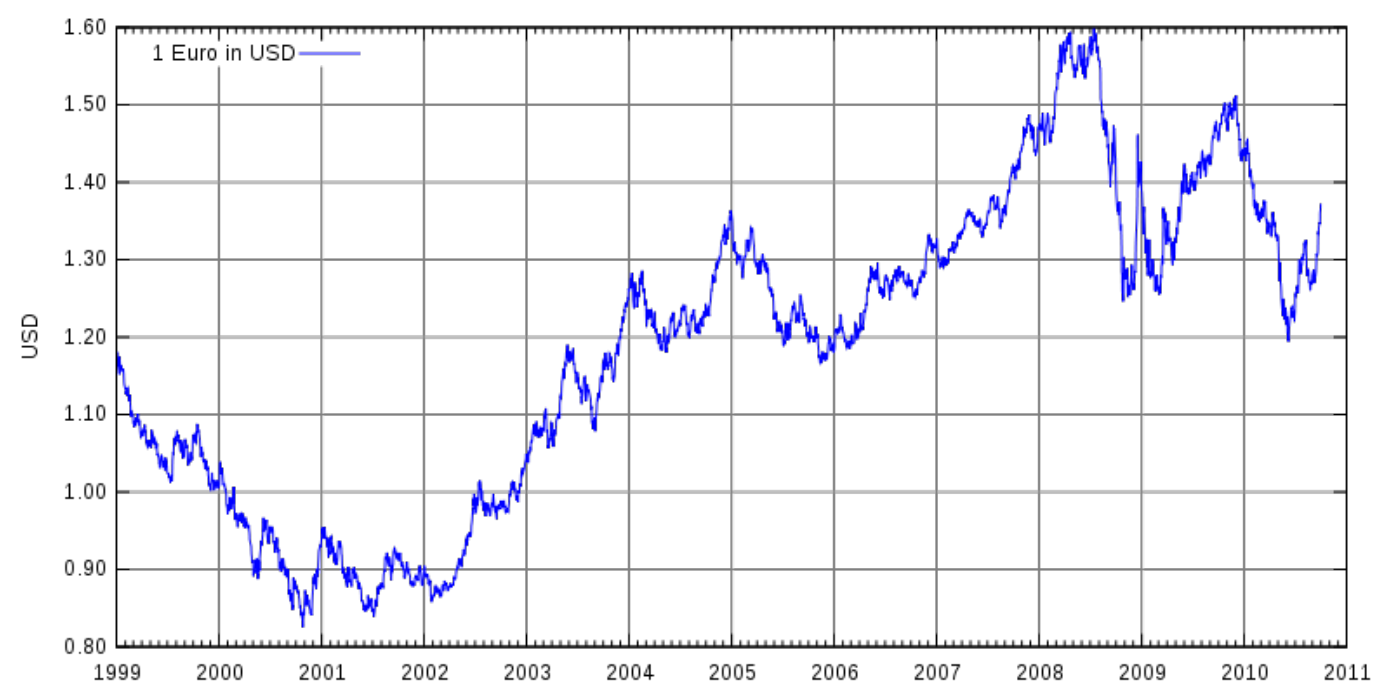

Hình 1.7: Tỷ giá giữa EUR và USD 


\section{Chương 2}

\section{Thị trường tài chính}

Các thị trường tài chính (financial markets) là nơi giao dịch các sản phẩm tài chính (financial products), còn gọi là các công cụ tài chính (financial instruments), trong đó có các loại tiền tệ, các món nợ ngân hàng, và các loại sản phẩm tài chính khác, như cổ phiếu, trái phiếu, hợp đồng tương lai, v.v., gọi chung là các chứng khoán (securities). Ở trong chương này, chúng ta sẽ tìm hiểu qua về chức năng và cấu trúc của các thị trường tài chính, các đối tượng tham gia thị trường tài chính, và các loại sản phẩm tài chính được giao dịch ở đó.

\subsection{Chức năng và cấu trúc của thị trường tài chính}

Chức năng cơ bản nhất của các thị trường tài chính là luân chuyển vốn từ những người có vốn dư thừa (ví dụ như những người có tiền tiết kiệm chưa dùng đến, các quỹ đầu tư, các khoản tiền dự trữ của các công ty bảo hiểm, v.v.) đến những người cần vốn (ví dụ như các doanh nghiệp đang có các dự án đầu tư có triển vọng đem lại hiệu quả cao nhưng đang thiếu vốn để thực hiện các dự án đó, các chính phủ cần vốn đề bù vào thậm hụt ngân sách, v.v.). Ngoài chức năng luân chuyển vốn, thị trường tài chính còn có các chức năng khác như: tạo thanh khoản trong kinh tế, cung cấp phương tiện quản lý rủi ro, cung cấp phương tiện thanh toán thương mại, v.v.

Nói chung, sự luân chuyển vốn trên thị trường tài chính đem lại lợi ích xã hội, vì nó tạo ra sự hợp tác hai bên cùng có lợi giữa người cung cấp vốn và người sử dụng vốn, để vốn được sử dụng vào những chỗ đem lại hiệu quả cao nhất, đem lại năng suất cao hơn cho nền kinh tế nói chung. Sự tồn tại của thị trường tài chính cũng có lợi ngay cả nếu ai đó vay vốn nhằm mục đích mua sắm thay vì nhằm tăng lợi nhuận trong kinh doanh. 
Ví dụ như một người muốn mua một ngôi nhà đẹp, nhưng chưa có đủ tiền. Nhờ có thị trường tài chính, người đó có thể vay tiền mua nhà với một mức lãi suất nào đó, trả dần trong nhiều năm từ thu nhập của mình, có thể được hưởng thụ ngay một ngôi nhà đẹp thay vì phải ở chui rúc cho đến khi tiết kiệm được đủ tiền mua nhà.

Thị trường tài chính thực hiện việc luân chuyển vốn thông qua tài chính trực tiếp hoặc tài chính gián tiếp. Tài chính trực tiếp là khi những người cần vốn có thể huy động vốn trực tiếp từ những người có vốn, bằng cách bán các chứng khoán như cổ phiếu hay trái phiếu. Các chứng khoán (securities) có nghĩa là các hợp đồng tài chính hay là các giấy tờ ghi nhận quyền sở hữu đến các tài sản nào đó, ví dụ như một cổ phiếu (stock) là giấy tờ chứng nhận quyền sở hữu một phần vốn cổ phần của một doanh nghiệp cho người cầm nó, còn một trái phiếu (bond) là một phiếu nợ theo đó người phát hành trái phiếu (con nợ) hứa trả người giữ trái phiếu (chủ nợ) những khoản tiền nào đó vào các thời điểm nào đó. Các thị trường tài chính trực tiếp thường được gọi là các thị trường chứng khoán: ở đó các chứng khoán có thể được mua bán, chuyển tay từ người này sang người khác. "Trực tiếp" không có nghĩa là người mua và người bán phải gặp nhau "mặt đối mặt", mà họ có thể thực hiện việc mua bán chứng khoán thông qua các nhà môi giới (ví dụ như các công ty chứng khoán).

Tài chính gián tiếp là khi có các trung gian tài chính đứng giữa, kinh doanh vốn, bằng cách huy động vốn từ những người có vốn, rồi chuyển vốn đó đến những người cần vốn. Ví dụ như ngân hàng, vay tiền từ người có vốn ở một mức lãi suất thấp, rồi lấy số tiền đó cho người cần vốn vay ở một mức lãi suất khác cao hơn, và hưởng chênh lệch ở giữa. Ngoài các ngân hàng, còn có các trung gian tài chính khác như: các công ty tài chính, công ty bảo hiểm, các quỹ hưu trí, quỹ đầu tư, ngân hàng đầu tư, v.v. Theo kênh tài chính gián tiếp, thì những người sử dụng vốn và những người cung cấp vốn không liên hệ trực tiếp với nhau. Các trung gian tài chính, hay được gọi là các tổ chức tài chính (financial institutions), đóng một vai trò quan trọng trong nền kinh tế, bởi vì thường qua họ mà các công ty cần vốn huy động được vốn, và những người dân có chỗ để gửi tiền tiết kiệm của mình. Các trung gian tài chính cũng có tác dụng làm giảm rủi ro tài chính cho khách hàng của họ. Ví dụ, một người có tiền dư thừa, có thể cho vay hoặc đầu tư vào đâu đó. Nhưng nếu cho một cá nhân vay thì có khả năng rủi ro là bị quịt nợ mất hết tiền, nếu đầu tư vào cổ phiếu của một công ty nào đó, thì cũng có rủi ro là không đủ thông tin và khả năng phân tích xem công ty đó làm ăn ra sao, có thể đầu tư nhầm vào công ty sẽ phá sản. Đầu tư thông qua một trung gian tài chính, ví dụ như một quỹ đầu tư, thì sẽ đỡ gặp phải các rủi ro đó hơn. Các rủi ro về tài chính do tai ương (như cháy nhà, tai 
nạn giao thông, v.v.) gây ra đối với người dân cũng được giảm thiểu, bởi có các công ty bảo hiểm (là một loại trung gian tài chính) bán bảo hiểm cho họ.

Các thị trường chứng khoán có thể được chia thành thị trường sơ cấp và thị trường thứ cấp: Thị trường sơ cấp (primary market) là thị trường cho việc phát hành các chứng khoán, còn thị trường thứ cấp (secondary market) là nơi mua đi bán lại các chứng khoán đã được phát hành. Ví dụ, khi Vietcombank phát hành cổ phiếu ra công chúng lần đầu (tiếng Anh gọi là initial public offering, viết tắt là IPO), thì các nhà đầu tư mua cổ phiếu Vietcombank từ Vietcombank, và nơi diễn ra việc mua bán này được gọi là thị trường sơ cấp. Sau đó, các nhà đầu tư mua bán cổ phiếu Vietcombank với nhau, và nơi diễn ra việc mua bán này (các sàn chứng khoán) được gọi là thị trường thứ cấp. Ở thị trường sơ cấp, thường có các công ty chứng khoán đứng ra làm bảo lãnh phát hành: họ mua sỉ chứng khoán từ nhà phát hành với số lượng lớn và giá thỏa thuận (thường thấp hơn mức giá công bố) để rồi bán lẻ lại cho các nhà đầu tư trên thị trường thứ cấp. Sự khác nhau chủ yếu giữa thị trường sơ cấp và thị trường thứ cấp là ở chỗ hoạt động của thị trường sơ cấp làm gia tăng thêm vốn cho nền kinh tế còn hoạt động của thị trường thứ cấp chỉ làm thay đổi quyền sở hữu và giá của các chứng khoán đã phát hành, mà không trực tiếp làm tăng thêm lượng vốn đầu tư cho nền kinh tế.

Giữa thị trường sơ cấp và thị trường thứ cấp có mối liên hệ tác động qua lại lẫn nhau. Thị trường sơ cấp đóng vài trò tạo cơ sở cho hoạt động của thị trường thứ cấp vì nó là nơi tạo ra hàng hóa để mua bán trên thị trường thứ cấp. Thị trường thứ cấp cũng có tác dụng trở lại đối với thị trường sơ cấp, đóng vai trò tạo động lực cho sự phát triển của thị trường này. Tác dụng của thị trường thứ cấp tới thị trường sơ cấp được thể hiện ở hai chức năng của nó: Thứ nhất, chúng làm cho quá trình bán các công cụ tài chính nhằm huy động vốn trở lên nhanh hơn và dễ dàng hơn bằng cách làm cho những công cụ này có tính thanh khoản cao hơn, nhờ đó khiến chúng được ưa chuộng hơn và dễ dàng cho tổ chức phát hành chứng khoán bán trên thị trường sơ cấp. Thứ hai, giá chứng khoán giao dịch trên thị trường thứ cấp được các tổ chức phát hành và các nhà đầu tư lấy làm giá tham chiếu để định giá chứng khoán trên thị trường sơ cấp.

Các thị trường chứng khoán thứ cấp có thể được tổ chức theo kiểu thị trường tập trung (gọi là thị trường niêm yết) hay thị trường phi tập trung (gọi là thị trường OTC, viết tắt của cụm từ "over the counter"). Thị trường chứng khoán New York (New York Stock Exchange, viết tắt là NYSE) và Sở giao dịch chứng khoán TpHCM (Hochiminh City Stock Exchange, viết tắt là HOSE) là hai ví dụ về thị trường niêm yết. Ở thị trường niêm yết, tất cả các lệnh mua/bán một cổ phiếu nào đó được đưa về cùng một danh sách, 
để từ đó khớp lệnh giữa những người muốn mua và muốn bán theo một thuật toán đảm bảo giá tối ưu cho cả bên mua và bên bán, và tại mỗi thời điểm trên thị trường chỉ có 1 giá giao dịch. Ở các thị trường OTC thì khác, không có một danh sách lệnh chung, mà có nhiều điểm trao đổi cổ phiếu khác nhau, với giá cả có thể chênh lệch nhau. Tuy nhiên, với sự điện tử hóa các thị trường chứng khoán, trên thế giới không còn có sự phân biệt lớn giữa các thị trường niêm yết và thị trường $\mathrm{OTC}$, vì chúng đều trở thành các trung tâm giao dịch điện tử. Kể cả đối với các cổ phiếu giao dịch OTC, thì lệnh mua/bán thường cũng được chuyển đến trung tâm giao dịch điện tử nào có giá tốt nhất, và lệnh có thể được chuyển từ trung tâm giao dịch điện tử này sang trung tâm giao dịch điện tử khác chỉ trong tích tắc để khớp lệnh. Ở Việt Nam, hai sàn chứng khoán niêm yết ở TP Hồ Chí Minh và Hà Nội sử dụng giao dịch điện tử, và từ năm 2009 một số cổ phiếu OTC lớn cũng được giao dịch điện tử thông qua một mạng điện tử gọi là UPCoM. Những cổ phiếu OTC nào mà chưa có giao dịch điện tử thì việc mua bán chúng còn khá bất tiện.

Các thị trường tài chính còn có thể được phân loại theo sản phẩm tài chính được giao dịch trên đó. Một số loại thị trường tài chính và sản phẩm tài chính tương ứng phổ biến nhất là:

Thị trường ngoại hối (foreign exchange, viết tắt là FOREX hay $\mathrm{FX}$ ), là nơi mua bán trao đổi giữa các loại tiền với nhau (ví dụ như mua EUR bằng USD). Thị trường FOREX là một thị trường khổng lồ, với tổng lượng giao dịch trên thế giới vào khoảng 1 triệu tỷ $\left(10^{15}\right)$ USD trong năm 2010, gấp gần 20 lần tổng GDP của thế giớ:(1) (GDP của thế giới là vào khoảng 60 nghìn tỷ USD). Lượng giao dịch lớn như vậy không phải là do nhu cầu đổi tiền thực sự lớn đến vậy, mà là do ngày nay phần lớn lượng giao dịch trên các thị trường tài chính (hơn 90\%) là do giới đầu cơ tạo ra, mua đi bán lại nhiều lần nhằm kiếm lời.

Thị trường nợ (debt market), hay còn gọi là gọi là thị trường trái phiếu (bond market), hay thị trường thu nhập cố định (fixed income market), là nơi giao dịch các trái phiếu, tức là các chứng khoán nợ. Tổng giá trị của các trái phiếu trên các thị trường thế giới đạt khoảng khoảng 91 nghìn tỷ USD vào năm 2009(2), trong đó thị trường Mỹ chiếm $39 \%$ và thị trường Nhật chiếm $18 \%$.

Thị trường tiền tệ (money market) là thị trường chuyên về các sản phẩm nợ ngắn hạn (thời hạn dưới 1 năm) và có tính thanh khoản và an toàn cao gần như là tiền mặt, ví dụ như các tín phiếu ngắn hạn của chính phủ. Thị trường này thích hợp cho các đầu

\footnotetext{
${ }^{(1)}$ Xem: http://en.wikipedia.org/wiki/Foreign_exchange_market

${ }^{(2)} \mathrm{Xem}$ : http://en.wikipedia.org/wiki/Bond_market
} 
tư rất ngắn hạn và đòi hỏi độ an toàn rất cao (trong khi chờ đợi tiêu tiền vào việc khác). Thị trường tiền tệ được chia nhỏ thêm thành thị trường liên ngân hàng (interbank market), tức là giữa các ngân hàng với nhau, và thị trường mở là nơi mà các tổ chức và cá nhân không phải ngân hàng cũng tham gia. Ở Việt Nam, từ những năm 1993-1994, cũng có thị trường liên ngân hàng cho nội tệ và ngoại tệ.

Thị trường cổ phiếu (stock market) là nơi giao dịch các cổ phiếu, tức là quyền sở hữu các doanh nghiệp. Người giữ trái phiếu của một doanh nghiệp là chủ nợ của doanh nghiệp, còn người giữ cổ phiếu của doanh nghiệp là người góp vốn vào doanh nghiệp để thành chủ sở hữu của doanh nghiệp. Các thị trường cổ phiếu và các thị trường trái phiếu (loại có kỳ hạn trên 1 năm) được gọi chung là các thị trường vốn, bởi vì phát hành cổ phiếu và phát hành trái phiếu là hai cách thông dụng nhất để một doanh nghiệp huy động vốn.

Thị trường commodities là nơi giao dịch các hợp đồng (chủ yếu là hợp đồng tương lai, xem Mục 2.4.1) cho các loại hàng hóa thông dụng nhất (gọi là các commodities) như dầu hỏa, vàng, bạc, cà phê, v.v. Một ví dụ là Chicago Mercantile Exchange (CME).

Thị trường chứng khoán phái sinh là nơi giao dịch các chứng khoán phái sinh (derivatives). Các chứng khoán phái sinh là các chứng khoán, mà giá trị của chúng được xác định theo giá trị của các chứng khoán khác hay các tài sản khác hay các chỉ số tài chính khác. Các loại chứng khoán phái sinh phổ biến là: các quyền chọn (options, tức là quyền mua hay quyền bán những chứng khoán nào đó theo những điều kiện nào đó về giá cả và thời hạn), các hợp đồng kỳ hạn (forward contracts), các hợp đồng tương lai (futures), và các hợp đồng hoán đổi chứng khoán (swaps), và chúng được dùng trên đủ các thứ như cổ phiếu, trái phiếu, tỷ giá ngoại hối, tỷ giá lãi suất, commodities (xem Mục 2.4). Thị trường chứng khoán phái sinh cũng là một thị trường khổng lồ, và phát triển rất nhanh trong mấy thập kỷ qua. Vào năm 2008, tổng giao dịch chứng khoán phái sinh trên thế giới lớn hơn gấp 5 lần GDP của toàn thế giới, còn tổng giá trị của các chứng khoán được "phái sinh hóa" (tức là các chứng khoán làm cơ sở cho các chứng khoán phái sinh đang có trên thị trường) lên đến hơn 11 lần GDP của toàn thế giớ: (3). Đây cũng là thị trường có độ rủi ro cao nhất. Trong giai đoạn khủng hoảng tài chính thế giới 2008-2009, hàng loạt tổ chức tài chính lớn phá sản hoặc thua lỗ nặng vì chứng khoán phái sinh.

Cho đến thế kỷ 20, các chứng khoán thường ở dạng các tờ giấy thực sự, và khi mua bán chứng khoán là trao tay thực sự các tờ giấy đó. Ngày nay, tương tự như đối với tiền tệ, phần lớn các chứng khoán là ở dạng điện tử, giao dịch chứng khoán là giao dịch điện

${ }^{(3)}$ Xem: http://en.wikipedia.org/wiki/Derivative_(finance) 
tử, với các con số hiện lên trong tài khoản, chứ không còn trao tay trực tiếp các tờ giấy nữa. Việc điện tử hóa các chứng khoán và các thị trường chứng khoán khiến cho việc quản lý và giao dịch chứng khoán trở nên thuận tiện và hiệu quả hơn nhiều so với trước kia, và góp phần quốc tế hóa các thị trường chứng khoán. Ví dụ, cổ phiếu của công ty LDK Solar của Trung Quốc (chuyên sản xuất các hệ thống điện năng lượng mặt trời) lại được niêm yết ở thị trường chứng khoán New York (NYSE) ở Mỹ, và một người ngồi ở Pháp có thể đặt các lệnh mua bán cổ phiếu LDK Solar này trực tiếp trên NYSE qua internet.

Các giao dịch điện tử trên các thị trường chứng khoán không phải là được thanh toán trực tiếp giữa người mua và người bán trên thị trường, mà là thông qua trung tâm thanh toán (clearing center). Ở Việt Nam, trung tâm thanh toán này được gọi là Trung tâm lưu ký chứng khoán Việt Nam. Ví dụ, một người A trong 1 ngày mua 300 cổ phiếu $\mathrm{XYZ}$ từ một người $\mathrm{B}$ và sau đó bán 200 cổ phiếu $\mathrm{XYZ}$ cho người $\mathrm{C}$, thì không có nghĩa là A nhận được trực tiếp của B 300 cổ phiếu XYZ rồi phải chuyển lại trực tiếp cho $\mathrm{C} 200$ cổ phiếu XYZ. Trong ngày đó, tính tổng cộng lại, A mua 100 cổ phiếu $(=300-200)$, và A sẽ nhận được 100 cổ phiếu từ trung tâm thanh toán (chứ không phải trực tiếp từ $\mathrm{B}$ ), và cũng không phải chuyển cho $\mathrm{C}$ cổ phiếu nào, vì có trung tâm thanh toán làm việc đó. Vì trung tâm thanh toán mất thời gian để làm các công việc cộng trừ số lượng chứng khoán cho các bên, nên sinh ra các nguyên tắc như kiểu $\mathrm{T}+2$ (tức là 2 ngày sau khi thực hiện một lệnh mua/bán chứng khoán thì mới thanh toán xong cho lệnh đó).

Trong các mục dưới đây, chúng ta sẽ bàn thêm về một số loại chứng khoán phổ biến nhất và các thị trường của chúng.

\subsection{Các sản phẩm nợ}

Các trái phiếu có kỳ hạn càng dài thì độ rủi ro về lãi suất, tức là giá của chúng thay đổi khi lãi suất thay đổi, càng cao. (Điều này sẽ được giải thích rõ hơn trong Chương 4. Các trái phiếu rất ngắn hạn thì hầu như không có rủi ro về lãi suất, tức là kể cả khi lãi suất đi lên, thì giá của chúng nói chung cũng không bị giảm đi. Chính vì vậy mà các chứng khoán nợ trên thị trường tiền tệ đều là các chứng khoán nợ ngắn hạn. Một số loại chứng khoán nợ ngắn hạn chủ yếu trên thị trường tiền tệ là:

Tín phiếu kho bạc (treasury bills) là loại trái phiếu ngắn hạn của chính phủ (khi phát hành thường có kỳ hạn là 3 tháng, 6 tháng, hay 1 năm), được chính phủ bán ra với giá dưới mệnh giá, và bởi vậy chúng còn được xếp vào loại trái phiếu chiết khấu (discount bond). Người giữ tín phiếu này đến lúc đáo hạn thì được chính phủ trả cho tiền đúng 
bằng mệnh giá. Tín phiếu kho bạc có tính thanh khoản cao nhất trong số các công cụ của thị trường tiền tệ do chúng được mua bán rộng rãi nhất. Loại tín phiếu này cũng là công cụ thị trường tiền tệ an toàn nhất do không có khả năng xảy ra vỡ nợ, vì cùng lắm thì chính phủ có thể in tiền để trả nợ cho loại tín phiếu này. Phần lớn tín phiếu kho bạc được các trung gian tài chính, đặc biệt là các ngân hàng, nắm giữ. Ngân hàng trung ương của các nước thường sử dụng việc mua/bán tín phiếu kho bạc trên thị trường mở như là một công cụ điều hành chính sách tiền tệ.

Thương phiếu (commercial papers) là một công cụ nợ ngắn hạn được các ngân hàng lớn và các công ty lớn có uy tín cao, ví dụ như General Electric, phát hành. Sự tăng trưởng của thị trường thương phiếu khá ổn định: tổng số dư của thương phiếu tăng hơn 1200\% (từ 122 tỉ đôla đến 1544 tỉ đôla) trong khoảng thời gian 1980 - 2005.

Chứng chỉ tiền gửi (certificates of deposit, viết tắt là CDs) là một loại công cụ nợ chủ yếu do các ngân hàng phát hành, có kỳ hạn (với các kỳ hạn thường là 3 tháng, 6 tháng, hoặc là từ 1 đến 5 năm), có được bảo hiểm (kể cả khi ngân hàng phá sản, thì người giữ $\mathrm{CD}$ vẫn được hoàn lại tiền), và bởi vậy cũng an toàn như là tiền mặt. Đi vào chi tiết hơn thì có nhiều loại $\mathrm{CD}$ khác nhau ${ }^{(4)}$. Một số loại $\mathrm{CD}$ có thể được giao dịch trên thị trường chứng khoán thứ cấp. Thị trường chứng chỉ tiền gửi (tính riêng ở Mỹ năm 2010 là khoảng 2 nghìn tỷ USD) là một nguồn lớn để các nhà băng và các trung tâm tài chính huy động vốn.

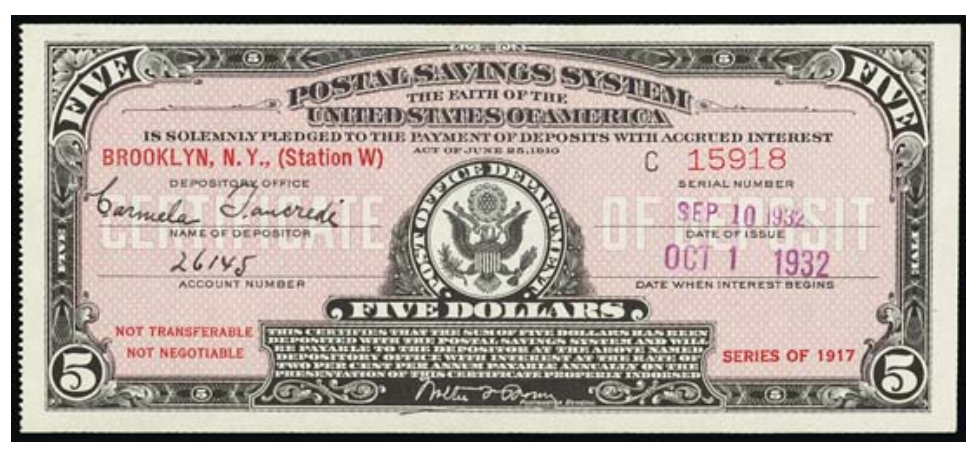

Hình 2.1: Một chứng chỉ tiền gửi mệnh giá 5 \$ phát hành ở Mỹ năm 1932

Chấp phiếu ngân hàng (banker's acceptances, viết tắt là BAs) là một loại hối phiếu do công ty phát hành và được ngân hàng chấp nhận thanh toán bằng cách đánh dấu chấp nhận lên hối phiếu. Nó tương tự như là một tấm séc có đảm bảo của ngân hàng là sẽ được thanh toán trong tương lai, và được sử dụng trong các thương vụ mua bán quốc tế

${ }^{(4)}$ Xem: http://en.wikipedia.org/wiki/Certificate_of_deposit 
từ hàng trăm năm nay. Công ty phải nộp một khoản lệ phí cho ngân hàng (một thứ lệ phí bảo hiểm) để hối phiếu được đóng dấu chấp nhận. Nếu như sau đó công ty không có tiền thanh toán chấp phiếu ngân hàng của mình, thì ngân hàng sẽ phải đứng ra thanh toán khoản tiền đó. Các chấp phiếu ngân hàng này dễ được các đối tác nước ngoài chấp nhận vì có bảo hiểm của ngân hàng. Các chấp phiếu ngân hàng hay được bán lại giảm giá trên thị trường thứ cấp, tương tự như là tín phiếu kho bạc.

Hợp đồng mua lại chứng khoán (repurchase agreements, viết tắt là repos) là các hợp đồng cho vay, thường có kỳ hạn thanh toán ngắn, trong đó một số chứng khoán (như tín phiếu hay cổ phiếu) được đem ra làm tài sản thế chấp, tức là tài sản mà người cho vay sẽ nhận được nếu người đi vay không trả được nợ. Ví dụ, một ngân hàng có thể vay công ty Microsoft 1 triệu USD trong 2 tuần bằng cách làm một hợp đồng repo, trên danh nghĩa là bán cho Microsft 1 triệu USD tín phiếu kho bạc và hứa mua lại chỗ tín phiếu đó với giá cao hơn một chút sau 2 tuần. Những nhà cho vay quan trọng nhất trên thị trường repo này là những công ty lớn.

Quĩ dự trữ bắt buộc (để ở ngân hàng trung ương, ở Mỹ gọi là FED Funds). Một ngân hàng, khi số tiền dự trữ để ở ngân hàng trung ương giảm xuống dưới mức tối thiểu bắt buộc, có thể vay ngắn hạn (từng ngày một, gọi là vay qua đêm) từ một ngân hàng khác đang có số tiền dự trữ ở ngân hàng trung ương cao hơn mức bắt buộc, để bù cho khoản dự trữ bắt buộc để ở ngân hàng trung ương. Lãi suất vay qua đêm cho các khoản vay cho dự trữ bắt buộc này là thước đo độ căng thẳng của thị trường tín dụng trong hệ thống ngân hàng: khi lãi suất này cao thì tức là các ngân hàng đang rất kẹt tiền trong ngắn hạn.

Eurobonds là tên gọi các trái phiếu được phát hành theo một đồng tiền khác với đồng tiền sở tại của nơi phát hành (chứ nó không cần có gì liên quan châu Âu hay đồng Euro). Ví dụ, một trái phiếu tính theo USD do chính phủ Việt Nam phát hành ở Singapore cũng được gọi là Eurobond. Đến $80 \%$ các trái phiếu phát hành trên thế giới ngày nay là loại Eurobonds (trong đó có các trái phiếu ngắn hạn).

Các sản phẩm nợ dài hạn hơn (thuộc về thị trường vốn, thay vì thị trường tiền tệ) gồm có những loại chính như sau:

Trái phiếu chính phủ (government bonds) do các chính phủ phát hành, để trang trải cho các thiếu hụt trong ngân sách của chính phủ, thường là loại trái phiếu được giao dịch nhiều nhất trên thị trường, tức là có tính thanh khoản cao nhất. Các trái phiếu chính phủ thường được coi là có rủi ro vỡ nợ thấp hơn so với các trái phiếu khác ở trong nước. Ngoài ra còn có trái phiếu chính quyền địa phương, hay còn được gọi là trái phiếu 
đô thị (municipal bonds), do các chính quyền địa phương phát hành, và trái phiếu của các tổ chức chính phủ.

Trái phiếu công ty (corporate bonds), do các công ty phát hành. Các trái phiếu công ty thường trả lãi định kỳ, ví dụ một năm 2 lần, và cho lãi suất cao hơn là lãi suất trái phiếu chính phủ. Lượng trái phiếu công ty trên thị trường chứng khoán chỉ bằng khoảng $1 / 5$ so với trái phiếu chính phủ, và chúng cũng ít được giao dịch hơn so với trái phiếu chính phủ. Tuy nhiên thị trường trái phiếu công ty và biến động lãi suất rất là quan trọng đối với các công ty, và lượng trái phiếu công ty mới được phát hành hàng năm lớn hơn là lượng cổ phiếu mới được phát hành.

Trái phiếu chuyển đổi (convertible bonds) là một loại trái phiếu công ty có quyền chuyển đổi thành cổ phiếu của công ty theo giá định trước, với một số điều kiện nào đó. Nó có thể coi như là trái phiếu đi kèm theo quyền chọn mua cổ phiếu. Một số nhà đầu tư có thể thích trái phiếu chuyển đổi hơn là trái phiếu thông thường, vì khi giá cổ phiếu của công ty không đi lên thì trái phiếu chuyển đổi vẫn trả lãi, còn khi giá cổ phiếu của công ty lên cao thì lại được đổi trái phiếu lấy cổ phiếu theo giá thỏa thuận từ trước để hưởng lợi nhiều hơn từ việc tăng giá của cổ phiếu. Bởi vậy, công ty có thể phát hành trái phiếu chuyển đổi ở mức lãi suất thấp hơn so với trái phiếu thường, và như vậy giảm bớt được gánh nặng về tiền trả lãi. Bù lại, các cổ đông hiện hữu của công ty sẽ bị giảm phần sở hữu công ty đi nếu như các nhà đầu tư vào trái phiếu chuyển đổi quyết định đổi chúng lấy cổ phần của công ty.

Vay thương mại hay tiêu dùng, do các ngân hàng hay các tổ chức tài chính khác cho các doanh nghiệp hay người tiêu dùng vay. Những khoản nợ này khó chuyển nhượng, nên chúng kém tính thanh khoản nhất trong các công cụ ở thị trường vốn.

Vay thế chấp. Vay thế chấp thường là những khoản nợ của các hộ gia đình hoặc các công ty khi mua nhà đất hay những tài sản có giá trị lâu bền khác, và những tài sản đó được làm thế chấp cho khoản vay. Ở Mỹ, thị trường vay thế chấp là thị trường nợ lớn nhất, với tổng số dư các món nợ thế chấp nhà đất (để mua nhà ở) nhiều gấp 4 lần so với vay thế chấp thương mại và nông trại. Hình thức vay thế chấp mua nhà phổ biến là vay trả góp (mortgage), trả dần hàng tháng trong nhiều năm, có thể đến 20 hay thậm chí đến 50 năm.

CDO (collateralised debt obligation - chứng khoán nợ có thế chấp). Đây là loại chứng khoán được tạo ra bằng cách chứng khoán hóa (securitisation) các khoản vay thế chấp: ngân hàng và tổ chức tài chính tập hợp một rổ lớn các khoản vay thế chấp lại với nhau thành một gói sản phẩm nợ, rồi dùng các công thức toán chia nhỏ gói đó ra thành nhiều 
phần gọi là các $\mathrm{CDO}$, rồi bán lại các $\mathrm{CDO}$ đó cho các nhà đầu tư trên thị trường chứng khoán(5). Các nhà đầu tư khi mua các CDO như vậy trở thành những người cho vay thế chấp gián tiếp (không phải là cho một người cụ thể nào vay, mà là cho chung toàn bộ những người trong rổ các khoản vay thế chấp vay), và chịu rủi ro vỡ nợ của những người vay thế chấp.

\subsection{Cổ phiếu}

Một công ty cổ phần là một công ty trách nhiệm hữu hạn (tức là các chủ sở hữu không có trách nhiệm phải trả nợ cho công ty trong trường hợp bị vỡ nợ), mà quyền sở hữu nó được chia làm nhiều phần, gọi là các cổ phần. Giấy tờ ghi nhận quyền sở hữu các cổ phần đó thường được gọi là cổ phiếu (stock, share): thông thường thì mỗi cổ phiếu ứng với một cổ phần. Những người sở hữu các cổ phần này, tức là những người nắm giữ các cổ phiếu, chính là các chủ sở hữu của công ty, và được gọi là các cổ đông (stockholder hay shareholder). Ví dụ: công ty cổ phần Sữa Việt Nam (Vinamilk, mã cổ phiếu trên thị trường Việt Nam: VNM) có tổng cộng khoảng 351 triệu cổ phiếu lưu hành vào đầu năm 2010. Điều đó có nghĩa là quyền sở hữu công ty được chia thành 351 triệu phần, và nếu người nào có 1000 cổ phiếu của Vinamilk thì tức là sở hữu 1000 phần 351 triệu (bằng khoảng $0,000285 \%$ ) công ty đó.

Khi một công ty cổ phần muốn có thêm vốn để phát triển, thì có thể gọi vốn bằng cách phát hành thêm cổ phiếu, tức là "in ra" cổ phiếu mới bán cho các nhà đầu tư. Khi làm như vậy, thì tỷ lệ sở hữu công ty của mỗi cổ phiếu giảm đi (ví dụ như khi số cổ phiếu của công ty tăng từ 9 triệu lên 10 triệu, thì mỗi cổ phần đang từ sở hữu 1 phần 9 triệu công ty giảm xuống còn 1 phần 10 triệu), nhưng bù lại tổng giá trị của công ty tăng lên (vì có thêm tiền bán cổ phiếu vào tài sản của công ty). Ngược lại, khi công ty có thừa tiền dự trữ, có thể mua lại bớt cổ phiếu của chính công ty trên thị trường chứng khoán. Khi làm như vậy thì số cổ phiếu của công ty giảm đi, kéo theo tỷ lệ sở hữu công ty của mỗi cổ phần tăng lên, nhưng bù lại tổng giá trị của công ty cũng giảm đi vì đã chi tiền cho việc mua cổ phần.

Các công ty cổ phần thường có chế độ phát hành một số cổ phiếu của công ty cho các nhân viên của công ty, theo một chế độ ưu đãi về giá và thời hạn mua. Việc bán "cổ phiếu ưu đãi" này là một hình thức trả thù lao cho các nhân viên của công ty, làm cho các nhân viên cũng trở thành cổ đông của công ty, với mục đích khiến cho họ gắn bó hơn

${ }^{(5)}$ Xem: http://en.wikipedia.org/wiki/Collateralized_debt_obligation 
với công ty và tích cực làm việc hiệu quả hơn, vì khi họ là cổ đông thì nếu công ty làm ăn có lãi họ cũng được hưởng theo.

Khi một công ty cổ phần làm ra lợi nhuận, thì thường giữ một phần lợi nhuận để phát triển doanh nghiệp, phần còn lại rút ra khỏi công ty để chia cho các cổ đông một cách tỷ lệ thuận với số cổ phần nắm giữ của từng cổ đông. Phần lợi nhuận đó được gọi là cổ tức (dividend), và lượng cổ tức mà mỗi cổ đông nhận được trong một lần chia cổ tức bằng số cổ phiếu của cổ đông đó nhân với số cổ tức trên đầu 1 cổ phiếu. Ví dụ, công ty General Electrics (mã cổ phiếu trên thị trường chứng khoán Mỹ: GE) trả cổ tức cho quí I năm 2010 là 0,10 USD/cổ phiếu. Như vậy, nếu ai sở hữu 1000 cổ phiếu GE, thì sẽ được trả cổ tức $1000 \times 0.1=100$ USD vào quí I năm 2010 .

Một điểm đặc biệt của các công ty cổ phần ở Việt Nam so với thế giới vào những năm đầu thế kỷ 21 là các công ty ở Việt Nam không chỉ chia cổ tức bằng tiền mặt, mà còn chia cổ tức bằng cổ phiếu. Ví dụ trong một lần chia, người nào đang giữ 10 cổ phiếu của công ty XYZ nào đó ở Việt Nam được thêm 5 cổ phiếu XYZ nữa, và 5 cổ phiếu đó được gọi là "cổ tức trả bằng cổ phiếu". Ở nước ngoài, việc chia này không gọi là "chia cổ tức" mà gọi là "chia nhỏ cổ phiếu" (stock split), bởi vì việc chia này không hề rút tiền ra khỏi công ty để chia cho cổ đông, mà chỉ làm tổng số cổ phiếu tăng lên và tỷ lệ sở hữu công ty của mỗi cổ phiếu giảm đi tương ứng. Ở Việt Nam, sở dĩ nó được gọi là "cổ tức trả bằng cổ phiếu" bởi vì mệnh giá (par value) của cổ phiếu ở Việt Nam thường là cố định (phổ biến nhất là loại mệnh giá 10 nghìn VND), công ty muốn tăng số cổ phiếu lên thì cần tăng vốn pháp định (legal capital) (số cổ phiếu bằng vốn pháp định chia cho mệnh giá của một cổ phiếu), và các công ty cổ phần ở Việt Nam (hoặc mới cổ phần hoá) thường lấy vốn chủ sở hữu làm vốn pháp định. Trong khi đó, ở nước ngoài, khái niệm mệnh giá của cổ phiếu là một khái niệm "cổ xưa" (archaic) chỉ còn được dùng với tính chất tượng trưng chứ không ai còn quan tâm đến nó, vì nó không phản ảnh gì hết. Ví dụ, mệnh giá của cổ phiếu của hãng Google (mã chứng khoán: GOOG) là 0.001USD trong khi giá cổ phiếu của Google vào thời điểm đầu năm 2010 là hơn 500USD, tức là gấp hơn 500 nghìn lần mệnh giá.

Độ lớn của một công ty cổ phần có thể được đo bằng nhiều thước đo khác nhau, ví dụ như doanh thu trong một năm, số nhân viên, v.v., và một cách đo phổ biến trên thị trường chứng khoán là vốn hóa (market capitalization), hay còn gọi là thị giá vốn. Vốn hóa của một công ty cổ phần bằng giá của cổ phiếu của công ty đó nhân với tổng số cổ phiếu phát hành. Nói cách khác, vốn hóa của một công ty cổ phần là giá trị của nó, tính theo giá cổ phiếu trên thị trường chứng khoán. Công ty nào có vốn hóa càng cao thì tức 
là được các nhà đầu tư đánh giá là càng có giá trị. Tất nhiên, giá cổ phiếu trên thị trường biến động thường xuyên theo qui luật cung cầu, và do đó vốn hóa của một công ty cổ phần cũng biến động theo.

Các công ty có vốn hóa lớn nhất trên một thị trường cổ phiếu nào đó thường được gọi theo tiếng lóng là các blue chip. Ví dụ, Tập đoàn Bảo Việt (mã chứng khoán: BVH) là một blue chip trên thị trường Việt Nam, với vốn hóa vào $01 / 2011$ vào khoảng 60 nghìn tỷ VND (gần 3 tỷ USD). Nguồn gốc của thuật ngữ blue chip là từ sòng bạc ở Monte Carlo: blue chip là loại đồng xu của sòng bạc có giá trị cao nhất trong các đồng xu dùng để đặt cược đánh bạc. Thuật ngữ này cũng cho thấy "khía cạng sòng bạc" của thị trường chứng khoán: thị trường chứng khoán còn được gọi là sòng bạc lớn nhất thế giơoi, bởi có rất nhiều người tham gia nó không phải do nhu cầu hay mục đích đầu tư thật sự, mà là để mua đi bán lại nhiều lần các chứng khoán nhằm kiếm lời nhanh chóng, nhưng chịu rủi ro rất cao và rất dễ bị thua lỗ, như là đánh bạc. Một ví dụ về sự mua đi bán lại nhiều lần đó là cổ phiếu của một hãng dược phẩm nhỏ có tên là XOMA: công ty XOMA chỉ có tổng cộng gần 22 triệu cổ phiếu phát hành, nhưng trong hai tháng 12/2010 và 01/2011 đã giao dịch đến 200 triệu cổ phiếu trên thị trường, tức là trung bình mỗi cổ phiếu XOMA được mua đi bán lại 9 lần trong vòng 2 tháng đó!

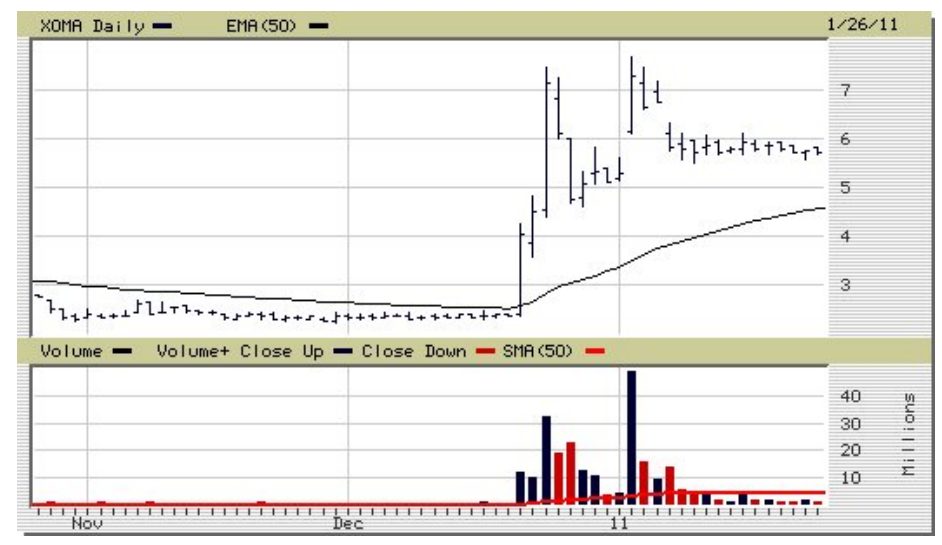

Hình 2.2: Giá và lượng giao dịch cổ phiếu XOMA, 11/2010-01/2011

Độ lớn của một thị trường cổ phiếu có thể được đo bằng tổng vốn hóa (total market capitalization) của thị trường đó, tức là tổng vốn hóa của các công ty cổ phần có cổ phiếu được giao dịch trên thị trường. Vào thời điểm cuối năm 2009, thị trường chứng khoán Việt Nam là một thị trường "mới nổi" còn nhỏ, tổng vốn hóa của các cổ phiếu phiếu niêm yết ở Việt Nam (không kể các cổ phiếu "over-the counter" (OTC), tức là các cổ phiếu có giao dịch nhưng không có niêm yết chính thức) là vào khoảng 600 nghìn tỷ VND, tương 
đương với hơn 30 tỷ USD. Để so sánh, vào thời điểm đó, tổng vốn hóa của các thị trường cổ phiếu trên thế giới là vào khoảng 50 nghìn tỷ USD (gấp hơn 1 nghìn lần so với Việt Nam), và một công ty lớn như Procter and Gamble (có nhiều sản phẩm gia dụng bán ở Việt Nam) đã có vốn hóa ở mức 180 tỷ USD.

Hầu hết các cổ phiếu trên thị trường chứng khoán là cổ phiếu phổ thông (common stock), cho quyền bỏ phiếu về các hoạt động của công ty, bầu ban giám đốc, v.v., với mỗi cổ phiếu thì được 1 phiếu biểu quyết. Ngoài cổ phiếu phổ thông, có những cổ phiếu đặc biệt có quyền biểu quyết nhiều hơn các cổ phiếu khác (ví dụ như cổ phiếu do các cổ đông sáng lập của một công ty nắm giữ có thể có quyền biểu quyết gấp mấy lần các cổ phiếu khác của công ty đó), nhưng những cổ phiếu như vậy nói chung rất hiếm và không có giao dịch trên thị trường. Có một loại cổ phiếu khác, đối ngược lại với cổ phiếu phổ thông, tương đối hiếm nhưng có giao dịch trên thị trường thế giới, gọi là cổ phiếu ưu tiên (preferred stock). Cổ phiếu ưu tiên không cho quyền bỏ phiếu về các hoạt động của công ty. Bù lại nó được ưu tiên hơn cổ phiếu phổ thông về mặt tài chính: đảm bảo hơn về trả cổ tức so với cổ phiếu phổ thông, và nếu công ty phá sản, phải thanh toán hết tài sản đi để trả nợ, thì sau khi trả nợ hết xong (nếu có đủ tiền để trả hết nợ sau khi thanh toán tài sản), phần còn lại phải chia cho các cổ phiếu ưu tiên trước, nếu còn gì thì mới đến lượt cổ phiếu phổ thông. Trong cuốn sách này, chúng ta sẽ tạm thời bỏ qua các loại cổ phiếu ưu tiên và cổ phiếu đặc biệt, và khi nói đến các cổ phiếu, chúng ta sẽ hiểu là cổ phiếu phổ thông. Các cổ phiếu trên các sàn giao dịch chứng khoán ở Việt Nam vào thời điểm 2010 đều là cổ phiếu phổ thông.

Trên thế giới, khoảng một nửa số cổ phiếu là do các cá nhân nắm giữ; phần còn lại nằm trong tay các tổ chức tài chính, như là các quỹ lương hưu, quỹ tương hỗ, công ty bảo hiểm.

Một xu hướng trên thế giới trong những năm gần đây là sự phát triển của các quỹ được gọi theo tiếng Anh là Exchange Traded Funds (viết tắt là ETFs), tức là các quỹ đầu tư chứng khoán, mà quyền sở hữu tài sản của chúng cũng được chia thành các cổ phần, và cổ phiếu của chúng cũng được giao dịch trên thị trường chứng khoán, y như là các công ty cổ phần. Loại cổ phiếu ETFs này mới xuất hiện ở Mỹ từ năm 1993 và ở châu Âu từ năm 1999, và ngày nay đã trở thành một công cụ đầu tư được ưa chuộng. Ví dụ như nếu một nhà đầu tư muốn đầu tư vào ngành công nghệ bán dẫn điện tử, thì có thể mua cổ phiếu của một ETF đại diện cho ngành đó, sẽ dễ quản lý hơn và chịu phí giao dịch thấp hơn là nếu mua trực tiếp cổ phiếu của nhiều công ty khác nhau trong ngành đó. Vào năm 2010, chỉ riêng nước Mỹ đã có đến hơn 900 ETFs, với tổng tài sản lên đến 
gần 900 tỷ USD(6).

Có nhiều ETFs khác nhau, đầu tư vào các loại chứng khoán hay tài sản khác nhau, và do đó nhà đầu tư có thể chọn mua bán cổ phiếu của ETF nào đó như là một hình thức đầu tư vào loại tài sản hay chứng khoán tương ứng. Một số ví dụ trên thị trường Mỹ:

- Quỹ đầu tư theo chỉ số S\&P500, với mã chứng khoán SPY. Cổ phiếu SPY là cổ phiếu có tính thanh khoản cao nhất trên thế giới.

- Quỹ đầu tư trái phiếu dài hạn, với mã chứng khoán TLT. Thay vì mua các trái phiếu chính phủ dài hạn, có thể mua TLT, sẽ được mức lợi nhuận tương tự, mà lại có thể được lệ phí giao dịch rẻ hơn là nếu mua thẳng các trái phiếu, và có thể mua ở số lượng nhỏ hơn so với nếu mua trái phiếu.

- Quỹ đầu tư vào vàng, với mã chứng khoán GLD. Thay vì mua bán vàng (là một công việc lích kích hơn), có thể đầu cơ giá vàng bằng cách mua bán GLD trên thị trường cổ phiếu.

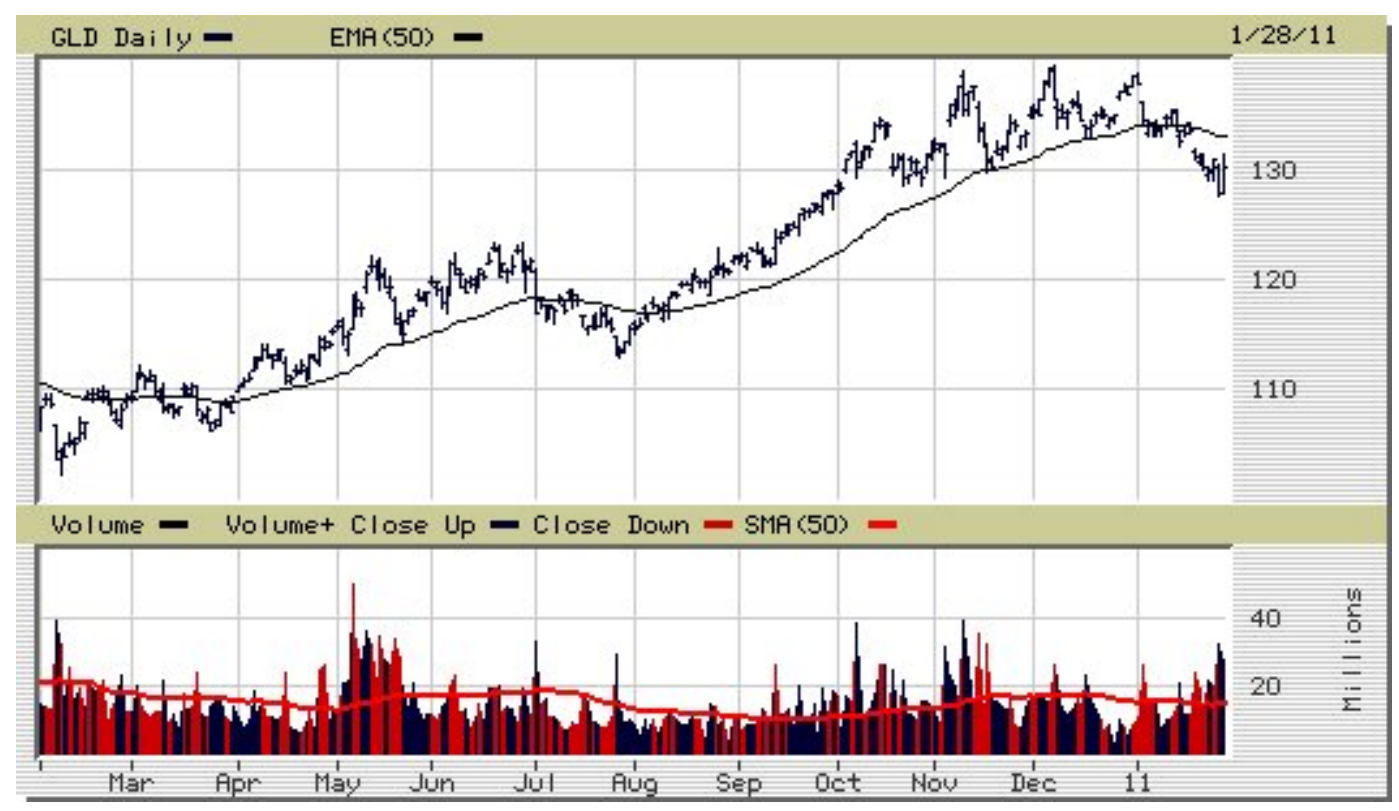

Hình 2.3: Giá cổ phiếu GLD (02/2010-01/2011) phản ánh giá vàng

${ }^{(6)}$ Xem: http://en.wikipedia.org/wiki/Exchange-traded_fund 


\subsection{Các chứng khoán phái sinh}

Các chứng khoán phái sinh (derivatives) là các chứng khoán được sinh ra từ các chứng khoán khác. Trong phần này chúng ta sẽ điểm qua một số chứng khoán phái sinh thông dụng nhất trên các thị trường tài chính.

\subsubsection{Hợp đồng kỳ hạn và hợp đồng tương lai}

Hình dung một tình huống sau: một công ty xây dựng sẽ cần nhiều thép cho các hợp đồng xây dựng được ký từ trước nhưng có giai đoạn đến năm sau mới triển khai, với giá thành xây dựng đã được cố định trong hợp đồng. Công ty sẽ không tích trữ thép từ bây giờ để năm sau dùng, vì làm như vậy sẽ vừa kẹt tiền vừa tốn công bảo quản. Thế nhưng, nếu đợi đến năm sau mới mua thép cho nhu cầu của năm sau, thì sẽ có một rủi ro là giá thép trên thị trường có thể tăng mạnh, làm cho lợi nhuận của tông ty trở nên bấp bênh. Để giảm thiểu sự bấp bênh đó, công ty có thể ký một hợp đồng với một công ty sản xuất hay thương mại thép, mua thép cho năm sau, đến năm sau mới trao hàng và giả tiền, nhưng cố định giá từ bây giờ. Một hợp đồng kiểu như vậy gọi là một hợp đồng kỳ hạn (forward contract), hay còn gọi là hợp đồng đặt trước. Đối với công ty sản xuất thép, việc ký các hợp đồng kỳ hạn để bán thép cũng có lợi là làm đảo bảo doanh thu, giảm được rủi ro về doanh thu nếu như giá thép giảm đi trong năm tới.

Theo ngôn ngữ tài chính, một hợp đồng kỳ hạn (forward contract) là một hợp đồng mua bán một mặt hàng nào đó, với một giá ân định nào đó gọi là giá kỳ hạn (forward price), vào một thời điểm nào đó trong tương lai (kỳ hạn của hợp đồng), gọi là thời điểm giao hàng (delivery time). Các hợp đồng kỳ hạn (nếu được dùng đúng đắn) có tác dụng giúp cho cả bên mua lẫn bên bán giảm thiểu được rủi ro về biến động giá cả, kiểm soát được tốt hơn tình hình tài chính.

Hầu như mặt hàng nào cũng có thể trở thành đối tượng của hợp đồng kỳ hạn. Nếu mặt hàng là một loại chứng khoán, ví dụ như cổ phiếu của một công ty nào đó, thì hợp đồng kỳ hạn trở thành một loại chứng khoán phái sinh từ cổ phiếu đó.

Các hợp đồng kỳ hạn đóng vai trò quan trọng trong quản lý tài chính, nhưng chúng vẫn đi kèm một số rủi ro như:

- Rủi ro về đối tác: một trong hai bên ký hợp đồng kỳ hạn có thể bị phá sản, hay đơn phương phá hợp đồng, gây thiệt hại cho bên kia.

- Rủi ro về thanh khoản: khó khăn trong việc chuyển nhượng hợp đồng, nếu như đổi 
ý không còn muốn giữ hợp đồng nữa.

Đối với những các hàng hóa thông dụng nhất, ví dụ như vàng, dầu hỏa, gạo, cà phê, ngoại tệ mạnh, v.v., có một loại sản phẩm phái sinh khác, gọi là hợp đồng tương lai (futures), tương tự như là hợp đồng kỳ hạn, nhưng cộng thêm với ưu điểm là có tính thanh khoản cao (có thể mua đi bán lại dễ dàng trên thị trường), và giảm thiểu rủi ro về đối tác.

Tương tự như hợp đồng kỳ hạn, mỗi hợp đồng tương lai cũng có qui định mặt hàng (loại hàng và số lượng), và thời điểm kỳ hạn. Ví dụ, một hợp đồng tương lai vào thời điểm 30/01/2011 có thể là cho "một thùng dầu hỏa vào thời điểm 30/04/2011". Điểm khác biệt lớn nhất giữa hợp đồng tương lai và hợp đồng kỳ hạn, là hợp đồng tương lai thanh toán bằng tiền, chứ không có sự trao đổi hàng hóa thực sự khi đáo hạn. Ví dụ, một người mua một hợp đồng tương lai "một thùng dầu hỏa vào thời điểm 30/04/2011 với giá 95\$". Giá $95 \$$ ở đây không có nghĩa là người mua phải trả $95 \$$ để có hợp đồng tương lai đó, mà là giá tương lai của thùng dầu cho thời điểm tương lai 30/04/2011. (Khi bắt đầu mua hay bán hợp đồng tương lai, thì không phải trả tiền gì cả và cũng không được nhận tiền gì cả, ngoài chuyện trả lệ phí môi giới chứng khoán). Đến thời điểm đáo hạn 30/04/2011, nếu giá thùng dầu hỏa là $100 \$$, thì người mua hợp đồng tương lai trên lãi $5 \$=100 \$$ $95 \$$, còn người bán thì bị lỗ từng đó. Nhưng không có dầu hỏa nào trao tay, mà chỉ có khoản tiền $5 \$$ chạy từ tài khoản của người bán sang tài khoản của người mua. Ngược lại, nếu giá dầu hỏa lúc đó là $87 \$$, thì $95 \$-87 \$=8 \$$ chạy từ tài khoản của người mua sang người bán.

Thực ra, không phải đợi đến lúc đáo hạn hợp đồng tương lai, thì tiền mới chạy từ người bị lỗ sang người được lãi từ hợp đồng tương lai giữa các bên tham gia, mà là tiền chạy giữa các tài khoản một cách liên tục hàng ngày, tùy theo giá của hợp đồng tương lai tăng lên hay giảm đi. Chẳng hạn khi giá tăng lên, thì giá trị tài khoản của người mua được tự khắc tính tăng lên theo, còn giá trị tài khoản của người bán bị tính giảm đi. Để có thể tham gia các hợp đồng tương lai, các bên mua và bên bán (gọi là Long và Short) các hợp đồng đó không cần phải có đủ tiền để mua được lượng hàng hóa ghi trong hợp đồng tương lai (và không cần phải có hàng để giao), mà chỉ cần có một khoản tiền tối thiểu để trong tài khoản chứng khoán (gọi là margin requirement) đảm bảo cho khả năng thanh toán bằng tiền mặt (tức là trong trường hợp bị thua, thì tài khoản cũng không bị về số âm). Nếu như giá trị của tài khoản bị giảm xuống dưới mức yêu cầu margin tối thiểu, thì các hợp đồng đang giữ có thể bị công ty chứng khoán tự động hủy đi (đem ra bán lại trên thị trường) để ngăn chặn rủi ro phá sản của người giữ tài khoản. 
Do thanh toán bằng tiền thay vì bằng hàng, tính thanh khoản cao tiện lợi cho việc mua bán, và do yêu cầu vốn tối thiểu (margin requirement) đảm bảo hầu như không có rủi ro về đối tác, nên nhiều hợp đồng tương lai (đặc biệt là cho các loại hàng phổ biến nhất như dầu hỏa và vàng) trở thành các công cụ đầu cơ lớn được giới đầu cơ ưa thích. Ví dụ có rất nhiều người không hề có nhu cầu về dầu hỏa, nhưng vẫn đầu cơ giá dầu hỏa theo các hợp đồng tương lai. Việc đầu cơ này dẫn đến sự biến động giá cả rất mạnh của nhiều mặt hàng thông dụng.

Phần lớn các giao dịch trên thị trường commodities là các giao dịch hợp đồng tương lai. Có thể xem giá cả cho hợp đồng tương lai của các mặt hàng phổ biến trên nhiều trang web khác nhau, ví dụ như Wall Street Journal ${ }^{(7)}$ CNN money ${ }^{(8)}$, v.v. Ngoài hợp đồng tương lai cho commodities, trên thị trường tài chính còn có các hợp đồng tương lai cho các thứ khác, ví dụ như hợp đồng tương lai cho trái phiếu chính phủ, hợp đồng tương lai cho chỉ số S\&P500, hợp đồng tương lai cho ngoại tệ, v.v.

\subsubsection{Quyền chọn}

Một quyền chọn (option) là quyền được mua hay bán một chứng khoán nào đó, với những điều kiện nào đó được đặt trước. Thị trường quyền chọn bắt đầu bùng nổ từ những năm 1970, sau khi xuất hiện các công trình lý thuyết về việc định giá quyền chọn của Black, Scholes, Merton. Scholes và Merton được giải thưởng Nobel năm 1997 vì các công trình này (lúc dó Black đã chết, và giải Nobel chỉ trao cho người còn sống). Hai loại quyền chọn phổ biến nhất là quyền chọn kiểu Âu (European option) và quyền chọn kiểu Mỹ (American option), mà chúng ta sẽ nghiên cứu kỹ hơn trong Chương 8 . Ngoài ra, trên thị trường còn có nhiều loại quyền chọn khác ít phổ biến hơn, được gọi chung là quyền chọn lạ (exotic options), ví dụ như quyền chọn có giới hạn (barrier option), quyền chọn kiểu Á (Asian option), v.v ${ }^{(9)}$

${ }^{(7)}$ Xem http://online.wsj.com/mdc/public/page/mdc_commodities.html

${ }^{(8)} \mathrm{Xem}$ http://money.cnn.com/data/commodities/

${ }^{(9)}$ Xem http://en.wikipedia.org/wiki/Option_(finance) 


\begin{tabular}{|c|c|c|c|c|c|c|c|}
\hline \multicolumn{8}{|c|}{ Giá quyền chọn của BAC, vào cuối ngày 28/01/2011 } \\
\hline \multicolumn{8}{|c|}{ Call Options Expire at close Friday, April 15, 2011} \\
\hline Strike & Symbol & Last & Chg & Bid & Ask & Vol & Open Int \\
\hline 12.00 & BAC110416C00012000 & 1.91 & +0.01 & 1.89 & 1.91 & 1011 & 4585 \\
\hline 13.00 & BAC110416C00013000 & 1.18 & +0.01 & 1.17 & 1.19 & 2372 & 9719 \\
\hline 14.00 & BAC110416C00014000 & 0.66 & +0.03 & 0.65 & 0.66 & 27321 & 52210 \\
\hline 15.00 & BAC110416C00015000 & 0.33 & +0.02 & 0.33 & 0.34 & 6859 & 46497 \\
\hline \multicolumn{8}{|c|}{ Put Options Expire at close Friday, April 15, 2011} \\
\hline Strike & Symbol & Last & Chg & Bid & Ask & Vol & Open Int \\
\hline 12.00 & BAC110416P00012000 & 0.29 & +0.03 & 0.28 & 0.29 & 907 & 31596 \\
\hline 13.00 & BAC110416P00013000 & 0.56 & +0.05 & 0.56 & 0.57 & 4243 & 40087 \\
\hline 14.00 & BAC110416P00014000 & 1.03 & +0.06 & 1.03 & 1.05 & 2950 & 22739 \\
\hline 15.00 & BAC110416P00015000 & 1.72 & -0.05 & 1.71 & 1.73 & 776 & 7696 \\
\hline
\end{tabular}

Để làm ví dụ, bảng phía trên là bảng giá một số quyền chọn kiểu Mỹ cho cổ phiếu $\mathrm{BAC}$ (Bank of America) với kỳ hạn là 15/04/2011, vào thời điểm cuối ngày 28/01/2011 (thông tin lấy từ trang web http://finance.yahoo.com). Một trong các dòng ở bảng trên cho ta thấy chứng khoán có mã là BAC110416C00014000 là American Call của cổ phiếu $\mathrm{BAC}$, với ngày hết hạn là ngày 15/04/2011, và giá thực hiện (strike price) là 14\$. Có nghĩa là, 1 cái Call BAC110416C00014000 cho phép người giữ nó mua 100 cổ phiếu BAC trước cuối ngày 16/04/2011 với giá $14 \$$ một cổ phiếu. (Một đơn vị option thường ứng với 100 cổ phiếu; ngày thứ sáu 15/04/2011 là ngày cuối cùng có thể mua bán quyền chọn này, nhưng ngày thứ bẩy 16/04/2011 là ngày cuối cùng được phép sử dụng quyền chọn này để mua cổ phiếu). Open interest của BAC110416C00014000 là 52210, có nghĩa là hiện có tổng cộng 52210 đơn vị chứng khoán BAC110416C00014000 được thiết lập trên thị trường (tức là các nhà đầu tư bên mua quyền chọn nắm giữ tổng cộng 52210 cái Call đó, ứng với quyền mua hơn 5 triệu cổ phiếu $\mathrm{BAC}$ với giá $14 \$$, và ngược lại các nhà đầu tư bên bán quyền chọn bán ra từng đó cái Call cổ phiếu $\mathrm{BAC}$ với giá thực hiện 14 và kỳ hạn 15/04/2011). Giá của Call đó là $0.66 \$$ trên một đơn vị cổ phiếu, có nghĩa là $66 \$$ cho một đơn vị quyền chọn, bởi vì mỗi quyền chọn ở đây ứng với 100 cổ phiếu. Con số Volume 27321 là số lượng đơn vị quyền chọn mua này được giao dịch trong ngày 28/01/2011 trên thị trường, giá Bid 0.65\$ là giá mua (có người muốn mua với giá đó), giá Ask $0.66 \$$ là giá bán (có người muốn bán với giá đó). Giá Last tức là giá giao dịch của lần giao dịch cuối cùng. Change (Chg) tức là độ thay đổi giá so với ngày hôm trước.

Các quyền chọn có nhiều công dụng khác nhau như: 
Phòng chống rủi ro. Ví dụ nếu ai đó sợ là giá chứng khoán mình đang giữ có thể bị giảm mạnh, thì có thể mua Put (quyền chọn bán) để đề phòng sự sụt giảm đó, vì Put cho phép bán lại chứng khoán với giá cố định từ trước. Mua Put cho chứng khoán đang giữ là hình thức làm bảo hiểm cho chứng khoán đó, và giá của Put là giá phải trả cho sự bảo hiểm này.

Thêm thu nhập. Ví dụ giá cổ phiếu của BAC vào thời điểm 28/01/2011 là 13.59\$. Một người giữ 100 cổ phiếu BAC có thể bán 1 đơn vị Call BAC (ứng với 100 cổ phiếu) loại giá thực hiện $=15$ và hết hạn vào $15 / 04 / 2011$ đi, được $33 \$$ (chưa trừ phí giao dịch) thêm vào thu nhập. Nếu như đến cuối ngày 15/04/2011 mà giá của BAC dưới 15\$, thì người ngày vẫn giữ nguyên 100 cổ phiếu $\mathrm{BAC}$ của mình, và được hưởng không chỗ $33 \$$ từ việc bán Call. Nếu như giá cổ phiếu BAC vào cuối ngày 15/04/2011 lên trên $15 \$$, thì người này bắt buộc phải bán đi 100 cổ phiếu của mình với giá $15 \$$, vì cái Call mà người đó bán. Nhưng trong trường hợp này thì cũng có lãi đáng kể so với trước, bởi vì lúc trước giá $\mathrm{BAC}$ chỉ có $13.59 \$$ mà sau đó bán đi với giá $15 \$$, cộng thêm với tiền thu được từ bán Call, tức là tương đương với việc bán được $\mathrm{BAC}$ với giá 15.33 \$ trong trường hợp thứ hai này.

Đòn bẩy đầu cơ. Ví dụ, có một người khác đoán rằng giá của $\mathrm{BAC}$ vào cuối ngày $15 / 04 / 2011$ sẽ là $17 \$$. Nếu mua cổ phiếu với giá $13.59 \$$ và đợi đến lúc đó thì sẽ lãi $17 \$-13.59 \$=3.41 \$$, tức là lãi khoảng $25 \%$ trên số tiền vốn bỏ ra. Nhưng nếu mua Call phía trên với giá $0.33 \$$ trên đầu 1 cổ phiếu, thì cái Call đó đến ngày 15/04/2011 sẽ có giá trị thành $17 \$-15 \$=2 \$$ trên đầu 1 cổ phiếu, tức là lãi trên $500 \%$ nếu là mua Call, thay vì chỉ lãi $25 \%$ nếu là mua cổ phiếu. Đấy chính là tính chất đòn bẩy của quyền chọn: cùng một lượng tiền bỏ ra, thì dùng quyền chọn có thể "điều khiển" được một lượng cổ phiếu nhiều gấp mấy lần so với nếu mua cổ phiếu. Tất nhiên, đòn bẩy càng cao thì mức độ rủi ro càng cao, càng dễ bị mất hết tiền khi gặp tình huống không thuận lợi.

\subsubsection{Hợp đồng hoán đổi}

Một hợp đồng hoán đổi (swap) là một hợp đồng đổi một chứng khoán hay tài sản nào đó lấy một chứng khoán hay tài sản khác. Một ví dụ phổ biến là swap lãi suất (interest rate swap): một chứng khoán nợ với lãi suất cố định (fixed rate) có thể được đổi lấy một chứng khoán nợ với lãi suất thay đổi (variable rate - có những hợp đồng nợ, mà mức lãi suất của nó thay đổi theo mức lãi suất tham chiếu của ngân hàng trung ương, hay là thay đổi theo tỷ lệ lạm phát, v.v.). 
Các hợp đồng bảo hiểm cũng có thể coi như là các chứng khoán swap: đổi những khoản tiền đóng bảo hiểm định kỳ, lấy một khoản tiền lớn nếu mà tình huống nào đó xảy ra. Tài sản thứ nhất là một dòng tiền định kỳ, tài sản thứ hai là một loại quyền chọn có điều kiện: nếu điều gì đó xảy ra thì sẽ được trả bao nhiêu tiền, và hai tài sản đó được đổi cho nhau trong một hợp đồng bảo hiểm.

Trên thị trường chứng khoán nợ, ngoài các swap lãi suất, còn có một loại swap rất phổ biến khác, là CDS (credit default swap). CDS là một hình thức bảo hiểm cho các chứng khoán nợ (ví dụ như các trái phiếu hay các CDO). Theo hợp đồng CDS này, thì bên mua CDS sẽ nộp tiền định kỳ cho bên bán CDS, và nếu như các con nợ của các chứng khoán nợ qui định trong CDS đó bị vỡ nợ, giá trị của chứng khoán nợ sụt giảm mạnh, thì bên bán CDS phải bồi thường một khoản tiền nào đó cho bên mua CDS trong trường hợp đó.

So với các hợp đồng bảo hiểm nợ thông thường, thì CDS có những điểm rất khác biệt như sau:

- Bên mua CDS không nhất thiết phải giữ chứng khoán nợ ghi trong hợp đồng CDS. Khi các chứng khoán nợ đó mất giá trị, thì bên mua CDS nhận được tiền từ bên bán CDS, dù có là đang giữ các chứng khoán nợ đó hay không.

- Bên bán CDS không nhất thiết phải là công ty bảo hiểm, mà có thể đơn thuần là các nhà đầu tư hay đầu cơ.

Nói cách khác, các CDS dựa trên mô hình bảo hiểm nợ, nhưng trở thành công cụ đầu cơ trong tay nhiều người. Một phần lớn CDS đang có trên thị trường chứng khoán không thực sự phục vụ bảo hiểm cái gì hết, mà chỉ là trò đầu cơ và đánh cược giữa các bên với nhau.

Thường chỉ có các nhà đầu tư lớn và các tổ chức tài chính tham gia thị trường CDS, bởi mỗi hợp đồng CDS là ứng với (bảo hiểm một lượng) chứng khoán nợ có giá trị 10-20 triệu USD, và giá phải trả cho một CDS thường không dưới 50 nghìn USD một năm(10).

\subsection{Các trung gian tài chính}

Các trung gian tài chính, tức là các tổ chức tài chính, thường được chia làm 3 loại như sau:

1) Các tổ chức nhận tiền gửi, như các ngân hàng, tổ chức tín dụng, hiệp hội cho vay và tiết kiệm.

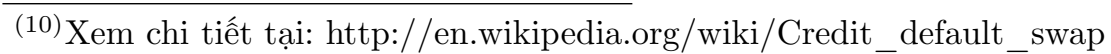


2) Các công ty bảo hiểm và quỹ lương hưu.

3) Các trung gian đầu tư, như các công ty chứng khoán, quỹ đầu tư, ngân hàng đầu tư , công ty tài chính.

Nhờ có ba loại trung gian tài chính này mà các khoản vốn dự trữ của mọi người, từ những người dân thường có ít tiền tiết kiệm cho đến các công ty lớn có nhiều tiền dư thừa, có thể được huy động triệt để.

Tất nhiên, cách chia trên chỉ là tương đối, và có những tổ chức tài chính lớn có thể thuộc vào cả 3 loại trên. Có thể hiểu đây là cách chia theo mức độ rủi ro và lợi nhuận mà các tổ chức tài chính mang lại cho các khách hàng:

Loại tổ chức tài chính thứ nhất là nơi cung cấp dịch vụ thanh toán và gửi tiền cho khách hàng. Những khoản tiền thừa chưa chi tiêu vào đâu, thì gửi ở ngân hàng là an tâm nhất, và khi cần chi tiêu có thể thanh toán qua các dịch vụ của ngân hàng (như dùng thẻ nhà băng, ký séc, thanh toán điện tử, hay rút tiền mặt). Nhưng gửi ở đó thì nói chung chỉ được lãi suất thấp (so với nếu đem đi đầu tư), thậm chí nhiều nơi lãi suất bằng 0 . Có thể nói là các tổ chức tài chính thuộc loại thứ nhất không làm tăng giảm rủi ro tài chính đáng kể cho khách hàng gửi tiền, nhưng cũng không đem lại cho các khách hàng đó nhiều thu nhập từ số tiền mà họ có.

Loại tổ chức tài chính thứ hai cung cấp dịch vụ bảo hiểm cho khách hàng (lương hưu cũng được coi là một thứ bảo hiểm tài chính cho lúc tuổi già không còn sức làm việc). Nhờ có loại này, mà các khách hàng được an toàn hơn về tài chính. Ví dụ, nếu một người đi ô tô gây ra tai nạn, mà không có bảo hiểm, thì có khi sạt nghiệp vì tiền phải đền cho các nạn nhân, nhưng khi có bảo hiểm thì công ty bảo hiểm sẽ đứng ra đền cho. (Cũng chính vì vậy, mà ở nhiều nước, xe ô tô bắt buộc phải có bảo hiểm trách nhiệm). Tất nhiên, để có bảo hiểm, khách hàng phải mua bảo hiểm, và tổng các khoản tiền mua bảo hiểm từ các khách hàng khác nhau nói chung phải lớn hơn đáng kể tổng các khoản tiền bồi thường mà công ty bảo hiểm phải chi ra. Từ góc độ lợi nhuận, thì lợi nhuận của khách hàng mua bảo hiểm là số âm, nhưng bù lại khách hàng giảm thiểu được các rủi ro tài chính.

Loại tổ chức tài chính thứ ba là loại cung cấp cho khách hàng kỳ vọng lợi tức cao hơn cho số vốn của khách hàng, nhưng đổi lại khách hàng phải chấp nhận mức rủi ro tài chính cao hơn, so với nếu gửi tiền ở loại tổ chức tài chính thứ nhất. Muốn có thu nhập cao hơn từ tiền vốn của mình, thì thay vì gửi tiền ở ngân hàng, một người có thể đem tiền đi đầu tư, ví dụ bằng cách cho ai đó vay với lãi suất cao, hoặc mua cổ phiếu của một công ty nào đó. Nhưng nếu cho trực tiếp người nào đó vay, thì khả năng rủi ro bị quịt nợ có thể cao, và nếu mua cổ phiếu nào đó, mà không nắm được rõ cổ phiếu mình mua ra sao, thì 
khả năng rủi ro bị thua lỗ cũng rất cao. Hơn nữa, những việc đầu tư như vậy có thể rất tốn thời gian công sức và các chi phí khác (chi phí giao dịch, chi phí thông tin, v.v.). Để hòng giảm bớt rủi ro và chi phí, mà vẫn kỳ vọng có được mức lợi nhuận lớn hơn là gửi tiền ở ngân hàng, thì người đó có thể tìm đến loại trung gian tài chính thứ ba, tức là các trung gian đầu tư.

Đối với các khách hàng cần vốn, thì cả ba loại tổ chức tài chính trên đều có thể cung cấp vốn hoặc giúp tìm nguồn vốn, dưới các hình thức khác nhau, tùy theo mức độ rủi ro chấp nhận được. Các ngân hàng hầu như sẽ không mua cổ phần của các công ty, mà chủ yếu là cho vay trực tiếp đến các công ty và người tiêu dùng hay mua trái phiếu chính phủ, là những hình thức tương đối ít rủi ro và đem lại tiền lãi đều đặn. Các công ty bảo hiểm và quỹ hưu trí có thể mua cả trái phiếu lẫn cổ phiếu, nhưng vẫn phải đảm bảo mức rủi ro tương đối thấp và đảm bảo thanh khoản cho tài sản của mình, vì các tổ chức tài chính này vẫn luôn cần trích tiền ra để trả lương hưu và bồi thường bảo hiểm. Các trung gian đầu tư thì ít bị hạn chế hơn về mức rủi ro chấp nhận được, và nói chung công cụ tài chính nào cũng có trung gian đầu tư tham gia được. Đặc biệt là có các quỹ đầu tư mạo hiểm, gọi là hedge funds, chuyên đầu tư vào các chứng khoán phái sinh có độ rủi ro rất cao.

Chi tiết thêm về các loại tổ chức tài chính phổ biến nhất:

Ngân hàng thương mại (commercial banks). Các ngân hàng thương mại huy động vốn chủ yếu dưới dạng: tiền gửi thanh toán (checkable deposits), tiền gửi tiết kiệm (saving deposits), tiền gửi có kì hạn (time deposits). Vốn huy động được dùng để cho vay, như cho vay thương mại (commercial loans), cho vay tiêu dùng (consumer loans), cho vay bất động sản trả góp (mortgage loans) và để mua chứng khoán chính phủ, trái phiếu của chính quyền địa phương. Ngoài ra, ngân hàng thương mại còn cung cấp các dịch vụ thanh toán và buôn bán ngoại tệ. Ngân hàng thương mại dù ở quốc gia nào cũng đều là nhóm trung gian tài chính lớn nhất. Đây cũng là các trung gian tài chính mà các chủ thể kinh tế giao dịch thường xuyên nhất.

Hiệp hội cho vay và tiết kiệm (savings and loan associations, viết tắt là $S \& L$ ). Các hiệp hội này huy động vốn chủ yếu thông qua tiền gửi tiết kiệm, tiền gửi có kỳ hạn và tiền gửi có thể viết séc được. Trước đây, những tổ chức này bị buộc phải dùng tiền để cho vay thế chấp nhà ở, nhưng về sau phạm vi cho vay được nới ra, và biên giới phân biệt giữa các hiệp hội $\mathrm{S} \& \mathrm{~L}$ và các ngân hàng lu mờ dần, và có thể coi chúng cũng giống như các ngân hàng.

Quỹ tín dụng (credit unions). Các quỹ tín dụng là tổ chức cho vay có tính chất hợp 
tác xã nhỏ và được tổ chức xung quanh một nhóm đặc biệt: các thành viên của hội, các nhân viên của một công ty nào đấy, vv. Họ huy động vốn từ các khoản tiền gửi gọi là cổ phần, và cơ bản là cho vay tiêu dùng. Ở Việt Nam, quỹ tín dụng tồn tại dưới dạng các tổ chức tín dụng hợp tác. Đây là tổ chức kinh doanh tiền tệ và làm dịch vụ ngân hàng, do các tổ chức, cá nhân và hộ gia đình tự nguyên thành lập để hoạt động ngân hàng theo Luật các tổ chức tín dụng và Luật hợp tác xã nhằm mục tiêu chủ yếu là tương trợ nhau phát triển sản xuất, kinh doanh và đời sống. Tổ chức tín dụng hợp tác gồm ngân hàng hợp tác, quỹ tín dụng nhân dân, hợp tác xã tín dụng và các hình thức khác.

Công ty bảo hiểm (insurance companies). Các công ty bảo hiểm có thể chia thành bảo hiểm nhân thọ và các loại bảo hiểm khác. Phần vốn chủ yếu của các công ty này là do bán các hợp đồng bảo hiểm. Người mua hợp đồng bảo hiểm phải trả tiền bảo hiểm định kỳ để duy trì các hợp đồng này. Các công ty sẽ phải trả tiền cho người mua hợp đồng bảo hiểm trong trường hợp có tai ương nào đó xảy ra (như cháy nhà, mất trộm, tai nạn giao thông, v.v.), theo qui định của hợp đồng. Trong trường hợp bảo hiểm nhân thọ, thì nếu người đóng bảo hiểm bị chết, người nhà sẽ nhận được các khoản tiền bồi thường theo hợp đồng. Số tiền mà các công ty bảo hiểm nhận được, trong khi chưa phải dùng để bồi thường cho các tai ương, được đầu tư trên thị trường tài chính, chủ yếu là vào các sản phẩm tài chính có độ rủi ro tương đối thấp, ví dụ như các trái phiếu của chính quyền địa phương. Một phần nhỏ số tiền cũng có thể được đầu tư vào các chứng khoán có độ rủi ro cao hơn, như là các cổ phiếu.

Quỹ lương hưu (pension funds). Các quỹ lương hưu có thể là quỹ nhà nước hay quỹ tư nhân. Các quỹ này thu tiền (trực tiếp hay gián tiếp) từ những người đang làm việc, và trả lương hưu cho những người đã nghỉ hưu. Những người đang làm việc thường bị trừ một phần tiền lương để đóng vào quỹ lương hưu bắt buộc, ngoài ra có thể tự nguyện đóng bổ sung vào các quỹ hưu không bắt buộc. Tài sản chủ yếu của các quỹ lương hưu nằm ở các trái phiếu và cổ phiếu được nắm giữ.

Công ty tài chính (financial companies). Các công ty tài chính có thể huy động vốn bằng cách bán thương phiếu ngắn hạn, phát hành cổ phiếu, trái phiếu, v.v., tương tự như là các công ty khác. Sau đó họ đầu tư vào những đối tượng khó huy động vốn hơn họ, ví dụ như cho các doanh nghiệp nhỏ vay vốn, cho người tiêu dùng vay tiền mua xe ô tô, v.v. Một số công ty tài chính có thể là công ty con của một doanh nghiệp lớn, chủ yếu phục vụ cho khách hàng của công ty mẹ. Ví dụ như Tổ chức tín dụng Ford Motor cho người tiêu dùng vay tiền để mua xe Ford của họ.

Quỹ đầu tư (investment funds). Các quỹ đầu tư, thường được gọi là các quỹ tương 
hỗ (mutual funds), huy động vốn từ các nhà đầu tư qua việc bán cổ phần, rồi đầu tư vào các chứng khoán khác nhau. Từ "hỗ tương" ở đây có nghĩa là các nhà đầu tư vào quỹ chia sẻ rủi ro (do đầu tư được vào nhiều chứng khoán khác nhau thông qua quỹ), chi phí quản lý đầu tư, và lợi nhuận. Các quỹ đầu tư có thể đầu tư trên thị trường tiền tệ, thị trường vốn, hoặc sử dụng những công cụ tài chính khác có rủi ro cao hơn, ví dụ như các sản phẩm phái sinh. Các quỹ đầu tư sử dụng các công cụ tài chính có độ rủi ro cao (hòng đạt lợi nhuận cao) được gọi là các hedge fund. Trong khi các quỹ đầu tư "cổ điển" khó có thể phá sản, thì các hedge fund có độ rủi ro phá sản cao, với một trong các ví dụ điển hình là hedge fund "Long Term Capital Management" phá sản vào năm 1998(11).

Ngân hàng đầu tư (investment banks). Các ngân hàng đầu tư không phải là các ngân hàng theo nghĩa thông thường, mà thực ra là các công ty kinh doanh chứng khoán lớn, với một trong các công việc chính là giúp các khách hàng (là các tổ chức hay doanh nghiệp) phát hành chứng khoán. Đầu tiên họ đưa ra lời khuyên cho các tổ chức và doanh nghiệp nên phát hành loại chứng khoán nào (trái phiếu, cổ phiếu, hay trái phiếu chuyển đổi, v.v.) Sau đó họ làm bảo lãnh phát hành, tức là đảm bảo cho việc phát hành các chứng khoán được thành công, bằng cách mời chào các nhà đầu tư, mua một số lượng lớn chứng khoán từ nhà phát hành chứng khoán với giá thỏa thuận rồi bán lại chúng trên thị trường. Các ngân hàng đầu tư còn giúp các công ty thực hiện các việc mua bán hay sát nhập công ty (mergers and acquisitions, viết tắt là $M \& A)$, và hưởng phí dịch vụ từ hoạt động $M \& A$ đó. Các nghiệp vụ bảo lãnh phát hành và $M \& A$ được gọi là investment banking.

Dưới đây là một bảng thống kê tổng giá trị tài sản của một số loại trung gian tài chính phổ biến ở Mỹ vào các năm 1980 và 2005. So sánh các con số giữa năm 1980 và năm 2005 cho thấy sự phát triển rất nhanh của các tổ chức tài chính (và theo đó là sự phát triển rất nhanh của thị trường tài chính) trong 25 năm đó.

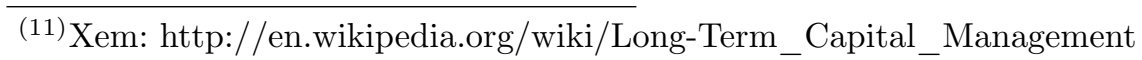




\begin{tabular}{|l|l|l|}
\hline Giá trị tài sản (cuối năm, theo đơn vị tỷ USD) & 1980 & 2005 \\
\hline Các ngân hàng thương mại & 1481 & 9156 \\
Các hiệp hội cho vay và tiết kiệm & 792 & 1750 \\
Các quỹ tín dụng & 67 & 688 \\
Các công ty bảo hiểm nhân thọ & 464 & 4351 \\
Các công ty bảo hiểm tai nạn và hỏa hoạn & 182 & 1242 \\
Các quỹ lương hưu tư nhân & 504 & 4527 \\
Các quỹ lương hưu nhà nước & 197 & 2661 \\
Các công ty tài chính & 205 & 1439 \\
Các quỹ đầu tư chứng khoán & 70 & 5882 \\
Các quỹ thị trường tiền tệ & 76 & 1877 \\
\hline
\end{tabular}

\subsection{Quản lý hệ thống tài chính}

Tầm quan trọng của hệ thống tài chính đối với một nền kinh tế có thể so sánh với tầm quan trọng của hệ thống tuần hoàn máu đối với cơ thể người: qua hệ thống tài chính mà vốn đến được nơi cần đến, qua đó kinh tế phát triển được. Khi hệ thống tài chính bị "mắc bệnh" thì sẽ ảnh hưởng rất xấu đến xã hội. Khủng hoảng tài chính thế giới 2008-2009, dẫn đến suy thoái kinh tế thế giới trong những năm đó, là một ví dụ. Để đảm bảo có một hệ thống tài chính lành mạnh thực hiện đúng các chức năng của nó, cần có các biện pháp quản lý và kiểm soát hiệu quả. Đây là một vấn đề rất phức tạp. Trong mục này chúng ta sẽ chỉ điểm qua một số biện pháp chính được áp dụng trên thế giới.

Hạn chế mạo hiểm. Các trung gian tài chính phải tuân theo một số qui định nào đó về quản lý rủi ro, hạn chế sử dụng đòn bẩy tài chính, và hạn chế các sản phẩm tài chính có mức mạo hiểm cao. Ví dụ, các ngân hàng thương mại có thể bị yêu cầu tuân theo các qui định Base $\underbrace{(12)}$, và bị hạn chế tham gia thị trường chứng khoán, để đảm bảo khỏi bị phá sản khi thị trường không thuận lợi. Đối với các công ty bảo hiểm, cũng có các qui định về lượng chứng khoán mạo hiểm (như cổ phiếu, chứng khoán phái sinh) được phép giữ. Đối với các cá nhân, cũng có qui định về hạn chế lượng mua bán chứng khoán và lượng tiền tối đa được phép vay, nhằm tránh cho họ khỏi bị phá sản.

Bảo hiểm tiền gửi. Chính phủ có thể bảo đảm tiền gửi của công dân để họ không phải chịu những thiệt hại tài chính lớn nếu trung gian tài chính giữ tiền của họ phá sản. Ví dụ, một loạt ngân hàng ở Mỹ phá sản trong giai đoạn suy thoái 1930-1933, làm cho

${ }^{(12)} \mathrm{Xem}$ http://en.wikipedia.org/wiki/Basel_Accords 
nhiều người dân mất tiền oan. Để ngăn chặn tình trạng đó, Mỹ đã thiết lập tổ chức bảo hiểm tiền gửi liên bang (FDIC) vào năm 1933, có nhiệm vụ bảo hiểm cho các tài khoản tiền gửi ở các ngân hàng, và các ngân hàng phải đóng tiền bảo hiểm cho FDIC. Từ năm 2008, số tiền tối đa mà FDIC bảo hiểm cho mỗi tài khoản tiền gửi là 250 nghìn USD.

Hạn chế lãi suất. Có các qui định về việc cấm các trung gian tài chính không được vay hay cho vay với lãi suất cao hơn những mức nào đó. Các qui định này có thể nhằm bảo vệ người đi vay khỏi bị bóc lột. Các qui định về lãi suất này cũng có thể xuất phát từ quan điểm điều tiết hoạt động của các ngân hàng, nhằm ngăn chặn sự cạnh tranh "quá đáng" về lãi suất giữa các ngân hàng (có nguy cơ làm nhiều ngân hàng phá sản).

Hạn chế tiếp cận. Có các qui định về các điều kiện tối thiểu để được phép tham gia những mảng nào đó trên thị trường tài chính. Ví dụ, một nhà đầu tư cần có vốn tối thiểu là bao nhiêu để được tham gia những loại hình đầu tư mạo hiểm cao. Một người phải có các chứng chỉ hành nghề nhận được qua các kỳ thi nào đó chứng tỏ đủ trình độ mới được phép làm các công việc trung gian tài chính nào đó. Một ngân hàng muốn được thành lập phải có đủ số vốn tối thiểu nào đó, và một lượng tối thiểu nhân viên có nghiệp vụ ngân hàng, v.v.

Minh bạch thông tin. Có các qui định về việc các thông tin quan trọng liên quan đến giá trị của các sản phẩm tài chính phải được công bố một cách minh bạch. Những qui định này nhằm giảm thiểu tình trạng thông tin bất đối xứng, đảm bảo quyền lợi cho các bên tham gia thị trường tài chính. Ví dụ, theo qui định của các ủy ban chứng khoán (là cơ quan chính phủ kiểm soát hoạt động của thị trường chứng khoán), các công ty cổ phần có cổ phiếu giao dịch trên các sàn chứng khoán phải thông báo công khai bảng cân đối kế toán tài chính định kỳ hàng quí, và thông báo công khai các tin tức quan trọng khác liên quan trực tiếp đến giá trị của cổ phiếu của công ty.

Kiểm toán độc lập. Để đảm bảo các thông tin tài chính công bố được trung thực và không có gian lận, trên thế giới có các công ty kiểm toán (audit firms), có chức năng kiểm tra sổ sách của các công ty khác. Tổng doanh thu (từ dịch vụ kiểm toán độc lập) của bốn công ty kiểm toán lớn nhất thế giới (Deloitte Touche Tohmatsu, PricewaterhouseCoopers, Ernst \& Young, KPMG)(13) trong năm 2010 đã lên đến gần 100 tỷ USD, chứng tỏ nhu cầu về kiểm toán trên thế giới rất lớn.

Đi kèm với việc yêu cầu minh bạch thông tin là chống giao dịch nội gián và chống lũng đoạn thị trường. Nếu như có những người "tay trong" (ví dụ một giám đốc điều hành của một công ty, hay người nhà của giám đốc) mà giao dịch cổ phiếu của công ty

(13) Xem http://en.wikipedia.org/wiki/Big_Four_(audit_firms) 
dựa trên thông tin quan trọng ảnh hưởng lớn đến giá trị cổ phiếu của công ty, mà thông tin đó chưa được công bố ra ngoài, thì bị phạm tội giao dịch nội gián (insider trading), có thể bị xử tù theo luật hình sự. Có những nhân vật nổi tiếng, ví dụ như bà Martha Stewart ${ }^{(14)}$, cũng đã từng bị xử tù vì giao dịch nội gián. Lũng đoạn thị trường là khi có một nhóm người cố tình lũng đoạn giá chứng khoán (ví dụ như thổi giá của một chứng khoán nào đó lên mức cao bất bình thường trong một thời gian ngắn, qua các hình thức như tự mua tự bán cho chính mình để làm giá, tung các tin đồn hay báo cáo phân tích rởm, v.v.), qua đó kiếm lợi và gây thiệt hại cho các nhà đầu tư khác. Tuy rằng các cơ quan kiểm soát có điều tra về các hiện tượng lũng đoạn thị trường, nhưng nó vẫn hay xảy ra trên thế giới, và thị trường hay chứng khoán nào càng nhỏ thì càng dễ bị lũng đoạn, gây thiệt hại cho các nhà đầu tư.

${ }^{(14)}$ Xem http://en.wikipedia.org/wiki/Martha_Stewart 


\section{Chương 3}

\section{Kinh doanh chênh lệch giá}

\subsection{Khái niệm kinh doanh chênh lệch giá}

Ở dạng đơn giản nhất, cơ hội kinh doanh chênh lệch giá (arbitrage) xảy ra khi mà tại một thời điểm nào đó, giá cả của cùng một mặt hàng có sự chênh lệch giữa một người muốn bán và một người muốn mua, và giá rao mua lại cao hơn giá rao bán. Ví dụ, một nhà đầu tư $\mathrm{A}$ muốn mua một cổ phiếu $\mathrm{X}$ nào đó với giá 75 , trong khi cùng lúc đó một nhà đầu tư $\mathrm{B}$ muốn bán $\mathrm{X}$ với giá 74 , thì khi đó một người trung gian $\mathrm{C}$ có thể mua cổ phiếu từ $\mathrm{B}$ và bán lại ngay cho $\mathrm{A}$, và hưởng chênh lệch giá $75-74=1$. Việc làm này của người $C$ được gọi là kinh doanh chênh lệch giá, và nó có thể coi là không có mạo hiểm, vì có lợi nhuận chắc chắn là số dương.

Ở dạng phức tạp hơn, cơ hội kinh doanh chênh lệch giá xảy ra khi có hai tài sản $X$ và $X^{\prime}$ sao cho giá của $X$ sẽ chắc chắn lớn hơn giá của $X^{\prime}$ trong một thời điểm tương lai nào đó, nhưng vào thời điểm hiện tại có thể mua $X$ với giá nhỏ hơn hoặc bằng giá bán $X^{\prime}$. Khi đó người kinh doanh chênh lệch giá có thể mua $X$ và bán $X^{\prime}$ tại thời điểm hiện tại, rồi bán $X$ mua $X^{\prime}$ tại thời điểm tương lai.

Vi du 3.1. Giả sử $S$ là một cổ phiếu nào đó, $C$ là quyền mua $S$ sau đúng 1 tháng (European Call) với giá $40 \$$, và $P$ là quyền bán $S$ (European Put) với giá $40 \$$ và cùng thời hạn 1 tháng với $C$. Giả sử giá hiện tại của $S$ là $40 \$$, của $C$ là $4 \$$, của $P$ là $3 \$$, và lãi suất ngắn hạn là $0.25 \% /$ tháng $(3 \% /$ năm). Xét hai tài sản sau:

- Tài sản $X$ gồm có $S$ cộng với $P$ trừ đi $C$. ( $S$ trừ đi $C$ được gọi là covered call, vì Call $C$ với số lượng âm được "covered” (đảm bảo) bởi cái cổ phiếu $S$ với số lượng dương, tức là khi nhà đầu tư giữ cổ phiếu và bán đi cái quyền mua cổ phiếu đó). 
- Tài sản $X^{\prime}$ là $39 \$$ tiền gửi với lãi suất ngắn hạn.

Cả hai tài sản trên đều có giá là $39 \$$ vào thời điểm hiện tại. Nhưng đúng 1 tháng sau, thì $X^{\prime}$ trở thành $39 \$$ cộng với tiền lãi suất $39 \times 0.25 \% \approx 0.1 \$$, tức là quãng $39.1 \$$, trong khi đó $X$ trở thành $40 \$$. Thật vậy, nếu giá của $S$ lúc đó trên $40 \$$ thì $P$ lúc đó có giá trị bằng 0 , và $S$ trừ $C$ chuyển thành $40 \$$ vì cổ phiếu bị "gọi đị" theo giá $40 \$$, tức là người giữ Call $C$ lúc đó sẽ sử dùng quyền mua với giá $40 \$$ của mình để đổi $C$ cộng $40 \$$ lấy $S$. Ngược lại, nếu giá của $S$ lúc đó dưới $40 \$$, thì Call $C$ không có giá trị gì (không ai dùng $C$ để mua $S$ với giá $40 \$$ làm gì, khi có thể mua trên thị trường với giá rẻ hơn), nhưng khi đó có thể đổi $S$ cộng $P$ lấy $40 \$$, tức là sử dụng quyền Put để bán $S$ theo giá $40 \$$, và bởi vậy $X$ lúc đó vẫn trở thành $40 \$$. Như vậy, vào thời điểm hiện tại thì $X$ và $X^{\prime}$ có giá bằng nhau là $39 \$$, nhưng sau 1 tháng thì $X$ thành $40 \$$ trong khi $X^{\prime}$ chỉ thành $39.1 \$$ dù tình huống nào xảy ra, và do đó có một cơ hội arbitrage giữa $X$ và $X^{\prime}$. Trong thực tế, có xảy ra những cơ hội arbitrage kiểu như vậy trên thị trường chứng khoán thế giới.

Mọi sự buôn bán tất nhiên dựa trên chênh lệch giá. Ví dụ như các cửa hàng mua đồ vào với giá thấp hơn là giá bán ra, các nhà băng vay tiền vào với lãi suất thấp hơn là lãi suất cho vay lại. Thế nhưng, các cửa hàng và nhà băng vẫn có chịu mạo hiểm về giá: các cửa hàng có thể bị ế hàng không bán được với giá dự định, các nhà băng có thể bị kẹt tiền phải vay giới lãi suất cao hơn là lãi suất đã cho người khác vay, v.v. Ý tưởng chính của kinh doanh chênh lệch giá là kinh doanh mà không phải chịu mạo hiểm (hoặc rất ít mạo hiểm) về giá. Tất nhiên, kể cả khi không có mạo hiểm về giá, thì vẫn còn những rủi ro khác, ví dụ như người mua không chịu trả tiền, người bán không chịu giao hàng, v.v. Nhưng ở đây ta sẽ tạm thời bỏ qua các rủi ro đó, coi nó là nhỏ không đáng kể, và chỉ chú ý đến giá.

Nói một cách hình thức toán học, ta có thể định nghĩa như sau:

Định nghĩa 3.1. Ta nói rằng trên một thị trường nào đó có có độ chênh thị giá, hay có cơ hội kinh doanh chênh lệch giá, tại thời điểm $T_{0}$ (thời điểm hiện tại), nếu nhu có thể thiết lập một rổ tài sản $Y$, trong đó có thể có cả các tài sản với số lượng dương (giá trị dương) lẫn các tài sản có số lượng âm (giá trị âm), sao cho tổng giá trị của Y tại thời diểm $T_{0}$ bằng 0 , thế nhưng tổng giá trị của $Y$ tại một thời điểm $T_{1}>T_{0}$ (tức là lợi nhuận của chiến lược này tại thời diểm tương lai $T_{1}$ ) là không âm dù bất kỳ tình huống nào xảy ra, và có kỳ vọng là số dương.

Một chiến lược lập rổ tài sản $Y$ với lợi nhuận luôn không âm và kỳ vọng lợi nhuận là số dương như trong định nghĩa trên được gọi là một chiến lược kinh doanh chênh 


\section{lệch giá, hay chiến lược arbitrage.}

Ghi chú 3.1. Trong định nghĩa trên, ta coi giá của $Y$ tại thời điểm $T_{1}$ như là một biến ngẫu nhiên, mà ta sẽ ký hiệu là $Y_{T_{1}}: \Omega \rightarrow \mathbb{R}$, trên một mô hình không gian xác suất $\Omega$ nào đó các tình huống có thể xảy ra (với mỗi tình huống, thì tài sản $Y$ tại thời điểm $T_{1}$ có một giá trị). Không gian $\Omega$ này có một độ đo xác suất $p$ (phụ thuộc vào mô hình và các thông tin có được về thị trường vào thời điểm $T_{0}$ ). Nói rằng kỳ vọng của $Y_{T_{1}}$ là số dương có nghĩa là

$$
\mathbb{E}\left(Y_{T_{1}}\right):=\int_{\Omega} Y_{T_{1}} d p>0
$$

Trong trường hợp mà $\Omega=\left\{\omega_{1}, \omega_{2}, \ldots\right\}$ là một không gian rời rạc (cùng lắm là đếm được) với các xác suất $p\left(\omega_{i}\right)>0$ tương ứng (ta coi rằng phần tử nào trong $\Omega$ cũng phải có xác suất dương, vì nếu bằng 0 thì tức là "không thể xảy ra được", và ta có thể loại nó ra khỏi $\Omega)$, thì kỳ vọng của $Y_{T_{1}}$ là $\mathbb{E}\left(Y_{T_{1}}\right)=\sum_{i} p\left(\omega_{i}\right) Y_{T_{1}}\left(\omega_{i}\right)$, tức là kỳ vọng chẳng qua là giá trị trung bình theo các trọng số $p\left(\omega_{i}\right)$. (Xem [7] về kỳ vọng của các biến ngẫu nhiên). Khi $Y_{T_{1}}\left(\omega_{i}\right) \geq 0$ với mọi $\omega_{i} \in \Omega$, thì điều kiện $\mathbb{E}\left(Y_{T_{1}}\right)>0$ tương đương với điều kiện tồn tại ít nhất một tình huống $\omega_{i}$ sao cho $Y_{T_{1}}\left(\omega_{i}\right)>0$. Bởi vậy, trong định nghĩa trên, trong trường hợp không gian các tình huống có thể xảy ra là rời rạc, thì thay vì nói rằng kỳ vọng của $Y$ cho thời điểm $T_{1}$ là số dương, ta có thể nói rằng tồn tại ít nhất một tình huống sao cho trong tình huống đó thì giá trị của $Y$ tại thời điểm $T_{1}$ là số dương.

Ghi chú 3.2. Để chứng minh là một thị trường nào đó có độ chênh thị giá, người ta có thể xây dựng một chiến lược mà có lợi nhuận luôn lớn hơn 0 trong mọi tình huống. Ta sẽ gọi một chiến lược như vậy là một chiến lược arbitrage mạnh. Một chiến lược arbitrage mạnh tất nhiên là một chiến lược arbitrage, vì nếu lợi nhuận dương trong mọi tình huống thì kỳ vọng lợi nhuận cũng dương, tuy điều ngược lại không đúng.

Ví du 3.2. Giả sử có 3 con ngựa $X, Y, Z$ trong một cuộc chạy đua, và sẽ có 1 và chỉ 1 trong 3 con thắng cuộc. Có thể cá cược vào các con ngựa này bằng cách mua/bán vé: mỗi vé con $X$ có giá 1 đồng, và nếu $X$ thắng thì sẽ đổi được thành 2 đồng còn thua thì không được gì, tức là tỷ lệ giải thưởng khi $X$ thắng là 1 ăn 2 . Vé con $Y$ có tỷ lệ giải thưởng là 1 ăn 3 , và vé con $Z$ có tỷ lệ giải thưởng là 1 ăn 4 . Ta giả sử là có thể mua hoặc bán vé, tức là đặt cược với số tiền dương hoặc âm vào các con ngựa (trong thực tế nhà cái là người đặt cược với số tiền âm ở các cuộc cá ngựa). Hỏi rằng có cách đặt cược nào để luôn thắng dù cho con ngựa nào thắng cuộc không ?

Ta coi một chiến lược đặt cược là một rổ tài sản $R$ trong đó có tiền, và các vé của 3 con ngựa, sao cho tại thời điểm $T_{0}$ (trước khi ngựa chạy) thì giá trị của rổ tài sản bằng 
0 :

$$
R=x \cdot V_{X}+y \cdot V_{y}+z \cdot V_{Z}-(x+y+z) .
$$

Ở đây, $V_{X}, V_{Y}, V_{Z}$ là giá trị của vé các con ngựa $X, Y, Z$, và $x, y, z$ là các số lượng vé (có thể là số âm). Tại thời điểm $T_{0}$ ta có giá trị của $V_{X}, V_{Y}, V_{Z}$ đều bằng 1 . Tại thời điểm $T_{1}$ (sau khi các con ngựa chạy, và có 1 con thắng), có 3 tình huống có thể xảy ra: nếu $X$ thắng thì $V_{X}=2$ và $V_{Y}=V_{Z}=0$, nếu $Y$ thắng thì $V_{Y}=3$ và $V_{X}=V_{Z}=0$, nếu $Z$ thắng thì $V_{Z}=4$ và $V_{X}=V_{Y}=0$. Tại thời điểm $T_{1}$, giá trị của rổ tài sản $R$ là một trong 3 số sau, tùy tình huống xảy ra: $2 x-(x+y+z), 3 y-(x+y+z)$, và $4 z-(x+y+z)$. Câu hỏi là có tồn tại một chiến lược luôn thắng, tức là có tồn tại $x, y, z$ sao cho giá trị của $R$ tại thời điểm $T_{1}$ luôn lớn hơn 0 dù tình huống nào xảy ra, hay nói cách khác,

$$
\min \{2 x-(x+y+z), 3 y-(x+y+z), 4 z-(x+y+z)\}>0 ?
$$

Câu trả lời là có, ví dụ $x=-6, y=-4, z=-3$. Tức là nếu ta bán vé các con ngựa $X, Y, Z$ theo tỷ lệ $6: 4: 3$, thì sẽ luôn thắng, dù con ngựa nào thắng cuộc. Có nghĩa là, tồn tại chiến lược arbitrage mạnh trong trò cá ngựa này.

Trong ví dụ cá ngựa phía trên, thường chỉ có nhà cái sử dụng được chiến lược kinh doanh chênh lệch giá, vì những người chơi cá cược bình thường không đặt cược được với số lượng âm. Trên thị trường chứng khoán thì "bình đẳng" hơn, vì mỗi khi có cơ hội arbitrage thì nhiều nhà đầu tư có thể tham gia chứ không chỉ có "nhà cái". Cũng chính vì sự bình đẳng này, nên các cơ hội arbitrage trên thị trường chứng khoán tuy có xảy ra nhưng thường ở mức độ nhỏ, vì nếu có cơ hội lớn, thì sẽ có nhiều nhà đầu tư cạnh tranh với nhau để tận dụng nó, khiến cho nó nhỏ lại. Trong mô hình thị trường "hiệu quả" lý tưởng hoá, người ta coi rằng không có cơ hội kinh doanh chênh lệch giá. Đó chính là nguyên lý no-arbitrage. Nguyên lý này là cơ sở cho hầu hết các công thức định giá trong toán tài chính, đặc biệt là cho các sản phẩm tài chính phái sinh. Khi mà giá các chứng khoán trên thị trường không thoả mãn nguyên lý no-arbitrage, thì có nghĩa là thị trường bị "mất thăng bằng", và có cơ hội kinh doanh chênh lệch giá.

\section{2 Định lý kinh doanh chênh lệch giá}

Định lý kinh doanh chênh lệch giá, còn được gọi là định lý cơ bản của toán tài chính, có thể được phát biểu một cách nôm na như sau: Giả sử rằng, trên một thị trường chứng khoán, được phép bán khống và chi phí giao dịch bằng 0 . Khi đó, một và chỉ một trong hai khả năng sau xảy ra: hoặc là tồn tại chiến lược arbitrage, hoặc là tồn tại một phân 
bố xác suất không suy biến trên tập hợp các tình huống có thể xảy ra, sao cho đối với phân bố xác suất đó, thì mọi chiến lược kinh doanh đều có kỳ vọng lợi nhuận bằng 0 . Tất nhiên hai khả năng này loại trừ lẫn nhau, vì một chiến lược kinh doanh chênh lệch giá sẽ có kỳ vọng lợi nhuận là dương chứ không thể bằng 0 , dù là có thay đổi phân bố xác suất. Trong trường hợp thứ hai, thì phân bố xác suất này được gọi là phân bố xác suất trung hòa rủi ro (risk-neutral probability distribution), hay còn gọi là độ đo xác suất martingale (chúng ta sẽ giải thích ở những phần sau vì sao nó được gọi như vậy).

Để phát biểu chính xác định lý kinh doanh chênh lệch giá, ta sẽ xét mô hình sau: thị trường có $n$ loại tài sản $X_{1}, \ldots, X_{n}$, giao dịch tại hai thời điểm $T_{0}$ và $T_{1}>T_{0}$. Không gian các tình huống có thể xảy ra tại thời điểm $T_{1}$, ký hiệu là $\Omega$, là một không gian hữu hạn với $m$ phần tử: $\Omega=\left\{\omega_{1}, \ldots, \omega_{m}\right\}$. Tại thời điểm $T_{0}$, người kinh doanh chưa biết tình huống nào sẽ xảy ra tại thời điểm $T_{1}$ trong số các tình huống $\omega_{j}$. Nếu như mua 1 đơn vị tài sản $X_{i}$ tại thời điểm $T_{0}$ và bán lại nó tại thời điểm $T_{1}$, thì lợi nhuận (return) thu được tại thời điểm $T_{1}$ sẽ là $r_{i j}$ nếu như tình huống $\omega_{j}$ xảy ra (các con số $r_{i j}$ có thể là dương hoặc âm, tức là có thể lãi hoặc lỗ). Một chiến lược kinh doanh (hay đặt cược) sẽ được xác định bởi một vector $\mathbf{x}=\left(x_{1}, \ldots, x_{n}\right) \in \mathbb{R}^{n}$, gọi là vector chiến lược (hay gọi vắn tắt là chiến lược $\mathbf{x}$ ), ứng với việc mua (hoặc bán) $x_{i}$ đơn vị tài sản $X_{i}$ tại thời điểm $T_{0}$ và bán (hoặc mua) lại nó tại thời điểm $T_{1}$ với mọi $i=1, \ldots, n$. Ở đây $x_{i}$ có thể dương hoặc âm hoặc bằng 0 , nếu âm thì có nghĩa là bán một lượng $\left|x_{i}\right|$ tài sản $X_{i}$ tại thời điểm $T_{0}$ và mua lại nó tại thời điểm $T_{1}$. Nếu tình huống $\omega_{j}$ xảy ra vào thời điểm $T_{1}$, thì lợi nhuận của chiến lược $\mathbf{x}$ là:

$$
R(\mathbf{x})=R_{j}(\mathbf{x})=\sum_{i=1}^{n} x_{i} r_{i j}
$$

Ở đây ta giả sử chi phí giao dịch bằng 0 , có thể bán hay mua một lượng tùy ý các tài sản, và giá của các tài sản không phụ thuộc vào số lượng mua/bán của ta.

Một phân bố xác suất $p$ trên không gian các tình huống $\Omega$ có thể được coi như là một bộ $m$ số $\left(p_{1}, \ldots, p_{m}\right)$ không âm với tổng bằng 1 , mỗi số ứng với xác suất của một phần tử của $\Omega$ : $p_{j}=p\left(\omega_{j}\right), j=1, \ldots, m$. Phân bố xác suất $p$ trên $\Omega$ được gọi là không suy biến (non-degenerate) nếu $p_{j}=p\left(\omega_{j}\right)>0$ với mọi $j$. Lợi nhuận kỳ vọng (expected return) của chiến lược $\mathbf{x}$ theo phân bố xác suất $p$ là:

$$
\mathbb{E}(R(\mathbf{x}))=\sum_{j=1}^{m} p_{j} R_{j}(\mathbf{x})=\sum_{j=1}^{m} \sum_{i=1}^{n} x_{i} r_{i j} p_{j}=\sum_{i=1}^{n} x_{i}\left(\sum_{j=1}^{m} r_{i j} p_{j}\right) .
$$

Phân bố xác suất $p$ trên $\Omega$ được gọi là trung hòa rủi ro nếu như kỳ vọng lợi nhuận của mọi chiến lược $\mathbf{x}$ theo $p$ đều bằng 0 . 
Định lý 3.2 (Định lý arbitrage). Với mọi ma trận lợi nhuận $\left(r_{i j}\right)_{i=1, \ldots, n}^{j=1, \ldots, m}$ bất kỳ cho trước, có một và chỉ một khẳng dịnh trong hai khẳng định sau đây là đúng:

1. Tồn tại một chiến lược arbitrage $\mathbf{x}=\left(x_{1}, x_{2}, \ldots, x_{n}\right)$, tức là luôn có lợi nhuận không âm dù tình huống nào xảy ra, và có lợi nhuận dương trong ít nhất một tình huống:

$$
\min _{j} R_{j}(\mathbf{x}) \geq 0 ; \max _{j} R_{j}(\mathbf{x})>0
$$

2. Tồn tại một phân bố xác suất trung hòa rủi ro không suy biến, có nghĩa là, tồn tại một bộ $n$ số dương $\mathbf{p}=\left(p_{1}, \ldots, p_{m}\right)$ có tổng bằng 1 sao cho

$$
\sum_{j=1}^{m} r_{i j} p_{j}=0 \text { với mọi } i=1,2, \ldots, n \text {. }
$$

Chứng minh. Dễ thấy rằng hai khẳng định trong định lý trên loại trừ lẫn nhau, nên không thể cả hai đều đúng cùng một lúc. Ta sẽ chứng minh rằng có một trong hai khẳng định đó là đúng.

Ký hiệu $\mathcal{P}(\Omega)$ là tập hợp tất cả các phân bố xác suất trên $\Omega$ (kể cả các xác suất suy biến). Mỗi phần tử của $\mathcal{P}(\Omega)$ có thể coi là một bộ $m$ số $\mathbf{p}=\left(p_{1}, \ldots, p_{m}\right)$ không âm có tổng bằng 1 (xác suất của phần tử $\omega_{i}$ bằng $p_{i}$ ).

Gọi $I$ là tập hợp con các phần tử của tập các chỉ số $\{1,2, \ldots, m\}$, sao cho với mọi $i \in I$ tồn tại ít nhất một xác suất trung hòa rủi ro (có thể suy biến) $\left(p_{1}, \ldots, p_{m}\right) \in \mathcal{P}(\Omega)$ với $p_{i}>0$. Có một và chỉ một trong 3 trường hợp sau xảy ra:

1) $I=\emptyset$ là tập rỗng. Đây là trường hợp không tồn tại xác suất trung hòa rủi ro nào, kể cả suy biến.

2) $I=\{1,2, \ldots, m\}$.

3) $\emptyset \neq I \neq\{1,2, \ldots, m\}$.

Trường hợp 1: Ta sẽ chứng minh rằng trong trường hợp này tồn tại một chiến lược arbitrage mạnh (và do đó khẳng định thứ nhất của định lý đúng trong trường hợp này). Với mỗi $\mathbf{p} \in \mathcal{P}(\Omega)$, xét vector

$$
\text { p. }\left(r_{i j}\right)^{T}=\left(\sum_{j=1}^{m} r_{1 j} p_{j}, \ldots, \sum_{j=1}^{m} r_{n j} p_{j}\right) .
$$

Vector này là vector kỳ vọng lợi nhuận của bộ các chiến lược đơn: một chiến lược đơn là một chiến lược chỉ mua 1 đơn vị tài sản $X_{i}$ và không mua/bán các tài sản khác, và kỳ vọng lợi nhuận của chiến lược đơn này theo phân bố xác suất $\mathbf{p}$ bằng $\sum_{j=1}^{m} r_{i j} p_{j}$. (Có $n$ 
chiến lược đơn, ứng với $n$ tài sản, và bởi vậy vector kỳ vọng lợi nhuận của bộ các chiến lược đơn có $n$ thành phần, mỗi thành phần là kỳ vọng lợi nhuận của một chiến lược đơn). Đặt

$$
E=\left\{\mathbf{p} .\left(r_{i j}\right)^{T} \mid \mathbf{p} \in \mathcal{P}(\Omega)\right\}
$$

là tập hợp tất cả các vector kỳ vọng lợi nhuận có thể của bộ các chiến lược đơn. E là một đa diện lồi compact (tức là đóng và bị chặn) trong không gian Euclide $n$ chiều $\mathbb{R}^{n}$, bởi vì $E$ là ảnh của $\mathcal{P}(\Omega)$ qua một phép biến đổi tuyến tính, và bản thân $\mathcal{P}(\Omega)$ là một đa diện lồi compact trong $\mathbb{R}^{m}$. Chú ý rằng với mọi $j=1, \ldots, m$, vector

$$
\rho_{j}=\left(r_{1 j}, \ldots, r_{n j}\right)
$$

nằm trong $E$, vì nó là vector kỳ vọng lợi nhuận ứng với phân bố xác suất tập trung tại phần tử $\omega_{j}$ (xác suất của $\omega_{j}$ bằng 1 còn của tất cả các phần tử còn lại bằng 0 ). Bản thân $E$ chính là bao lồi của các vector $\rho_{j}$ này. Dễ thấy rằng, một xác suất $\mathbf{p}$ là trung hòa rủi ro khi và chỉ khi $\mathbf{p} .\left(r_{i j}\right)^{T}=0$. Bởi vậy, trường hợp 1 chính là trường hợp mà $E$ không chứa không điểm của $\mathbb{R}^{n}$. Vì tính compact của $E$, nên tồn tại một điểm $\mathbf{x}=\left(x_{1}, \ldots, x_{n}\right) \in E$ có độ dài ngắn nhất, tức là $\|\mathbf{x}\|=\min \{\|\mathbf{y}\| \mid \mathbf{y} \in E\},\|\mathbf{x}\|>0$. Khi đó, với mọi $j=1, \ldots, m$, góc Euclide giữa vector $\mathbf{x}$ và vector $\rho_{j}=\left(r_{1 j}, \ldots, p_{n j}\right)$ phải là góc nhọn, hay nói cách khác, tích vô hướng của chúng phải lớn hơn 0 :

$$
\left\langle\mathbf{x}, \rho_{j}\right\rangle:=\sum_{i=1}^{n} x_{i} r_{i j}>0
$$

bởi vì nếu không thì với mọi $\epsilon>0$ đủ nhỏ, vector $\epsilon \rho_{j}+(1-\epsilon) \mathbf{x}$ sẽ nằm trong $E$ (do tính lồi của $E$ ) và có độ dài nhỏ hơn $\mathbf{x}$, mâu thuẫn với điều kiện $\|\mathbf{x}\|$ là nhỏ nhất trong $E$. (Thật vậy, $\left\|\epsilon \rho_{j}+(1-\epsilon) \mathbf{x}\right\|^{2}-\|\mathbf{x}\|^{2} \approx-2 \epsilon\left(\|\mathbf{x}\|^{2}-\left\langle\mathbf{x}, \rho_{j}\right\rangle\right)<0$ khi $\epsilon$ đủ nhỏ, nếu như $\left.\left\langle\mathbf{x}, \rho_{j}\right\rangle:=\sum_{i=1}^{n} r_{i j} x_{j} \leq 0\right)$. Như vậy $\mathbf{x}$ chính là một chiến lược arbitrage mạnh.

Trường hợp 2: Đây chính là trường hợp tồn tại một xác suất trung hòa rủi ro không suy biến (tức là khẳng định thứ hai của định lý đúng trong trường hợp này). Thật vậy, trong trường hợp này, với mỗi $j=1, \ldots, m$, tồn tại ít nhất một phân bố xác suất trung hòa rủi ro $\mathbf{p}^{j}=\left(p_{1}^{j}, \ldots, p_{m}^{j}\right)$ thỏa mãn điều kiện $p_{j}^{j}>0$. Nhưng khi đó, trung bình cộng $\mathbf{p}=(1 / m)\left(\mathbf{p}^{1}+\ldots+\mathbf{p}^{m}\right)=\left(\sum_{j} p_{1}^{j} / m, \ldots, \sum_{j} p_{m}^{j} / m\right)$ cũng là một phân bố xác suất trung hòa rủi ro, và hơn nữa, phân bố này không suy biến.

Trường hợp 3: Trường hợp này là trường hợp tồn tại một xác suất trung hòa rủi ro suy biến, nhưng không tồn tại một xác suất trung hòa rủi ro không suy biến. Ta sẽ chứng minh rằng, trong trường hợp này, khẳng định thứ nhất của định lý là đúng, tức là tồn tại 
một chiến lược arbitrage (tuy rằng sẽ không tồn tại một chiến lược arbitrage mạnh trong trường hợp này). Gọi $W$ là không gian vector con của $\mathbb{R}^{n} \sinh$ bởi các vector $\rho_{j}, j \in I$, và $F$ là bao lồi của các vector $\rho_{j}, j \in \bar{I}:=\{1, \ldots, m\} \backslash I$.

Chú ý rằng $W$ và $F$ không giao nhau: $W \cap F=\emptyset$. Thật vậy, nếu chúng giao nhau, thì có nghĩa là tồn tại các số thực không âm $a_{j}, j \in \bar{I}$ với tổng bằng 1 , và các số thực $a_{j}, j \in I$, sao cho $\sum_{j=1}^{m} a_{j} \rho_{j}=\left(\sum_{j \in \bar{I}} a_{j} \rho_{j}\right)-\left(\sum_{j \in I}\left(-a_{j}\right) \rho_{j}\right)=0$. Ta có thể chọn một chỉ số $j_{0} \in \bar{I}$ sao cho $a_{j_{0}}>0$. Tương tự như trong trường hợp 3 , tồn tại mội xác suất trung hòa rủi ro $\left(p_{1}, \ldots, p_{m}\right)$, tức là $\sum_{j} p_{j} \rho_{j}=0$, sao cho $p_{j}>0$ với mọi $j \in I$. Đặt $c_{j}=a_{j}+M p_{j}$ trong đó $M>0$ là một số dương đủ lớn nào đó, ta có $c_{j} \geq 0$ với mọi $j, c_{j_{0}}>0$, và $\sum_{j} c_{j} \rho_{j}=0$. Đặt $q_{j}=c_{j} /\left(\sum_{j} c_{j}\right)$. Khi đó $\left(q_{1}, \ldots, q_{m}\right)$ là một xác suất trung hòa rủi ro, với $q_{j_{0}}>0$, có nghĩa là $j_{0} \in I$, mâu thuẫn điều kiện lúc trước là $j_{0} \in \bar{I}=\{1, \ldots, m\} \backslash I$.

Gọi $W^{\perp}$ là phần bù vuông góc của $W$ trong $\mathbb{R}^{n}$, tức là không gian các vector của $\mathbb{R}^{n}$ mà vuông góc với $W$, và gọi $\hat{F}$ là ảnh của phép chiếu vuông góc của $F$ lên $W^{\perp}$. Vì $W$ và $F$ không giao nhau nên $\hat{F}$ không chứa không điểm 0 . Tương tự như trong trường hợp 1, tồn tại một điểm $\mathbf{x} \in \hat{F}$ có độ dài ngắn nhất trong số các điểm của $\hat{F}$. Suy luận một cách hoàn toàn tương tự như trong trường hợp 1 , dễ thấy rằng $\mathbf{x}$ chính là một chiến lược arbitrage. Chú ý rằng, lợi nhuận của chiến lược này khi tình huống $\omega_{j}$ xảy ra sẽ là số dương nếu $j \in \bar{I}$ và sẽ bằng 0 nếu $j \in I$, tức là chiến thuật này không phải là một chiến lược arbitrage mạnh.

Ghi chú 3.3. Một phiên bản khác của định lý arbitrage, được viết trong sách của Buchanan [2], phát biểu như sau: Có một và chỉ một trong hai khả năng sau xảy ra: hoặc là tồn tại một chiến lược arbitrage mạnh, hoặc là tồn tại một xác suất trung hòa rủi ro (có thể suy biến). Bạn đọc có thể nhận thấy rằng phiên bản này cũng được chứng minh trong chứng minh định lý 3.2 phía trên. Thật vậy, trường hợp 1 là trường hợp có chiến lược arbitrage mạnh, còn các trường hợp 2 và 3 là các trường hợp tồn tại xác suất trung hòa rủi ro (có thể suy biến). Trong các phần sau của quyển sách này, khi nói đến chiến lược arbitrage, ta sẽ không yêu cầu điều kiện mạnh, nhưng khi nói đến xác suất trung hòa rủi ro nói chung ta sẽ yêu cầu điều kiện không suy biến.

Ghi chú 3.4. Định lý kinh doanh chênh lệch giá có thể được mở rộng lên trường hợp có vô hạn các khả năng xảy ra, tức là khi không gian các tình huống $\Omega$ gồm có vô hạn các phần tử. Trong trường hợp $\Omega$ là tập hợp vô hạn, ta sẽ coi rằng định lý vẫn đúng, chấp nhận nó mà không chứng minh. Các mô hình xác suất với vô hạn các phần tử có thể coi là các giới hạn của các mô hình với hữu hạn các phần tử, còn trong tính toán thực tế thì mọi thứ chỉ là hữu hạn. 
Bài tập 3.1. Xét một cuộc đua ngựa, với $n$ con ngựa, thay vì chỉ có 3 con như trong ví dụ 3.2. Giả sử sẽ chỉ có 1 con được giải. Tỷ lệ giải thưởng cho việc đặt cọc vào con thứ $i$ là $1: g_{i}$ (tức là nếu đặt 1 đồng, mà con thứ $i$ đoạt giải, thì được $g_{i}$ đồng, $g_{i}>1$ với mọi $i=1, \ldots, n)$. Tìm một điều kiện cần và đủ cho bộ số $\left(g_{1}, \ldots, g_{n}\right)$ để sao cho tồn tại:

a) chiến lược arbitrage,

b) chiến lược arbitrage mạnh.

\section{3 Định lý đối ngẫu của qui hoạch tuyến tính}

Định lý kinh doanh chênh lệch giá 3.2 có thể được coi như là một hệ quả của định lý đối ngẫu (duality theorem) trong qui hoạch tuyến tính (linear programming). Trong phần này, chúng ta sẽ thảo luận định lý đối ngẫu của qui hoạch tuyến tính, và cách suy ra định lý 3.2 từ định lý đối ngẫu.

Qui hoạch tuyến tính là một công cụ toán học rất quan trọng trong kinh tế, vì phần lớn các vấn đề tối ưu hóa và kế hoạch hóa của kinh tế có thể viết xấp xỉ dưới dạng bài toán qui hoạch tuyến tính, tức là bài toán có dạng: cần xác định điểm cực tiểu hoặc cực đại của một hàm (ví dụ như lợi nhuận hay chi phí), hàm đó là hàm tuyến tính theo các biến (ví dụ như số lượng sản xuất của các sản phẩm), và các biến đó phải thỏa mãn một số điều kiện ràng buộc có dạng phương trình hoặc bất phương trình tuyến tính (công suất máy móc có hạn, kho chứa có hạn, thời gian sản xuất có hạn, v.v.). Nhà toán học Leonid Kantorovich (1912-1986) $)^{(1)}$ người Liên Xô duy nhất được giải Nobel về kinh tế, được coi là cha đẻ của qui hoạch tuyến tính.

Mọi bài toán qui hoạch tuyến tính đều có thể được đưa về dưới dạng sau:

(*) Tìm max cx, với điều kiện ràng buộc: $\mathbf{A x} \leq \mathbf{b}$,

trong đó $\mathbf{x}$ là $n$ biến số, viết dưới dạng vector cột $n$ chiều, $\mathbf{c}$ là một vector hàng $n$ chiều được cho trước, $\mathbf{A}$ là một ma trận $m \times n$ được cho trước, và $\mathbf{b}$ là một vector cột $m$ chiều được cho trước. Bất đẳng thức $\mathbf{A x} \leq \mathbf{b}$ có nghĩa là mọi phần tử của $\mathbf{A x}$ đều nhỏ hơn hoặc bằng phần tử tương ứng của $\mathbf{b}$.

Ví $d u$ 3.3. Tìm cực đại của $3 x_{1}+5 x_{2}+x_{3}$, với các điều kiện ràng buộc $x_{1}>0, x_{1}+x_{2} \leq$ $10, x_{2} \leq 8, x_{2}+x_{3}=1$.

Ta có thể loại bớt biến $x_{3}$ đi, thay nó bằng $1-x_{2}$, và đưa bài toán trên về dạng $(*)$

${ }^{(1)}$ Xem http://en.wikipedia.org/wiki/Leonid_Kantorovich 
với

$$
\mathbf{x}=\left(\begin{array}{l}
x_{1} \\
x_{2}
\end{array}\right), \mathbf{c}=\left(\begin{array}{ll}
3 & 4
\end{array}\right), \mathbf{A}=\left(\begin{array}{cc}
-1 & 0 \\
1 & 1 \\
0 & 1
\end{array}\right), \mathbf{b}=\left(\begin{array}{c}
0 \\
10 \\
8
\end{array}\right)
$$

Miền khả thi của bài toán $\left(^{*}\right)$ là tập hợp tất cả các $\mathbf{x}$ thỏa mãn điều kiện ràng buộc $\mathbf{A x} \leq \mathbf{b}$. Nều miền này không rỗng thì $(*)$ được gọi là khả thi (feasible), còn nếu nó rỗng thì $(*)$ được gọi là không khả thi (infeasible). Nếu miền khả thi là không rỗng, thì nó có tính chất lồi, tức là nếu có hai điểm nằm trong miền, thì đoạn thẳng nối hai điểm đó cũng nằm trong miền. Bài toán $\left(^{*}\right)$ được gọi là không bị chặn nếu cực đại của nó là $+\infty$, có nghĩa là với mọi $M>0$ tồn tại $\mathbf{x}$ thỏa mãn điều kiện ràng buộc $\mathbf{A x} \leq \mathbf{b}$ sao cho $\mathbf{c x}>M$. Dễ thấy rằng, một bài toán qui hoạch tuyến tính có nghiệm (tức là có điểm cực trị nằm trong miền khả thi) khi và chỉ khi nó khả thi và bị chặn.

Đi đôi với bài toán (*) là bài toán sau, được gọi là bài toán đối ngẫu của nó:

(**) Tìm min $\mathbf{y b}$, với điều kiện ràng buộc: $\mathbf{y} \mathbf{A}=\mathbf{c}$ và $\mathbf{y} \geq 0$,

trong đó biến số $\mathbf{y}$ được viết dưới dạng một vector hàng $m$ chiều.

Bài tập 3.2. Lập bài toán đối ngẫu của bài toán trong ví dụ 3.3. Vẽ các miền khả thi của hai bài toán này, rồi tìm các điểm cực trị.

\section{Định lý 3.3 (Định lý đối ngẫu của qui hoạch tuyến tính).}

i) Với mọi $\mathbf{x}$ thỏa mãn diều kiện ràng buộc của bài toán (*) và mọi $\mathbf{y}$ thỏa mãn điều kiện ràng buộc của bài toán (**), ta có $\mathbf{c x} \leq \mathbf{y b}$. Nếu tồn tại $\mathbf{x}_{0}$ và $\mathbf{y}_{0}$ trong các miền khả thi sao cho $\mathbf{c x}_{0}=\mathbf{y}_{0} \mathbf{b}$, thì $\mathbf{x}_{0}$ và $\mathbf{y}_{0}$ chính là nghiệm của hai bài toán.

ii) Có 1 và chỉ 1 trong 4 trường hợp sau xảy ra:

a) Bài toán (*) không bị chặn, và bài toán (**) không khả thi.

b) Bài toán (**) không bị chặn, và bài toán (*) không khả thi.

c) Cả hai bài toán (*) và (**) đều không khả thi.

d) Cả hai bài toán $\left(^{*}\right)$ và $\left(^{* *}\right)$ đều bị chặn và khả thi. Khi đó tồn tại nghiệm $\mathbf{x}_{0}$ cho bài toán (*) và nghiệm $\mathbf{y}_{0}$ cho bài toán (**), và ta có $\mathbf{c x}_{0}=\mathbf{y}_{0} \mathbf{b}$.

Phần i) của định lý trên được gọi là định lý đối ng ẫu yếu của qui hoạch tuyến tính.

Chứng minh. i) Giả sử $\mathbf{x}$ và $\mathbf{y}$ nằm trong các miền khả thi tương ứng của $(*)$ và $(* *)$. Theo định nghĩa, ta có $\mathbf{A x} \leq \mathbf{b}, \mathbf{y} \mathbf{A}=\mathbf{c}$, và $\mathbf{y} \geq 0$. Vì $\mathbf{y} \geq 0$ nên ta có thể nhân cả hai vế của bất đẳng thức $\mathbf{A x} \leq \mathbf{b}$ với $\mathbf{y}$ về phía bên trái để được $\mathbf{y} \mathbf{A x} \leq \mathbf{y b}$. Thế nhưng $\mathbf{y A}=\mathbf{c}$, do đó ta có bất đẳng thức $\mathbf{c x} \leq \mathbf{y b}$. Nếu $\mathbf{c x}_{0}=\mathbf{y}_{0} \mathbf{b}$ thì với mọi $\mathbf{x}$ nằm trong 
miền khả thi của $\left(^{*}\right)$ ta có $\mathbf{c x} \leq \mathbf{y}_{0} \mathbf{b}=\mathbf{c x}_{0}$, và do đó $\mathbf{x}_{0}$ chính là điểm cực đại của hàm tuyến tính cx trên miền khả thi của bài toán $\left(^{*}\right)$, tức là nó là nghiệm của bài toán $\left(^{*}\right)$. Tương tự như vậy, $\mathbf{y}_{0}$ cũng là nghiệm của bài toán (**).

ii) Bạn đọc có thể xem chứng minh trong các quyển sách về qui hoạch tuyến tính (xem chẳng hạn [30]), hoặc là tự chứng minh bằng cách tương tự như chứng minh của định lý arbitrage phía trên. Ở đây chúng ta sẽ tạm thời bỏ qua chứng minh phần này.

Có nhiều cách khác nhau để biểu diễn bài toán tồn tại chiến lược kinh doanh chênh lệch giá $\mathbf{x}$ dưới dạng một bài toán qui hoạch tuyến tính, và suy ra định lý 3.2 từ định lý 3.3. Chẳng hạn, ta có thể làm như sau:

Coi các thành phần $x_{1}, \ldots, x_{n}$ của vector chiến lược $\left(x_{1}, \ldots, x_{n}\right)$ như là các biến số của một bài toán qui hoạch tuyến tính. Các điều kiện ràng buộc là $\sum_{i=1}^{n} x_{i} r_{i j} \geq 0$ với mọi $j=1, \ldots, m$, tức là lợi nhuận luôn không âm. Hàm tuyến tính mà ta muốn tìm cực đại là hàm tổng lợi nhuận của tất cả các tình huống: $\sum_{j=1}^{m} \sum_{i=1}^{n} x_{i} r_{i j}$. Bài toán cực đại này có dạng $(*)$ với

$$
\mathbf{c}=\left(\sum_{j=1}^{m} r_{1 j}, \ldots, \sum_{j=1}^{m} r_{n j}\right), \mathbf{A}=\left(-r_{i j}\right)^{T}, \mathbf{b}=0 .
$$

Bài toán đối ngẫu $(* *)$ là bài toán tìm cực tiểu của $\mathbf{y b}$ thỏa mãn điều kiện $\mathbf{y} \geq 0$ và $\mathbf{y A}=\mathbf{c}$.

Vì $\mathbf{b}=0$ nên $\mathbf{y b}=0$ với mọi $\mathbf{y}$, và bài toán $(* *)$ có nghiệm khi và chỉ khi nó khả thi, tức là khi tồn tại $\mathbf{y}$ thỏa mãn các điều kiện $\mathbf{y} \geq 0$ và $\mathbf{y A}=\mathbf{c}$. Vì $\mathbf{c}$ là tổng của các hàng trong ma trận $\left(r_{i j}\right)^{T}=-\mathbf{A}$, nên phương trình $\mathbf{y} \mathbf{A}=\mathbf{c}$ có thể viết thành $\left(y_{1}+1, \ldots, y_{m}+1\right)\left(r_{i j}\right)^{T}=0$. Nếu tồn tại vector hàng $\left(y_{1}, \ldots, y_{m}\right)$ thỏa mãn phương trình này và điều kiện không âm, thì đặt $p_{j}=\left(y_{j}+1\right) /\left(\sum_{j}\left(y_{j}+1\right)\right)$, ta được một phân bố xác suất trung hòa rủi ro không suy biến $\left(p_{1}, \ldots, p_{m}\right)$. Có nghĩa là, trường hợp mà các bài toán $\left(^{*}\right)$ và $(* *)$ phía trên có nghiệm chính là trường hợp tồn tại một xác suất trung hòa rủi ro không suy biến.

Bài toán $\left(^{*}\right)$ luôn luôn khả thi (vì điểm 0 nằm trong miền khả thi), nên nếu nó không có cực đại thì tức là nó không bị chặn. Bài toán $\left(^{*}\right)$ không bị chặn khi và chỉ khi tồn tại $\mathbf{x}$ khả thi sao cho $\sum_{j=1}^{m} \sum_{i=1}^{n} x_{i} r_{i j}>0$. Đây chính là trường hợp tồn tại chiến lược arbitrage.

Như vậy, định lý đối ngẫu của qui hoạch tuyến tính cho ta kết luận: hoặc là tồn tại một phân bố xác suất trung hòa rủi ro không suy biến, hoặc là tồn tại một chiến lược arbitrage. 
Bài tập 3.3. Xét bài toán qui hoạch tuyến tính: tìm max $10 x_{1}+7 x_{2}$ với điều kiện

$$
\left(\begin{array}{ll}
x_{1} & x_{2}
\end{array}\right)\left(\begin{array}{cccc}
3 & 3 & -2 & 0 \\
-11 & 0 & 4 & 3
\end{array}\right) \leq\left(\begin{array}{llll}
3 & 4 & 12 & 5
\end{array}\right) .
$$

Viết bài toán đối ngẫu của bài toán trên, rồi giải hai bài toán.

\subsection{No-arbitrage và xác suất trung hòa rủi ro}

Tuy rằng, trên thực tế, có các cơ hội arbitrage trên thị trường tài chính, nhưng chúng thường nhỏ và không kéo dài quá lâu, bởi vì mỗi khi có các cơ hội như vậy, thì sẽ có các cá nhân hay tổ chức tìm ra và tận dụng các cơ hội đó để kiếm lời, và hành động mua bán của những người này sẽ khiến cho giá cả điều chỉnh lại, đến mức không còn cơ hội arbitrage nữa. Trong một thị trường có tính thanh khoản cao, với rất nhiều người tham gia, chúng ta có thể hình dung là các cơ hội arbitrage sẽ nhỏ đến mức có thể bỏ qua.

Nói cách khác, chúng ta sẽ coi rằng nguyên lý no-arbitrage được thỏa mãn, có nghĩa là không có cơ hội arbitrage, trong các thị trường (được lý tưởng hóa) mà chúng ta xét đến. Tất cả các các định lý toán tài chính, mà chúng ta sẽ bàn đến trong quyển sách này, về việc định giá các chứng khoán, hay là về quan hệ giá giữa các chứng khoán khác nhau, sẽ dựa trên nguyên lý no-arbitrage.

Định kinh doanh chênh lệch giá 3.2 có thể được phát biểu lại như sau:

Định lý 3.4. Với giả thiết là thị trường thỏa mãn nguyên lý no-arbitrage, luôn tồn tại một phân bố xác suất trung hòa rủi ro (risk-neutral probability distribution) không suy biến trên không gian tất cả các tình huống có thể xảy ra.

Nhắc lại rằng, theo định nghĩa, kỳ vọng lợi nhuận của mọi chiến lược theo xác suất trung hòa rủi ro đều bằng 0 .

Vi du 3.4. Giả sử một công ty công nghệ sinh học nhỏ, đang tập trung nghiên cứu một loại thuốc chống ung thư, có giá cổ phiếu ngày hôm nay là $10 \$$. Sau giờ đóng cửa thị trường ngày hôm nay, công ty sẽ công bố kết quả nghiên cứu loại thuốc chống ung thư đó. Giả sử ta biết rằng sẽ có một trong hai tình huống xảy ra:

a) Tình huống thuốc có tác dụng, với xác suất xảy ra là $60 \%$, và nếu xảy ra thì giá cổ phiếu ngày hôm sau sẽ tăng lên thành $16 \$$.

b) Tình huống thuốc không có tác dụng, với xác suất xảy ra là $40 \%$, và nếu xảy ra thì giá cổ phiếu ngày hôm sau sẽ giảm còn $5 \$$. 
Trong ví dụ này, kỳ vọng của giá cổ phiếu của công ty cho ngày hôm sau là $60 \%$ × 16 + $40 \% \times 5=11.6$ đô la, so với giá ngày hôm nay là $10 \$$. Tức là nếu mua 1 cổ phiếu của công ty ngày hôm nay, và giữ đến ngày hôm sau, thì kỳ vọng lợi nhuận sẽ là 11.6 - 10 = 1.6. (Ở đây, để cho đơn giản, ta coi lãi suất bằng 0 , vì ảnh hưởng của lãi suất cho thời hạn 1 ngày thường rất là nhỏ, có thể bỏ qua). Nhưng đây là kỳ vọng lợi nhuận ứng với phân bố xác suất thực tế của các tình huống có thể xảy ra, chứ không phải là kỳ vọng lợi nhuận ứng với phân bố xác suất trung hòa rủi ro, vì kỳ vọng lợi nhuận ứng với phân bố xác suất trung hòa rủi ro phải bằng 0 . (Xác suất thực tế là một khái niệm trừu tượng và khó xác định, nhưng ta có thể tạm hiểu là: dựa trên tất cả các thông tin đã có được, thì xác suất để xảy ra các tình huống được đánh giá như vậy). Để tính xác suất trung hòa rủi ro, gọi xác suất trung hòa rủi ro của tình huống thuốc có tác dụng là $p_{*}$. Khi đó xác suất trung hòa rủi ro của tình huống thuốc không có tác dụng là $1-p_{*}$. Kỳ vọng giá cổ phiếu của ngày hôm sau theo xác suất trung hòa rủi ro bằng $16 p+5(1-p)$ đô la. Vì kỳ vọng lợi nhuận của cổ phiếu theo xác suất trung hòa rủi ro bằng 0 , nên ta có $16 p_{*}+5\left(1-p_{*}\right)=10$, từ đó tính được $p_{*}=5 / 11$ và $1-p_{*}=6 / 11$.

Ví dụ trên cho thấy xác suất trung hòa rủi ro nói chung khác với xác suất thực tế. Kỳ vọng lợi nhuận theo xác suất trung hòa rủi ro bằng 0 , trong khi theo xác suất thực tế có thể là số dương, hoặc cũng có thể là số âm, tùy trường hợp. Nếu chúng ta giả sử rằng các nhà đầu tư không quan tâm đến rủi ro (tức là khả năng bị lỗ), mà chỉ quan tâm đến kỳ vọng lợi nhuận (sẵn sàng đặt cược bất cứ chỗ nào có kỳ vọng lợi nhuận dương, dù mức độ rủi ro ra sao), thì khi đó xác suất thực tế sẽ chính bằng xác suất trung hòa rủi ro (vì nếu không thì lại thành có cơ hội arbitrage - hãy chứng minh điều đó). Thế nhưng, nói chung các nhà đầu tư trên thị trường chứng khoán có quan tâm đến rủi ro, và đó là một trong những lý do vì sao xác suất thực tế khác với xác suất trung hòa rủi ro.

Trong "điều kiện bình thường", thì các nhà đầu tư sẽ chỉ đầu tư khi mà kỳ vọng lợi nhuận là số dương (theo xác suất thực tế) và đủ lớn so với những rủi ro có thể xảy ra, trong khi theo xác suất trung hòa rủi ro thì kỳ vọng lợi nhuận luôn băng 0 . Kỳ vọng lợi nhuận dương này có thể coi là một thứ phí mạo hiểm (risk premium), dành cho những người chấp nhận rủi ro. Sự thú vị của xác suất trung hòa rủi ro nằm ở chỗ phí rủi ro được tính luôn vào phân bố xác suất, hay nói cách khác, sự chênh lệch kỳ vọng giữa phân bố xác suất thực tế và phân bố xác suất trung hòa rủi ro thể hiện chính cái phí mạo hiểm đó. Trong một số trường hợp, điều ngược lại có thể xảy ra, tức là kỳ vọng lợi nhuận theo xác suất thực tế có thể là số âm, khi có quá nhiều người thích mạo hiểm. Ví dụ như ở sòng bạc, các con bạc sẵn sàng bỏ tiền ra đặt cọc tuy biết rằng kỳ vọng lợi nhuận là âm. 
Tuy rằng xác suất trung hòa rủi ro là xác suất "bịa", có thể hoàn toàn khác xa với xác suất thực tế, nhưng nó lại vô cùng quan trọng trong việc tính toán tài chính, đặc biệt là việc định giá các sản phẩm phái sinh, như ví dụ đơn giản sau cho thấy.

Ví $d u$ 3.5. Ta tiếp tục ví dụ 3.4 cùng với các giả thuyết trong ví dụ đó. Gọi $S$ là 1 cổ phiếu của công ty sinh học, và $C$ là quyền chọn mua nó (call option) vào ngày hôm sau với giá $10 \$$. Hỏi rằng giá của $C$ vào thời điểm hôm nay là bao nhiêu thì hợp lý ? Nếu tính theo phân bố xác suất thực tế, thì có hai khả năng xảy ra với $C$ :

a) Giá cổ phiếu lên thành $16 \$$ vào ngày hôm sau, và $C$ sẽ có giá trị bằng $16-10=6$ đô la. Khả năng này có xác suất xảy ra là $60 \%$

b) Giá cổ phiếu xuống còn $5 \$$, và lúc đó thì giá trị của $C$ bằng 0 . Khả năng này có xác suất xảy ra là $40 \%$. Như vậy, giá trị kỳ vọng của $C$ theo phân bố xác suất thực tế bằng $60 \% .6+40 \% .0=3.6$ đô la. Thế nhưng, giá trị kỳ vọng này của $C$ theo phân bố xác suất thực tế không phải là giá hợp lý của $C$ vào thời điểm ngày hôm nay, vì giá này không thỏa mãn nguyên lý no-arbitrage !

Thật vậy, giả sử ta có thể mua/bán $C$ với giá $3.6 \$$ trong ngày hôm nay. Khi đó ta có thể làm chẳng hạn như sau: mua 6 cổ phiếu $S$ với giá $10 \$$ một cổ phiếu, và bán 10 call $C$ với giá $3.6 \$$, như vậy ta bỏ ra tổng cộng $6 \times 10-10 \times 3.6=24$ đô la cho rổ tài sản $6 S-10 C$, hay nói cách khác, rổ tài sản $6 S-10 C$ có giá là $24 \$$ ngày hôm nay. Sang ngày hôm sau có hai tình huống có thể xảy ra: hoặc là $S$ có giá $16 \$$ và $C$ có giá $6 \$$ và khi đó rổ tài sản $6 S-10 C$ có giá $6 \times 16-10 \times 6=36 \$$, hoặc là $S$ có giá $5 \$$ và $C$ có giá $0 \$$, và khi đó rổ tài sản $6 S-10 C$ có giá $6 \times 5-10 \times 0=30 \$$. Trong cả hai trường hợp thì giá của rổ tài sản đều tăng lên so với ngày hôm trước (từ $24 \$$ lên thành $36 \$$ hoặc $30 \$$ ) và như vậy đây là một cơ hội kinh doanh chênh lệch giá, trái ngược với nguyên lý no-arbitrage.

Nếu như giá hợp lý của $C$ không phải là $3.6 \$$, thì nó là bao nhiêu ? Câu trả lời là nó chính bằng giá trị kỳ vọng của $C$ tính theo phân bố xác suất trung hòa rủi ro! Theo phân bố xác suất trung hòa rủi ro thì xác suất của tình huống giá của $X$ lên thành $16 \$$ là $5 / 11$ còn xác suất của tình huống giá của $X$ giảm xuống còn $5 \$$ là $6 / 11$, và do đó giá trị kỳ vọng của $C$ theo phân bố xác suất này bằng $(5 / 11) \cdot 6+(6 / 11) \cdot 0=30 / 11 \$ \approx 2.73 \$$, tức là giá hợp lý của $C$ trong ngày hôm nay là $2.73 \$$, chứ không phải $3.6 \$$.

Bài tập 3.4. Chứng minh rằng, trong ví dụ trên, giá $30 / 11 \$$ của $C$ chính là giá duy nhất thỏa mãn nguyên lý no-arbitrage.

Ví dụ trên là một trường hợp riêng của nguyên tắc quan trọng sau trong toán tài chính: để định giá các sản phẩm phái sinh, phân bố xác suất mà ta cần dùng không phải là phân bố xác suất thực tế, mà chính là phân bố xác suất trung hòa rủi ro. 
Nguyên lý no-arbitrage cộng với định lý kinh doanh chênh lệch giá cho ta sự tồn tại của xác suất trung hòa rủi ro, nhưng chúng không nói gì đến việc phân bố xác suất trung hòa rủi ro có duy nhất hay không. Ví dụ đơn giản sau cho thấy có những mô hình mà trong đó nó không duy nhất.

Vi du 3.6. Giả sử thị trường chứng khoán có lãi suất bằng 0 , và giao dịch duy nhất một loại cổ phiếu $X$, ở thời điểm hiện tại $T_{0}$ và một thời điểm tương lai $T_{1}$. Tại thời điểm hiện tại $T_{0}$ thì giá của $X$ là $100 \$$. Vào thời điểm $T_{1}$ thì có thể có 3 tình huống xảy ra với giá của $X: 140 \$, 90 \$$, và $80 \$$. Hỏi phân bố xác suất trung hòa rủi ro trên tập các tình huống đó ra sao ?

Gọi xác suất của tình huống giá $140 \$$ là $p_{1}$, của tình huống giá $90 \$$ là $p_{2}$, và của tình huống giá $80 \$$ là $p_{3}$. Khi đó $\left(p_{1}, p_{2}, p_{3}\right)$ là một bộ 3 số không âm, thoả mãn hai phương trình

$$
p_{1}+p_{2}+p_{3}=1
$$

và

$$
p_{1} .140+p_{2} .90+p_{3} .80=100 \text {. }
$$

Phương trình thứ hai là phương trình lợi nhuận kỳ vọng bằng 0 . Vì ở đây ta có những 3 ẩn số $p_{1}, p_{2}, p_{3}$ mà chỉ có 2 phương trình, nên có vô hạn các nghiệm, có nghĩa là tập hợp các phân bố xác suất trung hòa rủi ro ở đây là một tập vô hạn, và ta không có tính duy nhất của xác suất trung hòa rủi ro trong bài toán này. Ví dụ, ta có thể đặt $\left(p_{1}=1 / 5, p_{2}=4 / 5, p_{3}=0\right)$ hoặc $\left(p_{1}=1 / 3, p_{2}=0, p_{3}=2 / 3\right)$.

Trong ví dụ trên, sở dĩ xác suất trung hòa rủi ro không duy nhất, bởi vì số tài sản giao dịnh trên thị trường quá ít so với số các tình huống xảy ra (ở đây có 3 tình huống trong khi chỉ có 1 tài sản). Nếu số tài sản đủ nhiều so với số các tình huống, thì số phương trình tuyến tính trong hệ phương trình xác định phân bố xác suất trung hòa rủi ro sẽ đủ nhiều, để nó chỉ có 1 nghiệm duy nhất. Chẳng hạn, nếu thị trường có giao dịch $n$ cổ phiếu, và vào thời điểm tương lai $T_{1}$ có $n+1$ tình huống có thể xảy ra, thì nói chung xác suất trung hòa rủi ro sẽ duy nhất.

Bài tập 3.5. (Một mô hình cây nhị phân đơn giản). Trong bài tập này, ta giả sử là lãi suất là cố định ở mức $10 \% /$ năm lãi kép theo năm, có nghĩa là có thể vay tiền và một năm sau trả lãi $10 \%$, hoặc cho vay tiền và một năm sau nhận được lãi $10 \%$, số lượng không hạn chế. Giả sử là có một chứng khoán $X$ vào thời điểm hiện tại $(t=0)$ có giá 100 . Vào thời điểm một năm sau $(t=1)$ có hai tình huống có thể xảy ra với $X$ : hoặc là $X$ lên giá thành 150 , hoặc là giảm giá còn 70 . Nếu giá của $X$ vào thời điểm $t=1$ là 150 , thì vào thời điểm 
1 năm sau đó nữa $(t=2)$ có hai tình huống có thể xảy ra: hoặc là $X$ lên giá thành 200 , hoặc là giảm giá thành 110 . Nếu $X=70$ tại thời điểm $t=1$, thì tại thời điểm $t=2$ cũng có hai tình huống có thể xảy ra: hoặc là $X$ lên giá thành 100 , hoặc là $X$ giảm giá thành 50. Thị trường ở đây chỉ mở cửa tại các thời điểm $0,1,2$, và chỉ gồm chứng khoán $X$ và tiền mặt với lãi suất 10\%. Tìm xác suất trung hòa rủi ro của thị trường này (trên không gian tất cả các tình huống có thể xảy ra được mô tả phía trên), và chứng minh tính duy nhất của nó.

Ghi chú 3.5. Để tính toán giá trị của các sản phẩm phái sinh bằng cách sử dụng phân bố xác suất trung hòa rủi ro, nói chung ta sẽ phải giả sử là phân bố xác suất này là duy nhất, vì nếu không thì sẽ bất tiện, vì có thể có nhiều đáp số khác nhau cho cùng một câu hỏi về giá. Bởi vậy, các mô hình biến động giá cả của thị trường chứng khoán mà chúng ta xét ở những phần sau thường sẽ chỉ có một xác suất trung hòa rủi ro duy nhất. Tính duy nhất của xác suất trung hòa rủi ro tương đương với một tính chất khác của thị trường, gọi là tính đầy đủ. Ta sẽ chỉ xét các mô hình thị trường dầy đủ (complete market) khi nghiên cứu các sản phẩm phái sinh trong các chương sau.

\section{5 Định giá hợp đồng kỳ hạn và hợp đồng tương lai}

Để làm ví dụ minh họa cho nguyên lý no-arbitrage, ở mục này chúng ta sẽ thảo luận các công thức định giá cho hợp đồng kỳ hạn và hợp đồng tương lai cho các hàng hóa. Nhắc lại rằng, các hợp đồng này là các chứng khoán phái sinh, đã được nhắc đến trong Mục 2.4.

Trong trường hợp mà mặt hàng của hợp đồng kỳ hạn là loại có dự trữ lớn, dễ bảo quản, không hao mòn hay lỗi thời theo thời gian, nhưng cũng không sinh ra lợi tức theo thời gian, thì ta có công thức giá kỳ hạn như sau:

$$
F(0, T)=(1+R)^{T} S(0),
$$

trong đó $T$ là thời gian tính từ thời điểm thiết lập hợp đồng (thời điểm 0 ) cho đến kỳ hạn của hợp đồng, theo đơn vị năm, $S(0)$ là giá của mặt hàng tại thời điểm $0, R$ là lãi suất tính theo năm, và $F(0, T)$ là giá kỳ hạn tại thời điểm thiết lập hợp đồng cho mặt hàng $S$ và kỳ hạn $T$.

Để hiểu ý nghĩa của công thức trên, xét hai lựa chọn sau đối với người mua:

1) Mua mặt hàng ngay bây giờ, với giá $S(0)$, và giữ nó đến thời điểm $T$. (Ở đây ta giả thiết là việc giữ này không tốn tiền, nhưng cũng không sinh ra tiền). 
2) Cho vay số tiền $S(0)$ với lãi suất $R$ (tính lãi kép trả theo năm), sau thời hạn $T$ thì số tiền $S(0)$ trở thành $(1+R)^{T} S(0)$, và đem số tiền đó đổi lấy mặt hàng tại thời điểm $T$ theo hợp đồng kỳ hạn. (Ở đây, để đơn giản, ta giả thiết là ai cũng có thể vay hoặc cho vay với lãi suất $R$ ).

Hai chọn lựa đó phải cho kết quả tương đương, tức là ta phải có $F(0, T)=(1+R)^{T} S(0)$, bởi vì nếu $F(0, T)>(1+R)^{T} S(0)$ thì người mua sẽ chỉ chọn lựa phương án thứ nhất, tức là mua ngay, chứ không chịu mua theo hợp đồng kỳ hạn, vì tính ra mua theo hợp đồng kỳ hạn như vậy tốn kém hơn. Ngược lại, nếu $F(0, T)<(1+R)^{T} S(0)$ thì không ai chịu dự trữ mặt hàng này từ thời điểm hiện tại cho đến thời điểm $T$ nữa (trái ngược với giả thuyết là mặt hàng này có lượng dự trữ lớn), mà sẽ tìm cách bán nó đi tại thời điểm hiện tại, lấy tiền đem cho vay từ thời điểm hiện tại đến thời điểm $T$, rồi mua lại tại thời điểm $T$, để được lợi hơn. Việc bán đi theo giá hiện tại và mua lại theo hợp đồng kỳ hạn nhằm kiếm lời đó khiến cho giá hiện tại giảm đi và giá kỳ hạn tăng lên, cho đến khi đạt sự cân bằng, tức là khi $F(0, T)=(1+R)^{T} S(0)$. Nói cách khác, nếu $F(0, T)>(1+R)^{T} S(0)$ thì có một cơ hội kinh doanh chênh lệch giá như sau: vay 1 khoản tiền $S(0)$ với lãi suất $R$, mua hàng với số tiền đó, rồi làm hợp đồng kỳ hạn để bán hàng đó đi với giá kỳ hạn $F(0, T)$. Như vậy vào thời điểm 0 thì không phải bỏ ra đồng nào (tiền vay bằng tiền mua hàng), và vào thời điểm $T$ thì thu được $F(0, T)-(1+R)^{T} S(0)$ tiền lời (sau khi đã bán hàng theo hợp đồng kỳ hạn, và trả hết nợ kể cả tiền lãi suất). Nếu $F(0, T)<(1+R)^{T} S(0)$ thì cũng có cơ hội arbitrage ngược lại: vay hàng (với giả sử là sự vay này không phải trả lãi, nếu như sau kỳ hạn $T$ trả đúng mặt hàng và số lượng như cũ) bán đi lấy tiền, cho vay tiền, đến kỳ hạn $T$ lấy lại tiền, mua hàng theo hợp đồng kỳ hạn ký từ thời điểm 0 , trả lại hàng, và được lời. Bởi vậy, với giả sử là nguyên lý no-arbitrage được thỏa mãn, thì ta phải có $F(0, T)=(1+R)^{T} S(0)$.

Đối với một số mặt hàng như sắt thép, dầu hỏa, vàng, cổ phiếu không trả cổ tức, thì công thức giá kỳ hạn phía trên khá là chính xác. Nhưng cũng có những mặt hàng mà công thức trên không còn chính xác, bởi vì chúng không thỏa mãn các tính chất đòi hỏi, chẳng hạn như:

- Các mặt hàng khó bảo quản. Hoa tươi là một ví dụ. Giá hoa tươi thường đắt hơn vào dịp lễ so với ngày thường, nhưng không thể mua sẵn hoa tươi trước 3 tháng để sử dụng vào ngày lễ được. Bởi vậy nếu kỳ hạn rơi đúng vào dịp lễ, thì giá kỳ hạn có thể đắt hơn nhiều giá hiện tại.

- Các mặt hàng có xu hướng giảm giá nhanh chóng theo thời gian. Ví dụ như, ta có thể kỳ vọng là, 1 gigabyte bộ nhớ máy tính sau hai năm sẽ có giá thấp hơn giá hiện tại, 
vì công nghệ máy tính phát triển nhanh. Do vậy giá kỳ hạn 2 năm cho 1 gigabyte bộ nhớ máy tính phải thấp hơn nhiều so với giá hiện tại.

- Các mặt hàng sinh thu nhập cho người giữ nó. Ví dụ như cổ phiếu có trả cổ tức. Giả sử một cổ phiếu sẽ trả một lượng cổ tức bằng tiền mặt là $D$ tại một thời điểm $t$ trước kỳ hạn $T, 0<t<T$. Khi đó công thức giá kỳ hạn phải được điều chỉnh như sau:

$$
F(0, T)=(1+R)^{T} S(0)-(1+R)^{T-t} D,
$$

hay là

$$
F(0, T)+(1+R)^{T-t} D=(1+R)^{T} S(0) .
$$

Thật vậy, một người có thể mua cổ phiếu với giá $S(0)$ tại thời điểm hiện tại, đồng thời lập hợp đồng kỳ hạn để bán nó tại thời điểm $T$ với giá $F(0, T)$, và khi đến thời điểm $t$ nhận được cổ tức $D$ thì đem cho vay cổ tức này với lãi suất $R$. Khi đó đến thời điểm $T$, sẽ có tổng cộng số tiền là $F(0, T)+(1+R)^{T-t} D$ sinh ra từ $S(0)$ vào thời điểm 0 . Hoặc người đó có thể cho vay khoản tiền $S(0)$ vào thời điểm 0 , thì đến thời điểm $T$ sẽ được thành khoản tiền $(1+R)^{T} S(0)$. Theo nguyên lý no-arbitrage, thì hai cách đó phải cho cùng hiệu quả tài chính, tức là ta phải có đẳng thức $F(0, T)+(1+R)^{T-t} D=(1+R)^{T} S(0)$.

Trong trường hợp mà cổ phiếu trả cổ tức nhiều lần trong giai đoạn trước kỳ hạn, thì ta cũng có công thức tương tự như trên để tính giá kỳ hạn:

$$
F(0, T)=(1+R)^{T} S(0)-\sum_{i}(1+R)^{T-t_{i}} D_{i}
$$

trong đó $D_{i}$ là các cổ tức trả tại các thời điểm $t_{i}$ trước kỳ hạn $T$.

Một ví dụ khác về mặt hàng sinh thu nhập là ngoại tệ, với mức thu nhập do lãi suất của ngoại tệ đó đem lại. Khi đó công thức giá kỳ hạn cũng cần được điều chỉnh tương ứng.

Ví du 3.7. Giả sử rằng vào thời điểm 31/01/2011, tỷ giá USA/VND là 20000 (tức là 1 USD $=20000$ VND), lãi suất (tính theo năm) của VND là $13 \%$, còn lãi suất của USD là $3 \%$. Hỏi rằng vào thời điểm 31/01/2011 tỷ giá kỳ hạn USD/VND của một hợp đồng kỳ hạn đổi VND lấy USD cho kỳ hạn 1 năm là bao nhiêu ? Câu trả lời là:

$$
F(0,1)=20000 \times(1+13 \%) /(1+3 \%) \approx 21942,
$$

bởi vì một người có thể dùng VND mua USD từ thời điểm 31/01/2011 rồi cho vay bằng tiền USD trong 1 năm, hoặc là cho vay số tiền VND đó trong 1 năm rồi dùng số tiền VND cộng với lãi có được sau 1 năm chuyển thành USD theo hợp đồng kỳ hạn, và hai cách đó phải cho kết quả tương đương. 
Ví dụ trên cho thấy một qui tắc thú vị là: nếu có hai loại tiền $\mathrm{A}$ và $\mathrm{B}$, trong đó lãi suất của $\mathrm{B}$ thấp hơn lãi suất của $\mathrm{A}$, thì tỷ giá kỳ hạn của $\mathrm{B} / \mathrm{A}$ sẽ cao hơn là tỷ giá hiện tại, có nghĩa là người ta kỳ vọng là đồng tiền $\mathrm{B}$ sẽ lên giá so với đồng tiền $\mathrm{A}$ (nếu như bỏ qua các yếu tố khác). Điều này có thể được giải thích một phần qua sự liên quan giữa lãi suất và lạm phát: đồng tiền có lãi suất cao hơn thường ứng với lạm phát cao hơn, do đó giá trị giảm đi nhanh hơn, và tỷ giá hối đoái cũng phải giảm đi theo thời gian so với đồng tiền có lãi suất thấp hơn và lạm phát thấp hơn.

Giá trị của hợp đồng kỳ hạn: Giá trị của hợp đồng kỳ hạn là khoản lỗ/lãi tạo ra bởi hợp đồng kỳ hạn, cho bên mua của một hợp đồng kỳ hạn, do sự biến động của giá cả theo thời gian.

Vi du 3.8. Giả sử ta có một hợp đồng kỳ hạn sau, thiết lập vào ngày 31/12/2010: mua 1 thùng dầu hỏa tại kỳ hạn 31/12/2011 với giá kỳ hạn là 89\$. Giả sử rằng, giá dầu hỏa tăng lên trong đầu năm 2011, và nếu ký hợp đồng kỳ hạn để mua dầu hỏa tại thời điểm 31/03/2011 cho kỳ hạn 31/12/2011, sẽ phải trả giá kỳ hạn là $95 \$$ thay vì $89 \$$ như trước. Sự chênh lệch giá $95 \$$ - $89 \$=6 \$$ đó là khoản lợi mà hợp đồng kỳ hạn ban đầu của ta đem lại vào thời điểm 31/03/2011: ta có thể ký thêm một hợp đồng kỳ hạn bán 1 thùng dầu hỏa tại thời điểm 31/03/2011 cho kỳ hạn 31/12/2011 với giá kỳ hạn 95\$. Hai hợp đồng kỳ hạn này của ta, một bán và một mua, bù trừ cho nhau, nhưng với giá khác nhau: vào thời điểm 31/12/2011 thì ta mua với giá $89 \$$ theo hợp đồng mua và bán lại với giá $95 \$$ theo hợp đồng bán, lãi $6 \$$. Số tiền lãi này phải đợi đến 31/12/2011 mới nhận được, chứ không phải nhận được ngay vào thời điểm 31/03/2011. Vì tiền có thể cho vay sinh lãi hoặc phải đi vay trả lãi, nên $6 \$$ vào thời điểm $31 / 12 / 2011$ chỉ có giá trị bằng $6 \times(1+R)^{-3 / 4} \$$ vào thời điểm 31/03/2011, trong đó $R$ là lãi suất còn $3 / 4$ là khoảng thời gian tính theo năm. Chẳng hạn nếu lãi suất là $R=3 \%$ thì $6(1+R)^{-3 / 4}=5.87$, và ta có thể coi rằng giá trị của hợp đồng kỳ hạn ban đầu của ta vào thời điểm 31/03/2011 là 5.87\$.

Nói một cách tổng quát, ta có công thức sau để tính giá trị của một hợp đồng kỳ hạn:

$$
V(t)=[F(t, T)-F(0, T)](1+R)^{-(T-t)},
$$

trong đó $T$ là thời điểm đáo hạn hợp đồng (tính theo đơn vị năm), 0 là thời điểm thiết lập hợp đồng, $V(t)$ là giá trị của hợp đồng tại thời điểm $t(0 \leq t \leq T), F(t, T)$ là giá kỳ hạn của hợp đồng kỳ hạn có thể thiết lập tại thời điểm $t$ cho cùng một mặt hàng và cùng thời điểm đáo hạn $T$, còn $R$ là mức lãi suất (tính theo năm). Bởi vì $F(t, T)=S(t)(1+R)^{(T-t)}$ trong đó $S(t)$ là giá của hàng hóa tại thời điểm $t$ (với giả sử là hàng hóa được xét ở đây thuộc loại dễ bảo quản, không sinh lợi tức nhưng cũng không mất giá trị theo thời gian) 
nên ta cũng có thể viết:

$$
V(t)=S(t)-F(0, T)(1+R)^{-(T-t)}
$$

Tại thời điểm ban đầu thì giá trị của hợp đồng kỳ hạn $V(0)=0$, tức là bên mua và bên bán không có bên nào lỗ lãi vì hợp đồng này. Tại thời điểm đáo hạn $T$ thì $F(T, T)=S(T)$ là giá thị trường cho mặt hàng tại thời điểm đó, và giá trị của hợp đồng kỳ hạn lúc đó là $V(T)=S(T)-F(0, T)$, bằng chênh lệch giữa giá thị trường tại thời điểm đó và giá kỳ hạn được thiết lập tại thời điểm ban đầu.

Công thức (3.14) cũng chính là công thức tính giá trị tại thời điểm $t$ của một hợp đồng tương lai lập tại thời điểm 0 cho kỳ hạn $T$ : tại thời điểm $t$ thì tài khoản của người mua hợp đồng tương lai được cộng vào một khoản tiền là $V(t)$ so với thời điểm 0 (tài khoản tăng lên nếu $V(t)$ dương và giảm đi nếu $V(t)$ âm), còn đối với người bán thì ngược lại, tài khoản được trừ đi một khoản tiền là $V(t)$ so với thời điểm 0 . 


\section{Chương 4}

\section{Lãi suất và trái phiếu}

Trong chương này, chúng ta sẽ nghiên cứu một số khía cạnh cơ bản của các loại lãi suất, các cách tính toán với chúng, cấu trúc của chúng, và ảnh hưởng của chúng đến giá trị của dòng tiền tệ nhận được trong tương lai, cũng như đến các sản phẩm nợ như là trái phiếu.

\subsection{Các cánh tính lãi suất}

Có nhiều qui ước đo lãi suất khác nhau, cùng là một sản phẩm tài chính nhưng khi tính lãi suất theo các qui ước khác nhau đó sẽ ra các mức lãi suất danh nghĩa (nominal interest rate) khác nhau! Bởi vậy khi nói đến lãi suất cần phải nói cụ thể hơn là lãi suất đó được tính theo qui ước nào. Trong phần này chúng ta sẽ bàn đến một số qui ước tính lãi suất thông dụng nhất, trong đó có: lãi đơn (qui ước của các khoản vay ngắn hạn trên thị trường tiền tệ), lãi chiết khấu (qui ước của một số sản phẩm nợ ngắn hạn như thương phiếu và tín phiếu kho bạc), lãi kép theo năm (còn gọi là lãi suất hiệu dụng, hay lợi suất theo trái phiếu), và lãi kép liên tục (là cách tính thuận tiện nhất trong việc phân tích nhiều sản phẩm tài chính phái sinh). Khi tính toán với lãi suất, cần phải biết là sản phẩm tài chính nào trên thị trường nào được tính lãi suất theo qui ước nào, để khỏi bị tính sai.

\subsubsection{Lãi đơn}

Khi một người cho vay một số tiền $P$, với lãi suất ả $R$, tính theo lãi đơn (simple interest), trong thời hạn $t$ (tính theo đơn vị năm), thì sau thời gian $t$ sẽ nhận lại được 
một số tiền là:

$$
V(t)=(1+t R) P=P+t R P
$$

trong đó $P$ là số tiền gốc, và $t R P$ là số tiền lãi.

Cho các thời hạn ngắn dưới 1 năm, người ta hay dùng đơn vị thời gian là ngày thay vì đơn vị năm. Khi đó, trước khi dùng công thức trên, phải qui đổi số ngày ra thành số năm theo công thức

$$
t=d / N
$$

trong đó $d$ là số ngày của thời hạn, còn $N$ là số ngày trong năm. Số $N$ này không nhất thiết phải là số ngày thực tế của một năm, mà là số ngày qui ước theo qui ước của thị trường! Một số nơi (như ở Anh và Nhật) qui ước là một năm có $N=365$ ngày, trong khi đó phần lớn các nơi khác trên thế giới (trong đó có Việt Nam, Mỹ, và các nước châu Âu ngoài Anh) dùng qui ước một năm chỉ có $N=360$ ngày (tương đương 12 tháng mỗi tháng 30 ngày) cho các thời hạn ngắn. Bởi vậy, cần phải biết là dùng qui ước nào về tính số ngày (day-count) để tính toán khỏi nhầm lẫn.

Công thức 4.1) cũng có thể được viết lại như sau:

$$
V(t)=\left(1+\frac{d R}{N}\right) P
$$

Vi du 4.1. Giả sử rằng khoản tiền $2000 \$$ được gửi vào ngân hàng trong vòng 20 ngày với lãi suất đơn $4 \%$ và qui ước một năm có 360 ngày. Như vậy $t=\frac{20}{360}$ và $R=0.04$. Sau 20 ngày khoản tiền gửi sẽ tăng lên thành $V\left(\frac{20}{360}\right)=\left(1+\frac{20}{360} \times 0.04\right) \times 2000 \$ \cong 2004.49 \$$, có nghĩa là tiền lãi nhận được cho khoản tiền gửi này là $4.49 \$$.

Vi du 4.2. Tìm số tiền gốc được gửi ban đầu vào 1 tài khoản có lãi suất đơn là $8 \%$ nếu cần thu được tổng cộng $100000 £$ sau 91 ngày (3 tháng), với qui ước một năm có 365 ngày. Ta có gốc $P$ phải thỏa mãn

$$
V=\left(1+\frac{91}{365} \times 0.08\right) P=100000
$$

từ đó suy ra $P \cong 98044 £$.

Ví dụ trên là một trường hợp của bài toán: tìm số tiền gốc $P=V(0)$ ban đầu (của một khoản tiền cho vay) khi biết giá trị $V(t)$ của nó vào thời điểm $t$. Trong trường hợp lãi đơn câu trả lời dễ dàng tìm được bằng cách giải (4.1) để tìm gốc. Thật vậy, ta có

$$
V(0)=(1+t R)^{-1} V(t)
$$


Con số $V(0)$ này được gọi là giá trị hiện tại (present value) hay giá trị chiết khấu (discounted value) của $V(t)$, còn $(1+t R)^{-1}$ được gọi là thừa số chiết khấu (discount factor). Con số

$$
K(0, t):=\frac{V(t)-V(0)}{V(0)}
$$

được gọi là mức lợi nhuận (return) cho giai đoạn thời gian từ 0 đến $t$ cho mọi khoản đầu tư mà giá trị tại thời điểm 0 (thời điểm ban đầu) là $V(0)$ và tại thời điểm $t$ là $V(t)$. Trong trường hợp mà lãi tiền gửi được tính theo qui ước lãi đơn, thì mức lợi nhuận của tiền gửi trong khoảng thời gian $t$ với lãi suất $R$ chính bằng $t R$ :

$$
K(0, t)=t R
$$

Qui ước tính lãi theo lãi đơn là qui ước được dùng cho các khoản tiền gửi và vay nợ ngắn hạn liên ngân hàng (interbank deposits and loans) ở các thị trường tiền tệ (money market), tức là các thị trường tài chính dành cho các sản phẩm nợ ngắn hạn. Bởi vậy, kiểu tính theo lãi đơn còn được gọi là qui ước tính lợi suất theo thị trường tiền tệ (moneymarket yield convention). Nhắc lại rằng, theo qui ước này, giá hiện tại $V(0)$ của một khoản đầu tư trên thị trường tiền tệ có giá trị $V(t)$ sau thời gian $t$ (tính theo năm) và mức lãi suất danh nghĩa $R$ sẽ là:

$$
V(0)=\frac{V(t)}{1+t R}
$$

Tiền mặt ở trong các tài khoản chứng khoán trên thế giới thường là được trả lãi hàng tháng, vào đầu tháng sau cho tiền để trong tài khoản trong tháng trước, theo qui ước lãi đơn: tiền lãi được tính cho từng ngày một (bằng lãi suất tiền gửi thời hạn 1 ngày, nhân với số tiền mặt có trong tài khoản vào thời điểm cuối ngày), nhưng tổng số tiền lãi của các ngày trong tháng được cộng lại cho cả tháng đến đầu tháng sau mới được trả vào tài khoản.

Bài tập 4.1. Một nhà đầu tư mua một sản phẩm nợ trên thị trường tiền tệ. Sản phẩm nợ này còn kỳ hạn 14 ngày, và sẽ có giá trị là 1 triệu $\$$ sau 14 ngày khi hết kỳ hạn. Giả sử người này được hưởng lãi suất đơn $R=5.3 \%$, và qui ước 1 năm $=360$ ngày. Hỏi người này phải trả bao nhiêu tiền để mua sản phẩm nợ trên?

Bài tập 4.2. Một khoản tiền $10000 \$$ được gửi vào nhà băng trong vòng 61 ngày, với lãi đơn, sẽ thu về $\$ 10076$ khi đáo hạn. Tìm lãi suất đơn $R$ của khoản tiền gửi này, và mức lợi nhuận (return) của nó. (Qui ước 1 năm = 360 ngày). 
Bài tập 4.3. Giả sử một người có một tài khoản chứng khoán, với số tiền mặt trong tài khoản là $12000 \$$ trong 17 ngày đầu tháng, $15000 \$$ trong 13 ngày cuối tháng, của một tháng nào đó có 30 ngày. Giả sử lãi suất mà người này nhận được cho khoản tiền mặt của mình là 3\%/năm, tính theo qui ước lãi đơn như trên, với qui ước 1 năm là 365 ngày. Hỏi đầu tháng sau người này được bao nhiêu tiền lãi cho khoản tiền mặt ở trong tài khoản?

\subsubsection{Lãi suất chiết khấu}

Một số sản phẩm tài chính ngắn hạn thông dụng, đặc biệt là các thương phiếu (commercial paper) và các tín phiếu kho bạc (treasury bill ) có kỳ hạn không quá 1 năm, không dùng qui ước tính lãi đơn, mà dùng một qui ước khác, gọi là qui ước lãi suất chiết khấu (discount rate). Những sản phẩm mà lãi suất được tính theo qui ước lãi suất chiết khấu này sẽ được gọi chung là trái phiếu chiết khấu (discount bond). Ý nghĩa của từ chiết khấu ở đây là: giá của một trái phiếu chiết khấu nhỏ hơn mệnh giá của nó, và phần chênh lệch gọi là phần chiết khấu (discount), và đấy chính là phần lãi trả cho trái phiếu cho đến khi đáo hạn. Càng xa thời điểm hết hạn, thì giá của trái phiếu chiết khấu càng giảm đi, một cách tuyến tính theo thời gian còn lại, với hệ số là lãi suất chiết khấu (với giả sử là lãi suất này không thay đổi).

Nếu như một trái phiếu chiết khấu có tổng kỳ hạn là $T$, có giá trị tại thời điểm hết hạn (mệnh giá) là $F=V(T)$, và mức lãi suất chiết khấu là $R$, thì giá $V(t)$ của nó tại thời điểm $t$ (kể từ khi phát hành) được tính theo công thức sau:

$$
V(t)=(1-(T-t) R) V(T)
$$

Ngược lại, nếu biết giá $V(t)$, thì mức lãi suất chiết khấu là

$$
R=\frac{V(T)-V(t)}{(T-t) V(T)}
$$

Mức lợi nhuận $K(t, T):=(V(T)-V(t)) / V(t)$ cho giai đoạn từ thời điểm $t$ đến thời điểm $T$ của trái phiếu chiết khấu có thể được tính ra từ lãi suất chiết khấu $R$ theo công thức:

$$
K(t, T)=\frac{1}{1-(T-t) R}-1=\frac{(T-t) R}{1-(T-t) R} .
$$

Tất nhiên, qui ước lãi suất chiết khấu không tương đương với qui ước lãi đơn: nếu hai sản phẩm nợ có cùng thời hạn và mức lãi suất danh nghĩa, nhưng lãi suất của sản phẩm thứ nhất là lãi đơn còn lãi suất của sản phẩm thứ hai là lãi suất chiết khấu, thì sản phẩm thứ hai trả lãi cao hơn sản phẩm thứ nhất. 


\subsubsection{Lãi kép}

Giả sử một người cho vay một khoản tiền $P$ dài hạn, với thời hạn là $t$, lãi suất cố định là $R$, và được trả lãi định kỳ mỗi năm $m$ lần (ví dụ $m=4$ nếu được trả lãi mỗi quí một lần), nhưng thay vì rút tiền lãi ra khỏi tài khoản, người này tiếp tục cho vay các khoản tiền lãi nhận được. Như vậy, không chỉ có tiền gốc sinh ra lãi, mà các khoản tiền lãi cũng sinh ra lãi, hay còn gọi là lãi mẹ đẻ lãi con. Để tính tổng cộng số tiền mà người này sẽ nhận được khi hết kỳ hạn cho vay trong trường hợp này, công thức tính lợi suất theo lãi đơn không còn thích hợp nữa, mà ta phải tính như sau: vào thời điểm 0 , tài khoản cho vay của người này có giá trị là $V(0)=P$. Tại thời điểm $1 / m$ (sau khi được trả lãi lần đầu tiên), tài khoản này trở thành $V(1 / m)=(1+R / m) P=P+(R / m) P$ như theo công thức tính lãi đơn. Cho giai đoạn thời gian từ $1 / m$ đến $2 / m$, người này cho vay không chỉ gốc ban đầu $P$, mà là toàn bộ $V(1 / m)$ trong đó có cả gốc ban đầu và lãi nhận được lần đầu tiên. Như vậy, tại thời điểm $2 / m$, tài khoản này trở thành $V(2 / m)=(1+R / m) V(1 / m)=(1+R / m)^{2} P$. Cứ tiếp tục $k$ lần như vậy, tại thời điểm $k / m$, tài khoản này trở thành $V(k / m)=(1+R / m)^{k} P$. Đặt $t=k / m$ (giả sử là $k=t m$ là số nguyên), ta được công thức sau:

$$
V(t)=\left(1+\frac{R}{m}\right)^{t m} P .
$$

Nói cách khác, mức lợi nhuận $K(0, t)=(V(t)-V(0)) / V(0)$ trong trường hợp này chính bằng

$$
K(0, t)=\left(1+\frac{R}{m}\right)^{t m}-1
$$

Các công thức trên được gọi là các công thức tính lãi kép (compound interest), bởi vì nó có tính đến chuyện lãi mẹ đẻ lãi con. Kể cả khi mà $t m$ không phải là số nguyên, thì công thức tính lãi kép này vẫn được sử dụng theo các qui ước tính lợi suất theo lãi kép.

Với cùng một mức lãi suất danh nghĩa như nhau, và cùng một kỳ hạn tiền gửi như nhau, thì lãi kép sẽ cho mức lợi nhuận cao hơn là lãi đơn:

$$
\left(1+\frac{R}{m}\right)^{t m}-1>t R,
$$

bởi vì công thức tính lãi đơn không tính đến chuyện lãi mẹ đẻ lãi con.

Vi du 4.3. Giả sử một tài khoản có lãi suất danh nghĩa là 5,75\%/năm tính theo qui ước lãi kép theo tháng (tức là $R=0.0575$ và $m=12$ trong các công thức trên). Nếu tiền gốc là $10000 \$$ thì sau ba năm rưỡi, giá trị của tài khoản sẽ là $V(3.5)=\left(1+\frac{0.0575}{12}\right)^{12 \times 3.5} \times$ 
$10000 \$=12223.42 \$$. Trong khi đó, nếu tính theo lãi đơn thì giá trị của tài khoản sẽ chỉ là $(1+0.0575 \times 3.5) 10000 \$=12012.5 \$$.

Mệnh đề 4.1. Hàm mức lợi nhuận $K(t ; R ; m):=\left(1+\frac{R}{m}\right)^{t m}-1$ của công thức lãi kép là hàm đơn diệu tăng theo các biến $R$ (lãi suất), $t$ (thời hạn) và $m$ (số lần trả lãi trong $m \hat{o ̣ t ~ n a ̆ m) . ~}$

Tính đơn điệu tăng của hàm $K(t ; R ; m)$ theo các biến $R$ và $t$ là tương đối hiển nhiên. Để thấy rằng hàm $K(t ; R ; m)$ cũng đơn điệu tăng theo $m$, ta có thể lấy đạo hàm của nó theo biến $m$, rồi chứng minh là đạo hàm đó luôn dương. Việc chứng minh này là một bài tập giải tích tương đối đơn giản, dành cho bạn đọc.

Bài tập 4.4. Giả sử một khoản tiền có thể được gửi theo 2 cách: hoặc lãi suất $15 \%$ tính lãi kép theo ngày, hoặc lãi suất $15.5 \%$ tính lãi kép theo nửa năm. Hỏi cách nào đem lại mức lợi nhuận cao hơn cho thời hạn 1 năm ?

\subsubsection{Lãi suất hiệu dụng và lợi suất trái phiếu}

Mức lợi nhuận cho khảng thời gian 1 năm của các khoản tiền gửi hoặc vay được gọi là mức lãi suất hiệu dụng (effective interest rate). Giả sử một khoản tiền được tính mức lãi kép theo $m$ lần một năm là $R^{\prime}$. Khi đó lãi suất hiệu dụng của nó bằng

$$
R=K\left(1 ; R^{\prime} ; m\right)=\left(1+\frac{R^{\prime}}{m}\right)^{m}-1
$$

Nếu như khoản tiền được tính lãi kép theo năm, với mức lãi kép theo năm bằng $R$, thì nó cũng có mức lãi suất hiệu dụng đúng bằng $R$. Bởi vậy, mức lãi suất hiệu dụng chính là mức lãi kép theo năm với lợi nhuận tương đương: Mức lãi kép $R^{\prime}$ tính theo $m$ lần 1 năm và mức lãi kép theo năm $R$, tuy khác nhau về con số danh nghĩa $\left(R \neq R^{\prime}\right)$, nhưng bằng nhau về bản chất, vì cùng cho một mức lợi nhuận hàng năm như nhau.

Mức lợi nhuận cho khoảng thời gian 1 năm của một trái phiếu dài hạn (có hạn dài hơn 1 năm) còn được gọi là lợi suất (yield) của nó, hay nói cách khác, lợi suất của trái phiếu chính là lãi suất hiệu dụng của nó. Đối với các sản phẩm nợ dài hạn nói chung, lãi suất hiệu dụng của chúng còn được gọi là lợi suất kiểu trái phiếu (bond-equivalent yield).

Đối với các trái phiếu zero-coupon [1) thì lợi suất được tính từ giá của nó như sau: Ta sẽ dùng ký hiệu $B(t, T)$ để chỉ giá của một trái phiếu zero-coupon có mệnh giá là 1 (1 ở

\footnotetext{
(1) Nhắc lại rằng các trái phiếu zero-coupon là các trái phiếu không có trả lãi giữa chừng, mà chỉ trả một lần tiền, bằng mệnh giá (face value) của nó, khi đáo hạn
} 
đây hiểu là một đơn vị nào đó, ví dụ có thể là 1 triệu VND), có thời hạn là $T$, và đã phát hành được một khoảng thời gian là $t$, tức là $t$ là thời gian đã trôi qua (running time) kể từ khi trái phiếu được phát hành, $T-t$ là thời gian còn lại cho đến khi đáo hạn. Thời điểm $t=0$ là thời điểm trái phiếu mới được phát hành. Khi đó:

$$
B(t, T)=(1+R)^{t-T}=(1+R)^{-d / 365},
$$

trong đó $R$ là lợi suất của trái phiếu, $d$ là số ngày còn lại cho đến khi đáo hạn, $T-t=d / 365$ là thời gian còn lại tính theo đơn vị năm, theo qui ước là 1 năm có 365 ngày (chứ không phải 360 ngày như đối với lãi suất ngắn hạn). Công thức ngược lại để tính lợi suất từ giá là:

$$
R=\exp \left(\frac{-\ln B(t, T)}{T-t}\right)-1
$$

Trái phiếu zero-coupon có giá là $B(t, T)$ vào thời điểm $t$ và bằng 1 vào thời điểm $T$ (khi đáo hạn) thì có mức lợi nhuận cho khoảng thời gian từ $t$ đến $T$ là:

$$
K(t, T)=\frac{1}{B(t, T)}-1=(1+R)^{T-t}-1
$$

Công thức trên là công thức qui đổi giữa lợi suất $R$ của trái phiếu và mức lợi nhuận $K(t, T)$.

Ghi chú 4.1. Công thức $B(t, T)=(1+R)^{t-T}$ cho ta một số hệ quả đơn giản nhưng quan trọng sau đây về trái phiếu zero-coupon: giá $B(t, T)$ của trái phiếu luôn nhỏ hơn là mệnh giá của nó (nếu lãi suất $R$ là số dương, và $T-t>0$ ), và tiến tới mệnh giá 1 của nó khi mà thời gian tiến đới điểm đáo hạn, tức là thời gian còn lại $T-t$ tiến tới 0 . Lãi suất $R$ càng cao thì giá $B(t, T)$ càng nhỏ, và ngược lãi nếu lãi suất càng thấp thì giá của trái phiếu càng cao.

Bài tập 4.5. a) Tìm số tiền cần phải đầu tư ban đầu để với lãi suất kép theo năm là $12 \%$, ta thu được $1000 \$$ sau 3 năm.

b) Nếu như bây giờ ta phải trả $800 \$$ để 3 năm sau thu được $1000 \$$ thì ta được hưởng lợi suất kiểu trái phiếu là bao nhiêu?

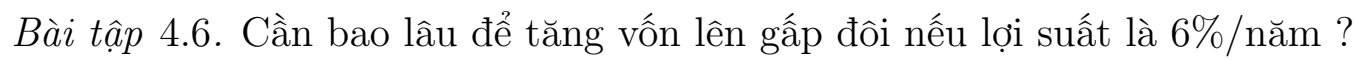

Bài tập 4.7. Nếu một khoản tiền gửi, được tính lãi kép theo năm, tăng lên gấp đôi sau 10 năm, thì mức lợi suất (lãi kép theo năm) của nó là bao nhiêu?

Bài tập 4.8. Tính lãi suất hiệu dụng của một khoản tiền gửi có lãi kép theo tháng là $10 \% /$ năm.

Bài tập 4.9. Nếu lãi suất hiệu dụng là 10\%/năm, thì lãi suất danh nghĩa trong đó lợi tức được trả theo tuần (tức là mức lãi kép tính theo 52 lần một năm) là bao nhiêu ? 


\subsubsection{Qui ước về tính số ngày}

Các sản phẩm nợ khác nhau trên các thị trường tài chính trên thế giới không những chỉ khác nhau về qui ước tính lợi suất từ lãi suất, mà còn khác nhau về qui ước đếm số ngày tính lãi (day count). Có rất nhiều qui ước khác nhau về việc đếm số ngày: số ngày trong một năm có thể là 360 (được dùng rất phổ biến cho các khoản tiền gửi, tiền vay), nhưng cũng có thể là 365 (hay được dùng cho trái phiếu), hoặc có khi lại là số ngày thực sự của năm (ví dụ cho năm nhuận có 366 ngày). Số ngày vay nợ có thể là số ngày thực tế, hoặc cũng có khi được điều chỉnh theo tháng (cho những tháng có số ngày khác 30 ngày). Bởi vậy, việc tính toán các khoản lãi tuy khá đơn giản về lý thuyết, nhưng trong thực tế có thể khá rắm rối, và người thực hành tính toán phải biết là mình dùng công thức gì, có đúng so với các qui ước cho sản phẩm và thị trường mà mình tính không. Giữa các sản phẩm và thị trường khác nhau, thì có các công thức chuyển đổi, để đưa chúng về cùng một "hệ qui chiếu" trước khi so sánh chúng với nhau. Bạn đọc có tìm hiểu chi tiết qui ước về việc tính ngày (day count) trong Chương 2 của cuốn sách của Neftci [19] hoặc tra trên internet.

\subsubsection{Lãi kép liên tục}

Nhắc lại rằng, nếu một khoản tiền $P$ được gửi theo lãi kép $r$, thì sau thời gian $t$ nó có giá trị là:

$$
V(t)=\left(1+\frac{r}{m}\right)^{t m} P,
$$

trong đó $m$ là số lần tính trả lãi trong 1 năm. Khi $m$ tiến tới vô cùng, ta có công thức giới hạn sau:

$$
\lim _{m \rightarrow \infty}\left(1+\frac{r}{m}\right)^{t m}=\exp (t r)
$$

Như vậy, nếu ta giả sử là lãi được trả liên tục (tức là coi số lần trả lãi tiến tới vô cùng), thì ta được công thức sau:

$$
V(t)=e^{t r} P
$$

Công thức trên được gọi là công thức tính theo lãi kép kiên tục (continuously compound interest).

Vi du 4.4. Giả sử tài khoản ban đầu 30 triệu VND được trả lãi kép liên tục ở mức 9.5\%. Sau hai năm rưỡi tổng số tiền trong tài khoản (cả gốc lẫn lãi) là

$$
V(2.5)=\exp (0.095 \times 2.5) \times 30 \approx 38.04
$$

triệu VND. 
Ghi chú 4.2. Vì hàm $\left(1+\frac{r}{m}\right)^{t m}$ là hàm đơn điệu tăng theo $m$, và giới hạn của nó khi $m$ tiến tới vô cùng là $\exp (r t)$, nên ta có $\left(1+\frac{r}{m}\right)^{t m}<\exp (r t)$. Có nghĩa là, với cùng một mức lãi suất danh nghĩa, thì lợi suất tính theo lãi kép liên tục lớn hơn là lợi suất tính theo mọi lãi kép khác.

Mọi lãi kép đều có thể qui đổi tương đương về lãi kép liên tục như sau. Nếu $V(t)$ là giá trị tại thời điểm $t$ của một tài khoản với lãi kép $R$ tính theo $m$ lần một năm, thì ta có

$$
V(t)=(1+R / m)^{t m} V(0)=\exp (t m \ln (1+R / m)) V(0)=\exp (t r) V(0)
$$

với $r=m \ln (1+R / m)$, hay nói cách khác,

$$
\left(1+\frac{R}{m}\right)^{m}=\exp (r)
$$

Điều đó có nghĩa là, mức lãi suất kép $R$ tính theo $m$ lần 1 năm tương đương với mức lãi suất kép liên tục $r=m \ln (1+R / m)$.

Trường hợp riêng $m=1$ cho ta các công thức chuyển đổi sau giữa mức lãi suất hiệu dụng (= lãi suất kép theo năm) $R$, và mức lãi suất kép liên tục $r$ :

$$
r=\ln (1+R)
$$

và

$$
R=e^{r}-1
$$

Ghi chú 4.3. Vì mức lãi suất hiệu dụng còn được gọi là lợi suất, nên mức lãi kép liên tục còn được gọi là lợi suất log (logarithmic yield). Nói chung, nếu một khoản đầu tư có mức lợi nhuận là $K(t, T)=(V(T)-V(t)) / V(t)$ trong khoản thời gian từ $t$ đến $T$, thì đại lượng $k(t, T)=\ln (K(t, T)+1)=\ln (V(T) / V(t))=\ln V(T)-\ln V(t)$ được gọi là mức lợi nhuận log (logarithmic return) tương ứng. Mức lợi nhuận log có tính cộng tính theo thời gian: $k\left(t_{1}, t_{2}\right)+k\left(t_{2}, t_{3}\right)=k\left(t_{1}, t_{3}\right)$ với mọi $t_{1} \leq t_{2} \leq t_{3}$.

Bài tập 4.10. Tính mức lợi suất log (tức là mức lãi kép liên tục tương đương) cho các mức lãi kép sau:

i) $10 \%$ tính theo quí,

ii) $9.8 \%$ tính theo ngày,

iii) $10.2 \%$ tính theo năm. 


\subsection{Giá trị và lợi suất của dòng tiền tệ}

\subsubsection{Công thức dòng tiền chiết khấu}

Nếu ta có một lượng tiền $V$ và có thể gửi nó với mức lãi kép liên tục $r$, tức là với mức lợi suất $R=\exp (r)-1$, thì sau một khoảng thời gian $t$ lượng tiền đó sẽ trở thành $W=e^{t r} V$. Tính ngược lại, với một mức lãi kép liên tục $r$ cho trước, thì một lượng tiền $W$ mà đến thời điểm $t$ mới được nhuận sẽ chỉ "quî" bằng lượng tiền $V=e^{-t r} W$ nhận được ngay vào thời điểm hiện tại. Lượng tiền $W=e^{t r} V$ được gọi là giá trị tương lai của lượng tiền $V$, còn $V=e^{-t r} W$ được gọi là giá trị hiện tại của lượng tiền $W$ (với mức lãi kép liên tục $r$ và khoảng cách thời gian $t$ ). Công thức

$$
V=e^{-t r} W
$$

được gọi là công thức giá trị chiết khấu, tức là chiết khấu đi từ giá trị tương lai $W$ bằng cách nhân nó với một hệ số $e^{-t r}$ nhỏ hơn 1, để tính ra giá trị hiện tại của nó.

Nói một cách tổng quát hơn, giả sử ta sẽ nhận được một dòng tiền tệ, tức là một dãy các lượng tiền $C_{1}, C_{2}, \ldots$ vào các thời điểm $t_{1}, t_{2}, \ldots$ tương ứng. Giả sử mức lãi kép liên tục $r$ là cố định. Khi đó giá trị hiện tại của $C_{i}$ là $\exp \left(-t_{i} r\right) C_{i}$, và như vậy tổng giá trị hiện tại của dòng tiền mà ta sẽ nhận được là:

$$
V=\sum_{i} \exp \left(-t_{i} r\right) C_{i}
$$

Công thức trên gọi là công thức dòng tiền chiết khấu hay công thức giá trị hiện tại, để tính giá trị hiện tại của một dòng tiền tệ nhận được trong tương lai, với giả sử là mức lãi kép liên tục $r$ là một hằng số đã được biết.

Nếu thay vì sử dụng mức lãi kép liên tục $r$, ta sử dụng mức lãi kép $R^{\prime}$ tính theo $m$ lần một năm $\left(\exp (r)=\left(1+\left(R^{\prime} / m\right)\right)^{m}\right)$, thì công thức giá trị hiện tại của dòng tiền phía trên có thể được viết lại như sau:

$$
V=\sum_{i}\left(1+\frac{R^{\prime}}{m}\right)^{-m t_{i}} C_{i} .
$$

Trường hợp riêng của công thức trên là khi $m=1$ và $R=\exp (r)-1$ là mức lợi suất, ta có:

$$
V=\sum_{i}(1+R)^{-t_{i}} C_{i}
$$


Vi du 4.5. Giả sử một nhà đầu tư sẽ nhận tiền tại cuối mỗi năm trong vòng 6 năm với số tiền như trong bảng sau:

\begin{tabular}{c|c|c|c|c|c|c} 
Năm & 1 & 2 & 3 & 4 & 5 & 6 \\
\hline Tiền & 465 & 233 & 632 & 365 & 334 & 248
\end{tabular}

Đây là một dòng tiền tệ xảy ra trong 6 năm. Nếu mức lãi kép theo tháng là 3,99\%, thì giá trị hiện tại của khoản đầu tư là bao nhiêu? Vì khoản tiền đầu tiên nhận được sau một năm kể từ thời điểm hiện tại, giá trị hiện tại là tổng

$$
\begin{gathered}
465\left(1+\frac{0.0399}{12}\right)^{-12}+233\left(1+\frac{0.0399}{12}\right)^{-24}+632\left(1+\frac{0.0399}{12}\right)^{-36}+365\left(1+\frac{0.0399}{12}\right)^{-48} \\
+334\left(1+\frac{0.0399}{12}\right)^{-60}+248\left(1+\frac{0.0399}{12}\right)^{-72} \approx 2003.01
\end{gathered}
$$

Chú ý rằng giá trị hiện tại của khoản đầu (tổng cộng bằng 2277) tư sẽ khác so với tổng các khoản tiền nhận được trong vòng 6 năm.

Bài tập 4.11. Giả sử một người sẽ nhận được nhuận bút cho một quyển sách của mình tổng cộng 5 lần: lần đầu tiên là $3000 \$$ ngay ngày hôm nay, lần thứ hai là $2000 \$$ sau 6 tháng, lần thứ ba là $1500 \$$ sau 1 năm, lần thứ tư là $2000 \$$ sau hai năm, và lần cuối cùng là $2500 \$$ sau 3 năm. Giả sử là mức lợi suất (= lãi kép theo năm) là $5 \%$. Hỏi giá trị hiện tại của dòng tiền nhuận bút mà người này sẽ nhận được cho quyển sách là bao nhiêu?

Ghi chú 4.4. Giá trị hiện tại của một dòng tiền tệ là hàm đơn điệu giảm theo biến lợi suất (= lãi suất hiệu dụng tương ứng): nếu lợi suất giảm, thì giá trị hiện tại tăng, và nếu lợi suất tăng thì giá trị hiện tại giảm (và tiến đến 0 khi lợi suất tiến đến vô cùng). Bởi vậy, nếu ta biết một dòng tiền, và biết giá trị hiện tại của dòng tiền đó, thì cùng thể tính ngược lại ra lợi suất của dòng tiền đó. Việc tính ngược này đòi hỏi phải giải một phương trình có thể khá là phức tạp, bởi vậy cách tính tốt nhất là dùng phần mềm máy tính (dựa trên những thuật toán tính toán để giải phương trình, ví dụ như thuật toán Newton).

Vi du 4.6. Giả sử bạn vay một người bạn $100 \$$ với thỏa thuận là sẽ trả cho anh ta trong 5 năm, mỗi năm một lần, các khoản tiền $\{21,22,23,24,25\}$ (mỗi năm một lần, theo thứ tự của dãy). Lợi suất $R$ của dòng tiền tệ này sẽ là nghiệm thực (duy nhất) của phương trình

$$
\frac{21}{1+R}+\frac{22}{(1+R)^{2}}+\frac{23}{(1+R)^{3}}+\frac{24}{(1+R)^{4}}+\frac{25}{(1+R)^{5}}=100 .
$$

Có thể sử dụng máy tính để tính xấp xỉ nghiệm $R \approx 0.047$. 
Ghi chú 4.5. Thay vì nói đến lãi suất, ta cũng có thể nói đến tỷ lệ lạm phát (inflation): lạm phát là khi sức mua của tiền giảm đi theo thời gian (giá cả trung bình của các mặt hàng tăng lên). Tỷ lệ lạm phát cũng được tính theo đơn vị \%/năm, với qui ước tương tự như là lãi kép theo năm. Tỷ lệ lạm phát nói chung là số dương, nhưng đôi khi cũng có những giai đoạn giảm phát (deflation), khi sức mua của tiền lại tăng lên so với thời gian. Trong công thức giá trị hiện tại, nếu $R$ là tỷ lệ lạm phát theo năm (thay vì lãi suất kép theo năm) thì ta được sức mua hiện tại của dòng tiền thay vì giá trị hiện tại. Nếu như lợi suất bằng đúng tỷ lệ lạm phát (tiền lãi vừa đủ bù cho lạm phát) thì sức mua hiện tại bằng giá trị hiện tại. Thường là lợi suất cao hơn là tỷ lệ lạm phát (tuy cũng có lúc thấp hơn - khi thấp hơn thì người gửi tiền bị thiệt hại tài sản, vì sức mua của khoản tiền gửi, kể cả lãi, không tăng lên mà lại giảm đi theo thời gian), và do vậy sức mua hiện tại của dòng tiền tệ thường là lớn hơn giá trị hiện tại của nó.

Ghi chú 4.6. Khi người ta nói đến một dòng tiền tệ, thường được hiểu là các khoản tiền đều là số dương. Tuy nhiên, các công thức vẫn dùng được cho trường hợp tổng quát hơn, khi mà có các khoản tiền là số âm, tuy rằng khi đó giá trị hiện tại của dòng tiền không nhất thiết phải tăng lên khi mà lãi suất giảm đi. (Hình dung như là một tài khoản, có lúc nhận được tiền vào nhưng cũng có lúc phải trả tiền ra).

\subsubsection{Dòng niên kim}

Dòng niên kim (annuity) là một trường hợp đặc biệt của dòng tiền tệ, khi mà các khoản tiền được xuất hiện tại các mốc thời gian cách đều nhau (ví dụ cứ đúng mỗi tháng một lần) và có trị số bằng nhau (ví dụ mỗi lần đều là 3.5 triệu VND). Trong thực tế có nhiều dòng niên kim, ví dụ như: tiền lương hưu, tiền trả nợ hàng tháng cho một khoản nợ mua nhà trả góp, tiền lãi nhận được định kỳ từ trái phiếu coupon, v.v.

Việc tính giá trị hiện tại của dòng niên kim đơn giản hơn là trường hợp dòng tiền tệ tổng quát, nhờ công thức

$$
1+q+q^{2}+\ldots+q^{n-1}=\frac{1-q^{n}}{1-q}
$$

(với $q \neq 1$ ). Giả sử ta có một dòng niêm kim với $n$ khoản tiền, mỗi khoản đều bằng $C$, tại các thời điểm $t_{1}=1 / m, t_{2}=2 / m, \ldots, t_{n}=n / m$ (tính theo năm), và mức lãi suất kép $R$ tính theo $m$ lần một năm. Khi đó giá trị hiện tại của dòng niên kim này là (đặt $\left.q=\left(1+\frac{R}{m}\right)^{-1}\right)$ :

$$
V=\sum_{i=1}^{n}\left(1+\frac{R}{m}\right)^{-i} C=\sum_{i=1}^{n} q^{i} C=\frac{1-q^{n}}{1-q} q C
$$


hay có thể viết lại thành:

$$
V=\frac{\left(1-\left(1+\frac{R}{m}\right)^{-n}\right)}{R / m} C=P\left(\frac{R}{m}, n\right) C,
$$

trong đó hệ số

$$
P\left(\frac{R}{m}, n\right)=\sum_{i=1}^{n}\left(1+\frac{R}{m}\right)^{-i}=\frac{\left(1-\left(1+\frac{R}{m}\right)^{-n}\right)}{R / m}
$$

được gọi là thừa số giá trị hiện tại (present value factor) của dòng niêm kim.

Vi du 4.7. (Vay trả góp) Nếu một người vay $20000 \$$ trong 5 năm với lãi suất kép theo tháng là 4.80\% và trả các khoản tiền bằng nhau hàng tháng, khoản phải trả hàng tháng sẽ là một số $x$ (tính theo đơn vị \$) sao cho dòng niêm kim trong vòng 5 năm mỗi tháng một lần (tổng cộng $5 \times 12=60$ lần) mỗi lần bằng $x$ có giá trị hiện tại là 20000 theo lãi suất kép theo tháng $4.8 \%$. Từ đó suy ra tiền trả nợ hàng tháng là: $x=\frac{20000}{P\left(\frac{0.048}{12}, 60\right)}$, với $P\left(\frac{0.048}{12}, 60\right)=P(0.004,60)=\frac{\left(1-(1+0.004)^{-60}\right)}{0.004} \approx 53.249$, tức là $x=\frac{20000}{53.249} \approx$ 375.59 .

Vi du 4.8. Xét khoản cho vay $1000 \$$ phải trả làm 5 lần như nhau, mỗi năm 1 lần (vào thời điểm cuối năm), với lãi suất kép theo năm là $15 \%$. Khi đó số tiền phải trả hàng năm là:

$$
\frac{1.000}{P(15 \%, 5)} \approx 298.32
$$

Vi du 4.9. (Tiền tiết kiệm). Giả sử có hai người 20 năm nữa sẽ về hưu. Một người bắt đầu tiết kiệm tiền cho tiền hưu trí ngay từ bây giờ nhưng do bị thất cơ lỡ vận nên phải dừng lại sau 4 năm. Số tiền anh ta đã đầu tư trong 4 năm đầu vẫn được giữ nguyên nhưng trong suốt 16 năm tiếp theo đó anh ta không tiết kiệm thêm được chút nào nữa. Một người thì sau 4 năm đầu không tiết kiệm và trong 16 năm làm việc tiếp theo thì anh ta liên tục gửi tiết kiệm. Ta sẽ xem xét sự chênh lệch trong số tiền tiết kiệm cuối cùng mà hai người nhận được. Ta giả sử lãi suất kép theo tháng là $R=0.05$ và cả hai người hàng tháng cùng gửi tiết kiệm số tiền $x$. Người đầu tiên có số tiền trong sổ tiết kiệm với giá trị hiện tại là

$$
\sum_{i=1}^{48}\left(1+\frac{0.05}{12}\right)^{-i} x \approx 43.42 \times x .
$$

giá trị hiện tại của tổng số tiền đầu tư của người thứ hai là

$$
\sum_{i=49}^{240}\left(1+\frac{0.05}{12}\right)^{-i} x \approx 108.10 \times x .
$$


Như vậy người thứ nhất có thời gian (và tổng số tiền rót vào) gửi tiết kiệm chỉ bằng $25 \%$ người thứ hai (4 năm so với 16 năm), nhưng tài khoản tiết kiệm của người thứ nhất vào thời điểm về hưu có giá trị xấp xỉ bằng $40 \%$ của người thứ hai. Đó chính là do người thứ nhất gửi tiết kiệm sớm hơn. Bài học: tiết kiệm và đầu tư từ càng sớm thì càng có lợi về sau.

Vi du 4.10. (Tính quỹ hưu). Giả sử một người muốn lập một quỹ hưu (một tài khoản trong ngân hàng dành riêng cho việc trả lương hưu về sau). Người này sẽ làm việc 30 năm nữa, và mỗi tháng sẽ rót vào quỹ hưu một khoản tiền đều đặn là $x$ trong vòng 30 năm làm việc. Khi về hưu (30 năm sau), người này sẽ rút ra từ quỹ hưu của mình mỗi tháng là $2000 \$$, trong vòng 20 năm (sau 20 năm thì vừa vặn hết quỹ hưu). Giả sử rằng mức lãi suất mà người này nhận được cho quỹ hưu của mình là cố định bằng $5 \%$ theo lãi kép tính theo tháng. Hỏi giá trị của quỹ hưu vào thời điểm người này về hưu là bao nhiêu, và người này phải nộp hàng tháng bao nhiêu tiền vào quỹ hưu ?

Gọi giá trị của quỹ hưu vào thời điểm nghỉ hưu bằng $W$. Khi đó $W$ có thể coi là giá trị hiện tại của dòng niên kim kéo dài $20 \times 12=240$ tháng, mỗi tháng 2000 \$. Lãi suất kép theo tháng là $R=5 \%$, bởi vậy ta có thừa số giá trị hiện tại bằng $P\left(\frac{R}{m}, n\right)=$ $P(0.05 / 12,240)=\left(1-(1+0.05 / 12)^{-240}\right) /(0.05 / 12) \approx 151.525$, do đó

$$
W=2000 \times 151.525 \approx 303050
$$

tức là giá trị của quỹ hưu tại thời điểm nghỉ hưu bằng $303050 \$$.

$W$ là giá trị của quỹ hưu vào thời điểm sau 30 năm làm việc. Giá trị chiết khấu của $W$ cho thời điểm 30 về trước, khi mới lập quỹ hưu, là:

$$
V=\left(1+\frac{R}{m}\right)^{-30 m} W=(1+0.05 / 12)^{-360} W \approx 0.2238266 W=0.2238266 \times 303050 \approx 67831 .
$$

Vì tiền trong quỹ hưu được tạo ra là do dòng niên kim mà người đi làm nộp vào quỹ hưu trong 30 năm, nên $V$ cũng chính bằng giá trị hiện tại (tính tại thời điểm mới lập quỹ hưu) của dòng niên kim đó, bởi vậy ta có số tiền cần nộp hàng tháng là:

$$
x=\frac{V}{P(0.05 / 12,360)}=\frac{67831}{\left(1-(1+0.05 / 12)^{-3600}\right) /(0.05 / 12)} \approx \frac{67831}{186.28} \approx 364.13
$$

Như vậy, chỉ cần nộp 364.13\$ một tháng cho quỹ hưu trong vòng 30 năm, thì có thể nhận được lương hưu $2000 \$$ một tháng trong vòng 20 năm, nếu lãi suất kép theo tháng là $5 \% /$ năm.

Tất nhiên, trên thực tế, hiếm ai biết được trước là mình sẽ cần nhận được bao nhiêu tháng lương hưu kể từ khi về hưu, vì tuổi thọ mỗi người một khác. Bởi vậy, lương hưu 
thường do các công ty bảo hiểm nhân thọ quản lý, để bù trừ tuổi thọ của mọi người cho nhau khi tính số tháng lương hưu trung bình.

Bài tập 4.12. Trong ví dụ phía trên, nếu chỉ đóng quỹ hưu trong vòng 15 năm thay vì 30 năm, và vẫn muốn nhận được 20 năm lương hưu với mức lương hưu 2000\$/tháng, và mức lãi suất kép theo tháng vẫn là $5 \% / n a ̆ m$, thì cần đóng bao nhiêu tiền một tháng vào quỹ hưu?

Bài tập 4.13. Trong ví dụ phía trên, ta giả sử là tỷ lệ lạm phát là $2 \% /$ năm, các số liệu khác vẫn như cũ, trừ mức lương hưu muốn nhận được hàng tháng. Nếu như người này muốn nhận được một khoản lương hưu không phải là 2000\$/tháng, mà là lương hưu hàng tháng có sức mua bằng $2000 \$$ của thời điểm mới mở quỹ hưu, thì sẽ phải đóng bao nhiêu tiền một tháng vào quỹ hưu ?

\subsubsection{Trái phiếu coupon và trái phiếu vô thời hạn}

Một trái phiếu coupon là một trái phiếu mà người sở hữu nó được trả lãi định kỳ (ví dụ 6 tháng một lần) một khoản tiền lãi $C$ cố định nào đó gọi là tiền coupon, và đến khi đáo hạn thì trả một lần tiền lãi cuối cùng cộng với một khoản tiền "gốc" $F$ bằng mệnh giá (face value) của trái phiếu. Nói cách khác, giá trị của một trái phiếu coupon chính là giá trị của một dòng tiền tệ gồm hai phần: một dòng niên kim các khoản tiền coupon, và một khoản "gốc" trả vào cuối kỳ hạn của trái phiếu. Bởi vậy, các công thức để tính toán với các dòng tiền tệ nói chung và dòng các dòng niên kim nói riêng có thể được dùng để tính toán với trái phiếu coupon.

Vi du 4.11. Một trái phiếu có mệnh giá $F=10$ triệu $\mathrm{VND}$, với kỳ hạn $T=5$ năm, coupon $C=1$ triệu VND được trả hàng năm. Tức là sẽ có 1 dòng các khoản tiền trả 1 , $1,1,1,11$ (triệu VND) vào cuối mỗi năm liên tiếp. Cho lãi kép liên tục $r$ là $12 \%$, ta tìm được giá của trái phiếu vào thời điểm phát hành là:

$$
V(0)=1 e^{-r}+1 e^{-2 r}+1 e^{-3 r}+1 e^{-4 r}+11 e^{-5 r} \approx 9.027
$$

triệu VND, tức là 9 triệu 27 nghìn VND.

Vi du 4.12. Tiếp tục ví dụ 4.11. Sau 1 năm phát hành, khi coupon vừa được trả, trái phiếu trở thành trái phiếu còn kỳ hạn 4 năm trị giá

$$
V(1)=1 e^{-r}+1 e^{-2 r}+1 e^{-3 r}+11 e^{-4 r} \approx 9.178 .
$$

triệu VND. Chú ý rằng rằng tổng tài sản vào thời điểm 1 là

$$
V(1)+C=9.178+1=10.178=9.027 \times \exp (0.12)=V(0) e^{r} .
$$


6 tháng sau đó trái phiếu sẽ có trị giá

$$
V(1.5)=1 e^{-0,5 r}+1 e^{-1,5 r}+1 e^{-2,5 r}+11 e^{-3,5 r} \approx 9.745
$$

Giả sử là coupon được trả mỗi năm 1 lần, khi đó tỷ lệ $C / F$ giữa coupon và mệnh giá của trái phiếu được gọi là lãi suất coupon của trái phiếu.

Mệnh đề 4.2. Giả sử coupon được trả mỗi năm 1 lần. Khi đó lãi suất coupon bằng lợi suất của trái phiếu khi và chỉ khi giá của trái phiếu bằng đúng mệnh giá của nó. Trong trường hợp này ta nói trái phiếu được mua bán ở giá danh nghĩa (tức là mệnh giá).

Việc chứng minh mệnh đề trên tương đối dễ dàng và là bài tập dành cho bạn đọc. Nếu một trái phiếu coupon được bán dưới mệnh giá, thì điều đó có nghĩa là lợi suất cao hơn lãi suất coupon, và ngược lại, nếu nó được bán cao hơn mệnh giá, thì có nghĩa là lợi suất thấp hơn lãi suất coupon.

Trái phiếu vô thời hạn, hay còn gọi là trái phiếu vĩnh cửu (perpetual bond) là một trường hợp đặc biệt của trái phiếu coupon, khi mà người sở hữu trái phiếu nhận được các khoản tiền coupon một cách vô thời hạn (vĩnh cửu), và trái phiếu không đáo hạn lúc nào cả, tức là không trả tiền "gốc" lúc nào cả. Đối với trái phiếu vô thời hạn, thì mệnh giá không còn ý nghĩa, mà cái xác định giá trị của nó chính là độ lớn và tần số của các coupon được trả. Trên thị trường tài chính thế giới có các trái phiếu vô thời hạn. Ví dụ,

Ta có thể coi trái phiếu vô thời hạn như là một dòng niên kim vĩnh cửu (có độ dài vô hạn). Nhắc lại rằng, một dòng niên kim gồm $n$ khoản tiền thì có thừa số giá trị hiện tại bằng

$$
P\left(\frac{R}{m}, n\right)=\frac{1-(1+(R / m))^{-n}}{R / m}
$$

trong đó $m$ là số lần xuất hiện tiền trong 1 năm của dòng niên kim, và $R$ là lãi kép tính theo $m$ lần 1 năm. Khi $n$ tiến tới vô cùng thì $(1+(R / m))^{-n}$ tiến tới 0 (với giả sử là $R>0)$, bởi vậy ta có thừa số giá trị hiện tại của dòng niên kim vô hạn là:

$$
P\left(\frac{R}{m}, \infty\right)=\frac{1}{R / m}=\frac{m}{R} .
$$

Vi du 4.13. Giả sử có một trái phiếu vô thời hạn với lợi suất (= lãi suất kép theo năm) $5.2 \%$, và cứ sau mỗi năm thì trả coupon $C=100$, tính từ thời điểm hiện tại. Hỏi giá của trái phiếu này bằng bao nhiêu?

Theo công thức giá trị hiện tại của dòng niên kim vô hạn, ta có

$$
V=C P\left(\frac{R}{m}, \infty\right)=\frac{m C}{R} .
$$


Ở đây $m=1, C=100, R=0.052$, bởi vậy giá trị hiện tại của trái phiếu này là $V=$ $100 / 0.052 \approx 1923.07$

Bài tập 4.14. Tính giá trị hiện tại của trái phiếu vô thời hạn trả coupon mỗi quí một lần 5 triệu VND, biết rằng lãi suất kép liên tục là 10.5\%/năm.

\subsubsection{Lãi suất hoàn vốn}

Nhắc lại rằng, nếu ta có một dòng tiền tệ $C_{1}, C_{2}, \ldots$ nhận được tại các thời điểm $t_{1}, t_{2}, \ldots$ tương ứng tính từ thời điểm hiện tại và đo theo đơn vị năm, và mức lãi suất hiệu dụng (tức là mức lãi suất tính theo qui ước lãi kép theo năm) là $R$, thì giá trị hiện tại của dòng tiền đó là:

$$
V(0)=\sum_{i}(1+R)^{-t_{i}} C_{i}
$$

Ngược lại, giả sử ta đã biết giá trị hiện tại $V(0)$ của một sản phẩm nợ cho một dòng tiền $\left(C_{i}, t_{i}\right)$. Ví dụ: sản phẩm nợ đó là trái phiếu coupon, dòng tiền này là các coupon định kỳ, cộng với phần gốc trả khi đáo hạn, và $V(0)$ là giá của trái phiếu coupon này trên thị trường. Khi đó (với giả sử là $C_{i}>0$ và $t_{i}>0$ với mọi $i$ ), tồn tại duy nhất một số $R$ sao cho công thức 4.35 phía trên được thỏa mãn. Số $R$ đó được gọi là lãi suất hoàn vốn hay lợi suất hoàn vốn (yield to maturity) của sản phẩm nợ đó.

Nói cách khác, lãi suất hoàn vốn của một sản phẩm nợ chính là mức lãi suất hiệu dụng, sao cho nếu tính theo mức lãi suất hiệu dụng đó, thì giá trị hiện tại của dòng tiền của sản phẩm nợ đó chính bằng giá giao dịch của nó trên thị trường. Để so sánh các khoản nợ khác nhau (với các kiểu trả nợ khác nhau, thời gian đáo hạn khác nhau, v.v.) xem khoản nào có lãi suất cao hơn, người ta có thể tính lãi suất hoàn vốn của chúng, rồi so sánh các lãi suất hoàn vốn đó (chứ không phải là so sánh các lãi suất danh nghĩa).

Ví du 4.14. Một người vay trả góp $10000 \$$, và phải trả trong 5 năm (60 tháng), cứ cuối mỗi tháng trả một lần $235 \$$. Hỏi lãi suất hoàn vốn của khoản vay này là bao nhiêu ? Để trả lời câu hỏi đó, ta viết phương trình

$$
\sum_{n=1}^{60}(1+R)^{-n / 12} \times 235=10000 .
$$

Đặt $x=(1+R)^{-1 / 12}$, ta được phương trình

$$
\sum_{n=1}^{60} x^{n}=\left(x-x^{61}\right) /(1-x)=10000 / 235 \approx 42.5532 .
$$


Sử dụng máy tính để giải phương trình trên, ta được nghiệm $x \approx 0.988105$, từ đó suy ra

$$
R=x^{-12}-1 \approx 0.1544
$$

có nghĩa là lãi suất hoàn vốn của khoản vay này vào khoảng 15,44\%.

Vi du 4.15. Giả sử có một trái phiếu coupon mệnh giá 1000\$, còn hạn 10 năm, và có coupon là $100 \$$ (tức là cứ cuối mỗi năm nhận được $100 \$$ tiền lãi, ứng với lãi suất coupon của trái phiếu đó là $10 \%$ ). Giá của trái phiếu này trên thị trường sẽ không cố định là $1000 \$$, mà có thể tăng hay giảm tùy tình hình thị trường. Khi mà giá trái phiếu này tăng lên, thì tức là lãi suất hoàn vốn của nó giảm đi, và ngược lại khi mà giá trái phiếu giảm đi, thì tức là lãi suất hoàn vốn của nó tăng lên. Khi mà giá trái phiếu đúng bằng $1000 \$$, thì lãi suất hoàn vốn đúng bằng lãi suất coupon, tức là $10 \%$. Dưới đây là một bảng lãi suất hoàn vốn của trái phiếu này, ứng với giá của nó trên thị trường (tức là giá của nó là bao nhiêu, thì cho lãi suất hoàn vốn bằng bao nhiêu):

\begin{tabular}{|r|r|}
\hline Giá trái phiếu $(\$)$ & Lãi suất hoàn vốn $(\%)$ \\
\hline 1200 & 7.13 \\
1100 & 8.48 \\
1000 & 10.00 \\
900 & 11.75 \\
800 & 13.81 \\
\hline
\end{tabular}

\subsection{Duration của trái phiếu}

Như chúng ta đã thấy phía trên, giá trị hiện tại của một dòng tiền tệ (và do đó giá của các trái phiếu) phụ thuộc vào lãi suất: lãi suất giảm thì giá trị hiện tại của nó tăng, và lãi suất tăng thì giá trị hiện tại của nó giảm (với giả sử là các khoản tiền là số dương). Để phân tích cụ thể hơn sự phụ thuộc này, ta có thể làm như sau: Gọi $B$ là giá trị hiện tại (hay giá hiện tại) của một dòng tiền (hay một trái phiếu nào đó), khi đó đạo hàm

$$
\frac{\partial \ln B}{\partial r}=\frac{1}{B} \frac{\partial B}{\partial r}
$$

của log của $B$ theo mức lãi kép liên tục hiện tại $r$ là đại lượng biểu thị "độ nhậ" log của $B$ theo lãi suất. Ở đây ta dùng mức lãi kép liên tục $r$ thay vì dùng lợi suất $R=\exp (r)-1$ tương đương, vì các công thức tính theo $r$ sẽ gọn nhẹ hơn. 
Khi $B=\exp ((t-T) r)$ là giá của một trái phiếu zero-coupon còn thời hạn là $T-t$ (trong đó $T$ là toàn bộ kỳ hạn, $t$ là thời gian đã trôi qua), thì ta có:

$$
\frac{\partial \ln B}{\partial r}=t-T=-(T-t)
$$

Do vậy, khi $B$ là giá của trái phiếu zero-coupon, thì đại lượng $-\frac{\partial \ln B}{\partial r}$ chính là thời hạn còn lại của trái phiếu.

Một hệ quả quan trọng là: trái phiếu zero-coupon có thời hạn còn lại càng dài thì có giá càng nhạy với lãi suất, và độ nhạy log của giá theo lãi suất chính bằng thời hạn còn lại của trái phiếu.

Mở rộng từ trường hợp trái phiếu zero-coupon lên trường hợp dòng tiền hay trái phiếu (hay một rổ các trái phiếu) bất kỳ, ta có định nghĩa sau:

Định nghĩa 4.3. Giả sử ta có một dòng tiền (hay một rổ các trái phiếu) mà giá trị hiện tại (hay giá hiện tại) là một hàm số B phu thuộc vào mức lãi suất kép liên tục r. Khi đó dai lượng

$$
-\frac{\partial \ln B}{\partial r}
$$

được gọi là duration hay kỳ hạn trung bình của dòng tiền (hay rổ trái phiếu) này.

Từ duration có nghĩa là độ dài về thời gian. Ở đây, nó được hiểu là độ dài trung bình về thời gian, tức là kỳ hạn trung bình, của các khoản tiền trong dòng tiền, hay là của tất cả các trái phiếu và các coupon trong rổ trái phiếu.

Vi du 4.16. Giả sử có 1 trái phiếu mới phát hành có kỳ hạn $T=3$ năm, có mệnh giá $F=10$, và có trả lãi 3 lần, mỗi năm một lần, mỗi lần một coupon $C=1$. Giá của trái phiếu này, tính theo lãi suất kép liên tục, là:

$$
B=1 \cdot \exp (-r)+1 \cdot \exp (-2 r)+11 \cdot \exp (-3 r)
$$

Từ đó suy ra duration của nó là:

$$
D=-\frac{\partial \ln B}{\partial r}=-\frac{\partial B}{\partial r} \frac{1}{B}=\frac{1 \cdot e^{-r}+2 \cdot e^{-2 r}+33 \cdot e^{-3 r}}{1 \cdot e^{-r}+1 \cdot e^{-2 r}+11 \cdot e^{-3 r}} .
$$

Từ công thức trên, ta có thể thấy ngay rằng duration của trái phiếu này nhỏ hơn 3 , tức ngắn hơn kỳ hạn của trái phiếu, nhưng lớn hơn 1 . Đó là bởi vì trái phiếu này có thể coi là 1 dòng tiền gồm 3 phần: 1 phần có duration bằng 1 (coupon đầu tiên), 1 phần có duration bằng 2 (coupon thứ hai), và một phần có duration bằng 3 (coupon thứ ba cộng với mệnh giá). Duration của trái phiếu là trung bình cộng có trọng lượng của ba cái duration khác nhau đó, bởi vậy nó nằm giữa 1 và 3 . 
Bài tập 4.15. Trong ví dụ 4.16 phía trên (với giả sử là lãi kép liên tục $r$ là số dương), chứng minh rằng duration $D$ của trái phiếu không những nhỏ hơn 3 mà còn thỏa mãn bất đẳng thức $D<36 / 13$.

Công thức tính duration của trái phiếu cho thấy, trái phiếu nào có kỳ hạn càng dài, thì giá của nó sẽ càng nhạy so với sự thay đổi lãi suất. Ví dụ, đối với một trái phiếu có duration là 20 năm, thì chỉ cần lãi suất thay đổi $0.2 \%$ đủ làm cho giá của nó thay đổi khoảng $20 \times 0.2 \%=4 \%$. Điều này giải thích vì sao giá của các trái phiếu dài hạn trên thị trường có độ giao động lớn (trong khi giá của các trái phiếu ngắn hạn ít giao động). Ví dụ, trong vòng 5 tháng 04-08/2010, giá của các trái phiếu chính phủ dài hạn ở Mỹ (loại 20 năm trở lên) tăng trung bình hơn $20 \%$, ứng với việc lãi suất trái phiếu chính phủ giảm khoảng $1.5 \%$.

Khái niệm duration là một khái niệm vô cùng quan trọng trong tài chính, và nó liên quan trực tiếp đến vấn đề đầu tư và quản lý rủi ro các sản phẩm nợ. Ví dụ, nếu một nhà đầu tư trái phiếu nghĩ rằng lãi suất đang cao, sẽ giảm đi, thì thường sẽ chọn giữ các trái phiếu có duration lớn, vì duration càng lớn thì giá sẽ càng tăng mạnh khi mà lãi suất giảm xuống. Ngược lại, nếu nhà đầu tư đó nghĩ rằng lãi suất đang thấp, có thể tăng lên, thì sẽ ngần ngại khi đầu tư vào các trái phiếu có duration lớn, mà sẽ chọn các trái phiếu với duration ngắn, đỡ bị giảm giá khi lãi suất tăng. Các nhà băng nếu vay vào ngắn hạn mà cho vay ra dài hạn, thì sẽ có khả năng rủi ro là: khi lãi suất cao lên thì các khoản cho vay dài hạn bị giảm giá trị đi nhiều so với các khoản vay vào ngắn hạn, dẫn đến nhà băng bị lỗ. (Điều này từng xảy ra trên thực tế). Đó chính là rủi ro về lãi suất, hay còn có thể gọi là rủi ro về thời hạn, khi mà duration của tổng các khoản vay vào và cho vay ra là khác 0 .

Giả sử một người muốn đầu tư trái phiếu trong một khoảng thời gian $T$ nào đó (vào thời điểm $T$ thì người này cần rút tiền ra). Nếu có trái phiếu zero-coupon còn thời hạn đúng bằng $T$, thì cách đơn giản nhất cho người này là mua trái phiếu đó, sẽ biết chắc là đến thời điểm $T$ mình sẽ có bao nhiêu tiền. Nhưng nếu trên thị trường không có trái phiếu như vậy, thì việc đầu tư có thể trở nên bấp bênh hơn, vì không biết là đến thời điểm $T$ sẽ có bao nhiêu tiền, và có thể có rủi ro về lãi suất (lãi suất có thể dao động "ngược hướng" làm ảnh hưởng xấu đến khoản tiền sẽ có tại thời điểm $T$ ). Để giảm thiểu rủi ro này, và yên tâm hơn về số tiền sẽ có tại thời điểm $T$ (không bị thấp hơn so với là nếu mua được trái phiếu zero-coupon với thời hạn như ý muốn), người này có thể tìm cách đầu tư vào một rổ trái phiếu có duration ban đầu bằng $T$, rồi điều chỉnh nó tại các thời điểm sau sao cho duration luôn bằng thời gian đầu tư còn lại. Định lý sau cho thấy về mặt "lý thuyết" 
làm như vậy sẽ loại bỏ được rủi ro về lãi suất. Chú ý rằng bản thân duration cũng biến động theo lãi suất, và bởi vậy phải điều chỉnh lại rổ trái phiếu thường xuyên nếu muốn có duration luôn bằng kỳ hạn còn lại dự kiến của khoản đầu tư.

Định lý 4.4. Giả sử là, vào mỗi thời điểm bất kỳy, lợi suất của mọi trái phiếu có trên một thị trường nào đó đều bằng nha民"(2), và phí giao dịch bằng 0 . Giả sử có một rổ trái phiếu được điều chinh liên tụ $\oint^{(3)}$ sao cho tại mọi thời diểm $t(0 \leq t \leq T)$, duration của nó bằng $T-t$. Khi đó giá trị của rổ trái phiếu này vào thời diểm $T$ chính bằng $\exp \left(\operatorname{Tr}_{0}\right) . V(0)$, trong đó $r_{0}$ là lãi kép liên tục tại thời điểm 0 ban đầu, và $V(0)$ là giá trị của rổ trái phiếu tại thời điểm ban đầu.

Chú ý là, trong định lý trên, mức lợi nhuận $K(0, T)=\exp \left(T r_{0}\right)-1$ của rổ trái phiếu cho khoảng thời gian từ 0 đến $T$ hoàn toàn được xác định tại thời điểm 0 , không bị ảnh hưởng của biến động của lãi suất, và nó chính bằng mức lợi nhuận của một trái phiếu zero-coupon có thời hạn $T$ và lãi kép liên tục $r_{0}$.

Chứng minh. Ta sẽ ký hiệu giá trị của rổ trái phiếu tại thời điểm $t$ bằng tổng

$$
V(t)=\sum_{i} \alpha_{i}(t) B_{i}(t)
$$

trong đó $B_{i}$ là trái phiếu thứ $i$ trên thị trường, $B_{i}(t)$ là giá của nó tại thời điểm $t$, và $\alpha_{i}(t)$ là số lượng trái phiếu thứ $i$ trong rổ. Ký hiệu $r(t)$ là mức lãi kép liên tục vào thời điểm $t, r(0)=r_{0}$. Để đơn giản, ta sẽ giả sử $r(t)$ là hàm khả vi liên tục theo $t$, các hàm $\alpha_{i}(t)$ cũng khả vi liên tục hầu khắp nơi theo $t$ trừ một số hữu hạn các điểm gián đoạn, và hàm $V(t)$ là hàm liên tục theo $t$.

Giá của trái phiếu $B_{i}$ phụ thuộc vào $r=r(t)$ và $t: B_{i}=B_{i}(t, r)=\exp \left(\left(t-T_{i}\right) r\right)$ (ta coi mệnh giá của nó bằng 1 ), trong đó $T_{i}$ là thời hạn (hay duration) của $B_{i}$ tính từ thời điểm 0 . Bởi vậy ta có các công thức sau:

$$
\frac{\partial B_{i}}{\partial t}=r B_{i}
$$

và

$$
\frac{d B_{i}}{d t}=\frac{\partial B_{i}}{\partial t}+\frac{\partial B_{i}}{\partial r} \frac{d r}{d t}=r B_{i}+\frac{\partial B_{i}}{\partial r} \frac{d r}{d t}
$$

\footnotetext{
${ }^{(2)}$ tức là lợi suất có thể thay đổi theo thời gian nhưng không phụ thuộc vào bản thân trái phiếu

${ }^{(3)}$ diều chỉnh tức là mua bán trái phiếu trong rổ, nhưng không rút tiền khỏi rổ hoặc cho tiền thêm vào, và các coupon nhận được thì cũng để lại trong rổ để đầu tư tiếp cho đến khi hết kỳ hạn $T$
} 
Việc điều chỉnh rổ trái phiếu nhưng không thêm bớt tiền vào đó thể hiện qua đẳng thức sau:

$$
\sum_{i} \frac{d \alpha_{i}}{d t} B_{i}=0
$$

Đẳng thức trên có nghĩa là tổng tiền của các sự mua bán trái phiếu trong rổ tại thời điểm $t$ (làm thay đồi $\alpha_{i}$ ) bằng 0 . Nói cách khác, ta có:

$$
\frac{d V}{d t}=\sum_{i} \alpha_{i} \frac{d B_{i}}{d t}
$$

tức là "ở mức vi phân" (infinitesimally) thì sự thay đổi giá trị của rổ tài khoản theo thời gian là do sự thay đổi giá của các trái phiếu trong tài khoản đem lại, chứ không phải do sự thay đổi các số lượng trái phiếu đem lại. Theo giả thuyết, duration của rổ trái phiếu tại thời điểm $t$ bằng $T-t$, bởi vậy theo công thức tính duration ta có

$$
T-t=-\frac{\partial V}{\partial r} \cdot \frac{1}{V}=-\frac{1}{V} \sum_{i} \alpha_{i} \frac{\partial B_{i}}{\partial r}
$$

có nghĩa là

$$
(t-T) V=\sum_{i} \alpha_{i} \frac{\partial B_{i}}{\partial r}
$$

Kết hợp các đẳng thức trên lại với nhau, ta có

$$
\frac{d V}{d t}=\sum_{i} \alpha_{i} \frac{d B_{i}}{d t}=\sum_{i} \alpha_{i} r B_{i}+\left(\sum_{i} \alpha_{i} \frac{\partial B_{i}}{\partial r}\right) \frac{d r}{d t}=r V+(t-T) V \frac{d r}{d t},
$$

tức là

$$
\frac{d(\ln V)}{d t}=r+(t-T) \frac{d r}{d t}=\frac{d(r t)}{d t}-T \frac{d r}{d t}
$$

(với hầu hết mọi $t$, trừ một số hữu hạn các điểm). Lấy tích phân hai phía của đẳng thức trên theo $t$ từ 0 đến $T$ ta được

$$
\ln V(T)-\ln V(0)=\int_{t=0}^{T}\left(\frac{d(r t)}{d t}-T \frac{d r}{d t}\right) d t=r(T) T-T(r(T)-r(0))=T r(0)=T r_{0},
$$

chính là điều cần phải chứng minh.

Bài tập 4.16. i) Giả sử có hai loại trái phiếu sau: loại A là trái phiếu zero-coupon có mệnh giá $100 \$$ và còn hạn 1 năm. Loại $B$ là trái phiếu còn hạn 4 năm với mệnh giá $100 \$$ và mỗi năm trả một coupon 10\$. Giả sử lợi suất (của cả hai loại trái phiếu) là 8\%. Hãy tính giá hiện tại của mỗi loại trái phiếu, và lập một rổ trái phiếu từ hai loại này sao cho giá trị của rổ bằng $10000 \$$ và duration của rổ bằng 2 năm.

ii) Nếu 1/4 năm sau lãi suất tăng lên thành $10 \%$, thì cần điều chỉnh rổ trái phiếu này thế nào, để có duration bằng $7 / 4$ năm vào thời điểm đó ? 


\section{4 Đường lợi suất}

Trong các phần trên của chương này, khi nói đến lãi suất hay lợi suất của các dòng tiền tệ, chúng ta coi rằng lãi suất không phụ thuộc vào kỳ hạn, tức là chúng ta áp dụng cùng một mức lợi suất cho các khoản tiền (trong cùng 1 dòng tiền tệ) nhận được ở các thời điểm khác nhau. Tuy nhiên, trong thực tế, lãi suất có phụ thuộc vào kỳ hạn: lợi suất của các trái phiếu với các kỳ hạn dài ngắn khác nhau có thể khác nhau một cách đáng kể. Bởi vậy, mức lợi suất trong công thức tính giá trị chiết khấu cần được hiểu là mức lợi suất trung bình, cho các khoản tiền khác nhau tại các thời hạn khác nhau trong dòng tiền tệ. Đối với các trái phiếu coupon thì mức lợi suất trung bình được sử dụng này còn được gọi là lãi suất hoàn vốn (yield to maturity).

Trong mục này và mục sau, chúng ta sẽ xem xét việc lãi suất phụ thuộc vào kỳ hạn ra sao, và điều đó ảnh hưởng như thế nào đến lãi suất kỳ hạn (forward rates), tức là lãi suất cho các khoản tiền gửi hoặc vay hoặc trái phiếu trong tương lai nhưng được thoả thuận về giá cả từ thời điểm hiện tại.

Đường lợi suất (yield curve) là đồ thị biểu hiện sự phụ thuộc của lợi suất vào kỳ hạn. Lợi suất trên đường lợi suất thường được hiểu là lợi suất của các trái phiếu chính phủ của một nước nào đó, với hai 2 tính chất sau: thanh khoản cao (có thể mua bán các trái phiếu này dễ dàng trên thị trường, với chi phí thấp, chênh lệch giữa giá mua và giá bán không đáng kể), và có độ rủi ro về đối tác coi như bằng 0 (tức là chính phủ luôn luôn trả tiền cho các trái phiếu chính phủ theo như cam kết - điều này có thể không đúng đối với một số nước vào một số thời điểm, tuy nhiên nó được coi là đúng cho phần lớn các nước có thị trường tài chính phát triển).

Hình 4.1 là một ví dụ minh họa: trên hình này có 3 đường lợi suất của trái phiếu chính phủ Úc (Australia), một đường ứng với thời điểm 22/12/2008, một đường ứng với thời điểm 22/06/2009, và một đường ứng với thời điểm 22/12/2009. Các đường này cho thấy lợi suất của trái phiếu chính phủ Úc có phụ thuộc vào kỳ hạn, và có thay đổi theo thời gian. Ví dụ, trong vòng 1 năm từ 22/12/2008 đến 22/12/2009, lãi suất ở Úc đi lên khoảng $1.5 \%$ (ví dụ như lợi suất cho trái phiếu chính phủ còn kỳ hạn 4 năm đi lên từ $3.5 \%$ thành 5\%), trừ lãi suất rất ngắn hạn lại hơi đi xuống.

Trong điều kiện kinh tế "phát triển ổn định" thì đường lợi suất thường có dáng điệu đi lên, tức là kỳ hạn càng dài thì lợi suất càng cao. Có thể giải thích bằng một số lý do sau: 1) Cho vay ngắn hạn có nhiều lựa chọn hơn là cho vay dài hạn: khi hết hạn cho vay ngắn hạn có thể quyết định đầu tư mới, hoặc là tiếp tục cho vay hoặc là đầu tư chỗ khác 


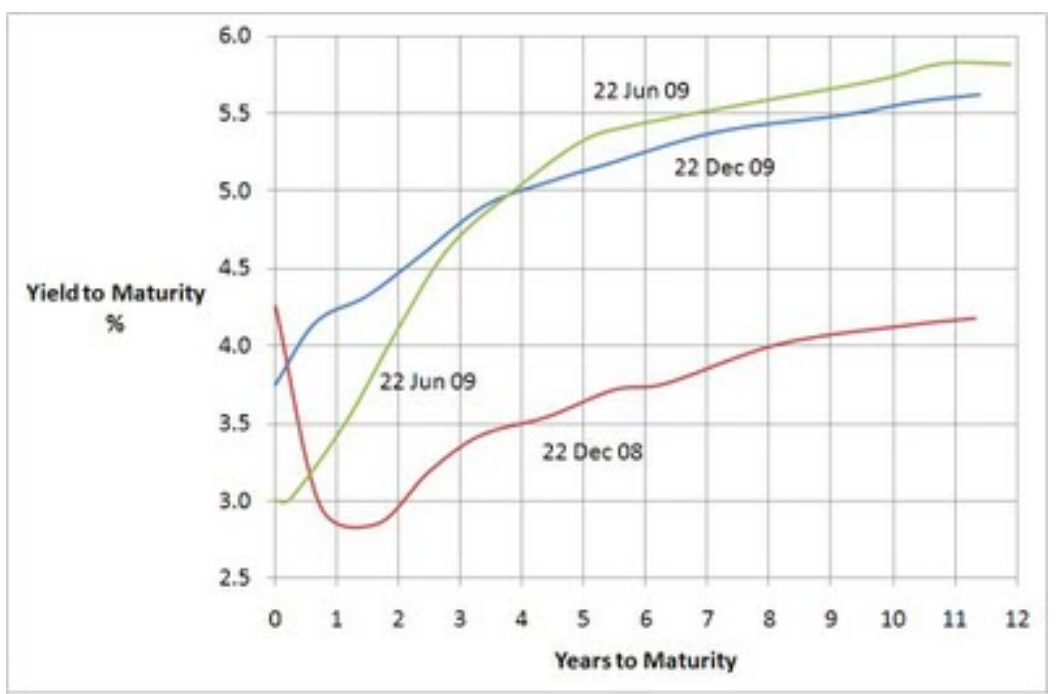

Hình 4.1: Các đường lợi suất của trái phiếu chính phủ Australia

hay hơn, nhưng người cho vay dài hạn thì bị kẹt tiền dài hạn, không có nhiều lựa chọn bằng. 2) Giá của trái phiếu dài hạn giao động mạnh mỗi khi có giao động về lãi suất (vì nó có duration cao) trong khi giá của trái phiếu ngắn hạn không giao động đáng kể theo lãi suất, có nghĩa là trái phiếu dài hạn có rủi ro về lãi suất cao hơn nhiều so với trái phiếu ngắn hạn. Ví dụ khi lạm phát tăng, dẫn đến lãi suất tăng, thì người đầu tư trái phiếu dài hạn có thể bị thiệt hại nặng, trong khi người đầu tư trái phiếu ngắn hạn không bị thiệt hại đáng kể. Bởi vậy, người đầu tư trái phiếu dài hạn thường đòi hỏi phải có lợi suất cao hơn, để bù lại cho mức rủi ro cao hơn, và mức lựa chọn kém hơn.

Có những khi mà đường lợi suất lại đi ngược, tức là có lợi suất ngắn hạn cao hơn lợi suất dài hạn. Những được lợi suất như vậy gọi là những đường lợi suất bị lộn ngược (inverted yield curve). Chẳng hạn như đường lợi suất ở Úc vào tháng 12/2008 là một đường bị lộn ngược cho khoảng kỳ hạn từ 0 đến 1,5 năm. Một ví dụ khác là hình 4.2 về đường lợi suất của đồng Bảng Anh (GBP) vào 02/2005. Đường này bị lộn ngược cho toàn bộ khoảng kỳ hạn từ 1 năm đến 30 năm.

Có nhiều lý dó khiến cho đường lợi suất có thể bị lộn ngược. Ví dụ như khủng hoảng về thanh khoản ngắn hạn, khiến cho lãi suất ngắn hạn tăng vọt lên, trong khi lãi suất dài hạn thì ổn định hơn, ít thay đổi. Cũng có thể là do triển vọng kinh tế về dài hạn không được tốt, có ít cơ hội tốt cho đầu tư dài hạn. Khi dự báo là tăng trưởng kinh tế sẽ giảm đi, kéo theo lãi suất sẽ giảm đi trong tương lai, tức là các mức lãi suất kỳ vọng cho tương lai giảm đi, thì nó kéo các mức lãi suất dài hạn hiện tại giảm đi theo. (Thật vậy, mức lãi 


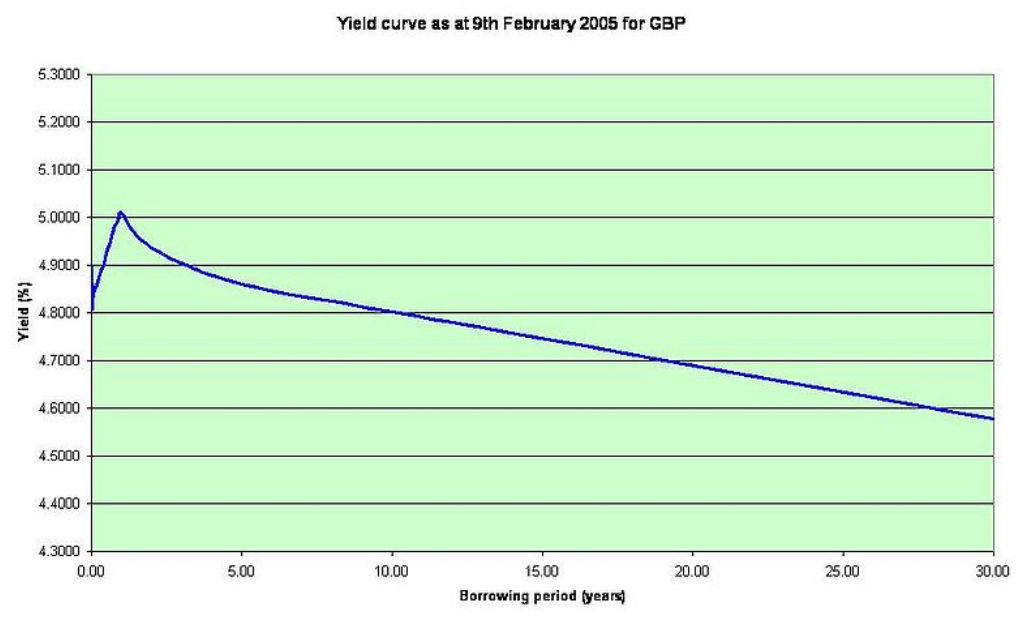

Hình 4.2: Đường lợi suất của trái phiếu chính phủ Anh vào 02/2005 (nguồn: wikipedia)

suất hiện tại cho kỳ hạn $2 T$ có thể coi là trung bình của mức lãi suất hiện tại cho kỳ hạn $T$ và mức lãi suất kỳ vọng cho khoảng thời gian từ $T$ đến $2 T$ trong tương lai. Nếu mức lãi suất kỳ vọng này giảm đi, mức lãi suất hiện tại cho kỳ hạn $2 T$ sẽ phải giảm theo). Thường là khi mà đường lợi suất bị lộn ngược mạnh, thì đó là dấu hiệu của khủng hoảng tài chính hoặc là suy thoái về kinh tế.

Đường lợi suất, hay nói cách khác là hàm lợi suất $R(t)$ theo biến kỳ hạn $t$, cho phép chúng ta xác định được chính xác giá trị tương lai $V(t)$ của một khoản tiền $V(0)$ có tại thời điểm hiện tại, cho bất kỳ thời điểm tương lai $t$ nào, theo công thức

$$
V(t)=V(0) \cdot(1+R(t))^{t}=V(0) \cdot \exp (\operatorname{tr}(t))
$$

trong đó $R(t)$ là lợi suất cho kỳ hạn $t$, tức là điểm $(t, R(t))$ là một điểm nằm trên đường lợi suất, và $r(t)=\ln (R(t)+1)$ là lợi suất $\log$ tương ứng. Thật vậy, một cách chắc chắn để biến khoản tiền $V(0)$ hiện tại thành $V(t)=V(0) \cdot(1+R(t))^{t}$ tại thời điểm $t$ là mua trái phiếu chính phủ zero-coupon còn thời hạn $t$ và hưởng lợi suất $R(t)$. (Trong trường hợp không có trái phiếu zero-coupon còn thời hạn $t$ thì trên thị trường tài chính có những sản phẩm "tổng hợp" (synthetic) cho kết quả tương tự, vì thế người ta mới tính được lợi suất $R(t)$ ). Hơn nữa, không có cách đầu tư nào mà chắc chắn biến được khoản tiền $V(0)$ hiện tại thành một khoản tiền lớn hơn $V(t)$ vào thời điểm $t$ trên thị trường tài chính dù tình huống nào xảy ra, vì nếu có cách như vậy thì tức là có cơ hội kinh doanh chênh lệch giá (bán khống trái phiếu zero-coupon còn thời hạn $t$ và lấy tiền bán được đầu tư theo cách đó), trái ngược lại với nguyên lý no-arbitrage.

Đối với một dòng tiền tệ $C_{1}, C_{2}, \ldots$ xảy ra tại các thời điểm $t_{1}, t_{2}, \ldots$ trong tương lai, 
thì công thức chính xác để tính giá trị hiện tại (hay là giá của nó vào thời điểm hiện tại) là

$$
V(0)=\sum_{i}\left(1+R\left(t_{i}\right)\right)^{t_{i}} C_{i}
$$

và để tìm lợi suất đến khi đáo hạn $R$ của dòng tiền đó, cần giải phương trình sau theo biến $R$ :

$$
\sum_{i}(1+R)^{t_{i}} C_{i}=\sum_{i}\left(1+R\left(t_{i}\right)\right)^{t_{i}} C_{i}
$$

Bài tập 4.17. Giả sử lãi suất trái phiếu chính phủ Mỹ cho kỳ hạn 1 năm là $4 \%$, kỳ hạn 2 năm là $4.2 \%$, kỳ hạn 3 năm là $4.3 \%$, và kỳ hạn 4 năm là $4.4 \%$. Xét một trái phiếu coupon chính phủ còn kỳ hạn 4 năm, mệnh giá $100 \$$, trả lãi coupon 5 sau mỗi năm. Tính giá (= giá trị hiện tại) của trái phiếu coupon này, lợi suất đến khi đáo hạn của nó, và duration của nó (dùng lợi suất đến khi đáo hạn làm lợi suất khi tính duration).

Bài tập 4.18. Tìm và phân tích một số đường lợi suất của Việt Nam và trên thế giới.

Ghi chú 4.7. Các lợi suất trên đường cong lợi suất có thể được dùng như lãi suất tham chiếu (reference rates) để dựa vào đó các lãi suất cho các phẩm vay nợ khác nhau được xác định. Khi cho một đối tác vay, ngoài vấn đề kỳ hạn, còn vấn đề mức tín nhiệm (credit rating), hay độ rủi ro vỡ nợ (default risk), sẽ được bàn đến trong Mục 4.6. Trên thế giới có một số công ty, trong đó có Moody's, Standard and Poors, và Fitch's, chuyên đánh giá chấm điểm mức tín nhiệm của các doanh nghiệp và tổ chức, theo thang điểm gọi là credit rating. Ví dụ, Standard and Poors cho credit rating ở các mức sau, xếp hạng từ cao xuống thấp: AAA (ổn định nhất có thể), AA, A, BBB, BB (bấp bênh theo tình hình kinh tế - Việt Nam vào năm 2009 được đánh giá ở quãng mức này), B, CCC, CC, C, CI (không trả được lãi đúng hẹn), R, SD, D (coi như phá sản), NR (không xếp hạng). Credit rating mà càng cao thì có thể vay được với lãi suất càng thấp, tức là chênh lệch giữa lãi suất tiền vay và lãi suất cho bởi đường cong lợi suất càng thấp. Nếu đi gửi tiền vào nhà băng, thì nói chung không thể được lãi suất cao hơn là lãi suất cho bởi đường cong lợi suất.

\subsection{Cấu trúc kỳ hạn tổng quát}

Như chúng ta đã thấy ở các phần trên, khi ta biết đường cong lợi suất $(t, R(t)$ ) (với mọi $t>0)$, thì tức là ta biết giá trị tương lai $V(t)$ của một khoản tiền $V(0)$ hiện tại cho 
mọi thời điểm $t$ trong tương lai, theo công thức

$$
V(t)=V(0)(1+R(t))^{t}=V(0) \exp (\operatorname{tr}(t))=\frac{V(0)}{B(0, t)}
$$

trong đó $B(0, t)=\exp (-\operatorname{tr}(t))=(1+R(t))^{-t}$ là ký hiệu giá tại thời điểm hiện tại của trái phiếu chính phủ zero-coupon còn kỳ hạn là $t$ và có mệnh giá là 1 .

Để đơn giản, tất cả các trái phiếu mà ta nói đến trong phần này sẽ là trái phiếu chính phủ zero-coupon có mệnh giá bằng 1 .

Các lợi suất $R(t)$ và lợi suất $\log r(t)=\ln (R(t)+1)$ được gọi là lợi suất giao ngay (spot rates).

Một cách tổng quát hơn, ta sẽ dùng ký hiệu $B(s, t)$ để chỉ giá, được xác định vào thời điểm hiện tại, cho một trái phiếu sẽ mua vào thời điển $s$ và đáo hạn vào thời điểm $t(t>s)$. Tức là, vào thời điểm hiện tại, người ta có thể làm một hợp đồng kỳ hạn(4) (forward contract), như sau: bên A sẽ bán cho bên B một trái phiếu chính phủ, tại thời điểm $s$ (thời điểm thực hiện hợp đồng), với giá cố định là $B(s, t)$, một trái phiếu đáo hạn vào thời điểm $t$. Theo thoả thuận của hợp đồng này, khi đến thời điểm $s$, dù cho giá của trái phiếu chính phủ zero-coupon mệnh giá 1 đáo hạn tại thời điểm $t$ được bán trên thị trường với giá bao nhiêu, thì bên $\mathrm{A}$ vẫn cứ phải bán nó cho bên $\mathrm{B}$ với giá $B(s, t)$ và bên $\mathrm{B}$ vẫn cứ phải mua từ bên $\mathrm{A}$ với giá như vậy. Giá $B(s, t)$ là giá được chọn vào thời điểm hợp đồng được thiết lập (thời điểm 0 ) sao cho hai bên $\mathrm{A}$ và $\mathrm{B}$ không có bên nào bị thiệt, hay nói cách khác, không có cơ hội kinh doanh chênh lệch giá với hợp đồng như vậy.

Mệnh đề 4.5. Các giá $B(s, t)$ thỏa mãn dẳng thức sau:

$$
B(0, t)=B(0, s) B(s, t)
$$

với mọi $0 \leq s \leq t$.

Chứng minh. Nếu như $B(0, t)<B(0, s) B(s, t)$ thì có chiến lược kinh doanh chênh lệch giá sau: tại thời điểm 0 , mua một trái phiếu còn kỳ hạn $t$ với giá $B(0, t)$, bán $B(0, t) / B(0, s)$ trái phiếu còn kỳ hạn $s$ với giá $B(0, s) \times B(0, t) / B(0, s)=B(0, t)$, và lập một hợp đồng kỳ hạn để bán tại thời điểm $s$ một trái phiếu đáo hạn tại thời điểm $t$, với giá $B(s, t)$. Tổng số tiền bỏ ra tại thời điểm 0 là 0 . Khi đến thời điểm $s$, thì bán lại 1 trái phiếu kỳ hạn $t$ theo hợp đồng kỳ hạn để được số tiền là $B(s, t)$, đồng thời phải trả một số tiền là $B(0, t) / B(0, s)$ cho $B(0, t) / B(0, s)$ trái phiếu kỳ hạn $s$ đã bán, và như vậy tại thời điểm $s$ thì không còn

\footnotetext{
${ }^{(4)}$ nhắc lại rằng, từ "kỳ hạn" trong cụm từ "hợp đồng kỳ hạn" là để chỉ thời điểm mà hợp đồng được thực hiện trong tương lai, chứ không phải là để chỉ kỳ hạn của trái phiếu
} 
giữ trái phiếu hay hợp đồng nào, và được lợi nhuận là $B(s, t)-B(0, t) / B(0, s)>0$. Nếu như $B(0, t)>B(0, s) B(s, t)$ thì làm ngược lại như trên (đổi bán thành mua, mua thành bán), ta sẽ được một lợi nhuận dương ở thời điểm $s$. Như vậy, nếu bất đẳng thức xảy ra theo chiều nào thì ta cũng có cơ hội kinh doanh chênh lệch giá. Bởi vậy, theo nguyên lý no-arbitrage, ta phải có đẳng thức $B(0, t)=B(0, s) B(s, t)$.

Người mua trái phiếu, tại thời điểm $s$, trái phiếu có kỳ hạn đến $t$, theo hợp đồng kỳ hạn thiết lập tại thời điểm 0 , có thể coi là người đầu tư trái phiếu trong khoảng thời gian từ $s$ đến $t$, nhưng với lợi suất đầu tư được biết trước từ thời điểm 0 , chứ không phải đến thời điểm $s$ mới biết. Ký hiệu lợi suất này là $R(s, t)$, và lợi suất log tương ứng là $r(s, t)$, ta có

$$
B(s, t)=(1+R(s, t))^{-(t-s)}=\exp (-(t-s) r(s, t)),
$$

bởi vì khoảng thời gian đầu tư là $t-s$, và theo đầu tư này thì một khoản tiền là $B(s, t)$ vào thời điểm $s$ sẽ trở thành 1 vào thời điểm $t$.

Các lợi suất $R(s, t)$ và lợi suất $\log r(s, t)$ được gọi là các lợi suất kỳ hạn (forward rates), để phân biệt với các lợi suất giao ngay $R(0, t)=R(t)$ và $r(0, t)=r(t)$. Nói một cách nôm na, các lợi suất kỳ hạn là các lợi suất của các khoản đầu tư hay vay nợ được thỏa thuận trước theo các hợp đồng kỳ hạn (và khi đến kỳ hạn của hợp đồng thì mới thực hiện).

Mệnh đề 4.6. Các lợi suất log kỳ hạn $r(s, t)$ có thể được tính theo công thức sau:

$$
r(s, t)=\frac{\operatorname{tr}(0, t)-s r(0, s)}{t-s}
$$

với mọi $0 \leq s<t$.

Chứng minh. Mệnh đề 4.5 cùng với các công thức tính lợi suất cho ta đẳng thức sau:

$$
\exp (-\operatorname{tr}(0, t))=\exp (-s r(0, s)) \exp (-(t-s) r(s, t))
$$

Lấy $\log$ của cả hai vế rồi đổi dấu, ta được $\operatorname{tr}(0, t)=s r(0, s)+(t-s) r(s, t)$, từ đó suy ra công thức cần chứng minh.

Ghi chú 4.8. Với giả sử là cấu trúc kỳ hạn tổng quát thỏa mãn nguyên lý no-arbitrage, tức là không có độ chênh thị giá, thì lợi suất log kỳ hạn $r(s, t)$ bằng chính lợi suất log kỳ vọng của thị trường tại thời điểm hiện tại, theo một phân bố xác suất trung hòa rủi ro, cho các trái phiếu zero-coupon phát hành vào thời điểm $s$ và đáo hạn vào thời điểm $t$. Chứng minh của điều này là bài tập cho bạn đọc. 
Hàm lợi suất $\log r(s, t)$ theo hai biến $s, t$ (biến $s$ là biến kỳ hạn của hợp đồng kỳ hạn, biến $t$ là biến kỳ hạn của trái phiếu) được gọi là cấu trúc kỳ hạn tổng quát (general term structure) của lợi suất. Công thức (4.55) cho thấy cấu trúc kỳ hạn tổng quát được hoàn toàn xác định bởi hàm lợi suất log giao ngay $r(t)=r(0, t)$ một cách khá đơn giản. Hàm lợi suất log giao ngay $r(t)$ còn được gọi là cấu trúc ban đầu (initial structure) của lợi suất.

Ghi chú 4.9. Cấu trúc kỳ hạn tổng quát rất quan trọng trong việc xác định lãi suất của các hợp đồng vay nợ kỳ hạn. Ví dụ, hình dung một doanh nghiệp lên kế hoạch xây nhà máy mới để phát triển sản xuất, và cần vay tiền cho việc đó. Nhưng không phải là cần vay ngay, mà là 1 năm sau mới cần vay. Nếu như doanh nghiệp này đợi một năm đúng đến lúc cần tiền mới đi vay, thì có thể sẽ phải chịu rủi ro về lãi suất: nếu lúc đó mà lãi suất tăng lên ngoài dự kiến, thì khoản vay sẽ trở nên đắt hơn dự kiến, ảnh hưởng xấu đến tài chính của doanh nghiệp, và có thể biến một dự án đang từ lãi trở thành lỗ. Để tránh rủi ro đó, doanh nghiệp sẽ làm một hợp đồng kỳ hạn từ bây giờ cho khoản vay vào 1 năm sau, với một lãi suất kỳ hạn xác định từ bây giờ. Câu hỏi là lãi suất kỳ hạn đó bằng bao nhiêu là hợp lý ? Câu trả lời phụ thuộc vào độ tín nhiệm về tài chính (credit rating) của danh nghiệp, và cấu trúc kỳ hạn tổng quát. (Khi độ tín nhiệm ở mức cao nhất, có thể vay với lãi suất kỳ hạn cho bởi cấu trúc kỳ hạn tổng quát).

\subsection{Cấu trúc rủi ro của lãi suất}

Một tổ chức hay cá nhân đi vay nợ để làm ăn hay tiêu dùng, nhưng sau đó, do làm ăn thất bát hoặc do các lý do khác, có thể không trả được nợ theo thỏa thuận mà hoãn nợ hay quịt nợ. Những khoản nợ kiểu như vậy được gọi là nợ xấu. Hầu như trong danh sách tài sản của nhà băng nào cũng có những khoản nợ xấu, lên đến $2 \%$ hoặc thậm chí hơn thế, tổng dư nợ của nhà băng, và đây là những khoản nợ gây lỗ cho nhà băng. Để có tiền bù lỗ cho những khoản nợ xấu như vậy, nhà băng phải cho vay với lãi suất cao hơn đáng kể so với lãi suất không có rủi ro (tức là lãi suất cho những khoản vay mà xác suất thu hồi được lại đủ cả tiền vốn lẫn tiền lãi đúng hạn là 100\%). Sự chênh lệch đó một phần là để dự trữ bù lỗ cho các nợ xấu, phần còn lại là đem lại lợi nhuận cho nhà băng.

Nếu như xác suất để một khoản nợ trở thành nợ xấu cao, thì tức là nguy hiểm cao đối với người cho vay, dự trữ bù lỗ cho nợ xấu cũng phải cao, và do đó chênh lệch giữa lãi suất của khoản nợ đó so với lãi suất không rủi ro cũng phải cao. Ngược lại, nếu như khả năng một khoản nợ trở thành nợ xấu rất thấp, thì không cần nhiều dự trữ bù lỗ cho nợ 
xấu, và do đó không cần chênh lệch cao giữa lãi suất của khoản nợ đó và lãi suất không có rủi ro. Đấy chính là sự phụ thuộc của lãi suất vào mức độ rủi ro vỡ nợ. Sự chênh lệch giữa lãi suất của khoản nợ có rủi ro vỡ nợ và khoản nợ không có rủi ro (cho cùng một thời hạn) được gọi là phí rủi ro (risk premium).

Xác suất vỡ nợ của bên đi vay (bên đi vay đó có thể là chính phủ, tổ chức, doanh nghiệp, hay cá nhân) thường được đánh giá theo một hệ thống thang điểm nào đó, gọi là mức tín nhiệm (credit rating). Có những công ty như Moody's, Standard and Poor's (viết tắt là $\mathrm{S} \& \mathrm{P}$ ) và Fitch chuyên về đánh giá cho điểm mức tín nhiệm cho các chính phủ và doanh nghiệp lớn. Các thang điểm của Moody's và S\&P như sau(5).

\begin{tabular}{|l|l|l|l|l|}
\hline Moody's & S\&P & Ý nghĩa & Ví dụ năm 2010 & Premium \\
\hline Aaa & AAA & an toàn nhất & General Electric & 80 \\
Aa & AA & chất lượng cao & Walmart, PepsiCo & 90 \\
A & A & trên trung bình & McDonald's, Boeing & 120 \\
Baa & BBB & trung bình & Motorola, FedEx & 180 \\
Ba & BB & dưới trung bình & Ford, Chính phủ Việt Nam & 350 \\
B & B & rủi ro cao & Levi Strauss & 600 \\
Caa & CCC, CC & đang khất nợ & Integrated Electrical Services & 1300 \\
C & D & đang vỡ nợ & Northwest Airlines & \\
\hline
\end{tabular}

Cột cuối cùng của bảng là ước lượng độ chênh lệch về lãi suất (risk premium) so với một trái phiếu chính phủ Mỹ (được coi là không có rủi ro), tính theo "basic points". Ví dụ như 350 "basic points" có nghĩa là chênh lệch lãi suất là 3.5\%, nếu trái phiếu chính phủ Mỹ có lãi suất khoảng $3 \%$ thì lãi suất của bên vay với mức tín nhiệm $\mathrm{BB}$ sẽ phải vào khoảng $6.5 \%$ (nếu là vay tiền USD). Các con số này chỉ có tính chất tham khảo, và cũng không phải là hằng số. Khi mà "risk appetite" (sự thích mạo hiểm) của các nhà đầu tư tăng lên trên thị trường, thì phí rủi ro (risk premium) cho các khoản nợ sẽ giảm đi, và ngược lại, khi các nhà đầu tư trở nên lo ngại hơn với rủi ro (ví dụ như vì kỳ kinh tế suy thoái, khiến các nhà đầu tư dè dặt hơn) thì phí rủi ro sẽ tăng lên.

Các trái phiếu có mức tín nhiệm từ $\mathrm{BBB}$ (Baa) trở lên được gọi là có investment grade (thích hợp cho các quỹ đầu tư ít mạo hiểm, ví dụ như các quỹ hưu trí), còn từ $\mathrm{BB}$ (Ba) trở xuống thì được gọi là speculative bonds (trái phiếu đầu cơ), hay còn được gọi là junk bonds (trái phiếu phế phẩm), chỉ thích hợp với các nhà đầu cơ hay đầu tư sẵn sàng chấp nhận mạo hiểm cao.

${ }^{(5)}$ Xem chi tiết về các thang điểm tín nhiệm tại: http://en.wikipedia.org/wiki/Credit_rating 
Mức tín nhiệm của một doanh nghiệp hay tổ chức không phải là một hằng số, mà thay đổi theo thời gian, phụ thuộc vào việc tình hình tài chính của doanh nghiệp hay tổ chức đó tốt lên hay xấu đi. Ví dụ, mức tín nhiện của nước Hy Lạp bị giảm liên tiếp trong giai đoạn 2009-2010, và đang từ "investment grade" A xuống thành "junk" BB, do chính phủ nước này nợ nần quá nhiều và trở nên có nguy cơ vỡ nợ.

Ở một số nơi trên thế giới, cũng có chấm điểm tín nhiệm tài chính (gọi là điểm tín dụng, credit score) đối với các cá nhân(6) Ví dụ, ở Mỹ, có một hệ thống tính credit score cho các cá nhân được sử dụng rộng rãi, do công ty Fair Isaac Corporation (FICO) thiết lập, với thang điểm từ 300 đến 850, và điểm tín nhiệm của một người Mỹ trung bình theo hệ thống này là 723. Ngoài FICO còn có một số công ty khác tham ra việc tính điểm tín dụng, với các cách tính khác nhau $[(7)$. Người nào có điểm tín nhiệm càng cao, thì càng dễ vay được tiền nhà băng với lãi suất thấp

${ }^{(6)} \mathrm{Xem}$ : http://en.wikipedia.org/wiki/Credit_score

${ }^{(7)}$ Xem: http://en.wikipedia.org/wiki/Credit_score_(United_State) 


\section{Chương 5}

\section{Phân tích giá cổ phiếu}

Một trong những ứng dụng quan trọng nhất của toán tài chính là đầu tư chứng khoán, dựa trên các lý thuyết về quản lý danh mục đầu tư, và các lý thuyết về phân tích giá trị và sự biến động giá cả của các chứng khoán, trong đó có hai loại hình chứng khoán phổ biến nhất là trái phiếu và cổ phiếu. Đầu tư vào trái phiếu thường được gọi là loại hình đầu tư có thu nhập cố định (fixed-income investments), tương đối ít rủi ro, vì người giữ trái phiếu thường biết trước sẽ được nhận lợi nhuận là bao nhiêu, và giá của trái phiếu trên thị trường (đặc biệt là các trái phiếu ngắn hạn) ít khi có biến động mạnh. Đối với các các cổ phiếu thì ngược lại, mức thu nhập rất khó xác định trước và có khi là âm, và giá cả thường thay đổi mạnh hơn nhiều so với trái phiếu. Bởi vậy, nói chung đầu tư vào cổ phiếu mạo hiểm hơn so với đầu tư vào trái phiếu, nhưng bù lại nó cũng cho kỳ vọng lợi nhuận cao hơn.

Ở trong chương này và chương 7, chúng ta sẽ tìm hiểu những yếu tố ảnh hưởng đến giá trị và sự biến động giá cả của các cổ phiếu, và việc xây dựng các mô hình toán học nhằm mô tả và nghiên cứu sự biến động giá. Trong Chương 6 chúng ta sẽ bàn đến việc quản lý danh mục đầu tư chứng khoán.

\subsection{Giá thị trường và giá trị thật}

Khi phân tích cổ phiếu, chúng ta cần phân biệt giữa hai khái niệm giá thị trường (market price, gọi tắt là giá) và giá trị thật (fair value), hay còn gọi là giá trị nội tại (intrinsic value). Giá thị trường của cổ phiếu là khái niệm đơn giản dễ hiểu: đó là giá giao dịch của cổ phiếu trên thị trường, tức là có người mua và người bán trên thị trường với giá như vậy. Ví dụ, giá đóng cửa (tức là giá giao dịch cuối cùng của phiên giao dịch) 
của cổ phiếu của công ty Vietcombank (Ngân hàng Ngoại thương Việt Nam, mã chứng khoán: VCB) trên thị trường cổ phiếu Việt Nam ngày 22/03/2010 là 44.8 (nghìn VND / cổ phiếu). Đó là giá thị trường, và thông tin về giá đó có thể lấy được dễ dàng từ nhiều nguồn tin khác nhau, ví dụ như các trang web về tài chính hay các công ty chứng khoán.

Giá trị thật là một khái niệm trừu tượng và tế nhị hơn nhiều khái niệm giá thị trường. Chúng ta có thể định nghĩa nó như sau:

Định nghĩa 5.1. Giá trị thật (fair value) của một công ty cổ phần nào đó (tại thời điểm $t_{0}$ ) là giá trị hiện tại kỳ vọng (tại thời điểm $t_{0}$ ) của dòng tiền tệ (và tài sản qui đổi ra tiền) mà công ty sẽ đem lại cho các cổ đông. Giá trị thật của một cổ phiếu của một công ty cổ phần bằng giá trị thật của công ty chia cho tổng số cổ phiếu của công ty.

Một công ty cổ phần có thể tồn tại mãi mãi (về mặt lý thuyết) hoặc là sẽ thay đổi cấu trúc vào một thời điểm nào đó, không còn là công ty cổ phần cũ nữa (đây là điều nói chung sẽ xảy ra với mọi công ty - phần lớn các công ty cổ phần lớn của thế giới vào thời điểm cách đây 1 thế kỷ bây giờ đã mất đi, nhường chỗ cho các công ty mới mọc lên). Ví dụ, nó có thể tự giải thể, hoặc phá sản, hoặc tách ra thành nhiều công ty riêng biệt, hoặc sát nhập lại với công ty khác, v.v. Trong suốt quá trình tồn tại của một công ty cổ phần (tính từ một thời điểm nào đó, cho đến khi nó không còn nữa), nó có thể chia cho các cổ đông của mình các lợi tức và các tài sản khác (ví dụ như cổ phần trong các công ty mới), và đó là toàn bộ những gì mà các cổ đông sẽ nhận được. Tổng giá trị của các lợi tức và các tài sản này chính là giá trị thật của công ty (đối với các cổ đông). Như chúng ta đã thấy trong Chương 4 , những khoản tiền mà trong tương lai mới nhận được thì cần phải được chiết khấu đi theo một mức lãi suất nào đó, để tính ra giá trị hiện tại. Đối với các tài sản khác cũng vậy. Bởi vậy, định nghĩa giá trị thật phía trên sử dụng giá trị hiện tại, tức là đã chiết khấu, của dòng tiền tệ và tài sản qui đổi ra tiền.

Chú ý rằng, các khoản lợi nhuận của một công ty cổ phần phụ thuộc rất nhiều vào các yếu tố có thể coi là ngẫu nhiên, sẽ xảy ra trong tương lai, không biết trước được, và nằm ngoài tầm kiểm soát của công ty. Bởi vậy, ta cũng không thể biết trước được là dòng tiền tệ (và tài sản qui ra tiền) mà công ty sẽ đem lại trong tương lai cho cổ đông sẽ thực sự là bao nhiêu, mà chúng ta chỉ có thể xét dòng tiền tệ đó như là một biến ngẫu nhiên, và nói đến giá trị kỳ vọng của biến ngẫu nhiên đó (trên không gian các tình huống có thể xảy ra, với xác suất "thực tế" về khả năng xảy ra của mỗi tình huống). Đó chính là nguyên nhân tại sao có từ kỳ vọng trong định nghĩa giá trị thật.

Tương tự như giá cổ phiếu, giá trị thật của cổ phiếu cũng thay đổi theo thời gian, khi 
mà có những thông tin mới về tình hình kinh tế và tình hình làm ăn của công ty cổ phần, làm thay đổi kỳ vọng về lợi nhuận và về giá trị của các tài sản của công ty.

Khác với giá thị trường, không có một nguồn tin nào có thể cho ta biết là giá trị thật của một cổ phiếu vào một thời điểm nào đó là bao nhiêu. Chúng ta chỉ có thể ước lượng giá trị thật đó, dựa trên các thông tin có được, với độ tin cậy và khoảng tin cậy nào đó (nói theo ngôn ngữ của thống kê toán học), chứ không thể biết được chính xác giá trị thật. Việc ước lượng này sẽ được bàn đến trong phần sau của chương. Ta sẽ coi là, với mỗi cổ phiếu, tại mỗi thời điểm, chỉ có 1 giá trị thật (mà không ai biết là bằng bao nhiêu), nhưng có thể có nhiều ước lượng khác nhau về giá trị thật đó, và giá trị thật ước lượng (estimated intrinsic value) có thể được hình dung như là một biến ngẫu nhiên. Biến ngẫu nhiên đó có thể có dải giá trị rất rộng: không hiếm trường hợp mà trong cùng một thời điểm, cho cùng một cổ phiếu, nhà đầu tư này ước lượng giá trị thật của nó cao gấp 2-3 lần so với nhà đầu tư khác.

Khi mà nền kinh tế có dấu hiệu phát triển, thì nói chung triển vọng lợi nhuận của các công ty cổ phần tăng lên, kéo theo giá trị thật của chúng tăng lên, và thường là giá cổ phiếu cũng tăng lên trong những giai đoạn kinh tế tăng trưởng. Ngược lại, khi kinh tế bắt đầu có dấu hiệu suy thoái, thì kỳ vọng lợi nhuận giảm đi, và giá cổ phiếu trên thị trường cũng giảm đi. Về nguyên tắc, giá của cổ phiếu trên thị trường phải phản ảnh giá trị thật của công ty, tức là nói chung khi giá trị thật tăng lên thì giá cổ phiếu tăng lên, khi giá trị thật giảm đi thì giá cổ phiếu giảm đi, và cổ phiếu nào có giá trị thật lớn hơn thì cũng sẽ có giá cao hơn. Trong "điều kiện lý tưởng" thì giá phải trùng với giá trị thật. Tuy nhiên, trên thực tế, rất it khi mà giá cổ phiếu trùng với giá trị thật. Không cần phải xác định được giá trị thật, chúng ta cũng có thể nhận thấy điều đó. Thật vậy, giá trị thật của các công ty cổ phần có thay đổi theo thời gian, nhưng thường là thay đổi một cách từ từ và mỗi thay đổi lớn thường đòi hỏi một thời gian dài. Trong khi đó, giá cổ phiếu có thể thay đổi rất nhanh trong một thời gian ngắn. Trong quá trình thay đổi giá nhanh như vậy, nếu có một thời điểm nào đó mà giá bằng giá trị thật, thì tại những thời điểm sau giá sẽ không còn bằng giá trị thật nữa, mà có thể là cao hơn rất nhiều hoặc thấp hơn rất nhiều so với giá trị thật.

Một trong những lý do khiến cho giá có thể lệch nhiều so với giá trị thật chính là tính bất xác định của giá trị thật. Giá cổ phiếu phản ảnh giá trị thật, không phải là một cách trực tiếp, mà là thông qua các giá trị thật ước lượng, bởi vì các nhà đầu tư có thể ước lượng giá trị thật chứ không biết chính xác nó bằng bao nhiêu. Khi mà có nhiều ước lượng khác nhau, chênh nhau nhiều, tạo ra mội dải giá trị ước lượng lớn, thì giá cổ phiếu 
cũng "không biết" là phải "chọn" ước lượng nào, và bởi vậy nó dễ bị giao động trong một dải lớn. Nhưng đó không phải là lý do duy nhất khiến cho giá cổ phiếu khác với giá trị thật. Các yếu tố thị trường, như là cung cầu và tâm lý thị trường, cũng ảnh hưởng rất lớn đến sự biến động của giá cổ phiếu.

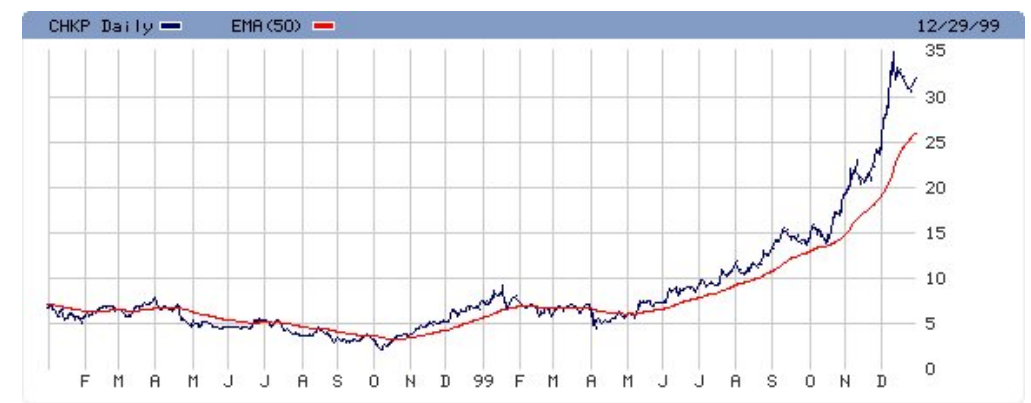

Hình 5.1: Giá cổ phiếu của CHKP trong 2 năm 1998-1999

Vi du 5.1. Công ty Checkpoint Software (mã chứng khoán trên thị trường Mỹ: CHKP) là một công ty phần mềm tin học khá lớn với sản phẩm được bán khắp nơi trên thế giới, chuyên về an toàn thông tin trên internet. Vào thời điểm đầu năm 2010, nó có giá cổ phiếu khoảng 34\$, vốn hóa vào khoảng 7 tỷ USD, và lợi nhuận trên 350 triệu USD một năm. Hình 5.1 là đồ thị giá (đã điều chỉnh) của CHKP trong 2 năm 1998-1999. Nhìn vào đồ thị này ta thấy, trong năm 1998 có lúc giá cổ phiếu CHKP đi xuống mất hai phần ba, từ quãng $7.5 \$$ còn quãng 2.5\$. Vào đầu năm 1999 cũng có giai đoạn cổ phiếu CHKP đi xuống mất một nửa, từ gần $10 \$$ còn dưới $5 \$$. Giá cổ phiếu ở điểm thấp nhất và điểm cao nhất của CHKP trong hai năm 1998-1999 chênh lệch nhau đến 15 lần. Nhưng điều đó không có nghĩa là giá trị thật của CHKP có lúc giảm những $2 / 3$ trong giai đoạn đó, hoặc là có lúc giá trị thật tăng đến 15 lần trong vòng hơn 1 năm. Trên thực tế, trong hai năm 1998-1999 công ty CheckPoint Software luôn làm ăn rất tốt, sản phẩm có sức cạnh tranh mạnh, mức lợi nhuận cao, và phát triển nhanh (ở mức 40\%/năm lúc đó), triển vọng sáng sủa vì nhu cầu an toàn internet trên thế giới càng ngày càng tăng. Có thể nói là giá trị thật của CHKP luôn luôn tăng lên trong giai đoạn 1998-1999, và những lúc giá CHKP giảm không phải do là giá trị thật của nó giảm, mà là do các yếu tố khác của thị trường.

Trong ba năm 2000-2002, CHKP tiếp tục giao động lên xuống nhiều lần rất mạnh, có lúc lên trên $110 \$$, rồi sau đó lại giảm xuống chỉ còn hơn $10 \$$. Phần lớn sự giao động đó là do các yếu tố khác tạo nên, chứ giá trị thật của CHKP không thay đổi nhanh đến vậy. Ở đây ta sẽ không đi vào phân tích ước lượng giá trị thật của CHKP, nhưng ta có thể phán đoán rằng, khi CHKP còn giá dưới $2.5 \$$ trong năm 1998, thì giá đó quá thấp so với giá 


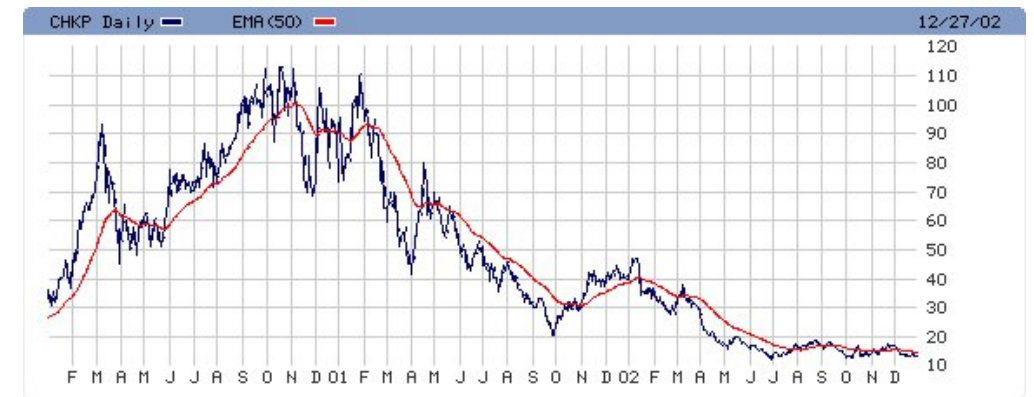

Hình 5.2: Giá cổ phiếu của CHKP trong 3 năm 2000-2002

trị thật của CHKP vào lúc đđ(1) nhưng khi giá của CHKP đi lên trên $110 \$$ vào cuối năm 2000 thì giá đó lại vượt lên quá cao so với giá trị thật.

Cổ phiếu tuy có lúc lên rất cao, và có lúc xuống rất thấp, so với giá trị thật, nhưng trong một quá trình dài nhiều năm, có thể kỳ vọng rằng giá cổ phiếu sẽ có nhiều lần giao với giá trị thật. Điều này gần giống như việc hầu như chắc chắn là một chuyển động ngẫu nhiên (random walk) 1 chiều sẽ có vô số lần đi qua điểm 0 . Thực ra, việc giá cổ phiếu quay về giá trị thật dễ dàng xảy ra hơn nhiều so với việc một random walk quay về điểm ban đầu, bởi vì khi giá đi ra quá xa so với giá trị thực đến mức nhà đầu tư nào cũng nhận ra, thì sẽ có lực đẩy ngược giá lại về gần giá trị thật, trong khi đó trong một random walk không có lực đẩy ngược như vậy. Tuy về ngắn hạn, giá và giá trị thật có thể khác nhau nhiều và hoàn toàn có thể chuyện động ngược hướng với nhau, nhưng về dài hạn, thì nói chung giá sẽ đi theo giá trị thật. Có thể nói một cách nôm na rằng, quan hệ giữa giá và giá trị thật tương tự như là quan hệ giữa một con chó và người chủ của nó: chủ đi đâu thì chó đi theo đấy, nhưng có lúc chó chạy lên phía trước có lúc lại chạy xuống phía sau, chứ hiếm khi đi ngang bằng với chủ.

Vi du 5.2. Trong giai đoạn 15 năm, từ đầu năm 1986 đến cuối năm 1999, giá cổ phiếu của hãng Microsoft (mã chứng khoán trên thị trường Mỹ: MSFT) tăng lên khoảng 500 lần, từ quãng $0.1 \$$ (sau khi đã điều chỉnh sau các lần chia nhỏ cổ phiếu) lên thành quãng $50 \$$. Tất nhiên, trong giai đoạn đó, không phải giá cổ phiếu lúc nào cũng tăng, mà cũng có những lúc nó giảm vài chục phần trăm. Thế nhưng, nếu tính cho cả 15 năm, thì trung bình mỗi năm giá cổ phiếu tăng lên hơn $50 \%$ (theo cấp số nhân). 15 năm đó cũng là thời kỳ hoàng kim của hãng Microsoft, từ một công ty tương đối nhỏ trở thành một công ty khổng lồ, nhờ vị trí gần như độc quyền trên thị trường phần mềm máy tính cá nhân.

(1) lúc đó chỉ số $\mathrm{P} / \mathrm{E}$ của $\mathrm{CHKP}$ dưới 5 , công ty không bị mắc nợ và đang đà phát triển mạnh 
Ghi chú 5.1. Một điều thú vị là giá của cổ phiếu cũng có thể ảnh hưởng ngược lại đến giá trị thật của nó. Ví dụ, nếu một công ty cổ phần thấy giá cổ phiếu của mình đang cao hơn nhiều so với giá trị thật, thì công ty đó có thể phát hành thêm cố phiếu (secondary offering), bán ra với giá rất cao đó. Việc bán này sẽ làm tăng giá trị thật của cổ phiếu của công ty (giá trị thật mới này là một số trung bình cộng có trọng giữa giá trị thật cũ và giá cổ phiếu đem bán), tuy rằng có thể làm cho những cổ đông mới của công ty bị thiệt (những người mua với giá cao hơn giá trị thật), nhưng lại làm có lợi cho các cổ đông cũ. Ngược lại, nếu công ty thấy giá cổ phiếu đang thấp hơn nhiều giá trị thật, thì có thể mua lại một phần cổ phiếu của chính mình (share buy-back), làm giảm lượng cổ phiếu đi, và việc mua lại này khi đó sẽ làm tăng giá trị thật của cổ phiếu. Suy luận ngược lại, khi trên thị trường có công ty nào mua lại cổ phiếu của mình thì đó có thể là dấu hiệu cổ phiếu đó đang "undervalued" (có giá thấp hơn giá thị thật).

\section{2 Ước lượng giá trị thật của cổ phiếu}

Việc phân tích giá trị thật của một công ty cổ phần là một việc phức tạp, đòi hỏi nhiều kiến thức và kinh nghiệm về tài chinh doanh nghiệp (corporate finance) và nhiều kiến thức khác. Muốn đánh giá được chính xác một công ty nào đó, thì phải tìm hiểu nó rất sâu, đánh giá từng lợi thế và yếu thế của nó, các đối thủ cạnh tranh với nó, giá trị thực sự của từng tài sản của nó, triển vọng của từng thị trường mà nó tham gia, v.v. Những cái đó nằm ngoài khuôn khổ của quyển sách này. Ở đây, chúng ta sẽ chỉ điểm qua một số cách ước lượng giá trị khá thô sơ, tương đối dễ sử dụng, tuy độ chính xác không cao, nhưng cũng cho một cái nhìn sơ bộ về các cổ phiếu.

Một bài tập thực hành quan trọng cho bạn đọc: hãy ước lượng giá trị của một số cổ phiếu lớn trên thị trường chứng khoán Việt Nam và các thị trường chứng khoán thế giới. Tìm một số báo cáo của các công ty chứng khoán, ngân hàng đầu tư, hay các dịch vụ tư vấn đầu tư, về đánh giá giá trị của các cổ phiếu, đọc và phân tích các báo cáo đó.

\subsubsection{Dòng tiền lợi tức, và lợi suất của cổ phiếu}

Mỗi công ty cổ phần đều có vốn chủ sở hữu (equity, hay còn gọi là book value), bằng tổng số tài sản (assets) trừ đi tổng số nợ (liabilities). Tuy nhiên, giá trị của một công ty có thể rất khác xa vốn chủ sở hữu của nó. Cùng có vốn chủ sở hữu như nhau, nhưng công ty nào làm ra nhiều lợi nhuận hơn, đem lại nhiều cổ tức cho cổ đông hơn, thì 
giá trị phải cao hơn là công ty có ít lợi nhuận. Những công ty siêu lợi nhuận có thể có giá trị lớn gấp nhiều lần vốn chủ sở hữu. Để ước lượng giá trị của một công ty, một điều rất quan trọng là ước lượng tổng số lợi nhuận mà công ty đó sẽ đem lại trong tương lai cho các cổ đông, thường là dưới hình thức cổ tức (dividend), tức là tiền lợi nhuận trả hàng năm cho cổ đông.

Giả sử công ty tồn tại vĩnh viễn, và cổ tức của công ty trả vào năm thứ $n$ (tính từ thời điểm hiện tại) sẽ là một đại lượng (ngẫu nhiên) nào đó có kỳ vọng bằng $D_{n}$. (Nếu trả cổ tức nhiều lần một năm, ví dụ mỗi quí một lần, thì qui đổi ra theo năm). Khi đó, dòng tiền tệ mà nhà đầu tư sẽ nhận được trên đầu 1 cổ phiếu có các giá trị kỳ vọng là: $D_{1}, D_{2}, D_{3}, \ldots$ Nếu như đây là tất cả những gì mà cổ phiếu đem lại cho nhà đầu tư (tức là nhà đầu tư sẽ không nhận được thêm tài sản nào khác ngoài các cổ tức này), thì giá trị của cổ phiếu chính bằng giá trị hiện tại của dòng cổ tức kỳ vọng này, tức là ta có thể sử dụng công thức dòng tiền chiết khấu ở Chương 4 để ước lượng giá trị cổ phiếu vào thời điểm hiện tại:

$$
V=\sum_{n=1}^{\infty} \frac{D_{n}}{(1+R)^{n}},
$$

trong đó $R$ là một mức lãi suất "thích hợp" (cao hơn là lãi suất không rủi ro, vì nó có tính đến độ rủi ro của các cổ phiếu). Việc xác định $R$ sẽ được bàn phía dưới.

Công thức (5.1) rất khó sử dụng trong thực tế, vì rất khó ước lượng các cổ tức kỳ vọng $D_{n}$ khi $n$ lớn. Để đơn giản hoá, ta sẽ tạm coi rằng công ty có một tốc độ tăng trưởng (trung bình trong rất nhiều năm) là $g$, và kỳ vọng cổ tức hàng năm tăng theo tốc độ này: $D_{n}=(1+g)^{n} D_{0}$. Khi đó ta được trường hợp riêng sau của công thức ước lượng trên:

$$
V=\sum_{n=1}^{\infty} \frac{D_{0}(1+g)^{n}}{(1+R)^{n}}=\frac{(1+g) \cdot D_{0}}{R-g}
$$

hay có thể viết là

$$
V=\frac{D_{1}}{R-g}
$$

(Tất nhiên, tốc độ tăng trưởng trung bình phải nhỏ hơn lãi suất, tức là ta phải có $R-g>0$, nếu không thì giá trị của công ty sẽ là vô cùng, là một điều không thể xảy ra).

Công thức 5.2 cho thấy, giá trị của công ty phụ thuộc vào mức lãi suất $R$ một cách rất nhạy: nó gần như là tỷ lệ nghịch với $R$. Trong trường hợp đặc biệt, khi $g=0$, thì ta được công thức đơn giản $V=D_{0} / R$ (tương tự như công thức giá trị hiện tại của trái phiếu vô thời hạn), và khi đó thì $V$ đúng là tỷ lệ nghịch với mức lãi suất $R$.

Quay lại câu hỏi: $R$ bằng bao nhiêu? 
Nếu như dòng cổ tức của cổ phiếu cũng chắc chắn sẽ đều đặn ổn định như dòng tiền coupon của trái phiếu vô thời hạn, thì cổ phiếu lúc đó không có gì rủi ro hơn trái phiếu, và nếu như vậy thì đặt $R=R_{0}$ là hợp lý, trong đó $R_{0}$ là lợi suất của trái phiếu vô thời hạn không rủi ro. Ta sẽ nói ngắn gọn là $R_{0}=$ lợi suất không rủi ro. Thế nhưng, lợi nhuận của các công ty cổ phần thường không đều đặn, có rủi ro, và bởi vậy $R \neq R_{0}$. Sự chênh lệch $R-R_{0}$ có thể được gọi là phí mạo hiểm dành cho những nhà đầu tư cổ phiếu chấp nhận rủi ro về lợi nhuận. Bởi vậy ta có thể viết

$$
R=\text { lợi suất không rủi ro + phí mạo hiểm }
$$

Phí mạo hiểm này phụ thuộc vào "mức độ rủi ro" của công ty, và phụ thuộc vào thị trường (thị trường chấp nhận phí bao nhiêu cho mức rủi ro như vậy).

Một hệ quả của công thức trên là, nếu giả sử phí rủi ro là không đổi, khi đó mức lãi suất $R$ được thay đổi theo mức lợi suất không rủi ro $R_{0}$ : nếu $R_{0}$ giảm thì kéo theo $R$ giảm, và làm cho giá trị của cổ phiếu theo công thức $(5.2)$ tăng lên. Điều này giải thích một phần vì sao khi lãi suất của tiền trên thị trường giảm (ví dụ chính phủ tuyên bố giảm lãi suất), thì giá cổ phiếu thường tăng lên, và ngược lại, khi lãi suất của tiền gửi tăng lên thì thị trường cổ phiếu đi xuống.

Để ước lượng phí mạo hiểm $R-R_{0}$, ta có thể làm như sau: Nhân hai vế của công thức (5.2) với $(R-g) / V$, rồi cộng với $g$, ta có

$$
R=g+\frac{D_{1}}{V}
$$

Thế nhưng, $g+D_{1} / V$ chính là lợi suất của đầu tư cổ phiếu, gồm có 2 phần: $g$ là tốc độ tăng trưởng của giá cổ phiếu (khi công ty tăng trưởng với tốc độ trung bình là $g$, thì giá cổ phiếu của nó cũng có tốc độ tăng trung bình là $g$ ), và $D_{1} / V$ là lợi suất cổ tức trên giá trị thật (nếu giá thị trường bằng giá trị thật thì lợi suất cổ tức bằng số đó). Tức là ta được công thức ước lượng sau:

$$
R=\text { lợi suất trung bình của cổ phiếu }
$$

Công thức trên cho phép ước lượng $R$ và phí mạo hiểm $R-R_{0}$, dựa trên các số liệu về lợi suất do đầu tư cổ phiếu đem lại, và lãi suất trái phiếu dài hạn.

Vi du 5.3. Trên thị trường Mỹ, nếu tính trong suốt gần 140 năm kể từ năm 1871 đến năm 2009, lợi suất trung bình hàng năm của cổ phiếu (CAGR, cumulative annual growth rate, tức là tính theo trung bình nhân), có kể cả lợi tức và tăng giá, là gần $9 \% /$ năm. Nếu trừ đi lạm phát thì lợi suất trung bình thực sự hàng năm của cổ phiếu Mỹ là vào khoảng 
6.7\%, nhưng ở đây ta dùng mức lợi suất chưa trừ đi lạm phát. Như vậy, đối với các cổ phiếu Mỹ, ta có thể ước lượng $R=9 \%$. Vào đầu năm 2010, mức $R_{0}$ trên thị trường $\mathrm{Mỹ}$ vào khoảng $4 \%$, và như vậy phí mạo hiểm cho cổ phiếu là vào khoảng $9 \%-4 \%=5 \%$. (Các thông tin trên lấy từ internet). Như vậy, trên thị trường Mỹ, ta có thể coi là đối với một công ty trung bình, có mức mạo hiểm trung bình, thì cần lấy $R=9 \%$. Nếu mức mạo hiểm của công ty cao hơn trung bình (ví dụ như công ty dùng đòn bẩy tài chính cao, vay nợ quá nhiều) thì phải điều chỉnh số $R$ cao lên.

Vi du 5.4. Ở các thị trường mới nổi (emerging markets), thì mức lợi suất không rủi ro, và kỳ vọng về lợi suất cổ phiếu, thường cao hơn là ở các thị trường đã phát triển, và mức lạm phát cũng thường cao hơn. Ví dụ, ở Việt Nam vào năm 2010, có thể ước lượng là $R_{0}=12 \%, R=17 \%$, phí mạo hiểm cổ phiếu cũng khoảng $5 \%$. (Vì lạm phát ở Việt Nam cao, nên mức lợi suất kỳ vọng thực sự ở Việt Nam sau khi đã trừ đi lạm phát không còn cao hơn nhiều so với ở Mỹ).

Bài tập 5.1. Hãy tìm hiểu mức lợi suất trung bình của cổ phiếu, và mức lợi suất không rủi ro, ở các nước trên thế giới, ví dụ như Nhật Bản, Trung Quốc, Anh, Pháp, Brazil, v.v.

Công thức $V=\frac{D_{1}}{R-g}$ thích hợp cho việc ước lượng giá trị của các công ty cổ phần có thể gọi là đã truởng thành, tức là có lợi tức tương đối ổn định hàng năm, và đã hết giai đoạn phát triển nhanh, đang ở giai đoạn mà tốc độ phát triển chỉ còn nhỏ thôi. Các cổ phiếu của các công ty như vậy trên thị trường được gọi là các cổ phiếu giá trị (value stock). Đặc trưng của cổ phiếu giá trị, là có lợi suất cổ tức (dividend yield, bằng lợi tức một năm chia cho giá) lớn, và tốc độc tăng trưởng nhỏ.

Để sử dụng công thức $(5.2)$, ngoài việc xác định $R$, chúng ta còn cần ước lượng được lợi tức $D_{1}$ của năm tới, và tốc độ tăng trưởng dài hạn $g$ của công ty. Các phân tích viên (analysts) làm việc cho các công ty tài chính, chuyên phân tích về cổ phiếu, thường có ước lượng tốc độ tăng trưởng của các cổ phiếu mà họ theo dõi, cho 5 năm tới (chứ không cho dài hạn hơn), và các thông tin về cổ tức và tốc độ tăng trưởng kỳ vọng cho 5 năm tới, đối với các cổ phiếu lớn được nhiều phân tích viên theo dõi, có thể tìm được từ các nguồn tin tài chính phổ biến. Một công thức để ước lượng mức tăng trưởng dài hạn là:

$$
g=\frac{g(5 \text {-year })+\text { inflation }}{2}
$$

trong đó $g(5$-year) là mức tăng trưởng kỳ vọng cho 5 năm tới, và inflation là mức lạm phát kỳ vọng. (Hình dung là tốc độ tăng trưởng sẽ giảm dần cho đến lúc chỉ còn bằng tốc độ lạm phát). 
Theo công thức $(5.2)$ thì

$$
\frac{D_{1}}{V}=R-g
$$

tức là lợi tức chia cho giá trị bằng lợi suất cổ phiếu trừ đi tốc độ tăng trưởng. Hệ quả là ta có ước lượng sơ bộ sau để đánh giá xem giá thị trường đang rẻ hơn hay đắt hơn so với giá trị thật:

Nếu lợi suất cổ tức lớn hơn $R-g$ thì giá cổ phiếu rẻ hơn giá trị thật (undervalued), còn nếu lợi suất cổ tức nhỏ hơn $R-g$ thì cổ phiếu đắt hơn giá trị thật (overvalued).

Nhắc lại rằng đây chỉ là ước lượng sơ bộ, và chỉ hợp với các cổ phiếu giá trị (value stocks).

Vi du 5.5. Cổ phiếu của công ty hóa chất Dupont (một trong 30 thành phần của chỉ số Dow Jones, mã chứng khoán trên thị trường New York: DD) là một cổ phiếu giá trị, với lợi suất cổ tức $4.35 \%$, tốc độ tăng trưởng kỳ vọng $g=(8 \%+2 \%) / 2=5 \%$. (Số liệu lây từ trang web finance.yahoo.com, vào thời điểm 26/03/2010). Nếu lấy $R=9 \%$, thì ta có $R-g=4 \%<4.35 \%$, tức là theo các ước lượng này thì giá của DD hơi rẻ hơn so với giá thị thật.

Bài tập 5.2. Ước lượng giá trị thật của các cổ phiếu khác trong chỉ số Dow Jone: (2) theo các công thức trên, và so sánh chúng với giá thị trường. Trong trường hợp mà độ chênh lệch giữa giá trị ước lượng và giá thị trường quá cao, hãy thử tìm hiểu tại sao.

Ghi chú 5.2. Trong một số trường hợp, giá trị của một công ty nằm chủ yếu ở một vài tài sản chủ chốt của nó, ví dụ như một mỏ vàng, hay bản quyền của một loại thuốc chống ung thư. Bản thân các tài sản đó có giá trị rất lớn, nhưng vì chưa khai thác nên chưa có lợi nhuận trên sổ sách. Trong những trường hợp như vậy, việc ước lượng giá trị của công ty qua lợi nhuận hay tăng trưởng là không khả thi, mà chủ yếu là phải ước lượng được giá trị của các tài sản chính của công ty, qua dòng tiền tương lai mà các tài sản đó có thể đem lại. Việc định giá tài sản là một việc rất khó, đặc biệt đối với các tài sản vô hình (intangible), ví dụ như các sở hữu trí tuệ (intellectual properties).

\subsection{2 Ước lượng giá trị của cổ phiếu tăng trưởng}

Khái niệm cổ phiếu tăng trưởng (growth stock) là khái niệm đối ngược lại với cổ phiếu giá trị. Nó dùng để chỉ cổ phiếu của các công ty đang còn trong giai đoạn tăng

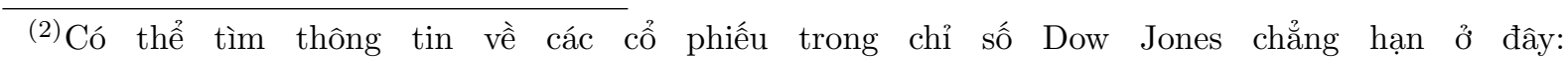
http://finance.yahoo.com/q/cp?s=^DJI 
trưởng nhanh về doanh thu và lợi nhuận. Nhanh ở đây được hiểu là tốc độ tăng trưởng cao hơn đáng kể so với mức lãi suất không rủi ro $R_{0}$ (bởi vì không có công ty nào có thể có mức tăng trưởng mãi mãi cao hơn mức lãi suất không rủi ro được), còn nếu thấp hơn $R_{0}$ thì coi là chậm, nếu thấp hơn mức lạm phát thì có nghĩa là không tăng trưởng mà co lại (tốc độ tăng trưởng thực sự, sau khi đã trừ đi lạm phát, là số âm). Cổ phiếu tăng trường thường được tìm thấy ở các ngành công nghiệp mới hình thành, các nền kinh tế mới nổi, hay các công ty có mức sáng tạo cao.

Đối với cổ phiếu tăng trưởng, công thức $(5.2)$ không dùng được vì bị sai số quá nhiều, và bởi vậy cần các cách ước lượng khác.

Hình dung 1 công ty đang trong giai đoạn tăng trưởng nhanh, với mức tăng trưởng lợi nhuận hiện tại là $g$. Để đơn giản, ta sẽ coi công ty đó sẽ tăng trưởng với tốc độ $g$ trong vòng $N$ năm nữa, rồi sau đó sẽ ngừng tăng trưởng, chỉ còn tăng lợi nhuận theo tốc độ lạm phát. Gọi lợi nhuận năm vừa qua là $E_{0}$. Khi đó lợi nhuận của $N$ năm sau sẽ là $(1+g)^{n} E_{0}$. Trong quá trình tăng trưởng nhanh, các công ty trả rất ít lợi tức, lợi nhuận chủ yếu giữ lại để tái đầu tư nhằm tăng trưởng. Nhưng khi ngừng tăng trưởng, thì có bao nhiêu lợi nhuận hàng năm sẽ trả hết cho cổ đông dưới dạng lợi tức. Như vậy ta sẽ coi rằng $N$ năm đầu tiên không có lợi tức: $D_{1}=\ldots=D_{N}=0$, và từ năm thứ $N+1$ thì lợi tức bằng lợi nhuận: $D_{N+n}=(1+g)^{N}(1+\Pi)^{n} E_{0}$ với mọi $n \geq 1$, trong đó $\Pi$ là tốc độ lạm phát. Áp dụng công thức dòng tiền chiết khấu cho dòng lợi tức này, ta được ước lượng sau về giá trị:

$$
V=\left(\frac{1+g}{1+R}\right)^{N} \frac{1+\Pi}{R-\Pi} E_{0} .
$$

(Nếu $N=0$ thì tức là không có năm nào tăng trưởng nhanh, mà chỉ tăng với tốc độ $\Pi$ là tốc độ lạm phát, và ta tìm lại được công thức ước lượng (5.2) ). Nếu có trả cổ tức trong $N$ năm đầu, thì phải điều chỉnh công thức ước lượng giá trị $V$ thành

$$
V=\left(\left(\frac{1+g}{1+R}\right)^{N} \frac{1+\Pi}{R-\Pi}+N p\right) E_{0}
$$

trong đó $p=D_{0} / E_{0}$ là tỷ lệ giữa cổ tức và lợi nhuận (payout ratio) trong những năm đầu.

Đối với các cổ phiếu phát triển, thì phần cổ tức $N p E_{0}$ trong $N$ năm đầu thường rất nhỏ so với phần chính $\left(\frac{1+g}{1+R}\right)^{N} \frac{1+\Pi}{R-\Pi} E_{0}$ trong công thức ước lượng giá trị, nên có thể bỏ qua mà không ảnh hưởng lắm đến ước lượng. Công thức 5.8 có thể được viết lại thành:

$$
V=M E_{1},
$$


với

$$
M=V / E_{1}=\left(\frac{1+g}{1+R}\right)^{N} \frac{1+\Pi}{(1+g)(R-\Pi)}
$$

được gọi là hệ số nhân giá trị (value multiple), để nếu biết lợi nhuận $E_{1}$ (cho năm tới) và biết hệ số nhân giá trị $M$ thì tính được giá trị của công ty.

Vi du 5.6. Hệ số nhân giá trị $M$ cho bởi công thức (5.11) rất nhạy theo các biến $g, N, R$ và $\Pi$. Một số ví dụ chứng tỏ độ nhạy này:

i) $M(g=20 \%, N=10, R=10 \%, \Pi=2 \%) \approx 25$

ii) $M(g=30 \%, N=10, R=10 \%, \Pi=2 \%) \approx 52$

iii) $M(g=20 \%, N=15, R=10 \%, \Pi=2 \%) \approx 39$

iv) $M(g=30 \%, N=10, R=15 \%, \Pi=7 \%) \approx 34$.

Như vậy, với giả sử $R=10 \%$ và $\Pi=2 \%$, nếu một công ty có thể tăng trưởng lợi nhuận $20 \%$ trong vòng 10 năm liền kể từ thời điểm hiện tại, thì giá trị của công ty có thể được đánh giá bằng quãng 25 lần lợi nhuận năm tới, hay nói cách khác, nếu chỉ số $\mathrm{P} / \mathrm{E}$ (price/earnings ratio, tức là giá chia cho lợi nhuận) của cổ phiếu của công ty bằng quãng 25 thì là "vừa phải", dưới đó thì là "rẻ" (undervalued) trên đó thì là "đắt" (overvalued). Nếu công ty tăng trưởng 30\%/năm trong vòng 10 năm, thay vì $20 \%$, thì giá trị của công ty sẽ bằng những 52 lần lợi nhuận! Nếu thay vì tăng trưởng $20 \%$ trong vòng 10 năm, công ty tăng trưởng $20 \%$ nhưng trong vòng 15 năm, thì giá trị sẽ nhảy lên từ 25 lần lợi nhuận thành 39 lần lợi nhuận. Nếu như công ty tăng trưởng được 30\%/năm trong vòng 10 năm, nhưng trong một môi trường với $R=15 \%$ và $\Pi=7 \%$, thì lúc đó giá trị của công ty chỉ còn là 34 lần lợi nhuận, thay vì 52 lần.

Chú ý rằng, chính vì hệ số nhân giá trị rất nhạy với các tham số, nên việc đánh giá giá trị của các cổ phiếu tăng trưởng rất khó chính xác, và hai đánh giá khác nhau có thể ra các con số chênh nhau đến vài lần.

Ghi chú 5.3. Mức tăng trưởng chúng ta bàn đến phía trên là mức tăng trưởng trên đầu một cổ phiếu. Nếu công ty tăng trưởng lợi nhuận bằng cách đi mua các công ty khác bằng cổ phiếu của mình, phình ra bằng cách tăng số cổ phiếu lên, thì có thể là lợi nhuận tính trên đầu cổ một phiếu không tăng. Việc đánh giá mức tăng trưởng trong tương lai là một việc khó, đòi hỏi có những phân tích vĩ mô (ví dụ về tỷ trọng của toàn bộ mảng thị trường mà công ty tham gia trong nền kinh tế, và mức tăng trưởng của mảng đó), và phân tích về vị thế cạnh tranh của công ty. Các đánh giá của các phân tích viên có những khi quá lạc quan, nếu nhìn từ quan điểm vĩ mô. Ví dụ như ở Mỹ, có lúc công ty thực phẩm nào cũng được đánh giá có tốc độ tăng trưởng cao đến gấp 2 lần tốc độ tăng 
trưởng của toàn bộ thị trường thực phẩm, và như thế thì không thể đúng được, vì tốc độ tăng trưởng doanh thu trung bình của các công ty thực phẩm không vượt quá được tốc độc tăng trưởng của toàn bộ thị trường thực phẩm.

Ghi chú 5.4. Lợi nhuận mà chúng ta nói đến trong các ước lượng giá trị là lợi nhuận thực sự, và trong nhiều trường hợp nó rất khác lợi nhuận công bố trong báo cáo tài chính, do vấn đề là các tài sản của công ty được đánh giá trong các báo cáo tài chính nhiều khi rất sai giá trị thật. Một mặt, có những tài sản có giá trị lớn nhưng không thể hiện trong báo cáo. Ví dụ có những bản quyền phát minh có giá trị hàng trăm triệu USD, nhưng trong báo cáo tài chính thì giá trị của nó bằng 0 . Công ty có thể công bố tài chính là lỗ, mà công bố như vậy là đúng theo các luật qui định, trong khi thực ra giá trị của công ty tăng lên. Mặt khác, có những "bong bóng" trong các báo cáo tài chính, có giá trị thực sự rất thấp so với giá trị được ghi. Một ví dụ điển hình là WorldCom, một công ty điện thoại lớn với hơn 80 nghìn nhân viên và vốn hóa trên 100 tỷ USD vào năm 2000, nhưng đến năm 2002 thì phá sản, vì toàn "lợi nhuận ảo" (do thổi phình tài sản) trong khi nợ chồng chất. Bởi vậy, để có thể ước lượng đúng giá trị của một công ty cổ phần, cần tìm được các con số phản ảnh đúng giá trị thực sự các tài sản của nó, chứ không chỉ đơn thuần nhìn vào các báo cáo tài chính.

Bài tập 5.3. Ước lượng hệ số nhân giá trị trong các trường hợp sau:

i) $g=40 \%, N=15, R=10 \%, \Pi=2 \%$.

i) $g=50 \%, N=10, R=13 \%, \Pi=4 \%$.

i) $g=15 \%, N=12, R=10 \%, \Pi=2 \%$.

Bài tập 5.4. Ước lượng giá trị của một số cổ phiếu lớn ở Việt Nam như VCB, SBT, FPT, VNM, v.v. (Thông tin tài chính của chúng có thể tìm được trên internet).

\subsection{Các lực tác động đến giá cổ phiếu}

Cổ phiếu cũng là một mặt hàng, và như vậy giá của nó cũng tuân theo qui luật cung cầu của thị trường. Mỗi khi có người đặt mua cổ phiếu, thì điều đó tạo một lực đẩy giá cổ phiếu đi lên. Ngược lại, mỗi khi có người đặt bán cổ phiếu, thì điều đó tạo một lực đẩy giá cổ phiếu đi xuống. Nếu như lực đẩy lên trung hòa với lực đẩy xuống, tức là số cổ phiếu muốn mua cân bằng với số cổ phiếu muốn bán, thì giá của cổ phiếu sẽ không thay đổi. Nhưng ít khi có sự cân bằng hoàn hảo. Vào một thời điểm bất kỳ, thường có sự chênh lệch về bên này hoặc bên kia giữa số cổ phiếu muốn mua và số cổ phiếu muốn bán 
(ở mức giá hiện tại), và trong một ngày sự chênh lệch này có thể đảo chiều rất nhiều lần. Bởi vậy chúng ta thường thấy giá cổ phiếu thay đổi một cách liên tục, có khi đảo chiều nhiều lần trong một ngày. Các chứng khoán khác cũng vậy.

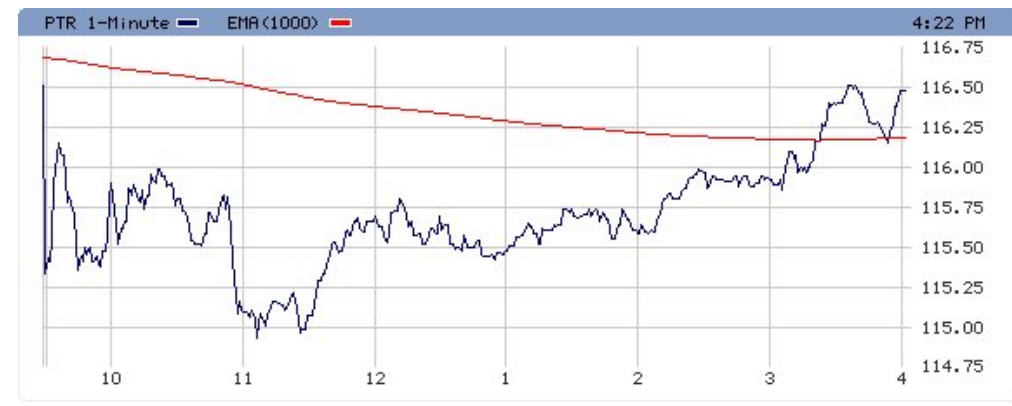

Hình 5.3: Giá cổ phiếu của PetroChina ngày 23/03/2010

Hình 5.3 là một ví dụ về sự giao động trong ngày của giá cổ phiếu trên sàn chứng khoán. Đấy là cổ phiếu của PetroChina (Dầu khí Trung Quốc, có vốn hóa trên 200 tỷ USD) trên sàn chứng khoán New York (NYSE) trong ngày 23/03/2010.

Do giá cổ phiểu chuyển động theo qui luật cung cầu, nên các lực làm thay đổi giá cổ phiếu chính là các lực, hay các "năng lượng" làm ảnh hưởng đến cung cầu của cổ phiếu. Nói theo ngôn ngữ vật lý, thì lực chuyển động là do năng lượng tạo ra, và khi ta xác định được hàm năng lượng của một hệ vật lý thì viết được phương trình chuyển động của nó. Để hiểu được và dự đoán được, theo nghĩa nào đó, chuyển động của giá cổ phiếu, chúng ta cần nhận biết và phân tích được những năng lượng này.

Trong vật lý, khi đã tìm được các lực tác động đến một vật nào đó, người ta có thể viết phương trình chuyển động của nó, dưới dạng phương trình sai phân (nếu xét các bước thời gian rời rạc) hoặc phương tình vi phân (thời gian liên tục). Trong ngôn ngữ toán học, các phương trình sai phân và vi phân được gọi là các hệ động lực. Việc nghiên cứu một hệ động lực không chỉ đơn thuần là giải phương trình sai phân hay vi phân tương ứng để tìm nghiệm, mà còn là việc nghiên cứu các tính chất của các nghiệm, ví dụ như là dáng điệu, tính ổn định, các miền đặc biệt, v.v. Tương tự như vậy, ta cũng có thể lập các mô hình hệ động lực để nghiên cứu sự biến động của giá cổ phiếu, và đưa vào đó các lực mà ta xác định được.

Như ta sẽ thấy, vì chuyển động của giá cổ phiếu có tính ngẫu nhiên, nên các hệ động lực mà chúng ta cần xét đến cũng là các hệ động lực ngẫu nhiên (stochastic dynamical systems), trong đó có cả các thành phần định tính và các thành phần ngẫu nhiên. Nghiệm của các hệ động lực ngẫu nhiên không phải là các quỹ đạo theo nghĩa thông thường, mà 
là các quỹ đạo ngẫu nhiên, hay còn gọi là các quá trình ngẫu nhiên. Chúng ta sẽ thảo luận lý thuyết toán học của các quá trình ngẫu nhiên trong Chương 7 .

\subsubsection{Chênh lệch giữa giá thị trường và giá trị thật}

Một trong các năng lượng quan trọng nhất ảnh hưởng đến cung cầu, và do đó đến giá cổ phiếu, chính là thế năng, tạo ra bởi sự chênh lệch giữa giá cổ phiếu và giá trị thật của nó.

Khi giá thị trường quá thấp so với giá trị thực, thì đến một lúc nào đó các nhà đầu tư đang giữ cổ phiếu sẽ không chấp nhận bán với giá thấp như vậy nữa, trong khi có những nhà đầu tư khác muốn mua cổ phiếu, khiến cho cầu nhiều hơn cung, đẩy giá lên về phía giá trị thực. Ngược lại, nếu giá cổ phiếu quá cao so với giá trị thực, thì đến một lúc nào đó các nhà đầu tư mới sẽ không muốn mua cổ phiếu này nữa vì thấy nó đã quá đắt, trong khi những nhà đầu tư đang giữ cổ phiếu thì muốn bán đi để hưởng lợi nhuận thu được từ giá cao này, khiến cho cung nhiều hơn cầu, và làm giá cổ phiếu đi xuống về phía giá trị thực. Như vậy, giá trị thực như là "điểm cân bằng" tạo lực kéo giá thị trường về phía nó. Điều này tương tự vị trí cân bằng của quả lắc hay của lò xo: nếu quả lắc hay lò xo nằm chệch vị trí cân bằng, thì nó có thế năng cao lên tạo ra lực đẩy nó ngược lại về vị trí cân bằng.

Chú ý rằng, khi giá cổ phiếu chênh lệch lớn so với giá trị thật, thì không phải là nó sẽ quay về giá trị thực ngay lập tức, mà có thể đòi hỏi thời gian rất dài, có khi là nhiều năm. Nói cách khác, ảnh hưởng của thế năng đến giá cổ phiếu là ảnh hưởng về lâu dài; cường độ của nó tại mỗi thời điểm có thể không lớn.

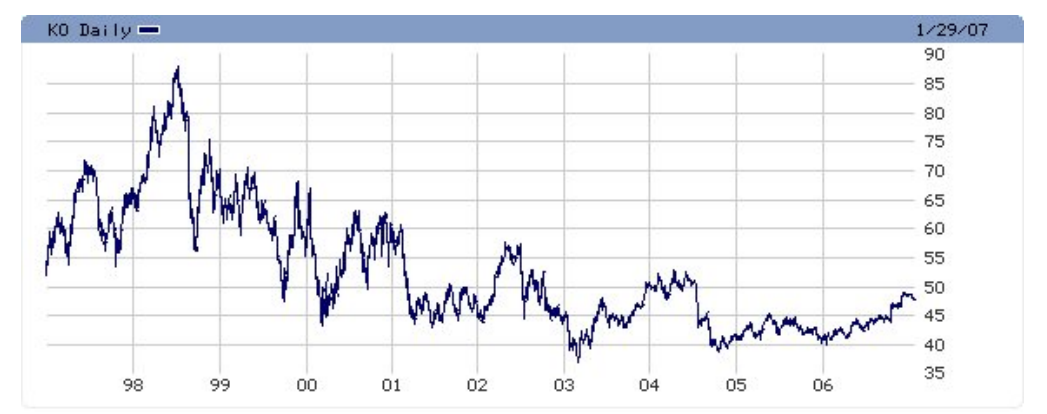

Hình 5.4: Giá cổ phiếu của Coca-Cola trong 10 năm 1997-2006

Vi du 5.7. Công ty nước giải khát Coca-Cola (mã chứng khoán: KO) vào thời điểm đầu năm 1998 là một trong những "con cưng” của thị trường chứng khoán Mỹ, và có giá lên 
đến trên 80\$/cổ phiếu. Một trong những lý do là trong hai thập kỷ 1980 và 1990 nó phát triển khá nhanh, bành trướng ra thế giới, cùng với sự toàn cầu hóa nền kinh tế, và nó được tỷ phú Buffet, thần tượng của thị trường chứng khoán, đầu tư (từ khi giá nó còn rất rẻ). Nhưng đến đầu năm 1998 thì Coca-Cola đã hết giai đoạn tăng trưởng nhanh (vì nó đã quá to, các thị trường cũ đã bão hòa, các thị trường mới và quan trọng như Trung Quốc đã thâm nhập rồi, không còn chỗ để phát triển nhanh nữa), tốc độ chậm lại chỉ còn trung bình dưới 5\%/năm. Nhưng vì "vị trí con cưng" của nó trên thị trường chứng khoán, và một phần là do thị trường lúc đó đang "nóng", nên nó vẫn có giá rất cao, với chỉ số $\mathrm{P} / \mathrm{E}$ (giá chia cho lợi nhuận một năm) trên 40. Theo các ước lượng về giá trị thực tế của $\mathrm{KO}$ vào thời điểm lúc đó, thì mức $\mathrm{V} / \mathrm{E}$ (giá trị chia cho lợi nhuận) của $\mathrm{KO}$ không thể quá 20, tức là giá của $\mathrm{KO}$ đắt hơn gấp đôi giá trị thực vào thời điểm đầu năm 1998 . Sự chênh lệch lớn này giữa giá thị trường và giá trị thật của $\mathrm{KO}$ tạo lực đẩy giá $\mathrm{KO}$ đi xuống. Thực tế xảy ra là, trong vòng 5 năm sau đó, giá của $\mathrm{KO}$ giảm một nửa còn $40 \$$ vào đầu năm 2003, và trong vòng 7 năm tiếp theo (cho đến đầu năm 2010) giao động trong quãng 40-60\$.

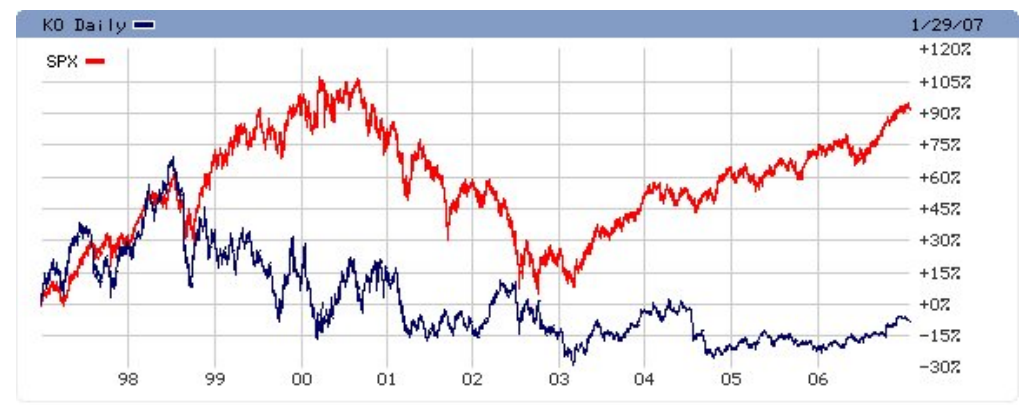

Hình 5.5: So sánh giữa giá cổ phiếu Coca-Cola và chỉ số SP500, 1997-2006

Phần lớn các nhà đầu cơ (mua đi bán lại chứng khoán trong thời gian ngắn hạn) ít để ý đến thế năng do chênh lệch giữa giá thị trường và giá trị thực tạo ra, mà chủ yếu quan tâm đến các lực thị trường khác, như là tâm lý thị trường, mà chúng ta sẽ bàn đến phía dưới. Nhưng đối với các nhà đầu tư dài hạn, thì thế năng này là yếu tố rất quan trọng cần xét đến. Xem, chẳng hạn, hai quyển sách của Greenblat [11, 12], về chiến lược đầu tư lâu dài, đơn giản và hiệu quả, dựa trên việc chọn lựa các cổ phiếu của các doanh nghiệp tương đối tốt (ít khả năng phá sản) và đang có giá thị trường thấp hơn giá trị thực. Trong ngôn ngữ đầu tư, việc phân tích giá trị của cổ phiếu và so sánh giữa giá trị thực và giá thị thường được gọi là phân tích cơ bản (fundamental analysis). 


\subsubsection{Tâm lý thị trường}

Yếu tố rất quan trọng khác ảnh hưởng đến cung cầu là tâm lý thị trường, tức là tâm lý chung của các nhà đầu tư tham gia thị trường. Nói theo ngôn ngữ vật lý, tâm lý thị trường có thể được coi như động năng của thị trường. Động năng là do bản thân chuyển động tạo ra, và tạo nên quán tính của chuyển động.

Khi các nhà đầu tư lạc quan về giá cổ phiếu, thì sẽ muốn mua vào, đẩy giá đi lên, và khi họ bi quan thì không muốn mua vào mà muốn bán ra, đẩy giá đi xuống. Bản thân việc giá cổ phiếu đi lên có thể khiến cho các nhà đầu tư trở nên lạc quan và khiến cho thị trường có đà tiếp tục đi lên. Ngược lại bản thân việc giá cổ phiếu đi xuống sẽ gây bi quan và khiến cho thị trường tiếp tục đi xuống. Hiện tượng này tạo quán tính thị trường, và có thể được giải thích một phần bởi tâm lý bầy đàn của con người. Ví dụ, ở Việt Nam, trong năm 2007, có rất nhiều nhà đầu tư mới tham gia thị trường cổ phiếu, mua cổ phiếu chỉ vì họ nghe nói là cổ phiếu đi lên, có những người giàu lên nhờ cổ phiếu, và họ cũng muốn bắt chước vậy, chứ thậm chí có khi không biết là mình mua cổ phiếu gì.

Do tâm lý thị trường, nên có nhiều khi mà giá cổ phiếu đã lên rất cao so với giá trị thật, nhưng vẫn còn lên tiếp, bởi vẫn có nhiều người mua vào ít người bán ra. Hiện tượng này gọi là thị trường bong bóng (market bubble) hay thị trường điên cuồng (market mania). Bong bóng thị trường là một "cơ chế" khiến cho nhiều người giầu lên nhanh (những người tham gia bong bóng trong giai đoạn phình lên của nó) và nhiều người khác nghèo đi nhanh (những người bị "mắc" vào bong bóng lúc nó xịt hoặc nổ), và có thể tạo những khủng hoảng về kinh tế xã hội. Các bong bóng có thể được giải thích bằng tâm lý bầy đàn cộng với lý thuyết kẻ ngốc hơn (greater fool theory): kể cả khi người ta biết rằng mua một cổ phiếu nào đó vào với giá quá cao là ngốc, nhưng người ta vẫn mua vào nếu như người ta nghĩ rằng sẽ còn có kẻ khác ngốc hơn sẽ mua lại cổ phiếu đó với giá còn cao hơn nữa.

Trong lịch sử thị trường chứng khoán thế giới có nhiều ví dụ về bong bóng. Nổi tiếng nhất có lẽ là tulipomania (điên cuồng hoa tulip) xảy ra ở Hà Lan vào đầu thế kỷ 17, khi mà, vào đỉnh cao của nó, một củ hoa tulip có giá bằng đến 10 năm lương của một thợ lành nghề ${ }^{(3)}$. Một ví dụ tương đối mới là bong bóng internet (dot com bubble) vào quãng năm 2000. Trong giai đoạn đó, internet trở thành đề tài "nóng", và rất nhiều công ty liên quan đến internet (như là máy móc cho mạng internet, dịch vụ truy cập internet, dịch vụ thông tin internet, bán hàng trên internet) có giá cổ phiếu tăng lên chóng mặt, kể cả khi

${ }^{(3)}$ Xem: http://en.wikipedia.org/wiki/Tulip_mania 
mà triển vọng lợi nhuận rất mơ hồ (nhiều công ty phá sản trong mấy năm sau đó), để rồi sau đó lại giảm xuống chỉ còn quãng một vài phần trăm so với lúc đỉnh điểm(4).

Trong ngôn ngữ đầu tư, việc phân tích tâm lý và động năng của thị trường cổ phiếu, dựa trên các thông tin về biến động giá cả, lượng giao dịch và các yếu tố thị trường khác đã xảy ra trong quá khứ (gọi chung là các chuỗi thời gian về thị trường), được gọi là phân tích kỹ thuật (technical analysis). Có rất nhiều sách về phân tích kỹ thuật, mà bạn đọc quan tâm có thể tìm đọc. Xem chẳng hạn [23]. Tuy nhiên, cần chú ý rằng, nhiều điều viết trong các sách đó là dựa trên kinh nghiệm nhận dạng (pattern recognition), nhưng thiếu cơ sở lý luận khoa học vì sao nó như vậy, và thiếu kiểm chứng chặt chẽ. Phân tích kỹ thuật khó hơn là nhiều người tưởng (các bình luận viên về thị trường trên tivi phân tích rất hay sai!), và nó cũng chỉ cho thông tin nhất định về một số lực tác động đến thị trường, chứ không phải là cho dự đoán chính xác về chuyển động của thị trường.

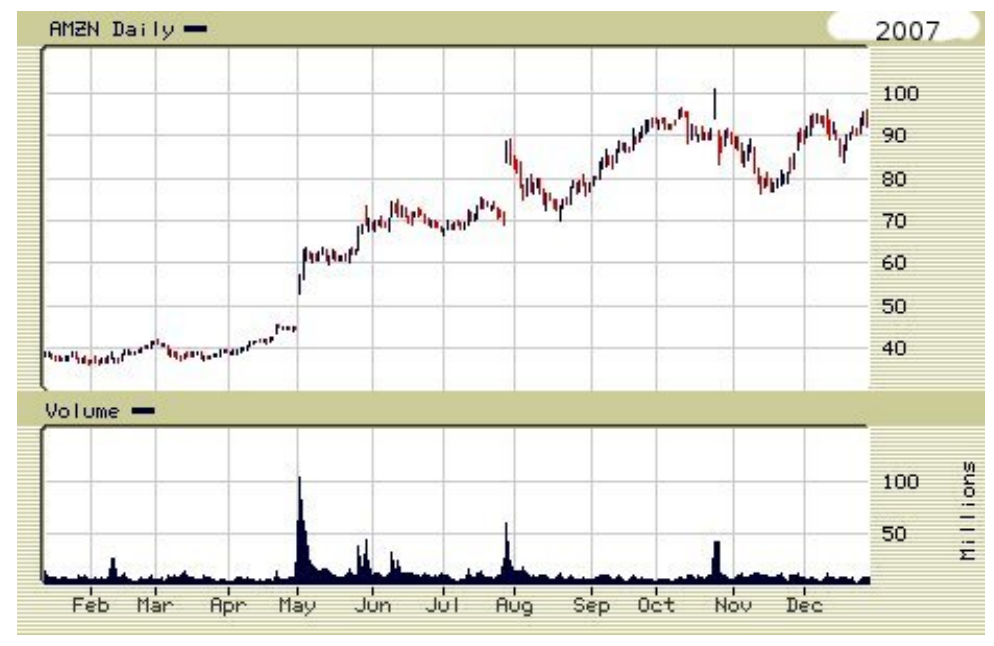

Hình 5.6: Đồ thị cổ phiếu Amazon.com năm 2007

Vi du 5.8. Hình 5.6 là đồ thị cổ phiếu của Amazon.com, một công ty bán lẻ lớn trên internet, vào năm 2007. Vào ngày 25/04/2007, sau một tin tốt về tình hình làm ăn của công ty, giá cổ phiếu AMZN tăng hơn $20 \%$ so với hôm trước (từ $44.75 \$$ lên $56.81 \$$ ), với lượng giao dịch là hơn 100 triệu cổ phiếu trong ngày đó, nhiều gấp hơn 10 lần lượng giao dịch trung bình. Sau hôm đó, thị trường trở nên lạc quan về công ty, và giá cổ phiếu sẽ còn tiếp tục tăng trong mấy tháng tiếp theo. Đây là một dạng thức (pattern) kiểu "tên lưa" hay xảy ra: khi giá cổ phiếu của một công ty lớn bật mạnh lên, kèm với lượng giao dịch rất lớn, thì là dấu hiệu tâm lý thị trường lạc quan về cổ phiếu, tạo đà tiếp tục đi lên

${ }^{(4)}$ Xem: http://en.wikipedia.org/wiki/Dot-com_bubble 
sau đó.

\subsubsection{Các ngoại lực}

Hiện tượng mất cân đối cung cầu cổ phiếu xảy ra không chỉ do những tác động bản thân bên trong của thị trường, mà còn do những tác động từ bên ngoài. Ví dụ, có khi có những nhà đầu tư lớn gặp khó khăn về tài chính, buộc phải phải bán ra những cổ phiếu mà họ đang giữ dù họ cho rằng các cổ phiếu này đang có giá thấp so với giá trị thực, khiến cho giá cổ phiếu sẽ bị giảm xuống, cho đến khi thị trường "tìm được" những nhà đầu tư mới để thay thế.

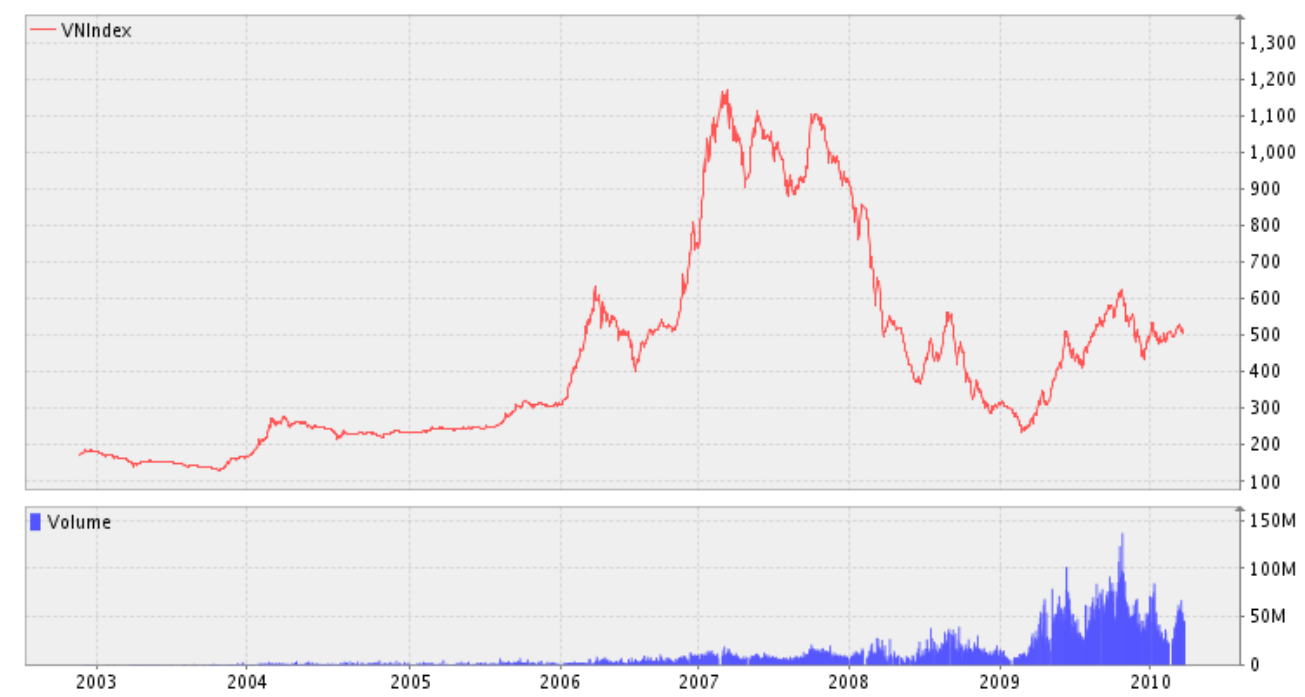

Hình 5.7: Đồ thị VnIndex

Vi du 5.9. Chỉ số VnIndex của thị trường cổ phiếu Việt Nam giảm từ 500 điểm xuống còn 240 điểm trong giai đoạn hè 2008 - xuân 2009, trước khi phục hồi lại, một phần là do có nhiều nhà đầu tư, trong đó có nhà đầu tư nước ngoài, rút ra khỏi thị trường, do ảnh hưởng của khủng hoảng tài chính thế giới.

Các ngoại lực cũng có thể tác động không phải là trực tiếp đến cung cầu của thị trường, mà là gián tiếp, qua việc làm thay đổi "năng lượng bên trong" của thị trường. Ví dụ như, nếu có ngoại lực làm cho giá trị thực của một cổ phiếu đi lên, thì điều đó làm thay đổi thế năng, kéo giá cổ phiếu lên theo.

Ghi chú 5.5. Ngoại lực là một khái niệm tương đối: một lực có thể là ngoại lực đối với một hệ này, nhưng sẽ trở thành nội lực nếu ta xét một hệ khác lớn hơn, chứa hệ ban đầu 
và cả các yếu tố tạo ra ngoại lực đó. Một hệ động lực mà "nhỏ" (tức là có ít thành phần, số chiều thấp) thì về nguyên tắc dễ nghiên cứu hơn một hệ động lực lớn (nhiều thành phần, phức tạp). Nhưng bù lại, một hệ lớn mà các lực trong đó chủ yếu là nội lực, viết ra được như là hàm số của các biến của bản thân hệ, thì có thể tính toán được chính xác hơn, so với nếu có nhiều ngoại lực mà ta không biểu diễn được cụ thể.

\subsubsection{Phạm vi ảnh hưởng của các lực}

Như chúng ta thấy phía trên, các lực tác động làm thay đổi giá của một cổ phiếu có thể chia làm hai nhóm chính: nhóm "cơ bản", "thế năng" (lực tác động đến giá trị thật của cổ phiếu, và lực tạo ra bởi sự chênh lệch giữa giá trị thật và giá thị trường), và nhóm "kỹ thuật", "động năng" (tâm lý thị trường, do bản thân diễn biến thị trường chứng khoán tạo nên). Chúng ta cũng có thể phân loại các lực theo phạm vi ảnh hưởng của nó. Chẳng hạn có thể chia làm 3 loại: 1) loại ảnh hưởng đến toàn thị trường, 2) loại ảnh hưởng đến một ngành (hay một vùng địa lý), và 3) loại ảnh hưởng riêng đến một mình công ty.

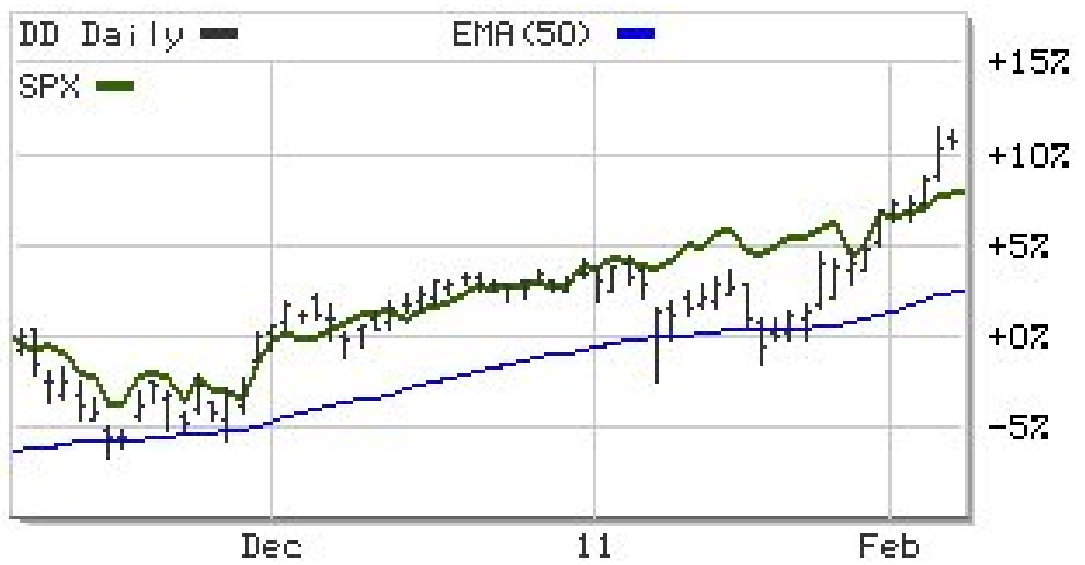

Hình 5.8: Cổ phiếu DD đi theo chỉ số S\&P500, 11/2010-02/2011

Những lực tác động chung đến toàn thị trường là những lực có tính vĩ mô, ví dụ như sự thay đổi của lãi suất, hay của tốc độ tăng trưởng kinh tế, v.v.. Khi lãi suất giảm đi, thì giá trị của trái phiếu và cổ phiếu đều tăng lên, theo công thức ước lượng giá trị, và bởi vậy nó tạo lực kích thích toàn bộ thị trường chứng khoán tăng giá. Khi thị trường chung đi lên, thì phần lớn các nhà đầu tư "phấn chấn" và dễ chấp nhận mua các cổ phiếu với giá cao hơn, và tạo "hiệu ứng lan tỏa" từ thị trường chung đến toàn bộ các cổ phiếu. Một lý do nữa khiến cho có những lực chung tác động đến giá của toàn bộ các cổ phiếu trên một thị trường là, có những quỹ đầu tư theo chỉ số (index funds, ví dụ như SPY đầu 
tư theo chỉ số SP500), khi quỹ mua vào thì là mua đồng loạt các cổ phiếu có trong chỉ số, và khi bán ra cũng bán đồng loại các cổ phiếu, làm cho các cổ phiếu đó tăng giá hay giảm giá cùng nhau. Các quỹ chỉ số ngày nay rất phổ biến trên thế giới. Riêng quỹ SPY đã có tài sản trên 75 tỷ USD vào đầu năm 2011, và mỗi ngày lượng giao dịch cổ phiếu của quỹ này lên đến hơn 18 tỷ USD. Hình 5.8 là một ví dụ về ảnh hưởng của thị trường chung đến cổ phiếu riêng lẻ: trong 3 tháng 11/2010 - 02/2011, hầu như cứ hôm này mà chỉ số SP500 đi lên thì cổ phiếu của công ty hóa chất Dupont (là công ty hóa chất lớn nhất thế giới, mã chứng khoán: DD) đi lên, còn hôm nào mà chỉ số S\&P500 đi xuống thì DD cũng đi xuống.

Có những lực không ảnh hưởng chung đến toàn thị trường, mà chỉ ảnh hưởng riêng đến một ngành nào đó. Ví dụ, khi ngành sản xuất ô tô bị khủng hoảng thừa, thì điều này xấu cho ngành ô tô nhưng không ảnh hưởng nhiều đến thị trường chung. Vào ngày 28/01/2011, tin xấu từ hãng Ford Motor báo hiệu điềm xấu chung cho toàn ngành sản xuất ô tô, khiến cổ phiếu của các hãng sản xuất ô tô đều giảm mạnh, trong đó Ford (mã chứng khoán: F) giảm 13\% và General Motors (mã chứng khoán: GM) giảm 6\%. Thị trường chung hôm đó cũng giảm, nhưng chỉ ở mức 1,5\%.

Có những lực tác động chỉ ảnh hưởng đến một cổ phiếu, hay là một nhóm rất nhỏ các cổ phiếu. Ví dụ, khi một công ty bị phát hiện là gian lận sổ sách tài chính, thì giá cổ phiếu của nó có thể bị giảm rất nhiều ngay sau đó, nhưng điều này không ảnh hưởng gì mấy đến thị trường chung.

\subsubsection{Các lực ngẫu nhiên}

Có nhiều lực, mà chúng ta không có cách xác định trước được, sẽ tác động đến thị trường trong tương lai. Các lực như vậy có thể được gọi là các lực ngẫu nhiên. Bởi vì giá cổ phiếu chịu ảnh hưởng của các lực ngẫu nhiên, nên bản thân sự thay đổi của giá cố phiếu theo thời gian có tính ngẫu nhiên, không thể xác định trước được một cách chính xác.

Có thể kiểm chứng tính ngẫu nhiên (không xác định trước được) của giá cổ phiếu trong tương lai. Thật vậy, giả sử một chứng khoán $\mathrm{S}$ có giá hiện tại trên thị trường là $S(0)>0$ đã biết, và giả sử là giá thị trường $S(t)$ của $\mathrm{S}$ cho thời điểm $t$ cũng đã được thị trường biết trước vào thời điểm hiện tại. Khi đó, theo nguyên lý no-arbitrage, $S(t)$ phải thỏa mãn đẳng thức

$$
S(t)=S(0) e^{t r}
$$


trong đó $r$ là lãi suất kép liên tục không rủi ro (lợi suất log của trái phiếu zero-coupon còn kỳ hạn $t$ ), bởi vì nếu không thì sẽ có một chiến lược kinh doanh chênh lệch giá, bằng cách mua $\mathrm{S}$ và bán trái phiếu zero-coupon thời hạn $t$ tại thời điểm 0 rồi bán $\mathrm{S}$ và thanh toán trái phiếu tại thời điểm $t$, hoặc ngược lại. Nói cách khác, nếu một chứng khoán có mức độ lợi nhuận đã được xác định và được thị trường biết trước cho một giai đoạn nào đó, thì mức độ lợi nhuận đó phải bằng đúng mức lợi nhuận không rủi ro (của trái phiếu zero-coupon không rủi ro), vì nếu không thì sẽ có cơ hội kinh doanh chênh lệch giá. Trong thực tế, rất hiếm khi mà cổ phiếu lại đem lại mức lợi nhuận giống trái phiếu, và đó là dấu hiệu cho thấy tính ngẫu nhiên của biến động của giá cổ phiếu.

Từ năm 1900, trong luận án tiến sĩ của mình, nhà toán học Luis Bachelier (5) (18701946) đã nghiên cứu biến động giá cổ phiếu, và các công thức định giá quyền chọn của cổ phiếu, dựa trên chuyển động ngẫu nhiên. Trong nửa sau thế kỷ 20, có những nhà kinh tế còn đi xa hơn nữa trong việc nhận định sự ngẫu nhiên này của giá cổ phiếu. Họ coi rằng sự thay đổi giá cổ phiếu trong tương lai là một chuyển động hoàn toàn ngẫu nhiên, không hề có một xu hướng nào hết, ngoài tốc độ tăng trưởng trung bình hàng năm của toàn bộ thị trường cổ phiếu. Cuốn sách $A$ random walk down Wall Street (xuất bản lần đầu năm 1973, tái bản nhiều lần) của Burton Malkie ${ }^{(6)}$ góp phần truyền bá tư tưởng chuyển động hoàn toàn ngẫu nhiên này, và có ảnh hưởng lớn đến giới tài chính.

Lý thuyết chuyển động hoàn toàn ngẫu nhiên của giá cổ phiếu xuất phát từ cái gọi là giả thuyết thị trường hiệu quả (efficient market hypothesi: $(7)$ ), được một số nhà kinh tế như Eugene Famą (8) đề xướng từ những năm 1960. Theo giả thuyết thị trường hiệu quả, thì mọi thông tin gì có thể có ảnh hưởng đến giá cổ phiếu mà thị trường được biết thì đều được "tính" vào giá của cổ phiếu ngay lập tức, và do đó mọi chuyển động giá cổ phiếu trong tương lai là do những tin tức hoàn toàn mới mang lại chứ không phải do tin tức cũ mang lại (vì ảnh hưởng của các tin cũ đã được thể hiện hết trong giá cổ phiếu rồi). Vì các tin mới xảy ra một cách hoàn toàn ngẫu nhiên, không ai dự đoán được trước nó sẽ tốt xấu ra sao, nên khi thị trường hiệu quả, thì chuyển động của giá cổ phiếu là hoàn toàn ngẫu nhiên.

Nếu như biến đổi giá cả của cổ phiếu là hoàn toàn ngẫu nhiên, không hề có xu hướng nào hết, thì tất cả mọi phân tích về cổ phiếu, kể cả phân tích cơ bản và phân tích kỹ

\footnotetext{
${ }^{(5)}$ Bachelier được coi là người đầu tiên nghiên cứu các tính chất toán học của quá trình ngẫu nhiên mà ngày nay người ta gọi là chuyển động Brown

${ }^{(6)}$ Xem: http://en.wikipedia.org/wiki/Burton_Malkiel

(7)Xem: http://en.wikipedia.org/wiki/Efficient-market_hypothesis

${ }^{(8)}$ Xem: http://en.wikipedia.org/wiki/Eugene_Fama
} 
thuật, đều tốn công vô ích cho việc đầu tư cổ phiếu, bởi vì các phân tích đó đều nhằm dẫn đến kết luận về một xu hướng nào đó của cổ phiếu, trong khi mà chuyển động của cổ phiếu hoàn toàn ngẫu nhiên không hề có xu hướng nào hết!

Giả thuyết thị trường hiệu quả, và tính hoàn toàn ngẫu nhiên của biến động giá cổ phiếu, được nhiều nhà kinh tế chấp nhận như là chân lý trong mấy thập kỷ sau khi chúng xuất hiện. Tuy nhiên, thực tế cho thấy, thị trường không hoàn toàn ngẫu nhiên. Một số phân tích chứng tỏ các yếu tố không ngẫu nhiên của thị trường được hai nhà kinh tế Andrew Lo và Craig MacKinlay trình bày trong cuốn sách A non-random walk down Wall Street (xuất bản lần đầu năm 1999). Bản thân ông Eugene Fama trong những năm về sau cũng phải thừa nhận rằng "thị trường không hiệu quả". Nói chính xác hơn là, thị trường không hiệu quả theo nghĩa của Fama, chứ nguyên lý no-arbitrage nói chung vẫn dùng được. Những nhà đầu tư rất thành công như Warren Buffet (tỷ phú giàu nhất thế giới vào năm 2008 với tài sản riêng 62 tỷ USD, đầu tư dựa trên phân tích cơ bản) hay James Simon: ${ }^{(9)}$ (nhà toán học trở thành tỷ phú, sử dụng các công cụ toán học để tìm xu hướng thị trường) cũng là những ví dụ chứng tỏ thị trường biến động một cách không hoàn toàn ngẫu nhiên, mà có nhiều yếu tố định tính. Bởi vậy, một mô hình động lực về sự biến đổi giá cổ phiếu, muốn sát với thực tế, cần có cả những lực ngẫu nhiên và những lực định tính. Khi nào mà lực định tính yếu và lực ngẫu nhiên mạnh, thì dáng điệu của thị trường sẽ gần như là chuyển động ngẫu nhiên hoàn toàn, nhưng ngược lại những khi nào mà lực định tính mạnh, thì thị trường sẽ có thể có xu hướng rõ ràng. Một lực ngẫu nhiên, sau khi đã xảy ra, thì trở thành định tính, và có thể có ảnh hưởng lâu dài đến thị trường chứ không chỉ ảnh hưởng trong một khoảnh khắc mà nó xảy ra.

Ghi chú 5.6. Về mặt lý thuyết, điều khiến cho giả thuyết thị trường hiệu quả không đúng được nằm ở chỗ nó bỏ qua yếu tố thời gian, và coi là "cái gì phải xảy ra thì sẽ xảy ra ngay" (thông tin ảnh hưởng đến cổ phiếu thì sẽ được tính hết vào giá cổ phiếu ngay). Thế nhưng, trong thế giới vật lý của chúng ta, mọi sự đều cần có thời gian để xảy ra, và thời gian đó có thể là rất dài. Ví dụ, vào năm 1944, sự thua trận của Đức quốc xã trong chiến tranh thế giới lần thứ II đã trở nên rõ ràng, nhưng chiến tranh còn kéo dài thêm 1 năm nữa trước khi Đức đầu hàng. Theo ngôn ngữ vật lý, để mô tả trạng thái của một vật, cần xác định cả vị trí lẫn vận tốc, và không gian pha sẽ có số chiều gấp hai lần số chiều không gian các vị trí. (Cũng chính vì vậy mà các phương trình vi phân mô tả chuyển động trong vật lý thường là phương trình vi phân bậc 2 nếu viết theo các biến vị trí, chứ không phải phương trình vi phân bậc 1). Thế nhưng, trong giả thuyết thị trường hiệu quả thì "vận

${ }^{(9)}$ Xem: http://en.wikipedia.org/wiki/James_Harris_Simons 
tốc" không được tính đến, chỉ có "vị trî" thôi, "không gian pha" mất đi một nửa số chiều, và một mô hình như vậy thì khó chính xác.

\subsection{Phân tích thống kê cho giá cổ phiếu}

Các phương pháp thống kê toán học, đặc biệt là phương pháp hồi qui (xem Chương 5 của [7]), hay được dùng để dự đoán phân bố xác suất và sự phụ thuộc vào nhau của các biến ngẫu nhiên hay các quá trình ngẫu nhiên hay các chuỗi thời gian. Áp dụng vào giá cổ phiếu, các phương pháp thống kê này sẽ cho chúng ta thông tin về hệ số volatility, và sự phụ thuộc của giá cổ phiếu vào sự thay đổi của các yếu khác, ví dụ như: chỉ số của toàn bộ thị trường cổ phiếu, mức tăng trưởng kinh tế, tỷ lệ lạm phát, độ tin tưởng trung bình của nhà đầu tư vào nền kinh tế, v.v.

\subsubsection{Hệ số volatility}

Các cổ phiếu khác nhau có độ giao động (hệ số volatility) khác nhau, và cùng một cổ phiếu thì hệ số volatility của nó cũng thay đổi theo thời gian, khi các điều kiện thay đổi. Hình 5.9 là một ví dụ minh họa, so sánh độ giao động giữa giá cổ phiếu của Wal-Mart (mã chứng khoán: WMT) và Walgreen (mã chứng khoán: WAG), là hai công ty bán lẻ lớn, trong vòng 3 tháng từ ngày 22/01/2010 đến ngày 22/04/2010. Đồ thị cho thấy WAG có độ giao động mạnh hơn WMT trong 3 tháng đó: thường những hôm nào giá cổ phiếu đi lên, thì WAG đi lên nhiều hơn WMT, và những hôm nào giá cổ phiếu đi xuống, thì WAG cũng xuống nhiều hơn là WMT, tuy rằng tổng cộng sau 3 tháng thì chênh lệch giữa sự thay đổi giá của WMT và của WAG không nhiều (chỉ khoảng 2\%).

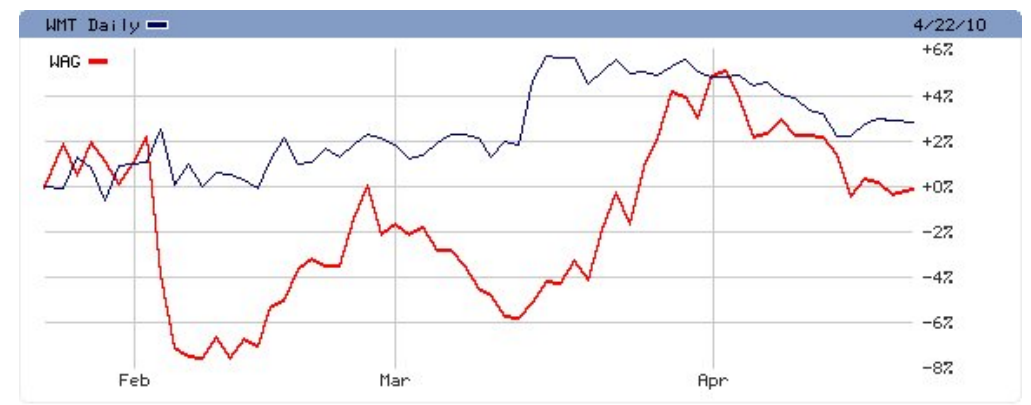

Hình 5.9: So sánh giao động của WMT và WAG trong 3 tháng

Có nhiều nguyên nhân khiến cho cổ phiếu này lại có độ giao động lớn hơn cổ phiếu 
khác, và trong giai đoạn này lại giao động nhiều hơn giai đoạn khác. Ví dụ, giá cổ phiếu của các công ty nhỏ, số lượng cổ phiếu phát hành ít (gọi là cổ phiếu nhỏ), thì dễ giao động mạnh hơn là giá cổ phiếu của các công ty lớn, với số lượng cổ phiếu phát hành nhiều, bởi vì chỉ cần một lượng mất cân đối cung cầu nhỏ đủ làm cho cổ phiếu nhỏ giao động mạnh, trong khi cổ phiếu lớn cần có sự mất cân đối cung cầu lớn hơn nhiều để đạt mức giao động tương đương. Những cổ phiếu đang trong giai đoạn có nhiều tin tức quan trọng ảnh hưởng đến giá trị và tâm lý thị trường, thì dễ giao động mạnh hơn là trong những giai đoạn "im ắng" ít tin tức. Những cổ phiếu nào mà có nhiều nhà đầu cơ ngắn hạn quan tâm, mua đi bán lại nhiều lần (tiếng lóng gọi là "lướt sóng"), thì cũng dễ giao động mạnh hơn là những cổ phiếu ít có đầu cơ. Ở đây, chúng ta sẽ không đi sâu tìm hiểu các nguyên nhân dẫn đến độ giao động của giá cổ phiếu, mà sẽ chỉ bàn đến cách tính độ giao động, tức là hệ số volatility.

Công thức để tính volatility của giá của một cổ phiếu như sau:

Theo qui ước, ta sẽ sử dụng giá đóng cửa hàng ngày (tức là giá vào thời điểm cuối phiên của mỗi ngày trên thị trường cổ phiếu). Gọi $S_{k}$ là giá đóng cửa của một cố phiếu vào ngày thứ $k$. Ta sẽ tính volatility của $S$ trong giai đoạn $n$ ngày, từ ngày thứ $N$ đến ngày thứ $N+n$, với giả sử rằng các số liệu đã được biết, tức là ngày thứ $N+n$ là một ngày trong quá khứ hoặc hiện tại chứ không phải trong tương lai. Đặt

$$
X_{i}=\ln \left(S_{N+i} / S_{N+i-1}\right)
$$

là độ thay đổi (đã log hóa) của giá cổ phiếu từ ngày thứ $N+i-1$ đến ngày thứ $N+i$, sau đó ta lấy độ lệch chuẩn của dãy số $\left(X_{1}, X_{2}, \ldots, X_{n}\right)$, tức là đặt

$$
\sigma=C \sqrt{\frac{\sum_{i=1}^{n}\left(X_{i}-M\right)^{2}}{n-1}},
$$

trong đó $M=\frac{\sum_{i=1}^{n} X_{i}}{n}$ là giá trị trung bình của các đại lượng $X_{i}$, còn $C$ là một hằng số, bằng căn bậc hai của số ngày mà thị trường cổ phiếu mở cửa trong một năm. (Có thể coi $C \approx \sqrt{252} \approx 16$, vì một năm có 52 tuần, mỗi tuần có 5 ngày mở cửa, nhưng trừ đi một số ngày lễ). Đại lượng $\sigma$ tính theo công thức trên được gọi là volatility, hay nói chính xác hơn, là volatility lịch sử (historical volatility) của cổ phiếu $S$ trong gian đoạn $n$ ngày kể từ ngày thứ $N$ cho đến ngày thứ $N+n$.

Cơ sở toán học của công thức (5.14 chính là phương pháp ước lượng độ lệch chuẩn bằng thống kê (xem Chương 5 của [7]), và mô hình biến động giá cổ phiếu

$$
\frac{d S_{t}}{S_{t}}=\mu d t+\sigma d B_{t}
$$


sẽ được bàn đến trong Chương 7 , trong đó biến thời gian $t$ được tính theo đơn vị năm, $B_{t}$ là chuyển động Brown, và để đơn giản ta giả sử là $\mu$ và $\sigma$ là hằng số. Ta có thể coi các đại lượng $X_{i}=\ln \left(S_{N+i} / S_{N+i-1}\right) \approx \frac{S_{N+i}-S_{N+i-1}}{S_{N+i-1}}$ là các giá trị thực nghiệm của một phân bố xác suất xấp xỉ bằng phân bố normal $N\left(\mu, \sigma^{2} / C^{2}\right)$ của $\mu+\sigma B_{1 / C^{2}}$ (vì một năm có $C^{2}$ ngày, nên 1 ngày bằng $1 / C^{2}$ năm). Từ các giá trị thực nghiệm $X_{i}$ ta ước lượng độ lệch chuẩn $\sigma / C$ của phân bố này, theo công thức (5.14).

Ghi chú 5.7. Công thức (5.14) là công thức để tính độ giao động đã xảy ra, và bởi vậy nó được gọi là volatility lịch sử. Độ giao động đã xảy ra này có thể hoàn toàn khác với độ giao động sẽ xảy ra trong tương lai. Không có cách nào để tính trực tiếp volatility tương lai, tuy rằng các volatility lịch sử cho ta một hình dung về độ giao động và ước lượng cho tương lai, với giả thiết rằng "lịch sử lặp lại", có nghĩa là những gì sẽ xảy ra trong tương lai cũng tuân theo cùng các qui luật như là những gì đã xảy ra trong quá khứ, và bởi vậy các độ giao động trong tương lai cũng tương tự như trong quá khứ. Có một cách tính gián tiếp độ giao động trong tương lai của giá cổ phiếu, thông qua giá của các quyền chọn, mà chúng ta sẽ đề cập đến trong Chương 8 . Độ giao động tính gián tiếp theo cách này được gọi là implied volatility.

Vi du 5.10. Volatility lịch sử của Walgreen cho khoảng thời gian 3 tháng tính đến ngày 22/04/2010 là 22.65\%, trong khi của Wal-Mart cho cùng quãng thời gian đó chỉ là 12.46\% . (Điều này thể hiện một cách trực giác trên Hình 5.9 . Chú ý rằng hệ số volatility thường được viết dưới dạng \%. Không có qui ước thế nào là volatility thấp hay cao, nhưng nói chung có thể hình dung rằng volatility dưới $20 \%$ thì là ở mức thấp, trên $40 \%$ thì là ở mức cao. Ví dụ, volatility lịch sử của công ty Baidu (một công ty internet lớn của Trung Quốc cạnh tranh với Google) cho khoảng thời gian 1 năm tính đến 22/04/2010 là 41\% (thuộc loại cao), của PetroBrasil (hãng Dầu hỏa Brazil) cho cùng thời gian đó là $36 \%$ (tương đối cao), của hãng xe Honda là $27 \%$ (quãng trung bình), của công ty Vivus (một công ty công nghệ sinh học, làm thuốc chống béo phì và một số thuốc khác) là $76 \%$ (rất cao), của Wal-Mart là 15\% (thuộc loại thấp). Số liệu lấy từ trang web http://morningstar.com.

Bài tập 5.5. Bài tập thực hành: tính volatility lịch sử của các cổ phiếu ở Việt Nam, cho các khoảng thời gian khác nhau (1 tháng, 3 tháng, 1 năm, v.v.)

\subsubsection{Hệ số beta}

Những hôm nào mà thị trường cổ phiếu đi lên thì hầu hết các cổ phiếu trên thị trường đi lên theo, và ngược lại khi thị trường đi xuống thì hầu hết các cổ phiếu đi xuống theo. 
Nói cách khác, chiều hướng thay đổi giá của một cổ phiếu phụ thuộc khá nhiều vào tình hình chung của thị trường. Hiện tượng phụ thuộc này có thể được giải thích bằng một số lý do như: có những yếu tố kinh tế vĩ mô ảnh hưởng chung đến toàn bộ các cổ phiếu, và tâm lý chung của thị trường loan tỏa đến toàn bộ các cổ phiếu. Nhiều nhà đầu tư không chọn lựa từng cổ phiếu riêng lẻ, mà đầu tư "cả thị trường", tức là khi mua/bán thì mua/bán một rổ rất nhiều cổ phiếu, đại diện cho toàn bộ thị trường. Xu hướng đầu tư kiểu này, gọi là đầu tư theo chỉ số (index investing), khá phổ biến, và bản thân nó cũng làm tăng sự phụ thuộc biến động giá cả giữa các cổ phiếu và toàn bộ thị trường.

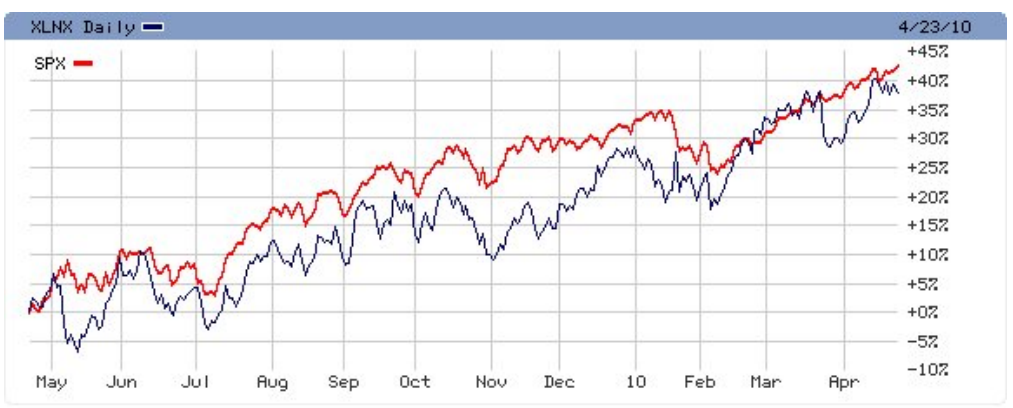

Hình 5.10: So sánh giao động của XLNX với S\&P 500

Hình 5.10 là một ví dụ minh họa, cho thấy cổ phiếu của công ty công nghệ bán dẫn Xilinx (mã chứng khoán: XLNX) có dáng điệu đi lên đi xuống gần giống hệt như là dáng điệu đi lên đi xuống của chỉ số S\&P500 đại diện cho toàn bộ thị trường chứng khoán Mỹ (trong vòng một năm từ 04/2009 đến 04/2010), tuy rằng volatility của XLNX cao hơn so với S\&P500. Dựa vào đồ thị này, ta có thể nói rằng, phần lớn sự giao động giá của XLNX là do sự giao động của toàn bộ thị trường tạo ra (trong quãng thời gian đó).

Tuy phần lớn cổ phiếu đi lên/đi xuống cùng với thị trường, nhưng có những cố phiếu đi lên đi xuống nhanh hơn thị trường và ngược lại có những cổ phiếu đi chậm hơn thị trường. Đại lượng đo tốc độ thay đổi của một cổ phiếu tương đối so với thị trường được gọi là hệ số beta của cổ phiếu đó.

Nói một cách cụ thể hơn, gọi $S$ là giá một cổ phiếu, $M$ là giá của một chỉ số đại diện cho toàn bộ thị trường (ví dụ như chỉ số VnIndex ở Việt Nam, hay Nikkei 225 ở Nhật Bản). Sự biến động giá của $S$ được tách làm 2 phần, một phần phụ thuộc vào thị trường, và một phần "của riêng" $S$ (stock-specific), độc lập với biến động chung của thị trường:

$$
\ln \left(S_{n} / S_{n-1}\right)=\beta \ln \left(M_{n} / M_{n-1}\right)+\left(\alpha+\epsilon_{n}\right)
$$


trong đó $\alpha$ và $\beta$ là các hệ số không phụ thuộc vào $n$, hay có thể viết là

$$
r_{n}^{S}=\alpha+\beta r_{n}^{M}+\epsilon_{n}
$$

trong đó $r_{n}^{S}=\ln \left(S_{n} / S_{n-1}\right)$ là độ thay đổi giá, hay còn gọi là mức độ lợi nhuận (đã log hóa) của $S$ từ ngày này sang ngày khác (hoặc từ tháng này sang tháng khác, nếu lấy bước thời gian là tháng), và $r_{n}^{M}=\ln \left(M_{n} / M_{n-1}\right)$ là độ thay đổi của toàn bộ thị trường. Trong phương trình trên, $\beta$ được gọi là hệ số beta của $S$, còn $\alpha+\epsilon_{n}$ là phần biến đổi của "của riêng" $S$, được tách tiếp làm hai phần: hằng số $\alpha$ và phần "nhiễu" $\epsilon_{n}$.

Theo giả thuyết của mô hình, thì phần nhiễu $\epsilon_{n}$, hay còn gọi là phần sai số, có giá trị trung bình (kỳ vọng) bằng 0 , và độc lập với biến động thị trường $r_{n}^{M}$ theo nghĩa: hệ số tương quan (correlation) giữa $\epsilon_{n}$ và $r_{n}^{M}$ (hiểu như là hai biến ngẫu nhiên) bằng 0 .

Các hệ số $\alpha$ và $\beta$ trong phương trình (5.17) được xác định theo phương pháp hồi qui tuyến tính (linear regression) với sai số bình phương nhỏ nhất (xem Chương 5 của [7]). Phương pháp hồi qui tuyến tính là phương pháp biểu diễn một đại lượng ngẫu nhiên (ở đây là $r_{n}^{S}$ ) như là một hàm tuyến tính (đa thức bậc 1) của một hay nhiều đại lượng ngẫu nhiên khác (ở đây là $r_{n}^{M}$ ) cộng với một sai số (ở đây là $\epsilon_{n}$ ), và các hệ số của hàm tuyến tính đó (ở đây là $\alpha$ và $\beta$ ) được chọn sao cho phần sai số là "nhỏ nhất" có thể.

Công thức tính các hệ số $\alpha$ và $\beta$, cho khoảng thời gian từ thời điểm $N_{1}$ đến thời điểm $N_{2}$ (thời điểm cuối này phải là một thời điểm trong quá khứ hoặc hiện tại, vì ta cần số liệu để tính) như sau:

$$
\beta=\frac{\operatorname{cov}\left(r^{S}, r^{M}\right)}{\operatorname{var}\left(r^{M}\right)}=\frac{\mathbb{E}\left(r^{S} r^{M}\right)-\mathbb{E}\left(r^{S}\right) \mathbb{E}\left(r^{M}\right)}{\mathbb{E}\left(\left(r^{M}\right)^{2}\right)-\left(\mathbb{E}\left(r^{M}\right)\right)^{2}}
$$

và

$$
\alpha=\mathbb{E}\left(r^{S}\right)-\beta \mathbb{E}\left(r^{M}\right),
$$

trong đó $\mathbb{E}\left(r^{S} r^{M}\right)=\frac{1}{N_{2}-N_{1}+1} \sum_{n=N_{1}}^{N_{2}} r_{n}^{S} r_{n}^{M}$ là giá trị kỳ vọng thực nghiệm (tức là giá trị trung bình) của $r^{S} r^{M}$ theo các số liệu lịch sử đã biết từ thời điểm $N_{1}$ đến thời điểm $N_{2}$, và tương tự như vậy cho các kỳ vọng khác trong hai công thức trên. Với $\alpha$ và $\beta$ được tính theo các công thức trên, thì phần sai số $\epsilon_{n}=r_{n}^{S}-\beta r_{n}^{M}-\alpha$ sẽ tự động thỏa mãn các tính chất sau: $\mathbb{E}(\epsilon):=\frac{1}{N_{2}-N_{1}+1} \sum_{n=N_{1}}^{N_{2}} \epsilon_{n}=0, \operatorname{cov}\left(\epsilon, r^{M}\right)=0$, và $\frac{1}{N_{2}-N_{1}+1} \sum_{n=N_{1}}^{N_{2}}\left(\epsilon_{n}\right)^{2}$ đạt cực tiểu, tức là tổng bình phương của các sai số là nhỏ nhất có thể.

Ví du 5.11. Vào thời điểm 22/04/2010, hệ số beta của Xilinx (Hình 5.10 là 0.99, của Wal-mart là 0.26 , của Intel là 1.17 , của Cisco là 1.23 , của Baidu là 1.79 , của Vivus là 
0.84. Số liệu lấy từ trang thông tin tài chính Google Finance. Hệ số beta càng cao thì tức là tốc độ tăng/giảm cùng chiều với thì trường càng lớn. Đa phần các cổ phiếu có hệ số beta là số dương (tức là chúng nói chung đi lên đi xuống cùng chiều với thị trường), nhưng cũng có những cổ phiếu nào đó trong những giai đoạn nào đó có hệ số beta là số âm (đi ngược lại thị trường).

Ghi chú 5.8. Việc tính toán hệ số beta phụ thuộc vào các tham số như: bước thời gian (ví dụ có nơi dùng ngày có nơi dùng tháng), và độ dài thời gian dùng để tính hồi qui (có thể dùng 1 năm, nhưng cũng có thể dùng các độ dài thời gian khác). Bởi vậy, các nguồn thông tin tài chính khác nhau có thể cho ra các con số về hệ số beta khác nhau cho cùng một cổ phiếu! Ví dụ, vào ngày 22/04/2010, theo Google Finance thì XLNX có hệ số beta là 0.99 nhưng theo Yahoo Finance thì nó có hệ số beta là 0.88. (Nói theo ngôn ngữ thống kê toán học, thì các con số khác nhau đó là các ước lượng của một hệ số beta trừu tượng của cổ phiếu). Hơn nữa, hệ số beta thay đổi theo thời gian, chứ không phải là hằng số. Theo lý thuyết CAPM (capital asset pricing model - mô hình định giá tài sản vốn), mà chúng ta sẽ đề cập đến trong Chương 6 , thì kỳ vọng lợi nhuận của một cổ phiếu chỉ phụ thuộc vào hệ số beta của nó chứ không phụ thuộc vào phần biến động giá $\alpha+\epsilon$ độc lập với thị trường! (Tương tự như là giả thuyết thị trường hiệu quả, lý thuyết CAPM là một lý thuyết thú vị, nhưng dựa trên những giả thiết rất mạnh, ít phù hợp với thực tế).

Ghi chú 5.9. Không những chỉ có các cổ phiếu riêng lẻ phụ thuộc vào sự giao động chung của một thị trường chứng khoán, mà các thị trường chứng khoán khác nhau cũng phụ thuộc lẫn nhau, và cũng có thể phân tích sự phụ thuộc đó bằng hồi qui tuyến tính. Hình 5.11 là ví dụ minh họa, cho thấy sự phụ thuộc lẫn nhau giữa thị trường chứng khoán Hong Kong (chỉ số Hang Seng) và thị trường Mỹ (chỉ số S\&P500) trong giai đoạn 5 năm (từ 04/2005 đến 04/2010). Theo đồ thị này, thị trường Hong Kong giao động mạnh hơn thị trường Mỹ, nhưng hai thị trường đi lên và đi xuống cùng nhau.

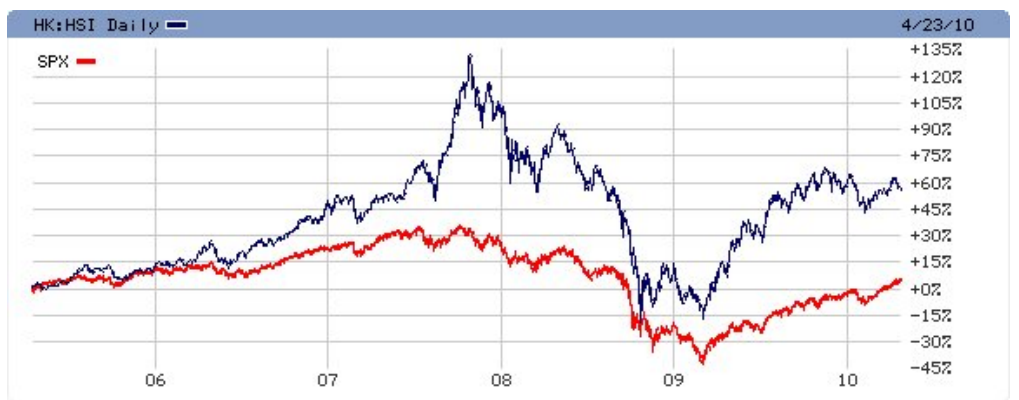

Hình 5.11: So sánh giao động của Hang Seng với S\&P 500 
Bài tập 5.6. Lập bảng hệ số beta và volatility của các cổ phiếu trên một thị trường nào đó, và kiểm định giả thuyết sau: có liên quan giữa volatility và hệ số beta theo chiều thuận, có nghĩa là cổ phiếu nào có hệ số beta càng cao, thì càng dễ có volatility lớn.

Bài tập 5.7. Chứng minh rằng trung bình cộng (có trọng) của các hệ số beta của các cổ phiếu trên một thị trường là bằng 1 . Hệ quả là, trên một thị trường cổ phiếu (với nhiều mã cổ phiếu), luôn có cổ phiếu có hệ số beta nhỏ hơn 1, và có cổ phiếu có hệ số beta lớn hơn 1.

Bài tập 5.8. Phân tích hồi qui tuyến tính chỉ số vnindex theo chỉ số S\&P500.

\subsubsection{Hồi qui theo nhiều biến}

Sự giao động của cổ phiếu, ngoài việc phụ thuộc vào sự giao động chung của toàn bộ thị trường, còn có thể phụ thuộc vào sự giao động của các biến khác, ví dụ như: sự phát triển của ngành công nghiệp mà công ty tham gia, độ tin tưởng của các nhà đầu tư vào nền kinh tế, tỷ lệ lạm phát, giá năng lượng, v.v. Để phân tích cự thể hơn sự phụ thuộc của cổ phiếu vào nhiều biến khác nhau, gọi là các biến giải thích (explanatory variable), dựa trên các suy luận logic về sự phụ thuộc này và các số liệu có được, có thể dùng phương pháp hồi qui theo nhiều biến (xem Chương 5 của [7] về phương pháp hồi qui).

Đơn giản nhất trong các mô hình hồi qui nhiều biến là mô hình hồi qui tuyến tính bội. Nó tương tự như là hồi qui tuyến tính đơn (theo một biến) dùng trong mục trước, nhưng với hai hay nhiều biến dùng để giải thích sự biến động của giá, thay vì chỉ có một biến thị trường: ta viết

$$
r_{n}^{S}=\alpha+\beta_{1} v_{n}^{1}+\ldots \beta_{k} v_{n}^{k}+\epsilon_{n},
$$

trong đó $r_{n}^{S}=\ln \left(S_{n} / S_{n-1}\right)$ là độ thay đổi giá cổ phiếu, và $v^{1}, \ldots, v^{k}$ là các biến giải thích. Các công thức hồi qui tuyến tính bội (xem chi tiết công thức trong Chương 5 của [7]) cho phép tìm các hệ số $\alpha$ và $\beta_{1}, \ldots, \beta_{k}$, (sao cho phần sai số $\epsilon_{n}$ là nhỏ nhất theo một nghĩa tự nhiên nào đó) dựa trên các số liệu lịch sử thu được về giá cổ phiếu và về các biến giải thích $v^{1}, \ldots, v^{k}$. Có thể bỏ qua hệ số $\alpha$ (đặt $\alpha=0$ ), nếu coi rằng phần biến động mà không giải thích được bằng các biến $v^{1}, \ldots, v^{k}$ là phần "nhiễu" có kỳ vọng bằng 0 . Khi đã có các số liệu về các biến giải thích và giá cổ phiếu, thì có thể dùng một chương trình máy tính với chức năng tính toán hồi qui để tính ra các hệ số $\beta$ một cách nhanh chóng.

Có sự tùy ý trong phương pháp phân tích hồi qui: không có qui định nào về việc các biến giải thích nào cần có trong mô hình. Ý tưởng chung là nên chọn các biến giải thích sao cho số lượng không quá lớn (để tránh chồng chéo nhiều lên nhau), mà giải thích được 


\subsection{PHÂN TÍCH THỐNG KÊE CHO GIÁ CỔ PHIẾU}

hầu hết sự biến động của cổ phiếu, tức là sao cho phần sai số $\epsilon$ còn lại rất nhỏ. Chú ý rằng, có những biến giải thích có thể quan trọng đối với cổ phiếu này nhưng không quan trọng đối với cổ phiếu khác. Ví dụ như biến "giá dầu hỏa" sẽ ảnh hưởng mạnh đến các công ty trong ngành dầu khí, nhưng ít ảnh hưởng đến các công ty trong ngành dược phẩm.

Vi du 5.12. Trong bài báo nổi tiếng Using macroeconomic factors to control portfolio risk ${ }^{(10)}$ của các tác giả Edwin Burmeister, Richard Roll và Stephen Ross, 03/2003, 5 biến giải thích sau, gọi là 5 yếu tố may rủi (risk factor) vĩ mô, được dùng trong phân tích hồi qui tuyến tính bội cho biến động của giá cổ phiếu:

- Investor confidence (niềm tin của nhà đầu tư), đo bằng độ chênh lệch giữa lợi suất trái phiếu chính phủ và lợi suất của trái phiếu doanh nghiệp có rủi ro và có cùng kỳ hạn 20 năm. Ý tưởng là, các nhà đầu tư càng tin tưởng vào triển vọng làm ăn và khả năng trả nợ của các doanh nghiệp, thì sẽ càng ít đòi hỏi về chênh lệch lãi suất giữa trái phiếu có rủi ro và trái phiếu không rủi ro.

- Time horizon (yếu tố thời hạn của đầu tư), được đo bởi độ chênh lệch lãi suất giữa trái phiếu chính phủ kỳ hạn 20 năm và tín phiếu kho bạc (treasury bill) kỳ hạn 30 ngày. Ý tưởng là các cổ phiếu tăng trưởng (khi phần lớn lợi nhuận của công ty nằm ở tương lai xa) sẽ nhạy hơn với độ chênh lệch này (khi độ chênh lệch cao lên thì giá trị của cổ phiếu giảm đi) so với các cổ phiếu khác.

- Inflation risk (rủi ro về lạm phát), được đo bằng độ chênh lệch giữa mức lạm phát thực tế xảy ra cho mỗi tháng và mức lạm phát kỳ vọng dự đoán vào đầu tháng cho tháng đó. Ý tưởng là, nếu làm phát tăng lên so với dự đoán, thì sức mua của người tiêu dùng giảm đi so với dự đoán, và điều này ảnh hưởng xấu đến độ tiêu dùng các hàng hóa có tính chất xa xỉ phẩm (và các công ty kinh doanh các hàng đó), trong khi các hàng hóa nhu yếu phẩm thì không bị ảnh hưởng bằng.

- Business cycle risk (rủi ro về chu kỳ kinh tế) được đo bằng sự thay đổi tốc độ phát triển kỳ vọng của một nền kinh tế qua từng tháng. Tháng nào mà chỉ số đó dương tức là tốc độ phát triển kỳ vọng của nền kinh tế tăng lên trong tháng đó. Ý tưởng là có những công ty (ví dụ như các công ty xây dựng) có thể nhạy hơn với sự thay đổi này so với những công ty khác.

- Market timing, dựa trên một chỉ số thị trường (trong bài báo là chỉ số S\&P500) để giải thích các biến động về giá cả trên thị trường mà không giải thích được bằng 4

${ }^{(10)}$ Có thể tìm đọc bài báo này ở nhiều nơi trên internet, chẳng hạn tại: http://www.birr.com 
yếu tố kinh tế vĩ mô phía trên.

Phân tích hồi qui tuyến tính của Burmeister, Roll và Ross về biến động giá của các cổ phiếu theo 5 biến giải thích trên góp phần khẳng định các suy luận logic về sự phụ thuộc của giá cổ phiếu vào các biến đó, và cho thông tin thú vị về mức độ phụ thuộc. Ví dụ, hệ số beta theo biến investor confidence của các cổ phiếu tăng trưởng là số dương còn của các cổ phiếu có mức cổ tức cao (high-yield stocks) là số âm. Có thể giải thích hiện tượng này như sau: khi mà niềm tin của nhà đầu tư vào nền kinh tế tăng lên, thì họ thích đầu tư vào các cổ phiếu tăng trưởng hứa hẹn lợi nhuận cao về lâu dài, hơn là các cổ phiếu giá trị trả lợi tức định kỳ đều đặn nhưng không hứa hẹn gì nhiều về lâu dài.

Ghi chú 5.10. Phương pháp hồi qui tuyến tính bội để phân tích giao động của giá cổ phiếu theo nhiều biến giải thích (còn được gọi là các yếu tố may rủi - risk factors) gắn liền với cái gọi là Arbitrage Pricing Theory (11) (lý thuyết APT) để giải thích biến động giá cổ phiếu, được Stephen Ross đề xướng vào năm 1976. Lý thuyết APT là một sự cải tiến của lý thuyết CAPM, và theo nó thì kỳ vọng lợi nhuận cổ phiếu giải thích được không phải là bằng một hệ số beta ứng với duy nhất một yếu tố may rủi hệ thống (systematic risk - trong mô hình CAPM yếu tố may rủi hệ thống này là sự giao động giá của tổng cộng toàn bộ thị trường cổ phiếu), mà là bằng một số hệ số beta ứng với một số yếu tố may rủi hệ thống khác nhau.

Bài tập 5.9. Đọc và phân tích các thông tin trong bài báo Using macroeconomic factors to control portfolio risk của Edwin Burmeister, Richard Roll và Stephen Ross, 03/2003

Bài tập 5.10. Phân tích hồi qui tuyến tính về biến động giá cổ phiếu của một số công ty lớn trong ngành dầu khí theo hai biến giải thích sau: giá dầu hỏa, và sự giao động của toàn bộ thị trường.

\footnotetext{
${ }^{(11)}$ Xem: http://en.wikipedia.org/wiki/Arbitrage_pricing_theory. Lý thuyết này còn được gọi đùa là "arbitrary pricing theory" (lý thuyết định giá tùy tiện), vì sự tùy tiện trong việc lựa chọn các yếu tố may rủi
} 


\section{Chương 6}

\section{Quản lý danh mục đầu tư}

Nền kinh tế thế giới phát triển được là nhờ có đầu tư, không có đầu tư thì không có phát triển. Đầu tư có nghĩa là đổ tiền của công sức vào những cái gì đó, với kỳ vọng là nó sẽ đem lại những của cải vật chất và tinh thần trong tương lai. Tất nhiên, không phải mọi đầu tư đều đem lại hiệu quả như nhau, hoặc là đều dễ đo hiệu quả. Ví dụ như giáo dục là loại hình đầu tư vô cùng quan trọng, nhưng đo hiệu quả của nó rất khó. Ngoài hiệu quả kinh tế mà giáo dục đem lại qua việc làm tăng trình độ chuyên môn của mọi người, còn có hiệu quả về văn hóa, làm cho xã hội văn minh lên, chất lượng cuộc sống tinh thần cao lên, và điều này không đo được bằng tiền.

Một thước đo hiệu quả đầu tư, từ quan điểm kinh tế vĩ mỗ, là chỉ số ICOR (incremental capital output ratio), tức là tỷ lệ tăng doanh thu trên vốn đầu tư thêm. Ví dụ, nếu đầu tư thêm $1 \$$ mà nhờ đó mỗi năm tăng thêm doanh thu $0.25 \$$, thì chỉ số ICOR bằng $1 / 0.25=4$. Nước nào hay công ty nào có chỉ số ICOR càng thấp thì tức là đầu tư càng hiệu quả về mặt kinh tế. Chẳng hạn, khi chỉ số ICOR dưới 3, như là trường hợp của Đài Loan hay Hàn Quốc trong giai đoạn phát triển nhanh, thì là hiệu quả đầu tư cao. Khi Việt Nam có chỉ số ICOR vào quãng 4 trong thập kỷ 1990, thì là hiệu quả đầu tư ở mức trung bình, nhưng khi chỉ số ICOR lên trên 5 những năm sau đó, rồi thậm chí lên đến 8 vào năm 2009, thì là hiệu quả đầu tư thấp, kéo theo vay nợ nước ngoài nhiều và bấp bênh về tài chính.

Ở đây, chúng ta sẽ không bàn về hiệu quả đầu tư từ khía cạnh kinh tế xã hội, mà là từ quan điểm các nhà đầu tư tài chính, tức là những người bỏ vốn ra đầu tư vào những loại hình đầu tư nào đó, nhằm thu lại được một khoản vốn lớn hơn trong tương lai, tuy tất nhiên hiệu quả đầu tư của các nhà đầu tư và hiệu quả đầu tư của các nơi nhận được đầu tư là hai khái niệm gắn nhiều với nhau, và các nhà đầu tư muốn đạt hiệu quả đầu 


\section{ICOR Việt Nam qua| các giai đoạn}

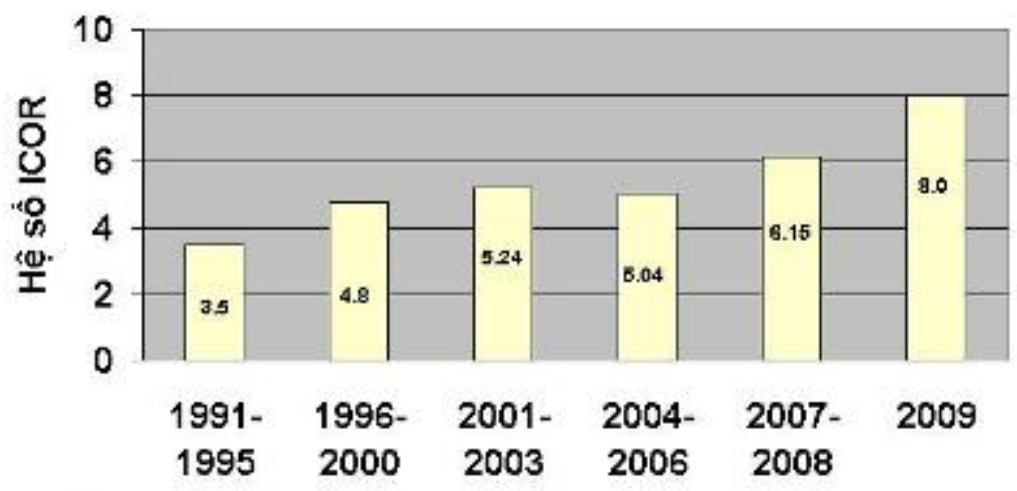

Hình 6.1: Chỉ số ICOR ở Việt Nam. (Nguồn: Tổng Cục Thống Kê)

tư cao thì phải tìm những nơi nào có hiệu quả đầu tư cao cho vốn đầu tư vào đó.

Đối với các nhà đầu tư, thì hiệu quả đầu tư được đo bằng tỷ lệ lợi nhuận, và mức độ an toàn hay bấp bênh về tài chính của các đầu tư. Câu hỏi đặt ra đối với các nhà đầu tư là: đầu tư vào những đâu, như thế nào, để đạt kỳ vọng lợi nhuận cao nhất, đồng thời đảm bảo mức an toàn chấp nhận được, không quá mạo hiểm. Lý thuyết toán tài chính nhằm trả lời những câu hỏi này gọi là lý thuyết quản lý danh mục đầu tư. Quản lý danh mục đầu tư và phân bổ tài sản (chia tài sản vào các loại hình đầu tư khác nhau thế nào sao cho hợp lý) là một vấn đề rất lớn của tài chính.

Trong khuôn khổ của chương này, chúng ta sẽ chỉ bước đầu tìm hiểu những nguyên tắc cơ bản trong việc quản lý danh mục đầu tư, nhằm tạo cơ sở để bạn đọc có thể xây dựng được triết lý đầu tư thích hợp cho mình, và nghiên cứu thêm về vấn này trong nhiều tài liệu chuyên về đầu tư cũng như qua thực hành đầu tư. Thuật ngữ "danh mục đầu tu" tiếng Anh là portfolio, tiếng Pháp là portefeuille, được hình thành từ hai từ "port" (hay "porte"), có nghĩa là mang giữ, và "folio" (hay "feillle"), có nghĩa là giấy tờ. Sở dĩ được gọi như vậy, vì trong lịch sử, các chứng khoán là các thứ giấy tờ, và portfolio có nghĩa là cặp giữ các giấy tờ chứng khoán khác nhau, hay nói rộng ra là giữ các loại tài sản khác nhau.

Trong các chứng khoán thì có thể có chứng khoán có giá trị âm, ví dụ như giấy ghi nhận là đang nợ ai đó. Lý thuyết quản lý một danh mục mà trong đó có cả các khoản âm lớn gọi là asset liability management $(\mathrm{ALM})$ có nghĩa là quản lý tài sản và nợ, đặc biệt quan trọng đối với các ngân hàng và hãng bảo hiểm. Nhưng chúng ta sẽ không bàn đến ALM trong chương này, mà sẽ hạn chế vào trường hợp phần lớn các khoản khác nhau 
trong một danh mục dầu tư có giá trị dương.

\subsection{Một số nguyên tắc chung về đầu tư}

\subsubsection{Quan hệ giữa rủi ro và lợi nhuận}

Tiếng Anh có câu "no pain, no gain" (không chịu đau khổ thì cũng không đạt thành quả), hay tiếng Việt có câu thành ngữ gần giống thế là "có chí làm quan, có gan làm giầu". Gan ở đây là khả năng chấp nhận rủi ro mạo hiểm. Điều này rất đúng trong đầu tư, khi mà nguy hiểm rủi ro và cơ hội lợi nhuận luôn đi liền với nhau. Như chúng ta sẽ thấy trong chương này, các loại hình đầu tư nào có kỳ vọng lợi nhuận cao hơn thì cũng thường đi kèm với mức độ rủi ro cao hơn. Rủi ro ở đây có thể hiểu là khả năng bị mất tiền (tiền thu lại được nhỏ hơn số tiền ban đầu bỏ ra) khi gặp những tình huống không thuận lợi. Ví dụ như gửi tiền tiết kiệm là hình thức đầu tư an toàn cao nhưng đem lại lợi nhuận thấp. Đầu tư vào cổ phiếu của các doanh nghiệp là hình thức đầu tư mà về lâu dài đem lại lợi nhuận trung bình cao hơn các hình thức đầu tư khác như đầu tư vào trái phiếu và bất động sản, thế nhưng nó cũng có mức rủi ro cao hơn. Tất nhiên, không phải cứ mức độ rủi ro cao thì kỳ vọng lợi nhuận nghiễm nhiên sẽ cao. Chẳng hạn, các loại hình đánh bạc có độ rủi ro rất cao, và kỳ vọng lợi nhuận là số âm.

Bài toán quản lý danh mục đầu tư là bài toán tối ưu hóa về rủi ro và lợi nhuận: một mặt phải quản lý rủi ro để giảm thiểu rủi ro, sao cho danh mục đầu tư được ổn định về giá trị, không bị thua lỗ quá mức chấp nhận được khi gặp các tình huống không thuận lợi, và mặt khác phải làm sao đạt mức lợi nhuận kỳ vọng lớn nhất có thể được, trong phạm vi mức độ rủi ro chấp nhận được đó. Chúng ta sẽ tiếp cận bài toán này, đầu tiên là bằng các phương pháp định tính (qualitative), tức là xác định các nguồn đem lại rủi ro và lợi nhuận, và các qui tắc chung nhằm quản lý rủi ro và tăng lợi nhuận, rồi đến định lượng (quantitative), tức là các công thức toán học để định nghĩa và tính toán với mức độ rủi ro (như volatility và value at risk) và kỳ vọng lợi nhuận, và các mô hình toán học cho chiến lược đầu tư nhằm tối ưu hóa rủi ro và lợi nhuận.

\subsection{2 Đa dạng hóa}

Tuy rằng các lý thuyết toán tài chính về đa dạng hóa (diversification) trong đầu tư, trong đó có lý thuyết gọi là modern portfolio theory (lý thuyết danh mục đầu tư hiện đại) 
đoạt giải Nobel về kinh tế của Harry Markowitz(1) mới chỉ xuất hiện từ giữa thế kỷ 20, nhưng các bài học về đa dạng hóa trong đầu tư trên thế giới đã có từ hàng ngàn đời nay. Theo Roger Gibson [10], từ hơn một nghìn năm trước công nguyên, trong sách Talmud (kinh thánh của đạo Do Thái(2) đã viết như sau:

Mỗi người phải chia tài sản của mình thành ba phần, một phần để vào đất đai, một phần để vào doanh nghiệp, và một phần để dự trữ.

Lời khuyên trên trong sách Talmud tuy rất đơn giản nhưng cũng rất sáng suốt và hiệu nghiệm. Nhà đất, doanh nghiệp, và dự trữ (như là vàng, hay tiền gửi ngân hàng) là ba loại hình đầu tư khác nhau, phục vụ các nhu cầu khác nhau, với các kỳ vọng về lợi nhuận và độ an toàn khác nhau, khi kết hợp với nhau thì cho được một rổ tài sản vừ đảm bảo có mức an toàn cao, vừa có triển vọng lợi nhuận tốt.

Nói một cách tổng quát, đa dạng hóa tài sản là biện pháp hiệu quả nhằm giảm rủi ro. Khi đa dạng hóa tài sản thì rủi ro giảm đi, bởi vì mỗi lúc rủi ro có thể xảy đến với một loại tài sản nào đó, chứ thường không xảy đến với tất cả các tài sản cùng một lúc. Nếu chỉ giữ một tài sản, mà rủi ro xảy đến với tài sản đó, thì sẽ bị thiệt hại nặng nề. Nhưng khi giữ nhiều loại tài sản, thì mức độ thiệt hại chung trên tổng tài sản sẽ nhẹ hơn nhiều khi rủi ro xảy ra với một trong các tài sản.

\subsection{3 Đòn bẩy tài chính}

Biểu hiện của việc sử dụng đòn bẩy đầu tư, là khi một tài khoản đầu tư vào một loại chứng khoán nào đó lại có tốc độ thay đổi giá trị nhanh hơn là chứng khoán đó. Ví dụ, một người có $1000 \$$ dầu tư vào vàng, nhưng vay công ty chứng khoán thêm $19000 \$$ để mua $20000 \$$ tiền vàng, với đòn bẩy là 20 lần. Nếu như giá vàng trong ngày tăng lên 1\%, thì thay vì chỉ được lãi $1 \%$ nếu chỉ đầu tư bằng vốn của mình, người này được lãi gấp 20 lần như vậy, tức là lãi 20\%, nhờ dùng đòn bẩy.

Đòn bẩy hấp dẫn với các nhà đầu tư (hay nói chính xác hơn là đầu cơ) và các quỹ đầu cơ (hedge fund: ${ }^{(3)}$ như là "tiếng gọi của nàng tiên cá", vì nó hứa hẹn triển vọng tăng lợi nhuận lên nhiều lần. Việc dùng đòn bẩy cao rất phổ biến trên các thị trường tài chính,

\footnotetext{
(1)Xem: http://en.wikipedia.org/wiki/Harry_Markowitz.

${ }^{(2)}$ Xem: http://en.wikipedia.org/wiki/Talmud

${ }^{(3)}$ hedge fund nếu dịch theo từng chữ thì có nghĩa là "quỹ phòng vệ", tức là các quỹ có sử dụng các chiến lược rảo cản (hedge) phòng chống rủi ro, nhưng trên thực tế đây thường là các quỹ đầu cơ với độ rủi ro cao hơn là quỹ tương hỗ thông thường, do sử dụng đòn bẩy tài chính.
} 
như là thị trường hàng hóa (commodities) và ngoại hối (forex). Tuy nhiên, đòn bẩy là con dao hai lưỡi rất nguy hiểm, và đi kèm triển vọng tăng lợi nhuận lên nhiều lần cũng là sự tăng độ rủi ro lên gấp bội. Trong ví dụ phía trên, nếu giá vàng không đi lên $1 \%$ mà lại giảm 5\%, thì người dùng đòn bẩy 20 lần để đầu cơ vàng sẽ phá sản. Khi thị trường cổ phiếu đi xuống, thì các nhà đầu tư cổ phiếu dùng đòn bẩy cao (ví dụ vay một lượng tiền bằng số tiền mình có, để có thể mua được một lượng cố phiếu nhiều lên gấp đôi) cũng gặp nguy cơ phá sản tương tự, như đã xảy ra với nhiều người ở Việt Nam trong giai đoạn 2008-2009.

Kể cả khi mà một người có những phán đoán rất đúng về giá của một chứng khoán nào đó, thì việc dùng đòn bẩy cao vẫn có thể gây ra phá sản, do các biến động ngắn hạn bất lợi của thị trường. Ví dụ, một người phán đoán là cổ phiếu XYZ sẽ đi lên rất mạnh trong 1 năm, và mua cổ phiếu đó với đòn bẩy 2 lần (tức là vay thêm số tiền bằng $100 \%$ vốn để mua). Quả thật, sau 1 năm, cổ phiếu XYZ tăng giá lên gấp 5 lần. Thế nhưng, trước khi đi lên mạnh như vậy, giá của XYZ đi xuống chỉ còn bằng $50 \%$ giá thời điểm mà người này mua vào (rồi sau đó tăng giá lên gấp 10 lần tính từ chỗ giá thấp), kịp làm cho người này phá sản và không còn được hưởng thành quả sự phán đoán đúng đắn của mình nữa. Trên thị trường chứng khoán không thiếu những ví dụ có thật về biến động giá như vậy.

Một trong các nguyên tắc quan trọng của đầu tư là, phải rất thận trọng với đòn bẩy (và với các quỹ đầu tư dùng đòn bẩy, như là các hedge funds), bởi đòn bẩy có thể làm tăng độ rủi ro lên quá mức chấp nhận được.

\subsection{4 Đệm an toàn}

Như chúng ta thấy từ Chương 5 , việc ước lượng giá trị của một cổ phiếu, hay nói một cách tổng quát hơn, của một số loại tài sản nào đó, là việc rất khó, và hai người khác nhau có thể cho hai giá trị ước lượng rất xa nhau đối với cùng một chứng khoán, ước lượng của người này có khi cao gấp đến mấy lần ước lượng của người kia. Người nào ước lượng ra giá trị của chứng khoán càng cao, thì càng dễ chấp nhận mua chứng khoán với giá cao, mà khi mua với giá cao như vậy thì dễ bị rủi ro về giá, bởi vì sau đó khó bán lại cho những người khác có ước lượng giá trị thấp hơn cho chứng khoán đó, sẵn sàng bán nó với giá rẻ hơn. Trong lý thuyết về các trò chơi đấu giá có một định lý gọi là "nỗi khổ của người thắng" (the winner's curse): người thắng cuộc trong một cuộc bán đấu giá là người trả giá cao nhất, và sau đó có thể hối hận vì đã trả giá cao đến vậy. 
Để tránh rơi vào tình trạng hối hận vì trả giá quá cao, có một nguyên tắc trong đầu tư, gọi là đệm an toàn (cushion of safety): một nhà đầu tư chỉ nên mua chứng khoán với giá thấp hơn đáng kể so với ước lượng giá trị của nhà đầu tư về chứng khoán đó. Sự chênh lệch giữa giá trị ước lượng, và giá mua vào, chính là đệm an toàn, để nếu chẳng may ước lượng có bị sai và cao quá so với các ước lượng của các nhà đầu tư khác, thì vẫn giảm được rủi ro về giá trị chứng khoán mua vào so với tiền bỏ ra để mua nó. Đệm an toàn chính là một trong các nguyên tắc đầu tư quan trọng nhất của tỷ phú Warren Buffet, người được mệnh danh là nhà đầu tư giỏi nhất thế giới.

\subsection{5 Độ dài thời gian}

Một cây ăn quả, từ lúc trồng đến lúc được hái quả, có khi phải đợi vài năm. Đối với đầu tư cũng vậy, mỗi loại hình đầu tư cũng thường đòi hỏi một độ dài thời gian nhất định. Ví dụ, với các trái phiếu chính phủ dài hạn, nếu giữ đến lúc đáo hạn thì nói chung đảm bảo là có lợi nhuận, nhưng nếu chỉ giữ một thời gian ngắn thì có thể bị lỗ vì rủi ro về lãi suất. Đối với cổ phiếu cũng tương tự như vậy: nếu giữ một rổ cổ phiếu lâu dài nhiều năm, thì nói chung là có lợi nhuận tốt, nhưng nếu chỉ giữ ngắn hạn (đầu tư theo kiểu lướt sóng, chạy theo "mốt" của thị trường) thì rủi ro cao, dễ thua lỗ do các biến động giá bất lợi xảy ra trong ngắn hạn.

Những tài liệu như Greenblatt [11, 12] và Shenoy [27] cho thấy, về mặt lý thuyết ai cũng có thể tìm được các cổ phiếu để đầu tư đạt mức lợi nhuận trung bình trên $20 \% /$ năm, theo những nguyên tắc tương đối đơn giản dễ áp dụng, thế nhưng rất hiếm người đạt hiệu quả đầu tư như vậy. Vấn đề nằm ở chỗ, phần lớn các nhà đầu tư có cái nhìn quá ngắn hạn, chạy theo "mốt" thị trường mà bỏ qua những cổ phiếu có giá thấp hơn nhiều giá trị thực. Đến khi các cổ phiếu như vậy trở thành "mốt" thì cũng là lúc giá của chúng đã cao lên nhiều rồi.

Theo nguyên tắc chung, những người càng có thể giữ dài hạn các khoản đầu tư, thì càng đỡ bị ảnh hưởng của rủi ro biến động giá trong ngắn hạn, và càng dễ chọn được các đầu tư mang lại kỳ vọng lợi nhuận trung bình hàng năm cao hơn. Về điểm này, những người còn trẻ tuổi có lợi thế hơn là những người đã nhiều tuổi.

\subsection{6 Đầu tư có tổ chức}

Công việc đầu tư là một công việc phức tạp, và muốn làm tốt nó đòi hỏi phải làm tốt nhiều công đoạn như: thu thập thông tin, phân tích tình hình thị trường, phân tích các 
cơ hội đầu tư, lập chiến lược đa dạng hóa và phân bổ tài sản, thực hiện mua bán, quản lý rủi ro, tính toán sổ sách, v.v. Vì có nhiều công việc như vậy, nên một cá nhân đơn lẻ thường không thể làm xuể một cách tối ưu được, mà cần có một tổ chức, có phân công công việc, tương trợ lẫn nhau, thì kết quả sẽ tốt hơn. Bởi vậy, người ta nói rằng "đầu tư là một môn thể thao tập thể" (investing is a team sport). Các nhà đầu tư nói chung nên tránh đầu tư riêng lẻ, mà nên tham gia một nhóm đầu tư, hay một công ty đầu tư có tổ chức tốt, hay gửi tiền vào một nơi như vậy, thì sẽ giảm được rủi ro và có được nhiều cơ hội đầu tư tốt hơn. Các nhà đầu tư lớn nhất thế giới đều là đầu tư có tổ chức, có nhiều người tham gia phụ trách các vấn đề khác nhau trong một bộ máy đầu tư.

\subsection{Các loại hình đầu tư}

Có nhiều loại hình đầu tư khác nhau. Ở đây chúng ta sẽ điểm qua một số loại hình đầu tư thông dụng nhất, và kỳ vọng lợi nhuận cũng như mức độ rủi ro của chúng.

\subsubsection{Vàng bạc châu báu}

Nói về lâu dài, thì vàng bạc châu báu chỉ là phương tiện giữ tài sản, chứ không sinh ra lợi nhuận (trừ khi đem cho vay lấy lãi, thì thành loại hình đầu tư cho vay nợ, hoặc đem dùng trong việc chế tạo cái gì đó, thì không còn là đầu tư theo nghĩa ở đây nữa, mà là sản xuất). Một cân vàng để 100 năm sau vẫn chỉ là một cân vàng chứ không sinh thêm ra của cải. Bởi vậy có thể nói, lợi nhuận trung bình từ đầu tư vàng bằng 0 . Đi vào chi tiết hơn, thì trong một quá trình dài hàng thế kỷ, độ tăng giá trung bình hàng năm của vàng xấp xỉ bằng mức độ lạm phát trung bình. Vào năm 1880, một lượng vàng có giá $20.67 \$$, và 130 năm sau, vào cuối năm 2010 nó có giá $1350 \$$, tức là tốc độ tăng giá trung bình vào khoảng $3,27 \% / n a ̆ m$, tương đương với tốc độ lạm phát trung bình của đồng USD trong 130 năm đó (hơn 3\%/năm). Về lâu dài, giá vàng không thể tăng nhanh hơn đáng kể so với tỷ lệ lạm phát, vì vàng trên thể giới không bị khan hiếm đi, và tỷ lệ giá trị của vàng so với tổng các tài sản trên thế giới không thế phình to quá được, cho nên giá của nó cũng không thể tăng quá cao so với giá của các thứ khác. Tất nhiên, do giao động của thị trường, có những giai đoạn mà giá vàng tăng nhanh, ví dụ trong 1 năm 1978-1979 giá vàng tăng hơn gấp đôi từ $208 \$$ lên $459 \$$ một lượng, nhưng cũng có những giai đoạn giá vàng không tăng mà lại giảm, ví dụ trong 10 năm 1987-1997 giá vàng giảm từ gần $500 \$$ xuống còn $290 \$$. Tính trung bình lại trong rất nhiều năm, thì độ tăng của giá vàng 
chỉ tương đương với tỷ lệ lạm phát. Từ quan điểm đầu tư dài hạn, thì giữ vàng không nhằm mục đích mang lại lợi nhuận, mà chỉ là cách phân bổ tài sản để nhằm giảm rủi ro và chống lạm phát. Những nhà đầu tư mua đi bán lại vàng thường xuyên trên thị trường tài chính phần lớn không phải là đầu tư theo đúng nghĩa, mà là đầu cơ giá vàng, hay là đánh bạc với vàng, với kỳ vọng lợi nhuận trung bình (sau khi trừ đi lạm phát) bằng 0 , hay thậm chí là số âm sau khi trừ chi phí giao dịch, và có thể có mức rủi ro rất cao (vì có nhiều người tham, dùng đòn bẩy mạnh, ví dụ có 1 đồng vay thêm 9 đồng để đầu cơ vàng, dễ bị mất hết tài sản).

\subsubsection{Bất động sản}

Một ví dụ nổi tiếng về thành công trong bất động sản là câu chuyện về bán đảo Manhattan (New York), một nơi thuộc loại giàu có và đắt đỏ nhất trên thế giới ngày nay, với hơn 1,6 triệu dân. Vào năm 1626, một thương gia gốc Hà Lan tên là Peter Minuit mua đảo này từ những người thổ dân da đỏ bằng một lượng hàng hóa trị giá chỉ khoảng $24 \$$ thời đó. Ngày nay, 385 năm sau, không ai biết bán đảo đó có giá trị là bao nhiêu. Nhưng ta cứ thử hình dung là trên đảo đó có 1,6 triệu dân giầu có, và họ trung bình có đất có giá trị cỡ 1 triệu USD mỗi người, thì ta được con số ước lượng là đất đảo Manhattan ngày nay trị giá khoảng 2 nghìn tỷ USD. Phép tính

$$
\left(2 \times 10^{12} / 24\right)^{1 / 385} \approx 1.0675
$$

cho ta thấy là giá của đảo này (tính theo USD, chưa trừ đi lạm phát) tăng trung bình khoảng $6.75 \%$ trong 385 năm. Nếu trừ đi lạm phát thì có lẽ còn dưới 5\%/năm. Mà đây là một thành công tuyệt vời về bất động sản, hiếm nơi nào được như vậy. Bởi vậy, có thể nói rằng, đầu tư vào bất động sản có đem lại lợi nhuận về lâu dài, nhưng tỷ lệ lợi nhuận trung bình không vượt quá 5\%/năm sau khi trừ đi lạm phát. (Tất nhiên, cũng có những giai đoạn giá nhà đất lên cơn sốt, tăng giá rất nhanh, nhưng về lâu dài vẫn không vượt $5 \%)$. Đầu tư vào vàng đem lại lợi nhuận bằng 0 , còn đầu tư bất động sản đem lại lợi nhuận dương, là bởi vì bất động sản có những hiệu ứng làm tăng giá trị mà vàng không có: khi một mảnh đất càng được xây dựng lên trên đó, càng có nhiều người muốn đến ở, trở thành trung tâm, thì giá trị của nó càng tăng lên.

Tất nhiên, đầu tư bất động sản cũng có rủi ro, đặc biệt đối với những ai mua vào lúc đang có bong bóng bất động sản. Ví dụ, bong bóng bất động sản ở Tokyo thập kỷ 1980 đẩy giá nhà đất lên đến "tận mây xanh", có những khu có giá đến 1 triệu USD một mét vuông, nhưng rồi giá giảm trong suốt nhiều năm sau đó. Vào năm 2004, giá nhà ở Tokyo 
chỉ còn bằng khoảng 1/10 giá năm 1989, và nhà đất khu tài chính ở Tokyo có giá chỉ còn bằng $1 / 100$ giá lúc đỉnh điểm của nợ(4).

Đối với những ai chưa có nhà ở, thì đầu tư bất động sản bằng việc mua nhà ở có thể là một hình thức đầu tư tốt và ít rủi ro, đặc biệt nếu như giá thuê nhà cao và có thể vay trả góp với lãi suất tương đối thấp (tiền trả góp hàng tháng có khi chỉ bằng tiền thuê nhà, mà lại được có nhà của mình).

Đầu tư vào nhà cho thuê cũng có thể là một hình thức đầu tư hấp dẫn (ngoài chuyện giá đất tăng nếu là chỗ tốt, còn thu được tiền nhà, nên có thể đạt lợi nhuận trung bình trên $5 \% /$ năm sau khi trừ lạm phát). Hình thức đầu tư này tương tự như là đầu tư vào một loại doanh nghiệp (với công việc là kiếm nhà rồi cho thuê). Các hình thức đầu tư như mua đất xây nhà hay sửa nhà cũ để bán lại cũng có thể coi là các hình thức đầu tư vào doanh nghiệp chứ không phải là bất động sản thuần túy.

\subsubsection{Các sản phẩm nợ}

Một loại hình đầu tư rất phổ biến là đầu tư vào các sản phẩm nợ, hay nói cách khác, tức là đi cho vay, trực tiếp hay gián tiếp. Tất nhiên, có nhiều kiểu cho vay khác nhau, và mức độ rủi ro và kỳ vọng lợi nhuận của chúng cũng khác nhau.

- Cho vay trực tiếp cá nhân, hoặc là đầu tư vào các trái phiếu "phế phẩm" (junk bonds, dễ vỡ nợ): nếu mục đích của việc cho vay này là để kiếm lợi nhuận từ lãi suất cao (hơn hẳn lãi suất trung bình), thì đây là hình thức đầu tư mạo hiểm cao, khả năng bị quịt nợ lớn. Những người đi vay với lãi suất rất cao so với trung bình là những người ít đáng tin cậy về tài chính.

- Gửi tiền tiết kiệm ở ngân hàng, hoặc là mua các trái phiếu ngắn hạn (đầu tư trên thị trường tiền tệ): độ an toàn nói chung rất cao, nhưng lợi nhuận thấp. Lãi suất thực tế của các khoản gửi tiết kiệm (sau khi đã trừ đi tỷ lệ lạm phát) và các sản phẩm nợ ngắn hạn trung bình trên thế giới không vượt quá 1-2\%/năm. Ví dụ, theo các thống kê, $1 \$$ đầu tư vào tín phiếu chính phủ ngắn hạn ở Mỹ trong suốt 80 năm từ 1925 đến 2005 sẽ được thành 18,40\$, nhưng do lạm phát nên 10,98\$ năm 2005 chỉ có giá trị bằng $1 \$$ năm 1925(5). Sau khi trừ đi lạm phát, thì tín phiếu ngắn hạn chỉ cho lợi nhuận trung bình là 0,65\%/năm trong 80 năm đó. Ở những nơi đang có nhiều cơ hội phát triển nhanh thì lãi

\footnotetext{
${ }^{(4)} \mathrm{Xem}$ http://en.wikipedia.org/wiki/Japanese_asset_price_bubble

${ }^{(5)}$ Các con số thống kê về thị trường Mỹ giai đoạn 1925-2005 ở đây là lấy từ Ibbotson Associates 2006 Yearbook
} 
suất gửi tiết kiệm cao hơn. Ví dụ, ở Việt Nam những năm 1990 lãi suất thực cho tiền gửi tiết kiệm lên đến 4-5\%/năm (sau khi trừ lạm phát).

- Trái phiếu dài hạn: lãi suất phụ thuộc vào kỳ hạn, và độ rủi ro vỡ nợ của trái phiếu. Các trái phiếu chất lượng thấp (ví dụ như có mức tín nhiệm là BB) thì có độ rủi ro vỡ nợ cao hơn là trái phiếu chất lượng cao (có mức tín nhiệm $\mathrm{A}+$ ), nhưng tính trung bình (đã trừ đi phần vỡ nợ) thì cho lợi nhuận cao hơn là trái phiếu chất lượng cao. Cho đến gần đây, người ta coi rằng trái phiếu chính phủ Mỹ là loại có chất lượng cao nhất. $1 \$$ đầu tư liên tục vào các trái phiếu dài hạn loại này vào năm 1925 sẽ cho $70,85 \$$ vào năm 2005 , tức là cho mức lợi nhuận trung bình hàng năm gần 2,5\% sau khi đã trừ đi lạm phát (hay gần 5,5\% khi chưa trừ đi lạm phát), tốt hơn đáng kể so với các loại cho vay ngắn hạn. Bù lại, trái phiếu dài hạn có rủi ro về biến động giá, đối với những người mua trái phiếu dài hạn nhưng không giữ đến lúc đáo hạn mà chỉ giữ một thời gian ngắn rồi bán đi: như chúng ta đã thấy từ Chương 4 , khi lãi suất tăng thì giá của trái phiếu giảm, và trái phiếu càng dài hạn thì độ giảm càng lớn khi lãi suất tăng. Có những giai đoạn mà giá trái phiếu chính phủ dài hạn có thể giảm trên $25 \%$.

\subsubsection{Cổ phiếu}

Cổ phiếu là một loại hình đầu tư có độ mạo hiểm cao, bởi vì giá cổ phiếu hay giao động mạnh, và có khả năng giảm xuống chỉ còn bằng một phần nhỏ giá lúc trước. Ví dụ, trên thị trường chứng khoán Việt Nam, giá các cổ phiếu giảm trung bình hơn $70 \%$ trong gian đoạn cuối 2007 - đầu 2009. Ở Mỹ, chỉ số Dow Jones Industrial (đại diện cho giá cổ phiếu của 30 công ty lớn vào loại nhất nước Mỹ) cũng có lúc giảm từ 381 xuống còn có 42 trong giai đoạn 1929-1033. Tuy nhiên, nếu tính về lâu dài, thì cổ phiếu lại là một hình thức đầu tư đem lại lợi nhuận cao hơn hẳn so với trái phiếu, và cũng cao hơn so với bất động sản. $1 \$$ đầu tư liên tục vào cổ phiếu của các công ty lớn ở Mỹ năm 1925 sẽ đem lại trung bình là $2657 \$$ vào năm 2005, tức là cho mức lợi nhuận trung bình $7.1 \%$ sau khi đã trừ lạm phát (10.3\% nếu chưa trừ đi lạm phát). Ở Việt Nam, sau nhiều lần thăng trầm, giá cổ phiếu tăng trung bình lên gấp hơn 4 lần trong 11 năm 2000-2011 (chỉ số VNINDEX tăng từ 100 lên trên 400), tức là tăng trung bình quãng 14\%/năm (chưa trừ đi lạm phát), vẫn tốt hơn so với gửi tiết kiệm.

Sở dĩ đầu tư vào cổ phiếu đem lại lợi nhuận trung bình cao về lâu dài, bởi vì đó là đầu tư vào các doanh nghiệp, mà danh nghiệp chính là nơi tạo ra sản phẩm hàng hóa dịch vụ, tạo thêm ra giá trị cho xã hội. Ví dụ, một cái điện thoại di động loại tốt có giá vài 
trăm USD, nhưng chất liệu thô cần thiết để sản xuất ra nó có giá thành rất thấp, giá trị của nó chủ yếu nằm ở công nghệ, tức là sản phẩm chất xám, do các công ty tạo ra. Các doanh nghiệp không ngừng thay đổi, sáng kiến cải tiến, tạo ra công nghệ mới, cách điều hành mới hiệu quả hơn, giá trị mới, và chính vị vậy mà giá trị của chúng tăng lên nhanh.

Nói chung, các công ty chỉ đi vay, khi mà việc vay đó có lợi cho công ty, có nghĩa là khi công ty sử dụng số tiền đi vay đem lại lợi nhuận nhiều hơn là lãi suất phải trả. Do đó, tính trung bình, vốn (equity) của các công ty phải tăng trưởng nhanh hơn là mức lãi suất. Điều này cũng giải thích vì sao đầu tư vào cổ phiếu đem lại lợi nhuận nhiều hơn là đầu tư vào trái phiếu về lâu dài.

Nói chung các doanh nghiệp nhỏ có độ rủi ro tài chính cao hơn là các doanh nghiệp lớn, nhưng cơ hội phát triển của chúng cũng lớn hơn. (Nhiều danh nghiệp lớn nổi tiếng ngày nay xuất phát là từ doanh nghiệp nhỏ, và khi đã lớn đến mức nào đó rồi thì không còn phát triển nhanh được nữa). Một phần bởi vậy mà đầu tư vào các cổ phiếu nhỏ (small-cap stocks, tức là cổ phiếu của các doanh nghiệp nhỏ) cũng có độ rủi ro cao hơn là đầu tư vào các cổ phiếu lớn, nhưng kỳ vọng lợi nhuận về lâu dài cũng cao hơn. $1 \$$ đầu tư liên tục vào các cổ phiếu nhỏ ở Mỹ năm 1925 sẽ đem lại trung bình là 13706 \$ vào năm 2005, thay vì chỉ có $2657 \$$ nếu đầu tư vào các cổ phiếu lớn.

Ghi chú 6.1. Để đầu tư vào doanh nghiệp, không nhất thiết phải mua cổ phiếu, mà còn có cách khác, là xây dựng doanh nghiệp. Cách này khó hơn là cách thứ nhất, và ít người làm được. Những người giầu nhất thế giới thường không phải là những người mua cổ phiếu giỏi, mà là những người xây dựng doanh nghiệp giỏi, tạo ra cổ phiếu bán cho người khác lấy vốn để xây doanh nghiệp. Thị trường chứng khoán có công dụng tạo điều kiện cho những người không biết xây dựng doanh nghiệp cũng có thể được hưởng lợi từ các doanh nghiệp tốt bằng việc đầu tư vào những người biết xây dựng doanh nghiệp. Ở trong sách này chúng ta sẽ không bàn đến việc xây dựng doanh nghiệp, mà chỉ bàn đến việc đầu tư chứng khoán vào các công ty đã có sãn.

\subsubsection{Chứng khoán phái sinh}

Các chứng khoán phái sinh ngày nay đã trở thành công cụ đầu tư yêu thích của rất nhiều người, đặc biệt là các quỹ đầu cơ (hedge funds). Chứng khoán phái sinh có thể được dùng để làm giảm rủi ro của các danh mục đầu tư (và bởi vậy có từ hedge, có nghĩa là hàng rào ngăn chặn rủi ro). Thế nhưng nó cũng có thể được dùng làm đòn bẩy để đầu cơ hòng kiếm lời nhanh chóng. Ví dụ, khi một cổ phiếu tăng 10\%, thì một số loại quyền 
chọn mua (Call) của nó có thể tăng theo những 100\%, nhanh gấp 10 lần so với cổ phiếu, và như vậy đầu tư vào Call trong trường hợp này cho đòn bẩy 10 lần, thắng nhanh gấp 10 lần so với đầu tư vào cổ phiếu. Tuy nhiên, các đòn bẩy trong tài chính luôn là các con dao hai lưỡi: nếu nó làm tăng kỳ vọng lợi nhuận, thì cũng làm tăng độ rủi ro. Các hedge funds thường có độ rủi ro cao hơn nhiều so với các loại hình đầu tư khác, do đòn bẩy tài chính mà họ dùng. Thực tế trên thế giới là có nhiều hedge funds phá sản, trong khi các quỹ đầu tư vào cổ phiếu hay trái phiếu nói chung không phá sản được.

\subsection{Lợi nhuận và lợi nhuận kỳ vọng}

\subsubsection{Các công thức tính lợi nhuận}

Nếu một người đầu tư một khoản tiền (hay tài sản trị giá) $V(0)$ và sau một thời gian $T$ đầu tư đó có (kể tất cả các khoản thu được) trị giá là $V(T)$, thì lợi nhuận của đầu tư này là $V(T)-V(0)$, và tỷ lệ lợi nhuận (rate of return, ROR, hay còn gọi là return on investment, ROI) là

$$
R=\frac{V(T)-V(0)}{V(0)} .
$$

Ghi chú 6.2. Công thức trên là công thức thường được dùng, nhưng nó không tính đến lạm phát. Nếu tính đến lạm phát (để được tỷ lệ lợi nhuận thực tế, sau khi đã trừ đi lạm phát), thì phải thay $V(0)$ bằng $(1+\Pi) V(0)$ trong công thức trên, trong đó $\Pi$ là tỷ lệ lạm phát xảy ra trong thời gian đầu tư, có nghĩa là lượng tiền $(1+\Pi) V(0)$ sau thời gian $T$ chỉ có sức mua bằng lượng tiền $V(0)$ vào thời điểm ban đầu.

Giả sử là quá trình đầu tư gồm nhiều giai đoạn, ví dụ $n$ năm, và sau năm thứ $i$ giá trị của tài khoản đầu tư là $V(i)$, và để đơn giản ta giả sử thêm rằng không có sự rút bớt tiền ra hay bỏ thêm tiền vào tài khoản đầu tư trong quá trình đó. Khi đó tỷ lệ lợi nhuận của năm thứ $i$ là

$$
R(i)=\frac{V(i)-V(i-1)}{V(i-1)},
$$

hay có thể viết là $V(i)=\left(1+R_{i}\right) V_{i-1}$, từ đó suy ra:

$$
V(n)=\prod_{i=1}^{n}\left(1+R_{i}\right) V(0),
$$

có nghĩa là tỷ lệ lợi nhuận của toàn quá trình đầu tư bằng

$$
R(n)=\prod_{i=1}^{n}\left(1+R_{i}\right)-1 .
$$


Con số

$$
\bar{R}=(1+R(n))^{1 / n}-1=\left(\prod_{i=1}^{n}\left(1+R_{i}\right)\right)^{1 / n}-1
$$

được gọi là tỷ lệ lợi nhuận trung bình hàng năm (hay trên một giai đoạn) của quá trình đầu tư $n$ năm (hay $n$ giai đoạn) với tỷ lệ lợi nhuận các năm (hay các giai đoạn) là $R_{i}(i=1, \ldots, n)$. Ý nghĩa của nó là, nếu như giai đoạn nào cũng có tỷ lệ lợi nhuận đúng bằng $\bar{R}$, thì tỷ lệ lợi nhuận sau $n$ giai đoạn sẽ đúng bằng $R(n)$. Trong trường hợp tính theo năm, con số $\bar{R}$ còn được gọi theo tiếng Anh là CAGR (compound annual growth rate).

Chú ý rằng, tỷ lệ lợi nhuận trung bình $\bar{R}$ không phải là trung bình cộng của các con số $R_{1}, \ldots, R_{n}$, mà nói chung nhỏ hơn trung bình cộng. (Nếu quỹ đầu tư nào đó quảng cáo lợi nhuận trung bình hàng năm bằng cách tính trung bình cộng, thì là thiếu trung thực!). Ví dụ, nếu đầu tư 2 năm, năm đầu có tỷ lệ lợi nhuận 100\% (tăng giá trị lên gấp đôi), và năm thứ hai có tỷ lệ lợi nhuận $-50 \%$ (giảm giá trị đi một nửa), thì lợi nhuận sau hai năm là bằng 0 , trong khi trung bình cộng của tỷ lệ lợi nhuận hàng năm là $+25 \%$.

Trong trường hợp mà danh mục đầu tư gồm có nhiều khoản đầu tư khác nhau, thì tỷ lệ lợi nhuận của toàn danh mục bằng trung bình cộng có trọng số của các tỷ lệ lợi nhuận của các khoản đầu tư trong đó: giả sử ta có một danh mục đầu tư gồm $m$ khoản đầu tư có giá trị $V_{1}(0), \ldots V_{m}(0)$ tương ứng tại thời điểm ban đầu, và tổng giá trị của danh mục là:

$$
V(0)=\sum_{j=1}^{m} V_{j}(0)
$$

Khi đó

$$
w_{j}=\frac{V_{j}(0)}{V(0)}
$$

được gọi là tỷ trọng (weight) của khoản đầu tư thứ $j$ trong danh mục. Nếu $R_{j}$ là tỷ lệ lợi nhuận của khoản đầu tư thứ $j$, và $R$ là tỷ lệ lợi nhuận của toàn danh mục đầu tư (tại cùng một thời điểm $T$ nào đó), thì ta có:

$$
R=\sum_{j=1}^{m} w_{j} R_{j}
$$

Bài tập 6.1. Hãy chứng minh công thức trên. 


\subsubsection{Lợi nhuận kỳ vọng}

Đối với các quá trình đầu tư đã xảy ra, nhà đầu tư có thể tính được là đã đạt lợi nhuận bằng bao nhiêu. Nhưng đối với các quá trình đầu tư đang hoặc sẽ xảy ra, nói chung không thể biết chính xác được lợi nhuận cho đầu tư đó vào một thời điểm trong tương lai sẽ là bao nhiêu, mà nhà đầu tư chỉ có thể dùng các cách khác nhau để ước lượng xem kỳ vọng lợi nhuận sẽ bằng bao nhiêu, chẳng hạn dựa trên số liệu lịch sử, hoặc là dựa trên các mô hình phân tích nào đó.

Vi du 6.1. Thống kê thị trường chứng khoán Mỹ trong vòng 80 năm 1925-2005 cho thấy, tỷ lệ lợi nhuận trung bình của việc đầu tư vào cổ phiếu là $10.3 \% /$ năm (chưa trừ đi lạm phát), tuy rằng có những giai đoạn thị trường đi xuống. Dựa vào con số đó, người ta cũng có thể kỳ vọng rằng, lợi nhuận trung bình của việc đầu tư vào cổ phiếu ở Mỹ trong những năm tới cũng sẽ đạt quãng 10\%/năm (hay 7\%/năm sau khi trừ đi lạm phát). Tương tự như vậy, dựa vào các con số thống kê trên thị trường Việt Nam trong giai đoạn 2000-2011, người ta cũng có thể kỳ vọng rằng lợi nhuận trung bình cho đầu tư cổ phiếu ở Việt Nam sẽ đạt quãng 14\%/năm (chưa trừ lạm phát) trong những năm sau đó.

Chú ý rằng, các kết luận thống kê mà chỉ dựa trên ít số liệu thì không đáng tin cậy (trong xác suất thống kê người ta gọi hiện tượng đó là luật số nhỏ ). Ví dụ, các nhà đầu tư nhìn thấy cổ phiếu đi lên rất nhanh, trên 40\%/năm, trong vòng 2 năm liền, mà vội kết luận là nó sẽ đi lên nhanh tiếp như vậy trong năm tiếp theo, thì sẽ rất dễ bị thất vọng. Đối với các quỹ đầu tư cũng vậy. Một hedge fund mà dùng một số chiến thuật đòn bẩy nào đó, có thể đem lại tỷ lệ lợi nhuận rất cao trong vài năm khi gặp điều kiện thuận lợi, nhưng điều đó không chứng tỏ là chiến lược của hedge fund đó sẽ cho lợi nhuận trung bình cao như vậy, mà có thể là đến năm sau khi gặp khó khăn thì hedge fund đó sẽ thua lỗ nặng hay thậm chí phá sản.

Vi du 6.2. Một xu hướng thế giới vào nửa đầu thế kỷ 21 là phát triển năng lượng tái tạo được (renewable energy), đặc biệt là năng lượng mặt trời, để thay thế cho các nguồn năng lượng hóa thạch (như dầu mỏ, than đá) vừa cạn kiệt nhanh vừa hại môi trường. Dựa trên các số liệu dự đoán về sự phát triển các nhà máy điện mặt trời trên thế giới, người ta có thể ước lượng rằng đầu tư cổ phiếu vào các công ty lớn chuyên về sản xuất và lắp đặt điện mặt trời sẽ mang lại lợi nhuận trung bình trên 20\%/năm trong giai đoạn 2010-2020, cao hơn so với lợi nhuận trung bình của các cổ phiếu khác.

Một cách ước lượng lợi nhuận kỳ vọng, là xây dựng nhiều kịch bản khác nhau, ước lượng xác suất xảy ra của mỗi kịch bản và tỷ lệ lợi nhuận trong trường hợp đó xảy ra, rồi lấy 
trung bình có trọng theo xác suất. Giả sử ta xây dựng được không gian $\Omega=\left\{\omega_{1}, \ldots, \omega_{k}\right\}$ các kịch bản $\omega_{1}, \ldots, \omega_{k}$ có thể xảy ra, với các xác suất xảy ra tương ứng là $P\left(\omega_{i}\right)=p_{i}$ $\left(\sum_{i=1}^{k} p_{i}=1\right)$, và ước lượng tỷ lệ lợi nhuận khi mà kịch bản thứ $i$ xảy ra là $R_{i}$. Khi đó kỳ vọng tỷ lệ lợi nhuận sẽ là:

$$
\mathbb{E}(R)=\sum_{i=1}^{k} p_{i} R_{i}
$$

(Chữ $\mathbb{E}$ trong công thức trên là để chỉ kỳ vọng, khi ta coi tỷ lệ lợi nhuận $R$ như là một biến ngẫu nhiên chưa xác định được).

Ví du 6.3. Giả sử một hãng dược phẩm bỏ 300 triệu $\$$ dể đầu tư vào nghiên cứu cho ra một loại thuốc giảm đau mới, và để cho đơn giản ta giả sử rằng có 3 kịch bản có thể xảy ra:

1) Nghiên cứu không thành công, mất toàn bộ tiền. Xác suất của kịch bản này là $65 \%$.

2) Nghiên cứu thành công, nhưng không phải là thuốc có hiệu quả cao lắm. Giá trị của thuốc nghiên cứu được là 600 triệu $\$$. Xác suất của kịch bản này là $25 \%$.

3) Thuốc rất tốt, có giá trị 3 tỷ $\$$. Xác suất của kịch bản này là $10 \%$

Kịch bản đầu tiên có tỷ lệ lợi nhuận là $R_{1}=-1$ (mất toàn bộ vốn đầu tư); kịch bản thứ hai có tỷ lệ lợi nhuận là $(600-300) / 300=1$; kịch bản thứ ba có tỷ lệ lợi nhuận là $(3000-300) / 300=9$. Tính tổng cộng lại, ta được kỳ vọng lợi nhuận là $\mathbb{E}(R)=$ $65 \% \times(-1)+25 \% \times 1+10 \% \times 9=50 \%$.

Nói một cách tổng quát hơn, nếu ta giả sử $(\Omega, \mathcal{F}, P)$ là không gian xác suất tất cả các tình huống có thể xảy ra đối với một danh mục đầu tư, và $R:(\Omega, \mathcal{F}, P) \rightarrow \mathbb{R}$ là biến ngẫu nhiên tỷ lệ lợi nhuận theo các tình huống xảy ra, thì kỳ vọng lợi nhuận của danh mục đầu tư chính là giá trị kỳ vọng của biến ngẫu nhiên $R$ :

$$
\mathbb{E}(R)=\int_{\Omega} R d P
$$

Vấn đề trong thực tế, là làm sao xây dựng được mô hình không gian xác suất $(\Omega, \mathcal{F}, P)$ hợp lý và có thể tính toán được với nó, và biến ngẫu nhiên $R$ hợp lý trên đó, dựa trên các mô hình phân tích khác nhau.

Ghi chú 6.3. Một vấn đề quan trọng khi tính toán với kỳ vọng là phải làm sao đảm bảo tính khách quan và nhất quán của nó. Ví dụ, nếu công ty nước giải khát nào cũng kỳ vọng tăng trưởng 10\%/năm, trong khi toàn bộ thị trường nước giải khát thế giới chỉ có kỳ vọng tăng trưởng $5 \% / n a ̆ m$, thì như vậy là không nhất quán, và điều đó có nghĩa là có thể nhiều công ty có kỳ vọng tăng trưởng chủ quan, thiếu thực tế. Tương tự như vậy, các 
con bạc thường có kỳ vọng lợi nhuận chủ quan là số dương, trong khi kỳ vọng lợi nhuận khách quan là số âm.

\subsection{Hàm thỏa dụng}

\subsubsection{Khái niệm hàm thỏa dụng}

Giả sử có hai chiến lược đầu tư $A$ và $B$ khác nhau cho một tài khoản đầu tư cho một giai đoạn nào đó. Chiến lược $A$ sẽ cho tỷ lệ lợi nhuận cố định bằng $5 \%$ dù bất cứ tình huống nào xảy ra. Chiến lược $B$ cho tỷ lệ lợi nhuận phụ thuộc vào tình huống: $+25 \%$ nếu tình huống tốt xảy ra, $-10 \%$ nếu tình huống xấu xảy ra, và giả sử là xác suất để mỗi tình huống xảy ra là $50 \%$. Khi đó, tỷ lệ lợi nhuận kỳ vọng của chiến lược $B$ sẽ là $(25 \%-10 \%) / 2=7.5 \%$, cao hơn là kỳ vọng lợi nhuận của $A$. Thế nhưng, một nhà đầu tư có thể sẽ thích chiến lược $A$ hơn chiến lược $B$, vì $A$ chắc chắn đem lại lợi nhuận còn $B$ thì bấp bênh, có thể gây lỗ. Khi đó, ta nói rằng, đối với nhà đầu tư, chiến lược $A$ có độ thỏa dụng (utility) cao hơn là chiến lược $B$. Độ thỏa dụng không chỉ phụ thuộc vào kỳ vọng lợi nhuận, mà còn phụ thuộc vào độ chắc chắn hay bấp bênh của các đầu tư.

Nói một cách tổng quát hơn, giả sử ta có không gian xác suất $(\Omega, \mathcal{F}, P)$ tất cả các tình huống có thể xảy ra. Ứng với mỗi chiến lược đầu tư $A$ có một biến ngẫu nhiên $R_{A}:(\Omega, \mathcal{F}, P) \rightarrow \mathbb{R}$ là tỷ lệ lợi nhuận sẽ đạt được theo chiến lược đó trong các tình huống. Gọi $F(\Omega, \mathcal{F}, P)$ là không gian tất cả các biến ngẫu nhiên (tức là các hàm đo được) trên $(\Omega, \mathcal{F}, P)$.

Định nghĩa 6.1. Một hàm số

$$
U: F(\Omega, \mathcal{F}, P) \rightarrow \mathbb{R} \cup\{-\infty\}
$$

được gọi là hàm thỏa dụng (utility function), hay còn gọi là hàm tiện ích, nếu nó thỏa mãn tính chất đơn điệu tăng sau: nếu $R_{A}$ và $R_{B}$ là hai biến ngẫu nhiên trên $(\Omega, \mathcal{F}, P)$ sao cho $R_{A} \geq R_{B}$ hầu khăp mọi nơi, thì ta cũng có $U\left(R_{A}\right) \geq U\left(R_{B}\right)$. Độ thỏa dụng, tính theo $U$, của một chiến lược dầu tư $A$ với biến tỷ lệ kỳ vọng lợi nhuận $R_{A}$, là $U\left(R_{A}\right)$.

Ý nghĩa của hàm thỏa dụng là: nếu hai chiến lược đầu tư $A$ và $B$ có $U\left(R_{A}\right)>U\left(R_{B}\right)$ thì nhà đầu tư sẽ thích $A$ hơn $B$. Nếu như chiến lược $A$ luôn cho lợi nhuận cao hơn chiến lược $B$ dù tình huống nào xảy ra, thì tất nhiên nhà đầu tư sẽ thích $A$ hơn $B$, tức là độ thỏa dụng của $A$ cao hơn của $B$. Đây chính là tính chất đơn điệu tăng của hàm thỏa 
dụng. Nếu độ thỏa dụng của một chiến lược nào đó là $-\infty$, thì tức là nhà đầu tư sẽ không bao giờ chấp nhận nó.

Chú ý rằng, hàm thỏa dụng không duy nhất, mà phụ thuộc vào sở thích của nhà đầu tư. Với hai chiến lược $A$ và $B$ có các biến ngẫu nhiên tỷ lệ lợi nhuận $R_{A}$ và $R_{B}$ cho trước, nhà đầu tư này có thể thích $A$ hơn $B$ trong khi nhà đầu tư khác lại thích $B$ hơn $A$. Chúng ta không thể biết được hàm thỏa dụng của mỗi nhà đầu tư cụ thể ra sao, nhưng có thể đưa ra một số hàm thỏa dụng hay được dùng, và giả sử là nhà đầu tư sẽ dùng một trong các hàm thỏa dụng như vậy khi lựa chọn chiến lược đầu tư.

Ghi chú 6.4. Mục đích chính của hàm thỏa dụng là để so sánh giữa các lựa chọn. Bởi vậy nếu $U, V$ là hai hàm thỏa dụng khác nhau thỏa mãn đẳng thức $U=f(V)$, trong đó $f$ là một hàm số thực đơn điệu tăng cho trước nào đó (ví dụ như $V=U+1$ hay $V=U^{3}$ ), thì hai hàm thỏa dụng $U$ và $V$ này có thể được coi là tương đương với nhau, vì chúng cho ra các lựa chọn giống nhau.

Nếu $U$ là một hàm thỏa dụng, thì nó cũng được xác định trên các hằng số, bởi vì mọi hằng số đều có thể coi là một biến ngẫu nhiên với giá trị là hằng số đó. Trên tập các hằng số (tức là tập số thực), $U$ cũng có tính đơn điệu tăng. Ngược lại, giả sử có một hàm đơn điệu tăng:

$$
u: \mathbb{R} \rightarrow \mathbb{R} \cup\{-\infty\} .
$$

Khi đó, ta có thể xây dựng một hàm thỏa dụng $U$ từ $u$ theo công thức giá trị kỳ vọng:

$$
U\left(R_{A}\right)=\mathbb{E}\left(u\left(R_{A}\right)\right)=\int_{\Omega} u\left(R_{A}\right) d P
$$

Các hàm thỏa dụng được xây dựng theo công thức trên được gọi là hàm thỏa dụng cộng tính, và giá trị của nó còn được gọi là độ thỏa dụng kỳ vọng (theo $u$ ). Hàm số $u$ ở đây cũng được gọi là hàm thỏa dụng. Loại hàm thỏa dụng cộng tính là loại hàm thỏa dụng phổ biến nhất trong tài chính. Theo một định lý của Von Neumann và Morgenstern từ năm $19444^{(6)}$, nếu một hàm thỏa dụng $U$ thỏa mãn một số tiên đề nào đó, thì nó sẽ là cộng tính, tức là tồn tại một hàm số $u$ thỏa mãn công thức phía trên.

\subsubsection{Hàm thỏa dụng Bernoulli}

Một trong các hàm thỏa dụng hay được dùng nhất là hàm thỏa dụng Bernoulli, do nhà toán học Daniel Bernoulli đề xướng từ năm 1838 trong lời giải cho "nghịch lý St.

${ }^{(6)}$ Xem http://en.wikipedia.org/wiki/Von_Neumann-Morgenstern_utility_theorem 
Petersbourg', (7),

Định nghĩa 6.2. Hàm thỏa dụng Bernoulli là hàm thỏa dụng cộng tính cho bởi hàm số

$$
u_{\text {Bernoulli }}(x)=\ln (1+x)
$$

có nghĩa là

$$
U_{\text {Bernoulli }}\left(R_{A}\right)=\int_{\Omega} \ln \left(1+R_{A}\right) d P
$$

Công thức trong định nghĩa trên được viết cho tỷ lệ lợi nhuận, với giả sử là tỷ lệ lợi nhuận luôn lớn hơn hoặc bằng -1 (tức là giả sử trường hợp xấu nhất thì mất $100 \%$ tiền đầu tư chứ không mất hơn vậy). Nếu $R_{A}$ có nhận giá trị nhỏ hơn -1 , thì ta coi là thỏa dụng Bernoulli của chiến lược $A$ bằng âm vô cùng.

Nếu ta coi là số tiền bỏ ra đầu tư là $V(0)=1$ (tính theo đơn vị nào đó), thì $V_{A}=1+R_{A}$ chính là tổng số tiền thu lại được từ đầu tư theo chiến lược $A$, và do đó ta cũng có thể viết công thức hàm thỏa dụng Bernoulli như sau:

$$
U_{\text {Bernoulli }}(A)=\mathbb{E}\left(\ln V_{A}\right)=\int_{\Omega} \ln \left(V_{A}\right) d P
$$

Nói cách khác, độ thỏa dụng Bernoulli bằng kỳ vọng của log của trị giá của tài sản. Bởi vậy, hàm thỏa dụng Bernoulli còn được gọi là hàm thỏa dụng log.

Theo hàm khả dụng Bernoulli, thì sự chênh lệch về độ thỏa mãn về tài chính giữa một người có 1 tỷ USD và một người có 1 triệu USD, cũng chỉ bằng sự chênh lệch về độ thỏa mãn về tài chính giữa một người có 1 triệu USD và một người có 1 nghìn USD, vì trong cả hai trường hợp thì người thứ nhất đều có tiền nhiều gấp 10 lần người thứ hai, và có độ chênh lệch về thỏa dụng Bernoulli so với người thứ hai là ln 10.

Một tính chất tự nhiên rất quan trọng của hàm thỏa dụng Bernoulli là tính cộng tính theo thời gian, tức là độ thỏa dụng của một đầu tư trong một giai đoạn từ $T_{1}$ đến $T_{2}$ cộng với độ thỏa dụng trong giai đoạn từ $T_{2}$ đến $T_{3}$ thì bằng độ thỏa dụng trong giai đoạn từ $T_{1}$ đến $T_{3}$. Chỉ có các hàm thỏa dụng dạng log mới có tính cộng tính theo thời gian như vậy.

\footnotetext{
(7)Xem http://en.wikipedia.org/wiki/St._Petersburg_paradox. Theo "nghịch lý" này, thì có một trò chơi ở St. Petersbourg mà phải mua vé mới được vào chơi, và về lý thuyết thì kỳ vọng lợi nhuận của trò chơi này là bằng vô cùng, nhưng người ta vẫn không sẵn sàng trả tiền vé cao quá một số tiền nào đó.
} 


\subsubsection{Tính lõm của hàm thỏa dụng}

Giả sử $U$ là một hàm thỏa dụng cộng tính cho bởi hàm số $u$, và $A$ là một chiến lược (hay danh mục) đầu tư nào đó. Vì $u$ là hàm đơn điệu tăng nên nói chung sẽ tồn tại duy nhất một số $\hat{R}_{A}$ sao cho

$$
U\left(R_{A}\right)=u\left(\hat{R}_{A}\right)
$$

có nghĩa là, một chiến lược đầu tư cho tỷ lệ lợi nhuận cố định bằng $\hat{R}_{A}$ thì sẽ có độ thỏa dụng bằng chiến lược $A$.

Các nhà đầu tư nói chung thường không ưa mạo hiểm. Có nghĩa là, một đầu tư có lợi nhuận bấp bênh thì phải có mức kỳ vọng lợi nhuận cao hơn so với là một đầu tư có mức lợi nhuận cố định, thì mới đem lại cho họ độ thỏa dụng bằng độ thỏa dụng của đầu tư có mức lợi nhuận cố định:

$$
\mathbb{E}\left(R_{A}\right) \geq \hat{R}_{A}
$$

Phần chênh lệch $\mathbb{E}\left(R_{A}\right)-\hat{R}_{A}$ có thể được gọi là phí mạo hiểm (risk premium) mà nhà đầu tư nhận được (hay không nhận được) nếu chấp nhận (hay không chấp nhận) đầu tư có mạo hiểm (tức là có lợi nhuận bấp bênh).

Từ bất đẳng thức trên, ta có $u\left(\mathbb{E}\left(R_{A}\right)\right) \geq u\left(\hat{R}_{A}\right)=U\left(R_{A}\right)=\mathbb{E}\left(u\left(R_{A}\right)\right)$. Bất đẳng thức

$$
u\left(\mathbb{E}\left(R_{A}\right)\right) \geq \mathbb{E}\left(u\left(R_{A}\right)\right)
$$

được gọi là bất đẳng thức Jensen, và nó được thỏa mãn với mọi biến ngẫu nhiên $R_{A}$ khi và chỉ khi hàm số $u$ là hàm lõm. (Trong trường hợp mà $u$ là hàm khả vi bậc hai, thì nó là hàm lõm khi và chỉ khi đạo hàm bậc hai của nó nhỏ hơn hoặc bằng 0 ).

Khi $u$ là hàm lõm, thì với mọi $0 \leq \lambda \leq 1$ và mọi biến ngẫu nhiên $R_{A}$ và $R_{B}$, ta cũng có

$$
U\left(\lambda R_{A}+(1-\lambda) R_{B}\right) \geq \lambda U\left(R_{A}\right)+(1-\lambda) U\left(R_{B}\right)
$$

Bất đẳng thức trên được gọi là tính lõm của hàm thỏa dụng $U$. Nó ứng với sự không ưa mạo hiểm (risk aversion) của các nhà đầu tư. Bởi vậy, tuy trong định nghĩa hàm thỏa dụng không có tính lõm, nhưng nói chung các hàm thỏa dụng được dùng trong tài chính đều có tính lõm.

Vi du 6.4. Các hàm $\ln (1+x), \sqrt{1+x}, 1-\exp (-1-x)($ cho $x \geq-1)$ là các hàm số đơn điệu tăng và lõm, và các hàm thỏa dụng cộng tính sinh bởi chúng thỏa mãn tính lõm. 


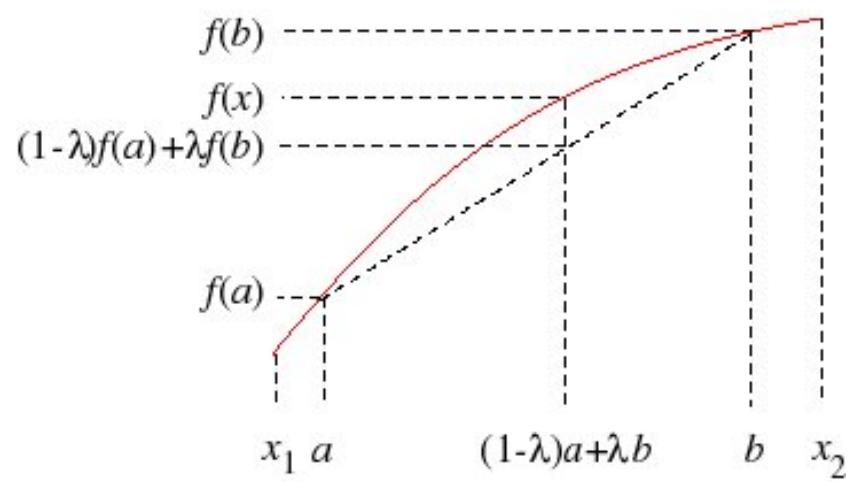

Hình 6.2: Đồ thị một hàm số lõm đơn điệu tăng

\subsection{Các thước đo rủi ro}

Rủi ro là khái niệm về khả năng xảy ra những tình huống xấu hơn dự kiến. Đối với đầu tư, đó có thể là khả năng bị mất tiền (rủi ro tuyệt đối), hay là được tiền nhưng thấp hơn mong đợi hay không được bằng một mức tham chiếu nào đó (rủi ro tương đối). Chúng ta có thể xét rủi ro tương đối tương tự như là rủi ro tuyệt đối, bằng cách chỉ tính lợi nhuận thặng dư (bằng lợi nhuận trừ đi mức lợi nhuận tham chiếu) thay vì tính tổng lợi nhuận. Ngược lại, khi ta có một thước đo rủi ro tương đối và biết được mức lợi nhuận tham chiếu, thì nó cũng cho ta một ước lượng về mức độ rủi ro tuyệt đối.

Ở trong mục này chúng ta sẽ điểm qua một số thước đo rủi ro "cổ điển" hay được dùng. Bạn đọc muốn tìm hiểu sâu thêm về các thước đo rủi ro có thể tham khảo các tài liệu như [17, 25]

\subsubsection{Phương sai và độ lệch chuẩn}

Gọi $V_{A}=\left(1+R_{A}\right) V(0):(\Omega, P) \rightarrow \mathbb{R}$ là biến giá trị tài sản của một danh mục đầu tư (hay chiến lược) $A$ nào đó, với giá trị ban đầu là $V(0)$, biến tỷ lệ lợi nhuận là $R_{A}$, và $(\Omega, P)$ là không gian xác suất các tình huống có thể xảy ra. Khi đó độ lệch chuẩn $\sigma$ của $V_{A}$, bằng căn bậc hai của phương sai var, định nghĩa theo công thức độ lệch chuẩn thông thường trong xác suất thống kê:

$$
\sigma\left(V_{A}\right)=\sqrt{\operatorname{var}\left(V_{A}\right)}=\sqrt{\mathbb{E}\left(\left(V_{A}-\mathbb{E}\left(V_{A}\right)\right)^{2}\right)}=\sqrt{\mathbb{E}\left(V_{A}^{2}\right)-\left(\mathbb{E}\left(V_{A}\right)\right)^{2}},
$$

hay được dùng như là một thước đo rủi ro của đầu tư $A$.

Thay vì tính độ lệch chuẩn của giá trị tài sản, ta cũng có thể tính độ lệch chuẩn của 
tỷ lệ lợi nhuận:

$$
\sigma\left(R_{A}\right)=\sqrt{\operatorname{var}\left(R_{A}\right)}=\sqrt{\mathbb{E}\left(\left(R_{A}-\mathbb{E}\left(R_{A}\right)\right)^{2}\right)} .
$$

Hai độ lệch chuẩn này liên hệ với nhau theo công thức đơn giản:

$$
\sigma\left(V_{A}\right)=\sigma\left(R_{A}\right) V(0) .
$$

Độ lệch chuẩn là một thước đo rủi ro tương đối, vì kể cả khi đầu tư không có khả năng bị thua lỗ (biến tỷ lệ lợi nhuận luôn có giá trị dương), thì độ lệch chuẩn vẫn có thể là số dương. Mức lợi nhuận tham chiếu ở đây chính là mức lợi nhuận kỳ vọng của bản thân đầu tư (chứ không phải là một mức cố định có sẵn, hay là một mức tham chiếu nào đó của thị trường). Bởi vậy, việc dùng độ lệch chuẩn làm thước đo rủi ro tạo ra một nghịch lý là: có thể có 2 chiến lược đầu tư khác nhau $A$ và $B$, sau cho $A$ luôn đem lại lợi nhuận cao hơn $B$ dù bất cứ tình huống nào xảy ra (và như vậy mọi nhà đầu tư có lý trí phải thích $A$ hơn $B$ ), thế nhưng độ lệch chuẩn tạo bởi $A$ lớn hơn độ lệch chuẩn tạo bởi $B$, và nếu chỉ tính theo độ lệch chuẩn thì $A$ lại được coi là có rủi ro cao hơn $B$ !

Vi du 6.5. Giả sử có hai tính huống tốt và xấu, với xác suất mỗi tình huống là $50 \%$. Chiến lược đầu tư $A$ cho lợi nhuận $50 \%$ trong trường hợp tốt, $0 \%$ trong trường hợp xấu. Chiến lược đầu tư $B$ cho lợi nhuận $7 \%$ trong trường hợp tốt, -7\% trong trường hợp xấu. Khi đó $A$ hiển nhiên là tốt hơn $B$. Thế nhưng độ lệch chuẩn của $B$ chỉ có $7 \%$, trong khi độ lệch chuẩn của $A$ những $25 \%$.

Tuy ví dụ trên cho thấy, độ lệch chuẩn là một thước đo rất thiếu chính xác của rủi ro, nhưng nó vẫn là một thước đo rủi ro được ưa chuộng trong các lý thuyết tài chính, vì một số lý do: Thứ nhất là nó dễ ước lượng (dựa trên số liệu lịch sử), đặc biệt trong thời kỳ mà công suất máy tính còn yếu và người ta phải dựa trên những thứ đòi hỏi ít thời gian sử dụng máy tính. Thứ hai là nó ứng với khái niệm ddộ giao động (volatility) của giá cả, trong các mô hình biến động giá cả của chứng khoán. Với giả sử là giá cả các chứng khoán tuân theo phân bố normal hay log-normal, thì phân bố đó được xác định bởi hai yếu tố: kỳ vọng và độ lệch chuẩn. Chính vì vậy mà độ lệch chuẩn đóng vai trò quan trọng trong các công thức tính toán ước lượng trong tài chính. (Trên thực tế thì phân bố xác suất của giá cả thường "nặng đuôi" hơn là phân bố log-normal, do có những tình huống có thể xảy ra khiến cho giá nhảy đột biến lên rất cao hoặc xuống rất thấp, nhưng có thể tạm coi là phân bố log-normal là xấp xỉ gần đúng của phân bố thực tế, với độ sai số tạm chấp nhận được).

Một cải tiến của độ lệch chuẩn và phương sai (phương sai chẳng qua là bình phương của độ lệch chuẩn), là khái niệm nửa phương sai (semi-variance). Định nghĩa của nửa 
phương sai svar tương tự như định nghĩa của phương sai var, nhưng chỉ tính đến những phần thấp hơn trung bình mà không tính đến những phần cao hơn trung bình:

$$
\operatorname{svar}\left(V_{A}\right)=\mathbb{E}\left\{\min \left(V_{A}-\mathbb{E}\left(V_{A}\right), 0\right)^{2}\right\}
$$

Theo Markowitz, người được giải Nobel kinh tế vì lý thuyết danh mục đầu tư, thì ông ta đã áp dụng nửa phương sai vào tính rủi ro cho một số tập đoán đầu tư từ những năm 1990 (xem Mục 2.3 của [1]). Nửa phương sai là một thước đo tốt hơn so với phương sai trong những tình huống mà phân phối xác suất của biến lợi nhuận không có tính đối xứng. Thế nhưng nghịch lý lúc trước về "đầu tư luôn cho kết quả tốt hơn lại bị coi là có rủi ro cao hơn" vẫn tồn tại khi sử dụng nửa phương sai làm thước đo rủi ro.

\subsubsection{Rủi ro thâm hụt (shortfall risk)}

Rủi ro thâm hụt là một khái niệm khá tự nhiên và quan trọng, nhưng nó mới chỉ được giới tài chính nghiên cứu một cách có hệ thống từ cuối những năm 1980. Bạn đọc muốn tìm hiểu kỹ thêm có thể xem chẳng hạn [1] và các bài báo được trích dẫn trong đó.

Ý tưởng như sau: Trên thị trường có những chiến lược đầu tư đơn giản và phổ biến thường được dùng làm tham chiếu. Ví dụ như chiến lược gửi tiết kiệm với lãi suất cố định, hay chiến lược đầu tư theo một chỉ số chứng khoán nào đó. Ta sẽ gọi một chiến lược như vậy là chiến lược thị trường $M$. Nhà đầu tư, khi xem xét một chiến lược đầu tư $A$ nào đó, sẽ đem nó so sánh với $M$. Nhà đầu tư biết rằng, ít ra có thể đạt được tỷ lệ lợi nhuận của $M$, và sẽ chỉ lựa chọn đầu tư vào $A$, nếu $A$ đem lại hiệu quả tốt hơn $M$. Những tình huống mà trong đó $A$ đem lại lợi nhuận thấp hơn so với $M, R_{A}<R_{M}$, thì được gọi là những tình huống rủi ro thâm hụt.

Giả sử $f: \mathbb{R}_{+} \rightarrow \mathbb{R}_{+}$là một hàm số liên tục đơn điệu tăng với $f(0)=0$ (ví dụ $f(x)=x^{n}$ trong đó $n$ là một số dương nào đó). Khi đó, độ rủi ro thâm hụt (về tỷ lệ lợi nhuận) của $A$ theo tham chiếu $M$ và theo hàm $f$ được định nghĩa là:

$$
\mathcal{S}_{f, M}(A)=f^{-1}\left(\mathbb{E}\left(f\left(\max \left(0, R_{M}-R_{A}\right)\right)\right)\right)
$$

Ví dụ, đặt $f(x)=x^{2}$, và cố định một chiến lược thị trường $M$, ta được thước đo rủi ro thâm hụt sau:

$$
\mathcal{S}(A)=\sqrt{\mathbb{E}\left(\max \left(0, R_{M}-R_{A}\right)^{2}\right)} .
$$

Thước đo rủi ro thâm hụt trên tương tự như là độ nửa lệch chuẩn (căn bậc hai của 
nửa phương sai), nhưng nó khác ở chỗ ta dùng $R_{M}$ thay vì kỳ vọng lợi nhuận của $A$ làm tham chiếu. Bởi vậy, thước đo rủi ro thâm hụt không bị dẫn đến nghịch lý về việc chiến lược tốt hơn lại bị coi là có rủi ro cao hơn, như là trường hợp của phương sai hay nửa phương sai: dễ thấy rằng, nếu chiến lược $A$ luôn cho lợi nhuận cao hơn chiến lược $B$, thì độ rủi ro thâm hụt của $A$ thấp hơn của $B$ (tính theo bất kỳ tham chiếu nào và bất kỳ hàm $f$ nào).

\subsubsection{Giá trị chịu rủi ro (value at risk)}

Khái niệm value at risk (VaR) rất phổ biến trong giới tài chính, đặc biệt kể từ khi nó được đưa vào trụ cột đầu tiên (một trong ba trụ cột) của Công ước Quốc tế Basel II(8) về quản trị rủi ro trong các ngân hàng. Chúng tôi chưa được biết thuật ngữ tiếng Việt tương ứng, và tạm dịch thành giá trị chịu rủi ro.

Ý tưởng chung là, một cá nhân hay tổ chức có thể chấp nhận mất tiền, nhưng không thể chấp nhận mất quá một mức nào đấy, vì để mất quá mức đó thì sẽ có ảnh hưởng rất xấu, rất khó hồi phục lại, hoặc thậm chí sẽ phá sản. Cá nhân hay tổ chức đó muốn rằng, với độ tin tưởng cao, ví dụ 99\%, số tiền bị mất sẽ không vượt quá ngưỡng nào đó. Ngưỡng đó là ngưỡng mà VaR không được vượt quá.

Định nghĩa hình thức của VaR như sau: giả sử có một tài khoản trị giá ban đầu là $V(0)$, và giả sử $\alpha$ là một số dương cho trước rất nhỏ nào đó, ví dụ $\alpha=1 \%$, và giả sử $T$ là một thời điểm cho trước nào đó trong tương lai. Gọi $V(T)$ là giá trị của tài khoản tại điểm $T$, được xét như là một biến ngẫu nhiên tại thời điểm ban đầu. Gọi $W$ là số thực sao cho xác suất để $V(T)<W$ bằng $\alpha$, có nghĩa là ta có thể tin rằng giá trị của $V(T)$ sẽ không nhỏ hơn $W$, với độ tin tưởng (confidence) bằng $1-\alpha$. Khi đó hiệu $V(0)-W$ (với giả sử rằng hiệu này là số dương) được gọi là value at risk $\mathrm{VaR}_{\alpha}$ của tài khoản, với độ tin tưởng bằng $1-\alpha$.

Có nhiều phương pháp để ước lượng VaR, ví dụ như: dùng các mô hình mô phỏng ngẫu nhiên về thị trường, phương pháp Monte-Carlo, sử dụng số liệu lịch sử với RiskMetric: (9). v.v. Tuy nhiên, Việc sử dụng VaR trong thực tế gặp phải những khó khăn lớn sau:

1) Tuy định nghĩa VaR tương đối dễ dàng, nhưng ước lượng được nó một cách đang tin lại là việc rất khó (bất kể dùng phương pháp nào), đặc biệt là với các chứng khoán phái sinh.

${ }^{(8)}$ Xem chẳng hạn: http://en.wikipedia.org/wiki/Basel_II

${ }^{(9)}$ Xem: http://en.wikipedia.org/wiki/RiskMetrics 
2) VaR chỉ cho ta biết là trong số $1-\alpha$ các tình huống "tốt" thì sẽ không bị mất quá $\mathrm{VaR}_{\alpha}$ nếu có mất tiền. Nhưng nó không nói cho ta biết, là nếu rơi vào $\alpha$ tình huống xấu còn lại, thì sẽ bị mất bao nhiêu: lượng tiền bị mất khi rơi vào $\alpha$ tình huống xấu có thể cao hơn nhiều lần $\operatorname{VaR}_{\alpha}$.

Để đối phó với vấn đề thứ hai, người ta đưa thêm vào những thước đo rủi ro mới, ví dụ như tail value at risk $\left(\mathrm{TVaR}_{\alpha}\right.$, giá trị chịu rủi ro ở đuôi $)$, hay còn gọi là tail conditional expectation (kỳ vọng đuôi có điều kiện): nó là kỳ vọng số tiền bị mất khi rơi vào $\alpha$ tình huống xấu. Công thức định nghĩa của nó là:

$$
\operatorname{TVaR}_{\alpha}(X)=\mathbb{E}\left[-X \mid X \leq-\operatorname{VaR}_{\alpha}(X)\right]
$$

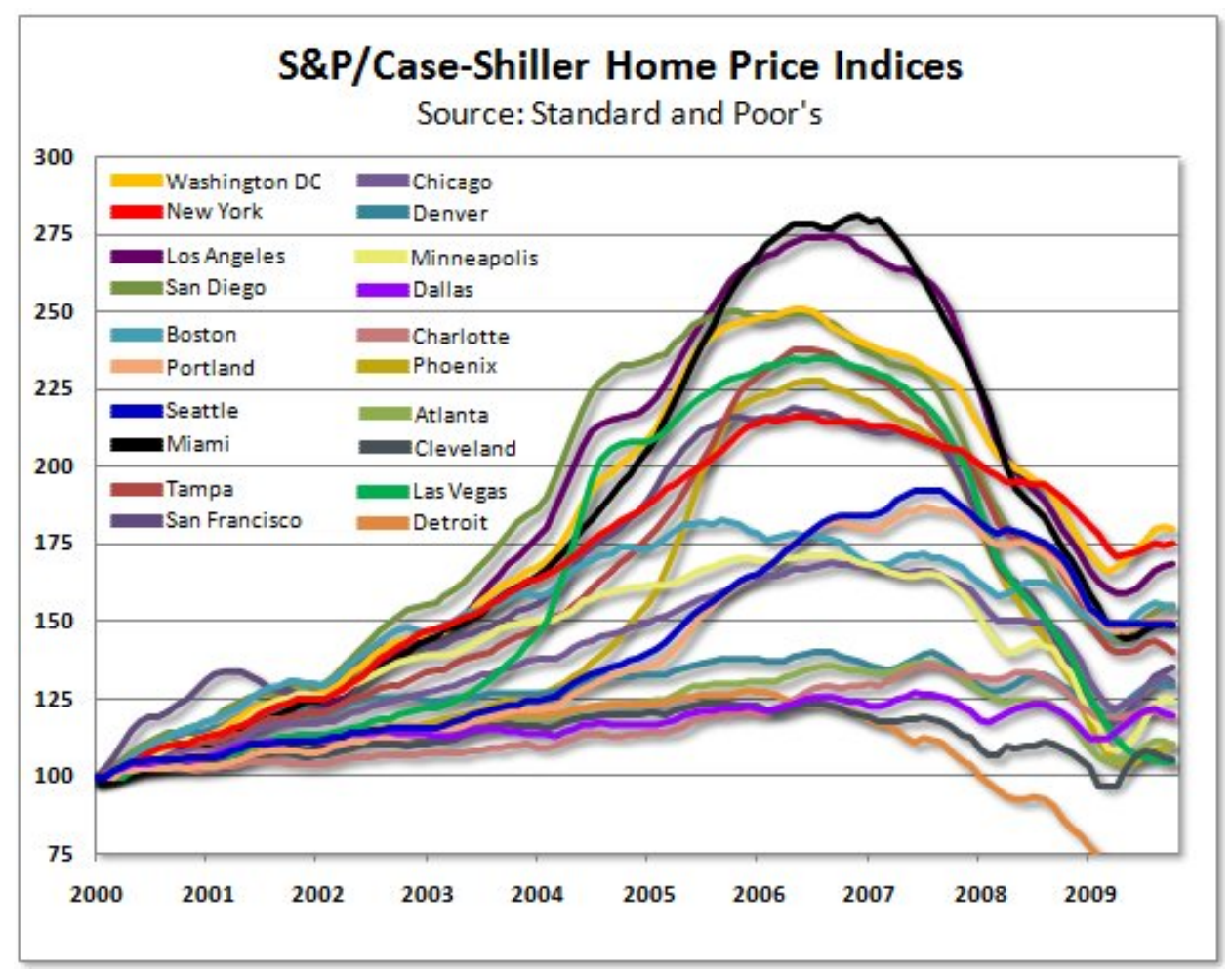

Hình 6.3: Giao động giá nhà đất ở Mỹ (chỉ số Case-Shiller), 2000-2010

Một ví dụ điển hình cho thấy hạn chế của VaR và các cách ước lượng chúng là vấn đề nợ trả góp dưới chuẩn ở Mỹ. Trong những năm 2000-2007, giá nhà đất ở Mỹ và nhiều nơi trên thế giới đi lên mạnh, tăng trung bình trên 100\% trong 7 năm đó. Cùng với việc giá nhà đi lên, là việc các công ty tài chính khuyến khích nhân dân vay tiền mua nhà, kể cả những người mà mức thu nhập không thể đủ để trả nợ tiền nhà, mà chỉ có thể giữ được nợ trong trường hợp giá nhà tiếp tục đi lên. Những khoản vay nợ kiểu như vậy gọi 
là nợ dưới chuẩn (suprime loans). Khi giá nhà còn đi lên, thì giá trị của các chứng khoán nợ tạo thành từ các khoản nợ dưới chuẩn trên thị trường chứng khoán rất ổn định, có volatility thấp, tạo ra một "sự an toàn" ảo về chúng, vì theo các ước lượng rủi ro chỉ dựa trên số liệu lịch sử thì các chứng khoán nợ này rất an toàn, có VaR thấp. Thế nhưng, về mặt cơ bản, đây là các chứng khoán nợ có rủi ro vô cùng lớn, vì chỉ cần giá nhà thôi không tăng nữa (như đã xảy ra vào quãng 2007), thì lập tức dẫn đến những người vay nợ dưới chuẩn vỡ nợ, bị tịch thu nhà bán lại cho người khác với giá rẻ hơn, dẫn đến hiệu ứng dây chuyền kéo giá nhà đi xuống và làm cho một tỷ lệ rất lớn các khoản nợ nhà đất trở thành nợ xấu, và đây chính là một trong các nguyên nhân dẫn đến khủng hoảng tài chính thế giới 2008-2009, kéo theo một loạt tổ chức tài chính lớn phá sản.

\subsection{Lý thuyết Markowitz}

Bài toán tối ưu hóa một danh mục đầu tư trong thực tế thường là một bài toán phức tạp, với nhiều ràng buộc và nhiều tiêu chí, ví dụ như chỉ được đầu tư vào một số chứng khoán nào đó, tỷ lệ không quá bao nhiêu đó, VaR hay TVaR không vượt quá bao nhiêu đó, muốn đạt cực trị cho những hàm thỏa dụng nào đó, v.v. Một mô hình đơn giản cho bài toán tối ưu này là lý thuyết modern portfolio theory của Markowitz(10), mà chúng ta sẽ bàn đến ở đây. Lý thuyết của Markowitz là lý thuyết về tối ưu hóa một danh mục đầu tư theo hai tiêu chí đơn giản: kỳ vọng lợi nhuận và độ lệch chuẩn (của phân bổ lợi nhuận, được dùng như là một thước đo rủi ro). Sở dĩ độ lệch chuẩn, chứ không phải các thước đo rủi ro khác, được dùng trong lý thuyết này, là bởi vì tính toán với độ lệch chuẩn dễ hơn là với các thước đo khác, và tuy rằng nó không phải là một thước đo "hoàn hảo" về rủi ro, nhưng lý thuyết vẫn cho ta các kết luận thú vị về thị trường, và về công dụng của việc đa dạng hóa tài sản.

Để đơn giản, chúng ta sẽ giả sử là danh mục đầu tư được thiết lập vào một thời điểm 0 ban đầu nào đó, và sẽ được giữ nguyên như vậy đến một thời điểm $T$ trong tương lai. Danh mục gồm có $n$ chứng khoán, đánh thứ tự từ 1 đến $n$. Tỷ lệ lợi nhuận của chứng khoán thứ $k$ trong tài khoản tại thời điểm $T$ là một biến ngẫu nhiên $R_{k}$, và chúng ta giả sử rằng phân bố xác suất đồng thời của $\left(R_{1}, \ldots, R_{k}\right)$ đã được xác định trước. (Chúng ta chưa biết lợi nhuận sẽ bằng bao nhiêu, nhưng biết là nó tuân theo phân bố xác suất nào). Giả sử là chứng khoán thứ $k$ chiếm tỷ trọng $w_{k}$ trong danh mục đầu tư $\left(\sum_{1}^{n} w_{k}=1\right)$. Ta

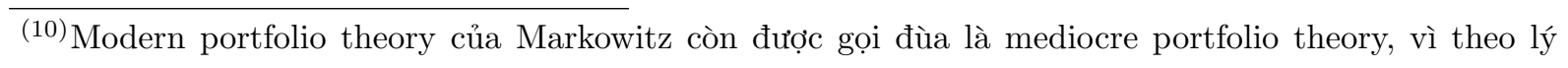
thuyết này thì không ai đầu tư được tốt hơn mức trung bình của toàn thị trường 
sẽ gọi $\mathbf{w}=\left(w_{1}, \ldots, w_{n}\right)$ là vector chiến lược. Khi đó tỷ lệ lợi nhuận của danh mục đầu tư với vector chiến lược $\mathbf{w}$ là biến ngẫu nhiên

$$
R_{\mathrm{w}}=\sum_{k=1}^{n} w_{k} R_{k}
$$

Nếu như có ít nhất một trong các tỷ trọng $w_{k}$ là số âm, thì ta nói rằng danh mục có bán khống (tức là giữ một lượng âm một loại chứng khoán nào đó), còn ngược lại thì ta nói là danh mục không có bán khống. Một số thị trường cho phép bán khống, còn một số thị trường không cho phép bán khống. Khi thị trường không có bán khống, thì ta sẽ coi là tập tất cả các chiến lược được phép sử dụng là tập tất cả các bộ $n$ số (tỷ trọng) không âm có tổng bằng 1 . Còn khi thị trường cho phép bán khống, thì ta bỏ đi điều kiện không âm.

Bài toán đặt ra là tìm $\mathbf{w}$ sao cho cặp số $\left(\mathbb{E}\left(R_{\mathrm{w}}\right), \sigma\left(R_{\mathrm{w}}\right)\right)$ (kỳ vọng và độ lệch chuẩn của biến lợi nhuận) đạt tối ưu theo nghĩa nào đó, ví dụ như sao cho độ lệch chuẩn $\sigma\left(R_{\mathrm{w}}\right)$ không vượt quá mức nào đó, còn kỳ vọng lợi nhuận $\mathbb{E}\left(R_{\mathrm{w}}\right)$ đạt mức cao nhất có thể.

\subsubsection{Trường hợp có hai chứng khoán}

Để đơn giản, trước hết ta xét trường hợp chỉ có 2 chứng khoán trong danh mục $\left(n=2, w_{1}+w_{2}=1\right)$.

Mệnh đề 6.3. Ta có các công thức sau để tính kỳ vọng và phương sai của biến lợi nhuận $R_{\mathbf{w}}=w_{1} R_{1}+w_{2} R_{2}$ của danh mục với vector chiến lược $\mathbf{w}=\left(w_{1}, w_{2}\right)$ :

$$
\mathbb{E}\left(R_{\mathrm{w}}\right)=w_{1} \mathbb{E}\left(R_{1}\right)+w_{2} \mathbb{E}\left(R_{2}\right)
$$

$v \grave{a}$

$$
\operatorname{var}\left(R_{\mathbf{w}}\right)=w_{1}^{2} \cdot \operatorname{var}\left(R_{1}\right)+w_{2}^{2} \cdot \operatorname{var}\left(K_{2}\right)+2 w_{1} w_{2} \cdot \operatorname{cov}\left(R_{1}, R_{2}\right),
$$

trong đó $\operatorname{cov}\left(R_{1}, R_{2}\right)$ là ký hiệu hiệp phương sai (covariance) của $R_{1}$ và $R_{2}$ :

$$
\operatorname{cov}\left(R_{1}, R_{2}\right)=\mathbb{E}\left(R_{1} R_{2}\right)-\mathbb{E}\left(R_{1}\right) \mathbb{E}\left(R_{2}\right)
$$

Chứng minh của công thức trên suy ra trực tiếp từ định nghĩa của phương sai, và tính tuyến tính của kỳ vọng, và đúng cho mọi cặp biến ngẫu nhiên.

Ghi chú 6.5. Một trường hợp riêng nhưng rất quan trọng của tài khoản với 2 chứng khoán, là khi chỉ có 1 chứng khoán có rủi ro, còn chứng khoán kia không có rủi ro: 
$\operatorname{var}\left(R_{1}\right)>0, \operatorname{var}\left(R_{2}\right)=0$. Khi đó thì độ lệch chuẩn lợi nhuận của danh mục tỷ lệ thuận với tỷ trọng tuyệt đối của chứng khoán có rủi ro trong tài khoản: $\sigma\left(R_{\mathrm{w}}\right)=\left|w_{1}\right| \sigma\left(R_{1}\right)$. Như vậy, trong trường hợp đơn giản này, độ chênh lệnh $\mathbb{E}\left(R_{\mathrm{w}}\right)-R_{2}$ giữa kỳ vọng lợi nhuận của danh mục và lợi nhuận không rủi ro $R_{2}$ tỷ lệ thuận với độ rủi ro $\sigma\left(R_{\mathrm{w}}\right)$ của danh mục, theo một hệ số tỷ lệ dương nếu như $R_{1}>R_{2}$ và $w_{1}>0$ hoặc $R_{1}<R_{2}$ và $w_{1}<0\left(w_{1}<0\right.$ có nghĩa là là giữ một lượng âm chứng khoán có rủi ro, hay còn gọi là bán khống), còn nếu ngược lại thì là theo một hệ số tỷ lệ âm, tức là càng tăng rủi ro lại càng làm giảm kỳ vọng lợi nhuận.

Giả sử là cả hai chứng khoán đều có rủi ro (ở đây có nghĩa là có lợi nhuận là biến ngẫu nhiên có độ lệch chuẩn dương). Để cho gọn, ký hiệu

$$
\begin{array}{cl}
\mu_{\mathbf{w}}=E\left(R_{\mathrm{w}}\right) & \sigma_{\mathbf{w}}=\sqrt{\operatorname{var}\left(R_{\mathrm{w}}\right)}, \\
\mu_{1}=E\left(R_{1}\right) & \sigma_{1}=\sqrt{\operatorname{var}\left(R_{1}\right)} \\
\mu_{2}=E\left(R_{2}\right) & \sigma_{2}=\sqrt{\operatorname{Var}\left(R_{2}\right)}
\end{array}
$$

và đặt $\rho_{12}=\frac{\operatorname{cov}\left(R_{1}, R_{2}\right)}{\sigma_{1} \sigma_{2}}$ là hệ số tương quan (khi mà $\left.\sigma_{1} \sigma_{2} \neq 0\right)$. Hệ số tương quan luôn thỏa mãn tính chất $-1 \leq \rho_{12} \leq 1$ (xem [7]). Ta có thể viết lại các công thức trên như sau:

$$
\mu_{\mathbf{w}}=w_{1} \mu_{1}+w_{2} \mu_{2}
$$

và

$$
\sigma_{\mathbf{w}}^{2}=w_{1}^{2} \sigma_{1}^{2}+w_{2}^{2} \sigma_{2}^{2}+2 w_{1} w_{2} \rho_{12} \sigma_{1} \sigma_{2}
$$

Vi du 6.6. Giả sử không gian các tình huống có thể xảy ra gồm có 3 tình huống $\omega_{1}, \omega_{2}, \omega_{3}$, với các xác suất, và các mức lợi nhuận $R_{1}$ và $R_{2}$ của hai chứng khoán trong các tình huống đó, được cho trong bảng sau:

Tình huống Xác suất Lợi nhuận $R_{1}$ Lợi nhuận $R_{2}$

$\begin{array}{cccc}\omega_{1} & 0.4 & -10 \% & 10 \% \\ \omega_{2} & 0.2 & 0 \% & 10 \% \\ \omega_{3} & 0.4 & 20 \% & 0 \%\end{array}$

Giả sử $w_{1}=40 \%, w_{2}=60 \%$. Bằng cách tính trực tiếp, ta rút ra được

$$
\sigma_{1}^{2} \cong 0,0184, \quad \sigma_{2}^{2} \cong 0,0024, \quad \rho_{12} \cong-0,96309
$$

từ đó suy ra

$$
\sigma_{\mathbf{w}}^{2} \cong 0,000736
$$


Chú ý rằng $\sigma_{\mathbf{w}}<\sigma_{1}$ và $\sigma_{\mathbf{w}}<\sigma_{2}$, tức là bằng cách kết hợp hai chứng khoán với nhau trong ví dụ này, ta đạt được độ rủi ro thấp hơn là nếu chỉ đầu tư vào một trong hai chứng khoán đó.

Vì $w_{2}=1-w_{1}$, nên các công thức phía trên trên cho thấy $\mu_{\mathbf{w}}$ là hàm bậc 1 theo $w_{1}$, còn $\sigma_{\mathbf{w}}^{2}$ là hàm bậc hai theo $w_{1}$. Nếu giả sử $\mu_{1} \neq \mu_{2}$, và ta cho phép các số $w_{1}, w_{2}$ có thể âm (nói cách khác, là tài khoản được phép bán khống), thì khi đó bằng cách thay đổi $w_{1}$ ta có thể đạt mức kỳ vọng lợi nhuận $\mu_{\mathrm{w}}$ cao tùy ý ! (Trên thực tế thì điều này không xảy ra, vì kể cả khi thị trường cho phép bán khống, thì cũng không được phép bán khống quá một mức nào đó so với tổng giá trị của tài khoản).

Tập hợp các giá trị có thể có của cặp số $\left(\sigma_{\mathbf{w}}, \mu_{\mathbf{w}}\right)$, khi $w_{1}$ thay đổi trong tập các số thực, tạo thành một đường đi qua hai điểm $\left(\sigma_{1}, \mu_{1}\right)$ (ứng với $w_{1}=1$ ) và $\left(\sigma_{2}, \mu_{2}\right)$ (ứng với $\left.w_{1}=0\right)$ trên mặt phẳng tọa độ. Hình 6.4 là một ví dụ minh họa.

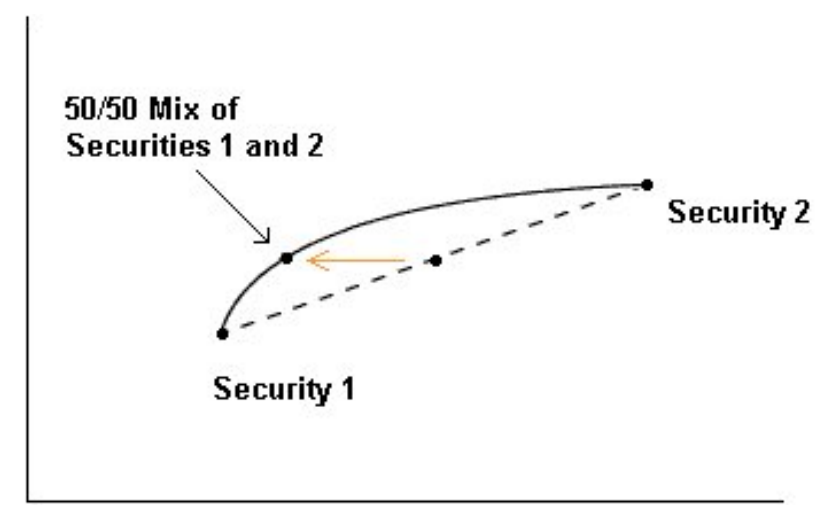

Hình 6.4: Một đoạn đường cong $\left(\sigma_{\mathbf{w}}, \mu_{\mathbf{w}}\right)$, với $0 \leq w_{1} \leq 1$

Nếu $\mu_{1} \neq \mu_{2}$, thì có thể viết $w_{1}=\left(\mu_{\mathbf{w}}-\mu_{2}\right) /\left(\mu_{1}-\mu_{2}\right)$, và thay công thức này vào biểu thức tính $\sigma_{\mathbf{w}}^{2}$, ta được một phương trình bậc hai dạng $\sigma_{\mathbf{w}}^{2}=A \mu_{\mathbf{w}}^{2}+B \mu_{\mathbf{w}}+C$, trong đó $A, B, C$ là ba hằng số. Từ đó suy ra rằng, trong trường hợp tổng quát, khi mà $\rho_{12} \neq \pm 1$ và $\mu_{1} \neq \mu_{2}$, thì tập hợp các giá trị có thể có của cặp số $\left(\sigma_{\mathbf{w}}, \mu_{\mathbf{w}}\right)$ là một đường cong bậc 2 dạng hyperbol nằm theo chiều ngang có đáy quay về phía bên trái mặt phẳng tọa độ $(\sigma, \mu)$. Một hệ quả đơn giản của dáng điệu hyperbolic quay đáy về bên trái này là bất đẳng thức sau:

Mệnh đề 6.4. Nếu $w_{1}, w_{2} \geq 0$ (tức là không có bán khống) thì

$$
\sigma_{V}^{2} \leq \max \left\{\sigma_{1}^{2}, \sigma_{2}^{2}\right\}
$$


Chứng minh. Giả sử $\sigma_{1}^{2} \leq \sigma_{2}^{2}$. Vì $w_{1}, w_{2} \geq 0$ nên ta có

$$
w_{1} \sigma_{1}+w_{2} \sigma_{2} \leq\left(w_{1}+w_{2}\right) \sigma_{2}=\sigma_{2} .
$$

Vì $-1 \leq \rho_{12} \leq 1$ nên

$$
\begin{aligned}
\sigma_{\mathbf{w}}^{2} & =w_{1}^{2} \sigma_{1}^{2}+w_{2}^{2} \sigma_{2}^{2}+2 w_{1} w_{2} \rho_{12} \sigma_{1} \sigma_{2} \\
& \leq w_{1}^{2} \sigma_{1}^{2}+w_{2}^{2} \sigma_{2}^{2}+2 w_{1} w_{2} \sigma_{1} \sigma_{2} \\
& =\left(w_{1} \sigma_{1}+w_{2} \sigma_{2}\right)^{2} \leq \sigma_{2}^{2} .
\end{aligned}
$$

Trường hợp $\sigma_{1}^{2} \geq \sigma_{2}^{2}$ được chứng minh tương tự.

Mệnh đề 6.5. Giả sử $-1<\rho_{12}<1$. Nếu cho phép bán khống, thì danh muc đầu tư có rủi ro ít nhất, theo nghĩa dộ lệch chuẩn lợi nhuận thấp nhất, là danh muc có $w_{1}=s_{0}$ cho bởi công thức

$$
s_{0}=\frac{\sigma_{2}^{2}-\rho_{12} \sigma_{1} \sigma_{2}}{\sigma_{1}^{2}+\sigma_{2}^{2}-2 \rho_{12} \sigma_{1} \sigma_{2}} .
$$

Nếu không cho phép bán khống, thì rủi ro thấp nhất xảy ra khi $w_{1}=s_{\min }$ cho bởi công thuic

$$
s_{\min }= \begin{cases}0, & s_{0}<0 \\ s_{0}, & 0 \leq s_{0} \leq 1 \\ 1, & 1<s_{0} .\end{cases}
$$

Trường hợp đặc biệt, khi mà $\rho_{12}= \pm 1$, thì tập các điểm $\left(\sigma_{\mathbf{w}}, \mu_{\mathbf{w}}\right)$ không phải là đường hyperbol trơn nữa, mà nó suy biến thành hai nửa đường thẳng trên mặt phẳng $(\sigma, \mu)$ gặp nhau tại một điểm có $\sigma=0$. Điểm đó được xác định như sau:

Mệnh đề 6.6. 1. Nếu $\rho_{12}=1$ và $\sigma_{1} \neq \sigma_{2}$ thì $\sigma_{\mathbf{w}}=0$ khi và chỉ khi

$$
w_{1}=\frac{-\sigma_{2}}{\sigma_{1}-\sigma_{2}}, \quad w_{2}=\frac{\sigma_{1}}{\sigma_{1}-\sigma_{2}}
$$

2. Nếu $\rho_{12}=-1$ thì $\sigma_{\mathbf{w}}=0$ khi và chì khi

$$
w_{1}=\frac{\sigma_{2}}{\sigma_{1}+\sigma_{2}}, \quad w_{2}=\frac{\sigma_{1}}{\sigma_{1}+\sigma_{2}}
$$

Chứng minh của các mệnh đề trên là bài tập dành cho bạn đọc.

Bài tập 6.2. Cho thông tin về một danh mục đầu tư như sau, trong đó $R_{1}$ và $R_{2}$ là tỷ lệ lợi nhuận của hai chứng khoán tương ứng:

$\begin{array}{cccc}\text { Kịch bản } & \text { Xác suất } & R_{1} & R_{2} \\ \omega_{1} & 0.3 & -5 \% & 5 \% \\ \omega_{2} & 0.3 & 20 \% & 10 \% \\ \omega_{3} & 0.4 & 10 \% & 25 \%\end{array}$


a) Tìm các tỷ trọng $w_{1}, w_{2}$ sao cho danh mục đạt kỳ vọng lợi nhuận bằng $15 \%$.

b) Tìm các tỷ trọng $w_{1}, w_{2}$ sao cho độ lệch chuẩn $\sigma_{\mathbf{w}}$ đạt cực tiểu.

\subsubsection{Trường hợp có nhiều chứng khoán}

Giả sử danh mục có thể giữ $n$ chứng khoán, với các biến tỷ lệ lợi nhuận tương ứng là $R_{1}, \ldots, R_{n}$. Gọi $\mu_{k}=\mathbb{E}\left(R_{k}\right)$ là kỳ vọng tỷ lệ lợi nhuận của chứng khoán thứ $k$. Gọi

$$
m=\left(\mu_{1}, \mu_{2}, \ldots, \mu_{n}\right)
$$

là vector kỳ vọng lợi nhuận, $\mathbf{w}=\left(w_{1}, \ldots, w_{n}\right)$ là vector chiến lược (các thành phần của vector chiến lược là các tỷ trọng của các chứng khoán trong danh mục), còn

$$
C=\left(C_{i j}\right), C_{i j}=\operatorname{cov}\left(R_{i}, R_{j}\right)
$$

là ma trận hiệp phương sai của các biến lợi nhuận. Ma trận hiệp phương sai luôn có các tính chất sau: đối xứng, và nửa xác định dương. Chúng ta sẽ giả sử rằng ma trận $C$ này là khả nghịch.

Tương tự như trong trường hợp với 2 chứng khoán, chúng ta có các công thức sau cho phép đánh giá kỳ vọng lợi nhuận và độ rủi ro của một danh mục đầu tư:

\section{Mệnh đề 6.7 .}

$$
\mu_{\mathbf{w}}=m \cdot \mathbf{w}^{T}
$$

và

$$
\sigma_{\mathbf{w}}^{2}=\mathbf{w} \cdot C \cdot \mathbf{w}^{T}
$$

Chưng minh.

$$
\begin{aligned}
\mu_{\mathbf{w}} & =\mathbb{E}\left(R_{\mathbf{w}}\right)=\mathbb{E}\left(\sum_{i=1}^{n} w_{i} R_{i}\right) \\
& =\sum_{i=1}^{n} w_{i} \mu_{i}=m \mathbf{w}^{T} \\
\sigma_{\mathbf{w}}^{2} & =\operatorname{var}\left(R_{\mathbf{w}}\right)=\operatorname{var}\left(\sum_{i=1}^{n} w_{i} R_{i}\right) \\
& =\operatorname{cov}\left(\sum_{i=1}^{n} w_{i} R_{i}, \sum_{j=1}^{n} w_{j} R_{j}\right) \\
& =\left(\sum_{i, j=1}^{n} w_{i} w_{j} C_{i j}\right)=\mathbf{w} C \mathbf{w}^{T}
\end{aligned}
$$


Ký hiệu

$$
u=(1, \ldots, 1)
$$

là vector $n$ chiều với tất cả các hệ số đều bằng 1 . Ta có $u \mathbf{w}^{T}=1$.

Mệnh đề 6.8. (Danh mục ít rủi ro nhất). Giả sử $u C^{-1} u^{T} \neq 0$. Khi đó danh muc có $\sigma_{\mathbf{w}}$ thấp nhất là danh muc cho bởi vector chiến lược

$$
\mathbf{w}=\frac{u C^{-1}}{u C^{-1} u^{T}}
$$

Chứng minh. Sử dụng phương pháp nhân tử Lagrange với

$$
F(\mathbf{w}, \lambda)=\frac{1}{2} \mathbf{w} C \mathbf{w}^{T}-\lambda u \mathbf{w}^{T}
$$

ta tính ra

$$
\mathbf{w}=\lambda u C^{-1} .
$$

Do đó

$$
\lambda u C^{-1} u^{T}=1
$$

Giải $\lambda$ và thay vào biểu thức của $\mathbf{w}$ ta có điều phải chứng minh.

Mệnh đề 6.9. (Rủi ro thấp nhất cho mức kỳ vọng lợi nhuận dịnh trước). Trong các danh muc có kỳ vọng lợi nhuận bằng một số $\mu_{V}$ cho trước, danh mục có $\sigma_{\mathbf{w}}$ thấp nhất là danh mục cho bởi vector chiến lược sau:

$$
\mathbf{w}=\frac{\left|\begin{array}{cc}
1 & u C^{-1} m^{T} \\
\mu_{V} & m C^{-1} m^{T}
\end{array}\right| u C^{-1}+\left|\begin{array}{cc}
u C^{-1} u^{T} & 1 \\
m C^{-1} u^{T} & \mu_{V}
\end{array}\right| m C^{-1}}{\left|\begin{array}{ll}
u C^{-1} u^{T} & u C^{-1} m^{T} \\
m C^{-1} u^{T} & m C^{-1} m^{T}
\end{array}\right|} .
$$

Chứng minh. Áp dụng phương pháp nhân tử Lagrange với

$$
G(\mathbf{w}, \lambda, \gamma)=\frac{1}{2} \mathbf{w} C \mathbf{w}^{T}-\lambda u \mathbf{w}^{T}-\gamma m \mathbf{w}^{T},
$$

ta rút ra

$$
\mathbf{w} C=\lambda u+\gamma m \text {. }
$$

Với giả sử rằng $C$ là ma trận đảo nghịch được, ta có

$$
\mathbf{w}=\lambda u C^{-1}+\gamma m C^{-1},
$$


từ đó suy ra hệ phương trình tuyến tính sau:

$$
\begin{aligned}
\lambda u C^{-1} u^{T}+\gamma u C^{-1} m^{T} & =1 \\
\lambda m C^{-1} u^{T}+\gamma m C^{-1} m^{T} & =\mu_{V}
\end{aligned}
$$

Giải hệ phương trình trên để tính $\lambda, \gamma$, rồi thế vào công thức của $\mathbf{w}$, ta được điều phải chứng minh.

Ghi chú 6.6. Công thức trong mệnh đề phía trên có thể cho một danh mục đầu tư có bán khống, tức là có một số chứng khoán có tỷ trọng âm. Nếut yêu cầu không được bán khống, thì phải điều chỉnh công thức, và kỳ vọng lợi nhuận không thể vượt qua một mức nào đó (vì tập các chiến lược được phép là một tập compact, nên tập các kỳ vọng lợi nhuận có thể đạt được cũng là tập compact).

Bài tập 6.3. Tính $\mu_{\mathbf{w}}$ và $\sigma_{\mathbf{w}}$ của một danh mục đầu tư biết:

$$
\begin{array}{lll}
w_{1}=50 \% & w_{2}=-20 \% & w_{3}=70 \% \\
\mu_{1}=8 \% & \mu_{2}=6 \% & \mu_{3}=10 \% \\
\sigma_{1}=1.5 & \sigma_{2}=0.5 & \sigma_{3}=1.7 \\
\rho_{12}=0.3 & \rho_{23}=0.2 & \rho_{31}=-0.2
\end{array}
$$

Bài tập 6.4. Cho danh mục đầu tư có

$$
\begin{array}{crl}
\mu_{1}=0.15 & \mu_{2}=0.12 & \mu_{3}=0.17 \\
\sigma_{1}=0.3 & \sigma_{2}=0.3 & \sigma_{3}=0.4 \\
\rho_{12}=0.5 & \rho_{23}=0.2 & \rho_{31}=0.3
\end{array}
$$

a) Tìm vector chiến lược $\mathbf{w}$ có $\sigma_{\mathbf{w}}$ thấp nhất, và tính độ lệch chuẩn thấp nhất đó.

b) Tìm vector chiến lược $\mathbf{w}$ có $\sigma_{\mathbf{w}}$ thấp nhất trong số các vector chiến lược cho kỳ vọng lợi nhuận $\mu_{\mathrm{w}}=15 \%$, và tính $\sigma_{\mathrm{w}}$ thấp nhất đó.

\subsubsection{Biên hiệu quả}

Định nghĩa 6.10. Một chiến lược đầu tư w được gọi là hiệu quả hơn một chiến lược dầu tư $\mathbf{w}^{\prime}$ nếu nhu $\mu_{\mathbf{w}} \geq \mu_{\mathbf{w}^{\prime}}$ và $\sigma_{\mathbf{w}} \leq \sigma_{\mathbf{w}^{\prime}}$, và it nhất một trong hai bất đẳng thức trên không phải là dẳng thức. Một chiến lược đầu tư được gọi là chiến lược hiệu quả nếu không có chiến lược nào hiệu quả hơn nó trong số các chiến lược cho phép. Tập hợp tất cả các điểm $\left(\sigma_{\mathbf{w}}, \mu_{\mathbf{w}}\right)$ trên mặt phẳng, trong đó $\mathbf{w}$ là chiến lược hiệu quả, được gọi là biên hiệu quả. 
Theo định nghĩa trên, thì tất cả các điểm $\left(\sigma_{\mathbf{w}}, \mu_{\mathbf{w}}\right)$ trong đó $\mathbf{w}$ là một chiến lược cho phép, nằm về phía dưới và bên phải của biên hiệu quả. Chú ý là biên hiệu quả phụ thuộc vào tập các chiến lược cho phép, ví dụ như có cho phép bán khống hay không.

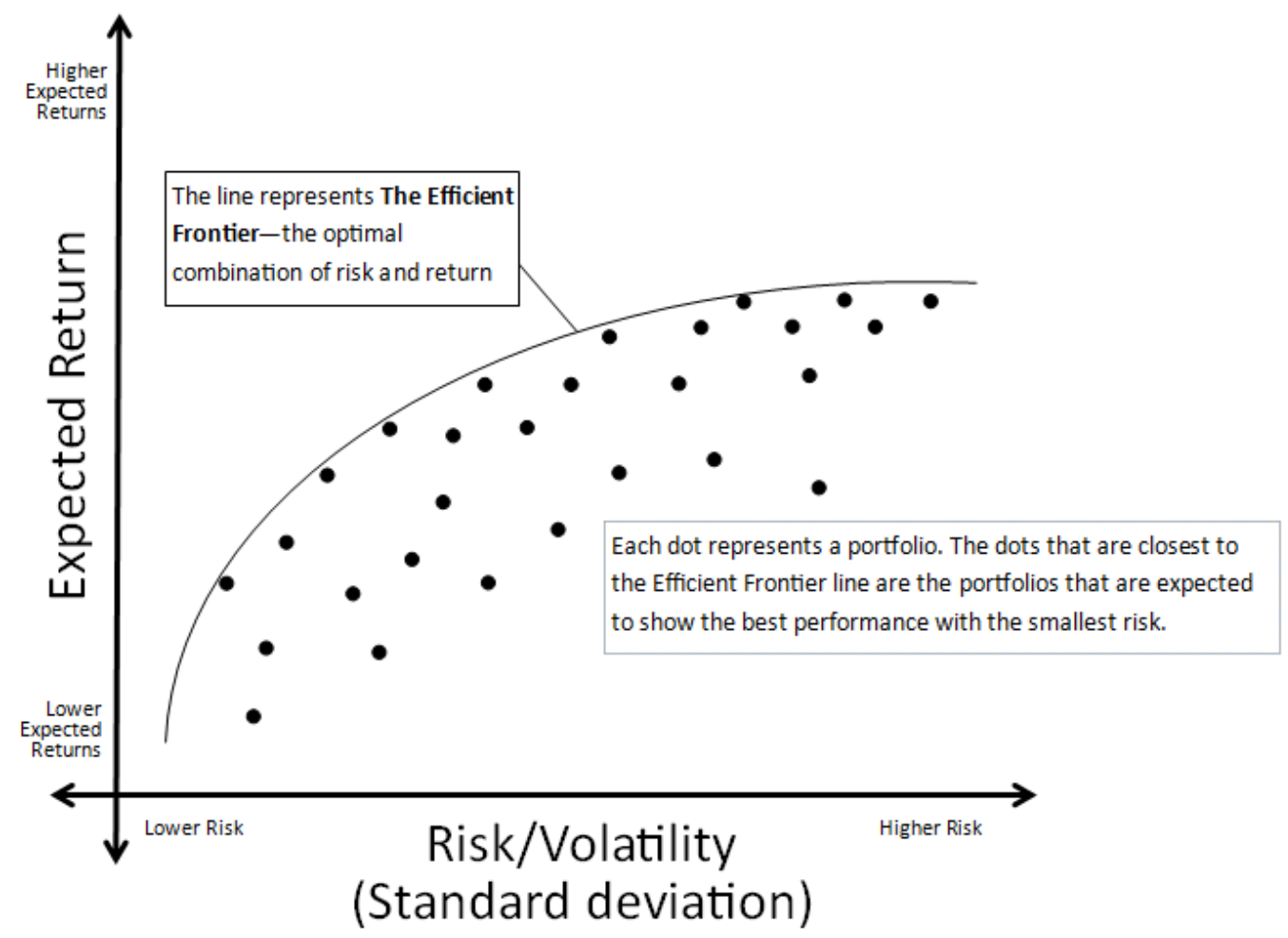

Hình 6.5: Hình minh họa về biên hiệu quả

Điểm cực trái của biên hiệu quả (điểm có tọa độ $\sigma$ nhỏ nhất) chính là điểm ứng với chiến lược đầu tư có độ lệch chuẩn thấp nhất. Nếu ta gọi $\mu_{0}$ là kỳ vọng lợi nhuận của danh mục đầu tư này, thì mọi chiến lược đầu tư hiệu quả phải có kỳ vọng lợi nhuận lớn hơn hoặc bằng $\mu_{0}$. Với mỗi $\mu_{V}>\mu_{0}$, chiến lược có độ lệch chuẩn thấp nhất trong số các chiến lược có kỳ vọng lợi nhuận bằng $\mu_{V}$ được cho bởi công thức trong Mệnh đề 6.9, và đó chính là một chiến lược tối ưu. Theo Mệnh đề 6.9, các chiến lược hiệu quả w này là các chiến lược được cho bởi tính chất: vector $\mathbf{w}$ là tổ hợp tuyến tính của hai vector $u=(1, \ldots, 1)$ và $m=\left(\mu_{1}, \ldots, \mu_{n}\right)$ :

$$
\mathbf{w} C=\lambda u+\gamma m .
$$

Mệnh đề 6.11. Dường biên hiệu quả có tính lồi (về phía bên trái). Có nghĩa là, nếu có 3 diểm $\left(\sigma_{1}, \mu_{1}\right),\left(\sigma_{2}, \mu_{2}\right),\left(\sigma_{3}, \mu_{3}\right)$ nằm trên đường biên hiệu quả, với $\mu_{2}=p \mu_{1}+(1-p) \mu_{3}$, $0 \leq p \leq 1$, thì $\sigma_{2} \leq p \sigma_{1}+(1-p) \sigma_{3}$. 
Chứng minh. Thật vậy, gọi $\mathbf{w}_{\mathbf{1}}$ là một chiến lược đầu tư ứng với $\left(\sigma_{1}, \mu_{1}\right)$, và $\mathbf{w}_{\mathbf{3}}$ là một chiến lược đầu tư ứng với $\left(\sigma_{2}, \mu_{2}\right)$, và đặt $\mathbf{w}_{\mathbf{2}}$ là tổ hợp tuyến tính của $\mathbf{w}_{\mathbf{1}}$ và $\mathbf{w}_{\mathbf{3}}: \mathbf{w}_{\mathbf{2}}=$ $p \mathbf{w}_{\mathbf{1}}+(1-p) \mathbf{w}_{\mathbf{3}}$. Khi đó ta có $\mu_{\mathbf{w}_{\mathbf{2}}}=\mu_{2}$, và $\sigma_{\mathbf{w}_{\mathbf{2}}} \leq p \sigma_{1}+(1-p) \sigma_{2}$. Mặt khác, vì $\left(\sigma_{2}, \mu_{2}\right)$ nằm trên biên hiệu quả, nên ta có $\sigma_{2} \leq \sigma_{\mathbf{w}_{2}}$.

\subsection{Mô hình định giá tài sản vốn (CAPM)}

Lý thuyết CAPM (capital asset pricing mode $]^{(11)}$ về thị trường chứng khoán được đưa ra từ đầu những năm 1960, dựa trên mô hình quản lý danh mục đầu tư của Markowitz, và nhờ nó mà William Sharpe, Harry Markowitz and Merton Miller được giải Nobel về kinh tế năm 1990. Tuy rằng CAPM dựa trên các giả thiết rất mạnh và tính sát thực của nó khá hạn chể(12), nhưng CAPM vẫn là một lý thuyết được giới tài chính rất ưa chuộng, bởi nó cho ra một số kết luận rất thú vị.

Một trong các kết luận quan trọng nhất của CAPM là: danh mục thị trường (market portfolio) chính là một chiến lược đầu tư hiệu quả. Danh mục thị trường tức là một danh mục đầu tư mà đầu tư vào tất cả các chứng khoán có trên thị trường, với tỷ trọng đầu tư vào mỗi chứng khoán tỷ lệ thuận với tổng giá trị của chứng khoán đó (vốn hóa của nó) trên thị trường, hay nói cách khác, tỷ trọng của một loại chứng khoán trong một danh mục thị trường bằng đúng tỷ trọng của toàn bộ loại chứng khoán đó trên toàn thị trường. Ví dụ như nếu một công ty cổ phần có vốn hóa bằng 2,5\% tổng vốn hóa của thị trường, thì tỷ trọng của cổ phiếu của công ty đó trong một danh mục thị trường cũng bằng 2,5\%.

Lý thuyết CAPM dựa trên các giả thiết sau đây về thị trường:

1) Thị trường có $n$ chứng khoán có rủi ro, và có một chứng khoán không có rủi ro (hình dung chứng khoán không có rủi ro này là tiền mặt hưởng lãi suất qua đêm). Tỷ lệ lợi nhuận của chứng khoán không có rủi ro là một số $R_{0}>0$ biết trước.

2) Tất cả các nhà đầu tư đều có thông tin giống nhau về kỳ vọng lợi nhuận và hiệp phương sai của các chứng khoán có rủi ro (cho một giai đoạn đầu tư nào đó), và các con số này được biết trước.

3) Mọi danh mục đầu tư của các nhà đầu tư đều là một danh mục đầu tư hiệu quả theo nghĩa của lý thuyết Markowitz.

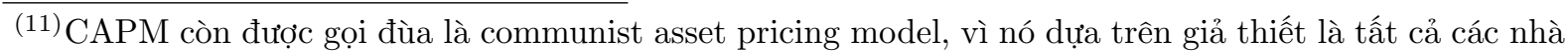
đầu tư có cùng thông tin và phân tích giống nhau về thị trường, và ai cũng có danh mục đầu tư hiệu quả theo cùng một kiểu

${ }^{(12)}$ Xem: http://en.wikipedia.org/wiki/Capital_asset_pricing_model 


\subsection{1 Đường thị trường vốn}

Xét các danh mục đầu tư chỉ chứa các chứng khoán có rủi ro mà không chứa chứng khoán không rủi ro. Theo lý thuyết Markowitz, ta có một đường biên hiệu quả trên mặt phẳng $(\sigma, \mu)$, mà ta sẽ ký hiệu là $\Gamma$, cho các danh mục đầu tư với $n$ chứng khoán có rủi ro này. Do tính lồi của đường biên hiệu quả $\Gamma$, nên có duy nhất một nửa đường thẳng $L$ xuất phát từ điểm $\left(0, R_{0}\right)$ (điểm của chứng khoán không rủi ro) và tiếp xúc với $\Gamma$. Ta sẽ giả sử là có một điểm tiếp xúc duy nhất, ký hiệu là $\left(\sigma_{M}, \mu_{M}\right)$, và gọi là điểm Markowitz.

Định lý 6.12. i) Nửa đường thẳng L là dường biên hiệu quả cho các danh mục có chứa cả chứng khoán không có rủi ro.

ii) Diểm Markowitz là điểm ứng với danh mục thị trường.

Chứng minh. i) Nếu một chiến lược w không chứa chứng khoán không rủi ro có độ lệch chuẩn và kỳ vọng tỷ lệ lợi nhuận là $\left(\sigma_{\mathbf{w}}, \mu_{\mathbf{w}}\right)$, thì chiến lược $(1-p, p \mathbf{w})$ chứa chứng khoán không rủi ro với tỷ trọng $1-p$ và phần còn lại với tỷ trọng $p$ được phân bổ theo tỷ lệ thuận với $\mathbf{w}$, là chiến lược có độ lệch chuẩn và kỳ vọng lợi nhuận là $\left(p \sigma_{\mathbf{w}},(1-p) R_{0}+p \mu_{\mathbf{w}}\right)$ (với giả sử $p>0)$. Điểm $\left(p \sigma_{\mathbf{w}},(1-p) R_{0}+p \mu_{\mathbf{w}}\right)$ nằm trên nửa đường thẳng xuất phát từ $\left(0, R_{0}\right)$ đi qua $\left(\sigma_{\mathbf{w}}, \mu_{\mathbf{w}}\right)$. (Nếu đòi hỏi $1-p \geq 0$, tức là tài khoản không được phép nợ loại chứng khoán không rủi ro, thì điểm này nằm trên đoạn thẳng nối từ $\left(0, R_{0}\right)$ đến $\left.\left(\sigma_{\mathbf{w}}, \mu_{\mathbf{w}}\right)\right)$. Như vậy, nếu ta có một điểm $\left(\sigma_{\mathbf{w}}, \mu_{\mathbf{w}}\right)$ ứng với một chiến lược nào đó, thì mọi điểm trên nửa đường thẳng xuất phát từ $\left(0, R_{0}\right)$ đi qua $\left(\sigma_{\mathbf{w}}, \mu_{\mathbf{w}}\right)$ đều có các chiến lược tương ứng. Mỗi điểm trên nửa đường thẳng Lứng với một chiến lược là tổ hợp tuyến tính của chứng khoán không có rủi ro và một chiến lược cho điểm Markowitz. Để chứng minh $L$ là biên hiệu quả (cho các danh mục có giữ cả chứng khoán không rủi ro), ta giả sử có một chiến lược với điểm $(\sigma, \mu)$ tương ứng nằm bên trái $L$ (tức là hiệu quả hơn so với chiến lược nào đó của $L$ ). Khi đó, bỏ phần không rủi ro khỏi chiến lược này, ta vẫn được một chiến lược $(\sigma, \mu)$ tương ứng nằm bên trái $L$, tức là nằm bên trái đường biên hiệu quả $\Gamma$, vì bản thân $L$ đã nằm phía bên trái của $\Gamma$, có nghĩa là đây là một chiến lược (không chứa chứng khoán không rủi ro) còn hiệu quả hơn là đường biên hiệu quả $\Gamma$, mâu thuẫn với định nghĩa của đường biên hiệu quả (cho các danh mục không chứa chứng khoán không rủi ro). Bởi vậy $L$ chính là đường biên hiệu quả cho các danh mục có thể chứa chứng khoán không rủi ro.

ii) Vì nhà đầu tư nào cũng theo một chiến lược hiệu quả theo giả thiết, nên các điểm $(\sigma, \mu)$ đều nằm trên đường $L$. Bỏ đi phần chứng khoán không rủi ro, thì các danh mục đó vẫn nằm trên đường $L$. Nhưng trên đường $L$ chỉ có một điểm ứng với danh mục không 
chứa chứng khoán không rủi ro, bởi vậy phần có rủi ro của các danh mục của mọi nhà đầu tư đều ứng với điểm Markowitz $\left(\sigma_{M}, \mu_{M}\right)$. Cộng tất cả các phần có rủi ro đó lại với nhau, ta được danh mục thị trường, và bởi vậy danh mục thị trường cũng có kỳ vọng lợi nhuận là $\mu_{M}$, còn độ lệch chuẩn nhỏ hơn hoặc bằng $\sigma_{M}$ (xem mệnh đề 6.4). Thế nhưng ứng với $\mu_{M}$ thì $\sigma_{M}$ đã là độ lệch chuẩn nhỏ nhất có thể, bởi vậy độ lệch chuẩn của danh mục thị trường chính bằng $\sigma_{M}$, và danh mục thị trường là một chiến lược đầu tư hiệu quả ứng với điểm Markowitz.

Ghi chú 6.7. Trong trường hợp mà các nhà đầu tư không được phép "bán khống chứng khoán không rủi ro", có nghĩa là không được vay tiền để đầu tư vào các chứng khoán có rủi ro, thì đường biên hiệu quả cho các danh mục có chứng khoán không rủi ro không phải là nửa đường thẳng $L$, mà gồm có đoạn thẳng nằm trên $L$ đi từ $\left(0, R_{0}\right)$ đến $\left(\sigma_{M}, \mu_{M}\right)$ cộng với đoạn đường cong $\Gamma$ (biên hiệu quả khi bỏ qua chứng khoán không rủi ro) nằm phía bên phải điểm $\left(\sigma_{M}, \mu_{M}\right)$. Có nghĩa là, các nhà đầu tư mà chấp nhận độ rủi ro trên $\sigma_{M}$ thì không cần giữ tiền mặt (chứng khoán không rủi ro) trong danh mục, còn nếu độ rủi ro chấp nhận được là dưới $\sigma_{M}$, thì việc giữ một phần tiền mặt sẽ làm tăng hiệu quả của danh mục đầu tư.

Định nghĩa 6.13. Nưa dường thẳng L trong định lý trên được gọi là đường thị trường vốn (capital market line).

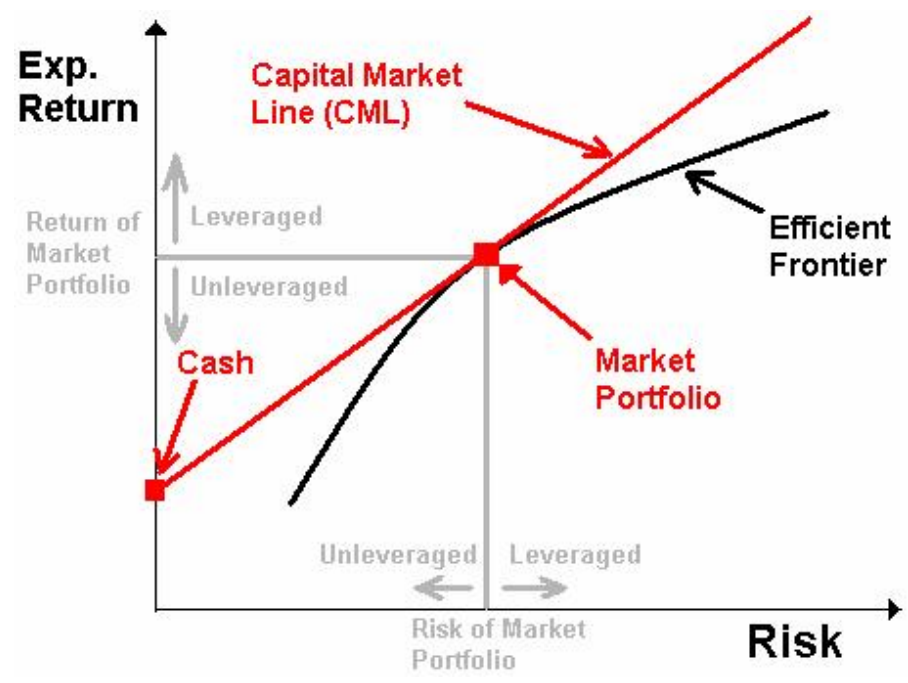

Hình 6.6: Đường thị trường vốn

Theo CAPM, thì các nhà đầu tư sẽ đều chọn danh mục đầu tư nằm trên đường thị trường vốn, và nằm ở điểm nào trên đường đó tùy thuộc vào mức độ rủi ro chấp nhận 
được của nhà đầu tư: những điểm gần $\left(0, R_{0}\right)$ dành cho các nhà đầu tư ít chấp nhận rủi ro, còn những điểm ở xa hơn dành cho các nhà đầu tư chấp nhận được mức rủi ro cao hơn.

\subsubsection{Nhân tử beta và đường thị trường chứng khoán}

Gọi $V$ là một chứng khoán hay danh mục đầu tư nào đó, còn $M$ là danh mục đầu tư thị trường, với các biến lợi nhuận tương ứng cho một giai đoạn nào đó là $R_{V}$ và $R_{M}$. Khi đó ta có thể viết

$$
R_{V}=\alpha_{V}+\beta_{V} R_{M}+\epsilon_{V}
$$

trong đó $\alpha_{V}$ và $\beta_{V}$ là hai hằng số, còn $\epsilon_{V}$ là biến ngẫu nhiên có kỳ vọng bằng 0 và hiệp phương sai với $R_{M}$ cũng bằng $0: \mathbb{E}\left(\epsilon_{V}\right)=0, \operatorname{cov}\left(\epsilon_{V}, R_{M}\right)=0$. Công thức để tính $\alpha_{V}$ và $\beta_{V}$ là:

$$
\begin{gathered}
\beta_{V}=\frac{\operatorname{cov}\left(R_{V}, R_{M}\right)}{\sigma_{M}^{2}}, \\
\alpha_{V}=\mu_{V}-\beta_{V} \mu_{M} .
\end{gathered}
$$

trong đó $\mu_{V}=\mathbb{E}\left(R_{V}\right), \mu_{M}=\mathbb{E}\left(R_{M}\right), \sigma_{M}^{2}=\operatorname{var}\left(R_{M}\right)$.

Hệ số $\beta_{V}$ được gọi là hệ số beta, hay nhân tử beta của $V$, và nó đo độ phụ thuộc vào thị trường chung của lợi nhuận của $V$. Chúng ta đã đề cập đến hệ số beta này từ Chương 5 khi phân tích cổ phiếu. Chú ý rằng, hệ số beta tạo chặn dưới của mức rủi ro. Thật vậy, ta có $\sigma_{V}^{2}=\beta_{V}^{2} \sigma_{M}^{2}+\sigma\left(\epsilon_{V}\right)^{2}$, suy ra

$$
\sigma_{V} \geq\left|\beta_{V}\right| \sigma_{M}
$$

Dấu bằng đạt được khi $V$ là một tổ hợp tuyến tính của danh mục thị trường với chứng khoán không rủi ro.

Bài tập 6.5. Cho bảng dữ liệu sau, hãy tính $\beta_{V}, \alpha_{V}$ :

$\begin{array}{cccc}\text { Kịch bản } & \text { Xác suất } & \text { Lợi nhuận } R_{V} & \text { Lợi nhuận } R_{M} \\ \omega_{1} & 0.1 & -7 \% & 8 \% \\ \omega_{2} & 0.3 & 0 \% & 10 \% \\ \omega_{3} & 0.4 & 5 \% & 9 \% \\ \omega_{4} & 0.2 & 20 \% & 13 \%\end{array}$

Bài tập 6.6. Chứng minh tính chất sau của nhân tử beta: nhân tử beta của một danh mục đầu tư $V$ gồm $n$ chứng khoán với các tỷ trọng $w_{1}, \ldots, w_{n}$ là

$$
\beta_{V}=w_{1} \beta_{1}+\ldots+w_{n} \beta_{n}
$$


trong đó $\beta_{k}$ là nhân tử beta của chứng khoán thứ $k$.

Nhắc lại rằng, theo $\mathrm{CAPM}$, danh mục đầu tư thị trường $M$ là một danh mục hiệu quả, và do đó theo công thức 6.44 ta có $\mathbf{w}_{M} C=\lambda u+\gamma m$, trong đó $\mathbf{w}_{M}$ là vector chiến lược của danh mục thị trường (hệ số ứng với chứng khoán không rủi ro của nó bằng 0 , còn các hệ số khác là các tỷ trọng vốn hóa của các chứng khoán có rủi ro trên thị trường), $C$ là ma trận hiệp phương sai của toàn bộ thị trường (kể cả chứng khoán không rủi ro), $m$ là vector kỳ vọng lợi nhuận của các chứng khoán, $u=(1, \ldots, 1)$, còn $\lambda$ và $\gamma$ là các số thực nào đó. Từ đó suy ra công thức sau cho nhân tử beta $\beta_{V}$ của một danh mục đầu tư $V$ bất kỳ:

$$
\beta_{V}=\frac{\operatorname{cov}\left(R_{V}, R_{M}\right)}{\sigma_{M}^{2}}=\frac{\mathbf{w}_{M} C \mathbf{w}_{V}^{T}}{\mathbf{w}_{M} C \mathbf{w}_{M}^{T}}=\frac{(\gamma u+\lambda m) \mathbf{w}_{V}^{T}}{(\gamma u+\lambda m) \mathbf{w}_{M}^{T}}=\frac{\mu_{V}+\gamma / \lambda}{\mu_{M}+\gamma / \lambda} .
$$

Trong trường hợp $V$ là chứng khoán không rủi ro, thì lợi nhuận của nó bằng hằng số $R_{0}$, còn nhân tử beta của nó bằng 0 , bởi vậy ta có $R_{0}+\lambda / \gamma=0$, nghĩa là $\lambda / \gamma=-R_{0}$, từ đó suy ra định lý sau:

Định lý 6.14. Theo lý thuyêt CAPM, thì kỳ vọng lợi nhuận của một danh muc dầu tư $V$ bất kỳ phu thuộc hoàn toàn vào nhân tử beta của nó theo công thức:

$$
\mu_{V}=R_{0}+\beta_{V}\left(\mu_{M}-R_{0}\right)
$$

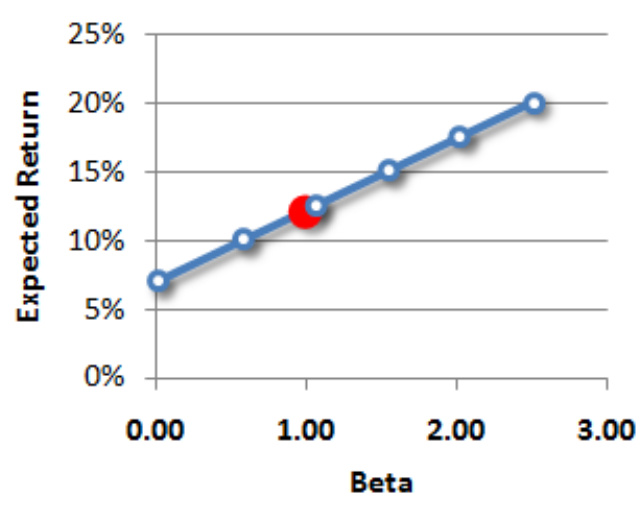

Hình 6.7: Hình minh họa về đường thị trường chứng khoán

Như vậy, tập hợp các điểm $\left(\beta_{V}, \mu_{V}\right)$ tạo ra bởi các chứng khoán và các danh mục đầu tư nằm trên một đường thẳng trên mặt phẳng $(\beta, \mu)$, gọi là đường thị trường chứng khoán (security market line). Theo kết luận trên của CAPM thì việc đi tìm chứng khoán hay danh mục "trội hơn" thị trường là vô nghĩa, vì muốn có kỳ vọng lợi nhuận cao cách duy nhất là tăng hệ số beta lên, và như vậy tăng mức rủi ro lên tương ứng. 


\section{Chương 7}

\section{Giải tích ngẫu nhiên}

Theo ngôn ngữ toán học, sự biến động theo thời gian của giá cả (như giá vàng, giá dầu hỏa, giá cổ phiếu của công ty Intel, v.v.), cũng như của các số liệu khác (ví dụ như mức tăng trưởng kinh tế, tỷ lệ thất nghiệp, v.v.) được gọi là các quá trình ngẫu nhiên (random process), bởi vì nói chung không ai có thể biết trước được một cách chính xác giá trị của chúng trong tương lai sẽ ra sao. Để nghiên cứu các quá trình ngẫu nhiên này, chúng ta sẽ cần dùng đến một bộ phận của toán học gọi là giải tích ngẫu nhiên (stochastic calculus). Giải tích ngẫu nhiên tức là giải tích toán học (các phép tính giới hạn, vi tích phân, v.v.) áp dụng vào các quá trình ngẫu nhiên, dựa trên cơ sở của lý thuyết xác suất thống kê.

Trong chương này chúng ta sẽ tìm hiểu một số kiến thức cơ bản nhất về giải tích ngẫu nhiên, cần thiết cho toán tài chính. Bạn đọc muốn nghiên cứu sâu thêm về giải tích ngẫu nhiên có thể tìm đọc các sách chuyên khảo, ví dụ như Øksendal [21], Karatzas và Shreve [15], hoặc quyển sách của tác giả Nguyễn Duy Tiến [29].

\subsection{Một số mô hình biến động giá chứng khoán}

Ở phần này, chúng ta sẽ coi giá $S$ của một cổ phiếu (hay nói một cách tổng quát hơn, của một chứng khoán có giá dương) như là một quá trình ngẫu nhiên nhận giá trị trong tập hợp các số thực dương, và chúng ta sẽ xét một số mô hình hệ động lực ngẫu nhiên một chiều đơn giản mô tả diễn biến của $S$ theo thời gian. Chú ý rằng, do chỉ có 1 chiều, nên các mô hình này tương đối thô: sự tương tác giữa các thành phần của thị trường không đưa được vào mô hình, và mô hình chỉ dựa trên các phương trình bậc 1 , thay vì phương trình bậc 2 như trong vật lý. Tuy là các mô hình tương đối thô, nhưng chúng vẫn 
rất quan trọng trong việc phân tích sự biến động giá của các cổ phiếu.

Trước hết, chúng ta sẽ định nghĩa một cách hình thức toán học thế nào là một quá trình ngẫu nhiên.

\subsubsection{Quá trình ngẫu nhiên}

Các quá trình biến đổi theo thời gian, ví dụ như giá cổ phiếu, lượng nước mưa trong tháng, số người mắc bệnh cúm, v.v., mà ta không thể dự đoán được trước một cách chính xác, thì được coi là các quá trình ngẫu nhiên. Một cách trực giác, để mô tả một quá trình ngẫu nhiên theo ngôn ngữ toán học, ta cần các yếu tố sau:

- Thời gian. Theo qui ước, có một mốc thời gian ban đầu, là 0 . Thời gian $t$ có thể là biến đổi liên tục, $t \in \mathbb{R}_{+}$, hoặc rời rạc, tức là ta chỉ xét một dãy các mốc thời điểm $0=t_{0}<t_{1}<t_{2}<\ldots$ nào đó. Trong trường hợp rời rạc, để cho đơn giản, ta sẽ giả sử thêm là các bước thời gian là bằng nhau, tức là $t_{i}-t_{i-1}=\tau$ là một hằng số không phụ thuộc vào $i$. Nhiều khi, ta sẽ dùng dãy số nguyên không âm $0,1,2, \ldots$ dể ký hiệu các mốc thời gian, thay vì dùng các thời điểm $t_{0}, t_{1}, t_{2}, \ldots$

- Không gian xác suất. Với mỗi mốc thời gian $t$, có thể coi là có một không gian $\Omega_{t}$ tất cả các tình huống có thể xảy ra từ thời điểm ban đầu cho đến thời điểm $t$. Không gian này là không gian xác suất, với một sigma-đại số $\mathcal{S}_{t}$ và một độ đo xác suất $P_{t}$ đi kèm (tức là xác suất của các tình huống có thể xảy ra cho đến thời điểm $t$ ).

Nếu $s$ và $t$ là hai mốc thời điểm nào đó với $s \leq t$, thì ta có một phép chiếu tự nhiên

$$
\pi_{s, t}:\left(\Omega_{t}, \mathcal{S}_{t}, P_{t}\right) \rightarrow\left(\Omega_{s}, \mathcal{S}_{s}, P_{s}\right)
$$

Khi $\omega_{t}$ là một tình huống có thể xảy ra cho đến thời điểm $t$, thì $\pi_{s, t}\left(\omega_{t}\right)$ là tình huống đó nhưng chỉ tính đến thời điểm $s$, bỏ qua những gì xảy ra sau thời điểm $s$. Các phép chiếu $\pi_{s, t}$ thỏa mãn các tính chất tự nhiên sau:

a) Toàn ánh (surjective), tức là mọi tình huống có thể xảy ra cho đến thời điểm $s$ thì phải có thể tiếp diễn để trở thành tình huống có thể xảy ra cho đến thời điểm $t$.

b) $\pi_{t, t}$ là ánh xạ đồng nhất trên $\Omega_{t}$.

c) Bắc c⿳亠㐅⿵u $u: \pi_{r, s} \circ \pi_{s, t}=\pi_{r, t}$ với mọi $r \leq s \leq t$.

d) Bảo toàn xác suất, có nghĩa là nếu $A \in \mathcal{S}_{s}$ là tập con đo được của $\left(\Omega_{s}, \mathcal{S}_{s}, P_{s}\right)$, thì ảnh ngược của nó trong $\Omega_{t}$ cũng là tập con đo được, và có cùng xác suất với nó:

$$
P_{t}\left(\pi_{s, t}^{-1}(A)\right)=P_{s}(A)
$$


Một dãy các không gian xác suất $\left(\Omega_{t}, P_{t}\right)$ với các phép chiếu $\pi_{s, t}$ thỏa mãn các tính chất phía trên sẽ được gọi là một họ lọc các không gian xác suất (filtered family of probability spaces).

Các không gian xác suất $\left(\Omega_{t}, \mathcal{S}_{t}, P_{t}\right)$ có thể được gộp chung lại (ngôn ngữ toán học gọi là lấy giới hạn xạ ảnh) thành một không gian xác suất $(\Omega, \mathcal{F}, P)$ tất cả các tình huống có thể xảy ra cho mọi thời gian: mỗi phần tử $\omega \in \Omega$ ứng với một họ các phần tử $\omega_{t} \in \Omega_{t}$ thích hợp với nhau, có nghĩa là $\pi_{s, t} \omega_{t}=\omega_{s}$ với mọi $s<t$. Ta có thể viết:

$$
\Omega=\lim _{t \rightarrow \infty} \Omega_{t}
$$

(giới hạn ở đây là giới hạn xạ ảnh, theo nghĩa như trên: mỗi phần tử $\omega \in \Omega$ ứng với một họ các phần tử $\omega_{t} \in \Omega_{t}$ thích hợp với nhau), với các phép chiếu tự nhiên

$$
\pi_{t}: \Omega \rightarrow \Omega_{t}
$$

$\pi_{t}(\omega)=\omega_{t}$, cũng thỏa mãn các tính chất toàn ánh và bắc cầu như phía trên.

Sigma-đại số trên $\Omega$ được xây dựng như sau: với mỗi $t$, gọi $\mathcal{F}_{t}$ là sigma đại số trên $\Omega$ sinh bởi ảnh ngược qua $\pi_{t}$ của các tập đo được trên $\Omega_{t}$. Nói cách khác, các phần tử của $\mathcal{F}_{t}$ là các tập con có dạng $\pi_{t}^{-1}\left(A_{t}\right)$ với $A_{t} \in \mathcal{S}_{t}$. Các tính chất phía trên của họ không gian xác suất $\left(\Omega_{t}, \mathcal{S}_{t}, P_{t}\right)$ cho ta thấy $\mathcal{F}_{s} \subset \mathcal{F}_{t}$ với mọi $s \leq t$. Có nghĩa là $t$ càng lớn thì càng có nhiều tập "đo được tại thời điểm $t$ ". Người ta gọi $\mathcal{F}_{t}$ là sigma-đại số sinh bởi các thông tin có được cho đến thời điểm $t$. Tất nhiên, khi $t$ càng lớn, thì càng có thêm nhiều thông tin, và do đó sigma-đại số tương ứng càng lớn, càng có nhiều thứ có thể đo được. Đặt

$$
\mathcal{F}=\bigcup_{t} \mathcal{F}_{t}
$$

Đó chính là sigma-đại số trên $\Omega$, và họ các sigma-đại số con $\left(\mathcal{F}_{t}\right)$ được gọi là một họ lọc (filtration) của $\mathcal{F}$.

Phân bố xác suất $P$ trên $\Omega$ cũng được định nghĩa qua các phép chiếu $\pi_{t}$ : Nếu $A=$ $\pi_{t}^{-1}\left(A_{t}\right) \in \mathcal{F}_{t}$, thì $P(A):=P_{t}\left(A_{t}\right)$. Chú ý rằng, do tính chất tương thích giữa các không gian xác suất $\left(\Omega_{t}, \mathcal{S}_{t}, P_{t}\right)$, định nghĩa này không phụ thuộc vào sự lựa chọn $t$ (sao cho tồn tại $A_{t} \in \mathcal{S}_{t}$ sao cho $\left.A=\pi_{t}^{-1}\left(A_{t}\right)\right)$.

Với định nghĩa sigma-đại số $\mathcal{F}=\bigcup_{t} \mathcal{F}_{t}$ và phân bố xác suất $P$ như trên, các ánh xạ $\pi_{t}:(\Omega, \mathcal{F}, P) \rightarrow\left(\Omega_{t}, \mathcal{S}_{t}, P_{t}\right)$ nghiễm nhiên trở thành các toàn ánh bảo toàn xác suất.

Để nhấn mạnh rằng $\mathcal{F}=\bigcup_{t} \mathcal{F}_{t}$ sinh bởi một họ lọc các sigma-đại số $\left(\mathcal{F}_{t}\right)$ (một họ lọc tức là một họ thỏa mãn điều kiện $\mathcal{F}_{s} \subset \mathcal{F}_{t}$ với mọi $s \leq t$ ), mô hình xác suất trên $\Omega$ 
được ký hiệu là $\left(\Omega,\left(\mathcal{F}_{t}\right)_{t \in T}, P\right)$, và được gọi là một không gian xác suất có lọc (filtered probability space).

- Biến ngẫu nhiên thay đổi theo thời gian. Nếu ta có một quá trình lọc các không gian xác suất $\left(\Omega_{t}, \mathcal{S}_{t}, P_{t}\right)$, và với mỗi mốc thời gian $t$ ta có một biến ngẫu nhiên $S_{t}$ thực với không gian xác suất tương ứng là $\left(\Omega_{t}, \mathcal{S}_{t}, P_{t}\right)$, có nghĩa là một hàm đo được

$$
S_{t}: \Omega_{t} \rightarrow \mathbb{R}
$$

(xem Chương 2 của [7] về các khái niệm cơ bản về biến ngẫu nhiên), thì ta nói rằng ta có một quá trình ngẫu nhiên (stochastic process) $S$ trên mô hình xác suất $\left(\Omega_{t}, \mathcal{S}_{t}, P_{t}\right)$. Hàm $S_{t}: \Omega_{t} \rightarrow \mathbb{R}$ chính là hàm giá trị của quá trình ngẫu nhiên $S$ tại thời điểm $t$.

Ta có thể coi $S_{t}$ như là biến ngẫu nhiên trên $\Omega$ qua các phép chiếu $\pi_{t}$ :

$$
S_{t} \circ \pi_{t}: \Omega \rightarrow \mathbb{R}
$$

Để cho tiện, ta cũng sẽ ký hiệu $S_{t} \circ \pi_{t}$ là $S_{t}$, khi đó nó là hàm số trên $\Omega$ và đo được theo sigma-đại số $\mathcal{F}_{t}$. Từ đó, ta có định nghĩa toán học sau đây về quá trình ngẫu nhiên:

Định nghĩa 7.1. Giả sử ta có một không gian xác suất có lọc $\left(\Omega,\left(\mathcal{F}_{t}\right)_{t \in T}, P\right)$, và một ho các biến ngẫu nhiên $S_{t}: \Omega \rightarrow \mathbb{R}$, sao cho $S_{t}$ là đo được theo sigma-đại số $\mathcal{F}_{t}$ với mọi $t$ (trong tập các mốc thời gian của lọc). Khi đó ho $S_{t}$ được gọi là một quá trình ngẫu nhiên với mô hình xác suất $\left(\Omega,\left(\mathcal{F}_{t}\right)_{t \in T}, P\right)$ và tương thích (compatible) với lọc $\left(\mathcal{F}_{t}\right)_{t \in T}$.

Trong định nghĩa 7.1 , các không gian $\left(\Omega_{t}, \mathcal{S}_{t}, P_{t}\right)$ bị bỏ qua, chỉ còn $\left(\Omega,\left(\mathcal{F}_{t}\right)_{t \in T}, P\right)$ được giữ lại. Nói cách khác, sự đưa vào các không gian không gian xác suất $\left(\Omega_{t}, \mathcal{S}_{t}, P_{t}\right)$ như trên là không cần thiết cho việc tính toán với các quá trình ngẫu nhiên. Nhưng chúng có tác dụng là giúp ta dễ hình dung hơn về mặt trực giác, và cũng không gây cản trở gì cho việc tính toán. Bởi vậy, trong chương này, để cho dễ hình dung, khi xét các quá trình ngẫu nhiên, ta sẽ luôn coi là không gian xác suất có lọc $\left(\Omega, \mathcal{F}_{t}, P\right)$ được sinh bởi một họ lọc các không gian xác suất $\left(\Omega_{t}, \mathcal{S}_{t}, P_{t}\right)$, và mỗi quá trình ngẫu nhiên $S$ đều được định nghĩa qua một họ các biến ngẫu nhiên $S_{t}:\left(\Omega_{t}, \mathcal{S}_{t}, P_{t}\right) \rightarrow \mathbb{R}$. Các quá trình ngẫu nhiên như vậy tất nhiên đều là các quá trình ngẫu nhiên tương thích với lọc $\left(\mathcal{F}_{t}\right)$.

Khi ta giả sử rằng tình huống $\omega$ xảy ra, thì quá trình ngẫu nhiên $S$ trở thành một hàm số theo biến thời gian: $t \mapsto S_{t}(\omega)$. Hàm số $S_{\omega}(t):=S_{t}(\omega)$ này được gọi là một quĩ đạo (sample path) của $S$, ứng với tình huống $\omega$.

Nếu $s<t$, và ta biết là tình huống $\omega_{s}$ xảy ra cho đến thời điểm $s$, thì ta biết giá trị $S(s)=S_{s}\left(\omega_{s}\right)$ của quá trình ngẫu nhiên tại thời điểm $s$ (và các thời điểm trước đó), 
nhưng chưa đủ thông tin để biết giá trị của $S$ tại thời điểm $t$. Nói các khác, nếu $t>s$ thì $S_{t}$ cũng là biến ngẫu nhiên tại thời điểm $s$, tuy đã biết tình huống nào xảy ra cho đến thời điểm $s$. Nhưng khi đã biết $\omega_{s}$, thì không gian xác suất của $S_{t}$ không còn là không gian $\left(\Omega_{t}, P_{t}\right)$, mà là không gian xác suất có điều kiện

$$
\left(\left.\Omega_{t}\right|_{\omega_{s}}:=\left\{\omega_{t} \in \Omega_{t} \mid \pi_{s, t}\left(\omega_{t}\right)=\omega_{s}\right\},\left.P_{t}\right|_{\omega_{s}}\right)
$$

với xác suất có điều kiện $\left.P_{t}\right|_{\omega_{s}}$. Trong trường hợp mà $P_{s}\left(\omega_{s}\right)>0$ thì xác suất có điều kiện $\left.P_{t}\right|_{\omega_{s}}$ có thể được định nghĩa theo công thức thông thường:

$$
\left.P_{t}\right|_{\omega_{s}}(A)=P_{t}\left(A \mid \omega_{s}\right)=\frac{P_{t}(A)}{P_{s}\left(\omega_{s}\right)}
$$

với mọi $A$ đo được trong $\left.\Omega_{t}\right|_{\omega_{s}}$. Trong trường hợp mà $P_{s}\left(\omega_{s}\right)=0$ thì định nghĩa xác suất có điều kiện phức tạp hơn, phải thông qua các giới hạn; chúng ta sẽ coi rằng các xác suất có điều kiện này tồn tại và thỏa mãn các tính chất thường dùng (xem [7] về xác suất có điều kiện cho biến ngẫu nhiên).

Hoàn toàn tương tự như trên, ta có thể định nghĩa quá trình ngẫu nhiên với giá trị là vector, hoặc tổng quát hơn, quá trình ngẫu nhiên trên một đa tạp hay một không gian metric nào đó.

\subsubsection{Mô hình một bước thời gian}

Trong mô hình một bước thời gian, ta chỉ quan tâm đến giá cổ phiếu $S_{T}$ tại một thời điểm $T$ trong tương lai, và ta muốn dự đoán $S_{T}$. Vì $S_{T}$ có tính ngẫu nhiên, nên việc dự đoán $S_{T}$ không có nghĩa là dự đoán 1 con số duy nhất cho $S_{T}$, mà là dự đoán theo nghĩa xác suất: Cái mà chúng ta có thể làm là, dựa trên các thông tin có được, xây dựng một không gian xác suất $\left(\Omega_{T}, P_{T}\right)$ (1) các tình huống có thể xảy ra đến thời điểm $T$, và biểu diễn $S_{T}$ như là một biến ngẫu nhiên, với mô hình không gian xác suất là $\left(\Omega_{T}, P_{T}\right)$ :

$$
S_{T}:\left(\Omega_{T}, P_{T}\right) \rightarrow \mathbb{R}_{+}
$$

Nhắc lại rằng (xem Chương 2 của [7]), mỗi biến ngẫu nhiên $Y:(\Omega, P) \rightarrow \mathbb{R}$ trên một mô hình không gian xác suất $(\Omega, P)$ cho một phân bố xác suất $P_{Y}$ trên $\mathbb{R}$ theo công thức:

$$
P_{Y}(A)=P\left(Y^{-1}(A)\right)
$$

\footnotetext{
${ }^{(1)}$ Trong ký hiệu của một mô hình xác suất thường có ký hiệu của sigma-đại số, nhưng để cho tiện ta sẽ hay bỏ qua ký hiệu của sigma-đại số, khi mà điều đó không gây ra sự hiểu lầm nào.
} 
cho mọi đoạn thẳng $A \subset \mathbb{R}$, và ta có thể định nghĩa các đại lượng đặc trưng của $Y$, ví dụ như các moment bậc k:

$$
M_{k}(Y)=\int_{\Omega} Y^{k} d P=\int_{\mathbb{R}} y^{k} d P_{Y}(y)
$$

Tuy rằng $Y$ là ngẫu nhiên, nhưng một khi ta đã biết phân bố xác suất của nó, thì các đại lượng đặc trưng của nó là các đại lượng xác định, và cho ta các thông tin về $Y$.

Trong các đại lượng đặc trưng, có hai đại lượng quan trọng nhất, là kỳ vọng và phương sai. Kỳ vọng $\mathbb{E}(Y)$ của $Y$ là:

$$
\mathbb{E}(Y)=\int_{\mathbb{R}} y d P_{Y}(y)
$$

và phương sai $\sigma^{2}(Y)$ của $Y$ là:

$$
\sigma^{2}(Y)=\int_{\mathbb{R}}(y-\mathbb{E}(Y))^{2} d P_{Y}(y)=\mathbb{E}\left((Y-\mathbb{E}(Y))^{2}\right)=\mathbb{E}\left(Y^{2}\right)-(\mathbb{E}(Y))^{2} .
$$

Căn bậc hai của phương sai, $\sigma(Y)$, được gọi là độ lệch chuẩn của $Y$. Khi mà phương sai càng nhỏ, thì tức là các giá trị của $Y$ càng gần giá trị kỳ vọng của nó, có nghĩa là độ ngẫu nhiên (bất định) của $Y$ càng nhỏ. Bởi vậy phương sai (hay độ lệch chuẩn) chính là một thước đo độ bất định.

Trong trường hợp mà biến ngẫu nhiên là giá cổ phiếu $S_{T}$, đại lượng

$$
\mu=\frac{\mathbb{E}\left(S_{T}\right)-S_{0}}{S_{0}}
$$

trong đó $S_{0}$ là giá cổ phiếu tại thời điểm 0 , chính là mức lợi nhuận kỳ vọng của cổ phiếu $S$ cho khoảng thời gian từ 0 đến $T$, còn

$$
\sigma=\frac{\sigma\left(S_{T}\right)}{S_{0}}
$$

là một đại lượng đo độ bất định của giá cổ phiếu, theo mô hình dự đoán.

Ta có thể coi $S$ như là một quá trình ngẫu nhiên với chỉ có 2 mốc thời gian 0 và $T$, và không gian xác suất chính là $\left(\Omega_{T}, P_{T}\right)$. Hệ động lực ngẫu nhiên mô tả chuyển động của $S$ sau 1 bước thời gian, từ 0 đến $T$, có thể được viết dưới dạng phương trình sai phân:

$$
\Delta S=\mu S+\sigma S E
$$

trong đó:

- $S=S_{0}$ là giá cổ phiếu tại thời điểm 0 , 
- $\Delta S=S_{T}-S_{0}$ là độ thay đổi giá cổ phiếu từ thời điểm 0 đến thời điểm $T$,

- $\mu$ là mức lợi nhuận kỳ vọng, còn được gọi là hệ số trượt (drift) của mô hình,

- $\sigma$ là hệ số đo độ bất xác định của giá $S_{T}$, hay còn gọi là hệ số volatility (độ giao động) của mô hình,

- $E=\left(S_{T}-\mathbb{E}\left(S_{T}\right)\right) /\left(\sigma S_{0}\right)$ là phần ngẫu nhiên đã chuẩn hóa của mô hình: kỳ vọng của $E$ bằng 0 và độ lệch chuẩn của $E$ bằng 1 .

Ví du 7.1. Tiếp tục ví dụ 3.4 về giá cổ phiếu của một công ty sinh học nhỏ. Kỳ vọng giá cổ phiếu của ngày hôm sau của công ty bằng $60 \% \times 16+40 \% \times 5=11.6$ đô la, phương sai bằng $60 \% \times(16-11.6)^{2}+40 \% \times(5-11.6)^{2}=29.04$, và độ lệch chuẩn bằng $\sqrt{29.04} \approx 5.4$. Ta có mô hình chuyển động giá cổ phiếu 1 bước

$$
\Delta S=\mu S+\sigma S E,
$$

với các tham số sau: $S_{0}=10, \mu=\left(\mathbb{E}\left(S_{1}\right)-S_{0}\right) / S_{0}=0.16, \sigma=\sigma\left(S_{1}\right) / S_{0}=0.54$, và $E$ là một biến ngẫu nhiên chỉ nhận hai giá trị, và có kỳ vọng bằng 0 và độ lệch chuẩn bằng 1 .

Ví du 7.2. Cổ phiếu Coca-Cola (mã chứng khoán: KO) đạt giá 80\$ vào đầu năm 1998 . Với các công thức ước lượng giá trị thực của cổ phiếu dựa trên lợi nhuận và tăng trưởng, vào thời điểm đầu năm 1998, có thể ước lượng là giá trị của KO vào thời điểm đầu năm 2003 sẽ không quá 50 \$ cổ phiếu. (Xem Ví dụ 5.7). Tạm coi nó là 50 \$. Vì yếu tố "con cưng của thị trường" sẽ mất dần đi theo thời gian khi mà công ty Coca-Cola không còn phát triển nhanh được nữa nên ta giả thiết là giá cổ phiếu sẽ đi về giá trị thực sau 5 năm, trong giai đoạn 1998-2003. Khi đó, vào đầu năm 1998, mô hình dự đoán giá KO cho thời điểm đầu năm 2003 sẽ là:

$$
\mathrm{KO}_{2003}=50+\sigma \cdot \mathrm{KO}_{1998} \cdot E
$$

trong đó $\mathrm{KO}_{1998}=80, E$ là một biến ngẫu nhiên nào đó đã chuẩn hóa (kỳ vọng bằng 0 , phương sai bằng 1$), \sigma$ là một số nào đó cần ước lượng. Theo mô hình này thì mức lợi nhuận kỳ vọng cho 5 năm sẽ bằng $(50-80) / 80 \approx-38 \%$, tức là kỳ vọng là giá cổ phiếu sẽ giảm gần $40 \%$ sau 5 năm. Ta sẽ tạm thời bỏ qua việc chọn $E$ và $\sigma$ ở đây. (Có thể tạm coi là $E$ có phân bố normal chuẩn tắc $N(0,1)$ dựa trên định lý giới hạn trung tâm trong xác suất, và ước lượng $\sigma$ dựa trên độ giao động lịch sử (historical volatility) của KO). Thực tế xảy ra là $\mathrm{KO}_{2003}=40$, khá gần với dự báo của mô hình. 


\subsubsection{Mô hình với thời gian rời rạc}

Tương tự như là trong mô hình với một bước thời gian, trong các mô hình với thời gian rời rạc (hệ động lực với thời gian rời rạc) cho giá cổ phiếu, với giả sử là giá cổ phiếu luôn luôn dương, ta có thể viết chuyển động của quá trình ngẫu nhiên $S$ theo phương trình sai phân

$$
\frac{S_{n}-S_{n-1}}{S_{n-1}}=\mu_{n}+\sigma_{n} E_{n}
$$

trong đó

- $S_{n}$ là giá cổ phiếu tại thời điểm thứ $n$ trong tập các mốc thời gian $\left(S_{0}>0\right.$ là giá tại thời điểm ban đầu).

- $\mu_{n}$ là mức lợi nhuận kỳ vọng tại thời điểm thứ $n-1$ cho một bước chuyển động của giá, còn gọi là hệ số trượt của mô hình,

- $\sigma_{n}$ là hệ số volatility (độ giao động) của mô hình,

- $E_{n}$ là phần ngẫu nhiên đã chuẩn hóa của mô hình: kỳ vọng của $E_{n}$ bằng 0 và phương sai của $E_{n}$ bằng 1 (hoặc là đặt bằng $\tau$, trong đó $\tau$ là bước thời gian).

Mức lợi nhuận $\mu_{n}$ được xác định tại thời điểm $n-1$ khi đã biết tình huống $\omega_{n-1} \in \Omega_{n-1}$ nào xảy ra, trong đó $\Omega_{n-1}$ là ký hiệu không gian tất cả các tình huống có thể xảy ra cho đến thời điểm thứ $n-1$. Bản thân $\mu_{n}$ cũng có thể coi là một quá trình ngẫu nhiên (vì không biết trước được $\mu_{n}$ tại thời điểm 0 ), nhưng được gọi là một quá trình dự đoán được (predictable) vì biết được $\mu_{n}$ tại thời điểm thứ $n-1$, tức là biết trước một bước thời gian. Phân bố xác suất của phần sai số ngẫu nhiên $\sigma_{n} E_{n}$ cũng được biết tại thời điểm $n-1$, và do đó $\sigma_{n}$ cũng là một quá trình dự đoán được.

Tùy bài toán, ta có thể đưa thêm các giả thiết và điều kiện vào mô hình. Ví dụ, để cho đơn giản, người ta có thể giả sử là các biến sai số $\sigma_{n} E_{n}$ là một họ các biến ngẫu nhiên độc lập có cùng phân bố xác suất. Hoặc có thể giả sử là các biến ngẫu nhiên $E_{n}$ là độc lập với nhau và có cùng phân bố xác suất, còn đại lượng volatility $\sigma_{n}$ thay đổi theo thời gian. Một giả thiết khác hay được dùng, là $\mu$ và $\sigma$ là các hàm số theo 2 biến $n$ và $S$ : $\mu_{n}=\mu\left(n, S_{n-1}\right), \sigma_{n}=\sigma\left(n, S_{n-1}\right)$. Nói cách khác, $\mu_{n}$ và $\sigma_{n}$ không phụ thuộc vào toàn bộ tình huống $\omega_{n-1}$, mà chỉ phụ thuộc vào giá $S_{n-1}$ tại thời điểm $n-1$ (nhiều tình huống khác nhau có thể dẫn đến cùng 1 giá tại thời điểm $n-1)$.

Ở phía dưới, chúng ta sẽ xét mô hình cây nhị phân, là một trường hợp đơn giản của mô hình thời gian rời rạc. Chính vì đơn giản, dễ tính toán, nên mô hình cây nhị phân này 
rất quan trọng trong thực tế. Nhiều chương trình tính giá quyền chọn trên các thị trường chứng khoán thế giới là dựa trên mô hình cây nhị phân.

\subsubsection{Mô hình cây nhị phân}

Giống như trước, ta ký hiệu bước thời gian là $\tau$, và gọi thời điểm $n \tau$ là thời điểm thứ $n$ (thời điểm thứ 0 là thời điểm 0 , tức là thời điểm ban đầu). Giá của cổ phiếu tại thời điểm thứ $n$ được ký hiệu là $S(n)$ hay $S_{n}$. Ta coi $\left(S_{n}\right)_{n \in \mathbb{Z}_{+}}$là một quá trình ngẫu nhiên với thời gian rời rạc, và ta sẽ viết phương trình mô tả chuyển động của nó.

Ta sẽ giả sử là bước thời gian $\tau$ nhỏ đến mức, từ thời điểm thứ $n-1$ đến thời điểm thứ $n$ giá cổ phiếu chỉ kịp thay đổi 1 lần, phụ thuộc vào 1 tin xảy ra trong khoảng thời gian đó. Tin ở đây sẽ chỉ là tốt (ký hiệu là $g$ ) hoặc xấu (ký hiệu là $b$ ), và giá cổ phiếu sẽ thay đổi, phụ thuộc vào tin tốt hay tin xấu, theo công thức sau:

$$
S_{n}=\left\{\begin{array}{l}
S_{n-1}\left(1+u_{n}\right) \text { nếu tin tốt } \\
S_{n-1}\left(1+d_{n}\right) \text { nếu tin xấu }
\end{array} .\right.
$$

Các đại lượng $u_{n}$ và $d_{n}$ không nhất thiết phải cố định, mà có thể phụ thuộc vào tình huống đã xảy ra cho đến thời điểm thứ $n-1$ (và được biết vào thời điểm thứ $n-1$ khi tình huống đó được biết). Nói cách khác, chúng là các hàm số trên không gian xác suất $\left(\Omega_{n-1}, P_{n-1}\right)$ các tình huống có thể xảy ra cho đến thời điểm thứ $n-1$ :

$$
u_{n}, d_{n}: \Omega_{n-1} \rightarrow \mathbb{R}
$$

Chúng ta sẽ giả sử rằng $S_{0}>0$, và các đại lượng $u_{n}$ và $d_{n}$ thỏa mãn các bất đẳng thức

$$
u_{n}>d_{n}>-1
$$

có nghĩa là giá cổ phiếu luôn luôn dương, và giá cổ phiếu khi tin tốt thì cao hơn giá cổ phiếu khi tin xấu.

Không gian xác suất $\left(\Omega_{n}, P_{n}\right)$ các tình huống có thể xảy ra đến thời điểm thứ $n$ là một tập hữu hạn gồm có $2^{n}$ phần tử: mỗi phần tử có thể được ký hiệu bởi một dãy $n$ chữ cái $\omega_{n}=\left(a_{1}, \ldots, a_{n}\right)$, trong đó mỗi chữ cái nhận một trong hai giá trị $g$ (tin tốt) hoặc $b$ (tin xấu), và chữ cái thứ $i$ trong dãy ứng với tin xảy ra từ thời điểm thứ $i-1$ đến thời điểm thứ $i$. Ta có thể viết:

$$
\Omega_{n} \cong\{g, b\}^{n}
$$




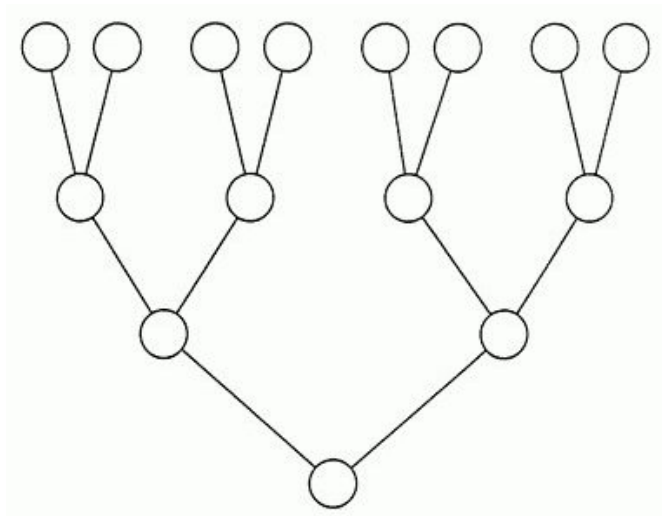

Hình 7.1: Cây nhị phân

Mô hình được gọi là cây nhị phân vì mỗi tình huống $\omega_{n-1}$ đến thời điểm $n-1$ được rẽ làm hai nhánh, thành 2 tình huống đến thời điểm $n$, ký hiệu là $\left(\omega_{n-1}, g\right)$ và $\left(\omega_{n-1}, b\right)$. Tại thời điểm 0 ban đầu thì cây chỉ có 1 nhánh, đến thời điểm thứ 1 thì thành 2 nhánh, đến thời điểm thứ 2 thì thành 4 nhánh, v.v.

Xác suất rẽ nhánh từ tình huống $\omega_{n-1}$ thành tình huống $\left(\omega_{n-1}, g\right) \in \Omega_{n}$ được ký hiệu là $p_{n}\left(\omega_{n-1}\right)$, và nó có thể được tính theo công thức xác suất có điều kiện:

$$
p_{n}\left(\omega_{n-1}\right)=P\left(\left(\omega_{n-1}, g\right) \mid \omega_{n-1}\right)=\frac{P_{n}\left(\omega_{n-1}, g\right)}{P_{n-1}\left(\omega_{n-1}\right)} .
$$

Ngược lại, khi ta biết các xác suất rẽ nhánh $p_{n}$, thì ta cũng có thể tìm lại được phân bố xác suất trên $\Omega_{n}$ theo công thức sau: với mọi $\omega_{n}=\left(a_{1}, \ldots, a_{n}\right) \in \Omega_{n}$, ta có

$$
P\left(\omega_{n}\right)=\prod_{i=1}^{n} \frac{P\left(\omega_{i}\right)}{P\left(\omega_{i-1}\right)},
$$

trong đó $\omega_{i}=\left(a_{1}, \ldots, a_{i}\right), \frac{P\left(\omega_{i}\right)}{P\left(\omega_{i-1}\right)}=p_{i}\left(\omega_{i-1}\right)$ nếu $a_{i}=g$ và $\frac{P\left(\omega_{i}\right)}{P\left(\omega_{i-1}\right)}=1-p_{i}\left(\omega_{i-1}\right)$ nếu $a_{i}=b$. Chúng ta sẽ giả sử các phân bố xác suất ở đây là không suy biến, có nghĩa là các xác suất rẽ nhánh thỏa mãn bất đẳng thức $0<p_{n}<1$.

Các đại lượng $u_{n}, d_{n}$ và $p_{n}$ có thể được coi như là các quá trình ngẫu nhiên, vì chúng không những phụ thuộc vào $n$, mà còn có thể phụ thuộc vào tình huống xảy ra. Các quá trình ngẫu nhiên này là dự đoán được, có nghĩa là từ thời điểm thứ $n-1$ đã biết được các giá trị của $u_{n}, d_{n}$ và $p_{n}$.

Vi $d u$ 7.3. Một mô hình nhị phân hai bước, tức là với $n=2$ :

$S_{0}=100$ (giá thời điểm 0 là 100)

$S_{1}(g)=125$ (giá thời điểm 1 là 125 nếu tin tốt) 
$S_{1}(b)=105$ (giá thời điểm 1 là 105 nếu tin xấu)

$p_{1}=0.5$ (xác suất để tin đầu tiên là tốt bằng 0.5 )

$S_{2}(g, g)=150$ (giá thời điểm 2 là 150 nếu tin đầu tốt tin sau cũng tốt)

$S_{2}(g, b)=115$ (giá thời điểm 2 là 115 nếu tin đầu tốt tin sau xấu)

$p_{2}(g)=0.4$ (nếu tin đầu tốt, thì xác suất để tin thứ hai cũng tốt là 0.4 )

$S_{2}(b, g)=130$ (giá thời điểm 2 là 130 nếu tin đầu xấu tin sau tốt)

$S_{2}(b, b)=90$ (giá thời điểm 2 là 115 nếu tin đầu xấu tin sau cũng xấu)

$p_{2}(b)=0.7$ (nếu tin đầu xấu, thì xác suất để tin thứ hai tốt là 0.7 )

Theo mô hình này, tại thời điểm $0, S_{2}$ là một biến ngẫu nhiên nhận 4 giá trị 150,115 , 130 và 90 , với các xác suất tương ứng là: $0.5 \times 0.4=0.2,0.5 \times(1-0.4)=0.3$, và $(1-0.5) \times 0.7=0.35,(1-0.5) \times(1-0.7)=0.15$. Tại thời điểm 1 , thì $S_{2}$ vẫn là biến ngẫu nhiên, nhưng nó chỉ còn nhận 2 giá trị, và phụ thuộc vào tính huống xảy ra cho đến thời điểm 1 . Ví dụ, nếu tin đầu tiên là tốt, thì khi đó $S_{2}$ là biến ngẫu nhiên với hai giá trị 150 và 115 , với các xác suất tương ứng là 0.4 và $1-0.4=0.6$.

Một trường hợp đặc biệt của cây nhị phân hay được dùng đến là khi $u_{n}=u, d_{n}=d$ và $p_{n}=p$ là những hằng số, không phụ thuộc vào $n$ cũng như là vào các tình huống xảy ra. Ta sẽ gọi mô hình cây nhị phân mà trong đó $u_{n}, d_{n}, p_{n}$ là các hằng số là mô hình cây nhị phân bất biến (invariant binary tree model), để phân biệt với mô hình cây nhị phân tổng quát. Mô hình cây nhị phân bất biến tất nhiên là tính toán dễ hơn so với mô hình nhị phân tổng quát vì có ít tham số hơn, và bởi vậy hay được dùng, nhưng bù lại nó không được chính xác bằng mô hình tổng quát.

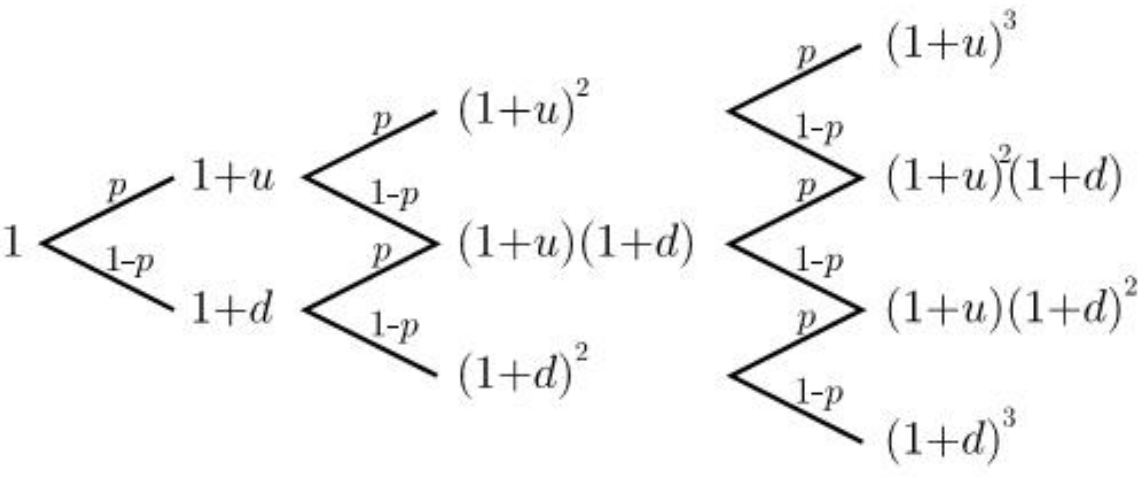

Hình 7.2: Cây nhị phân bất biến 3 bước

Bài tập 7.1. Viết lại phương trình chuyển động (7.21) của mô hình cây nhị phân dưới 
"dạng chuẩn" $\frac{S_{n}-S_{n-1}}{S_{n-1}}=\mu_{n}+\sigma_{n} E_{n}$ : tính $\mu_{n}, \sigma_{n}$ và tìm phân bố xác suất của $E_{n}$ từ các biến $u_{n}, d_{n}$ và $p_{n}$.

Bài tập 7.2. i) Chứng minh rằng, trong mô hình cây nhị phân bất biến, vào thời điểm 0 ban đầu, $S_{n}$ là một biến ngẫu nhiên nhận $n+1$ giá trị $(1+u)^{i}(1+d)^{n-i} S_{0}, i=0,1, \ldots, n$ (thay vì có thể nhận đến $2^{n}$ giá trị như trong mô hình cây nhị phân tổng quát), và mỗi giá trị $(1+u)^{i}(1+d)^{n-i} S_{0}$ có xác suất là $C_{n}^{i} p^{i}(1-p)^{n-i}$, trong đó $C_{n}^{i}=n ! /(i !(n-i)$ !) là nhị thức Newton. (Phân bố xác suất với các xác suất như vậy được gọi là phân bố nhị thức, xem [7]).

ii) Tính kỳ vọng $\mathbb{E}\left(S_{n}\right)$ của giá cổ phiếu sau $n$ bước trong mô hình cây nhị phân bất biến.

\subsubsection{Mô hình với thời gian liên tục}

Trong toán học, các mô hình với thời gian liên tục có thể được xây dựng như là giới hạn của các mô hình với thời gian rời rạc, khi mà bước thời gian tiến tới 0 . Đối với các quá trình ngẫu nhiên mô tả giá cổ phiếu cũng vậy: một quá trình với thời gian liên tục có thể nhận được bằng cách lấy giới hạn một quá trình với thời gian rời rạc, khi mà bước thời gian tiến tới 0 . Phương trình mô tả chuyển động của một quá trình ngẫu nhiên trong trường hợp thời gian liên tục sẽ là phương trình vi phân ngẫu nhiên (stochastic differential equation). Mô hình với thời gian liên tục đơn giản nhất, 1 chiều, mô tả sự thay đổi của giá cổ phiếu, có dạng sau:

$$
\frac{d S_{t}}{S_{t}}=\mu\left(t, S_{t}\right) d t+\sigma\left(t, S_{t}\right) d B_{t}
$$

hay còn viết là

$$
d S_{t}=\mu\left(t, S_{t}\right) S_{t} d t+\sigma\left(t, S_{t}\right) S_{t} d B_{t},
$$

trong đó $\mu\left(t, S_{t}\right)$ là hệ số trượt (drift), $\sigma\left(t, S_{t}\right)$ là hệ số volatility, là các hàm số với hai biến số thực, được cho bởi mô hình, (mỗi khi biết giá trị của $t$ và $S_{t}$ thì cũng biết giá trị của $\mu$ và $\sigma), B_{t}$ là một quá trình ngẫu nhiên gọi là chuyển động Brown (Brownian motion). Chuyển động Brown $B_{t}$ này được sinh ra bằng cách lấy giới hạn phần ngẫu nhiên trong mô hình rời rạc, khi khi bước thời gian $\tau$ tiến tới 0 .

Phương trình trên hiểu nghĩa như sau:

Khi mà thời gian $t$ dịch chuyển đi một đại lượng $\Delta t=t^{\prime}-t>0$ rất nhỏ, thì giá cổ phiếu cũng dịch chuyển đi một đại lượng $\Delta S_{t}=S_{t^{\prime}}-S_{t}$, bằng tổng của hai phần, một phần là dự đoán được tại thời điểm $t$, và một phần là không dự đoán được. Phần 
dự đoán được xấp xỉ bằng $\mu\left(t, S_{t}\right) \cdot S_{t} \cdot \Delta t$, còn phần không dự đoán được xấp xỉ bằng $\sigma\left(t, S_{t}\right) \cdot S_{t} \cdot\left(B_{t^{\prime}}-B_{t}\right)$.

Chúng ta sẽ định nghĩa chính xác chuyển động Brown, và nghiên cứu phương trình vi phân ngẫu nhiên (7.27), trong các phần phía sau của chương này. Các tính chất quan trọng nhất của một chuyển động Brown $B_{t}$ là:

- Bước chuyển động $B_{t^{\prime}}-B_{t}$ từ thời điểm $t$ đến thời điểm $t^{\prime}>t$ là độc lập theo nghĩa xác suất với mọi điều xảy ra cho đến thời điểm $t$.

- Phân bố xác suất của biến ngẫu nhiên $B_{t^{\prime}}-B_{t}$ (tại thời điểm $t$ ) là phân bố normal $N\left(0, t^{\prime}-t\right)$ với kỳ vọng bằng 0 và phương sai bằng $t^{\prime}-t$.

Các tính chất trên của thành phần chuyển động Brown $B_{t}$ trong phương trình vi phân ngẫu nhiên (7.27) có thể được giải thích một cách trực giác như sau:

- Bước chuyển động $B_{t^{\prime}}-B_{t}$ từ thời gian $t$ đến thời gian $t^{\prime}>t$ không phụ thuộc vào bất cứ điều gì xảy ra cho đến thời điểm $t$, bởi vì những cái gì mà phụ thuộc vào những chuyện xảy ra tại $t$ và các thời điểm trước đó thì coi là "dự đoán được" và có thể chuyển sang phần dự đoán được trong mô hình. Phần "hoàn toàn không dự đoán được" của mô hình là phần không hề phụ thuộc vào những điều xảy ra trước đó.

- Phần không dự đoán được có thể coi là có kỳ vọng bằng 0 , bởi vì bản thân kỳ vọng là đại lượng dự đoán được, nếu khác 0 có thể chuyển sang phần dự đoán được của mô hình.

- Phần không dự đoán được trong khoảng thời gian $\Delta t=t^{\prime}-t$ từ $t$ đến $t^{\prime}$ có thể chia thành tổng của $N$ phần không dự đoán được cho các khoảng thời gian có độ dài $\Delta t / N$ từ $t+(i-1) \Delta t / N$ dến $t+i \Delta t / N$. Như vậy nó là tổng của $N$ biến ngẫu nhiên, mà ta có thể coi là độc lập (do tính hoàn toàn không dự đoán được vừa nêu trên) và có phân bố xác suất tương tự nhau. Theo định lý giới hạn trung tâm (xem Chương 4 của [7]) thì một tổng như vậy, khi $N$ tiến tới vô cùng, phải tiến tới một biến ngẫu nhiên có phân bố xác suất là phân bố normal. Chính bởi vậy mà phần không dự đoán được $B_{t^{\prime}}-B_{t}$ trong mô hình có phân bố normal.

- Để xác định một phân bố xác suất normal, ta chỉ cần biết kỳ vọng và phương sai của nó. Ở đây ta đã biết kỳ vọng bằng 0 . Vì tính chất cộng tính của phương sai của 
tổng các biến ngẫu nhiên độc lập, và khi chia một bước chuyển động ngẫu nhiên $B_{t^{\prime}}-B_{t}$ thành nhiều bước nhỏ theo thời gian thì các bước đó độc lập với nhau, nên phương sai của $B_{t^{\prime}}-B_{t}$ có tính chất cộng tính theo thời gian, và nó được đặt bằng đúng $t^{\prime}-t$, sau khi ta đã chuẩn hóa nó bằng cách đưa hệ số volatility vào mô hình.

Ghi chú 7.1. Trong mô hình với thời gian liên tục (phương trình (7.27)) phía trên, giá chứng khoán cũng là hàm liên tục theo thời gian. Tuy nhiên, trong thực tế, có những lúc giá chứng khoán nhảy đột biến rất mạnh. Ví dụ, cổ phiếu của công ty công nghệ sinh học Orexygen Therapeutics (mã chứng khoán: OREX) có giá đóng cửa hôm 31/01/2011 là $9.09 \$$ mà giá mở cửa hôm sau chỉ còn $2.50 \$$, giảm $72 \%$, sau khi có tin loại thuốc chống béo mà hãng nghiên cứu bị chính phủ Mỹ từ chối chưa cho bán ra thị trường. Khi có những tình huống như vậy có thể xảy ra với giá chứng khoán, thì việc mô hình hóa bằng phương trình vi phân ngẫu nhiên như phương trình (7.27) không còn được chính xác, mà phải đưa vào thêm các gián đoạn (các bước nhảy đột biến). Các quá trình mà gián đoạn như vậy thường được gọi là các quá trình có nhảy (jump processes), và chúng đã được đưa vào các mô hình biến động giá chứng khoán trong các tài liệu gần đây, xem chẳng hạn [4] và Chương 7 của [16]. Tuy nhiên, trong khuôn khổ quyển sách nhập môn này, chúng ta sẽ tạm thời bỏ qua các gián đoạn, coi giá chứng khoán là liên tục theo thời gian và có thể mô tả dựa trên chuyển động Brown.

\subsection{Martingale}

\subsection{1 Định nghĩa tính chất martingale}

Nói một cách trực giác, một quá trình ngẫu nhiên $S_{t}$ được gọi là một martingale, hay thỏa mãn tính chất martingale, nếu như với mọi cặp thời điểm $s<t$, kỳ vọng có điều kiện của $S_{t}$, với điều kiện là đã biết những gì xảy ra cho đến thời điểm $s$, đúng bằng $S_{s}$. Nói cách khác, với tất cả các thông tin có được cho đến thời điểm $s$, thì kỳ vọng của gia số $S_{t}-S_{s}$ bằng 0 . Như vậy, một martingale là một quá trình ngẫu nhiên có thể thay đổi theo thời gian, nhưng mà kỳ vọng của sự thay đổi tại mọi thời điểm đều bằng 0 .

Để định nghĩa chính xác hơn tính chất martingale theo ngôn ngữ toán học, chúng ta cần khái niệm kỳ vọng theo sigma-đại số con: Nếu $X$ là một biến ngẫu nhiên trên không gian xác suất $(\Omega, \mathcal{F}, P)$, và $\mathcal{G}$ là một sigma-đại số con của $\mathcal{F}$, thì theo định nghĩa, kỳ vọng của $X$ theo $\mathcal{G}$ là một biến ngẫu nhiên $Y$ trên không gian xác suất $(\Omega, \mathcal{G}, P)$, tức là hàm $Y: \Omega \rightarrow \mathbb{R}$ đo được theo $\mathcal{G}$, sao cho với mọi tập con $A \subset \Omega$ đo được theo $\mathcal{G}$ (tức 
là $A \in \mathcal{G})$ ta có

$$
\int_{A} X d P=\int_{A} Y d P
$$

Chú ý rằng, $X$ nói chung không đo được theo $\mathcal{G}$, nên nói chung $Y$ không bằng $X$ : nếu đặt $Y$ bằng $X$ thì nó không đo được theo $\mathcal{G}$ tuy rằng 7.29 lúc đó hiển nhiên đúng.

Để hiểu ý nghĩa của đẳng thức (7.29), hình dung là $P(A)>0$, nhưng $A$ đủ nhỏ sao cho $Y$ là hằng số (hoặc gần như là hằng số) trên $A$. Chia cả hai vế của đẳng thức cho $P(A)$, ta được

$$
\mathbb{E}(X \mid A)=Y(A)
$$

trong đó vế trái là kỳ vọng có điều kiện của $X$ trong điều kiện $A$, và vế phải là giá trị (trung bình) của $Y$ trong (tập) tình huống $A$. Vì $A \in \mathcal{G}$ là tùy ý, nên ta nói rằng $Y$ là kỳ vọng của $X$ theo $\mathcal{G}$, và ta viết

$$
Y=\mathbb{E}(X \mid \mathcal{G})
$$

Ta có thể hình dung sigma-đại số $\mathcal{G}$ như là một lớp các điều kiện, còn $\mathbb{E}(X \mid \mathcal{G})$ là một biến ngẫu nhiên trên $(\Omega, \mathcal{G}, P)$ cho bởi các kỳ vọng có điều kiện, theo các điều kiện trong lớp đó. Nếu $X$ là biến ngẫu nhiên khả tích (tức là $\int_{\Omega}|X| d P<\infty$ ), thì $\mathbb{E}(X \mid \mathcal{G})$ luôn tồn tại và duy nhất theo nghĩa xác suất. Chứng minh của khẳng định này là bài tập dành cho bạn đọc.

Định nghĩa 7.2. Một quá trình ngẫu nhiên $S$ tương thích với một không gian xác suất có lọc $\left(\Omega,\left(\mathcal{F}_{t}\right), P\right)$ dược gọi là một martingale, hay gọi là thỏa mãn tính chất martingale, nếu nhu với mọi cặp mốc thời gian $s<t$, kỳ vọng của $S_{t}$ theo sigma-dại số $\mathcal{F}_{t}$ chính bằng $S_{s}$ :

$$
\mathbb{E}\left(S_{t} \mid \mathcal{F}_{t}\right)=S_{s} \text { với mọit }>s .
$$

\subsubsection{No-arbitrage và martingale}

Từ Chương 3 , chúng ta đã thấy rằng, với giả sử là thị trường không có độ chênh thị giá, thì tồn tại một xác suất trung hòa rủi ro: mọi chiến lược kinh doanh trên thị trường đều có kỳ vọng lợi nhuận bằng 0 theo xác suất đó. Nếu ta coi giá trị tài sản của một chiến lược kinh doanh trên thị trường là một quá trình ngẫu nhiên với chỉ có hai mốc thời điểm (trước và sau khi kinh doanh), thì quá trình ngẫu nhiên này chính là một martingale ứng với xác suất trung hòa rủi ro, vì kỳ vọng của lợi nhuận (độ thay đổi tài sản) bằng 0 .

Thị trường được xét tới trong Chương 3 là thị trường chỉ có một thời điểm kinh doanh. Ở đây, chúng ta sẽ mở rộng kết quả của Chương 3 cho thị trường với nhiều thời điểm 
kinh doanh, tức là thị trường mà giá cả được mô hình hóa bởi các quá trình ngẫu nhiên với nhiều mốc thời gian, hay thậm chí có thời gian liên tục.

Xét một thị trường chứng khoán. Ta sẽ giả sử rằng trên thị trường có một chứng khoán không rủi ro $A$, có giá tại thời điểm $t$ là $A(t)>0$, và tất cả các số $A(t)$ là cố định và được biết trước tại thời điểm 0 . (Chứng khoán không rủi ro này là cách để hình thức hóa tiền gửi sinh lãi trên thị trường tiền tệ, và để cho đơn giản ta giả sử là lãi suất không thay đổi theo thời gian, và có cùng một lãi suất cho mọi khoản tiền gửi và tiền vay). Ta sẽ giả sử là $A(t)$ là hàm đơn điệu không giảm theo $t: A(t) \geq A(s)$ với mọi $t \geq s$ (tiền cho vay phải có lãi ít ra là không âm, không thì không ai cho vay). Với mọi chứng khoán $S$ có giá $S(t)$ tại thời điểm $t$, ta đặt

$$
\tilde{S}(t)=S(t) \frac{A(0)}{A(t)}
$$

và gọi $\tilde{S}$ là giá chiết khấu của $S$ (mức chiết khấu được xác định bởi mức tăng trưởng của chứng khoán không rủi ro). Ta coi sự biến đổi theo thời gian của các giá chứng khoán chiết khấu là các quá trình ngẫu nhiên, trên mô hình xác suất các tình huống có thể xảy ra với thị trường.

Định lý 7.3. Xét một thị trường chứng khoán thỏa mãn nguyên lý no-arbitrage, và giả sử là có một chứng khoán không rủi ro A như phía trên. Gọi $\left(\Omega,\left(\mathcal{F}_{t}\right), P\right)$ là không gian có lọc xác suất các tình huống có thể xảy ra với thị trường. Khi đó tồn tại một phân bố xác suất $P_{*}$ trên $\left(\Omega,\left(\mathcal{F}_{t}\right)\right)$ sao cho các giá chiết khấu của các chứng khoán trên thị trường đều là martingale theo $P_{*}$ :

$$
\mathbb{E}_{*}\left(\tilde{S}_{t} \mid \mathcal{F}_{s}\right)=\tilde{S}_{s}
$$

với mọi chứng khoán $S$, mọi cặp mốc thời gian $s<t$, trong đó $\mathbb{E}_{*}$ là ký hiệu kỳ vọng tính theo $P_{*}$. Hơn nữa, hai phân bố xác suất $P_{*}$ và $P$ là lien tục tuyệt đối so với nhau, có nghĩa là một tập con của $\Omega$ có độ đo xác suất theo $P_{*}$ là số dương khi và chỉ khi nó có độ đo xác suất theo P là số dương.

Phân bố xác suất $P_{*}$ trong định lý trên gọi là phân bố xác suất trung hòa rủi ro, hay còn gọi là phân bố xác suất martingale hay độ đo martingale.

Ghi chú 7.2. Cách tiếp cận martingale trong tài chính (coi rằng mọi quá trình giá trên thị trường tài chính là martingale ứng với một xác suất trung hòa rủi ro nào đó) được khởi xướng bởi Michael Harrison và David Kreps từ năm 1979 với bài báo: J. M. Harrison, D. M. Kreps, Martingales and arbitrage in multiperiod securities markets, Journal of Economics Theory, 20 (1979), No. 1, 81-109. 
Ở đây, ta sẽ chứng minh Định lý 7.3 cho trường hợp thời gian là rời rạc (tức là ta sẽ chỉ xét thị trường tại các mốc thời gian $t=0,1,2, \ldots$ ), và không gian các tình huống $\Omega_{n}$ có thể xảy ra cho đến thời điểm $n$ là không gian hữu hạn với mọi số tự nhiên $n$. Trường hợp tổng quát của Định lý 7.3 sẽ được chấp nhập mà không chứng minh trong sách này.

Ta sẽ coi là $\Omega_{0}=\left\{\omega_{0}\right\}$ chỉ gồm một phần tử duy nhất, với xác suất bằng 1 . Ta sẽ coi là thị trường thỏa mãn các tính chất lý tưởng hóa sau:

Chi phí giao dịch bằng 0 , thị trường cho phép mua/bán với số lượng tùy ý kể cả bán khống, và tại mỗi thời điểm $n=0,1,2, \ldots$, mỗi mã chứng khoán trên thị trường chỉ có một giá duy nhất (giá đó phụ thuộc vào tình huống xảy ra cho đến thời điểm $n$, nhưng mọi giao dịch tại thời điểm đó thì sẽ có cùng 1 giá).

Xét một tài khoản chứng khoán trên thị trường, gồm có một số lượng các chứng khoán có rủi ro (tức là các chứng khoán có giá là các quá trình ngẫu nhiên $S^{i}$ không xác định được trước), và một lượng chứng khoán không rủi ro. (Không có tiền mặt, vì mọi khoản tiền mặt đã được tự động đổi thành chứng khoán không rủi ro). Gọi $m$ là số mã chứng khoán có rủi ro. Gọi số lượng chứng khoán có rủi ro thứ $i$ trong tài khoản, cho giai đoạn bắt đầu từ thời điểm $n-1$ cho đến thời điểm $n$, là $x_{i}(n)$, và số lượng chứng khoán không rủi ro trong tài khoản cho giai đoạn đó là $y(n)$. Khi đó, tổng giá trị của tài khoản vào thời điểm $n$ sẽ là:

$$
V(n)=\sum_{i=1}^{m} x_{i}(n) S^{i}(n)+y(n) A(n),
$$

trong đó $S^{i}(n)=S_{n}^{i}$ là giá của chứng khoán thứ $i$ tại thời điểm $n$. Đến thời điểm $n$ thì có thể mua bán cổ phiếu trong tài khoản, để được các lượng chứng khoán mới là $x_{i}(n+1)$ và $y(n+1)$ cho giai đoạn từ thời điểm $n$ đến thời điểm $n+1$, và cứ tiếp tục như vậy. Một dãy các số lượng chứng khoán $\left(x_{1}(n), \ldots, x_{m}(n), y(n)\right), n=1,2, \ldots$ như trên, được gọi là một chiến lược đầu tư.

Định nghĩa 7.4. Một chiến lược dầu tư $\left(x_{1}(n), \ldots, x_{m}(n), y(n)\right)(n \in \mathbb{N})$ dược gọi là: - Tự hạch toán (self-financing) nếu nhu tổng giá trị của các chứng khoán được mua/bán trong tài khoản vào mọi thời điểm n là bằng 0 .

- Dự đoán được (predictable), nếu nhu tại mỗi thời điểm n - 1 thì các đại lượng $x_{i}(n)$ và $y(n)$ là các số hoàn toàn được xác định bởi tình huống xảy ra với thị trường và với tài khoản cho đến thời điểm $n-1$. Nói theo ngôn ngứ các quá trình ngẫu nhiên, thì $x_{i}(n)$ và $y(n)$ là các quá trình dự đoán dược.

- Chấp nhận được (admissible) nếu nó là tư hạch toán, dư đoán dược, và có giá trị không âm $(V(n) \geq 0)$ tại mọi thời diểm $n=0,1,2, \ldots$. 
- Chiến lược arbitrage, nếu nó chấp nhận được, có giá trị ban đầu bằng $0, V(0)=0$, và tồn tại một số tự nhiên n sao cho kỳ vọng của $V(n)$ (theo phân bố xác suất trên không gian $\Omega_{n}$ các tình huống có thể xảy ra tới thời diểm n) là số dương.

Thị trường được gọi là thỏa mãn nguyên lý no-arbitrage nếu như không tồn tại chiến lược arbitrage theo như định nghĩa phía trên. Chúng ta sẽ giả thiết là thị trường thỏa mãn nguyên lý no-arbitrage này.

Ghi chú 7.3. Tính từ dự đoán được trong định nghĩa trên là nói về sự xác định được của các số lượng chứng khoán trong chiến lược vào mỗi thời điểm, chứ không phải là dự đoán trước được giá trị của tài khoản theo chiến lược. Chú ý là, khi ta đã cố định một chiến lược đầu tư dự đoán được (và đầu tư theo chiến lược đó), thì giá trị $V(n)$ của tài khoản vào thời điểm $n$ trở thành một hàm đơn trị trên không gian $\Omega_{n}$ các tình huống có thể xả ra với thị trường cho đến thời điểm $n$.

Khi biết các phân bố xác suất $P_{n}$ trên không gian $\Omega_{n}$ các tình huống có thể xảy ra cho tới thời điểm $n$, ta có thể định nghĩa các xác suất rẽ nhánh $P(n$, .) (là các xác suất có điều kiện) như sau:

$$
P\left(n, \omega_{n+1}\right)=\frac{P_{n+1}\left(\omega_{n+1}\right)}{P_{n}\left(\omega_{n}\right)},
$$

trong đó $\omega_{n}=\pi_{n, n+1}\left(\omega_{n+1}\right)$. Nói cách khác, $P(n)\left(\omega_{n+1}\right)$ là xác suất có điều kiện để xảy ra tình huống $\omega_{n+1}$, khi biết rằng tình huống $\omega_{n}$ xảy ra. Gọi là rẽ nhánh, vì từ một tình huống $\omega_{n}$ có thể rẽ nhánh ra thành nhiều tình huống $\omega_{n+1}$ khác nhau, khi thời gian chạy từ $n$ đến $n+1$. (Ta giả thiết là phân bố xác suất ở đây không suy biến, tức là mọi tình huống đều có xác suất dương).

Ngược lại, nếu biết các xác suất rẽ nhánh $P(n,$.$) , thì ta cũng tìm lại được các xác$ suất trên các không gian tình huống $\Omega_{n}$, theo công thức xác suất có điều kiện:

$$
P_{n}\left(\omega_{n}\right)=\prod_{k=1}^{n} \frac{P_{k}\left(\omega_{k}\right)}{P_{k-1}\left(\omega_{k-1}\right)}=\prod_{k=1}^{n} P\left(k-1, \omega_{k}\right),
$$

trong đó $\omega_{k}=\pi_{k, n}\left(\omega_{n}\right)$. Để xây dựng xác suất martingale $P_{*}$, ta chỉ cần xây dựng các xác suất rẽ nhánh $P_{*}(n,$.$) tương ứng, rồi áp dụng công thức tích phía trên để tính ra phân$ bố xác suất $P_{* n}$ trên $\Omega_{n}$ với mọi $n$. (Biết $P_{* n}$ với mọi $n$ tức là biết $P_{*}$ trên $\Omega$ ). Các xác suất rẽ nhánh $P_{*}(n,$.$) này chính là các xác suất rẽ nhánh trung hòa rủi ro, mà sự tồn tại$ của nó được cho bởi định lý 3.4 và bổ đề sau:

Bổ đề 7.5. Giả sử rằng vào thời điểm $n$, đã biết là tình huống $\omega_{n} \in \Omega_{n}$ xảy ra, và thị trường có một chiến lược arbitrage cho hai mốc thời gian $n$ và $n+1$, tức là có thể lập một 
rổ rài sản $\left(x_{1}(n), \ldots, x_{m}(n), y(n)\right)$ có tổng giá trị bằng 0 tại thời điểm $n$, nhưng có giá trị không âm tại thời điểm $n+1$, và có giá trị kỳ vọng dương tại diểm $n+1$. Khi đó tồn tại một chiến lược arbitrage (bắt đầu tù̀ thời diểm 0, và không có giả sử là tình huống nào xảy ra tại thời diểm $n$ ).

Bổ đề trên có nghĩa là, nếu thị trường không có chiến lược arbitrage, thì tại mỗi bước rẽ nhánh của thị trường cũng không có chiến lược arbitrage. (Giá trị kỳ vọng trong bổ đề trên là kỳ vọng theo phân bố xác suất rẽ nhánh "thực tế" $P\left(n, \omega_{n}\right)$ ban đầu).

Chứng minh. Thật vậy, giả sử là tồn tại chiến lược arbitrage $\left(x_{1}(n), \ldots, x_{m}(n), y(n)\right)$ tại nút $\omega_{n}$ của thị trường (tức là với giả sử rằng $\omega_{n}$ xảy ra). Khi đó, ta có thể xây dựng một chiến lược như sau từ thời điểm 0 :

- Tại các thời điểm < $n$, các số lượng chứng khoán đều bằng 0 .

- Tại thời điểm $n$ : nếu $\omega_{n}$ xảy ra, thì chọn các số lượng chứng khoán $\left(x_{1}(n), \ldots, x_{m}(n), y(n)\right)$ bằng đúng theo chiến lược arbitrage của nút $\omega_{n}$; nếu tình huống khác xảy ra, thì vẫn giữ nguyên mọi số lượng chứng khoán bằng 0 .

- Kết thúc tại thời điểm $n+1$ (tức là rút hết số lượng các chứng khoán rủi ro về 0 tại thời điểm này).

Dễ dàng thấy rằng chiến lược trên là dự chấp nhận được, và nó là một chiến lược arbitrage cho thị trường.

Theo giả thiết, thị trường không có chiến lược arbitrage. Do đó, tại mỗi nút cũng không có chiến lược arbitrage. Định lý 3.4 cho ta sự tồn tại của các xác suất rẽ nhánh trung hòa rủi ro không suy biến tại mỗi nút, mà ta sẽ ký hiệu là $P_{*}(n, \omega)$. Khi đã biết $P_{*}(n, \omega)$, ta có thể xây dựng các xác suất $P_{* n}$ trên $\Omega_{n}$ theo công thức tích như phía trên:

$$
P_{* n}\left(\omega_{n}\right)=\prod_{k=1}^{n} P_{*}\left(k-1, \omega_{k}\right) .
$$

Để kết thúc chứng minh định lý 7.3 , chúng ta còn cần phải kiểm tra rằng các phân bố xác suất $P_{* n}$ vừa xây dựng thỏa mãn tính chất martingale:

$$
\mathbb{E}_{*}\left(\tilde{S}_{N} \mid \omega_{n}\right)=\tilde{S}_{n}\left(\omega_{n}\right)
$$

với mọi chứng khoán $S$, mọi cặp thời điểm $N>n$, và mọi tình huống $\omega_{n}$ xảy ra đến thời điểm $n$, trong đó $\mathbb{E}_{*}$ là ký hiệu kỳ vọng theo xác suất $P_{*}$, và $\tilde{S}_{t}=S_{t} \frac{A(0)}{A(t)}$ là giá chiết khấu của chứng khoán $S$. 
Trường hợp $N=n+1$ : tại thời điểm $n$, khi $\omega_{s}$ đã biết, lập một rổ tài sản gồm có 1 đơn vị chứng khoán $S$, và $-S_{n}\left(\omega_{n}\right) / A(n)$ đơn vị chứng khoán không rủi ro $A$. Giá trị của rổ tài sản này tại thời điểm $s$ bằng 0 . Theo định nghĩa xác suất trung hòa rủi ro, thì kỳ vọng của rổ tài sản này theo phân bố xác suất $P_{*}\left(n, \omega_{n}\right)$ phải bằng 0 , tức là ta có:

$$
0=\mathbb{E}_{*}\left(S_{n+1}-\left(S_{n}\left(\omega_{n}\right) / A(n)\right) A(n+1) \mid \omega_{n}\right)=\mathbb{E}_{*}\left(S_{n+1} \mid \omega_{n}\right)-\tilde{S}_{n}\left(\omega_{n}\right) A(n+1) / A(0),
$$

từ đó suy ra

$$
\mathbb{E}_{*}\left(\tilde{S}_{n+1} \mid \omega_{n}\right)=\mathbb{E}_{*}\left(A(0) S_{n+1} / A(n+1) \mid \omega_{n}\right)=\tilde{S}_{n}\left(\omega_{n}\right),
$$

tức là ta đã chứng minh được tính chất martingale trong trường hợp riêng $N=n+1$. Trường hợp tổng quát $N>n$ suy ra được trực tiếp từ trường hợp riêng này, và các tính chất cơ bản của kỳ vọng (nếu sau mỗi bước kỳ vọng không thay đổi, thì sau $N-n$ bước kỳ vọng cũng không thay đổi - xem bài tập 7.3). Định lý 7.3 đã được chứng minh.

Bài tập 7.3. Chứng minh rằng nếu một quá trình ngẫu nhiên $S$ với thời gian rời rạc $t=0,1,2, \ldots$ thỏa mãn điều kiện

$$
\mathbb{E}_{*}\left(\tilde{S}_{n+1} \mid \omega_{n}\right)=\tilde{S}_{n}\left(\omega_{n}\right)
$$

với mọi $n$, thì nó là một quá trình martingale.

Bài tập 7.4. Chứng minh rằng các công thức sau tương đương với nhau và với điều kiện tự hạch toán của một chiến lược đầu tư:

1) Tổng giá trị giao dịch tại mỗi thời điểm bằng 0 :

$$
\sum_{i=1}^{m}\left(x_{i}(n+1)-x_{i}(n)\right) S_{i}(n)+(y(n+1)-y(n)) A(n)=0 \text { với mọi } n=1,2, \ldots
$$

2) Sự thay đổi giá trị của tài khoản sau mỗi bước thời gian là do sự thay đổi giá tạo ra:

$$
V(n+1)-V(n)=\sum_{i=1}^{m} x_{i}(n+1)\left(S_{i}(n+1)-S_{i}(n)\right)+y(n+1)(A(n+1)-A(n)) .
$$

3) Số lượng chứng khoán không rủi ro $y(n)$ được tự động xác định bởi các số lượng chứng khoán có rủi ro $x_{i}(n)$ muốn có trong tài khoản theo công thức

$$
y(n)=y(n-1)-\frac{\sum_{i=1}^{m}\left(x_{i}(n)-x_{i}(n-1)\right) S_{i}(n-1)}{A(n-1)} .
$$

Bài tập 7.5. Chứng minh rằng, nếu tồn tại một chiến lược tự hạch toán, dự đoán được, có $V(0)=0$ và $V(2)>0$ trong mọi tình huống, nhưng $V(1)$ có thể nhận giá trị âm (tức 
là có tình huống sao cho $V(1)<0)$, thì cũng tồn tại một chiến lược arbitrage mạnh, tức là một chiến chấp nhận được (thỏa mãn thêm điều kiện $V(1) \geq 0$ trong mọi tình huống), với $V(0)=0$ và $V(2)>0$ trong mọi tình huống . (Có thể thay 1 và 2 bằng hai số tự nhiên $k<n$ bất kỳ trong bài tập này).

Bài tập 7.6. Xét một thị trường với một chứng khoán không rủi ro $A$ thỏa mãn $A(0)=100$, $A(1)=110, A(2)=121$, và một cổ phiếu $S$. Giả sử có tất cả 3 tình huống có thể xảy ra, và giá của $S$ trong ba tình huống đó sẽ như sau:

$\begin{array}{llll}\text { Tình huống } & S(0) & S(1) & S(2) \\ \omega_{1} & 100 & 120 & 144 \\ \omega_{2} & 100 & 120 & 96 \\ \omega_{3} & 100 & 90 & 96\end{array}$

a) Có tồn tại chiến lược arbitrage không ? Nếu có thì hãy chỉ ra ví dụ.

b) Giả sử là không được phép bán khống, tức là số lượng cổ phiếu trong chiến lược phải luôn không âm. (Số lượng chứng khoán không rủi ro thì có thể là số âm, tức là có thể vay tiền). Hỏi rằng khi đó có tồn tại chiến lược arbitrage không ?

Bài tập 7.7. (Martingale trong mô hình cây nhị phân). Xét mô hình cây nhị phân tổng quát cho giá của một cổ phiếu, được xây dựng trong Mục 7.1.4. Để cho đơn giản, chúng ta sẽ giả sử là chứng khoán không rủi ro $A$ có tốc độ tăng giá trị cố định:

$$
A(n)=(1+R)^{n} A(0)
$$

trong đó $R>0$ là một mức lợi nhuận cố định nào đó cho một đơn vị thời gian. Nhắc lại rằng, trong mô hình cây nhị phân tổng quát, mỗi tình huống $\omega_{n}$ được phân nhánh làm 2 tình huống $\left(\omega_{n}, g\right)$ (tin tốt) và $\left(\omega_{n}, b\right)$ (tin xấu) khi thời gian đi từ $n$ đến $n+1$. Giá của cổ phiếu tại thời điểm $n+1$ là $S(n+1)=S(n)(1+u(n))$ nếu tin tốt xảy ra, và là $S(n+1)=S(n)(1+d(n))$ nếu tin xấu xảy ra trong khoảng thời gian từ $n$ đến $n+1$. Chứng minh rằng, mô hình cây nhị phân tổng quát thỏa mãn nguyên lý no-arbitrage khi và chỉ khi bất đẳng thức $d(n)<R<u(n)$ luôn được thỏa mãn. Trong trường hợp đó, tồn tại một phân bố xác suất martingale $p_{*}$ duy nhất, với các xác suất rẽ nhánh $p_{*}(n)$ cho bởi công thức sau:

$$
p_{*}(n)=\frac{R-d(n)}{u(n)-d(n)} .
$$

Kỳ vọng $\mathbb{E}_{*}\left(S(n) \mid \omega_{k}\right)$ của giá cổ phiếu theo phân bố xác suất martingale $p_{*}$, khi biết tình huống $\omega_{k}$ xảy ra cho đến thời điểm $k$, bằng:

$$
\mathbb{E}_{*}\left(S(n) \mid \omega_{k}\right)=S\left(k, \omega_{k}\right)(1+R)^{n-k}
$$


Trường hợp đặc biệt, khi $k=0$, ta có thể viết $\mathbb{E}_{*}(S(n))=S(0)(1+R)^{n}$.

\subsection{Chuyển động Brown}

Chuyển động Brown (Brownian motion) là một lớp các quá trình ngẫu nhiên mang tên nhà thực vật học Robert Brown (1773-1858) (2) người đã quan sát chuyển động của các hạt bụi (phấn hoa) trong nước thấy chúng đổi hướng liên tục (mỗi khi va đập phải các phân tử khác thì lại đổi hướng). Nó còn được gọi là quá trình Wiener, theo tên nhà toán học Robert Wiener (1894-1964), người có nhiều công trình nghiên cứu về các quá trình ngẫu nhiên và nhiễu(3). Từ năm 1900, ông Louis Bachelier đã đặt cơ sở cho toán tài chính hiện đại bằng việc dùng chuyển động Brown để mô hình hóa các quá trình biến động giá chứng khoán trong luận án tiến sĩ của mình, tuy rằng luận án của ông ta thời đó không được mấy ai quan tâm, và phải đến nửa sau thế kỷ 20 người ta mới thực sự quan tâm đến nó. Chuyển động Brown là một trong những lớp quá trình ngẫu nhiên quan trọng nhất, và phần lớn các chuyển động ngẫu nhiên có tính liên tục trong thực tế có thể được mô hình hóa dựa trên chuyển động Brown và các phép biến đổi giải tích. Ở đây, chúng ta sẽ định nghĩa về mặt toán học thế nào là một chuyển động Brown, và nghiên cứu một số tính chất quan trọng nhất của nó.

\subsection{1 Định nghĩa chuyển động Brown}

Trong khuôn khổ quyển sách này, chúng ta sẽ chỉ định nghĩa chuyển động Brown 1 chiều, trên tập hợp các số thực $\mathbb{R}$. Định nghĩa chuyển động Brown nhiều chiều hoàn toàn tương tự.

Định nghĩa 7.6. Một quá trình ngẫu nhiên tương thích $B_{t}$ nhận giá trị thực, với tập các mốc thời gian là $\mathbb{R}_{+}$, trên mô hình không gian xác suất có lọc $\left(\Omega,\left(\mathcal{F}_{t}\right), P\right)$, được gọi là một quá trình Wiener hay chuyển động Brown chuẩn tắc 1 chiều, nếu nó thỏa mãn các điều kiện sau:

i) Xuất phát điểm là $0: B_{0}=0$.

ii) $B_{t}$ là một quá trình liên tục. Có nghĩa là, với hầu hết mọi $\omega \in \Omega$, hàm số $B_{\omega}(t):=$ $B_{t}(\omega)$, tức là quỹ đạo của $B_{t}$ trong tình huống $\omega$, là hàm liên tục theo biến thời gian $t$.

\footnotetext{
${ }^{(2)}$ Xem: http://en.wikipedia.org/wiki/Robert_Brown_(botanist)

${ }^{(3)}$ Xem: http://en.wikipedia.org/wiki/Norbert_Wiener . Các nhiễu mà được mô hình bởi chuyển động Brown gọi là nhiễu trắng (white noise).
} 
iii) Với mọi $0 \leq s<t$, biến ngẫu nhiên $B_{t}-B_{s}$ (gọi là bước đi, hay gia số, của quá trình ngẫu nhiên từ s đến $t$ ) không phu thuộc vào tình huống xảy ra cho tới thời điểm s, hay nói cách khác, nó độc lập với sigma-đại số $\mathcal{F}_{s}$. Có nghĩa là, với mọi $A \in \mathcal{F}_{s}$ và $[a, b] \subset \mathbb{R}$ ta có

$$
P\left(A \cap\left(B_{t}-B_{s} \in[a, b]\right)\right)=P(A) \cdot P\left(B_{t}-B_{s} \in[a, b]\right) .
$$

iv) Với $t>s \geq 0$ bất kỳ, phân bố xác suất của $B_{t}-B_{s}$ là phân bố normal $N(0, t-s)$ với kỳ vọng bằng 0 và phương sai bằng $t-s$.

Khi nói một quá trình nào đó là chuyển động Brown mà không nói cụ thể thêm, chúng ta sẽ luôn hiểu đó là chuyển động Brown chuẩn tắc 1 chiều.

Trong định nghĩa trên, điều kiện i) là để chuẩn hóa, gọi điểm xuất phát của chuyển động là 0 . Điều kiện ii) là tính chất liên tục của chuyển động Brown. Ý nghĩa của điều kiện iii) cũng khá hiển nhiên: những bước chuyển động trong tương lai không hề phụ thuộc vào những gì đã xảy ra trong quá khứ. Điều kiện iv) xuất phát từ ý tưởng sau: bước chuyển động theo thời gian từ $s$ đến $t$, với độ dài thời gian bằng $t-s$, có thể chia nhỏ thành tổng của $N$ bước chuyển động độc lập, mỗi bước có độ dài thời gian là $(t-s) / N$ (với mọi số tự nhiên $N$ ). Khi $N$ tiến đến vô cùng, thì theo định lý giới hạn trung tâm (xem Chương 4 của [7]), tổng của $N$ biến ngẫu nhiên độc lập cùng phân bố xác suất sẽ có phân bố xác suất tiến đến một phân bố normal (sau khi chuẩn hóa). Bởi vậy, một cách trực giác, phân bố xác suất của $B_{t}-B_{s}$ phải là phân bố normal. Việc đặt phân bố normal đấy bằng $N(0, t-s)$ cũng là để chuẩn hóa.

Từ định nghĩa trên, suy ra ngay được rằng, nếu $B_{t}$ là một chuyển động Brown và $0<t_{1}<\ldots<t_{n}$ thì bộ $n$ biến ngẫu nhiên $\left(B_{t_{1}}, \ldots, B_{t_{n}}\right)$ có phân bố xác suất chung là phân bố normal $n$ chiều (xem Chương 3 của [7] về phân bố normal nhiều chiều).

Bài tập 7.8. Chứng minh rằng, nếu $B(t)$ là một chuyển động Brown, thì các quá trình $-B(t), B\left(t+t_{0}\right)-B\left(t_{0}\right)$ (trong đó $t_{0}>0$ là một hằng số), và $a B\left(t / a^{2}\right)$ (trong đó $a \neq 0$ là một hằng số) cũng là các chuyển động Brown.

Bài tập 7.9. Đặt $Z_{t}=a+\mu t+\sigma B_{t}$ trong đó $a, \mu, \sigma$ là các hằng số. Tìm phân bố xác suất của các gia số $Z_{t}-Z_{s}$, và chứng minh rằng quá trình $Z_{t}$ cũng là quá trình liên tục và có gia số độc lập, tức là nó thỏa mãn các tính chất iii) và iv) trong định nghĩa chuyển động Brown. (Quá trình $Z_{t}$ này có thể được gọi là một chuyển động Brown không chuẩn tắc, với xuất phát điểm là $a$, hệ số volatility là $\sigma$ và hệ số trượt là $\mu$ ).

Bài tập 7.10. Giả sử $B_{t}$ là một chuyển động Brown, và $a>0$ là một hằng số. Xây dựng một quá trình ngẫu nhiên $W_{t}$ sau, gọi là gương phản (reflection) của $B_{t}$ theo $a$ : 
- Nếu $B_{s}(\omega)<a$ với mọi $s<t$, thì $W_{t}(\omega)=B_{t}(\omega)$. (Tức là khi chưa đi lên chạm vào đến $a$, thì quá trình $W_{t}$ trùng với $\left.B_{t}\right)$.

- Nếu tồn tại $s<t$ sao cho $B_{s}(\omega)=a$, thì $W_{t}(\omega)=2 a-B_{t}(\omega)$. (Kể từ khi bắt đầu chạm vào $a$, thì $W_{t}$ là gương phản của $B_{t}$ qua $a$ ).

Chứng minh rằng quá trình $W_{t}$ xây dựng như trên cũng là một chuyển động Brown.

Bài tập 7.11. Chứng minh công thức xác suất vượt rào sau đây của chuyển động Brown:

$$
P\left\{\max _{0 \leq t \leq T} B_{t} \geq a\right\}=2 \int_{a}^{\infty} \frac{e^{-x^{2} / 2 T}}{\sqrt{2 \pi T}} d x .
$$

Hướng dẫn: viết sự kiện $\max _{0 \leq t \leq T} B_{t} \geq a$ dưới dạng hợp không giao nhau của hai sự kiện $B_{T} \geq a$ và $W_{T}>a$, trong đó $W_{t}$ là gương phản của $B_{t}$ qua $a$ như trong bài tập trước.

\subsubsection{Phân bố xác suất của chuyển động Brown}

Giả sử $S_{t}$ là một quá trình ngẫu nhiên tùy ý, tương thích với một mô hình xác suất $\left(\Omega, \mathcal{F}_{t}, P\right)$, và gọi $\mathcal{T}$ là tập các mốc thời gian của quá trình này. (Trường hợp $\mathcal{T}=\mathbb{R}_{+}$là trường hợp thời gian là liên tục, còn trường hợp $\mathcal{T}=\left\{0=t_{0}<t_{1}<t_{2}<\ldots\right\}$ là trường hợp với thời gian rời rạc; một quá trình ngẫu nhiên $S_{t}$ với thời gian rời rạc cũng có thể được coi là quá trình với thời gian liên tục bằng cách đặt $S_{t}=S_{t_{n}}$ nếu $t$ kẹp giữa hai mốc thời gian rời rạc $t_{n}$ và $\left.t_{n+1}: t_{n} \leq t<t_{n+1}\right)$. Ta có thể coi quá trình ngẫu nhiên $S_{t}$ như là một ánh xạ

$$
S: \Omega \rightarrow \mathbb{R}^{\mathcal{T}}
$$

từ không gian các tình huống $\Omega$ vào không gian $\mathbb{R}^{\mathcal{T}}$ các hàm số thực trên $\mathcal{T}$ : ảnh của một tình huống $\omega$ theo ánh xạ này chính là quỹ đạo $S_{\omega}()=$.$S . (\omega)$ của $S$ trong tình huống $\omega$. Quá trình ngẫu nhiên $S_{t}$ cũng sẽ được ký hiệu là $S$ hay $S(t)$, nếu ký hiệu như thế tiện hơn.

Nếu $X$ là một biến ngẫu nhiên (hay một vector ngẫu nhiên $n$ chiều), thì có một phân bố xác suất $P_{X}$ tương ứng trên $\mathbb{R}$ (hay trên $\mathbb{R}^{n}$ ), được định nghĩa bằng push-forward:

$$
P_{X}(A)=P(X \in A)
$$

trong đó $A$ là đoạn thẳng bất kỳ trên $\mathbb{R}$ (hay một hình hộp bất kỳ trong $\mathbb{R}^{n}$ ). Khi làm các phép tính với các biến ngẫu nhiên hay các vector ngẫu nhiên để ra các con số có ý nghĩa, thì mô hình không gian xác suất ban đầu nói chung không quan trọng, mà cái quan trọng chính là phân bố xác suất của nó trên $\mathbb{R}$ hay $\mathbb{R}^{n}$. Tương tự như vậy, khi tính toán với một quá trình ngẫu nhiên $S_{t}$, thì mô hình phân bố xác suất ban đầu $\left(\Omega,\left(\mathcal{F}_{t}\right), P\right)$ không quan 
trọng bằng phân bố xác suất $P_{S}$ trên $\mathbb{R}^{\mathcal{T}}$, nhận được từ phân bố xác suất trên $\Omega$ qua push-forward của ánh xạ $S$, và gọi là phân bố xác suất của quá trình ngẫu nhiên $S_{t}$ trên $\mathbb{R}^{\mathcal{T}}$ : Sigma-đại số trên $\mathbb{R}^{\mathcal{T}}$ là sigma-đại số Borel $\mathcal{B}$, sinh bởi các tập con có dạng

$$
C_{t_{1}, \ldots, t_{n}}^{A}=\left\{f: \mathcal{T} \rightarrow \mathbb{R} ;\left(f\left(t_{1}\right), \ldots, f\left(t_{n}\right)\right) \in A\right\}
$$

trong đó $n \in \mathbb{N}, t_{i}$ là các phần tử của $\mathcal{T}$ và $A \subset \mathbb{R}^{n}$ là một tập Borel. Các tập có dạng như vậy được gọi là các tập hình trụ (cylinder). Xác suất theo $P_{S}$ của tập hình trụ là:

$$
P_{S}\left(C_{t_{1}, \ldots, t_{m}}^{A}\right)=P\left\{\left(S_{t_{1}}, \ldots, S_{t_{n}}\right) \in A\right\}
$$

Sigma-đại số Borel $\mathcal{B}$ trên $\mathbb{R}^{\mathcal{T}}$ có một lọc tự nhiên các sigma-đại số con $\mathcal{B}_{\sqcup}$, gọi là lọc Borel: với mỗi $t \in \mathcal{T}, \mathcal{B}_{t}$ được sinh bởi các tập hình trụ $C_{t_{1}, \ldots, t_{n}}^{A}$ thỏa mãn điều kiện $t_{i} \leq t$ với mọi $i=1, \ldots, n$.

Sự tương thích của một quá trình $S_{t}$ với mô hình xác suất $\left(\Omega,\left(\mathcal{F}_{t}\right), P\right)$ tương đương với điều kiện sau: $S^{*} \mathcal{B}_{t} \subset \mathcal{F}_{t}$, trong đó $\mathcal{B}_{t}$ là lọc Borel trên $\mathbb{R}^{\mathcal{T}}$ và $S^{*} \mathcal{B}_{t}$ là ảnh ngược của nó trên $\Omega$ theo $S$. Ta có thể lấy luôn $S^{*} \mathcal{B}_{t}$ làm lọc cho mô hình không gian xác suất của $S$ trên $\Omega$, nếu lọc trên $\Omega$ chưa cố định. Lọc $S^{*} \mathcal{B}_{t}$ có tính chất tối ưu sau: mọi lọc khác trên $\Omega$ sao cho $S$ là tương thích phải chứa lọc này. Ta sẽ gọi $S^{*} \mathcal{B}_{t}$ là lọc $\sinh$ bởi $S$ trên không gian xác suất $\Omega$.

Chú ý rằng, mọi phân bố xác suất trên $\mathbb{R}^{\mathcal{T}}$, với sigma-đại số là sigma-đại số Borel sinh bởi các tập hình trụ, đều là phân bố xác suất của một quá trình ngẫu nhiên tương thích $S_{t}$ nào đó. Thật vậy, ta có thể xây dựng ví dụ như sau: đặt không gian các tình huống $\Omega$ bằng chính $\mathbb{R}^{\mathcal{T}}$ với phân bố xác suất này, đặt lọc $\mathcal{F}_{t}$ các sigma-đại số con bằng chính lọc Borel $\mathcal{B}_{t}$, và đặt $S_{t}(\omega)=\omega(t)$, tức là khi tình huống $\omega$ xảy ra thì quỹ đạo của quá trình ngẫu nhiên $S_{t}$ chính là hàm số $\omega$. Khẳng định này được gọi là định lý Kolmogorov về sự tồn tại của các quá trình ngẫu nhiên với phân bố xác suất cho trước.

Trong trường hợp mà $S_{t}=B_{t}$ là một chuyển động Brown, thì theo định nghĩa, với mọi $0 \leq t_{0}<t_{1} \ldots<t_{n} \leq t$ và các đoạn thẳng $D_{i} \in \mathbb{R}$, ta có:

$$
P\left(B_{t_{i}}-B_{t_{i-1}} \in D_{i} \forall i=1, \ldots, n\right)=\prod_{i=1}^{n} P\left(B_{t_{i}}-B_{t_{i-1}} \in D_{i}\right)=\prod_{i=1}^{n} \int_{D_{i}} \frac{1}{\sqrt{2 \pi}} e^{-x^{2} / 2} d x,
$$

và do đó xác suất của các tập hình trụ trên $\mathbb{R}^{\mathbb{R}_{+}}$theo phân bố xác suất của chuyển động Brown là:

$$
P_{S}\left(C_{t_{1}, \ldots, t_{m}}^{A}\right)=\frac{1}{(\sqrt{2 \pi})^{n}} \int_{A} e^{-x_{1}^{2} / 2} e^{-\left(x_{2}-x_{1}\right)^{2} / 2} \ldots e^{-\left(x_{n}-x_{n-1}\right)^{2} / 2} d x_{1} \ldots d x_{n}
$$


Để chứng tỏ sự tồn tại về mặt toán học của chuyển động Brown, ta có thể xây dựng ví dụ hoàn toàn tương tự như trong trường hợp tổng quát. Chỉ có điều khác là, thay vì đặt $\Omega=\mathbb{R}^{\mathbb{R}_{+}}$là không gian tất cả các hàm số thực trên nửa đường thẳng $\mathbb{R}_{+}$, ta đặt $\Omega=\left\{\omega \in C^{0}\left(\mathbb{R}_{+}, \mathbb{R}\right) \mid \omega(0)=0\right\}$ là không gian các hàm số liên tục trên $\mathbb{R}_{+}$và có giá trị bằng 0 tại 0 , để đảm bảo mọi quỹ đạo đều là liên tục. Các tập hình trụ, và các sigma-đại số, định nghĩa hệt như cũ, chỉ thêm điều kiện là các phần tử đều là các hàm liên tục. Ví dụ mô hình chuyển động Brown này cho thấy, quỹ đạo của một chuyển động Brown có thể là một hàm số liên tục bất kỳ. Tuy nhiên, như chúng ta sẽ thấy, hầu hết các quỹ đạo của một chuyển động Brown thỏa mãn một số tính chất đặc trưng như: không khả vi tại bất cứ điểm nào, và có biến phân vô hạn.

Ghi chú 7.4. Điều kiện iii) trong định nghĩa của chuyển động Brown hay được thay bằng điều kiện sau:

iii') Với mọi $0 \leq t_{0}<t_{1}<\ldots<t_{n}$, bộ $n$ biến ngẫu nhiên $\left(B_{t_{1}}-B_{t_{0}}, B_{t_{2}}-B_{t_{1}}, \ldots, B_{t_{n}}-\right.$ $\left.B_{t_{n-1}}\right)$ là một bộ biến ngẫu nhiên độc lập. Nói cách khác, các bước đi của chuyển động Brown là độc lập với nhau.

Một quá trình ngẫu nhiên thỏa mãn điều kiện iii') phía trên thì được gọi là một quá trình có gia số độc lập (independent increments).

Dễ thấy rằng điều kiện iii') là hệ quả của điều kiện iii). Trong trường hợp mà lọc $\mathcal{F}_{t}$ trong mô hình xác suất chính là lọc sinh bởi quá trình ngẫu nhiên, thì điều kiện iii') tương đương với điều kiện iii).

\subsubsection{Du dộng ngẫu nhiên}

Chuyển động Brown được dùng nhiều trong thực tế, chính là vì nó là giới hạn (liên tục hóa) của các quá trình ngẫu nhiên với thời gian rời rạc có dạng gọi là du động ngẫu nhiên, khi ta cho độ dài thời gian của mỗi bước đi tiến tới 0 . Các quan sát của Robert Brown dẫn đến chuyển động mang tên ông cũng chính là quan sát sự du động ngẫu nhiên của các hạt bụi trong nước (tức là thực ra trong các khoảng thời gian rất nhỏ, giữa 2 lần va đập vào các phân tử khác, thì chuyển động của một hạt bụi là có hướng nhất định, chứ không hoàn toàn vô hướng (kỳ vọng của gia số bằng 0 ) như trong định nghĩa của quá trình Wiener).

Nói một cách cụ thể hơn, xét một quá trình ngẫu nhiên $X^{\tau}$ với thời gian rời rạc, có bước thời gian bằng $\tau>0$. Giả sử là $X_{0}=0$, các gia số $X_{n \tau}-X_{(n-1) \tau}$ là độc lập với nhau và có cùng phân bố xác suất, là phân bố Bernoulli sau: xác suất để $X_{n \tau}-X_{(n-1) \tau}=a_{\tau}$ là 
$50 \%$ và xác suất để $X_{n \tau}-X_{(n-1) \tau}=-a_{\tau}$ cũng là $50 \%$, trong đó $a_{\tau}$ là một hằng số dương có phụ thuộc vào tham số $\tau$ mà chúng ta sẽ xác định sau. Một quá trình ngẫu nhiên như vậy được gọi là một quá trình du động ngẫu nhiên (random walk) một chiều, với độ dài của bước thời gian bằng $\tau$ và độ dài của bước du động bằng $a_{\tau}$ (tức là cứ sau mỗi khoảng thời gian $\tau$ thì lại dịch chuyển toàn toàn ngẫu nhiên, hoặc là sang trái hoặc là sang phải, một đoạn có độ dài $\left.a_{\tau}\right)$. Quá trình du động ngẫu nhiên này là một trường hợp đặc biệt của mô hình cây nhị phân.

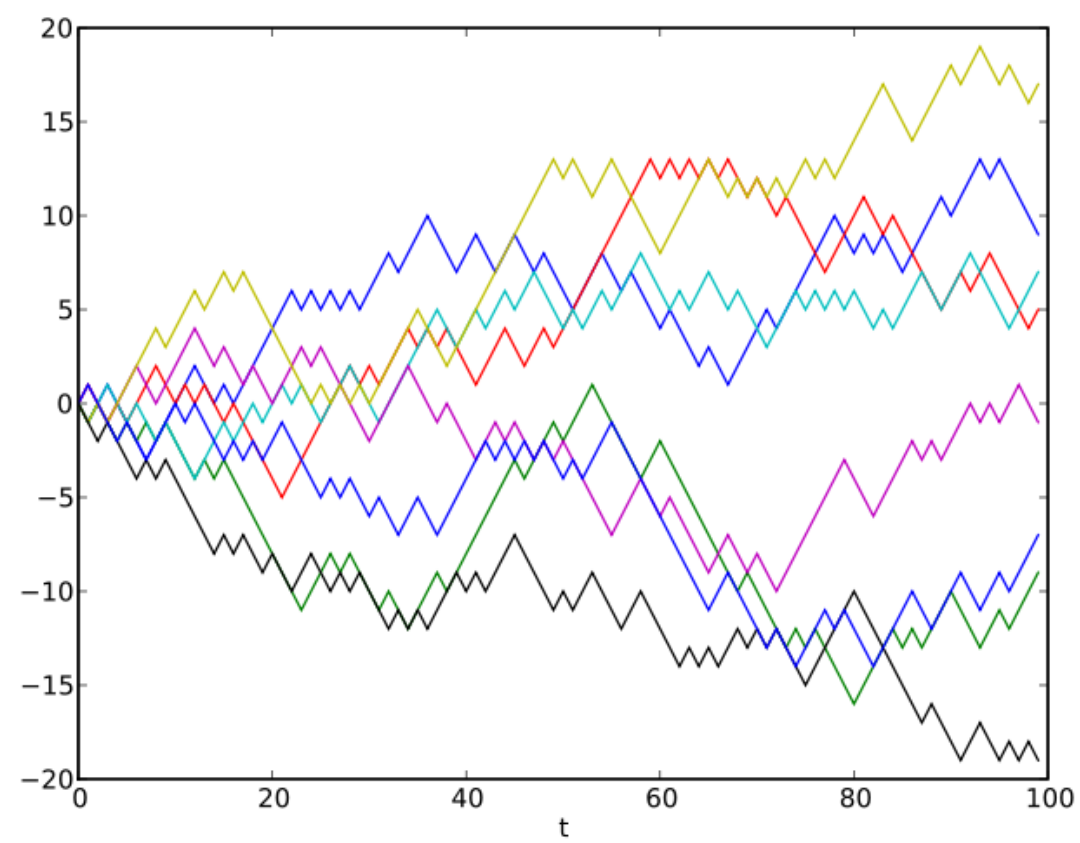

Hình 7.3: Một số ví dụ đồ thị đường du động ngẫu nhiên $\left(\tau=a_{\tau}=1\right)$

Xét quãng đường đi được $X_{t}^{\tau}-X_{s}^{\tau}$ của một quá trình du động ngẫu nhiên từ một thời điểm $s=M \tau$ đến một thời điểm $t=(M+N) \tau$. Ta có thể viết

$$
X_{t}^{\tau}-X_{s}^{\tau}=\sum_{i=1}^{N} Y_{M+i}^{\tau}
$$

trong đó $Y_{M+i}^{\tau}=X_{(M+i) \tau}^{\tau}-X_{(M+i-1) \tau}^{\tau}$ là từng bước đi một. Theo giả thiết, các bước đi $Y_{N+i}^{\tau}$ là độc lập với nhau và có cùng phân bố xác suất là phân bố Bernoulli, tức là $X_{t}^{\tau}-X_{s}^{\tau}$ là tổng của $N$ biến ngẫu nhiên cùng phân bố xác suất. Khi $N$ lớn (tức là $\tau$ nhỏ, vì ta giả sử $s$ và $t$ cố định, và $t-s=N \tau$ ), ta có thể sử dụng định lý giới hạn trung tâm để nghiên cứu phân bố xác suất của $X_{t}^{\tau}-X_{s}^{\tau}$. Trước hết, nhắc lại định lý giới hạn trung 
tâm (xem Chương 4 của [7]; trường hợp đặc biệt của nó, cho các phân bố Bernoulli, được chứng minh bởi de Moivre và Laplace từ thế kỷ 18):

Định lý 7.7 (Định lý giới hạn trung tâm). Giả sử $Y_{1}, Y_{2}, \ldots, Y_{n}, \ldots$ là một dãy các biến ngẫu nhiên độc lập có cùng phân bố xác suất với kỳ vọng bằng 0 và độ lệch chuẩn bằng $\sigma$ hũu hạn. Dặt $Z_{N}=\sum_{i=1}^{N} \frac{Y_{i}}{\sigma \sqrt{N}}$. Khi đó với mọi đoạn thẳng $[a, b] \subset \mathbb{R}$, ta có:

$$
\lim _{N \rightarrow \infty} P\left(a \leq Z_{N} \leq b\right)=\int_{a}^{b} \frac{1}{\sqrt{2 \pi}} e^{-x^{2} / 2} d x .
$$

Nói cách khác, phân bố xác suất của $Z_{N}$ tiến tới phân bố normal chuẩn tắc $N(0,1)$ khi $N$ tiến tới vô cùng.

Chú ý rằng, trong định lý giới hạn trung tâm, có đại lượng $\sqrt{N}$ xuất hiện. Để sử dụng định lý giới hạn trung tâm cho $X_{t}-X_{s}$, ta sẽ đặt $Y_{M+n}^{\tau}=Y_{n} / \sqrt{N /(t-s)}=\sqrt{\tau} Y_{n}$, hay $Y_{n}=Y_{M+n}^{\tau} / \sqrt{\tau}$. Ta sẽ coi là các biến $Y_{M+n}^{\tau} / \sqrt{\tau}$ có cùng phân bố xác suất và phân bố này không phụ thuộc vào $\tau$. Nhắc lại rằng, phân bố xác suất của $Y_{M+n}^{\tau}$ là phân bố Bernoulli, nhận hai giá trị $\pm a_{\tau}$, với xác suất $50 \%$ cho mỗi giá trị. Nói rằng phân bố xác suất của $Y_{M+n}^{\tau} / \sqrt{\tau}$ không phụ thuộc vào $\tau$ có nghĩa là $a_{\tau} / \sqrt{\tau}$ là hằng số không phụ thuộc vào $\tau$. Để cho tiện, ta sẽ đặt

$$
a_{\tau}=\sqrt{\tau}
$$

Khi đó độ lệch chuẩn của $Y_{M+n}^{\tau} / \sqrt{\tau}$ đúng bằng 1 , và ta có $X_{t}^{\tau}-X_{s}^{\tau}=\sum_{i=1}^{N} Y_{M+i}^{\tau}=$ $\sqrt{t-s} Z_{N}$. Như vậy, ta được hệ quả sau của định lý giới hạn trung tâm:

Định lý 7.8. Gọi $X_{t}^{\tau}$ là quá trình du động ngẫu nhiên 1 chiều với bước thời gian bằng $\tau$ và bước dịch chuyển bằng $\sqrt{\tau}$. Giả sử $t>s>0$ là hai mốc thời gian bất kỳ. Khi đó phân bố xác suất của $X_{t}^{\tau}-X_{s}^{\tau}$ tiến tới phân bố normal $N(0, \sqrt{t-s})$ khi mà $\tau$ tiến tới 0 .

Trong định lý trên, $t$ và $s$ không nhất thiết phải chia hết cho $\tau$ (bằng $\tau$ nhân với một số nguyên), vì mọi quá trình ngẫu nhiên $X_{t}$ với thời gian rời rạc đều có thể được coi là quá trình ngẫu nhiên với thời gian liên tục, qua một công thức nội suy. Ví dụ, nếu $t_{n}<t<t_{n+1}$, trong đó $t_{n}$ và $t_{n+1}$ là hai mốc thời gian liên tiếp của quá trình rời rạc, thì ta có thể đặt $X_{t}=X_{t_{n}}$ (coi nó là bất biến trên từng khúc thời gian), hoặc là đặt $X_{t}=\frac{t_{n+1}-t}{t_{n+1}-t_{n}} X_{t_{n}}+\frac{t-t_{n}}{t_{n+1}-t_{n}} X_{t_{n+1}}$ (để biến nó thành quá trình ngẫu nhiên liên tục tuyến tính từng khúc). Định lý trên đúng với cả hai cách đặt đó.

Định lý trên cho thấy các quá trình du động ngẫu nhiên $X_{t}^{\tau}$ (với bước thời gian bằng $\tau$ và bước dịch chuyển bằng $\sqrt{\tau}$ ) tiến tới (theo nghĩa phân bố xác suất) chuyển động Brown 
chuẩn tắc khi $\tau$ tiến tới 0 , và nó cũng giải thích vì sao ta yêu cầu rằng gia số $B_{t}-B_{s}$ của chuyển động Brown phải có phân bố xác suất là phân bố $N(0, \sqrt{t-s})$. Vì là quá trình du động ngẫu nhiên $X_{t}^{\tau}$ có bước dịch chuyển $\sqrt{\tau}$ tiến tới 0 khi $\tau$ tiến tới 0 , nên, một cách trực giác, giới hạn của $X_{t}^{\tau}$ khi $\tau$ tiến tới 0 phải là quá trình liên tục (tức là hầu hết mọi đường đi đều là liên tục). Do vậy mà ta có điều kiện liên tục trong định nghĩa của chuyển động Brown.

\subsubsection{Một số tính chất của chuyển động Brown}

Định lý 7.9. (Tính chất martingale). Với mọi $0 \leq s \leq t$ ta có

$$
\mathbb{E}\left(B_{t} \mid \mathcal{F}_{s}\right)=B_{s}
$$

hay còn có thể viết là:

$$
\mathbb{E}\left(B_{t}-B_{s} \mid \mathcal{F}_{s}\right)=0
$$

tức là kỳ vọng (có diều kiện) của mọi bước đi $B_{t}-B_{s}$ (dù tình huống xảy ra cho đến thời điểm s) đều bằng 0 .

Định lý trên chẳng qua là hệ quả trực tiếp của các điều kiện ii) và iii) trong định nghĩa chuyển động Brown.

Định lý 7.10. Giả sử $B_{t}$ là một chuyển động Brown. Khi đó tồn tại một tập con $\Omega^{\prime} \subset \Omega$ trong không gian các tình huống, có xác suất bằng 1 , sao cho với mọi tình huống $\omega \in \Omega^{\prime}$ thì quỹ đạo $B_{\omega}(t):=B_{t}(\omega)$ thỏa mãn các tính chất sau:

i) Với mọi $a \in \mathbb{R}$, có vô hạn các thời điểm $t \in \mathbb{R}_{+}$sao cho $B_{\omega}(t)=a$.

ii) Với mọi $\epsilon>0$, tập hợp các không diểm của $B_{\omega}$ (tức là các diểm $t$ sao cho $B_{\omega}(t)=0$ ) trên doạn thẳng $[0, \epsilon]$ là một tập vô hạn.

iii) $B_{\omega}$ không đơn diệu theo $t$ trên bất cứ đoạn thẳng nào.

iv) $B_{\omega}$ không khả vi tại bất cứ điểm nào theo $t$.

Nói cách khác, hầu hết các quỹ đạo của một chuyển động Brown thỏa mãn các tính chất trên.

Chứng minh. i) Ta sẽ giả sử $a>0$ (các trường hợp khác chứng minh tương tự). Dễ thấy rằng, nếu $B_{t}$ là chuyển động Brown và $\alpha>0$ là hằng số, thì $\frac{1}{\alpha} B_{\alpha^{2} t}$ cũng là chuyển động Brown. (Xem bài tập 7.8). Tính chất này gọi là tính chất scaling (phóng to thu nhỏ) của chuyện động Brown. Do tính chất scaling nên ta có

$$
P\left(B_{t}<x \mid B_{s}<y\right)=P\left(B_{\alpha^{2} t}<\alpha x \mid B_{\alpha^{2} s}<\alpha y\right)
$$


với mọi hằng số $x, y, \alpha, s$ và $t$ thỏa mãn $\alpha>0,0<s<t$. Trường hợp riêng của đẳng thức trên là

$$
P\left(B_{4^{n}}<2^{n} a \mid B_{4^{n-1}}<2^{n-1} a\right)=P\left(B_{4^{n+1}}<2^{n+1} a \mid B_{4^{n}}<2^{n} a\right)=c,
$$

với $c$ là một số nhỏ hơn 1 , lớn hơn 0 , và không phụ thuộc vào $n \in \mathbb{Z}$. Bởi vậy

$$
P\left(B_{4^{n}}<2^{n} \forall 0 \leq n \leq N\right)=P\left(B_{1}<a\right) \prod_{n=1}^{N} P\left(B_{4^{n}}<2^{n} a \mid B_{4^{n-1}}<2^{n-1} a\right)=c^{N} P\left(B_{1}<a\right)
$$

tiến tới 0 khi $N$ tiến tới vô cùng, và do vậy $P\left(B_{4^{n}}<2^{n} a \forall n \in \mathbb{Z}_{+}\right)=0$. Có nghĩa là, với hầu hết mọi tình huống $\omega$, tồn tại ít nhất một số nguyên không âm $n$ sao cho $B_{\omega}\left(4^{n}\right) \geq 2^{n} a \geq a$. Vì (với hầu hết mọi $\omega$ ) $B_{\omega}$ là hàm liên tục theo $t$, có giá trị bằng 0 tại 0 và giá trị lớn hơn hoặc bằng $a$ tại một thời điểm nào đó, nên nó cũng phải nhận $a$ làm giá trị tại thời điểm nào đó (theo định lý giá trị trung gian cho hàm liên tục). Như vậy ta đă chứng minh được rằng, trong hầu hết mọi tình huống $\omega$, thì tồn tại ít nhất 1 thời điểm sao cho giá trị của $B_{\omega}$ tại thời điểm đó bằng $a$. Tương tự như vậy, ta có thể chứng minh rằng, với mọi $M \in \mathbb{R}_{+}$, hầu như chắc chắn rằng quỹ đạo của chuyển động Brown có nhận giá trị bằng $a$ tại một thời điểm lớn hơn $M$. Vì $M$ là tùy ý, nên từ đó suy ra hầu như chắc chắn rằng quỹ đạo của chuyển động Brown có nhận giá trị bằng $a$ tại vô hạn các thời điểm. Thật vậy, gọi $A_{k, M}$ là tập các tình huống $\omega$ thỏa mãn điều kiện: trên đoạn thẳng $\left[0, M\left[\right.\right.$ có ít nhất $k$ thời điểm mà giá trị của $B_{\omega}$ bằng $a$. Vì hầu như chắc chắn rằng trên nửa đường thẳng $\left[M, \infty\left[\right.\right.$ có ít nhất 1 thời điểm mà giá trị của $B_{\omega}$ bằng $a$, nên $P\left(A_{k+1, \infty}\right) \geq P\left(A_{k, M}\right)$ với mọi $M$. Do đó $P\left(A_{k+1, \infty}\right) \geq \lim _{M \rightarrow \infty} P\left(A_{k, M}\right)=P\left(A_{k, \infty}\right)$, và theo qui nạp, ta có $P\left(A_{k, \infty}\right) \geq P\left(A_{0, \infty}\right)=1$, tức là $P\left(A_{k, \infty}\right)=1$. Vì tập các tình huống $\omega$ thỏa mãn điều kiện "có vô số thời điểm mà giá trị của quỹ đạo là $a$ " là tập $\bigcap_{k=1}^{\infty} A_{k, \infty}$, nên tập này cũng có xác suất bằng 1.

ii) Tương tự như phía trên, do tính chất scaling nên $P\left(B_{4^{-n} \epsilon}<2^{-n} \forall n \in \mathbb{Z}_{+}\right)=0$, do đó hầu như chắc chắn rằng tồn tại $n \in \mathbb{Z}_{+}$sao cho $B_{4^{-n} \epsilon} \geq 2^{-n}>0$. Tương tự như vậy, hầu như chắc chắn rằng tồn tại $m \in \mathbb{Z}_{+}$sao cho $B_{4^{-m_{\epsilon}}} \leq-2^{-m}<0$. Vì (với hầu hết mọi $\omega)$ quỹ đạo $B_{\omega}$ là liên tục và nhận cả giá trị âm lẫn giá trị dương trên đoạn thẳng nửa mở $] 0, \epsilon]$, nên nó phải có ít nhất một không điểm trên đoạn thẳng $] 0, \epsilon]$ này. Vì $\epsilon$ là tùy ý, nên từ đó suy ra là hầu hết mọi quỹ đạo $B_{\omega}$ phải có vô hạn không điểm trong đoạn $[0, \epsilon]$, cũng bằng lý luận tương tự như là trong chứng minh tính chất i).

iii) Chứng minh hệt như là chứng minh tính chất ii). (Chỉ cần chứng minh cho các đoạn thẳng có điểm đầu và điểm cuối là số hữu tỷ là đủ, và tập hợp các đoạn thẳng như vậy là tập đếm được). 
iv) Tính không khả vi tại bất cứ điểm nào cũng được chứng minh bằng tính chất scaling của chuyển động Brown và những lý luận tương tự như trong chứng minh các tính chất i) và ii). Chúng ta sẽ bỏ qua chứng minh của tính chất iii) ở đây. (Nó là một tính chất thú vị, nên được đưa vào để tham khảo, chứ chúng ta cũng sẽ không cần dùng đến nó trong quyển sách này).

\subsubsection{Biến phân và biến phân bình phương}

Theo định nghĩa, biến phân của một hàm số $f$ trên một đoạn thẳng $[a, b]$ là đại lượng

$$
V_{a}^{b}(f)=\sup \left\{\sum_{i=1}^{n}\left|f\left(x_{i}\right)-f\left(x_{i-1}\right)\right| ; n \in \mathbb{N}, x_{0}=a<x_{1}<\ldots<x_{n}=b\right\} .
$$

Nếu đại lượng đó bằng $+\infty$ thì ta nói rằng $f$ có biến phân vô hạn trên đoạn $[a, b]$, còn nếu nó nhỏ hơn $+\infty$ thì ta nói rằng $f$ có biến phân hữu hạn trên đoạn $[a, b]$. Ví dụ, nếu $f$ là hàm khả vi liên tục, thì nó có biến phân hữu hạn, bằng

$$
V_{a}^{b}(f)=\int_{a}^{b}\left|f^{\prime}(t)\right| d t
$$

Tổng quát hơn, mọi hàm số $f$ thỏa mãn điều kiện Lipschitz (tức là tồn tại một hằng số $K$ sao cho $|f(x)-f(y)| \leq K|x-y|$ với mọi $x$ và $y$ sẽ có biến phân hữu hạn: $V_{a}^{b}(f) \leq K(b-a)$.

Như ta đã thấy trong mục trước, chuyển động Brown là không khả vi. Hơn nữa, nó còn có biến phân vô hạn:

Định lý 7.11. Giả sử $B_{t}$ là một chuyển động Brown. Khi đó hầu hết mọi quỹ đạo $B_{\omega}$ của $B_{t}$ dều có biến phân vô hạn trên mọi doạn thẳng $[a, b](0 \leq a<b)$.

Chứng minh. Nó là hệ quả trực tiếp của định lý 7.12 dưới đây, bởi vì nếu một hàm liên tục có biến phân hữu hạn trên một đoạn thẳng nào đó, thì biến phân bình phương của nó trên đoạn đó bằng 0 , trong khi đối với chuyển động Brown, biến phân bình phương là khác 0 trên mọi đoạn thẳng.

Theo định nghĩa, biến phân bình phương (quadratic variation) của một hàm số $f$ trên một đoạn thẳng $[a, b]$ là giới hạn:

$$
Q V_{a}^{b}(f)=\lim _{\delta \rightarrow 0} \sum_{i=1}^{n}\left|f\left(x_{i}\right)-f\left(x_{i-1}\right)\right|^{2},
$$

trong đó $a=x_{0}<x_{1}<\ldots<x_{n}=b$ là một phân hoạch của đoạn $[a, b]$, và $\delta=$ $\max _{i}\left(x_{i}-x_{i-1}\right)$ là độ mịn $($ mesh) của phân hoạch, nếu như giới hạn đó tồn tại. (Nếu giới 
hạn không tồn tại, thì ta có thể thay lim bằng limsup, nhưng đối với chuyển động Brown, vấn đề này không đặt ra, vì như ta sẽ thấy, giới hạn này tồn tại cho hầu khắp mọi quỹ đạo của chuyển động Brown).

Dễ thấy rằng, nếu hàm số thỏa mãn điều kiện Lipschitz, thì nó có biến phân vình phương bằng 0 . Tổng quát hơn, nếu một hàm số là liên tục và có biến phân hữu hạn, thì biến phân bình phương của nó bằng 0 . (Khẳng định này dành cho bạn đọc như là một bài tập).

Đối với chuyển động Brown, thì biến phân bình phương là khác 0 nhưng hữu hạn trên các đoạn thẳng thời gian. Hơn nữa, nó bằng đúng độ dài của đoạn thẳng:

Định lý 7.12. Giả sủ B $B_{t}$ là một chuyển động Brown. Khi đó hầu hết mọi quỹ đạo $B_{\omega}$ của nó có biến phân bình phương trên doạn thẳng $[a, b]$ bất kỳ bằng đúng $b-a$ :

$$
Q V_{a}^{b}\left(B_{\omega}\right)=b-a
$$

Chứng minh. Chúng ta sẽ chứng minh khẳng định sau đây, hơi yếu hơn Định lý 7.12 một chút, nhưng đủ cho thấy bản chất vấn đề: với hầu hết mọi tình huống $\omega$ ta có

$$
\lim _{N \rightarrow \infty} \sum_{i=1}^{N}\left(B_{\omega}(i / N)-B_{\omega}((i-1) / N)\right)^{2}=1 .
$$

Đặt $Y_{N, i}=\frac{1}{N}\left(B_{\omega}(i / N)-B_{\omega}((i-1) / N)\right)^{2}$. Khi đó các biến ngẫu nhiên $Y_{N, i}$ đều có phân bố xác suất bằng phân bố xác suất của $\left(B_{1}\right)^{2}$, tức là phân bố khi bình phương $\chi_{1}^{2}$ (với 1 bậc tự do - xem chương 4 của [7] về phân bố khi bình phương). Nhắc lại rằng, phân bố $\chi_{1}^{2}$ có kỳ vọng bằng 1 . Ta cần chứng minh rằng

$$
\lim _{N \rightarrow \infty} \frac{1}{N} \sum_{i=1}^{N} Y_{N, i}=1
$$

hầu khắp mọi nơi. Thế nhưng đây chính là luật số lớn (dạng mạnh) áp dụng vào phân bố $\chi_{1}^{2}$, vì các biến ngẫu nhiên $Y_{N, 1}, \ldots, Y_{N, N}$ độc lập với nhau và có cùng phân bố xác suất $\chi_{1}^{2}$. (Xem Chương 3 của [7] về dạng mạnh của luật số lớn và cách chứng minh của nó tình huống ở đây hơi khác nhưng chứng minh vẫn thế). Bởi vậy ta được điều phải chứng $\operatorname{minh}$.

Có định lý ngược lại sau đây của Paul Lévy ${ }^{(4)}$, cho thấy vị trí quan trọng của chuyển động Brown trong lý thuyết các quá trình ngẫu nhiên:

\footnotetext{
${ }^{(4)}$ Paul Lévy (1886-1971) là nhà toán học Pháp nổi tiếng về các công trình về xác suất, xem: http://en.wikipedia.org/wiki/Paul_Pierre_Lévy
} 
Định lý 7.13 (Lévy). Mọi quá trình martingale(5) với thời gian liên tục, thỏa mãn tính chất liên tục (tức là hầu hêt mọi quỹ đạo đều liên tục), và có biến phân bình phương hũu hạn, đều là chuyển động Brown sau một phép biến đổi thời gian.

Có thể xem chứng minh của định lý Lévy này trong Chương 2 của quyển sách [15] của Karatzas và Shreve.

Bài tập 7.12. Thử chứng minh trực tiếp định lý 7.11 mà không cần dùng định lý 7.12

\subsubsection{Chuyển động Brown hình học}

Giá của cổ phiếu không thể âm (thậm chí ta sẽ coi nó là luôn dương, tuy trong thực tế nó có thể về 0 khi công ty phá sản), nên nó không thể là chuyển động Brown, bởi vì các quỹ đạo của chuyển động Brown xuống âm bao nhiêu cũng được. Thế nhưng, nếu ta lấy log của giá cổ phiếu, thì nó có thể âm, và có thể hình dung là chuyển động theo thời gian của log của giá cổ phiếu dưới tác động của các lực ngẫu nhiên ảnh hưởng tức thời trên thị trường tương tự như là chuyển động Brown. Bởi vậy, khái niệm chuyển động Brown hình học sau sẽ quan trọng trong việc mô tả sự biến động của giá cổ phiếu:

Định nghĩa 7.14. Nếu $B_{t}$ là một chuyển động Brown chuẩn tắc, và $a, b, \sigma$ là các hằng số $(\sigma>0)$, thì quá trình ngẫu nhiên $\exp \left(a+b t+\sigma B_{t}\right)$ được gọi là một chuyển động Brown hình học (geometric Brownian motion). Nói cách khác, một quá trình ngẫu nhiên $G_{t}$ dược gọi là một chuyển động Brown hình học khi và chỉ khi $\ln G_{t}$ là một chuyển dộng Brown (không nhất thiết chuẩn tắc).

Một biến ngẫu nhiên $X$ chỉ nhận giá trị dương được gọi là có phân bố xác suất lognormal nếu như $\ln X$ có phân bố xác suất normal. Từ định nghĩa trên, ta có ngay hệ quả sau: nếu $G_{t}$ là một chuyển động Brown hình học, và $t>s$, thì $G_{t} / G_{s}$ có phân bố xác suất log-normal.

Chú ý rằng, tuy chuyển động Brown $B_{t}$ là martingale, nhưng $\exp \left(B_{t}\right)$ không phải là martingale. Thật vậy, ta có

$$
\mathbb{E}\left(\exp \left(B_{t}\right)\right)=\frac{1}{\sqrt{2 \pi t}} \int_{-\infty}^{\infty} e^{x} e^{-x^{2} / 2 t} d x=\frac{1}{\sqrt{2 \pi t}} \int_{-\infty}^{\infty} e^{t / 2} e^{-(x-t)^{2} / 2 t} d x=e^{t / 2}
$$

\footnotetext{
${ }^{(5)}$ Một quá trình $S_{t}$ được gọi là martingale nếu $\mathbb{E}\left(\left|S_{t}\right|\right)<\infty$ với mọi $t$, và thỏa mãn tính chất martingale $\mathbb{E}\left(S_{t} \mid \mathcal{F}_{s}\right)=S_{s}$. Điều kiện $\mathbb{E}\left(\left|S_{t}\right|\right)<\infty$ là "hiển nhiên" đối với các quá trình thực tế, được cho thêm vào trong định nghĩa cho chặt chẽ về mặt toán học.
} 
tăng theo thời gian, chứ không bất biến, và do đó nó không thể là martingale. Tuy nhiên, đẳng thức trên cũng cho thấy $\mathbb{E}\left(\exp \left(B_{t}-t / 2\right)\right)=1$ là bất biến theo thời gian. Hơn nữa, ta có:

Định lý 7.15. (Định lý và định nghĩa). Nếu $B_{t}$ là chuyển động Brown thì quá trình ngẫu nhiên $\exp \left(B_{t}-t / 2\right)$ là martingale. Quá trình ngẫu nhiên $\exp \left(B_{t}-t / 2\right)$ này được gọi là chuyển động Brown hình học chuẩn tắc.

Chứng minh. Phía trên ta đã kiểm tra rằng $\mathbb{E}\left(G_{t} \mid \mathcal{F}_{0}\right)=G_{0}=1$, trong đó $G_{t}=\exp \left(B_{t}-\right.$ $t / 2)$ là chuyển động Brown hình học chuẩn tắc. Việc kiểm tra đẳng thức $\mathbb{E}\left(G_{t+s} \mid \mathcal{F}_{s}\right)=G_{s}$ với mọi $s \geq 0, t>0$ hoàn toàn tương tự, dựa trên tính chất của chuyển động Brown $B_{t}$. Thật vậy, khi $s$ cố định, thì $G_{t+s} / G_{s}=\exp \left(B_{t+s}-B_{s}-t / 2\right)$ cũng là một chuyển động Brown hình học chuẩn tắc, vì $B_{t+s}-B_{s}$ cũng là một chuyển động Brown, do đó ta có đẳng thức trên.

Bài tập 7.13. Giả sử $\mu$ là một hằng số tùy ý. Chứng minh rằng quá trình $\exp \left(\mu B_{t}-\frac{\mu^{2} t}{2}\right)$, trong đó $B_{t}$ là chuyển động Brown chuẩn tắc, là một quá trình martingale.

\subsection{Vi phân của các quá trình ngẫu nhiên}

Tương tự như đối với các hàm số, chúng ta cũng muốn làm các phép vi tích phân đối với các quá trình ngẫu nhiên, để có thể tìm lại được các quá trình ngẫu nhiên từ vi phân của nó, qua việc tính tích phân, giải các phương trình vi phân ngẫu nhiên (theo biến thời gian). Tuy nhiên, do các quá trình ngẫu nhiên nói chung không khả vi theo biến thời gian (chuyển động Brown là một ví dụ tiêu biểu), nên các phép tính vi tích phân của chúng phức tạp hơn về mặt kỹ thuật so với giải tích thông thường.

\subsubsection{Vi phân của chuyển động Brown hình học}

Để hiểu vi phân ngẫu nhiên, trước hết chúng ta xét một ví dụ cụ thể: vi phân của $\exp \left(B_{t}\right)$, trong đó $B_{t}$ là một chuyển động Brown chuẩn tắc.

Nhắc lại rằng, nếu $f(t)$ là một hàm khả vi theo $t$, thì ta có công thức sau:

$$
d \exp (f)=\exp (f) d f=\exp (f) f^{\prime} d t
$$

trong đó $f^{\prime}=d f / d t$ là đạo hàm của $f$ theo $t$. Thế nhưng, $B_{t}$ không khả vi theo $t$, và khi thay $f(t)$ bằng $B_{t}$ thì công thức trên không đúng nữa ! Để hiểu tại sao, chúng ta quay trở lại định nghĩa thế nào là vi phân. 
Vi phân $d f$ của một hàm số (hay ánh xạ) $f$ là một ký hiệu toán học, để chỉ độ thay đổi của $f$ khi các biến của nó thay đổi (ở đây chỉ có 1 biến, là biến thời gian $t$ ): khi $t$ thay đổi một đại lượng $\Delta t$, thì $f$ thay đổi một đại lượng là $\Delta f=f(t+\Delta t)-f(t)$, và tỷ lệ thay đổi giữa $f$ và $t$ bằng

$$
\frac{\Delta f}{\Delta t}=\frac{f(t+\Delta t)-f(t)}{\Delta t}
$$

Trong trường hợp mà tỷ lệ trên tiến tới mộ số nào đó khi $\Delta t$ tiến tới 0 , thì số đó được gọi là đạo hàm của $f$ theo $t$, thường ký hiệu là $f^{\prime}(t)$, và ta viết

$$
\frac{d f}{d t}=f^{\prime}(t)=\lim _{\Delta t \rightarrow 0} \frac{f(t+\Delta t)-f(t)}{\Delta t}
$$

hay

$$
d f=f^{\prime} d t
$$

Đẳng thức cuối cùng có nghĩa là khi mà $t$ thay đổi thì $f$ cũng thay đổi, với tốc độ thay đổi bằng $f^{\prime}$ lần tốc độ thay đổi của $t$.

Vi phân $d B_{t}$ cũng là khái niệm để đo độ thay đổi của $B_{t}$ khi mà $t$ thay đổi. Thế nhưng, vì $B_{t}$ không khả vi tại bất cứ điểm nào, nên không thể viết $d B_{t}$ dưới dạng $H_{t} d t$ (trong đó $H_{t}$ là một quá trình ngẫu nhiên). Bởi vậy, cách đơn giản là ta sẽ để nguyên $d B_{t}$, và hiểu nó như là một ký hiệu toán học để chỉ một biến động "vô cùng nhỏ" dạng chuyển động Brown. Vì chuyển động Brown là quá trình ngẫu nhiên "đơn giản nhất", quan trọng nhất, được nghiên cứu kỹ nhất, trong các loại quá trình ngẫu nhiên liên tục không khả vi, nên ta sẽ sử dụng $d B_{t}$ như một vi phân cơ sở tương tự như $d t$, và tìm cách biểu diễn vi phân của các quá trình ngẫu nhiên khác dưới dạng tổ hợp tuyến tính $H_{t} d t+F_{t} d B_{t}$ của $d t$ và $d B_{t}$ nếu có thể (trong đó $H_{t}$ và $F_{t}$ là hai quá trình ngẫu nhiên). Khi viết

$$
d G_{t}=H_{t} d t+F_{t} d B_{t}
$$

thì có nghĩa là

$$
G(t+\Delta t)-G(t)=H_{t} \cdot \Delta t+F_{t} \cdot(B(t+\Delta t)-B(t))+\epsilon
$$

trong đó là đại lượng rất nhỏ so với $\Delta t$, có thể bỏ qua: $\epsilon / \Delta t$ tiến tới 0 khi $\Delta t$ tiến tới 0 . Phần $F_{t} d B_{t}$ là phần không khả vi (theo nghĩa thông thường) và có kỳ vọng bằng 0 (vì kỳ vọng của $(B(t+\Delta t)-B(t))$ bằng 0$)$ của $d G_{t}$, và phần $H_{t} d t$ là phần khả vi. Tất nhiên, nếu có thể viết $d G_{t}=H_{t} d t+F_{t} d B_{t}$, thì $H_{t}$ và $F_{t}$ được xác định duy nhất theo $G_{t}$, vì tổng của một phần khả vi và một phần không khả vi không thể bằng 0 trừ khi cả hai phần bằng 0 . 
Áp dụng ý tưởng trên vào trường hợp $G_{t}=\exp \left(B_{t}\right)$. Ta có:

$$
\begin{aligned}
\frac{\Delta \exp \left(B_{t}\right)}{\exp \left(B_{t}\right)}=\frac{\exp (B(t+\Delta t))-\exp (B(t))}{\exp (B(t))} & =\exp (B(t+\Delta t)-B(t))-1 \\
& =\exp \left(\Delta B_{t}\right)-1=\Delta B_{t}+\frac{\left(\Delta B_{t}\right)^{2}}{2 !}+\frac{\left(\Delta B_{t}\right)^{3}}{3 !}+\ldots
\end{aligned}
$$

Nhắc lại rằng, biến phân bình phương của $B_{t}$ trên một đoạn thời gian $\Delta t$ bằng chính $\Delta t$. Do đó, $\left(\Delta B_{t}\right)^{2}$ xấp xỉ bằng $\Delta t$ khi mà $\Delta t$ nhỏ (trái ngược với trường hợp khả vi: nếu $f$ khả vi thì $(\Delta f)^{2}$ rất nhỏ so với $\Delta t$, có thể bỏ qua). Các đại lượng $\left(\Delta B_{t}\right)^{n}$ với $n$ từ 3 trở lên rất nhỏ so với $\Delta t$, có thể bỏ qua. Bởi vậy ta có

$$
\frac{\Delta \exp \left(B_{t}\right)}{\exp \left(B_{t}\right)}=\Delta B_{t}+\frac{\Delta t}{2}+\epsilon,
$$

trong đó $\epsilon / \Delta t$ tiến tới 0 khi $\Delta t$ tiến tới 0 (trong hầu khắp mọi tình huống), từ đó ta suy ra công thức vi phân sau:

$$
\frac{d \exp \left(B_{t}\right)}{\exp \left(B_{t}\right)}=d B_{t}+\frac{d t}{2}
$$

hay còn có thể viết là:

$$
d \exp \left(B_{t}\right)=\frac{1}{2} \exp \left(B_{t}\right) d t+\exp \left(B_{t}\right) d B_{t}
$$

Một cách hoàn toàn tương tự, dễ dàng kiểm tra rằng

$$
d \exp \left(B_{t}-\frac{t}{2}\right)=\exp \left(B_{t}-\frac{t}{2}\right) d B_{t}
$$

có nghĩa là vi phân của chuyển động Brown hình học chuẩn tắc bằng chính nó nhân với vi phân của chuyển động Brown chuẩn tắc. Chú ý rằng, trong vế bên phải của đẳng thức trên không có sự tham gia của $d t$, chỉ có sự tham gia của $d B_{t}$ là phần có kỳ vọng bằng 0 , và điều này cũng giải thích tại sao $\exp \left(B_{t}-\frac{t}{2}\right)$ lại là martingale (vi phân của nó luôn có kỳ vọng bằng 0 , nên các bước chuyển động cũng đều có kỳ vọng bằng 0 ).

Bài tập 7.14. Tính vi phân của một chuyển động Brown hình học tùy ý $\exp \left(a+b t+\sigma B_{t}\right)$, trong đó $a, b, \sigma$ là các hằng số, từ đó suy ra rằng các nghiệm của phương trình vi phân ngẫu nhiên

$$
\frac{d S_{t}}{S_{t}}=\mu d t+\sigma d B_{t}
$$

trong đó $\mu$ và $\sigma$ là các hằng số, chính là các chuyển động Brown hình học. 


\subsubsection{Bổ đề Itô}

Một trong những công thức quan trọng mà chúng ta dùng trong phân tích ở phía trên về vi phân của chuyển động Brown hình học là:

$$
\left(d B_{t}\right)^{2}=d t
$$

Công thức này có thể hiểu là

$$
\lim _{\Delta t \rightarrow 0+} \frac{\left(\Delta B_{t}\right)^{2}-\Delta t}{\Delta t}=0
$$

và nó ứng với công thức biến phân bình phương của chuyển động Brown. Ngoài công thức $\left(d B_{t}\right)^{2}=d t$, còn được viết là $d B_{t} \cdot d B_{t}=d t$, chúng ta còn có các công thức sau, tương đối hiển nhiên, cho việc tính vi phân các quá trình ngẫu nhiên:

$$
d t . d B_{t}=d t . d t=0
$$

Các công thức này được hiểu tương tự như trên, tức là các đại lượng $(\Delta t) \cdot\left(\Delta B_{t}\right)$ và $(\Delta t)^{2}$ là rất nhỏ so với $\Delta t$ (thương của chúng chia cho $\Delta t$ tiến tới 0 khi $\Delta t$ tiến tới 0 ), có thể bỏ qua trong các phép tính toán vi phân.

Các công thức trên là cơ sở của công thức sau, cho phép chúng ta tính vi phân của các quá trình ngẫu nhiên có dạng hàm số $f\left(t, B_{t}\right)$ theo hai biến $t$ và $B_{t}$ trong đó $B_{t}$ là chuyển động Brown:

Định lý 7.16. Nếu $F_{t}=f\left(t, B_{t}\right)$ trong đó $f(t, x)$ là một hàm khả vi liên tục theo biến $t$ và khả vi liên tục 2 lần theo biến $x$, thì

$$
d F_{t}=\frac{\partial f\left(t, B_{t}\right)}{\partial t} d t+\frac{\partial f\left(t, B_{t}\right)}{\partial x} d B_{t}+\frac{1}{2} \frac{\partial^{2} f\left(t, B_{t}\right)}{\partial x^{2}} d t
$$

Chứng minh của công thức trên hoàn toàn tương tự như chứng minh của công thức vi phân của $\exp \left(B_{t}\right)$. So với trường hợp khả vi, thì thành phần cần thêm vào trong công thức là $\frac{1}{2} \frac{\partial^{2} f\left(t, B_{t}\right)}{\partial x^{2}} d t$, và lý do chính là bởi vì $\left(d B_{t}\right)^{2}=d t$. Thật vậy, theo khai triển Taylor-Lagrange, ta có

$$
\begin{aligned}
\Delta f\left(t, B_{t}\right)=f(t & +\Delta t, B(t+\Delta t))-f\left(t, B_{t}\right) \\
=[f(t+\Delta t & , B(t+\Delta t))-f(t, B(t+\Delta t))]+\left[f(t, B(t+\Delta t))-f\left(t, B_{t}\right)\right] \\
& =\frac{\partial f\left(t, B_{t}+\Delta t\right)}{\partial t} \Delta t+\epsilon_{1}+\frac{\partial f\left(t, B_{t}\right)}{\partial x} \Delta B_{t}+\frac{1}{2} \frac{\partial^{2} f\left(t, B_{t}\right)}{\partial x^{2}}\left(\Delta B_{t}\right)^{2}+\epsilon_{2},
\end{aligned}
$$

trong đó $\epsilon_{1}$ và $\epsilon_{2}$ đều rất nhỏ (có thể bỏ qua) so với $\Delta t$, từ đó suy ra công thức trên. 
Ví $d u$ 7.4. Ta có $d\left(t B_{t}^{3}\right)=\left(B_{t}^{3}+3 t B_{t}\right) d t+3 t B_{t}^{2} d B_{t}$, bởi vì $\partial\left(t x^{3}\right) / \partial t=x^{3}, \partial\left(t x^{3}\right) / \partial x=$ $3 x^{2}$, và $\partial^{2}\left(t x^{3}\right) / \partial x^{2}=6 t x$.

Một cách tổng quát hơn, ta có công thức sau, gọi là công thức Itô, hay bổ đề Itô:

Định lý 7.17 (Bổ đề Itô). Giả sử $f(t, x)$ là một hàm số khả vi liên tục theo biến $t$ và khả vi liên tục 2 lần theo biến $x$, và $X_{t}$ là một quá trình Itô thỏa mãn $d X_{t}=\mu_{t} d t+\sigma_{t} d B_{t}$ trong đó $B_{t}$ là chuyển động Brown. Khi đó ta có:

$$
d f\left(t, X_{t}\right)=\left(\frac{\partial f}{\partial t}+\mu_{t} \frac{\partial f}{\partial x}+\frac{\sigma_{t}^{2}}{2} \frac{\partial^{2} f}{\partial x^{2}}\right) d t+\sigma_{t} \frac{\partial f}{\partial x} d B_{t}
$$

Trong định lý trên có khái niệm quá trình Itô. Một quá trình ngẫu nhiên $X_{t}$ được gọi là một quá trình Itô nếu nó là quá trình ngẫu nhiên với thời gian liên tục, và vi phân của nó có thể viết được dưới dạng (hay nói cách khác, nó thỏa mãn phương trình vi phân dạng):

$$
d X_{t}=\mu_{t} d t+\sigma_{t} d B_{t}
$$

trong đó $\mu_{t}$ và $\sigma_{t}$ là các các quá trình ngẫu nhiên tương thích (hoặc là các hàm số theo $t$ ) thỏa mãn điều kiện

$$
\mathbb{E}\left(\int_{0}^{t}\left|\mu_{s}\right|^{2} d s\right)<+\infty, \mathbb{E}\left(\int_{0}^{t}\left|\sigma_{s}\right|^{2} d s\right)<+\infty
$$

với mọi $t \geq 0$. Các quá trình ngẫu nhiên tương thích thỏa mãn điều kiện này được gọi là các quá trình ngẫu nhiên có bình phương khả tích (tức là có tích phân bình phương hưu hạn), hay còn gọi là thuộc lớp $L^{2}$.

Chứng minh của định lý 7.17 hoàn toàn tương tự như chứng minh công thức 7.82 . Điều kiện bình phương khả tích được dùng để kiểm soát các đại lượng nhỏ khi tính giới hạn để tìm vi phân.

Bài tập 7.15. Chứng minh công thức (7.83) trong trường hợp $\sigma_{t}$ và $\mu_{t}$ là các hàm số liên tục (không ngẫu nhiên) theo $t$.

\subsection{Tích phân Itô}

Nếu ta biết đạo hàm $f^{\prime}(t)$ của một hàm số khả vi $f(t)$, thì nói chung ta có thể tìm lại được $f$ từ $f^{\prime}$ bằng cách lấy tích phân:

$$
f(t)=f(0)+\int_{0}^{t} f^{\prime}(s) d s
$$


Tương tự như vậy, nếu ta biết vi phân của một quá trình Itô

$$
d X_{t}=\mu_{t} d t+\sigma_{t} d B_{t}
$$

thì về nguyên tắc, ta cũng phải tìm lại được quá trình ngẫu nhiên $X_{t}$ từ các quá trình ngẫu nhiên $\mu_{t}$ và $\sigma_{t}$ bằng cách lấy tích phân:

$$
X_{t}=X_{0}+\int_{0}^{t} \mu_{s} d s+\int_{0}^{t} \sigma_{s} d B_{s}
$$

Vấn đề là định nghĩa các tích phân trên sao cho thích hợp. Tích phân $\int_{0}^{t} \mu_{s} d s$ có thể được định nghĩa theo cách cổ điển (theo định nghĩa tích phân Riemann). Tuy nhiên, như chúng ta sẽ thấy, việc định nghĩa tích phân $\int_{0}^{t} \sigma_{s} d B_{s}$ phức tạp hơn, do $B_{t}$ có biến phân vô hạn. Trong phần này, chúng ta sẽ bàn cách định nghĩa tích phân $\int_{0}^{t} \sigma_{t} d B_{t}$ theo Kioshi Itô (1915-2008), một trong những cha đẻ của giải tích ngẫu nhiên, và tích phân này được gọi là tích phân Itô.

\subsubsection{Tích phân Riemann-Stieltjes}

Nhắc lại rằng, nếu $f$ và $g$ là hai hàm số trên một đoạn thẳng $[0, t] \subset \mathbb{R}$, thì tích phân

$$
\int_{0}^{t} f d g
$$

được định nghĩa như sau, và gọi là tích phân Riemann-Stieltjes: Đặt

$$
U_{\rho}(f, g)=\sum_{i=1}^{n} \sup _{x_{i} \in\left[a_{i-1}, a_{i}\right]} f\left(x_{i}\right)\left(g\left(a_{i}\right)-g\left(a_{i-1}\right)\right)
$$

và

$$
L_{\rho}(f, g)=\sum_{i=1}^{n} \inf _{x_{i} \in\left[a_{i-1}, a_{i}\right]} f\left(x_{i}\right)\left(g\left(a_{i}\right)-g\left(a_{i-1}\right)\right),
$$

trong đó $\rho$ là một phân hoạch của đoạn thẳng $[0, t]$ cho bởi một dãy các số $0=a_{0} \leq a_{1} \leq$ $\cdots \leq a_{n}=t$, rồi đặt

$$
\int_{0}^{t} f d g=\lim _{\operatorname{mesh}(\rho) \rightarrow 0} L_{\rho}(f, g)=\lim _{\operatorname{mesh}(\rho) \rightarrow 0} U_{\rho}(f, g) .
$$

nếu như các giới hạn đó tồn tại và bằng nhau. Ở đây mesh $(\rho)=\sup _{i}\left(a_{i}-a_{i-1}\right)$ là ký hiệu độ nhỏ của phân hoạch $\rho$. Nếu tích phân Riemann-Stieltjes tồn tại, thì mọi tổng có dạng $\sum_{i=1}^{n} f\left(x_{i}\right)\left(g\left(a_{i}\right)-g\left(a_{i-1}\right)\right)$, trong đó $x_{i} \in\left[a_{i-1}, a_{i}\right]$ có thể chọn tùy ý, đều tiến tới $\int_{0}^{t} f d g$ 
khi độ nhỏ mesh $(\rho)$ của phân hoạch $\rho$ tiến tới 0 , bởi vì tổng đó bị kẹp giữa $U_{\rho}(f, g)$ và $L_{\rho}(f, g)$. Trường hợp đặc biệt, khi mà $g(t)=t$, thì định nghĩa trên trùng với định nghĩa tích phân Riemann $\int_{0}^{t} f(s) d s$.

Nếu chẳng hạn $g$ là một hàm khả vi liên tục, và $f$ là hàm bị chặn và liên tục từng khúc, thì tích phân Riemann-Stieltjes $\int_{0}^{t} f d g$ tồn tại, và ta có công thức chuyển đổi sau:

$$
\int_{0}^{t} f d g=\int_{0}^{t} f g^{\prime} d s
$$

trong đó $g^{\prime}$ là đạo hàm của $g$.

Nếu $f$ và $g$ không phải là hàm số, mà là các quá trình ngẫu nhiên, sao cho $f$ liên tục và $g$ có biến phân phữu hạn, thì ta vẫn có thể định nghĩa được tích phân Riemann-Stieltjes $\int_{0}^{t} f d g$ như trên. (Bản thân tích phân cũng sẽ là một quá trình ngẫu nhiên, vì ta định nghĩa nó cho từng tình huống và từng mốc thời gian).

Vi du 7.5. Nếu $B_{t}$ là một chuyển động Brown, thì tích phân

$$
P_{t}=\int_{0}^{t} B_{s} d s
$$

tồn tại, và là một quá trình ngẫu nhiên khả vi liên tục theo thời gian. Trong một số mô hình vật lý, khi mà tốc độ của một điểm được mô tả như là một quá trình Wiener (vì có các lực ngẫu nhiên tác động làm thay đổi tốc độ), thì vị trí của điểm (bằng tích phân của tốc độ theo biến thời gian) là một quá trình ngẫu nhiên được biểu diễn bằng tích phân trên.

Khi mà $g=B_{t}$ là một chuyển động Brown, hay nói một cách tổng quá hơn, là một hàm số hay một quá trình ngẫu nhiên có biến phân vô hạn, thì định nghĩa tích phân Riemann-Stieltjes nói chung không còn áp dụng được nữa, như ví dụ đơn giản sau đây cho thấy.

Ví du 7.6. Giả sử ta muốn định nghĩa tích phân $\int_{0}^{t} B_{s} d B_{s}$, trong đó $B_{t}$ là một chuyển động Brown. Làm theo phương pháp Riemann-Stieltjes, ta viết

$$
\begin{aligned}
& U_{\rho}(B, B)=\sum_{i=1}^{n} \sup _{t_{i} \in\left[a_{i-1}, a_{i}\right]} B\left(t_{i}\right)\left(B\left(a_{i}\right)-B\left(a_{i-1}\right)\right), \\
& L_{\rho}(B, B)=\sum_{i=1}^{n} \inf _{t_{i} \in\left[a_{i-1}, a_{i}\right]} B\left(t_{i}\right)\left(B\left(a_{i}\right)-B\left(a_{i-1}\right)\right),
\end{aligned}
$$


trong đó $0=a_{0} \leq a_{1} \leq \ldots \leq a_{n-1} \leq a_{n}=t$ là một phân hoạch $\rho$ của đoạn thẳng $[0, t]$, rồi xét hiệu $U_{\rho}(B, B)-L_{\rho}(B, B)$. Dễ thấy rằng, với mỗi $i$ ta có

$$
\sup _{t_{i} \in\left[a_{i-1}, a_{i}\right]} B\left(t_{i}\right)\left(B\left(a_{i}\right)-B\left(a_{i-1}\right)\right)-\inf _{t_{i} \in\left[a_{i-1}, a_{i}\right]} B\left(t_{i}\right)\left(B\left(a_{i}\right)-B\left(a_{i-1}\right)\right) \geq\left(B\left(a_{i}\right)-B\left(a_{i-1}\right)\right)^{2},
$$

bởi vậy

$$
U_{\rho}(B, B)-L_{\rho}(B, B) \geq \sum_{i=1}^{n}\left(B\left(a_{i}\right)-B\left(a_{i-1}\right)\right)^{2} .
$$

Vế phải của bất đẳng thức trên, khi mesh $(\rho)$ tiến tới 0 , chính là biến phân bình phương của chuyện động Brown trên đoạn thẳng thời gian $[0, t]$. Thế nhưng, ta biết rằng, biến phân bình phương của chuyển động Brown trên đoạn thẳng $[0, t]$ bằng $t$, lớn hơn 0 . Do đó, $U_{\rho}(B, B)-L_{\rho}(B, B)$ không tiến tới 0 khi mesh $(\rho)$ tiến tới 0 , và bởi vậy không thể định nghĩa được tích phân $\int_{0}^{t} B_{s} d B_{s}$ theo kiểu Riemann-Stieltjes, vì $U_{\rho}(B, B)$ và $L_{\rho}(B, B)$ không thể có cùng giới hạn khi mesh $(\rho)$ tiến tới 0 .

Ví dụ trên cho thấy, vì biến phân bình phương của $B_{t}$ khác 0 , nên chúng ta không thể định nghĩa được tích phân $\int_{0}^{t} B_{s} d B_{s}$ theo kiểu Riemann-Stieltjes. Do đó chúng ta cần một định nghĩa tích phân khác, gọi là tích phân Itô.

\subsection{2 Định nghĩa tích phân Itô}

Chúng ta sẽ định nghĩa các tích phân Itô có dạng

$$
\int_{0}^{t} \phi_{s} d B_{s}
$$

trong đó $B$ là một chuyển động Brown chuẩn tắc, và $\phi$ là một quá trình ngẫu nhiên có bình phương khả tích, tức là $\mathbb{E}\left(\int_{0}^{t}|\phi(s)|^{2} d s\right)<\infty$ với mọi $t \in \mathbb{R}_{+}$.

Trước hết, ta sẽ định nghĩa tích phân Itô cho các quá trình sơ cấp. Một quá trình ngẫu nhiên $\rho_{t}$ được gọi là sơ cấp (elementary), hay còn gọi là đơn giản (simple), trên đoạn thẳng thời gian $[0, t]$ nếu như tồn tại một phân hoạch cố định $0=t_{0}<t_{1}<\ldots<t_{n}=t$ của đoạn thẳng $[0, t]$, sao cho trên mỗi đoạn thẳng nửa mở $\left[t_{i-1}, t_{i}[\right.$ thì $\rho(s, \omega)$ là hằng số theo thời gian (trong hầu hết mọi tình huống $\omega \in \Omega$ ), tức là $\rho(s, \omega)=\rho\left(t_{i-1}, \omega\right)$ với mọi $t_{i-1} \leq s<t_{i}$. Việc định nghĩa tích phân Itô cho các quá trình sơ cấp được suy ra trực tiếp từ tính chất cộng tính của tích phân và đẳng thức hiển nhiên cần phải đúng:

$$
\int_{a}^{b} d B_{s}=B_{b}-B_{a}
$$


Nếu $\phi$ là một quá trình sơ cấp theo phân hoạch $0=t_{0}<t_{1}<\ldots<t_{n}=t$ của đoạn thẳng $[0, t]$, thì ta có:

$\int_{0}^{t} \phi(s) d B(s)=\sum_{i=1}^{n} \int_{t_{i-1}}^{t_{i}} \phi(s) d B(s)=\sum_{i=1}^{n} \int_{t_{i-1}}^{t_{i}} \phi\left(t_{i-1}\right) d B(s)=\sum_{i=1}^{n} \phi\left(t_{i-1}\right)\left(B\left(t_{i}\right)-B\left(t_{i-1}\right)\right)$,

hay viết gọn lại là

$$
\int_{0}^{t} \phi(s) d B(s)=\sum_{i=1}^{n} \phi\left(t_{i-1}\right)\left(B\left(t_{i}\right)-B\left(t_{i-1}\right)\right) .
$$

Đẳng thức trên chính là định nghĩa tích phân Itô trong trường hợp mà $\phi_{s}$ là một quá trình sơ cấp. Dễ thấy rằng, định nghĩa này không phụ thuộc vào phân hoạch đoạn thẳng $[0, t]$ sao cho quá trình ngẫu nhiên $\phi$ là sơ cấp theo phân hoạch đó. Hơn nữa, có thể thấy rằng, khi mà $\phi_{s}$ là quá trình sơ cấp, thì tích phân Riemann-Stieltjes cũng có nghĩa, và trùng với tích phân Itô.

Khi mà $\phi$ là một quá trình ngẫu nhiên tổng quát thỏa mãn các điều kiện đã nêu ở trên, tích phân Itô được định nghĩa bằng cách lấy giới hạn, thông qua một dãy các quá trình sơ cấp hội tụ đến $\phi$. Sự tồn tại của dãy này được cho bởi định lý sau:

Định lý 7.18. Cố định một số $T>0$ tùy ý. Giả sử $\phi$ là một quá trình ngẫu nhiên tương thích có bình phương khả tích. Khi đó tồn tại các quá trình ngẫu nhiên $\phi_{n}(n \in \mathbb{N})$ tương thích và có bình phương khả tích, và sơ cấp trên doạn thẳng $[0, T]$, sao cho

$$
\lim _{n \rightarrow \infty} \mathbb{E}\left(\int_{0}^{T}\left|\phi_{n}(t)-\phi(t)\right|^{2} d t\right)=0
$$

Dãy quá trình ngẫu nhiên $\phi_{n}$ thỏa mãn điều kiện của định lý trên được gọi là hội tụ đến $\phi$ theo chuẩn $L_{2}[0, T]$. Theo định nghĩa, chuẩn $L_{2}[0, T]$ của $\phi$ là:

$$
\|\phi\|_{L_{2}[0, T]}:=\sqrt{\mathbb{E}\left(\int_{0}^{T}|\phi(t)|^{2} d t\right)} .
$$

Không gian các quá trình ngẫu nhiên tương thích có chuẩn $L_{2}[0, T]$ hữu hạn là một không gian Hilbert (sau khi ta coi rằng hai quá trình ngẫu nhiên là một, nếu chuẩn $L_{2}[0, T]$ của hiệu của chúng bằng 0$)$, và các phần tử của không gian này được gọi là các quá trình ngẫu nhiên có bình phương khả tích (cho đến thời điểm $T$ ). Định lý trên tương tự như định lý mọi hàm số có bình phương khả tích đều có thể được xấp xỉ bằng các hàm số dạng bậc thang một cách chính xác tùy ý theo chuẩn $L_{2}$. Ta sẽ bỏ qua chứng minh của nó ở đây. 
Khi ta đã tìm được một dãy quá trình ngẫu nhiên $\phi_{n}$ sơ cấp trên đoạn $[0, T]$ và hội tụ đến $\phi$ theo chuẩn $L_{2}[0, T]$, thì với mọi $t \leq T$ ta có thể định nghĩa tích phân Itô bằng giới hạn sau:

$$
\int_{0}^{t} \phi(s) d B(s):=\lim _{n \rightarrow \infty} \int_{0}^{t} \phi_{n}(s) d B(s)
$$

Giới hạn ở đây cũng được hiểu theo chuẩn $L_{2}[0, T]$ : nếu đặt $F_{n, t}=\int_{0}^{t} \phi_{n}(s) d B(s)$ và $F_{t}=$ $\int_{0}^{t} \phi(s) d B(s)$, thì nói rằng $F_{n, t}$ tiến tới $F_{t}$ có nghĩa là $\lim _{n \rightarrow \infty} \mathbb{E}\left(\int_{0}^{T}\left|F_{n}(t)-F(t)\right|^{2} d t\right)=0$. Để chứng tỏ rằng định nghĩa trên có nghĩa, ta phải chứng minh là giới hạn ở vế phải của công thức trên tồn tại (tức là dãy các tích phân Itô $F_{n, t}=\int_{0}^{t} \phi_{n}(s) d B(s)$ là một dãy Cauchy theo chuẩn $L_{2}[0, T]$ ), và không phụ thuộc vào sự lựa chọn dãy $\phi_{n}$. Các khẳng định này được suy ra từ một đẳng thức gọi là đẳng cự Itô (xem Định lý 7.19. Chúng ta sẽ bỏ qua chứng minh ở đây.

Trong trường hợp mà quá trình $\phi$ là liên tục bên trái và bị chặn địa phương (locally bounded - tức là tập hợp các tình huống sao cho quỹ đạo chạy ra vô cùng trong khoảng thời gian hữu hạn có xác suất bằng 0 - các quá trình ngẫu nhiên mà chúng ta quan tâm đến trong sách này đều bị chặn địa phương), ta có thể xây dựng dãy quá trình sơ cấp $\phi_{n}$ trên $[0, T]$ hội tụ đến $\phi$ theo chuẩn $L_{2}[0, T]$ như sau: đặt

$$
\phi_{n}(t)=\phi([n t / T] T / n)
$$

với mọi $t \leq T$, trong đó $[n t / T]$ là ký hiệu phần nguyên của số $n t / T$, có nghĩa là nếu $k T / n \leq t<(k+1) T / n$ thì $\phi_{n}(t)=\phi(k T / n)$, hay nói cách khác, giá trị của $\phi_{n}$ trên đoạn thẳng $[k T / n,(k+1) T / n$ [ là bất biến theo $t$ và bằng giá trị của $\phi$ tại điểm đầu của đoạn thẳng đó, tức là điểm $k T / n$. (Chú ý là ta không thể lấy giá trị của $\phi$ tại điểm cuối hay các điểm khác của đoạn thẳng $\left[k T / n,(k+1) T / n\right.$ [ để làm giá trị của $\phi_{n}$ trên đoạn thẳng đó, vì nếu lấy như vậy thì quá trình $\phi_{n}$ nói chung sẽ không phải là một quá trình tương thích). Theo cách chọn $\phi_{n}$ này, ta được công thức

$$
\int_{0}^{T} \phi_{t} d B_{t}=\lim _{n \rightarrow \infty} \sum_{k=0}^{n-1} \phi\left(\frac{k T}{n}\right)\left(B\left(\frac{(k+1) T}{n}\right)-B\left(\frac{k T}{n}\right)\right) .
$$

Vi du 7.7. Ta sẽ chứng minh rằng

$$
\int_{0}^{t} B_{s} d B_{s}=\frac{B_{t}^{2}}{2}-\frac{t}{2}
$$




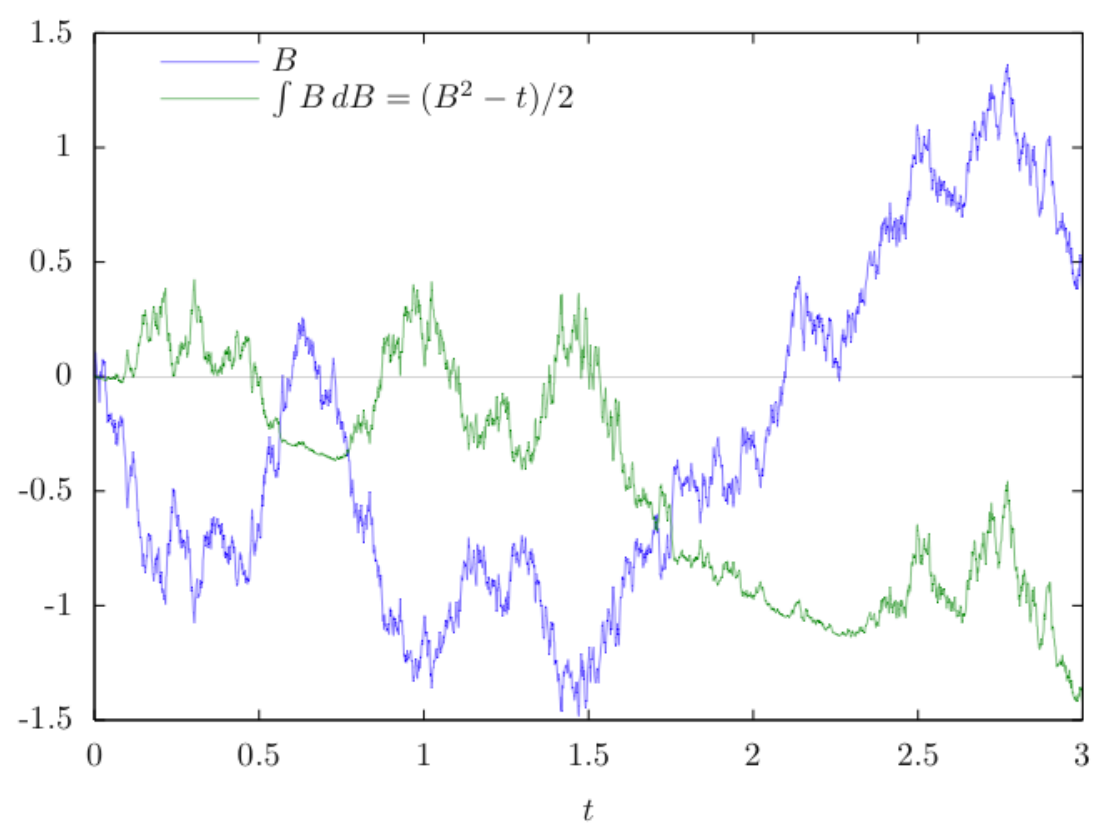

Hình 7.4: Một quỹ đạo của chuyển động Brown $B_{t}$ và tích phân Itô $\int_{0}^{t} B_{s} d B_{s}$

với mọi $t$, trong đó $B_{t}$ là chuyển động Brown. Thật vậy, theo công thức 7.106 ta có

$$
\begin{aligned}
& \int_{0}^{t} B_{s} d B_{s}=\lim _{n \rightarrow \infty} \sum_{k=0}^{n-1} B\left(\frac{k T}{n}\right)\left(B\left(\frac{(k+1) T}{n}\right)-B\left(\frac{k T}{n}\right)\right) \\
& =\lim _{n \rightarrow \infty} \frac{1}{2}\left[(B(t))^{2}-\sum_{k=0}^{n-1}\left(B\left(\frac{(k+1) T}{n}\right)-B\left(\frac{k T}{n}\right)\right)^{2}\right] .
\end{aligned}
$$

Theo tính chất biến phân bình phương của chuyển động Brown, ta có

$$
\lim _{n \rightarrow \infty} \sum_{k=0}^{n-1}\left(B\left(\frac{(k+1) T}{n}\right)-B\left(\frac{k T}{n}\right)\right)^{2}=t,
$$

từ đó ta được công thức tích phân cần chứng minh.

Chú ý rằng, nếu $F_{t}$ có biến phân bình phương bằng 0 và $F_{0}=0$, thì ta có $\int_{0}^{t} F_{s} d F_{s}=$ $F_{t}^{2} / 2$ (định nghĩa tích phân một cách tương tự, hoặc theo định nghĩa Riemann-Stieltjes), trong khi đó trong công thức (7.107) có thêm thành phần $t / 2$ ở vế phải. Ví dụ đơn giản này cho thấy ảnh hưởng của biến phân bình phương vào giá trị của tích phân Itô.

\subsubsection{Một số tính chất cơ bản của tích phân Itô}

Tương thích: Tích phân Itô là một quá trình tương thích với lọc sigma-đại số ban đầu. 
Tuyến tính: Tương tự như tích phân thông thường, tích phân Itô có tính chất tuyến tính: nếu $a$ và $b$ là hai hằng số thì

$$
\int_{0}^{t}\left(a \phi_{s}+b \psi_{s}\right) d B_{s}=a \int_{0}^{t} \phi_{s} d B_{s}+b \int_{0}^{t} \psi_{s} d B_{s}
$$

Liên tục: Nếu một quá trình ngẫu nhiên $F_{t}$ viết được dưới dạng tích phân Itô $F_{t}=$ $\int_{0}^{t} \phi_{s} d B_{s}$, thì hầu hết mọi quỹ đạo của $F_{t}$ là liên tục.

Tích phân Itô là phép tính ngược của vi phân: Tương tự như tích phân thông thường, tích phân Itô thỏa mãn tính chất cơ bản sau, liên hệ giữa phép tính vi phân và phép tính tích phân: nếu $F_{t}=\int_{0}^{t} \phi_{s} d B_{s}$, trong đó $\phi_{s}$ là một quá trình ngẫu nhiên có tích phân bình phương hữu hạn, thì $d F_{t}=\phi_{t} d B_{t}$, và ngược lại, nếu $d F_{t}=\phi_{t} d B_{t}$, thì $F_{t}=F_{0}+\int_{0}^{t} \phi_{s} d B_{s}$. Tổng quát hơn, nghiệm của phương trình vi phân ngẫu nhiên

$$
d X_{t}=\mu_{t} d_{t}+\sigma_{t} d B_{t}
$$

là

$$
X_{t}=X_{0}+\int_{0}^{t} \mu_{s} d_{s}+\int_{0}^{t} \sigma_{s} d B_{s} .
$$

Ví dụ, nghiệm của phương trình $d X_{t}=B_{t} d B_{t}$ là $X_{t}=X_{0}+\int_{0}^{t} B_{s} d B_{s}=X_{0}+B_{t}^{2} / 2-t / 2$. Tính ngược lại, theo bổ đề Itô, dễ dàng thấy rằng $d\left(B_{t}^{2} / 2-t / 2\right)=B_{t} d B_{t}$.

Đẳng cự Itô: Đẳng cự Itô là một công thức giải tích cho phép đánh giá chuẩn của các quá trình ngẫu nhiên (được dùng chẳng hạn trong việc chứng minh sự hội tụ của một dãy quá trình ngẫu nhiên định nghĩa theo tích phân Itô).

Định lý 7.19 (đẳng cự Itô). Nếu 申 là một quá trình ngẫu nhiên có bình phương khả tích thì ta có

$$
\mathbb{E}\left[\left(\int_{0}^{t} \phi_{s} d B_{s}\right)^{2}\right]=\mathbb{E}\left(\int_{0}^{t}\left|\phi_{s}\right|^{2} d s\right)
$$

với mọi $t \geq 0$.

Việc chứng minh đẳng cự trên là một bài tập dành cho bạn đọc trong trường hợp mà $\psi$ là một quá trình sơ cấp. Trường hợp tổng quát suy ra từ trường hợp các quá trình sơ cấp bằng phép lấy giới hạn.

Một hệ quả trực tiếp của đẳng cự Itô là: nếu $\phi_{s}$ là một quá trình có bình phương khả tích thì tích phân Itô $F_{t}=\int_{0}^{t} \phi_{s} d B_{s}$ cũng là một quá trình có bình phương khả tích.

Biến phân bình phương: Ta có đẳng thức sau cho biến phân bình phương của tích phân Itô:

$$
Q V_{0}^{t}(F)=\int_{0}^{t}\left|\phi_{s}\right|^{2} d s
$$


Tương tự như đẳng cự Itô, chứng minh của công thức trên trong trường hợp mà $\phi_{t}$ là một quá trình sơ cấp tương đối hiển nhiên và suy ra trực tiếp từ biến phân bình phương của chuyển động Brown.

Tính chất martingale:

Định lý 7.20. Tích phân Itô $F_{t}=\int_{0}^{t} \phi_{s} d B_{s}$ là một quá trình martingale (dịa phương), có nghĩa là

$$
\mathbb{E}\left(F_{t} \mid \mathcal{F}_{s}\right)=F_{s}
$$

với moi $t>s$.

Chứng minh. Trong trường hợp mà $\phi$ là một quá trình sơ cấp, thì định lý trên khá hiển nhiên, vì $\mathbb{E}\left(B_{t^{\prime}}-B_{t^{\prime \prime}} \mid \mathcal{F}_{t}\right)=B_{t}-B_{t}=0$ với mọi $t^{\prime}, t^{\prime \prime}>t$. Trường hợp tổng quát suy ra từ trường hợp riêng này bằng cách lấy giới hạn trong định nghĩa tích phân Itô.

Khẳng định ngược lại cũng đúng, và nó được biết dưới tên gọi định lý biểu diễn martingale: Nếu $M_{t}$ là một quá trình martingale, liên tục, tương thích với lọc sigma-đại số sinh bởi chuyển động Brown $B_{t}$, và có bình phương khả tích, thì nó viết được dưới dạng tích phân Itô.

Công thức tích phân từng phần. Trong tích phân $\int \phi_{t} d B_{t}$, thành phần $B_{t}$ được gọi là integrator (bội lấy tích phân). Định nghĩa tích phân Itô áp dụng được không những chỉ cho integrator là chuyển động Brown, mà còn cho các integrator tổng quát hơn, có dạng semi-martingale. Theo định nghĩa, một quá trình ngẫu nhiên $X_{t}$ được gọi là semimartingale nếu nó viết được dưới dạng tổng của hai thành phần, $X_{t}=A_{t}+M_{t}$, trong đó $A_{t}$ có biến phân hữu hạn, còn $M_{t}$ là martingale địa phương (tức là thỏa mãn tính chất martingale 7.113$)$ ). Tương tự như trường hợp tích phân Riemann-Stieltjes cổ điển, ta có công thức tích phân từng phần sau: nếu $X_{t}$ và $Y_{t}$ là hai semimartingale thì

$$
X_{t} Y_{t}=X_{0} Y_{0}+\int_{0}^{t} X_{s-} d Y_{s}+\int_{0}^{t} Y_{s-} d X_{s}+[X, Y]_{t}
$$

trong đó $X_{s-}$ là ký hiệu giới hạn bên trái, tức là $X_{s-}=\lim _{r \rightarrow s-} X_{r}$, và $[X, Y]_{t}$ là ký hiệu quá trình hiệp biến phân bình phương của $X$ và $Y$, định nghĩa như sau

$$
[X, Y]_{t}=\lim _{\operatorname{mesh}(\rho) \rightarrow 0} \sum_{i=1}^{n}\left(X_{a_{i}}-X_{a_{i-1}}\right)\left(Y_{a_{i}}-Y_{a_{i-1}}\right)
$$

(với giả sử là giới hạn đó tồn tại), trong đó $\rho=\left\{0=a_{0} \leq a_{1} \leq \ldots \leq a_{n}=t\right\}$ là ký hiệu một phân hoạch của đoạn thẳng $[0, t]$. Sự khác nhau giữa công thức tích phân từng phần 
cho tích phân Riemann-Stieltjes và công thức tích phân từng phần cho tích phân Itô nằm chính ở thành phần hiệp biến phân bình phương này.

Vi $d u$ 7.8. Trong trường hợp đặc biệt, khi $Y_{t}=X_{t}$ là cùng một quá trình ngẫu nhiên, thì $[X, Y]_{t}=[X, X]_{t}$ chính là quá trình biến phân bình phương của $X_{t}$, và ta được công thức sau:

$$
\int_{0}^{t} X_{s} d X_{s}=\frac{1}{2}\left(X_{t}^{2}-X_{0}^{2}-[X, X]_{t}\right)
$$

Bài tập 7.16. Tính các tích phân Itô sau:

a) $\int_{0}^{t} B_{s}^{2} d B_{s}$

b) $\int_{0}^{t} B_{s}^{3} d B_{s}$

c) $\int_{0}^{t} \exp \left(B_{s}\right) d\left(B_{s}+s\right)$

\subsection{Thay đổi phân bố xác suất}

Như chúng ta đã thấy từ Chương 3 về kinh doanh chênh lệch giá và Mục 7.2 về martingale, trong không gian các tình huống có thể xảy ra trên một thị trường chứng khoán, có (ít nhất) 2 phân bố xác suất khác nhau. Một phân bố là phân bố thực tế, còn một phân bố là phân bố trung hòa rủi ro. Giá chiết khấu (theo lãi suất không rủi ro) của các chứng khoán đều là các quá trình martingale theo phân bố trung hòa rủi ro, tuy rằng theo phân bố xác suất thực tế, thì chúng hoàn toàn có thể không phải là martingale. Ở phần này, chúng ta sẽ tìm hiểu một chút về lý thuyết các công thức biến đổi xác suất để chuyển từ một phân bố xác suất này sang phân bố xác suất khác. Ngoài việc giúp chúng ta hiểu sâu hơn quan hệ giữa xác suất thực tế và xác suất trung hòa rủi ro, các công thức biến đổi xác suất còn có vai trò quan trọng trong các phương pháp tính toán trong xác suất thống kê.

\subsection{1 Đạo hàm Radon-Nikodym}

Giả sử chúng ta có hai phân bố xác suất $P$ và $Q$ khác nhau, trên cùng một không gian xác suất $\Omega$, với cùng một sigma-đại số $\mathcal{F}$. Phân bố xác suất $Q$ được gọi là liên tục tuyệt đối theo phân bố xác suất $P$, nếu như với mọi tập tình huống $A$ sao cho $P(A)=0$ thì ta cũng có $Q(A)=0$, và nó được gọi là không suy biến theo phân bố xác suất $P$, nếu như ngược lại, với mọi tập tình huống $A$ sao cho $P(A)>0$ thì ta cũng có $Q(A)>0$. Tất nhiên, nếu $Q$ là liên tục tuyệt đối theo $P$ thì $P$ là không suy biến theo $Q$, và ngược lại. 
Theo định lý Radon-Nikodym trong lý thuyết độ đd ${ }^{(6)}$, nếu $Q$ là liên tục tuyệt đối theo $P$, thì tồn tại duy nhất (theo nghĩa xác suất) một hàm số $Z \geq 0$ đo được trên $\Omega$ sao cho với mọi tập đo được $A$ ta có:

$$
Q(A)=\int_{A} Z d P
$$

trong đó vế phải của đẳng thức trên là tích phân Lebesgue của $Z$ trên $A$ theo độ đo $P$. (Xem Chương 2 của [7] về khái niệm tích phân Lebesgue). Chúng ta sẽ chấp nhận định lý Radon-Nikodym mà không chứng minh ở đây. Hàm $Z$ này được gọi là đạo hàm Radon-Nikodym của $Q$ theo $P$, hay còn gọi là hàm tỷ lệ xác suất (likelyhood ratio), và ta viết:

$$
\frac{d Q}{d P}=Z
$$

Ngược lại, nếu $Z$ là một hàm số khả tích không âm bất kỳ trên $\Omega$ thỏa mãn điều kiện

$$
\mathbb{E}_{P}(Z):=\int_{\Omega} Z d P=1
$$

thì công thức (7.117) xác định trên $\Omega$ một phân bố xác suất liên tục tuyệt đối theo $P$, và có đạo hàm Radon-Nikodym bằng $Z$. Hơn nữa, $Q$ là không suy biến theo $P$ khi và chỉ khi hàm $Z$ khác 0 hầu khắp mọi nơi. Khi đó $P$ là liên tục tuyệt đối theo $Q$, và ta có:

$$
\frac{d P}{d Q}=\frac{1}{Z}
$$

Nếu giả sử ta đã biết phân bố xác suất $P$ mà chưa biết phân bố xác suất $Q$, thì để tìm $Q$ ta chỉ cần tìm đạo hàm Radon-Nikodym $d Q / d P$ của nó. Việc tính toán các đại lượng đặc trưng của các biến ngẫu nhiên theo xác suất $Q$ cũng có thể được đưa về việc tính toán các đại lượng đặc trưng của các biến ngẫu nhiên theo xác suất $P$, nếu ta biết đạo hàm Radon-Nikodym $Z=d Q / d P$. Chẳng hạn, ta có công thức sau:

$$
\mathbb{E}_{Q}(X)=\mathbb{E}_{P}(Z X)
$$

có nghĩa là

$$
\int_{\Omega} X d Q=\int_{\Omega} X Z d P
$$

cho mọi biến ngẫu nhiên $X$ trên $\Omega$.

Trong trường hợp mà không gian xác suất là một không gian có lọc $\left(\Omega,\left(\mathcal{F}_{t}\right), P\right)$, và $Q$ là một phân bố xác suất khác trên $\Omega$ liên tục tuyệt đối theo $P$, thì với mỗi $t$ ta có một

\footnotetext{
${ }^{(6)}$ Định lý này được Johann Radon thiết lập cho trường hợp không gian là $\mathbb{R}^{n}$, và Otton Nikodym mở rộng năm 1930 cho trường hợp tổng quát.
} 
đạo hàm Radon-Nikodym $Z_{t}=\left.\frac{d Q}{d P}\right|_{\mathcal{F}_{t}}$ theo sigma-đại số con $\mathcal{F}_{t}$, và khi đó $Z_{t}$ trở thành một quá trình ngẫu nhiên tương thích với mô hình xác suất $\left(\Omega,\left(\mathcal{F}_{t}\right), P\right)$. Ta sẽ gọi quá trình này là quá trình đạo hàm Radon-Nikodym.

Định lý 7.21. Quá trình đạo hàm Radon-Nikodym $Z_{t}=\left.\frac{d Q}{d P}\right|_{\mathcal{F}_{t}}$ là một martingale trên không gian xác suất có lọc $\left(\Omega,\left(\mathcal{F}_{t}\right), P\right)$. Ngược lại, nếu $Z_{t}$ là một martingale không âm trên $\left(\Omega, \mathcal{F}_{t}, P\right)$ có kỳ vọng bằng 1 , thì tồn tại duy nhất một phân bố xác suất $Q$ trên $\left(\Omega,\left(\mathcal{F}_{t}\right)\right)$ nhận $Z_{t}$ làm quá trình dạo hàm Radon-Nikodym $Z_{t}=\left.\frac{d Q}{d P}\right|_{\mathcal{F}_{t}}$.

Định lý trên suy ra trực tiếp từ định nghĩa đạo hàm Radon-Nikodym, và dành cho bạn đọc làm bài tập. Điều kiện kỳ vọng bằng 1 trong định lý trên có nghĩa là $\int_{\Omega} Z_{t} d P=1$ (với mọi $t$ ).

\subsection{2 Định lý Cameron-Martin}

Định lý Cameron-Martin (7), hay còn gọi là công thức Cameron-Martin, là một ví dụ về biến đổi xác suất, dùng để biến một chuyển động Brown có hệ số trượt khác 0 thành một chuyển động Brown chuẩn tắc.

Đặt $X_{t}=B_{t}+\mu t$, trong đó $B_{t}$ là chuyển động Brown chuẩn tắc với mô hình xác suất $\left(\Omega, \mathcal{F}_{t}, P\right)$, và $\mu \neq 0$ là một hằng số, gọi là hệ số trượt. Để cho tiện, chúng ta sẽ giả sử rằng lọc các sigma-đại số $\mathcal{F}_{t}$ chính là lọc sinh bởi chuyển động Brown $B_{t}$. Dễ thấy rằng, quá trình chuyển động Brown hình học $G_{t}=\exp \left(-\mu B_{t}-\frac{\mu^{2} t}{2}\right)$ là một quá trình martingale. (Xem bài tập $(7.13)$ ). Như vậy, ta có thể lấy nó làm quá trình đạo hàm Radon-Nikodym cho một phân bố xác suất khác trên $\left(\Omega, \mathcal{F}_{t}, P\right)$, mà ta sẽ gọi là $P_{\mu}$ :

$$
\left.\frac{d P_{\mu}}{d P}\right|_{\mathcal{F}_{t}}=G_{t}=\exp \left(-\mu B_{t}-\frac{\mu^{2} t}{2}\right) .
$$

Định lý 7.22 (Cameron-Martin). Quá trình ngẫu nhiên (chuyển động Brown có trượt) $X_{t}=B_{t}+\mu t$, là một chuyển động Brown chuẩn tắc trên không gian xác suất có lọc $\left(\Omega,\left(\mathcal{F}_{t}\right), P_{\mu}\right)$, với phân bố xác suất $P_{\mu}$.

Chứng minh. Chứng minh của định lý trên là sự kiểm tra các điều kiện của một chuyển động Brown. Ví dụ, ta sẽ kiểm tra rằng, với mỗi $t>0$, phân bố xác suất của biến ngẫu nhiên $X_{t}:\left(\Omega, \mathcal{F}_{t}, P_{\mu}\right) \rightarrow \mathbb{R}$ là phân bố normal $N(0, t)$.

\footnotetext{
${ }^{(7)}$ Định lý này được thiết lập năm 1944 trong bài báo: Cameron, R. H.; Martin, W. T., Transformations of Wiener Integrals under Translations, Annals of Mathematics 45 (2), 386-396 (1944).
} 
Thật vậy, ta có:

$$
\begin{aligned}
& P_{\mu}\left(X_{t} \leq a\right)=P_{\mu}\left(B_{t}+\mu t \leq a\right)=P_{\mu}\left(B_{t} \leq a-\mu t\right) \\
& \quad=\int_{B_{t} \leq a-\mu t} \exp \left(-\mu B_{t}-\frac{\mu^{2} t}{2}\right) d P=\int_{-\infty}^{a-\mu t} \exp \left(-\mu x-\frac{\mu^{2} t}{2}\right) \frac{1}{\sqrt{t 2 \pi}} \exp \left(\frac{-x^{2}}{2 t}\right) d x
\end{aligned}
$$

bởi vì phân bố xác suất của $B_{t}$ theo $P$ là phân bố $N(0, t)$ với hàm mật độ $\frac{1}{\sqrt{t 2 \pi}} \exp \left(\frac{-x^{2}}{2 t}\right)$. Đổi biến $y=x+\mu t$ vào tích phân trên, ta được:

$$
\left.\left.P_{\mu}\left(X_{t} \leq a\right)=\int_{-\infty}^{a} \frac{1}{\sqrt{t 2 \pi}} \exp \left(\frac{-y^{2}}{2 t}\right) d y=P_{N(0, t)}(]-\infty, a\right]\right)
$$

có nghĩa là phân bố xác suất của $X_{t}$ theo $P_{\mu}$ cũng chính là phân bố normal $N(0, t)$. Các điều kiện khác cũng được kiểm tra một cách tương tự.

Ghi chú 7.5. Vì $B_{t}=\left(B_{t}+\mu t\right)-\mu t$, và theo định lý trên thì $\left(B_{t}+\mu t\right)$ là chuyển động Brown chuẩn tắc theo phân bố xác suất $P_{\mu}$, nên $B_{t}$ trở thành chuyển động Brown có hệ số trượt bằng $-\mu$ theo phân bố xác suất $P_{\mu}$.

Bài tập 7.17. Áp dụng định lý trên, hãy tìm đạo hàm Radon-Nikodym của biến đổi xác suất để biến chuyển động Brown $B_{t}+\mu t$ với hệ số trượt $\mu$ thành một chuyển động Brown với một hệ số trượt $\nu$ khác cho trước.

\subsection{3 Ứng dụng vào định giá quyền chọn có giới hạn}

Để làm ví dụ ứng dụng cho công thức Cameron-Martin, ở đây chúng ta sẽ xét một mô hình khá đơn giản định giá một loại quyền chọn lạ, gọi là quyền chọn có giới hạn (barrier option). Việc định giá các quyền chọn thông dụng, gọi là quyền chọn kiểu Mỹ và quyền chọn kiểu Âu, sẽ được bàn trong chương sau.

Gọi $S_{t}$ là giá của một chứng khoán nào đó tại thời điểm $t$, và định nghĩa

$$
\eta=\mathbf{1}\left\{\max _{0 \leq t \leq T} S_{t} \geq A\right\}
$$

có nghĩa là, trong khoảng thời gian từ 0 đến $T$, nếu có ít nhất một thời điểm nào đó mà giá $S_{t}$ lớn hơn hoặc bằng $A$, thì $\eta$ bằng 1 , còn nếu giá $S_{t}$ luôn luôn nhỏ hơn $A$ trong khoảng thời gian từ 0 đến $T$ thì $\eta$ bằng 0 . Ở đây $T$ và $A$ là hai tham số cho trước.

Sản phẩm tài chính phái sinh cho phép người giữ nó được nhận một khoản tiền bằng $\eta$ định nghĩa theo công thức trên vào thời điểm $T$ được gọi là một quyền chọn có giới hạn 
(barrier option), với thời điểm đáo hạn là $T$, và barrier (thanh chắn, giới hạn) $A$. Câu hỏi đặt ra là: giá trị (giá hợp lý) của quyền chọn có giới hạn tại thời điểm 0 là bao nhiêu ?

Chúng ta sẽ giả sử là mức lãi kép liên tục trên thị trường là một hằng số $r$, và ứng với xác suất trung hòa rủi ro thì $S_{t}$ là một quá trình ngẫu nhiên Itô thỏa mãn phương trình vi phân

$$
d S_{t}=r S_{t} d t+\sigma d B_{t}
$$

trong đó hệ số volatility $\sigma$ cũng là một hằng số. Có nghĩa là, $S_{t}$ là một chuyển động Brown hình học:

$$
S_{t}=S_{0} \exp \left(\left(r-\sigma^{2} / 2\right) t+\sigma B_{t}\right)
$$

Theo nguyên lý no-arbitrage, ta có thể viết giá trị của quyền chọn có giới hạn tại thời điểm 0 bằng:

$$
V_{0}=e^{-r T} P\left\{\max _{0 \leq t \leq T} S_{t} \geq A\right\}
$$

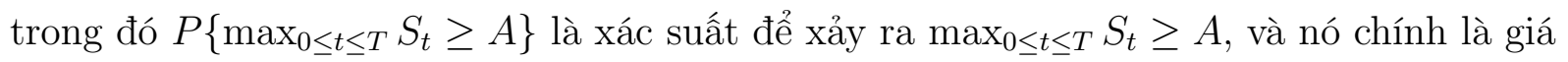
trị kỳ vọng của quyền chọn có giới hạn tại thời điểm $T$, còn $e^{-r T}$ là hệ số chiết khấu theo thời gian $T$ và mức lãi kép liên tục $r$. Như vậy, để tính giá trị của quyền chọn có giới hạn, ta cần tính

$$
P\left\{\max _{0 \leq t \leq T} S_{0} \exp \left(\left(r-\sigma^{2} / 2\right) t+\sigma B_{t}\right) \geq A\right\}=P\left\{\max _{0 \leq t \leq T}\left(\frac{r-\sigma^{2} / 2}{\sigma} t+B_{t}\right) \geq \frac{\ln \left(A / S_{0}\right)}{\sigma}\right\} .
$$

Đặt

$$
\mu=\frac{r-\sigma^{2} / 2}{\sigma} \text { và } \alpha=\frac{\ln \left(A / S_{0}\right)}{\sigma},
$$

ta cần tính

$$
P\left\{\max _{0 \leq t \leq T}\left(B_{t}+\mu t\right) \geq \alpha\right\} .
$$

Định lý Cameron-Martin cho biết $W_{t}=B_{t}+\mu t$ là chuyển động Brown chuẩn tắc theo phân bố xác suất $P_{\mu}$, với $d P=\exp \left(\mu B_{T}+\mu^{2} T / 2\right) d P_{\mu}=\exp \left(\mu W_{T}-\mu^{2} T / 2\right) d P_{\mu}$ trên sigma-đại số $\mathcal{F}_{T}$, và ta có:

$$
P\left\{\max _{0 \leq t \leq T}\left(B_{t}+\mu t\right) \geq \alpha\right\}=\mathbb{E}_{\mu}\left(\exp \left(\mu W_{T}-\mu^{2} T / 2\right) \mathbf{1}\left\{\max _{0 \leq t \leq T} W_{t} \geq \alpha\right\}\right),
$$

trong đó $\mathbb{E}_{\mu}$ là ký hiệu kỳ vọng theo $P_{\mu}$, và $\mathbf{1}\left\{\max _{0 \leq t \leq T} W_{t} \geq \alpha\right\}$ là hàm chỉ báo của sự kiện $\left\{\max _{0 \leq t \leq T} W_{t} \geq \alpha\right\}$.

Sự kiện $\left\{\max _{0 \leq t \leq T} W_{t} \geq \alpha\right\}$ là hợp của hai sự kiện không giao nhau $\left\{W_{t} \geq \alpha\right\}$ và $\left\{U_{t}>\alpha\right\}$, trong đó $U_{t}$ là quá trình gương phản của $W_{t}$ qua mốc $\alpha$, và $U_{t}$ cũng là chuyển 
động Brown chuẩn tắc theo phân bố xác suất $P_{\mu}$. Do đó:

$$
\begin{aligned}
& \mathbb{E}_{\mu}\left(\exp \left(\mu W_{T}-\mu^{2} T / 2\right) \mathbf{1}\left\{\max _{0 \leq t \leq T} W_{t} \geq \alpha\right\}\right) \\
& =\mathbb{E}_{\mu}\left(\exp \left(\mu W_{T}-\mu^{2} T / 2\right) \mathbf{1}\left\{W_{T} \geq \alpha\right\}\right)+\mathbb{E}_{\mu}\left(\exp \left(\mu W_{T}-\mu^{2} T / 2\right) \mathbf{1}\left\{U_{T} \geq \alpha\right\}\right) \\
& =\mathbb{E}_{\mu}\left(\exp \left(\mu W_{T}-\mu^{2} T / 2\right) \mathbf{1}\left\{W_{T} \geq \alpha\right\}\right)+\mathbb{E}_{\mu}\left(\exp \left(\mu\left(2 \alpha-U_{T}\right)-\mu^{2} T / 2\right) \mathbf{1}\left\{U_{T} \geq \alpha\right\}\right) \\
& =\int_{\alpha}^{\infty} \exp \left(\mu x-\mu^{2} T / 2\right) \frac{\exp \left(-x^{2} / 2 T\right)}{\sqrt{2 \pi T}} d x+\int_{\alpha}^{\infty} \exp \left((2 \mu \alpha-\mu x)-\mu^{2} T / 2\right) \frac{\exp \left(-x^{2} / 2 T\right)}{\sqrt{2 \pi T}} d x \\
& =\int_{\alpha}^{\infty}\left[\exp \left(\mu x-\mu^{2} T / 2\right)+\exp \left((2 \mu \alpha-\mu x)-\mu^{2} T / 2\right)\right] \frac{\exp \left(-x^{2} / 2 T\right)}{\sqrt{2 \pi T}} d x .
\end{aligned}
$$

Như vậy, ta được công thức sau để tính giá trị của quyền chọn có giới hạn:

$$
V_{0}=\exp \left(-r T-\mu^{2} T / 2\right) \int_{\alpha}^{\infty}[\exp (\mu x)+\exp (2 \alpha \mu-\mu x)] \frac{\exp \left(-x^{2} / 2 T\right)}{\sqrt{2 \pi T}} d x
$$

với

$$
\mu=\frac{r-\sigma^{2} / 2}{\sigma} \text { và } \alpha=\frac{\ln \left(A / S_{0}\right)}{\sigma}
$$

\subsection{4 Định lý Girsanov}

Định lý dưới đây của nhà toán học Igor Vladimirovich Girsanov (1934-1965) cho phép thay đổi hệ số trượt trong một quá trình Itô bất kỳ, nhưng không thay đổi hệ số volatility, bằng cách thay đổi phân bố xác suất. Nó là tổng quát hóa của định lý Cameron-Martin phía trước, và bởi vậy còn hay được biết đến dưới tên gọi định lý Cameron-Girsanov.

Định lý 7.23 (Girsanov). Giả sử

$$
d Y_{t}=\mu_{t} d t+\theta_{t} d B_{t}
$$

là một quá trình Itô trong một không gian xác suất có lọc $\left(\Omega,\left(\mathcal{F}_{t}\right), P\right)$. Giả sử u và $\nu_{t}$ là các quá trình ngẫu nhiên thỏa mãn đẳng thức

$$
\nu_{t}-\mu_{t}=\theta_{t} u_{t}
$$

Định nghĩa quá trình $M_{t}$ theo công thức

$$
M_{t}=\exp \left(\int_{0}^{t} u_{s} d B_{s}-\frac{1}{2} \int_{0}^{t}\left\|u_{s}\right\|^{2} d s\right)
$$

và định nghĩa phân bố xác suất $Q$ theo công thức

$$
\frac{d Q}{d P}=M_{T}
$$

Khi đó, ứng với phân bố xác suất $Q, Y_{t}$ thỏa mãn phương trình vi phân ngẫu nhiên sau:

$$
d Y_{t}=\nu_{t} d t+\theta_{t} d \hat{B}_{t}
$$

trong đó $\hat{B}_{t}$ là một chuyển động Brown theo phân bố xác suất $Q$. 
Trong định lý trên, quá trình $\theta_{t}$ (hệ số volatility) được giữ nguyên, còn quá trình $\mu_{t}$ (hệ số trượt) chuyển thành $\nu_{t}$, khi ta thay phân bố xác suất $P$ bằng phân bố xác suất $Q$. Trường hợp riêng của định lý Girsanov, khi $\nu_{t}=0$, cho công thức tính phân bố xác suất $Q$ sao cho đối với $Q$ thì $Y_{t}$ là martingale.

Chúng ta sẽ bỏ qua chứng minh định lý Girsanov trong quyển sách này. Bạn đọc có thể tham khảo cách chứng minh trong [21]. Định lý Girsanov có nhiều ứng dụng trong tính toán tài chính, ví dụ như trong mô hình biến động tỷ giá giữa hai đồng ngoại tệ có hai mức lãi suất khác nhau. 


\section{Chương 8}

\section{Quyền chọn}

Trên thế giới có nhiều loại quyền chọn khác nhau, nhưng chỉ có hai loại thông dụng nhất, là quyền chọn kiểu Âu (European-style option) và quyền chọn kiểu Mỹ (American-style option), và phổ biến nhất là kiểu Mỹ. Phần lớn quyền chọn của các cổ phiếu châu Âu cũng là quyền chọn kiểu Mỹ. Trong chương này, chúng ta sẽ tìm hiểu các tính chất cơ bản của các quyền chọn kiểu Âu và kiểu Mỹ, và các mô hình định giá chúng, đặc biệt là mô hình Black-Scholes, được Fisher Black và Myron Scholes xây dựng và Robert Morton phát triển từ năm 1973 cho quyền chọn kiểu Âu và mô hình nhị phân Cox-Ross-Rubinstein được xây dựng năm 1979. Mô hình nhị phân Cox-Ross-Rubinstein có thể áp dụng được cho nhiều trường hợp hơn là mô hình Black-Scholes, và được dùng làm phương pháp để tính giá quyền chọn kiểu Mỹ trên các thị trường chứng khoán trên thế giới, ví dụ như thị trường chứng khoán châu Âu Eurex (2).

Nhắc lại rằng, các quyền chọn mua (call option, gọi tắt là Call) là các quyền cho phép mua, nhưng không bắt buộc phải mua, các mặt hàng nào đó, tại các thời điểm nào đó, với giá nào đó theo thỏa thuận từ trước, trong các điều kiện nào đó. Tương tự như vậy, các quyền chọn bán (put option, gọi tắt là Put) là các quyền cho phép bán với các điều kiện nào đó, nhưng không bắt buộc phải bán.

Một quyền chọn mua kiểu Âu (European Call) là một hợp đồng cho phép nhà đầu tư mua một đơn vị của một hàng hóa hay tài sản $S$ nào đó (gọi là underlying asset) với một giá $X$ đã được cố định, gọi là giá thực hiện (exercise price hay strike price) tại một thời điểm $T$ trong tương lai cũng đã được cố định, gọi là thời điểm đáo hạn

\footnotetext{
${ }^{(1)}$ Scholes và Morton được trao giải thưởng Nobel về kinh tế năm 1997 nhờ mô hình này. Lúc đó Black đã qua đời, và giải Nobel chỉ trao cho người còn sống.

${ }^{(2)}$ Xem: http://www.eurexchange.com/index.html
} 
(exercise time hay expiry time). Nếu thay chữ mua bằng chữ bán trong định nghĩa này, thì ta được một quyền chọn bán kiểu Âu (European Put).

Một quyền chọn mua kiểu Mỹ (American Call) là một hợp đồng cho phép nhà đầu tư mua một đơn vị của một tài sản (underlying asset) $S$ với một giá thực hiện (strike price) $X$ đã được cố định tại mọi thời điểm cho đến một thời điểm đáo hạn (expiry time) $T$ trong tương lai cũng đã được cố định. Một quyền chọn bán kiểu Mỹ (American Put) cũng được định nghĩa tương tự như là một call option kiểu Mỹ, nhưng thay chũ mua bằng chữ bán.

Sự khác nhau giữa quyền chọn kiểu Âu và quyền chọn kiểu Mỹ là quyền chọn kiểu Mỹ cho quyền mua (nếu là Call) hoặc bán (nếu là Put) vào thời điểm $T$ hoặc mọi thời điểm trước đó, trong khi quyền chọn kiểu Âu chỉ cho quyền mua/bán tại đúng thời điểm $T$ thôi. Vì sự khác nhau này, việc đánh giá giá trị của quyền chọn kiểu Mỹ nói chung sẽ phức tạp hơn so với quyền chọn kiểu Âu, tuy rằng trong nhiều trường hợp thì giá của quyền chọn kiểu Mỹ và kiểu Âu sẽ gần như nhau, thậm chí đúng bằng nhau.

Để cho đơn giản, trong chương này, ta sẽ chỉ xét các quyền chọn của cổ phiếu, tức là ta sẽ coi rằng tài sản $S$ là cổ phiếu, có giá luôn không âm, tuy rằng nhiều công thức trong chương này có thể dùng được cho trường hợp tổng quát hơn. Ta sẽ luôn giả sử rằng gía thực hiện là số dương: $X>0$.

\subsection{Một số tính chất cơ bản của giá quyền chọn}

Một quyền chọn được xác định bởi thể loại của nó (Call hay Put, European hay American - ở đây ta sẽ giới hạn việc nghiên cứu quyền chọn vào các thể loại này), và các yếu tố: cổ phiếu (underlying asset) $S$, thời điểm đáo hạn (expiry time) $T$ và giá thực hiện (strike price) $X$ đã được cố định. Ta cũng sẽ dùng ký hiệu $S$ để chỉ giá của cổ phiếu. Giá của các quyền chọn sẽ được ký hiệu như sau:

- Eureopean Call được ký hiệu là $C^{E}$

- Eureopean Put được ký hiệu là $P^{E}$

- American Call được ký hiệu là $C^{A}$

- American Put được ký hiệu là $P^{A}$

Các giá này có thể được coi như các quá trình ngẫu nhiên, biến đổi theo thời gian $t \in[0, T]$.

Nhắc lại rằng, ta luôn giả sử là thị trường thỏa mãn nguyên lý no-arbitrage. Để đơn giản, ta sẽ giả sử là lãi suất kép liên tục trên thị trường là một hằng số r: mọi khoản tiền mặt âm hay dương trong các tài khoản trên thị trường đều tuân theo lãi suất này. Điều 
này tương đương với giả sử là có một chứng khoán không rủi ro $A$ trên thị trường có giá $A(t)$ thỏa mãn $A(t)=e^{r t} A(0)$ với mọi $t$, như ta làm trong những chương trước. Ở chương này, để cho các công thức được gọn nhẹ, một khoản tiền $Y$ tại thời điểm $t$ sẽ được viết nguyên là $Y$ chứ không viết thành $Y / A(t)$ đơn vị chứng khoán không rủi ro nữa. Nhưng nhớ là, $Y$ tiền ở thời điểm $t$ sẽ tự động biến thành $e^{(s-t) r} Y$ tiền tại mọi thời điểm $s \neq t$.

\subsubsection{Giá quyền chọn tại thời điểm đáo hạn}

Ta có một đánh giá sơ bộ đầu tiên về giá các quyền chọn như sau:

Định lý 8.1. i) Giá của các quyền chọn tại thời điểm đáo hạn $T$ được cho bởi công thức sau:

$$
\begin{aligned}
& C^{E}(T)=C^{A}(T)=(S(T)-X)^{+}:=\max (S(T)-X, 0), \\
& P^{E}(T)=P^{A}(T)=(X-S(T))^{+}:=\max (X-S(T), 0) .
\end{aligned}
$$

ii) Các giá quyền chọn $C^{E}, P^{E}, C^{A}, P^{A}$ luôn lớn hơn hoạc bằng 0 (tại bất cứ thời diểm $t \leq T$ nào).

Chứng minh. i) Đến thời điểm $T$, nếu $S(T)>X$ thì người giữ 1 Call kiểu Mỹ hay kiểu Âu đều có thể mua 1 cổ phiếu với giá $X$ theo quyền của cái Call đó, rồi bán lại ngay với giá $S(T)$, và thu được chênh lệch là $S(T)-X>0$. Trong trường hợp này thì con số đó chính là giá trị của Call, và bởi vậy cũng là giá của Call. Nếu $S(T) \leq X$, thì quyền để mua cổ phiếu với giá $X$ tại thời điểm $T$ không có giá trị gì, tức là giá của nó bằng 0 , vì có thể mua trên thị trường với giá $S(X)$ nhỏ hơn hoặc bằng $X$. Tương tự như vậy cho các Put.

ii) Vì các Call và Put chỉ là "quyền" chứ không có "nghĩa vụ" gì cả, nên giá của nó không thể âm. Giải thích theo nguyên lý no-arbitrage: vì giá trị của các Call và Put tại thời điểm $T$ luôn luôn lớn hơn hoặc bằng 0 , nên giá của chúng tại mọi thời điểm $t \leq T$ cũng không âm.

\subsubsection{Giá quyền chọn tính theo phân bố xác suất trung hòa rủi ro}

Ký hiệu $p_{*}$ là độ đo xác suất martingale (trung hòa rủi ro) trên thị trường. (Sự tồn tại của nó đã được bàn đến trong Chương 3 và Chương 7 ). Ký hiệu $\mathbb{E}_{*}$ là kỳ vọng theo 
xác suất martingale này. Như chúng ta đã thấy từ trong Ví dụ 3.4 , giá của quyền chọn không phải được xác định theo phân bố xác suất thực tế, mà là theo phân bố xác suất trung hòa rủi ro.

Định lý 8.2. Tại mọi thời điểm $t<T$, giá các quyền chọn kiểu Âu thỏa mãn các công thức sau:

$$
C^{E}(t)=e^{-(T-t) r} \mathbb{E}_{*}\left((S(T)-X)^{+} \mid \mathcal{F}_{t}\right)
$$

và

$$
P^{E}(t)=e^{-(T-t) r} \mathbb{E}_{*}\left((X-S(T))^{+} \mid \mathcal{F}_{t}\right),
$$

trong đó $\mathcal{F}_{t}$ là sigma-đại số (trong ho lọc các sigma-đại số của mô hình quá trình ngẫu nhiên giá cổ phiếu) ứng với toàn bộ các thông tin có được cho đến thời điểm $t$.

Định lý trên đưa việc tính giá quyền chọn về việc tính giá trị kỳ vọng $\mathbb{E}_{*}((S)$ $\left.X)^{+} \mid \mathcal{F}_{t}\right)$ và $\mathbb{E}_{*}\left((X-S(T))^{+} \mid \mathcal{F}_{t}\right)$ theo phân bố xác suất martingale. Ta sẽ bàn đến việc tính này trong các phần sau của chương.

Chứng minh. Theo tính chất martingale, trong trường hợp mà lãi suất kép liên tục $r$ là cố định, ta có $\mathbb{E}_{*}\left(C^{E}(T) \mid \mathcal{F}_{t}\right)=e^{(T-t) r} C^{E}(t)$. Thế nhưng $C^{E}(T)=(S(T)-X)^{+}$, nên ta có công thức trên cho $C^{E}(t)$. Tương tự như vậy cho $P^{E}(T)$.

\subsubsection{Quan hệ giữa quyền chọn kiểu Âu và kiểu $\mathrm{Mỹ}$}

Định lý 8.3. Option kiểu Âu luôn có giá nhỏ hơn hoặc bằng quyền chọn kiểu Mỹ (với cùng gía thực hiện và thời điểm đáo hạn):

$$
C^{E} \leq C^{A} ; P^{E} \leq P^{A}
$$

Chứng minh. Các quyền chọn kiểu Mỹ cho quyền lớn hơn các quyền chọn kiểu Âu: quyền chọn kiểu Âu chỉ cho quyền mua/bán tại đúng thời điểm $T$, trong khi quyền chọn kiểu Mỹ cho quyền mua bán cả ở các thời điểm trước $T$. Cái gì cho nhiều quyền hơn thì phải có giá trị lớn hơn hoặc bằng cái gì cho ít quyền hơn, theo nguyên lý no-arbitrage.

Định lý 8.4. Nếu cổ phiếu không trả cổ tức, thì Call kiểu Âu và Call kiểu Mỹ có giá bằng nhau (tại mọi thời điểm):

$$
C^{E}=C^{A}
$$


Chứng minh. Giả sử có một thời điểm $t$ nào đó mà $C^{E}(t)<C^{A}(t)$. Khi đó sẽ có chiến lược kinh doanh chênh lệch giá, với rổ tài sản gồm +1 Call kiểu Âu, -1 Call kiểu Mỹ tại thời điểm $t$, và một lượng tiền mặt $Y=C^{A}(t)-C^{E}(t)>0$. Thật vậy, giá trị của rổ tài sản này bằng 0 tại thời điểm $t$. Nếu như Call kiểu Mỹ không bị thực hiện tại thời điểm giữa chừng nào, tức là rổ tài sản này còn nguyên dạng như cũ cho đến thời điểm $T$, thì tại thời điểm $T$ nó có giá trị bằng $e^{r(T-t)} Y>0$. Nếu Call kiểu Mỹ bị thực hiện tại một thời điểm $s<T$ nào đó, thì tại thời điểm $s$ rổ tài sản này trở thành: -1 cổ phiếu $S$ cộng $X$ tiền cộng $Y e^{r(s-t)}$ tiền cộng +1 Call kiểu Âu. Nếu điều đó xảy ra, thì chuyển toàn bộ rổ tài sản về tiền mặt tại thời điểm $s$ (tức là mua +1 cổ phiếu $S$ và bán Call kiểu Âu), để được lượng tiền bằng

$$
\begin{aligned}
& X-S(s)+C^{E}(s)+Y e^{r(s-t)}=X-S(s)+e^{-(T-s) r} \mathbb{E}_{*}\left((S(T)-X)^{+} \mid \mathcal{F}_{t}\right)+Y e^{r(s-t)} \\
& \geq X-S(s)+e^{-(T-s) r} \mathbb{E}_{*}\left((S(T)-X)^{+} \mid \mathcal{F}_{t}\right)+Y e^{r(s-t)} \\
= & X-e^{-(T-s) r} X+e^{-(T-s) r} \mathbb{E}_{*}\left(S(T) \mid \mathcal{F}_{t}\right)-S(s)+Y e^{r(s-t)}=X-e^{-(T-s) r} X+Y e^{r(s-t)}>0
\end{aligned}
$$

(theo tính chất martingale). Như vậy, giá trị của rổ tài sản theo chiến lược sẽ luôn dương tại thời điểm $T$, trong khi nó bằng 0 tại thời điểm $t$, Ta đã giả sử là không có cơ hội arbitrage, bởi vậy điều trên không thể xảy ra, tức là ta phải có $C^{E}(t) \geq C^{A}(t)$. Mặt khác, ta đã biết $C^{E}(t) \leq C^{A}(t)$, bởi vậy ta có $C^{E}(t)=C^{A}(t)$.

Ghi chú 8.1. Nói chung không có đẳng thức chính xác tương tự giữa Put kiểu Mỹ và Put kiểu Âu, tuy trên thực tế giá của chúng cũng hay gần bằng nhau. Xem Ghi chú 8.2 phía dưới.

\subsubsection{Quan hệ tương ứng giữa Call và Put}

Định lý 8.5 (Put-Call parity). i) Giả sử là cổ phiếu S không trả cổ tức trong giai đoạn từ thời diểm $t$ đến thời điểm $T, t \leq T$. Khi đó giá của Call kiểu Âu $C^{E}(t)$, Put kiểu Âu $P^{E}(t)$, và của cổ phiếu $S(t)$ thỏa mãn đẳng thức sau:

$$
C^{E}(t)-P^{E}(t)=S(t)-X e^{-r(T-t)}
$$

ii) Nếu nhu cổ phiếu có trả cổ tức trong giai đoạn từ t đến T, thì công thức trên đổi thành

$$
C^{E}(t)-P^{E}(t)=S(t)-d i v_{t}^{T}-X e^{-r(T-t)},
$$

trong đó divồ là giá trị chiết khấu tại thời điểm t của dòng cổ tức nhận được trong khoảng thời gian tù̀ $t$ dến $T$ theo lãi kép liên tục $r$. 
Chứng minh. i) Xét một rổ tài sản thiết lập vào thời điểm $t$ gồm có: +1 cổ phiếu $S,+1$ Put kiểu $\hat{A} u,-1$ Call kiểu $\hat{A} u$, và $-X e^{-r(T-t)}$ đơn vị tiền. Đến thời điểm $T$ thì lượng $-X e^{-r(T-t)}$ tiền từ thời điểm $t$ trở thành $-X$ tiền, giá trị của +1 Put kiểu $\hat{A} u$ trở thành $(X-S(T))^{+}$, giá trị của -1 Call kiểu Âu trở thành $(S(T)-X)^{+}$, và giá trị của toàn bộ rổ tài sản này tại thời điểm $T$ sẽ là:

$$
S(T)+(X-S(T))^{+}-(S(T)-X)^{+}-X .
$$

Nếu $X \leq S(T)$ thì $(X-S(T))^{+}=0$ và $(S(T)-X)^{+}=S(T)-X$, còn nếu $X>S(T)$ thì $(X-S(T))^{+}=X-S(T)$ và $(S(T)-X)^{+}=0$. Dễ thấy rằng, trong cả hai trường hợp, rổ tài sản đều có giá trị đúng bằng 0 tại thời điểm $T$. Theo nguyên lý no-arbitrage, thì rổ tài sản cũng phải có giá bằng 0 tại thời điểm $t$, tức là $S(t)+P^{E}(t)-C^{E}(t)-X e^{-(T-t) r}=0$, từ đó suy ra điều phải chứng minh.

ii) Trường hợp có trả cổ tức, ta cũng có thể xét rổ tài sản hệt như trên. Nhưng giá trị của rổ này tại thời điểm $T$ sẽ không bằng 0 , mà bằng giá trị tương lai tại thời điểm $T$ của dòng cổ tức. Từ đó suy ra là giá trị của rổ này tại thời điểm $t$ bằng giá trị (chiết khấu) tại thời điểm $t$ của dòng cổ tức, và công thức trước phải được điều chỉnh theo giá trị này.

Vì quyền chọn kiểu Mỹ phức tạp hơn quyền chọn kiểu Âu, nên nói chung ta không có đẳng thức ràng buộc giữa Call kiểu Mỹ và Put kiểu Mỹ, mà có bất đẳng thức tương tự sau:

Định lý 8.6 (Put-Call parity estimate). i) Nếu cổ phiếu không trả cổ tức trong giai đoạn tù̀ $t$ đến $T$ thì ta có

$$
S(t)-X e^{-r(T-t)} \geq C^{A}(t)-P^{A}(t) \geq S(t)-X .
$$

ii) Nếu cổ phiếu có trả cổ tức thì ta có

$$
S(t)-X e^{-r(T-t)} \geq C^{A}(t)-P^{A}(t) \geq S(t)-d i v_{t}^{T}-X
$$

Chứng minh. i) Tương tự như trong chứng minh của định lý 8.5 , xét rổ chứng khoán tại thời điểm $t$ gồm: +1 cổ phiếu $S,-1$ Call kiểu Mỹ, +1 Put kiểu Mỹ, và $-X e^{-r(T-t)}$ tiền. Nếu trong giai đoạn từ $t$ đến $T$ có một thời điểm $s$ nào đó mà cái Call bị thực hiện, tức là có người đổi $X$ với 1 Call kiểu Mỹ lấy 1 cổ phiếu, thì tại thời điểm $s$ giá trị của rổ này sẽ là $X-X e^{-r(T-s)}+P^{A}(s) \geq 0$, và cứ giữ như vậy đến thời điểm $T$ thì giá gị của nó cũng không âm. Nếu như không có lúc nào cái Call bị thực hiện, thì 
tương tự như trong chứng minh của định lý 8.5, ta thấy rằng giá trị của rổ này tại thời điểm $T$ đúng bằng 0 . Như vậy, giá trị của rổ tại thời điểm $T$ luôn lớn hơn hoặc bằng 0 theo chiến lược trên, và do đó, theo nguyên lý no-arbitrage, giá trị tại thời điểm $t$ của rổ cũng phải không âm: $S(t)-X e^{-r(T-t)}+P^{A}(t)-C^{A}(t) \geq 0$, từ đó suy ra bất đẳng thức $S(t)-X e^{-r(T-t)} \geq C^{A}(t)-P^{A}(t)$.

Để chứng minh bất đẳng thức $S(t)-X \leq C^{A}(t)-P^{A}(t)$, ta xét chiến lược đầu tư với rổ chứng khoán tại thời điểm $t$ gồm có +1 Call, -1 Put, -1 cổ phiếu và $X$ tiền. Nếu Put bị thực hiện tại thời điểm $s \geq t$ nào đó, tức là -1 Put cùng với -1 cổ phiếu trong rổ bị đổi thành $-X$, thì tại thời điểm $s$ đó giá trị của rổ sẽ là $X e^{r(s-t)}-X+C^{A}(t) \geq 0$. Nếu Put không bị thực hiện lúc nào cả, thì giá trị của rổ tại thời điểm $T$ sẽ là $X e^{r(T-t)}-X>0$. Trong cả hai trường hợp thì giá trị của rổ là không âm, và bởi vậy giá trị của rổ tại thời điểm $t$ cũng không âm, từ đó suy ra bất đẳng thức cần chứng minh.

ii) Chứng minh hoàn toàn tương tự, và là bài tập dành cho bạn đọc.

Ghi chú 8.2. Khi mà thời hạn còn lại của quyền chọn tương đối ngắn, tức là $T-t$ tương đối nhỏ (chẳng hạn không quá 2 tháng) và lãi suất tương đối thấp (chẳng hạn dưới $5 \%$ ), thì $X e^{-r(T-t)}$ và $X$ chênh nhau rất ít (không quá $1 \%$ ), và bất đẳng thức 8.9 lúc đó sẽ gần như là một đẳng thức. Những quyền chọn ngắn hạn của cổ phiếu (có hạn không quá một vài tháng) thường là những quyền chọn được giao dịch nhiều nhất trên thị trường. Khi mà thời hạn ngắn, thì giá của quyền chọn kiểu Âu và kiểu Mỹ sẽ gần như là bằng nhau, bởi vì ảnh hưởng của lãi suất và của cổ tức thường là nhỏ đến mức có thể bỏ qua. Khi lãi suất bằng 0 và cổ tức cũng bằng 0 , thì có thể suy ra từ các định lý trên là giá của các quyền chọn kiểu Mỹ, kể cả Call và Put, sẽ đúng bằng giá của các quyền chọn kiểu Âu.

Bài tập 8.1. Giả sử giá cổ phiếu không hưởng cổ tức hiện tại là $32.65 \$$, và mức lãi kép liên tục là $4.7 \%$. Giả sử Call kiểu Âu với $X=35 \$$ và có thời hạn 3 tháng được giao dịch với giá $2.85 \$$. Hỏi giá của Put kiểu Âu với cùng $X$ và $T$ là bao nhiêu ?

Bài tập 8.2. (Một ví dụ thật trên thị trường chứng khoán Mỹ). Vào một thời điểm ngày 25/08/2009, cổ phiếu của công ty công nghệ sinh học Osiris (mã chứng khoán: OSIR) có giá là 14.40 đô la, September Call với giá thực hiện $X=12.5$ có giá là 4.50 , September Put với cùng giá thực hiện có giá là 3.05. Ở đây các Call và Put đều là kiểu Mỹ, và September có nghĩa là thời điểm đáo hạn của quyền chọn là vào ngày thứ bẩy của tuần thứ 3 của tháng 9 (năm 2009). Hỏi rằng thị trường của cổ phiếu và quyền chọn của Osiris vào thời điểm đó có thỏa mãn nguyên lý no-arbitrage không ? 


\subsubsection{Một số chặn trên và chặn dưởi của giá quyền chọn}

Nhắc lại rằng, nếu $Y$ là một đại lượng bất kỳ, thì ký hiệu $Y^{+}$dùng để chỉ phần dương của $Y$, có nghĩa là $Y^{+}=\max (Y, 0)$.

Định lý 8.7. Với mọi $t \leq T$ ta có các bất đẳng thức sau:

i)

$$
S(t) \geq C^{A}(t) \geq(S(t)-X)^{+}
$$

ii)

$$
X \geq P^{A}(t) \geq(X-S(t))^{+}
$$

iii)

$$
S(t) \geq C^{E}(t) \geq\left(S(t)-d i v_{t}^{T}-X e^{-r(T-t)}\right)^{+},
$$

iv)

$$
X e^{-r(T-t)} \geq P^{E}(t) \geq\left(X e^{-r(T-t)}-S(t)+d i v_{t}^{T}\right)^{+},
$$

trong đó divồ là ký hiệu giá trị chiết khấu tại thời điểm $t$ của dòng cổ tức được trả trong giai đoạn từ t đến $T$ (nếu cổ phiếu không trả cổ tức thì divot =0.).

Chứng minh. i) Thật vậy, tại mọi thời điểm $t \leq T$, nhà đầu tư giữ Call kiểu Mỹ có thể dùng nó để mua cổ phiếu với giá $X$ rồi bán lại ngay với giá $S(t)$ để hưởng chênh lệch $S(t)-X$ (nếu như $S(t)-X>0$ ), và do đó ta có $C^{A}(t) \geq S(t)-X$. Ta đã biết rằng $C^{A}(t) \geq 0$, bởi vậy $C^{A}(t) \geq(S(t)-X)^{+}$. Mặt khác, 1 Call không có giá trị bằng 1 cổ phiếu, bởi vì nếu muốn đổi Call lấy cổ phiếu còn phải nộp thêm $X$ tiền. Nói cách khác, một rổ chứng khoán gồm +1 cổ phiếu và -1 Call kiểu $M y ̃$ tại thời điểm $t$, thì dù Call có bị thực hiện hay không, cũng sẽ có giá trị không âm vào thời điểm $T$. Do đó ta có $S(t)-C^{A}(t) \geq 0$.

ii) Chứng minh hoàn toàn tương tự như i).

iii) Ta đã biết rằng $C^{E}(t) \geq 0$ và $C^{E}(t) \leq C^{A}(t) \leq S(t)$. Để chứng minh $C^{E}(t) \geq$ $S(t)-d i v_{t}^{T}-X e^{-r(T-t)}$, ta xét một chiến lược đầu tư, với rổ chứng khoán tại thời điểm $t$ gồm có +1 Call kiểu $\hat{A} u,-1$ cổ phiếu, và $+d i v_{t}^{T}+X e^{-r(T-t)}$ tiền. Giữ rổ này đến thời điểm $T$. Vì ta có -1 cổ phiếu, nên ta sẽ phải mất tiền cổ tức cho cổ phiếu, bởi vậy khi đến thời điểm $T$ thì phần $d i v_{t}^{T}$ tiền trong tài khoản mất đi, phần $X e^{-r(T-t)}$ tiền trong tài khoản trở thành $X$ tiền. Như vậy rổ chứng khoán này tại thời điểm $T$ gồm $+1 \mathrm{Call},-1$ cổ phiếu, và $X$ tiền, và có giá trị là $C^{E}(T)+X-S(T)=\max (S(T)-X, 0)+X-S(t) \geq 0$. Như vậy, rổ chứng khoán mà ta thiết lập tại thời điểm $t$ có giá trị luôn không âm tại tời 
điểm $T$, và do đó, theo nguyên lý no-arbitrage, giá trị của rổ chứng khoán cũng không âm tại thời điểm $t: C^{E}(t)-S(t)+d i v_{t}^{T}+X e^{-r(T-t)} \geq 0$.

iv) Chứng minh hoàn toàn tương tự như iii).

Ghi chú 8.3. Đại lượng $(S(t)-X)^{+}$được gọi là giá trị nội tại (intrinsic value) của một Call vào thời điểm $t$. Tương tự như vậy, đại lượng $(X-S(t))^{+}$được gọi là giá trị nội tại của một Put vào thời điểm $t$. Đối với các quyền chọn kiểu Mỹ, ta thấy rằng giá của chúng luôn lớn hơn hoặc bằng giá trị nội tại của chúng. Khoảng chênh lệch giữa giá và giá trị nội tại, tức là $C^{A}(t)-(S(t)-X)^{+}$đối với Call và $P^{A}(t)-(X-S(t))^{+}$đối với Put, được gọi là giá trị thời gian (time value) hay cước phí thời gian (time premium) của quyền chọn. Giá trị thời gian của quyền chọn nói chung là số dương, và tiến tới 0 khi $t$ tiến tới $T$, vì khi $t=T$ thì giá đúng bằng giá trị nội tại. Nếu giá trị nội tại của một quyền chọn là dương, thì quyền chọn được gọi là "có tiền bên trong" (in the money), tức là nếu thực hiện quyền mua/bán ngay lập tức vào thời điểm đó thì được một lượng tài sản dương bằng giá trị nội tại. Nếu $S(t)=X$ thì quyền chọn được gọi là "tới ngưỡng" (at the money), còn nếu $S(t)<X$ trong trường hợp quyền chọn là Call hoặc $S(t)>X$ trong trường hợp quyền chọn là Put, thì được gọi là "chưa có tiền" (out of the money), có nghĩa là nếu mà thực hiện quyền mua/bán khi mà quyền chọn đang "chưa có tiền", thì giá trị nhận được sẽ là số âm. Các khái niệm này cũng được dùng cho quyền chọn kiểu Âu (dựa trên giả sử là không có chênh lệch lớn giữa giá của quyền chọn kiểu Âu và quyền chọn kiểu Mỹ).

\subsection{Sự phụ thuộc của giá quyền chọn vào giá cổ phiếu và giá thực hiện}

\subsubsection{Sự phụ thuộc vào giá thực hiện}

Định lý 8.8. Giả sử cổ phiếu $S$, thời điểm đáo hạn $T$, và thời điểm t là cố định, xét sự phu thuộc của giá quyền chọn vào giá thực hiện. Khi đó, các hàm giá quyền chọn là các hàm đơn diệu theo giá thực hiện $X$ (tăng theo $X$ nếu là Put, giảm theo $X$ nếu là Call) và thỏa mãn các bất dẳng thức dạng Lipschitz sau, với mọi $X^{\prime}<X^{\prime \prime}$ là hai giá thực hiện khác nhau, và với mọi $t<T$ :

i)

$$
0 \leq C^{E}\left(X^{\prime}, t\right)-C^{E}\left(X^{\prime \prime}, t\right) \leq e^{-r(T-t)}\left(X^{\prime \prime}-X^{\prime}\right)
$$


ii)

$$
0 \leq P^{E}\left(X^{\prime \prime}, t\right)-P^{E}\left(X^{\prime}, t\right) \leq e^{-r(T-t)}\left(X^{\prime \prime}-X^{\prime}\right)
$$

iii)

$$
0 \leq C^{A}\left(X^{\prime}, t\right)-C^{A}\left(X^{\prime \prime}, t\right) \leq X^{\prime \prime}-X^{\prime}
$$

iv)

$$
0 \leq P^{A}\left(X^{\prime \prime}, t\right)-P^{A}\left(X^{\prime}, t\right) \leq X^{\prime \prime}-X^{\prime} .
$$

v) Hơn nưa, các hàm giá quyền chọn đều là hàm lồi theo biến $X$, tức là với mọi $\alpha \in[0,1]$ ta có

$$
C^{A}\left(\alpha X^{\prime}+(1-\alpha) X^{\prime \prime}, t\right) \leq \alpha C^{A}\left(X^{\prime}, t\right)+(1-\alpha) C^{A}\left(X^{\prime \prime}, t\right)
$$

và các bất đẳng thức tương tự cho $P^{E}, C^{A}$ và $P^{A}$.

Chứng minh. i) Giả sử $X^{\prime \prime}>X^{\prime}$. Khi đó $0 \leq\left(S(T)-X^{\prime}\right)^{+}-\left(S(T)-X^{\prime \prime}\right)^{+} \leq X^{\prime \prime}-$ $X^{\prime}$ trong mọi tình huống, từ đó suy ra $0 \leq \mathbb{E}_{*}\left(\left(S(T)-X^{\prime}\right)^{+}\right)-\mathbb{E}_{*}\left(\left(S(T)-X^{\prime \prime}\right)^{+}\right)=$ $e^{r(T-t)} C^{E}\left(X^{\prime}, t\right)-e^{r(T-t)} C^{E}\left(X^{\prime \prime}, t\right) \leq X^{\prime \prime}-X^{\prime}$, và ta được bất đẳng thức cần chứng minh.

ii) Chứng minh hoàn toàn tương tự như i).

iii) Có thể nhận thấy ngay rằng, tương tự như đối với Call kiểu Âu, $C^{A}\left(X^{\prime}\right)-C^{A}\left(X^{\prime \prime}\right) \geq$ 0 vì quyền mua với giá thấp hơn thì có giá trị hơn là quyền mua với giá cao hơn. Để chứng minh rằng $C^{A}\left(X^{\prime}\right)-C^{A}\left(X^{\prime \prime}\right) \leq X^{\prime \prime}-X^{\prime}$, ta xét một chiến lược với rổ chứng khoán tại thời điểm $t$ gồm có: +1 Call kiểu Mỹ với giá thực hiện $X^{\prime \prime},-1$ Call kiểu Mỹ với giá thực hiện $X^{\prime}$, và $X^{\prime \prime}-X^{\prime}$ tiền. Nếu như Call kiểu Mỹ với giá thực hiện $X^{\prime}$ không bị thực hiện lúc nào cả, thì đến khi hết hạn giá trị của nó về 0 , và tại thời điểm $T$ trong rổ còn Call kiểu Mỹ với giá thực hiện $X^{\prime \prime}$ (giá trị của Call này cũng bằng 0 , vì $S(T) \leq X^{\prime}<X^{\prime \prime}$ trong trường hợp này), và $\left(X^{\prime \prime}-X^{\prime}\right) e^{r(T-t)}>0$ tiền. Nếu như có một thời điểm $s$ nào đó, $t \leq s \leq T$, sao cho Call kiểu Mỹ với giá thực hiện $X^{\prime}$ bị thực hiện tại thời điểm $s$, thì ta có thể thực hiện luôn Call kiểu Mỹ với giá thực hiện $X^{\prime \prime}$ tại thời điểm $s$. Nếu làm như vậy thì trong rổ, tại thời điểm $s$, không còn chứng khoán nào ngoài lượng tiền bằng $\left(X^{\prime \prime}-X^{\prime}\right)\left(e^{r(s-t)}-1\right) \geq 0$. Như vậy, trong mọi tình huống, thì rổ chứng khooán theo chiến lược trên sẽ có giá trị không âm tại thời điểm $T$. Theo nguyên lý no-arbitrage, thì rổ chứng khoán này cũng phải có giá trị không âm tại thời điểm $t$, từ đó ta được bất đẳng thức cần chứng minh.

iv) Chứng minh tương tự như iii).

v) Xét một chiến lược đầu tư, với rổ chứng khoán tại thời điểm $t$ gồm có: $\alpha C_{X^{\prime}}^{A}+(1-$ $\alpha) C_{X^{\prime \prime}}^{A}-1 C_{\alpha X^{\prime}+(1-\alpha) X^{\prime \prime}}^{A}$, trong đó $C_{X}^{A}$ là ký hiệu Call kiểu Mỹ có giá thực hiện là $X$. Nếu 
như cho tới hết thời điểm $T$, không lúc nào $C_{\alpha X^{\prime}+(1-\alpha) X^{\prime \prime}}^{A}$ bị thực hiện, thì giá trị của cái Call này về 0 tại thời điểm $T$, và rổ chứng khoán này sẽ có giá trị không âm tại thời điểm $T$ (lúc đó giá trị của $(1-\alpha) C_{X^{\prime \prime}}^{A}$ cũng sẽ bằng 0 , nhưng giá trị của $\alpha C_{X^{\prime}}^{A}$ có thể là số dương). Nếu như có một thời điểm $s \leq T$ nào đó, sao cho $C_{\alpha X^{\prime}+(1-\alpha) X^{\prime \prime}}^{A}$ bị thực hiện tại thời điểm $s$, thì ta cũng thực hiện luôn $\alpha C_{X^{\prime}}^{A}+(1-\alpha) C_{X^{\prime \prime}}^{A}$ tại thời điểm $s$; làm như vậy sẽ đưa giá trị của rổ chứng khoán về đúng bằng 0 tại thời điểm $s$. Như vậy, theo chiến lược đầu tư này, dù tình huống nào xảy ra, giá trị nhận được từ rổ chứng khoán ban đầu vào thời điểm $T$ cũng sẽ không âm. Theo nguyên lý no-arbitrage, thì giá trị ban đầu của rổ chứng khoán cũng phải không âm.

Tính lồi của $P^{A}, C^{E}, P^{E}$ theo biến $X$ có thể được chứng minh một cách hoàn toàn tương tự.

Bài tập 8.3. Viết chứng minh tính lồi của $P^{A}, C^{E}$ và $P^{E}$ theo biến giá thực hiện $X$.

\subsubsection{Sự phụ thuộc vào giá của cổ phiếu}

Giá của quyền chọn tất nhiết là phụ thuộc vào giá của cổ phiếu, bởi vì khi quyền chọn được thực hiện (exercise), thì giá của nó chính bằng chênh lệch giữa giá thực hiện và giá cổ phiếu tại thời điểm thực hiện quyền. Tại các thời điểm khác, thì giá của cổ phiếu cũng ảnh hưởng đến giá quyền chọn.

Giả sử là giá của cổ phiếu thay đổi từ $S^{\prime}$ thành $S^{\prime \prime}$ trong một khảng thời gian rất ngắn, trong khi các yếu tố khác ảnh hưởng đến giá trị của quyền chọn chưa kịp thay đổi, thì giá của các quyền chọn sẽ thay đổi như sau: giá của cổ phiếu đi lên, thì giá của Call option cũng đi lên còn giá của Put đi xuống, và ngược lại khi mà giá của cổ phiếu đi xuống thì giá của Call đi xuống và giá của Put đi lên.

Nếu ta coi $C^{E}(t), P^{E}(t), C^{A}(t), P^{A}(t)$ là các hàm số theo biến $S$, trong đó $S=S(t)$ là giá của cổ phiếu tại thời điểm $t$, thì các hàm này là các hàm lồi theo biến $S$, và thỏa mãn các bất đẳng thức sau, trong đó $S^{\prime}<S^{\prime \prime}$ là hai giá trị khác nhau của biến $S$ :

$$
0<C^{E}\left(S^{\prime \prime}, t\right)-C^{E}\left(S^{\prime}, t\right)<S^{\prime \prime}-S^{\prime}, \quad 0<C^{A}\left(S^{\prime \prime}, t\right)-C^{A}\left(S^{\prime}, t\right)<S^{\prime \prime}-S^{\prime},
$$

và

$$
0<P^{E}\left(S^{\prime}, t\right)-P^{E}\left(S^{\prime \prime}, t\right)<S^{\prime \prime}-S^{\prime}, \quad 0<P^{A}\left(S^{\prime}, t\right)-P^{A}\left(S^{\prime \prime}, t\right)<S^{\prime \prime}-S^{\prime} .
$$

Để chứng minh các bất đẳng thức trên, chúng ta sẽ phải lập các mô hình định giá quyền chọn. Điều này sẽ được bàn đến trong những phần sau của chương. Một cách trực 
giác, ta có thể hình dung như sau: giá trị của quyền chọn phụ thuộc vào hiệu $S-X$ giữa giá cổ phiếu và giá thực hiện. Bởi vậy, cố định $X$ và thay đổi $S$, thì cũng tương tự như là cố định $S$ và thay đổi $X$ theo chiều ngược lại, và do đó tính đơn điệu và tính lồi của hàm giá quyền chọn theo $S$ cũng tương tự như tính đơn điệu (theo chiều ngược lại) và tính lồi của hàm giá quyền chọn theo $X$.

\subsection{Phương trình Black-Scholes}

Ở phần này, chúng ta sẽ thảo luận mô hình Black-Scholes để tính giá các quyền chọn kiểu Âu cho một cổ phiếu $S$. Các giả thiết của mô hình này là, trong khoảng thời gian được xét:

- Cố phiếu $S$ không trả cổ tức, và giá của $S$ luôn luôn dương.

- Có một mức lãi suất kép cố định, là hằng số $r>0$. Hay nói cách khác, tồn tại một chứng khoán không rủi ro $A$ sao cho

$$
A(t)=A(0) e^{r t}>0
$$

với mọi $t$. Có thể viết cách khác nữa là, $A$ thỏa mãn phương trình vi phân

$$
d A=r A d t
$$

với điều kiện biên $A(0)>0$.

- Thị trường thỏa mãn nguyên lý no-arbitrage. Hệ quả là có một phân bố xác suất martingale trên thị trường, ký hiệu là $p_{*}$.

- Cổ phiếu $S$ thỏa mãn phương trình vi phân ngẫu nhiên (theo phân bố xác suất thực tế của thị trường)

$$
d S_{t}=\mu S_{t} d t+\sigma S_{t} d B_{t}
$$

trong đó $\mu=\mu\left(t, S_{t}\right)$ và $\sigma=\sigma\left(t, S_{t}\right)$ là hai hàm số xác định theo 2 biến $t$ và $S_{t}$. Hàm $\mu$ được gọi là hệ số trượt còn $\sigma$ được gọi là hệ số volatility. Trong ứng dụng, để cho đơn giản, người ta hay coi $\sigma$ là hằng số.

Một quyền chọn kiểu Âu tổng quát $V(t)$ trên cổ phiếu $S$ với expiry time $T$ có thể được định nghĩa là một chứng khoán mà giá trị $V(T)$ vào thời điểm $T$ đúng bằng $G\left(S_{T}\right)$, trong đó $G$ là một hàm số một biến nào đó, và $S_{T}$ là giá của cổ phiếu tại thời điểm $T$. Hàm $G$ được gọi là payoff function (hàm payoff, hàm trả tiền), của quyền chọn. Ví dụ, đối với Call kiểu Âu có giá thực hiện $X$, thì hàm $G$ là hàm $G(S)=(S-X)^{+}$. 
Gọi $V$ là giá của một quyền chọn kiểu Âu, của một cổ phiếu $S$, với thời điểm đáo hạn là $T$ và hàm payoff là một hàm số $G$ nào đó. Ta giả sử rằng $V$ có thể được viết dưới dạng một hàm số của hai biến thời gian $t$ và giá cổ phiếu $S=S_{t}$ tại thời điểm $t: V=V(t, S)$. Khi đó, theo bổ đề Itô, ta có:

$$
d V_{t}=\frac{\partial V}{\partial t} d t+\frac{\partial V}{\partial S} d S+\frac{1}{2} \frac{\partial^{2} V}{\partial S^{2}} d S^{2}
$$

Thay $d S$ bằng $\mu S d t+\sigma S d B_{t}$ và $d S^{2}=\sigma^{2} S^{2} d t$ trong công thức trên, ta được:

$$
d V_{t}=\left(\frac{\partial V}{\partial t}+\mu S \frac{\partial V}{\partial S}+\frac{1}{2} \sigma^{2} S^{2} \frac{\partial^{2} V}{\partial S^{2}}\right) d t+\sigma S \frac{\partial V}{\partial S} d B_{t}
$$

Xét một rổ chứng khoán $\Pi$ gồm có 1 quyền chọn $V$ và $x$ cổ phiếu $S$, được thành lập vào một thời điểm $t=t_{0}$. Giá trị của $\Pi$ tại thời điểm $t>t_{0}$ là $\Pi_{t}=V_{t}+x S_{t}$, và vi phân của nó là

$$
d \Pi_{t}=d V_{t}+x d S_{t}=\left(\frac{\partial V}{\partial t}+\mu S \frac{\partial V}{\partial S}+\frac{1}{2} \sigma^{2} S^{2} \frac{\partial^{2} V}{\partial S^{2}}+x \mu S\right) d t+\sigma S\left(\frac{\partial V}{\partial S}+x\right) d B_{t} .
$$

Ta chọn $x=-\left.\frac{\partial V}{\partial S}\right|_{t=t_{0}}$ tại thời điểm $t=t_{0}$ ( $x$ là hằng số, không thay đổi theo $\left.t\right)$. Khi đó tại thời điểm $t=t_{0}$ ta có:

$$
\left.d \Pi_{t}\right|_{t=t_{0}}=\left(\frac{\partial V}{\partial t}+\frac{1}{2} \sigma^{2} S^{2} \frac{\partial^{2} V}{\partial S^{2}}\right) d t
$$

tức là vi phân của $\Pi_{t}$ theo thời gian tại thời điểm $t=t_{0}$ là đại lượng xác định chứ không ngẫu nhiên (phần ngẫu nhiên có hệ số bằng 0 tại thời điểm $t=t_{0}$ ). Do nguyên lý no-arbitrage, nên hệ số $\left(\frac{\partial V}{\partial t}+\frac{1}{2} \sigma^{2} S^{2} \frac{\partial^{2} V}{\partial S^{2}}\right)$ trong vế phải của công thức trên bằng đúng $r \prod_{t_{0}}$ (bởi vì mức lợi suất log vi phân của $\Pi$, khi nó là đại lượng xác định, phải bằng mức lợi suất log của chứng khoán không rủi ro). Bởi vậy phương trình

$$
\frac{\partial V}{\partial t}+\frac{1}{2} \sigma^{2} S^{2} \frac{\partial^{2} V}{\partial S^{2}}=r\left(V-\frac{\partial V}{\partial S} S\right)
$$

được thỏa mãn tại thời điểm $t=t_{0}$. Nhưng vì $t_{0}$ có thể được chọn tùy ý, nên thực ra phương trình trên được thỏa mãn với mọi $t$.

Phương trình trên chính là phương trình Black-Scholes. Nó thường được viết dưới dạng sau:

Định nghĩa 8.9. Phương trình Black-Scholes là phương trình đạo hàm riêng bậc hai:

$$
\frac{\partial V}{\partial t}+\frac{1}{2} \sigma^{2} S^{2} \frac{\partial^{2} V}{\partial S^{2}}+r \frac{\partial V}{\partial S} S-r V=0
$$

theo hai biến $t$ và $S$, với hàm ẩn là hàm $V=V(t, S)$. 
Phương trình Black-Scholes là phương trình đạo hàm riêng bậc 2 thuộc dạng phương trình parabolic, tương tự như phương trình truyền nhiệt (heat equation), được nghiên cứu nhiều trong toán học. Bởi vậy, sau khi ta đã thiết lập được phương trình Black-Scholes, thì có thể dùng lý thuyết phương trình đạo hàm riêng để giải nó và tìm hàm giá $V(t, S)$ cho quyền chọn.

Phương trình Black-Scholes cũng có thể được viết dưới dạng

$$
\frac{\partial V}{\partial t}=-\frac{1}{2} \sigma^{2} S^{2} \frac{\partial^{2} V}{\partial S^{2}}-r \frac{\partial V}{\partial S} S+r V
$$

và được hiểu như là một phương trình vi phân thường trên một không gian vô hạn chiều (không gian các hàm số với một biến $S$ ).

Một điều rất thú vị và quan trọng là, trong phương trình Black-Scholes, hoàn toàn không có sự tham gia của hệ số trượt $\mu$ của phương trình biến động giá cổ phiếu, mà chỉ có sự tham gia của hệ số volatility $\sigma$. Nói cách khác, giá của quyền chọn chỉ phụ thuộc vào volatility của cổ phiếu, chứ không hề phụ thuộc vào thành phần định tính trong sự biến động giá cổ phiếu!

Ta đã gặp hiện tượng này từ trong Ví dụ 3.5, cho thấy rằng giá của quyền chọn được xác định theo phân bố xác suất trung hòa rủi ro (phân bố martingale) $p_{*}$, chứ không phải là theo phân bố xác suất thực tế. Nếu ta thay phân bố xác suất thực tế bằng phân bố xác suất martingale $p_{*}$ trên không gian các tình huống có thể xảy ra, thì phương trình vi phân ngẫu nhiên mô tả chuyển động của giá $S$ trở thành:

$$
d S_{t}=r S_{t} d t+\sigma S_{t} d B_{t}
$$

tức là hệ số trượt trở thành hằng số $r$, còn hệ số volatility thì vẫn là hằng số $\sigma$ như cũ (không thay đổi). Thật vậy, hệ số trượt chính là lợi suất log trung bình của $S$, mà ứng với phân bố xác suất martingale thì lợi suất log trung bình của bất kỳ chứng khoán nào cũng bằng lợi suất log không rủi ro, tức là bằng $r$, và bởi vậy $\mu$ được thay thế bằng $r$ khi ta thay xác suất tực tế bằng xác suất martingale. Hệ số volatility $\sigma$ được giữ nguyên, bởi vì, nói một cách trực giác, nó vẫn chính là hệ số mà sẽ xuất hiện trong phương trình Black-Scholes.

Nói một cách chặt chẽ toán học hơn, thì sự tồn tại phép chuyển đổi từ phương trình 8.24 về phương trình (8.32) (bằng cách chuyển đổi phân bố xác suất) được cho bởi định lý Cameron-Girsanov đã được bàn đến trong chương 7. Biến đổi phân bố xác suất cho bởi định lý Cameron-Girsanov, không làm thay đổi hệ số volatility trong phương trình vi phân ngẫu nhiên mô tả chuyển động theo thời gian của giá cổ phiếu. 
Phương trình Black-Scholes cũng có thể được coi như là trường hợp riêng của công thức Feynman-Kac, sau khi ta đã thay thế phân bố xác suất thực tế bằng phân bố martingale. Công thức Feynman-Kac, đặt theo tên nhà vật lý Richard Feynman[(3) (1918-1988) và nhà toán học Mark Ką (4) (1914-1984), xuất hiện từ năm 1949 $9^{(5)}$ và được dùng nhiều trong vật lý lượng tử, là công thức liên hệ một số phương trình đạo hàm riêng bậc 2 dạng phương trình truyền nhiệt với các chuyển động ngẫu nhiên, và có thể được phát biểu như sau:

Định lý 8.10 (Feynman-Kac). Giả sử $\mu(t, x), \sigma(t, x)$, và $\psi(x)$ là các hàm số cho trước. Khi đó nghiệm của phương trình đạo hàm riêng bậc 2

$$
\frac{\partial f(t, x)}{\partial t}+\mu(t, x) \frac{\partial f(t, x)}{x}+\frac{1}{2} \sigma^{2}(t, x) S^{2} \frac{\partial^{2} f(t, x)}{\partial x^{2}}=0
$$

với điều kiện biên $f(T, x)=\psi(x)$ có thể được viêt dưới dạng kỳ vọng

$$
f(t, x)=\mathbb{E}\left(\psi\left(S_{T}\right) \mid S_{t}=x\right),
$$

trong đó S là một quá trình Itô thỏa mãn phương trình vi phân ngẫu nhiên

$$
d S_{t}=\mu(t, S) d t+\sigma(t, S) d B_{t}
$$

và B là chuyển động Brown.

Để suy ra phương trình Black-Scholes từ định lý 8.10, ta dùng phân bố xác suất martingale, đổi tên $x$ thành $S$, đặt $\mu(t, S)=r S, \psi=G$ là hàm payoff, còn $f(t, S)=$ $e^{r(T-t)} V(t, S)$ là giá trị tương lai tại thời điểm $T$ của giá quyền chọn tại thời điểm $t$. Khi đó, theo công thức Feynman-Kac, tức là theo định lý 8.10 , thì $f$ thỏa mãn phương trình đạo hàm riêng

$$
\frac{\partial f}{\partial t}+\frac{1}{2} \sigma^{2} S^{2} \frac{\partial^{2} f}{\partial S^{2}}+r S \frac{\partial f}{\partial S}=0
$$

Từ đó dễ dàng suy ra rằng $V(t, S)=e^{-r(T-t)} f(t, S)$ thỏa mãn phương trình Black-Scholes.

Bài tập 8.4. Chứng minh của định lý 8.10 tương đối đơn giản, và làm bài tập cho bạn đọc tự tìm hiểu. Hãy thử tự chứng minh nó, bằng cách áp dụng bổ đề Itô vào quá trình ngẫu nhiên $f\left(t, S_{t}\right)$. rồi lấy tích phân theo biến thời gian của hai vế. Nếu không có thể xem cách chứng minh chẳng hạn ở đây: http://en.wikipedia.org/wiki/Feynman-Kac_formula

\footnotetext{
${ }^{(3)}$ Xem: http://en.wikipedia.org/wiki/Richard_Feynman

${ }^{(4)}$ Xem: http://en.wikipedia.org/wiki/Mark_Kac

${ }^{(5)}$ Công thức này được thiết lập bởi Kac trong bài báo: M. Kac, On Distributions of Certain Wiener Functionals, Transactions of the American Mathematical Society 65 (1949), No. 1, 1-13.
} 


\subsection{Công thức định giá quyền chọn kiểu Âu}

Ở mục này, ta sẽ tìm công thức tính giá quyền chọn kiểu Âu theo mô hình BlackScholes, bằng cách sử dụng phân bố xác suất martingale $p_{*}$, trong trường hợp mà volatility $\sigma$ là hằng số. (Trong thực tế thì volatility có thể thay đổi theo thời gian, nhưng để đơn giản hóa sự tính toán người ta sẽ lấy một volatility "trung bình" cho khoảng thời gian được xét, coi nó như là hằng số).

Nhắc lại rằng, theo phân bố xác suất martingale $p_{*}$, giá của cổ phiếu $S$ thỏa mãn phương trình vi phân ngẫu nhiên:

$$
d S_{t}=r S_{t} d_{t}+\sigma S_{t} d B_{t}
$$

Phương trình này có thể giải được tương đối dễ dàng khi $r$ và $\sigma$ đều là hằng số, và nghiệm của nó là:

$$
S_{t}=S_{0} \exp \left(\left(r-\frac{\sigma^{2}}{2}\right) t+\sigma B_{t}\right)
$$

Thật vậy, chia cả hai vế cho $S_{t}$, ta được

$$
\frac{d S_{t}}{S_{t}}=r d_{t}+\sigma d B_{t}
$$

Mặt khác, áp dụng bổ đề Itô cho quá trình ngẫu nhiên $\ln S_{t}$, ta được công thức

$$
d\left(\ln S_{t}\right)=\frac{d S_{t}}{S_{t}}+\frac{1}{2} \frac{-1}{S_{t}^{2}}\left(d S_{t}\right)^{2}=\frac{d S_{t}}{S_{t}}-\frac{\sigma^{2}}{2} d t
$$

bởi vì $\left(d S_{t}\right)^{2}=(\sigma S)^{2}\left(d B_{t}\right)^{2}=\sigma^{2} S^{2} d t$. Do đó ta có:

$$
d\left(\ln S_{t}\right)=\left(r-\frac{\sigma^{2}}{2}\right) d t+\sigma d B_{t}
$$

hay còn có thể viết thành

$$
d\left(\ln S_{t}-\left(r-\frac{\sigma^{2}}{2}\right) t-\sigma B_{t}\right)=0
$$

từ đó suy ra $\ln S_{t}-\left(r-\frac{\sigma^{2}}{2}\right) t-\sigma B_{t}=\ln S_{0}$, và suy ra công thức (8.38) cho $S$.

Tương tự như vậy, tại một thời điểm $t$ cho trước, khi $S(t)$ coi như đã biết, ta cũng có thể viết, với $T>t$ :

$$
S_{T}=S_{t} \exp \left(\left(r-\frac{\sigma^{2}}{2}\right)(T-t)+\sigma \hat{B}_{T-t}\right)=S_{t} \exp (Y)
$$


trong đó $Y=\left(r-\frac{\sigma^{2}}{2}\right)(T-t)+\sigma \hat{B}_{T-t}$, và $\hat{B}_{s}$ là một chuyển động Brown bắt đầu tại thời điểm $t$ (thay vì bắt đầu tại thời điểm 0 , hay có thể viết rằng $\hat{B}_{s}=B_{t+s}-B_{t}$ ).

Nhắc lại rằng, nếu $B$ là một chuyển động Brown, thì với mỗi $s>0$ cố định, $B_{s}$ là một biến ngẫu nhiên có phân bố xác suất trên $\mathbb{R}$ là phân bố chuẩn (normal) $N(0, s)$ (kỳ vọng bằng 0 và độ lệch chuẩn bằng $\sqrt{s}$ ). Tại thời điểm $t$, biến ngẫu nhiên $Y=$ $\left(r-\frac{\sigma^{2}}{2}\right)(T-t)+\sigma \hat{B}_{T-t}$ có phân bố chuẩn $N\left(\left(r-\frac{\sigma^{2}}{2}\right)(T-t), \sigma^{2}(T-t)\right)$, với kỳ vọng bằng $\left(r-\frac{\sigma^{2}}{2}\right)(T-t)$ và phương sai bằng $\sigma^{2}(T-t)$, và hàm mật độ của nó là:

$$
\rho(t, y):=\rho_{Y}(y)=\frac{1}{\sqrt{2 \pi \sigma^{2}(T-t)}} \exp \left(\frac{-\left(y-\left(r-\frac{\sigma^{2}}{2}\right)(T-t)\right)^{2}}{2 \sigma^{2}(T-t)}\right) .
$$

Gọi $V_{t}=V(t)$ là giá tại thời điểm $t$ của quyền chọn kiểu Âu của cổ phiếu $S$ với expiry time $T$ và hàm payoff $G$. Nhắc lại rằng $V(T)=G\left(S_{T}\right)$. Theo tính chất martingale, tại thời điểm $t<T$ ta có:

$$
V\left(t, \omega_{t}\right)=e^{-r(T-t)} \mathbb{E}_{*}\left(G\left(S_{T}\right) \mid \omega_{t}\right)
$$

trong đó $\omega_{t}$ là tình huống xảy ra cho đến thời điểm $t$. Vì $S_{T}=S_{T}(Y)=S_{t} \exp (Y)$ là hàm số một biến theo $Y$, khi mà $T, t$ và $S_{t}$ đã cố định, nên ta cũng có thể coi $G\left(S_{T}\right)=G\left(S_{t} \exp (Y)\right)$ như là hàm số một biến theo $Y$. Dùng công thức tính kỳ vọng của một hàm số của một biến ngẫu nhiên, ta có:

$$
V\left(t, \omega_{t}\right)=e^{-r(T-t)} \mathbb{E}_{*}\left(G\left(S_{T}\right) \mid \omega_{t}\right)=e^{-r(T-t)} \int_{-\infty}^{\infty} G\left(S_{T}(y)\right) \rho(t, y) d y .
$$

Ta chỉ cần biết giá $S_{t}=S_{t}\left(\omega_{t}\right)$ của cổ phiếu tại thời điểm $t$ là xác định được vế phải của công thức trên (chứ không cần biết thêm thông tin gì về $\omega_{t}$ ). Bởi vậy ta có thể viết:

$$
V\left(t, S_{t}\right)=e^{-r(T-t)} \int_{-\infty}^{\infty} G\left(S_{t} e^{y}\right) \rho(t, y) d y
$$

với $\rho(t, y)=\frac{1}{\sqrt{2 \pi \sigma^{2}(T-t)}} \exp \left(\frac{-\left(y-\left(r-\frac{\sigma^{2}}{2}\right)(T-t)\right)^{2}}{2 \sigma^{2}(T-t)}\right)$.

Công thức thức trên chính là công thức định giá cho một quyền chọn kiểu Âu với hàm payoff là $G$, với điều kiện volatility $\sigma$ là hằng số. Ta sẽ kiểm tra rằng hàm $V\left(t, S_{t}\right)$ cho bởi công thức (8.47) thỏa mãn phương trình đạo hàm riêng Black-Scholes và điều kiện biên $V(T, S)=G(S)$.

Công thức 8.47) không định nghĩa trực tiếp cho $t=T$, nhưng có thể lấy giới hạn $V(T, S)=\lim _{t \rightarrow T} V(t, S)$ : Khi $t$ tiến tới $T-t$ thì phân bố xác suất $N\left(\left(r-\frac{\sigma^{2}}{2}\right)(T-\right.$ $t), \sigma^{2}(T-t)$ ), hội tụ (theo nghĩa hội tụ yếu của các phân bố xác suất) đến phân bố tập 
trung tại duy nhất một điểm 0 , và do đó vế phải của công thức 8.47 tiến tới $G\left(S_{T} \exp (0)\right)$ khi $t$ tiến tới $T$, tức là ta có điều kiện biên $V(T, S)=G(S)$.

Để kiểm tra rằng $V(t, S)$ cho bởi công thức 8.47 thỏa mãn phương trình 8.30 , ta có thể làm như sau:

Lấy đạo hàm của hai vế của công thức (8.47) theo biến $t$ ta được:

$$
\frac{\partial V(t, S)}{\partial t}=r V(t, S)+e^{-r(T-t)} \int_{-\infty}^{\infty} G\left(S e^{y}\right) \frac{d \rho(t, y)}{d t} d y
$$

Lấy đạo hàm của hai vế của công thức 8.47 theo biến $S$, rồi nhân với $S$, ta được:

$$
S \frac{\partial V(t, S)}{\partial S}=e^{-r(T-t)} \int_{-\infty}^{\infty} G^{\prime}\left(S e^{y}\right) S e^{y} \rho(t, y) d y=e^{-r(T-t)} \int_{-\infty}^{\infty} \frac{d G\left(S e^{y}\right)}{d y} \rho(t, y) d y
$$

trong đó $G^{\prime}$ là ký hiệu đạo hàm của $G$. Vì

$$
\int_{-\infty}^{\infty} \frac{d\left(G\left(S e^{y}\right) \rho(t, y)\right)}{d y} d y=0
$$

và

$$
\frac{d\left(G\left(S e^{y}\right) \rho(t, y)\right)}{d y}=\frac{d G\left(S e^{y}\right)}{d y} \rho(t, y)+G\left(S e^{y}\right) \frac{d \rho(t, y)}{d y}
$$

nên công thức phía trên có thể viết lại thành:

$$
S \frac{\partial V(t, S)}{\partial S}=-e^{-r(T-t)} \int_{-\infty}^{\infty} G\left(S e^{y}\right) \frac{d \rho(t, y)}{d y} d y
$$

Tương tự như vậy, ta có:

$$
S \frac{\partial}{\partial S}\left(S \frac{\partial V(t, S)}{\partial S}\right)=e^{-r(T-t)} \int_{-\infty}^{\infty} G\left(S e^{y}\right) \frac{d^{2} \rho(t, y)}{d y^{2}} d y
$$

Mặt khác, $S \frac{\partial}{\partial S}\left(S \frac{\partial V(t, S)}{\partial S}\right)=S^{2} \frac{\partial^{2} V(t, S)}{\partial S^{2}}+S \frac{\partial V(t, S)}{\partial S}$, bởi vậy ta có:

$$
S^{2} \frac{\partial^{2} V(t, S)}{\partial S^{2}}=e^{-r(T-t)} \int_{-\infty}^{\infty} G\left(S e^{y}\right)\left(\frac{d^{2} \rho(t, y)}{d y^{2}}+\frac{d \rho(t, y)}{d y}\right) d y
$$

Từ các đẳng thức 8.48, , 8.49 và 8.50 ta suy ra:

$$
\begin{aligned}
\frac{\partial V(t, S)}{\partial t} & -r V(t, S)+r S \frac{\partial V(t, S)}{\partial S}+\frac{1}{2} \sigma^{2} S^{2} \frac{\partial^{2} V(t, S)}{\partial S^{2}}= \\
& =e^{-r(T-t)} \int_{-\infty}^{\infty} G\left(S e^{y}\right)\left(\frac{d \rho(t, y)}{d t}-\left(r-\frac{\sigma^{2}}{2}\right) \frac{d \rho(t, y)}{d y}+\frac{\sigma^{2}}{2} \frac{d^{2} \rho(t, y)}{d y^{2}}\right) d y
\end{aligned}
$$


Để chứng minh rằng hàm $V(t, S)$ cho bởi công thức (8.47) thỏa mãn phương trình Black-Scholes (8.30), ta chỉ còn phải kiểm tra rằng hàm mật độ

$$
\rho(t, y)=\frac{1}{\sqrt{2 \pi \sigma^{2}(T-t)}} \exp \left(\frac{-\left(y-\left(r-\frac{\sigma^{2}}{2}\right)(T-t)\right)^{2}}{2 \sigma^{2}(T-t)}\right)
$$

thỏa mãn phương trình đạo hàm riêng bậc 2 sau:

$$
\frac{d \rho(t, y)}{d t}-\left(r-\frac{\sigma^{2}}{2}\right) \frac{d \rho(t, y)}{d y}+\frac{\sigma^{2}}{2} \frac{d^{2} \rho(t, y)}{d y^{2}}=0 .
$$

Khâu kiểm tra cuối cùng này là bài tập dành cho bạn đọc.

Áp dụng công thức 8.47$)$ vào trường hợp $G(S)=(S-X)^{+}$, ta được công thức định giá sau cho Call kiểu Âu:

$$
C^{E}(t, S)=e^{-r(T-t)} \int_{-\infty}^{\infty}\left(S e^{y}-X\right)^{+} \rho(t, y) d y
$$

trong đó $\rho(t, y)=\frac{1}{\sqrt{2 \pi \sigma^{2}(T-t)}} \exp \left(\frac{-\left(y-\left(r-\frac{\sigma^{2}}{2}\right)(T-t)\right)^{2}}{2 \sigma^{2}(T-t)}\right)$, hay còn có thể viết là:

$$
C^{E}(t, S)=e^{-r(T-t)} \int_{\ln X-\ln S}^{\infty}\left(S e^{y}-X\right) \rho(t, y) d y .
$$

Tương tự như vậy, cho Put kiểu Âu ta có:

$$
P^{E}(t, S)=e^{-r(T-t)} \int_{-\infty}^{\ln X-\ln S}\left(X-S e^{y}\right) \rho(t, y) d y .
$$

Các công thức trên có thể được đơn giản hóa, bằng cách khai triển và đổi biến, để trở thành các công thức sau, gọi là công thức Black-Scholes:

$$
C^{E}(t, S)=S N\left(d_{1}\right)-X e^{-r(T-t)} N\left(d_{2}\right),
$$

và

$$
P^{E}(t, S)=X e^{-r(T-t)} N\left(-d_{2}\right)-S N\left(-d_{1}\right)
$$

trong đó:

$$
N(x)=\int_{-\infty}^{x} \frac{1}{\sqrt{2 \pi}} e^{-y^{2} / 2} d y
$$

là hàm phân phối xác suất của phân bố normal chuẩn tắc $N(0,1)$, và

$$
d_{1}=\frac{\ln (S / X)+\left(r+\sigma^{2} / 2\right)(T-t)}{\sigma \sqrt{T-t}}, \quad d_{2}=\frac{\ln (S / X)+\left(r-\sigma^{2} / 2\right)(T-t)}{\sigma \sqrt{T-t}} .
$$

Bài tập 8.5. Chứng minh các công thức 8.56 và 8.57). 


\subsection{Các chữ cái Hy Lạp}

Trong ngôn ngữ toán tài chính, và trên thị trường chứng khoán, các đạo hàm của giá quyền chọn được gọi là các chữ cái $\mathbf{H y}$ Lạp, bởi vì chúng được ký hiệu bởi các chũ cái Hy Lạp.

Ký hiệu giá của một quyền chọn nào đó là $V$. Như ở phần trên ta đã thấy, trong mô hình Black-Scholes, thì $V$ được hoàn toàn xác định bởi các đại lượng sau: $t$ (thời gian), $S$ (giá cổ phiếu), $\sigma$ (volatility), $r$ (lãi suất), $X$ (giá thực hiện), và $T$ (thời điểm đáo hạn). Thời điểm đáo hạn và giá thực hiện được cố định cho mỗi quyền chọn, nên ở đây sẽ không coi là biến số. Bốn đại lượng còn lại, tức là $t, S, \sigma, r$ thì là biến số, vì nó không được cố định cho quyền chọn, mà có thể thay đổi. Chú ý rằng, trong lúc tìm công thức định giá quyền chọn, thì ta coi $\sigma$ và $r$ là hằng số, nhưng một khi đã có công thức, thì ta có thể cho phép nó thay đổi, và xem sự phụ thuộc của giá quyền chọn theo công thức đã tìm được) vào $\sigma$ và $r$ ra sao. Sự thay đổi $\sigma$ và $r$ có xảy ra trong thực tế, đặc biệt là $\sigma$ có thể thay đổi rất mạnh, và điều đó có thể làm cho giá quyền chọn thay đổi rất mạnh theo.

Ta sẽ coi $V=V(t, S, \sigma, r)$ là một hàm của 4 biến số (kể cả khi nó không phải là quyền chọn kiểu Âu tuân theo mô hình Black-Scholes). Các đạo hàm của $V$ theo 4 biến số này được gọi tên như sau:

i) $\operatorname{delta}_{V}=\frac{\partial V}{\partial S}$. (Chữ cái Hy Lạp delta viết là $\delta$, ứng với chữ cái La Mã d, là chữ cái đầu của từ derivative, tức là đạo hàm)

ii) thet $_{V}=\frac{\partial V}{\partial t}$. (Chữ cái Hy Lạp theta viết là $\theta$, ứng với chữ cái La Mã t, là chữ cái đầu của từ time, tức là thời gian)

iii) vega $a_{V}=\frac{\partial V}{\partial \sigma}$. (Trong bảng chữ cái Hy Lạp thực ra không có chữ cái vega, mà người ta bịa ra nó như là tên gọi Hy Lạp hóa của chữ v, chữ cái đầu của từ volatility).

iv) $r h o_{V}=\frac{\partial V}{\partial \rho}$. (Chữ cái Hy Lạp rho viết là $\rho$, ứng với chữ cái La Mã $r$, chữ cái đầu của từ rate, chỉ mức lãi suất)

v) $\operatorname{Gamma}_{V}=\frac{\partial^{2} V}{\partial S^{2}}$. (Chữ cái Hy lạp Gamma viết là $\left.\Gamma\right)$.

Các công thức sau để tính các chữ cái Hy lạp tại thời điểm $t=0$ cho Call kiểu Âu là hệ quả trực tiếp của công thức Black-Scholes:

i) $\operatorname{delta}_{C^{E}}=N\left(d_{1}\right)$.

ii) thet $_{C^{E}}=-\frac{S \sigma}{2 \sqrt{2 \pi T}} e^{-d_{1}^{2} / 2}-r X e^{-r T} N\left(d_{2}\right)$. 
iii) $v e g a_{C E}=\frac{S \sqrt{T} \sigma}{\sqrt{2 \pi}} e^{-d_{1}^{2} / 2}$.

iv) $r h o_{C^{E}}=T X e^{-r T} N\left(d_{2}\right)$.

v) $\operatorname{Gamma}_{C^{E}}=\frac{1}{S \sigma \sqrt{2 \pi T}} e^{-d_{1}^{2} / 2}$

Từ các công thức trên, ta rút ra một số kết luận sau về giá của Call kiểu Âu (cũng bằng giá của Call kiểu Mỹ, nếu cổ phiếu không trả cổ tức): $C^{E}$ là hàm đơn điệu tăng theo biến giá cổ phiếu $S$ (vì delta dương), và là hàm lồi (vì Gamma dương). Hơn nữa, nó là hàm đơn điệu giảm theo biến thời gian $t$ (vì theta âm: theta chính là mức suy giảm theo thời gian của giá quyền chọn), đơn điệu tăng theo biến lãi suất, và đơn điệu tăng theo biến volatility.

Ý nghĩa của các "chữ cái Hy Lạp" (các đạo hàm riêng của hàm giá quyền chọn), là nó cho phép tính toán quản lý rủi ro cho các danh mục đầu tư hay buôn bán chứng khoán có chứa quyền chọn. Ví dụ, một nhà đầu tư đang giữ cổ phiếu XYZ nào đó, nhưng e ngại về chuyện giá của XYZ có thể giao động mạnh theo chiều hướng bất lợi. Khi đó, nhà đầu tư có thể làm giảm độ ảnh hưởng của tài khoản vào độ giao động của giá cổ phiếu XYZ đi (tức là làm giảm delta của tài khoản theo giá cổ phiếu XYZ đi), bằng cách bán một lượng Call hoặc/và mua một lượng Put của XYZ. Lượng Call bán đi và Put mua vào tùy thuộc vào delta mà nhà đầu tư muốn có. Việc mua bán quyền chọn nhằm mục đích giảm delta như vậy có thể không làm thay đổi đáng kể kỳ vọng lợi nhuận của danh mục đầu tư, nhưng làm giảm được volatility, tức là làm giảm rủi ro cho danh mục đầu tư, khiến cho danh mục đầu tư trở nên hiệu quả hơn.

Bài tập 8.6. Chứng minh rằng hàm giá $P^{E}$ của Put kiểu Âu theo mô hình Black-Scholes là hàm đơn điệu giảm theo biến giá cổ phiếu, là hàm lồi theo biến giá cổ phiếu, đơn điệu giảm theo biến thời gian, đơn điệu giảm theo biến lãi suất, và đơn điệu tăng theo biến volatility.

\subsection{Mô hình Cox-Ross-Rubinstein}

Mô hình định giá quyền chọn của Cox-Ross-Rubinstein (viết tắt là CRR), công bố năm 1979 (6) , chính là mô hình cây nhị phân bất biến (đã được bàn đến trong Mục 7.1.4) áp dụng vào việc tính giá quyền chọn. Đối với các quyền chọn kiểu Âu cho các cổ phiếu

(6) Bài báo công bố là: Cox, John C., Stephen A. Ross, and Mark Rubinstein, Option Pricing: A Simplified Approach, Journal of Financial Economics 7, (1979) 229-263. 
không trả cổ tức, thì mô hình này là một sự xấp xỉ rời rạc của mô hình Black-Scholes, và khi các bước thời gian trong mô hình $\mathrm{CRR}$ tiến tới 0 , thì kết quả cho bởi mô hình CRR tiến tới kết quả cho bởi mô hình Black-Scholes. Vì mô hình CRR là một mô hình rời rạc, với thuật toán tính dễ đưa vào máy tính, nên nó cũng có thể được coi như là một phương pháp tính gần đúng giá quyền chọn cho theo công thức của Black-Scholes. Úng dụng của mô hình CRR không chỉ dừng lại ở chỗ làm phương pháp tính cho công thức Black-Scholes, mà nó còn sử dụng được để tính toán với những loại quyền chọn mà mô hình Black-Scholes không áp dụng được, trong đó có quyền chọn kiểu Mỹ và quyền chọn kiểu Bermuda(7)

Trong mô hình cây nhị phân bất biến CRR, khoảng thời gian từ thời điểm hiện tại 0 đến thời điểm đáo hạn $T$ được chia làm $n$ đoạn bằng nhau với độ dài $\Delta t=T / n$, trong đó $n$ là một số tự nhiên nào đó ( $n$ càng lớn thì công thức định giá sẽ càng chính xác). Gọi $S(k)$ là giá của cổ phiếu tại thời điểm $k \cdot \Delta t(k=0,1, \ldots, n)$. Gọi $S=S(0)$ là giá của cổ phiếu tại thời điểm ban đầu. Trong mỗi giai đoạn từ $k$ đến $k+1$ chỉ có 2 tình huống ngẫu nhiên có thể xảy ra, hoặc tốt hoặc xấu, xác suất của tình huống tốt là $p$, của tình huống xấu là $1-p$. Trong tình huống tốt thì

$$
S(k+1)=u \cdot S(k)
$$

còn trong tình huống xấu thì

$$
S(k+1)=d . S(k)
$$

(Nếu cổ phiếu có trả một lượng cổ tức $D$ tại thời điểm thứ $k$, thì các công thức trên chuyển thành $S(k+1)=u \cdot(S(k)-D)$ và $S(k+1)=u \cdot(S(k)-D)$ trong các tình huống tốt và xấu). Hệ số tăng giảm $u, d$ phụ thuộc vào volatility $\sigma$ của cổ phiếu, độ dài khoảng thời gian $\Delta t$. Có nhiều cách chọn lựa $u$ và $d$ khác nhau (miễn sao khi $n$ tiến tới vô cùng, thì mô hình cây nhị phân này hội tụ tới mô hình thời gian liên tục có volatility bằng $\sigma$ ). Ví dụ ta có thể đặt

$$
u=\exp (\sigma \cdot \sqrt{\Delta t}), \quad d=\exp (-\sigma \cdot \sqrt{\Delta t})
$$

Phân bố xác suất $(p, 1-p)$ mà chúng ta dùng để tính giá quyền chọn là phân bố xác suất trung hòa rủi ro, theo nguyên lý no-arbitrage. Có nghĩa là, theo phân bố xác suất này, thì tỷ lệ lợi nhuận kỳ vọng phải bằng mức lãi suất thị trường, do đó:

$$
p u+(1-p) d=\exp (r \Delta t)
$$

(7) Xem, chẳng hạn, http://en.wikipedia.org/wiki/Option_style, về các loại quyền chọn 
trong đó $r$ là mức lãi kép liên tục của thị trường. Từ đó ta được công thức sau để tính $p$ :

$$
p=\frac{\exp (r \Delta t)-d}{u-d}
$$

Phân bố xác suất của $S(k)$ cho thời điểm 0 là phân bố nhị thức: $S(k)$ có thể nhận một trong $k+1$ giá trị

$$
S(k, i)=u^{k-i} d^{i} S
$$

$i=0, \ldots, k$, với các xác suất tương ứng bằng $C_{k}^{i} p^{k-i}(1-p)^{i}$. (Nếu như có trả cổ tức giữa chừng, thì công thức trên được điều chỉnh tương ứng). Giá của Call và Put kiểu Âu cho thời điểm đáo hạn $T$ theo mô hình này là:

$$
\begin{aligned}
& C=\exp (-r T)\left[\sum_{i=0}^{n} C_{n}^{i} p^{n-i}(1-p)^{i} \max \left(u^{k-i} d^{i} S-X, 0\right)\right], \\
& P=\exp (-r T)\left[\sum_{i=0}^{n} C_{n}^{i} p^{n-i}(1-p)^{i} \max \left(X-u^{k-i} d^{i} S, 0\right)\right],
\end{aligned}
$$

trong đó $X$ là giá thực hiện (strike price).

Đối với quyền chọn kiểu Mỹ, vì nhà đầu tư có thể thực hiện quyền mua/bán trước khi đáo hạn quyền chọn, nên công thức tính giá phức tạp hơn. Mô hình CRR cho thuật toán tính giá quyền chọn kiểu Mỹ như sau:

Tính qui nạp theo $k=n, n-1, \ldots, 0$ ( $k$ chạy ngược từ $n$ về đến 0$)$. Với mỗi $k$ như vậy, gọi $P(k, i)$ là giá của Put kiểu Mỹ tại thời điểm thứ $k$ nếu mà giá của cổ phiếu lúc đó là $S(k, i)$. Khi $k=n$ ta có:

$$
P(n, i)=\max (0, X-S(n, i))
$$

Tại các thời điểm $k<n, P(k, i)$ được tính theo công thức qui nạp:

$$
P(k, i)=\max \{X-S(k, i),(p P(k+1, i)+(1-p) P(k+1, i+1)) \exp (-r \Delta T)\},
$$

bởi vì nếu $X-S(k, i)>(p P(k+1, i)+(1-p) P(k+1, i+1)) \exp (-r \Delta T) \geq 0$ thì nhà đầu tư có thể chọn thực hiện quyền Put tại thời điểm thứ $k$ để được $X-S(k, i)$ (và đại lượng này khi đó lớn hơn 0 ). Khi $k$ chạy về đến 0 , ta được

$$
P^{A}=P(0,0)
$$

chính là giá của Put kiểu Mỹ. Tương tự như vậy cho Call kiểu Mỹ. Thuật toán trên được viết dễ dàng thành chương trình máy tính để áp dụng tính giá quyền chọn kiểu Mỹ ở nhiều nơi. 
Ghi chú 8.4. Mô hình CRR rất là tổng quát và cho thuật toán tương đối đơn giản để tính nhiều loại quyền chọn khác nhau. Tuy nhiên, việc tính toán dùng đến phép lặp $(k$ chạy từ $n$ đến 0 ) có thể tốn khá nhiều công suất máy tính. Có một số thuật toán khác có thể cho phép tính giá quyền chọn một cách hiệu quả hơn trong một số trường hợp. Ví dụ như mô hình Whaley (phương pháp xấp xỉ bình phương) để tính quyền chọn kiểu Mỹ. Mô hình này xuất hiện từ năm 1987 trong bài báo: G. Barone-Adesi, R. E. Whaley, Efficient analytic approximation of American option values, Journal of Finance, Vol. 42, No. 2, 1987, 301 - 320. (Xem chẳng hạn [18]). 


\section{Chỉ mục}

đòn bẩy (leverage), 136

đệm an toàn (cushion of safety), 137

độ lệch chuẩn (standard deviation), 152

độ thỏa dụng, 148

đạo hàm Radon-Nikodym, 217, 219

định lý Cameron-Martin, 219

định lý Girsanov, 222

định lý Kolmogorov, 195

định lý đối ngẫu, 57

định lý arbitrage, 54

định lý giới hạn trung tâm, 198

đẳng cự Itô, 215

đường lợi suất (yield curve), 91

đường thị trường vốn (capital market line),

168

đa dạng hóa (diversification), 135

điểm Markowitz, 167

đinh lý Feynmann-Kac, 239

đường thị trường chứng khoán (security market line), 170

bất động sản, 140

bất đẳng thức Jensen, 151

bình phương khả tích, 212

bổ đề Itô, 208

biến phân, 201 cấu trúc kỳ hạn tổng quát (general term structure), 94

cố định tỷ giá (pegging), 18

cây nhị phân (binary tree), 179

cây nhị phân bất biến (invariant binary tree model), 181

công thức Black-Scholes, 243

công thức dòng tiền chiết khấu, 78, 107

công thức Fisher, 13

công thức Itô, 208

cổ phiếu, 30, 142

cổ phiếu giá trị (value stocks), 109

cổ phiếu tăng trưởng (growth stock), 110

CAGR, 145

CAPM, 166

chứng khoán phái sinh (derivatives), 35

chỉ số ICOR, 133

chiến lược arbitrage, 51, 188

chiến lược arbitrage mạnh, 51

chiến lược hiệu quả, 164

chuyển động Brown (Brownian motion), 192

chuyển động Brown hình học (geometric Brow-

$$
\text { nian motion), } 203
$$

CPI (consumer price index), 8

credit rating, 98

biến phân bình phương (quadratic variation), dòng niên kim (annuity), 80

201

biên hiệu quả (efficient frontier), 164 danh mục đầu tư (portfolio), 133

danh mục thị trường (market portfolio), 166 
du động ngẫu nhiên (random walk), 197 duration, 87

giá thực hiện (strike price), 225

giá trị hiện tại, 78

giá trị nội tại (intrinsic value), 101

giá trị thời gian (time value), 233

giá trị thật (fair value), 101

giả thuyết thị trường hiệu quả (efficient market hypothesis), 122

giảm phát (deflation), 9

gia số (increment), 193

gia số độc lập (independent increments), 196

hàm thỏa dụng (utility function), 148

hàm thỏa dụng Bernoulli, 150

hàm trả tiền (payoff function), 236

hệ số beta, 126, 169

hệ số khuyếch đại, 16

hệ số trượt (drift), 182

hợp đồng hoán đổi (swap), 39

hợp đồng kỳ hạn (forward contract), 35, 64

hợp đồng tương lai (futures), 35,64

hiệp biến phân bình phương, 216

implied volatility, 126

kỳ vọng theo sigma-đại số con, 184

không gian xác suất có lọc (filtered probability space), 174

kinh doanh chênh lệch giá (arbitrage), 49

lợi nhuận kỳ vọng (expected return), 53

lợi suất (yield), 74

lợi suất cổ tức (dividend yield), 109 lợi suất log (logarithmic yield), 77

lạm phát (inflation), 8

lượng cung tiền (money supply), 6

lãi đơn (simple interest), 69

lãi kép (compound interest), 73

lãi kép kiên tục (continuously compounded interest), 76

lãi suất (interest rate), 11,69

lãi suất chiết khấu (discount rate), 72

lãi suất coupon, 84

lãi suất hiệu dụng (effective interest rate),

\section{4}

lãi suất hoàn vốn (yield to maturity), 85

lãi suất kỳ hạn (forward rates), 91,96

lãi suất thực (real interest rate), 13

lãi suất tham chiếu (reference rate), 17

log-normal, 203

mô hình Cox-Ross-Rubinstein, 245

martingale, 184,185

modern portfolio theory, 157

nửa phương sai (semi-variance), 153

nguyên tắc tổng tiền bằng 0,5

no-arbitrage, 188

phí mạo hiểm (risk premium), 13, 108, 151

phương sai (variance), 152

phương trình Black-Scholes, 237

phương trình vi phân ngẫu nhiên (stochastic differential equation), 182

Put-Call parity, 229

quá trình Itô, 208

quá trình ngẫu nhiên (random process), 172 
quyền chọn (options), 37

quyền chọn có giới hạn (barrier option), 220

quyền chọn kiểu Âu (European-style option),

225

quyền chọn kiểu Mỹ (American-style option),

225

rủi ro thậm hụt (shortfall risk), 154

semi-martingale, 216

tích phân Itô, 211

tích phân Riemann-Stieltjes, 209

tổng cung tiền (monetary aggregate), 6

tổng tiền bằng 0,5

tỷ lệ dự trữ bắt buộc, 16

tỷ lệ lợi nhuận (rate of return), 144

thị trường đầy đủ (complete market), 64

thị trường thứ cấp (secondary market), 23

thi trường sơ cấp (primary market), 23

tiền tệ, 3

trái phiếu, 28, 69, 141

trái phiếu chiết khấu (discount bond), 72

trái phiếu coupon, 83

trái phiếu vĩnh cửu (perpetual bond), 84

trái phiếu zero-coupon, 74

trung hòa rủi ro (risk-neutral), 53,60

vàng, 4, 139

value at risk (VaR), 155

vector chiến lược, 53

volatility, 124, 182, 236

volatility lịch sử (historical volatility), 125 


\section{References}

[1] Noel Amenc \& Veronique Le Sourd, Portfolio theory and performance analysis, Wiley, 2003.

[2] Robert Buchanan, An undergraduate introduction to financial mathematics, World Scientific, 2006.

[3] Marek Capinski \& Tomasz Zastawniak, Mathematics for finance - An introduction to financial engineering, Springer, 2003.

[4] Rama Cont \& Peter Tankov, Financial modeling with jump processes, Chapman \& Hall/CRC Press, Second Edition, 2008.

[5] Jaksa Cvitani_c \& Fernando Zapatero, Introduction to the Economics and Mathematics of Financial Markets, The MIT Press, 2004.

[6] Glyn Davies, A History of money from ancient times to the present day, 3rd. ed. Cardiff: University of Wales Press, 2002. 720p.

[7] Nguyễn Tiến Dũng và Đỗ Đức Thái, Nhập môn hiện đại Xác suất Thống kê, NXB ĐHSPHN, 2010.

[8] Robert Elliott \& Ekkehard Kopp, Mathematics of financial markets, 2nd edition, Springer, 2005.

[9] Sergio Focardi \& Frank Fabozzi, The mathematics of financial modeling and investment management, Wiley, 2004.

[10] Roger Gibson, Asset Allocation, 4th edition, McGraw_Hill, 2008.

[11] Joel Greenblatt, You Can Be a Stock Market Genius: Uncover the Secret Hiding Places of Stock Market Profits, New York: Simon \& Schuster, 1997.

[12] Joel Greenblatt, The little book that beats the market, John Wiley \& Sons, 2006.

[13] John Hull, Options, Futures, and Other Derivatives, 8th edition, Pearson Education, 2011, 841pp.

[14] Nguyễn Văn Hữu \& Vương Quân Hoàng, Các phương pháp toán học trong tài chính, NXB ĐHQGHN, 2007.

[15] I. Karatzas and S. Shreve, Brownian Motion and Stochastic Calculus, 2nd ed., Springer, 1991. 
[16] Damien Lamberton \& Bernard Lapeyre, Stochastic Calculus Applied to Finance, Chapman \& Hall/CRC, 2000.

[17] A. McNeil, R. Frey, P. Embrechts, Quantitative risk management: concepts, techniques, and tools. Princeton University Press, 2005, 608 pp.

[18] Sheldon Natenberg, Option volatility and pricing, McGraw_Hill, 1994.

[19] Dalih Neftci, Principles of financial engineering, 2nd edition, Academic Press, 2008.

[20] Trần Trọng Nguyên, Cơ sở toán tài chính, NXB Khoa học \& Kỹ thuật, 2011.

[21] Bernt K. _ksendal, Stochastic Differential Equations: An Introduction with Applications, $\overline{5}$ th printing, Springer, Berlin, 2000.

[22] Stanley Pliska, Introduction to Mathematical Finance - Discrete Time Models, Wiley, 2001.

[23] Martin Pring, Technical Analysis Explained, 4th ed., McGraw_Hill, 2002.

[24] Mikken Rasmussen, Quantitative portfolio optimization, asset allocation and risk management, Palgrave Macmillan, 2003.

[25] Christian Y. Robert, Risk measures for insurance and finance, FrenchVietnamese thematic school _Mathematical Methods in Finance and Economics, Doson, 2011. Có thể tải xuống tập bài giảng này từ địa chỉ:

http://vie.math.ac.vn/doson2011/notes/Robert/Robert_RiskMeasures_slides2011.pdf

[26] Sheldon Ross, An introduction to mathematical finance, Cambridge University Press, 1999.

[27] Catherine Shenoy, Applied Portfolio Management, Wiley, 2008.

[28] Trần Hùng Thao, Nhập môn toán tài chính, 2009.

[29] Nguyễn Duy Tiến, Các mô hình xác suất và ứng dụng, Phần III: Giải tích ngẫu nhiên, NXB Đại học Quốc gia Hà Nội, 2005.

[30] Robert Vanderbei, Linear programming, foundations and extensions, Springer, 3rd edition, 2008.

[31] P. Wilmott et al., The mathematics of financial derivatives - A student introduction, Cambridge University Press, 1995. 